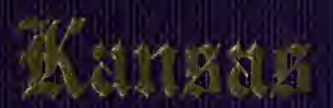

Shmorthnut:

$=$

c. 3. Have 


\section{LIBRARY}

UNIVERSITY OF CALIFORNIA

\section{DAVIS}



Digitized by the Internet Archive in 2007 with funding from Microsoft Corporation 


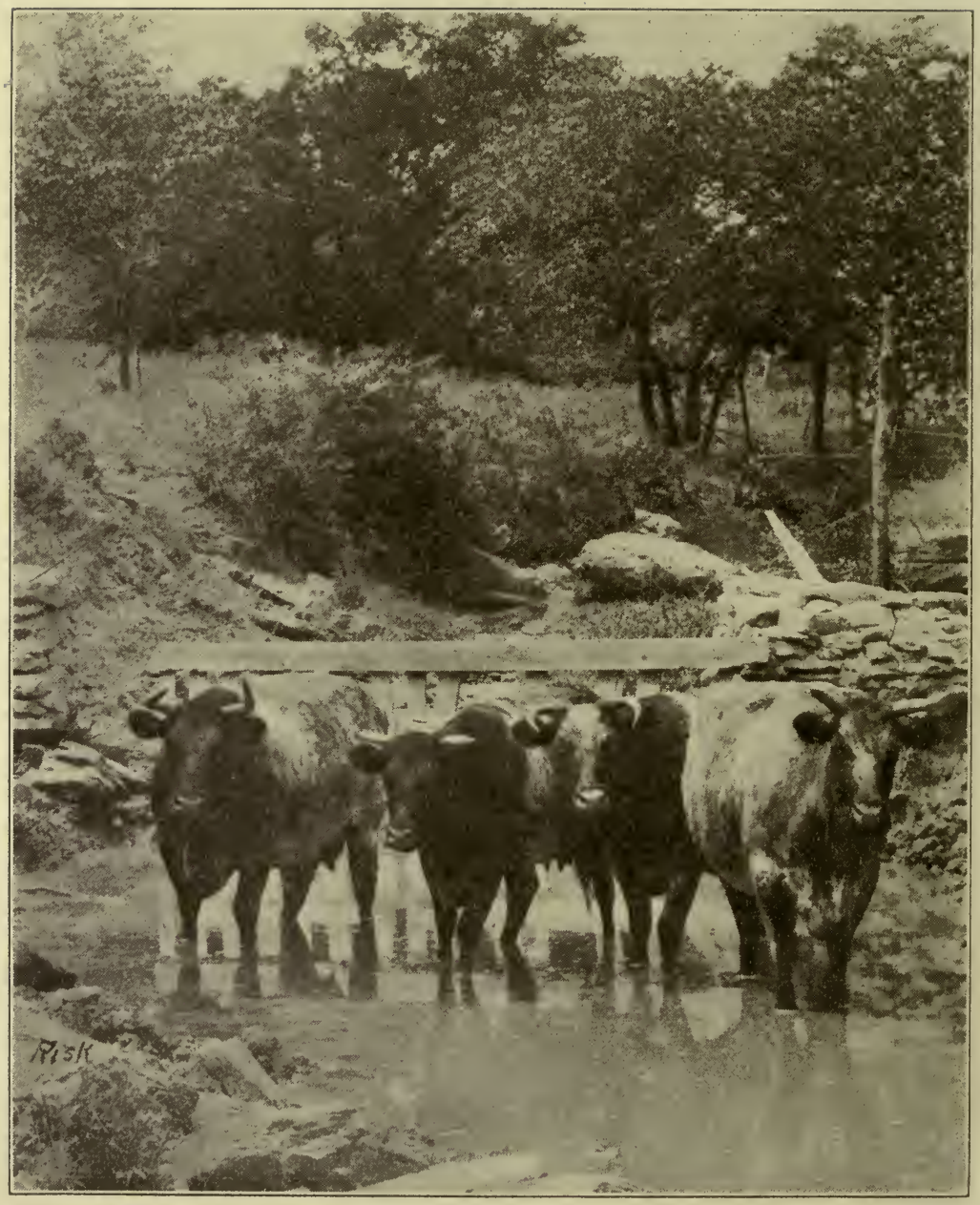




\title{
KANSAS SHORTHORNS
}

\author{
A HISTORY OF THE BREED IN \\ THE STATE FROM 1857 TO 1920
}

\section{By G. A. LAUDE}

Secretary Kansas Shorthorn

Breeders Association

COMPILED AND PUBLISHED UNDER THE DIRECTION OF THE COMMITTEE ON PUBLICATION OF THE KANSAS SHORTHORN BREEDERS ASSOCIATION

\section{Committee Personnel}

PARK E. SALTER, Wichita, Pres. Kansas Shorthorn Breeders Assn. JOHN R. TOMSON, Dover, Pres. Ame:ican Shorthorn Breeders Assn. W. A. COCHEL, Manhattan, Field Rep. Am. Shorthorn Breeders Assn. H. M. HILL, Lafontaine, Leading Breeder in Southeastern Kansas. SEN. FREMONT LEIDY, Leon, Extensive Breeder of Shorthorns. 
Published by authority and under the direction of the Kansas Shorthorn Breeders Association and based on information received during 1919 and 1920.

Copyright 1921

BY G. A. JAAUDE 


\section{PART I. \\ INTRODUCING SHORTHORNS}

It is not in human nature to anticipate emergencies. The average man-and we are nearly all average men-goes along in the regular way until he realizes that he is at "the parting of the ways," when he rises to the occasion or goes down in defeat.

The Kansas farmer has come to the parting of the ways. Over the greater portion of the state, in the region of the farm home, he has, with few exceptions been taking from the soil bountiful crops until for natural and well founded reasons the old farm is not so kindly in cultivation, nor so responsive to his efforts as it once was. He has been drawing on his bank account stored in the soil in the shape of fertility, and having made few if any deposits, his account has run low. He sees the warning signals-harder soil, less resistance to excessively wet or dry seasons and a lighter growth of vegetation that tell of less humus and less available fertility - and he is heeding the call now as never before.

There is an insistent demand for live stock on the farm. Why is it that only when brought face to face with necessity the farmer, both large and small, is planning to make his holding a stock farm? A cattle farm-for it is recog- 
nized that cattle alone have the capacity to turn the big crops of roughage into cash, yet leave the farm enriched in so doing. The answer is easy. He has told us time after time that it was easier and more profitable not to keep cattle and who will say that in many cases he was not right? But this was not altogether a true answer for some have made a financial success of the work. What is the trouble? The man who has failed to make cattle pay has kept the wrong kind of cattle or he has kept them in a way that outraged the laws of live stock husbandry. Keeping the right kind of cattle in the right way always pays and that is the problem of the Kansas farmer of the present and of the future, for only in doing that will he be able to profitably maintain a balance of soil fertility in his favor.

When a farmer begins to investigate the different breeds of cattle with a view of finding the one best suited to his requirements he will remember first of all that he wants an animal that can get almost everything needed for thrift and development from the roughage grown on the farm requiring only a small amount of grain to land it on a good market. He will remember that he needs not a cow that will fill either the requirements for beef or for dairy products alone, but one that will produce calves equal to any breed as beef animals and at the same time give milk and butter for his family and, in the 
case of the small farmer, for market also. In no other breed is found so well this happy combination as in the Shorthorn.

Shorthorn cattle are pre-eminently the great machine which turns roughage into eash. No other breed can approach them in availability for this purpose. It is not so much of a contest as to what breed of cattle will thrive best on corn, for as a grain consuming machine the hog will produce almost double the number of pounds for each bushel of corn consumed as will the steerand for this purpose the American hog is the uncrowned king of the universe! Shorthorn cattle with their big, thick, deep bodies and capacious digestive organs can consume more roughage and as a result get more pounds of gain daily from grass and rough feeds than cattle of any other breed. This means that they can put on the final pounds of finish for which grain is required more cheaply than can those of other breeds, for they do more with the cheap feeds of the farm. Shorthorn cattle are the great farm cattle for they have no rivals in utilizing the farm feeds whether it be for production of beef or for beef and milk.

The record price for range grass fat steers is held by grade Shorthorns marketed in Chicago at $\$ 18.00$ per ewt. The record price for feeder cattle is held by Shorthorn steers sold in Denver at $\$ 20.25$ per ewt. The greatest net return for a 
carload of steers at the International (except the grand champion herd the value of which was enhanced by winning of the ribbon) was secured from a load of Shorthorns. The International grand champions carried a large percentage of Shorthorn blood. The highest prices paid for steers at the Missouri River markets have gone to cattle tracing to a Shorthorn foundation. The additional weight of approximately 200 pounds on two-year-old steers which carry a large percentage of Shorthorn blood is a very important consideration when cattle sell at prevailing prices. The heavy loins, broad backs, deep hindquarters and natural flesh of the Shorthorn make them the ideal farm cattle.

In the herd of Shorthorns at the Kansas State Agricultural College Farm, Manhattan, there are seven thick-fleshed, broad-backed, low-set Scotch cows having milk records averaging considerably in excess of 7,000 pounds of milk per year. Their calves are of the same individual conformation and several of them have won prizes in the beef shows. But this is not allthese cows were not put to milking until after they had raised one or more calves. One of them had nursed her third calf before she was tried as a milker. Individually they will compare with the best cows in the leading herds of the country and no two are bred along the same line. One is a daughter of Matchless Dale, that sired the win- 
ning steer herd which the college had out two years. There is something in this double-purpose achievement. The Shorthorn is the farmer's cow.

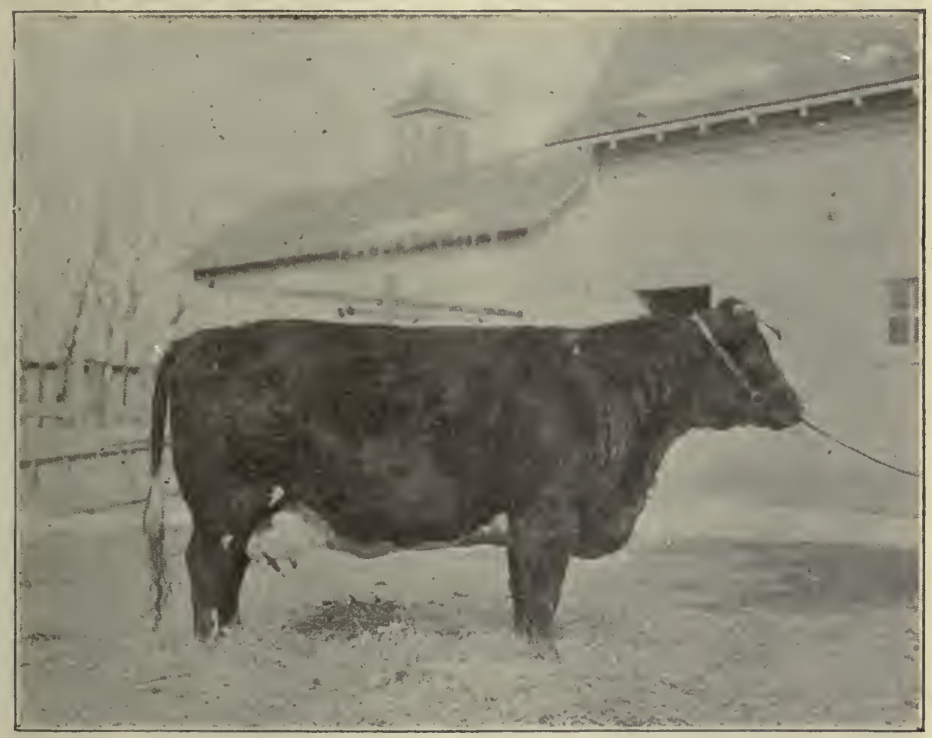

MATCHLESS QUEEN 100083

Milk record 8733.1 pounds. Owned by the Kansas Agricultural College.

At the Breeders Sale at Coffeyville, April 4, 1919, twenty Shorthorns from ten months to four years old, none of them ever in a large crowd before and many of them hardly halter broke, were led into Exposition Hall. When surrounded by an immense crowd they stood for fifteen minutes without showing any symptoms of nervousness, and in the sale of nearly 100 head not 
a single animal behaved in an unbecoming manner nor was the emergency post provided for nerrous cattle used once. No untrained and unhandled cattle of any other breed ever acted so well. Shorthorn cattle, by reason of their quiet, gentle disposition are the ideal farm cattle.

More than a century has now passed since the Shorthorn found its way from the rich valleys of England to the United States. During all this time they have been the popular cattle for the American farmer. Not only do they provide more beef than any other breed of cattle but they also furnish the family with all the milk and butter needed. After one hundred years they are firmly established, the great breed for every section of our country. Other breeds may be prime favorites in certain localities, but the Shorthorns are all right everywhere. Other breeds come and go, but the Shorthorn goes on forever. They have established themselves in the eastern part of our country where they are unrivaled producers of milk and butter. From Ohio to Kansas and from Canada to the Gulf they are firmly established and it is only in sections where they find any active competition. They have gone to the ranges of the central West and Southwest where they became the maternal ancestry of the range cattle that made Hereford popularity possible. They are now the popular beef cattle of the Pacific coast country and have 
no established rivals in that section. What is it that made all this possible? For answer, look the Shorthorn over. It is not a breed of extremes but one which combines the good qualities which

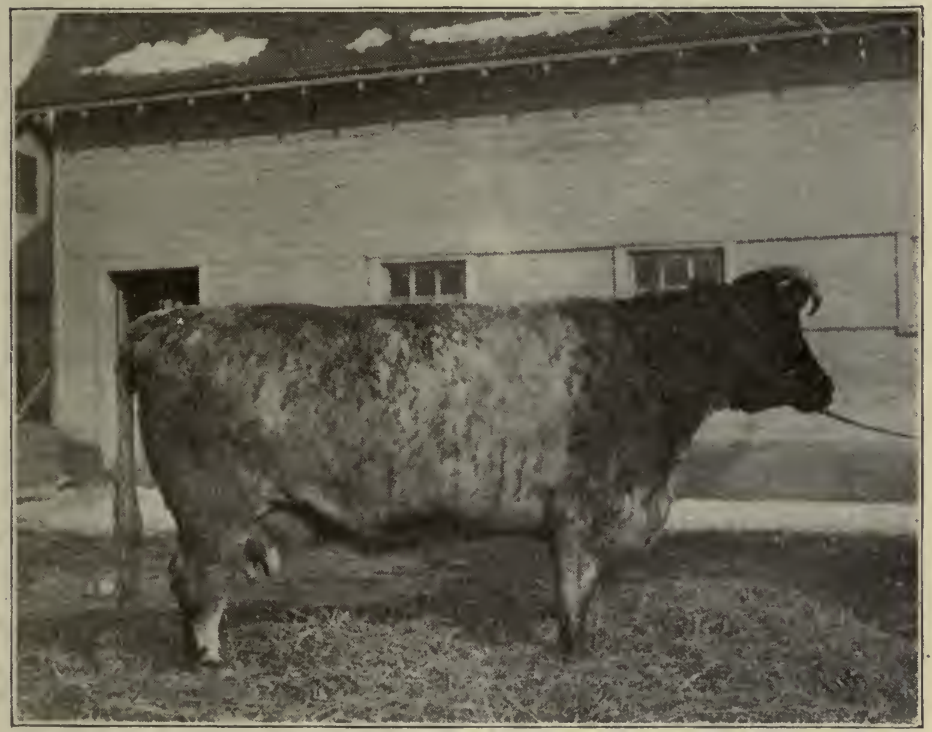

PRIDE'S BESSIE 206445

The first Scotch cow to be admitted to the advanced registry for milking Shorthorns. Milk record 9210.5 poun.ls. Owned by the Kansas Agricultural College.

are demanded by the farmer, not by the specialist; they are not the cows that do one thing only but they combine size, beef, milk, butter. They are the one and only great machine that turns the rough feeds of the farm into ready cash to the very best advantage. 
Shorthorns on The Beef Market.-It is sometimes stated that Shorthorns do not command the highest market price. This is a mistake. Good, well finished Shorthorns sell at the highest price paid. They have topped the Kansas City market for 1920 as will be seen from the following letter:

\section{Stockyards Station, Kansas City, Mo.}

$$
7|15| 20 .
$$

Mr. G. A. Laude, Secretary,

Humboldt, Kansas.

Dear Sir :

Replying to yours of the 13 th beg to say the cattle we sold for Sni-A-Bar Farms at $\$ 17$ were the top for their weight for the year. Some yearlings brought \$17.25.

The Sni-A-Bar cattle have always killed very satisfactorily and are particularly liked by the Harvey people.

$$
\begin{aligned}
& \text { Yours truly, } \\
& \text { SWIFT \& HENRY, } \\
& \text { by J. C. Swift. }
\end{aligned}
$$

A Record.-H. M. Hill, the well known breeder of Montgomery county, has during the past few years bought many Shorthorn cows of varying quality. A few years ago he castrated twenty bull calves. These calves were the poorer ones and the off-colored ones from all the cows on the farm only a few having been of Mr. Hill's breeding. They were wintered so as to maintain thrift and a good growth, and during the next summer were fed only a little grain on pasture. Toward fall the grain was increased and for the last sixty 
days they were on full feed. They were sold at an average age of but little over twenty months and brought on the Kansas City market $\$ 224.60$ each.

Another Shorthorn Achievement.-In the fall and early winter of 1918 H. O. Peck \& Son, of Wellington castrated five out of twelve bull calves, these like Mr. Hill's having been the ones undesirable for bulls. They were calved from September to December. They were given a little grain while sucking the cows during the winter, were weaned in the spring and ran on pasture the next summer. They had access to a shed and alfalfa hay and received a very small grain ration. They were on full feed a little more than sixty days and were sold at an average of sixteen months at the Peck farm for \$119.70. This sale was made on the low market last March. These cases show the value of pure bred Shorthorn cows as producers of beef cattle. Only little grain is required for this class of eattle.

Shorthorns Feed Well for Baby Beef.-W. J. Sayre of Cedar Point, Chase county, now a well known breeder of Shorthorns, was until recently a breeder of Shorthorn calves for beef. These calves were nearly all of his own breeding from high grade and pure bred cows. During a period of ten years Mr. Sayre fed annually a carload of these calves and nine years out of the ten he topped the Kansas City market on baby beeves 
for the year. An account of the one time he failed to sell at the highest price for the year is given in a letter as follows:
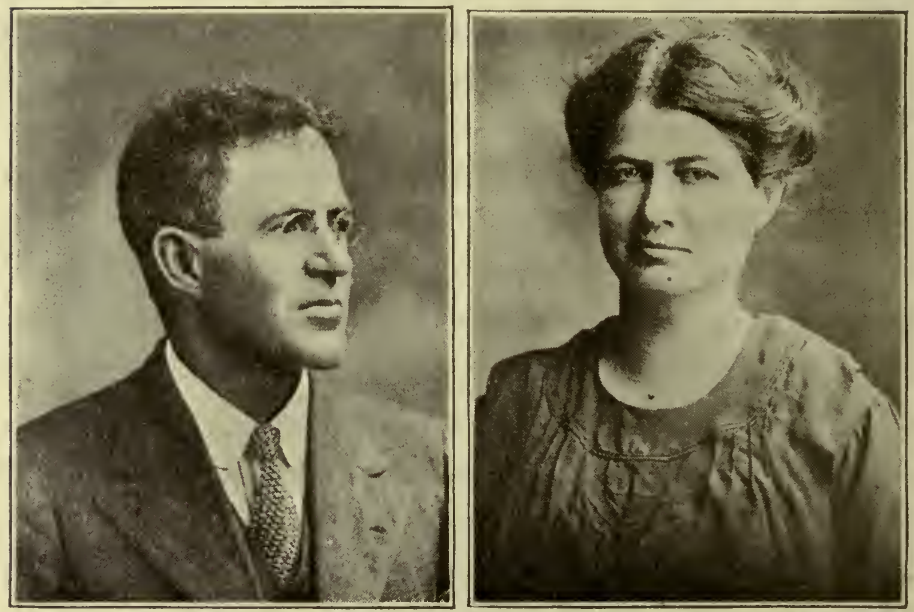

MR. AND MRS. W. J. SAYRE

Cedar Point, Kansas.

July 25, 1920.

Dear-Mr. Laude :

I think I have told you why I failed to receive the top price one year. It was because mine were too heavy. The buyers were wanting them very small that spring and some 500 pound S. M. S. heifers sold a little higher than my Shorthorns, but the Shorthorns brought many more dollars. Several times I have bought the very best Herefords I could buy and fed them with my own and at no time did any of them gain as much as the Shorthorns and only on one occasion were they good enough to sell with them.

Sincerely, W. J. SAYRE. 
Shorthorn Show Steers.-Aside from an occasional steer and a few carloads shown by individuals it has remained for the Kansas State Agricultural College to carry on the production of show steers. The great success which has attended their efforts has attracted international attention to Kansas as one of the leading states to be reckoned with at the big American shows. The steers shown by the college in recent years. were nearly all sired by the now thirteen-year-old Matchless Dale, a bull that has proved himself one of the great sires of the breed. In ordinary pasture flesh Matchless Dale weighed 2400 pounds and no one ever handled a mellower hide. His splendid disposition, wonderful quality and character have won the admiration of every breeder that has seen him. The record made by steers sired by him is remarkable. The college has shown eighteen steers sired by Matchless Dale that have been placed not lower than third at the American Royal or International Live Stock Shows. At the American Royal they won two championships, nine firsts, seven seconds and six thirds. At the International they won one championship, two reserve championships, six firsts, four seconds and three thirds.

A Notable Carlot From Kansas.-It was in about 1910 that a car load of all red yearling steers found their way to the American Royal. They came from near Lancaster in Atchison 
county and proved little less than a national sensation. Their uniformity and general excellence were remarkable and before the final contest it was admitted by all interested parties that they were the best load of steers on the ground. These calves were bred and developed by K. G. Gigstad and were the product of his Shorthorn herd, now one among the best in Kansas. As predicted immediately after their arrival, they won everything in sight including the grand championship over all breeds and they sold at the high price of the sale.

The McGregor Exhibits.-E. A: McGregor of Washington county, an extensive feeder of good cattle, sent two loads of Shorthorn steers to the 1919 International, that on the face of the returns as interpreted by most breeders and feeder's would be pronounced the most profitably produced cattle sold in the sales. The cattle in one load were bred by Symns Bros. of Troy, Kansas, the other load by Fred L. Weiss of Elizabeth, Colorado. The Kansas load was bought in January 1919 at the average weight of 752 pounds. They sold ten and a half months later weighing 1438 pounds, a gain of 686 pounds. These cattle were first in the Shorthorn Special and sold for $\$ 24.50$, dressing 63.9 per cent. The Colorado bred Shorthorns won second place in heavy competition and sold for $\$ 26.50$. They dressed 64.5 per cent. 
A HISTORY OF SHORTHORNS IN KANSAS

Mr. McGregor, while looking these cattle over, told me he had always fed Herefords and had considered them the best feeders to be had but these cattle made him feel that there were none better than good Shorthorns, as they had outdone all of his choice Angus and Herefords. 


\section{SHORTHORN REVIEW 1810-1857}

Forty-seven years before this story begins, the. first great auction sale of Shorthorns was held at Ketton, England, by Charles Colling, justly called one of the improvers of the breed. The original Duchess cow, ancestress of that tribe bought in 1783 on the Darlington Market for $\$ 65$, was dead. Thomas Bates, destined to become the leading breeder of Great Britain, bought one of her descendants. She was a little shabby in appearance but he called her the most valuable cow in the world and it is reported that he declared he would not take $\$ 5000$ for his bargain.

Here began the boom that made sane men lose their heads in the greatest era of folly known in live stock history. Bates heralded his claim for the Duchess cow and her descendants: Thomas Booth developed a class of Shorthorns that vied with those bred by Bates and for several decades the fight for supremacy was waged. The nobility lined up on the Bates side and threw victory to Bates' cattle with the Duchess tribe in the lead.

The excellent importation made by Col. Lewis Sanders in 1817 which included the Teeswater Cow, the Durham Cow and Mrs. Motte, filled parts of Kentucky and Ohio with splendid cattle. Later importations, notably the descendants of 
the one made by the Ohio Company in 1836, were used to discredit the descendants of the importation of 1817. Though not able to claim and substantiate superiority in fact, appeal was made to fads and the older importation lost popularity.

In 1840 George Vail of New York imported from Mr. Bates' herd a bull calf combining two of his most precious families. Later he bought some heifers, also. Mr. Bates died in 1849 and at the dispersion of his herd in 1850 three head were bought by Morris and Becar of New York. In 1853 Samuel Thorne bought at the sale of Earl Ducie, the man upon whom Mr. Bates' mantle seems to have fallen, three Duchess cows, and a year or two later he bought the Morris and Becar herd. He now had a monopoly of the Bates' Duchess and Oxford blood in America. Numerous importations of excellent cattle had been made prior to this time, most of them by Kentucky and Ohio breeders, and there had been little discrimination in favor of any family.

R. A. Alexander of Kentucky made his notable importation of thirty-six cows and five bulls in 1853 and in 1855 he imported Duke of Airdrie, the bull that was to revolutionize public sentiment in America by turning it toward the Bates standard. Imported Duke of Airdrie began making his influence felt at the time this story opens and when Shorthorns had become well established from the Atlantic to the Mississippi. 


\section{SHORTHORNS IN KANSAS 1857-1880}

Kansas developed its early Shorthorn interests slowly. This fact is not surprising when conditions existing at the time are considered. A few herds had been established west of the Mississippi, principally in Cooper county, Missouri, before the Civil War, but interest in the breed had assumed no proportions west of the river. It was hundreds of miles from the Shorthorn country to the Kansas border and transportation facilities were limited to the slow steaniboats plying on the rivers.

The Civil War, preceded by the border struggle, which in turn gave way to the raids of the bushwhackers, discouraged any attempt to develop the new industry; yet it was under these trying conditions that the first Shorthorn herd was brought to the country known as "The Great American Desert."

The First Herd-The American herd book, vol. 6, contains the pedigrees of fifteen cows and three bulls owned in Kansas and they are credited to S. S. Tipton, Mineral Point, Anderson county. Ten of the fifteen females were bred by the Shakers of Union Village, Ohio, two by $\mathrm{H}$. C. Alkire of Sterling, Ohio, and the other three by Mr. Tipton himself. The bulls were all bred 
by Mr. Tipton. The oldest of the three cows of Mr. Tipton's breeding is recorded as Bertha Belle, vol. 6, p. 197. She was a white, calved March 1859, and according to the herd book was the first Shorthorn bred in Kansas.

The herd proved prolific and the records show that Mr. Tipton sold many bulls and females in Anderson and adjoining counties. The first recorded bull sold was a roan, calved June 10, 1862; that went to Morgan Russell \& Co. of Lawrence. His name and number were Opothoholo 50441/2.

Mr. Tipton continued his operations with success for more than thirty years. In all this time he made no effort to follow the lead of fashion but kept on breeding the families he had originally brought to the state. He did, however, buy some good bulls. Among them was Procurator 30710, a son of Starlight out of a dam by General Grant. Mr. Tipton's cattle furnished the foundation for numerous herds in his locality, though it is doubtful whether many could be found at this time that are descended from the first Shorthorn herd in Kansas.

Interesting facts concerning Mr. Tipton were furnished by his son-in-law, S. S. Patton, now ninety-four years old and his grandson, Charles Patton who was born on the farm in 1858 and as a boy herded his grandfather's cattle.

Mr. Tipton left Stillwater, Ohio in 1855, going to Fairfield, Iowa where he lived two years, com- 
ing from there to Anderson county in June, 1857. He brought with him about fifty head of cattle, most of which were pure bred Shorthorns. The place where he located is four and one-half miles southwest of Harris and the stone house that he built still stands on a hill overlooking a tract of bottom land where at times as many as 300 head of pure bred Shorthorns grazed. The farm is now in the hands of grandsons. $\mathrm{Mr}$. Tipton bred Shorthorns until the day of his death and he always went to Kentucky or Ohio for his herd bulls. Mr. Charles Patton recalls one bull, a big white fellow that cost $\$ 700$ when cattle were cheap. With few exceptions, surplus cattle were sold privately, but on one occasion, seventy-five head of young bulls were shipped to Colorado to be sold and consignments were later made to sales in Kansas City. The elder Mr. Patton remembers that nearly all the pure bred cattle Mr. Tipton brought with him from Ohio were of light colors and many were whites. Later he began to breed for roans and finally for reds.

At the time of Mr. Tipton's death in 1889 the farm on which he had settled had increased to 720 acres, valued under the low prices then prevailing at $\$ 25,000$, a large amount for those days. The extent and value of the farm proved conclusively that his Shorthorns had been a good source of income. 
The Pioneer of Northern Kansas.-J. M. Huber came from Pleasant Plains, Illinois in 1860 to the farm near Meriden, now owned by H. E. Huber, his son, bringing with him some Shorthorns. He was not married and made his home for a time with the Leidy family living on the farm. It was here that Fremont Leidy, one of the leading breeder's of Butler county, was born and H. E. Huber was born in the same cabin later. J. M. Huber's name first appears in vol. $9 \mathrm{~A}$. H. B. as the owner of Bismarck, a roan bull bred in Illinois and calved in 1868. The first animal bred and recorded by him was calved December 2, 1870. Volume 11 contains the pedigrees of two Illinois bred cows calved in 1858 and 1860, both owned by him, from which it appears he did not record his earlier calves.

Mr. Huber later became one of the leading breeders of his section. In 1880 he won first prize of $\$ 100$ on best herd under two years at Bismarck Grove and the thirteen-year-old son, H. E., helped care for the cattle and show them. Shortly after this Mr. Huber bought a good bull and heifer of Albert Crane and some of the choice cattle found on the farm today descend from that heifer. A few years later he bought of Col. Harris the bull Golden Belt by Baron Victor out of Linwood Golden Drop. About 1890 Mr. Huber retired from business, turning over the farm and the cattle to his boys. In 1902 he passed out of an 


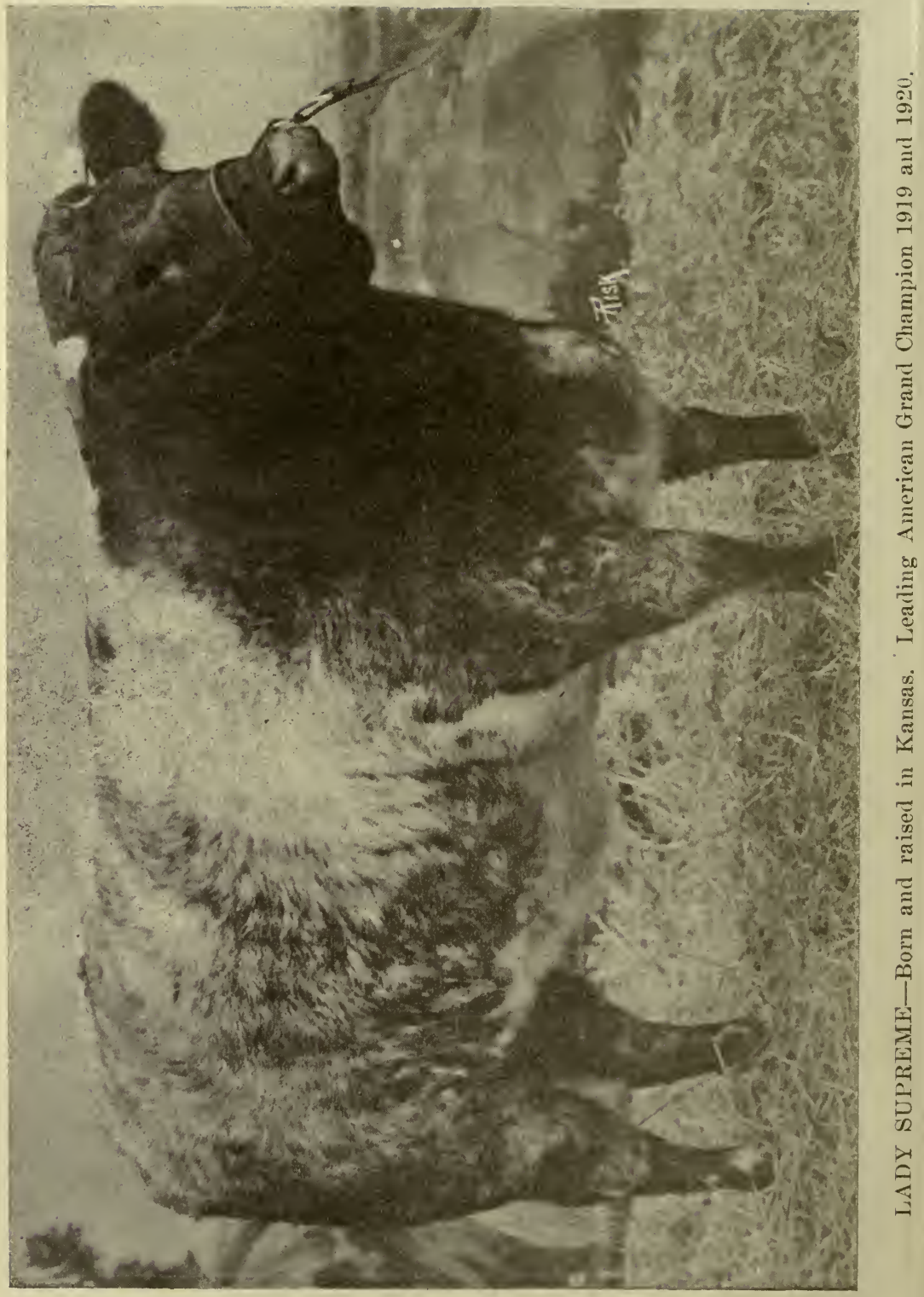


eminently useful life. Several of his sons retain Shorthor'n interests.

From Anderson County to Woodson.-Volume 6 of the American herd book in which the Tipton cattle were recorded was published in 1863 and up to that time no other Shorthorns were recorded from Kansas, but in vol. 7, published three years later, the name of Joel Moody of Belmont, Woodson county, appears as the breeder of the white bull, King of Kansas. He was by Pascova 50591/2, a Tipton bred bull and out of Queen of Kansas, a cow bred by the Shakers and purchased from Mr. Tipton, probably in 1864. Mr. Moody recorded the produce of this cow for four years and after that neither he nor his cattle appear on record.

Shorthorns Enter Shawnee County.-Volume 7 also contains the pedigrees of two bulls and nine cows owned by Alkire \& Wardell of Anderson county. Several of these were bred by them and calved in 1864 and 1865 from purchases made in Ohio and Kentucky probably early in 1863. The difficulties attending the transporting of cattle to Kansas in those critical days must have been almost insurmountable. It is not certain that these cattle were brought to Kansas before the Civil War ended in 1865, and though bred by Alkire \& Wardell and credited to Anderson county, it is quite possible that they were bred in Ohio and not recorded until after the 
change of residence to Anderson county. This herd was kept up for several years but as early as 1865 a number of the cows found their way to Shawnee county into the herd of M. J. Alkire. Indications are that the Shawnee county herd absorbed the Anderson county herd before 1868 . M. J. Alkire remained in the business for many years, consistently breeding a desirable class of cattle. His name still appears occasionally in pedigrees of Kansas and Oklahoma herds.

The First Touch of Fashion.-Up to this time the cattle brought to Kansas had been of the kind termed "plainly bred" by leaders in the business. The first attempt to conform more closely to popular blood lines of the day must be credited to John Inlow of Johnson county. It was probably in 1865 that Mr. Inlow brought in the excellent red and white bull calf, 1st Grand Duke of Kansas by the Bates bull 3d Grand Duke of Oxford, and several good cows. One of the cows was by the famous bull Gen. Grant 4825 and out of a daughter of imp. Easter Day. He also owned and used the $3 \mathrm{~d}$ Grand Duke of Oxford and while his herd did not assume large proportions, yet he produced desirable cattle and their descendants are still found in good herds. The red and white Miss Watson of his breeding was the ancestress of many of the valuable cattle sent out from the Glick herd some years later. Among Mr. Inlow's sales were the bull 1st Grand Duke 
of Kansas and several cows to N. L. Chaffee of Manhattan, a few cows to Andrew Wilson and some choice animals to George W. Greever, mention of which will be made later.

Better Cattle from Better Herds.--At the close of the sixties Andrew Wilson of Shawnee county was probably the most discriminating buyer of foundation stock in the new state. Cattle of his breeding calved as early as 1870 are on record and it was in that year, that in addition to the purchases made from John Inlow, Mr. Wilson made other memorable purchases which attracted the attention of the whole country. From the herd of James N. Brown \& Sons of Illinois, then one of the leading Shorthorn establishments in the United States, he secured a number of high class cows. Grace Young 4th and Grace Young 5 th, two cows of national reputation as prize winners, sired by Tycoon, one of the greatest bulls of his day, were added to the herd. Minister, for several years the leading show bull of the West, was bought at W. R. Duncan's sale for $\$ 1760$. Mr. Wilson now had eattle from which a fortune could have been made, but for some reason he soon gave up the business. On August 20, 1873 Grace Young 4th and Grace Young 5th, the plums of the herd, were sold in a public sale at Silver Lake, to the Kansas State Agricultural College for $\$ 800$ and $\$ 1080$, and later at the college they produced a family of excellent cattle, 
the descendants of which can still be found in Kansas herds. Although Mr. Wilson's period of active operation was short, he had brought a class of stock to the new state, not seen prior to that date and it would be unfair to measure the value of his service by the brief time he was engaged in breeding.

George W. Greever.-At the time John Inlow was selling his cattle, George W. Greever of Wyandotte county bought the cow Prairie Flower by 1st Grand Duke of Kansas. From this cow he raised three heifers, two by the fine sire Basil Duke and one by Master of Ravenswood. The small but choice herd was sold to C. B. Norris of Geneva in 1878. The bull Basil Duke 4th by Basil Duke was included in the sale.

John F. Piper.-In 1860 John F. Piper, then a resident of Kentucky, bought the imported cow Hasty, bred by Mr. Burnett and imported by The Mason \& Bracken Company. From her he raised three heifers calved in 1861, 1862 and 1864, named Spot, Humpback and Violet. Mr. Piper came to Labette county, Kansas late in the sixties bringing with him numerous descendants of imp. Hasty, none of which were recorded, and it was not until 1879 that the pedigree of the imported cow and eleven of her daughters and granddaughters were placed on record. How many cattle from this herd were sold in these years at less than their value if recorded, can only be 
guessed. Members of the Piper family and several other persons living in Labette county produced small herds of Shorthorns during the eighties from this lot of cattle, and a number of herds in that section are descended from the Piper heifers.

Wabaunsee County's First Herd.-L. A. Knapp came from La Salle county, Illinois, settling on a farm in Wabaunsee county a few miles northwest of Dover, in 1870. He brought with him a good knowledge of Shorthorns, plenty of enthusiasm, a good bull and two cows. One of these cows, Bluebird 2d, has descendants in several Kansas herds. A little more than a year later he formed a partnership with George W. Glick and transferred his energies to Shannon Hill where he remained until 1876 or 1877 when he returned to his Wabaunsee county farm with quite a number of good cattle from the Glick herd which came to him through the partnership. As L. A. Knapp of Dover, he became one of the well known breeders of the state, producing many creditable specimens of the breed. Some of these in other hands went to build good herds. The farm upon which Mr. Knapp settled is now owned and occupied by his son, E. L. Knapp, who is raising Shorthorns, some of which are descended in the female line from the cows brought from Illinois in 1870.

James O'Neal \& Son.-Mr. O'Neal had been 
breeding Shorthorns in Canada and moved to Jefferson county, Kansas about 1870 bringing with him some of his cattle. The early produce of the herd was sold as far west as Manhattan. He later made purchases from Albert Crane including the Alexander bred Gwynne Duke of Woodburn by 26th Duke of Airdrie, and Loudon Duke 13th by 5th Duke of Geneva, indicating his appreciation of quality in bulls. Only a few females were bought. His work was continued in the eighties but was practically local in character.

Shorthorns Reach Greenwood County.-Hart Bros. were breeders of Shorthorns in Waukesha county, Wisconsin, in the sixties. In 1870 or 1871 they came to Greenwood county bringing with them the bull Imperial Hendon and the cows Roan Duchess 5th, Delphena, and Royal Duchess 5th, all from the herd of John P. Roe of Waukesha. These cows proved prolific and a large herd was built from them in ten years. The herd of C. L. Hart of Eureka was descended from these cows.

A Brown County Pioneer.-G. Y. Johnson of Brown county, soldier of the Civil War, big in stature and character, began breeding Shorthorns in 1870. His start was made with the socalled Bates crossed standard families of that time and he was more regular and systematic in recording the produce than any other early Kan- 
sas breeder. When the Cruickshank cattle came in, he bought an imported Scotch bull but soon sold him and bought another named Lavender

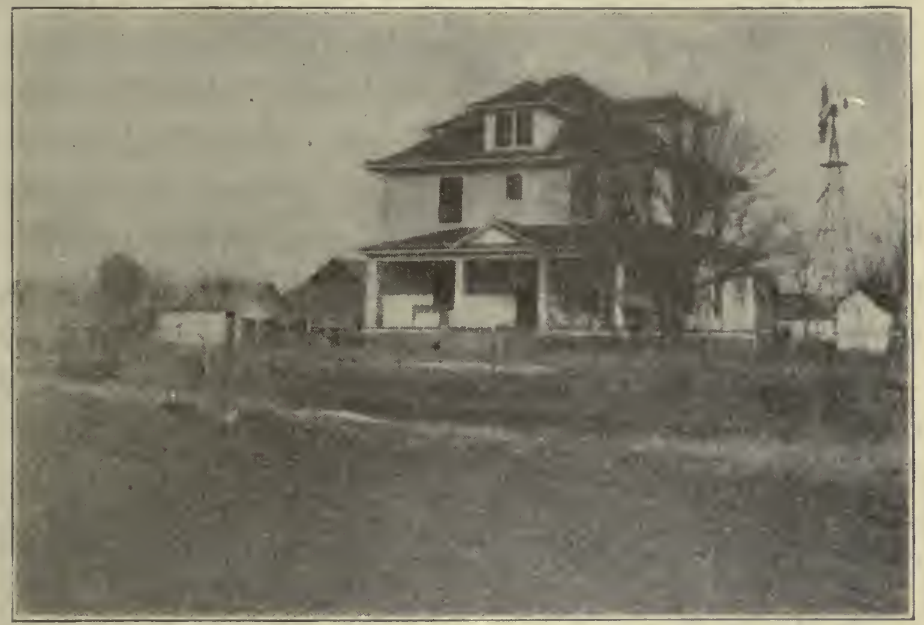

RESIDENCE OF T. J. SANDS, ROBINSON

Mr. Sands laid the foundation for prosperity at Mr. Johnson's dispersion sale.

Lad. Later he bought imp. Nonpareil 35th by Kintore Hero. From this cow he raised a bull, Nonpareil Lad, used in the herd until the time of his sale about 1900. Mr. Johnson sold many good bulls in his part of the state and he always sold to the man who wanted one on eredit. "I always thought," he said, "that a man who was ambitious enough to own a good bull couldn't be far wrong.',

A Period of Expansion.-The year 1870 saw 
Shorthorns well established, but not numerous in the state. This date may be safely fixed, however, as the beginning of a period of expansinn. A number of herds destined to more than local prominence were founded, but probably no other was so widely known and carried on under more broad-minded management than the one owned by Albert Crane of Chicago, on his immense tract of land in Marion county and called by that generation and later generations, The Durham Park Herd.

The Durham Park Herd.-The first purchases for this herd, abont fifty females, were what is generally known as nicely bred stock, so popular in Kentucky and Illinois at that time. Mr. Crane showed but little inclination to indulge in the pure Bates speculation, having bought only one cow, Oxford Myrtle, of that strain. Included among his early purchases was the bull Loudon Duke 13th by 5th Duke of Geneva. This was one of E. G. Bedford's famous Loudon Duchess family. Of J. M. Woodruff of Indiana, he bought $2 d$ Duke of Jubilee. Both these bulls were strongly bred along Bates lines.

Although these purchases had been made from some of the best herds in the country, most of them were not from the herds that had the greatest prestige. Mr. Crane was not satisfied. He began operations on a scale attracting general attention. The $23 \mathrm{~d}$ Duke of Airdrie and the 
imported Booth cow Joan of Arc, were bought at long prices. Of M. H. Cochrane he bought the imported Booth bull Lord Abraham by the great Breastplate; and of Chas. E. Coffin, the bull Lord Abraham 2d by Lord Abraham and out of imp. Maiden. In 1875 he bought the Bates bull, Lord Bates $2 \mathrm{~d}$ by the exported 24th Duke of Airdrie, of A. J. Alexander. From F. W. Beldon he secured the Cochran bred Lord of the Lake. Mr. Crane was now well supplied with herd bulls of both Bates and Booth blood lines.

In this time nearly fifty females from some of the best herds in Great Britain and the United State had been bought. Mr. Crane's own importation which left Liverpool October 14, 1875, consisted of six Bates cows and the Torr bred Telluaria Wassail, illustrated in vol. 16. Of this importation, the cow Lady Mary 6th gave birth to the white bull Panic, and Telluaria Wassail to the roan, Knight of the Crescent, thus adding to Mr. Crane's long list of excellent bulls, an imported Bates and an imported Booth bull.

Shortly after this Mr. Crane bought two more bulls, the imported Booth bull Royal Deerham from Simon Beattie and imp. Royal Lancaster, illustrated in vol. 16, from John Hope. Imported Royal Lancaster was of the Cambridge Rose tribe, of the same origin as the Rose of Sharons. Among the cows purchased were imp. Regal Star 
(Booth) and the Bates cows, imp. Kirklevington 15th illustrated in vol. 16, and the Canada bred Duchess of York 9th. Airdrie Duchess 2d and Airdrie Duchess 3d were bought of Mr. Alexander for $\$ 21,000$ and $\$ 23,600$ and a long price was paid for 28th Duke of Airdrie. In $1878 \mathrm{Mr}$. Crane exported a lot of Shorthorns to England. Among them was the 27th Duke of Airdrie. The Durham Park herd comprised a wonderful collection of Shorthorns, carrying as values then rated, the highest priced blood lines in the world. No such toleration as Mr. Crane's had been shown for the several rival strains of blood since R. A. Alexander had founded the great herd at Woodburn.

The Shannon Hill Herd.-While Albert Crane was busy collecting some of the breed's choicest specimens for the great Durham Park herd he had established in the comparatively new part of the state, a quiet, conservative man of Atchison county was carrying on operations in the older settled portion. George W. Glick began his work well, not by following the dictates of fashion, but by buying a few good cows and a good bull. It was in about 1870 that the original purchases were made and like Mr. Crane's first selections, they did not indicate partiality for any particular strain. They were, however, of what was then considered good standard breeding. In $1872 \mathrm{Mr}$. Glick added by purchase in 
Kentucky, a bull and two heifers and maintained the conservative course of selling the bulls at fair prices and retaining the females. It was in about 1872 that a partnership was formed with L. A. Knapp, a breeder of Wabaunsee county and Mr. Knapp moved to Atchison county to take charge of the herd. The firm name was Glick \& Knapp. When Mr. Knapp returned to his own farm, Mr. Glick became associated with a Mr. Carmichael for a short time. He always had the assistance of his son, Fred, who owned an interest in the herd and had quite a number of the cattle recorded in his name.

It will be recalled that during the seventies the Bates Shorthorns were the popular ones and the big prices paid for even inferior individuals descended in the female line from cattle bred by Thos. Bates were used by the entire speculative element of the Shorthorn fraternity to boom their own interests. In vain it was pointed out that practically all the Shorthorns of the country were so full of Bates blood that they were virtually Bates cattle. Hitherto no Kansas breeder had heeded the call of the "purist", but about 1879, Mr. Glick changed his course. He owned through an exchange, the Princess (Bates) bull, Claud Weatherby and he decided to purchase some females whose breeding would be within clearly recognized pure Bates lines. In May of that year he bought of W. S. Slater of Massachu- 
setts the bull calf that won considerable fame as Duke of Shannon Hill and a heifer calf, Lady Sale of Atchison. He also bought 10th Lady Sale of Brattleboro, 15th Lady Sale of Brattleboro, Queen of the East by 22d Duke of Airdrie and Zora by 15th Duke of Airdrie. To his credit it must be said that he did not condemn all Shorthorns of mixed breeding as unworthy and he retained many of his older cattle, but he nevertheless became a leader of Bates forces in the West at the inopportune time that the "plain bred" Cruickshank cattle from Scotland were making the fight for supremacy and winning.

Elected governor in 1882, G. W. Glick's name became a household word in Kansas and elsewhere. His love for his favorite Bates cattle was so firmly rooted that, unlike most other leading breeders, he did not fall in with the trend of the times, but kept on breeding from his females and put the 53d Duke of Airdrie, an excellent Bates bull, in service. That Mr. Glick built up a good herd is admitted, but that he could have done much better had he fallen in line with other leading breeders, using the Cruickshank bulls even if not the females, is also quite evident. Had he used his wonderful personality in cooperation with such a man as Col. Harris, his achievements would have been far greater. All Gov. Glick's effort to stem the tide was wasted. The hour had come when merit, though stigma- 
tized as plainly bred, won, and the aristocracy of the breed went down to defeat. On November 17, $1889 \mathrm{Mr}$. Glick sold the entire herd including the much advertised Shannon Hill farm to Dawdy \& Company of Illinois, who sold the ninetyone Bates cattle at auction at the old horse barn in Kansas City, April 11 and 12, 1890. The average price was $\$ 225$. W. R. Nelson, owner and editor of The Kansas City Star and founder of the Sni-A-Bar farm, bought fifteen of these cattle including 53d Duke of Airdrie.

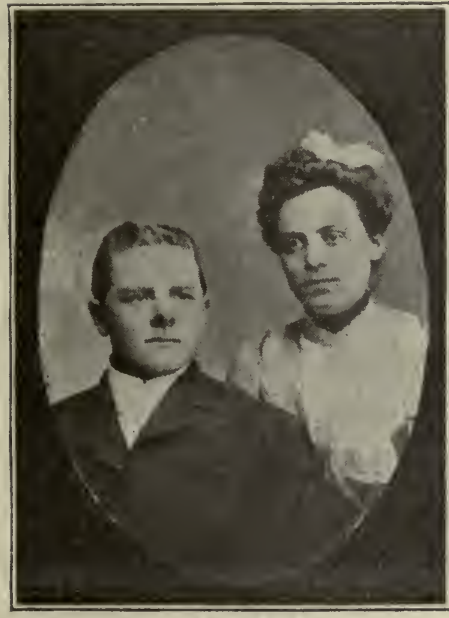

MR. AND MRS.A.A.TENNYSON Lamar

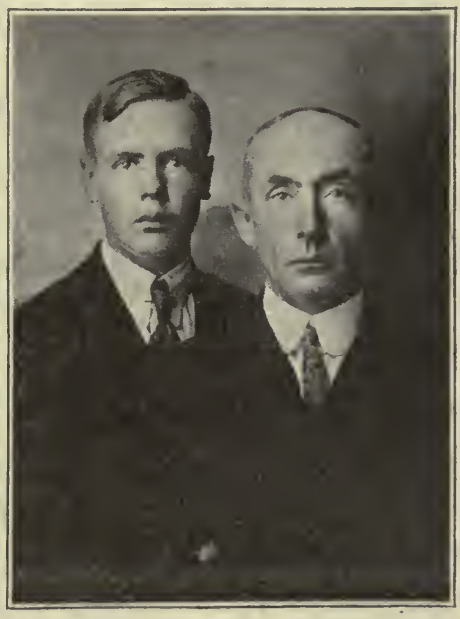

MILTON POLAND \& SON Sabetha

An Early Herd in Nemaha County.-The herd of W. S. White of Sabetha was established in 1872 by the purchase of females from Kentucky, 
Illinois and Missouri breeders, and of two bulls from J. H. Spears \& Son of Illinois. Occasional purchases were made later and the heifers were nearly all retained for several years. Measured by numbers this grew to be one of the state's leading herds but the proprietor made little effort to keep up with the procession until the hard times of the eighties rendered all efforts of no avail.

Late in 1883 or early in $1884 \mathrm{Mr}$. White bought three cows of Mr. Spears. He also bought a daughter of imp. Duke of Hazelcote 19th from S. C. Duncan, and a daughter of Loudon Duke 6 th from J. G. Cowan \& Son. The same year females were added to the herd from the Illinois herds of Wm. Stevenson \& Sons and E. M. Golf. Liberal use had been made of the bull Cherub $2 d$ 16470 , a son of the $\$ 6000$ imp. Cherub and imp. Lady Highthorne. Cato 25866, a Kentucky bred bull of only ordinary descent, was also used freely. Mr. White next began using Mazurka Duke 52758, a fashionably bred Bates bull from Bow Park by the celebrated 4th Duke of Clarence; Royal Duke of Oakland, a bull of his own breeding, by Cherub 2d; and Emperor 62667, a Kentucky bred son of $2 d$ Duke of Xalapa. In 1887 he secured from the Luther Adams importation the Duthie bred Lord Haddow and began using him at once. At the time Lord Haddov was bought, good cows weighing from 1000 to 
1200 pounds could hardly be sold for as much as $\$ 15$ a head. Many changed hands at less. $\mathrm{Had}$ it not been for this condition Mr. White might have been able to overcome the losses he had sustained by sticking to the lost hope of Bates supremacy, and to retrieve his fortune. As it was, like many others, he failed to realize on his investments. The last cattle of his breeding were calved in 1890 .

Mr. White was a man of pleasing personality. He was president of the short-lived Kansas State Shorthorn Breeder's Association, an organization that like many of its members, suspended operations in about 1888.

Leavenworth's First Importation.-In 1872 Crespigny \& Seiver imported from England the roan bull Duke of Hazelcote 19th bred by Col. Kingscote, the roan cow Listless and the red cow Likely, both bred by Thomas Morris of Mausamore Court. Both cows were carrying calves at the time of their importation. Listless produced a red bull calf Lord Lytton 17575 and Likely, a roan heifer named Lovely, vol. 13-743. These calves were sold to Matthew Ryan of Leavenworth. Duke of Hazelcote 19th and the two cows went to S. C. Duncan, the well known breeder in Clay county, Missouri. Mr. Ryan recorded no produce from his purchase until 1881 when a large number of ealves and yearlings went on record as bred by him. They were nearly all 
sired by Lord Lytton, but only one, a daughter of imp. Lovely, was descended on the maternal side from this importation.

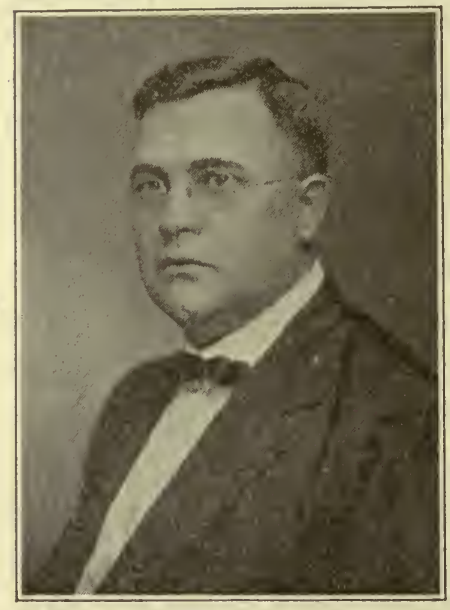

I. N. CHAPMAN

County Agent, Leavenworth

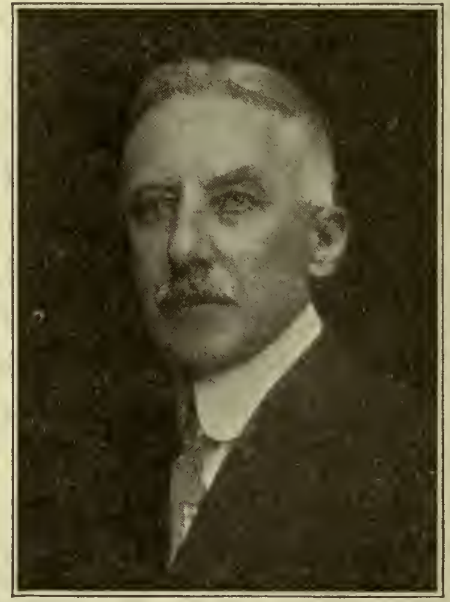

OTTO H. WULFEKUHLER Banker, Leavenworth

These men have started more than 40 new Shorthorn breeders in Leavenworth county since January 1919.

Victoria Colony Shorthorns.-George Grant, of poor Scotch parentage, found his way to London where he worked in a store, later engaging in merchandizing on his own account. He was a born promoter and organizer. He is reputed to have run a corner on erepe when the prince consort died and on silk during the Paris Exposition. He was considered a plunger with a shrewd head. When he came to Kansas he saw his opportunity. He agreed with the Kansas Pacific Railroad 
company to sell a lot of land and settle it. The result of this project was the far-famed Victoria Colony, established in Ellis county on the border line of civilization in 1872 and settled by the aristocracy of Great Britain. According to best information, members of the colony were high livers. Most of them were on remittances from home sent by parents who hardly knew what else to do with their sons. Grant himself is said to have been fond of women and whiskey and to have been a poor sort of guardian for wealthy gentry. However that may be, no one can question his nerve, for he brought to this then desolate country a lot of high priced Shorthorns and planted them among the most unfavorable conditions.

In November $1871 \mathrm{Mr}$. Grant imported from England the roan six-month-old bull calf Lord of the Manor; the white seven-month-old heifer Fairy Verulam, and the red yearling heifer Niobe 8th. In 1872 he imported the bull Goggles 17193 and later the roan cow Dimples, purchased from Queen Victoria's herd. In 1876 he resumed importation having purchased from the Queen's herd seven heifers and the bull Royal George 27797. The lot consisted of Cold Cream 10th and Countess $2 \mathrm{~d}$, two years old, that produced bull calves shortly after importation, named Royal Windsor and Manrico 2d; Rosa and Minette, two years old; and Roseleaf, Matilda and Peer- 
less, yearlings. The importation also included a bull, Royal Duke, bred by Dr. Armstrong. Mr. Grant sold the bull calf Manrico $2 \mathrm{~d}$ to Thomas R. Clark who was living in New York City and was associated with the Victoria Colony. Within a year or two after the importation, Mr. Clark had secured most of the eattle. From the service of imp. Goggles, imp. Niobe 8th had produced a heifer called Ida that was sold at four years old with calf at foot to Archibald Kerr of Eureka. It should be mentioned that the first importation was kept for a time in Clay county.

Mr. Grant died in April 1878 and lies buried near a little Episcopalian church which he himself had built with funds he had collected. His will, which it is said provided for the disposal of millions, was a farce, as but little money or other property was left when he died.

Thos. R. Clark who was a member of the firm of Fiske, Clark \& Flagg, Gents' Furnishing Goods, New York City, subscribed to Grant's Victoria Colony and is said to have been the one man who came out ahead. He bought most of the cattle of the Grant importation and also a lot of fashionably bred Bates cows of the B. B. Groom assignees at the time when Bates was giving way to Scotch. The ranch was kept stocked, but whether with descendants of the Grant importation, is uncertain. After Clark's death some ten or fifteen years ago, the land and 
cattle were sold to the late Conrad Kreuger who for years had been one of his employees.

In 1877 John Bowman of the Victoria Colony imported from the herd of R. Jefferson, England, the red and white cow Proud Butterfly, in calf to British Boy (30597). The produce was a heifer recorded as Pearl Butterfly. Bred again to the Crane bull, Lord of the Lake (see Crane sketch) she produced the bull Royal Moresby. Mr. Bowman had also bought of Albert Crane Cinderella 17th, that with her daughter Second Cinderella of Moresby, was sold to T. J. McClelland of Haynesville, Missouri.

A Good Foundation.-Archibald Kerr laid the foundation for his Greenwood county herd in about 1876. Mr. Kerr was an Englishman who maintained a large establishment and spent money extravagantly. Though not a member of the Victoria Colony his business and social relations brought him in close contact with its members. Among other Shorthorns purchased from George Grant of the colony were imp. Niobe 8th and her heifer calf by imp. Goggles. He also purchased from Albert Crane a bull, Lord Hamlet 33072, a combination of Bates and Booth blood he having been by Lord Bates 30th and out of Miss Wiley $2 d$ by Star of the Realm. From W. T. Benson of Canada he secured the cow Daisy Eyebright vol. 12 and her heifer calf Josephine by imp. Tambour came from John Snell's Sons of On- 
tario. Mr. Kerr also purchased the entire herd of G. Van Horn who had been breeding Shorthorns in Montgomery county, later locating on a section of land lying fifteen miles northwest of Yates Center which to this time is known as the Van Horn Ranch.

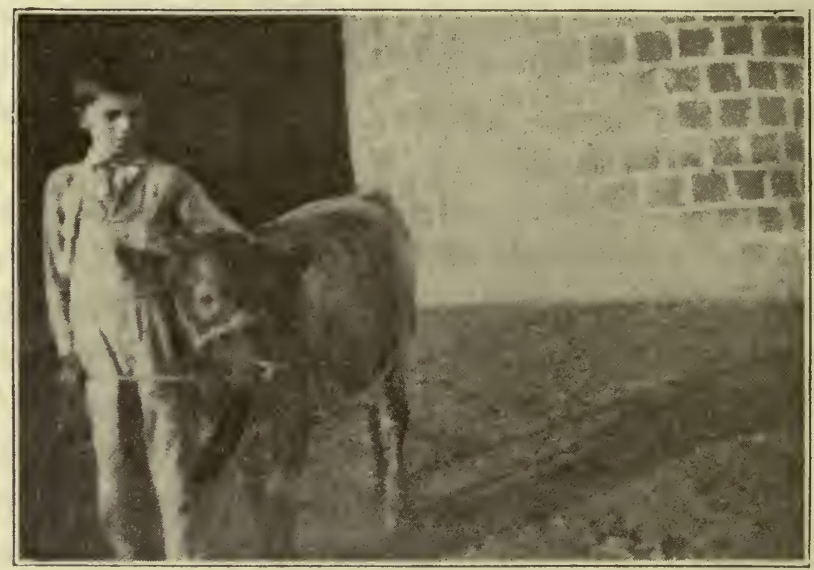

A 'SHORTHORN BOY AND A SHORTHORN CALF

A foundation for good eitizenship and prosperity.-Courtesy of R. C. Watson \& Sons, Altoona.

Shorthorns Go With Berkshires-A. W. Rollins of Riley county was better known as a breeder of prize winning Berkshire hogs than as a breeder of Shorthorns. His herd of cattle, while not large, was carefully selected and represented the more popular blood lines of the day. His surplus found ready sale among farmers and local breeders and he occasionally added choice ani- 
mals to the herd which he owned from about 1874 until late in the eighties.

First Shorthorns for Barton County.-In about 1875 or 1876 Matthew Toews settled near Ellinwood coming from Omro, Wisconsin. He had been breeding in that state and brought a small herd to his new home.

T. M. Marcy.-Mr. Marcy had been breeding Shorthorns in Ohio, from which state he came to Kansas in about 1877 locating in Shawnee county. He secured three bulls from R. S. Streater of Cleveland, Ohio. They were Breadalbane $2 \mathrm{~d}$ 31887, a roan by the Torr bred Booth bull, imp. Breadalbane and out of imp. Golden Symp, vol. 15; Henry 3d, a roan also by imp. Breadalbane out of Calm 15th, vol. 8; and imp. St. Albans, a calf out of imp. Golden Symp by the Booth bull, Athelstane. These bulls were all used to some extent, though St. Albans was used more heavily than the others in the early period of the herd's existence. Breadalbane $2 d$ was used most on the heifers sired by St. Albans. While other bulls saw service in the herd, only one, Commodore 59188, was the sire of many of the young cattle produced in the middle and latter eighties.

Commodore was bred by Col. Harris and was calved at the very time that Baron Victor reached Linwood. He represented the Kentucky line of breeding made popular in the West by the 
Hamiltons. The M. H. Lyons herd, one of the first, if not the very first established in Oklahoma, was founded by the purchase of ten young cows and heifers from Marcy \& Son in 1891. These cows were nearly all by Commodore and were among the last of the larger lots bred and sold from the farm. The surplus produce of the fifteen or more years found a ready sale locally and a number of sales were made in Iowa and Nebraska. The herd was a creditable one and had Mr. Marcy taken advantage of conditions by buying a top bull at Linwood in 1883 or 1884 , he would doubtless have profited largely from the cross with his good strong femailes.

A Student of Type and Pedigrees.-A herd that was founded in the seventies and maintained for nearly forty years was that of Andrew Pringle of Wabaunsee county. Mr. Pringle's strongest point was that he was a stickler for good bulls. His early purchases of females were made from local breeders and later when the Scotch cattle came in he bought Scotch and Scotch topped cows of merit from such herds as those of Col. Harris and B. O. Cowan. Collegian, a son of the great cow, Grace Young 5th by Tycoon, Jas. N. Brown's noted show bull and sire, was one of the first bulls used. When Col. Harris made his start with Cruickshank cattle $\mathrm{Mr}$. Pringle recognized their value and as long as the Linwood herd existed he made annual or semi- 
annual visits of a day or two days, studying and learning. In this way he acquired not only a correct idea of modern Shorthorn type and character, but also a broad knowledge of pedigrees. He obtained his herd bulls from the Linwood herd as long as he could and later bought from J. G. Robbins \& Son, John Dryden of Canada, F. W. Ayers of Illinois and Carpenter \& Ross. Few herds in Kansas were owned by men who more consistently than Mr. Pringle bought high class sires. The bulls produced in the herd nearly all went to the western trade and other bulls from the locality adjacent to Mr. Pringle's farm went with them. Most of the females were retained until the herd, at its best, numbered more than one hundred head. After this they were sold to breeders or used in founding new herds. Six or seven years ago the entire herd including the Avondale herd bull, Maxwalton Rosedale, was sold to Tomson Bros. who retained some of the most desirable specimens.

G. W. K. Bailey \& Sons.-Late in the seventies these men came from Pike county, Missouri to Kansas, locating on a splendid tract of land at the head of Fall River, fifteen miles northwest of Eureka. During the eighties they bred a large herd of good, useful cattle which were an important factor in local live stock improvement.

W. E. W. Bailey, the oldest son of the family, also owned a good herd. Both herds went the 
way of so many other Shorthorns during the trying times of 1884 to 1897 ; but as this is being written I am in receipt of a letter from Mr. Bailey stating that he wants to buy a few good Shorthorns. This goes to show that good cattle of the breed have a lasting influence over a man and that when he has once formed the habit, he will revert to his old love after many years. Mr. Bailey is probably past sixty and lives at Utopia in Greenwood county. He will be successful with his cattle when he buys them.

C. B. Norris.-In about 1877 C. B. Norris of Allen county purchased a few females closely descended from John Inlow's Prairie Flower by 1st Duke of Kansas. He also secured the bull

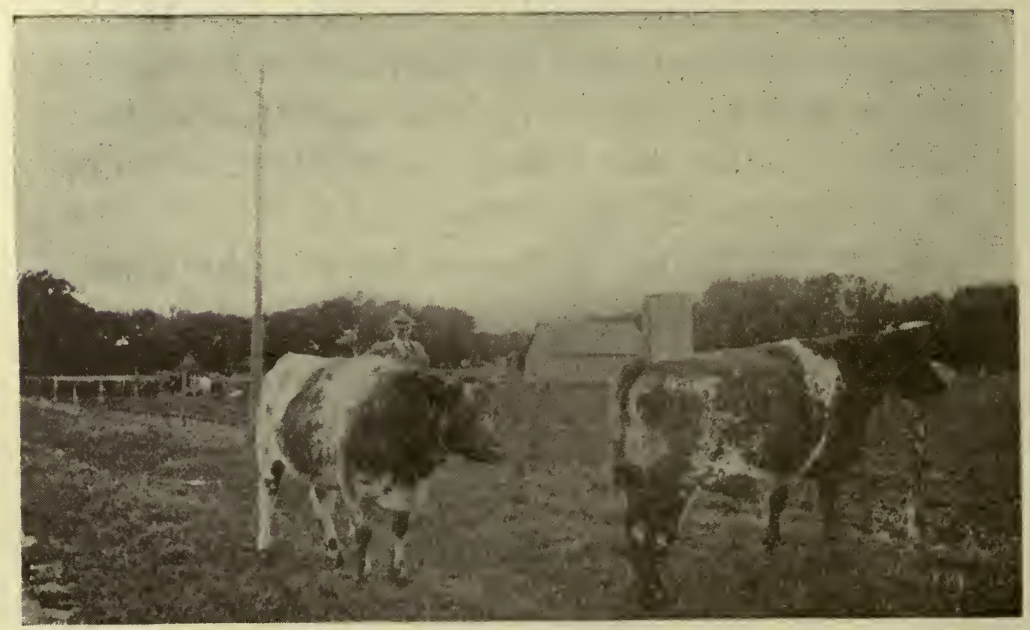

GOOD FOUNDATION STOCK USED BY E. S. DALE, PROTECTION 
Basil Duke 4th, a son of Basil Duke 6434, a bull of wide reputation in Henry Laramore's Calloway county, Missouri, herd. Two of the cows were by Basil Duke. In 1880 these cows were sold to W. B. Woodside of Rose and at Mr. Woodside's dispersion sale in 1893 a four-yearold daughter of one of the cows was sold to Samuel Kahl of Buffalo, at the high price of $\$ 50$. Mr. Kahl bred some excellent cattle from this cow and the good herd of F. A. Dumond of Yates Center comes from the Kahl cows.

Towne \& Boomer.-This Brown county firm began breeding Shorthorns about 1877 . They owned, among others, the imported cow Charlotte 4th by Duke of Knowlmere and a lot of cows sired by the Princess bull, Claud Wetherby, purchased about 1878 by G. W. Glick. (See Glick sketch). It is quite likely that Claud Wetherby was received by $\mathrm{Mr}$. Glick in exchange for the bull Gustavus 17276, which bull Towne \& Boomer began using at the same time that Mr. Glick began using Claud Wetherby. The herd did not assume more than local proportions and while consisting of splendid cattle, was like so many others lost in the change from Bates to Scotch in the desperately trying times of the middle and latter eighties.

A Wide Range of Purchase.-Late in $1875 \mathrm{H}$. A. Stratton of Lyon county bought the bull Prince, 27484 bred by A. C. Funk of Illinois. 
Within twelve months from that time he secured a number of cows from Albert Crane, W. W. Tipton of Coffey county, Childs \& Sweet of Illinois, H. H. Hankins of Ohio and T. H. Brettel of Canada. The herd was maintained for a good many years and was prolific. Mr. Stratton lived in that part of Kansas where farmers early learned the value of improved stock and his surplus was readily disposed of locally.

An Early Rice County Herd.-Avery Bros. and R. H. Avery of Rice county worked together, Avery Bros. later having possession of the R. $\mathrm{H}$. Avery herd. R. H. Avery had been a Shorthorn breeder at Galesburg, Illinois and came to Kansas late in 1877 or early in 1878 bringing some Shorthorns with him. In addition to the purchase of the R. H. Avery herd, Avery Bros. bought stock from Albert Crane and from other Kansas breeders, some of which represented popular blood lines. In 1882 quite a number of the cattle went to George Avery Jr., of Sterling.

Joseph E. Guild.-Joseph E. Guild of Silver Lake, Shawnee county, a prominent farmer of his section, purchased in 1879 the red bull Baron Adelaide 34427, the red cows, Lady Leonard 2d and Lady Leonard $3 d$, both by the famous sire and show bull, Oakland Favorite, and the red, Lady Cundiff, of Dr. W. H. Cundiff, Pleasant Hill, Missouri. These cattle represented the Leonard Flora family, then one of the best in the 
West. The Guild herd while not large was quite favorably known for a good many years, but probably few if any Shorthorns descended from Mr. Guild's breeding could now be found.

First Shorthorns in Northwest Kansas.Simpson Flinn's were the first Shorthorns for the extreme northwest part of Kansas. The herd consisted of two bulls and three heifers recorded as calved in 1880 . He also recorded a cow bred by D. M. Flinn of Iowa, from which it is inferred that Simpson Flinn of Rawlins county was of the well known Iowa family of that name.

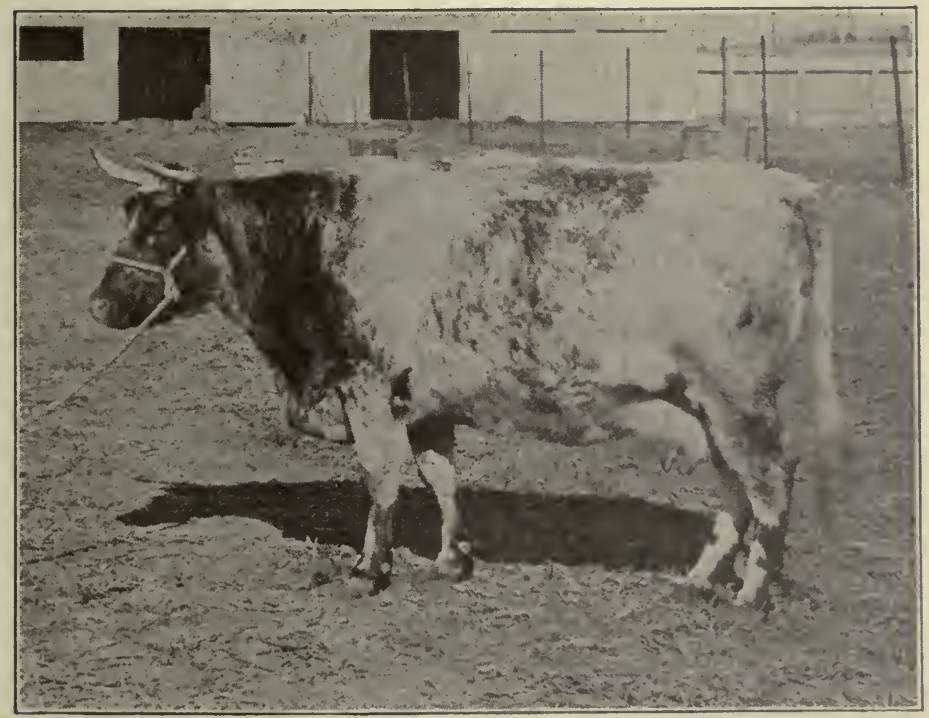

GWENDOLINE 79th 217427

With a record of 5796.1 pounds of milk as a two-year-old. Owned by the Kansas Agricultural College. 
Breeding for Milk Production.-Swain Bros. \& Bates of Lawrence bought a choicely bred lot of cattle, including the bulls Earl of Athol 32485 and Grand Juror 32769. This was about 1878. Earl of Athol was out of Maid of Athol, a cow that gave 12875 pounds of milk, making 513 pounds of butter in a year. Her greatest ten day yield was 581 pounds of milk and 211/4 pounds of butter. Grand Juror, bred by Albert Crane, was by Lord Bates $2 \mathrm{~d}$. The cows were from the herds of John Inlow, Avery \& Murphy and the well known William Miller herd in Canada.

Col. Harris and a Mr. Swain, probably the same person mentioned above, were associated and a few animals were recorded as owned jointly by them. Several of Col. Harris' early purchases came from R. D. Swain.

A Breeder in the Making.-Col. W. A. Harris of Linwood did not differ from other breeders except in two respects. He held positive convictions and he had the courage to assert and uphold the correctness of his views against the whole world if necessary. His first Shorthorn purchase is recorded in vol. 18, published in April 1879, where it is stated that on February 20th of that year he bought of Dr. Cundiffe, Prince Leonard 5th, the unfashionably colored red and white bull. It was probably about the same time that he showed his disregard of fashion by buying a roan cow for roan was a color 
which then had no place in most Shorthorn herds. 'There was nothing in the record of W. A. Harris prior to 1880 which would lead one to suspect that America's greatest breeder was making his start.

Minor Shorthorn Operations.-The herds mentioned thus far all assumed considerable prominence and were a strong factor in building up Shorthorn interests in Kansas. There were many small breeders scattered over the state prior to 1880 of whom it is possible to give only limited information. Most of these men did not handle Shorthorns a great length of time nor did their work have any influence on present day herds.

In 1872 Robert Cook of Allen county bought four females from Ohio breeders. He continued his work for nine years producing cattle of fair quality which were sold locally.

S. L. Shotwell of ElDorado bought a bull and seven cows of M. B. Robertson, Sonora, Ohio in 1879. Three of the cows produced heifer calves shortly after reaching Kansas and by $1880 \mathrm{Mr}$. Shotwell had a good little herd. No record of later operations appears.

Two herds of national reputation, those of $\mathrm{J}$. P. Sanborn of Michigan and William Miller of Canada, furnished the foundation for a herd in Dickinson county. The cattle were owned a few years by G. E. Hunton and included the imported cow Young Bracelet from which he raised three heifers that were retained. 
In about 1877 W. S. Burkham of Douglas county bought from Pickrell \& Kissinger and from the Bow Park herd in Canada a few cows of very choice ancestry. But little record of his work appears later and this splendid foundation which might have been crossed with Cruickshank bulls and made one of the outstanding herds of the state seems to have been lost to the breed.

In March 1877 J. E. Woodford of Burlington bought of the estate of W. W. Tipton of Coffey county the red roan heifer, Belle, then just one month old. It is probable that he also secured her dam, Belle of Bristle, vol. 10. At the time of this purchase or very shortly thereafter, $\mathrm{Mr}$. Woodford bought several other females and he retained Shorthorns for twenty years. At no time, however, did the herd assume more than local importance. It might be of interest to know that the heifer calf mentioned above was a descendant in the maternal line from the first Shorthorns brought to Kansas by S. S. Tipton in 1857.

Reynolds \& Pritchard, whose main establishment was located near Madison in Greenwood county, bred and handled Shorthorns extensively from 1870 to 1886. In addition to the Greenwood county ranch they also operated a large establishment near Augusta and one in Sedgwick county. This firm should probably be classed as dealers rather than as breeders. 
Harvey county became the home of a lot of cows from the historic Dunn herd in Ohio. In 1875 Armenia Casterline started a herd which he cared for under good conditions. The bull calves were all sold locally and the heifers kept. The early history of the establishment indicated permanency but for some cause which the records do not disclose, Mr. Casterline ceased operations.

W. G. Anderson began business in Johnson county about 1875 by purchases made in Ohio and Kentucky and for a number of years the heifers produced were retained. The bulls found ready sale in the surrounding territory.

Burtiss Bros. and C. L. Burtiss of Jefferson county, whose operations were closely connected, owned a small herd in the middle seventies which they sold to Frank Leach of Waterville. In 1875 or 1876 Mr. Leach bought from N. L. Chaffee of Manhattan a number of cows and probably also the well known bull, Oxford Wiley. Some females were secured from $O$. W. Bill of Manhattan. Mr. Leach continued to breed until the early eighties.

G. T. Watkins came to Jackson county about 1870 from Pike county, Illinois, where he had been breeding Shorthorns. He made few purchases and recorded but little produce the first ten years, but during the eighties he carried on more extensive breeding operations and stock from his herd was widely scattered. 
It was toward the close of the seventies that M. V. Davis and J. W. Martin, both of Labette county, each bought a number of cows from the Piper herd. Their breeding operations continued in a limited way for several years.

R. Williams \& Son of Lincoln county were breeders from 1872 until early in the eighties. The herd was not large and was little known outside the immediate vicinity.

Levi Dumbauld was a prominent breeder from 1874 to 1885 . During these years he maintained a good Shorthorn herd on his Lyon county farm. The territory around his home furnished a market for his young bulls and a female now and then. He used extensively and probably for too long, a bull, King of the Prairie, bought of A. C. Funk of Illinois.

Although F. McHardy of Emporia bred a few Shorthorns he can not be properly classed as a breeder. He was rather a dealer who bought and sold cattle in large numbers and of varying quality to suit the purchaser. Later he transferred his activities to the Galloways and became a leading promoter of that breed in the early and middle eighties.

Two Marion county herds which existed from 1873 to 1888, producing a good many Shorthorns from which a few cattle now living are descended, were those of A. H. and H. H. Lackey. There is nothing to indicate that they produced any- 


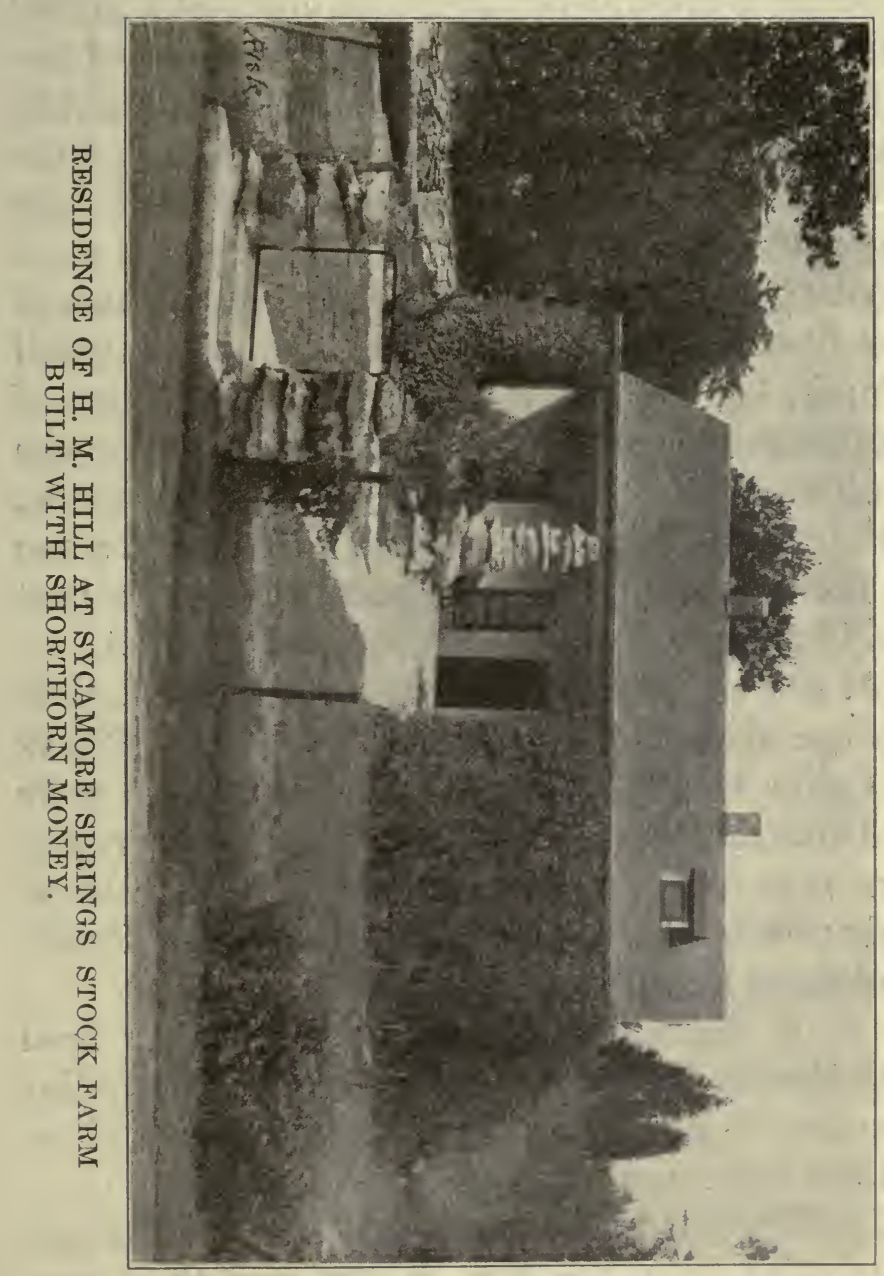


thing better than medium cattle. The Lackeys were quite good advertisers and enjoyed a liberal patronage. Another Marion county herd of the same time was that of John Kraft who bought in Canada the bull, Lord Barrington 36022 and the cow, Lady Aileen 2d. The records show only one heifer produced from this cow.

W. C. Bancroft of Solomon Rapids was one of the first breeders, if not the first, in Mitchell county. In 1877 he bought of N. L. Chaffee of Manhattan, a lot of cows that were sired by the excellent bulls, Oxford Wiley, imp. Clarendon, 1st Grand Duke of Kansas and Red Wiley, a son of Oxford Wiley. The general opinion is that the Chaffee cattle were a very desirable lot.

At one of the numerous sales held by J. C. \& George Hamilton in Kansas City, T. J. Peters of Osage county bought three cows. Two were by Duke of Noxubee and one by Earl of Barrington, both well known and very popular sires. This purchase was made in 1879 and Mr. Peters continued his opcrations for a few years.

E. R. Brown of Pottawatomie county bred Shorthorns from about 1872 to 1880. A peculiar feature of his work was that he recorded no cattle earlier than vol. 20.

In 1879 Geo. 'T. Polson of Riley county bought four cows from the well known and then popular herds of A. M. Winslow \& Sons and William Stevenson \& Sons. Before the end of 
the year the cows produced one heifer and two bull calves. Another Riley county herd that was established about this time or a little earlier was that of John J. Lovett. Some of his cattle were very good and some were of quite medium quality. He kept his herd only a short time, selling some to local breeders and some to the Hamiltons of Kentucky, who put them in their Kansas City sales.

Late in the seventies Lanson Eaton bought a number of good cattle from James O'Neal \& Son and other local breeders which were kept for a few years on his Shawnee county farm. 


\section{SHORTHORNS IN KANSAS 1880-1920}

A quarter of a century had passed since R. A. Alexander imported Duke of Airdrie and set him to work in the great herd at Woodburn. Duke of Airdrie proved a sire of extraordinary bulls that fairly made the reputation of the Bates cattle throughout the western Shorthorn country. Abram Renick bred one of his Rose of Sharon cows to him and secured Airdrie 2478, the bull that made the Rose of Sharons famous on both sides of the water.

Leading breeders all over the country wanted Bates bulls and those of secondary importance wanted the Rose of Sharons. They indulged in speculation in pedigrees so that cattle with little to recommend them except that they were of fashionable blood, sold for several times more than far better ones descended from better ancestry. Thousands of dollars were paid for pedigrees called pure or straight, or on the strength of an ancestor of whose blood nothing remained but the name. Thousands of dollars were deducted for the insertion, ever so far back, of a so-called unfashionable cross. This situation culminated in the great New York Mills sale with its $\$ 40,600$ for 8 th Duchess of Geneva, a cow normally near the end of her usefulness. 
Many leading American breeders had refused to be stampeded or to worship at the shrine of ancient ancestry. Among these were William Warfield who through sane and sensible methods produced real cattle; J. H. Pickrell, later secretary of The American Shorthorn Breeders Association; James N. Brown \& Sons; J. H. Potts \& Son of Duke of Richmond fame; J. H. Kissenger, associate of Mr. Pickrell; and C. E. Ticonard who made the name of Ravenswood familiar. These level-headed men failed to stem the tide, but they saved the breed for America.

The Hamiltons of Kentucky virtually invaded Kansas at the close of the seventies and with the cry of "Flat Creek Marys" created a demand for Young Mary bulls. Flat Creek Mary was descended from imp. Young Mary, a cow probably without a peer among imported Shorthorns. The year 1880 found good Shorthorn herds here and there and also herds of badly battered and injured cattle whose owners were trying to maintain the prestige of the breed against Herefords and Angus, then being brought into the West in large numbers. Although Kansas had to some extent been made the dumping ground for inferior specimens yet there were many good Shorthorns in the state, a considerable proportion of which would be called good even now.

The time was ripe for a change from the old system of selection by pedigree to the sensible 
one of selection for individual merit and quality of immediate ancestry. It required only a commander-in-chief to rally the people of America to the standard of right thinking and it fell to Kansas to furnish the man, W. A. Harris of Linwood.

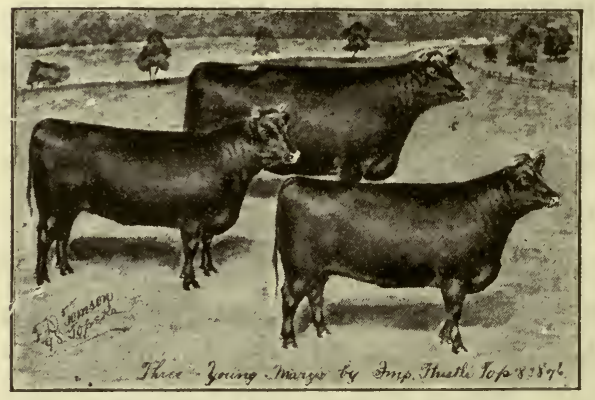

THIS IS WHAT THE SCOTCH CROSS DID TO A M E R I C A N SHORTHORNS

W. A. Harris.-Col. W. A. Harris, soldier, statesman and leading American breeder of Shorthorns, was a shining example of a man who could have accumulated great wealth but who unselfishly gave himself to others. As a breeder he stands alone in that he dared to stem the tide and dared to do what seemed best at the risk of incurring the disapproval of his fellow breeders. A born leader, Col. Harris succeeded in accomplishing on his Leavenworth county farm, what no other breeder in America since his day has accomplished. What Amos Cruickshank was to Scotland, Col. Harris was to the country west of the Mississippi and especially to Kansas. It is 
fitting that the account of the period from 1880 to the present be begun with the story of the achievements of W. A. Harris.

It was in the fall of 1880 or a little later, that J. C. Stone, Jr. of Leavenworth had bought a lot of bull calves of W. E. Simmes of Kentucky. They were all the popular Bates, crossed or straight Bates breeding, except one, a red, calved December 3, 1879, called Golden Drop of Hillhurst. He was by the fashionably bred 4 th Duke of Hillhurst and his dam was by the equally popular 7th Earl of Oxford, but his grandam was a plainly bred cow, Wastell's Golden Drop 4th bred in Scotland by one Sylvester Campbell. This calf was not considered especially desirable and Mr. Stone may have taken him in order to close the deal. In any event it is not likely that he took him from choice.

Col. Harris saw this young bull and, asserting that independence which led him to buy a red and white bull while everything except dark red was being tabooed, and a roan cow when roans were not wanted in good herds, he bought this bull, Golden Drop of Hillhurst. Mr. Sanders says it was through this bull that Mr. Harris became favorably inclined toward Scotch cattle. At any rate, after a year's ownership of this fellow, 75 per cent Bates and 25 per cent Scotch, he decided to look for a Scotch bull and at the sale held by J. H. Kissenger of Missouri on May 3, 1882, he 
bought imp. Baron Victor of Mr. Cruickshank's breeding. He also bought three cows, Victoria 63d, Victoria 69th and Violet Bud. The bull cost $\$ 1100$ and the cows, $\$ 530, \$ 390$ and $\$ 450$. Baron Victor was at once freely used, not only on the cows bought with him, but also on the Bates crossed cows in the herd. Results were next to marvelous. In the section tributary to Kansas City nothing like the Baron Victor calves had been seen, more especially nothing equal to the calves that were not from Cruickshank cows. Two of these calves were offered at the Breeders Sale in Kansas City and the battle was won for the Cruickshank kind.

Col. Harris decided to buy more cows of Mr. Cruickshank's breeding and within a year he added Barmpton Violet, Gladiolus, Gardenia, Lavender 32d, Marsh Violet and Sorrel, all bred by Mr. Cruickshank. He also bought Butterfly 2d, Harmony 2d and Ury 11th of Scotch extraction but somewhat Bates crossed.

It is said that Col. Harris was a good salesman but he was also a liberal buyer of the imported Cruickshank cows and other good cattle wherever he found them. The Warfield bred heifer, Primrose, by 2d Duke of Grasmere was bought and bred to Baron Victor. She produced Dr. Primrose that became a noted show bull in the Williams \& Householder herd. Col. Harris further violated the conventionalities by buying 
A HISTORY OF SHORTHORNS IN RANSAS

Norton's Golden Drop by the Bates bull, imp. Underley Wild Eyes, and from her he bred Golden Knight, a bull used with marked success in the herd. From this half Bates cow, Norton's

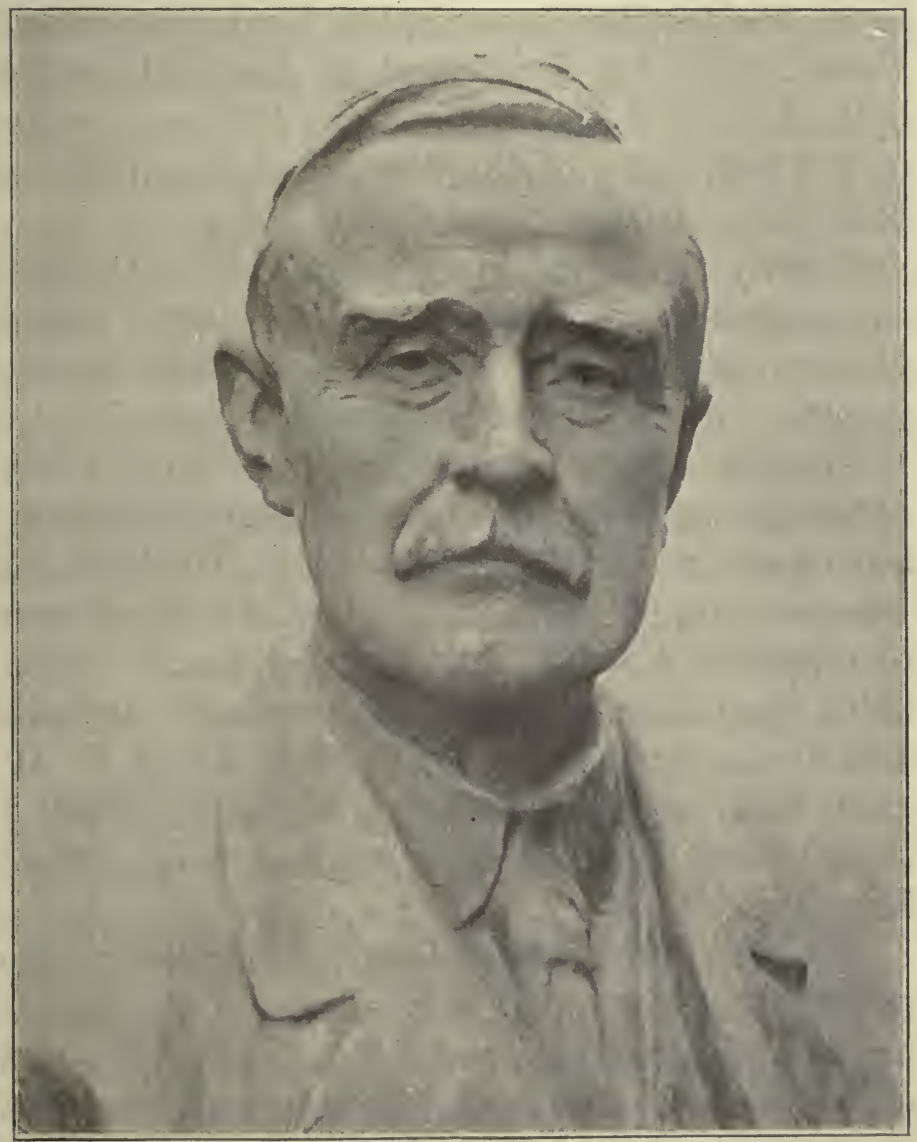

PHOTOGRAPH FROM THE BUST OF COL. W. A. HARRIS.

-Courtesy Breeder's Gazette. 
Golden Drop, he bred the Golden Drop family and the verdict of those familiar with the operations of Col. Harris is that the Golden Drops were the crowning triumph of his work as a breeder. It is of interest to know that Golden Lord, the last bull used in the herd, was out of Norton's Golden Drop and by Lord Mayor, a bull of his own breeding. Lord Mayor was one of the best bulls of the breed and was used in Kansas for fifteen years.

Shortly after the purchases of the Cruickshank cows mentioned above, Col. Harris added Golden Thistle and Lavender 36th by Roan Gauntlet and Lavender 33d and Sapphire by Barmpton. Among later purchases were Lady of the Meadow, the dam of Lord Mayor ; Barmpton Crocus; Lavender 38th; the Duchess of Gloster trio, the 26th, 27th and 28th Duchesses of Gloster; Wood Violet; Lovely 41st; Victoria 76th; Stephanotis whose descendants became famous in the herds of S. C. Hanna and H. M. Hill; Lady of Shallott; Vera; March Violet, and the greatest of all, imp. Princess Alice by Field Marshal.

At about the time Col. Harris had reached the point where financial returns would have been heavy under normal conditions, the country was suffering from an era of low prices and the cattle market was such as to discourage production. Many good herds were sold and the demand for 
the product of this herd fell to the lowest level. The output was, however, taken as rapidly as produced. It should be borne in mind that the foundation for the Linwood herd had been laid from the best Shorthorns then in the world and from a herd which had admittedly reached its highest possible stage of perfection.

The problem Col. Harris had to solve was one which has always been hard for the breeder. So good an authority as Mr. Sanders tells us the resort to inbreeding as practiced by Thomas Bates, Abram Renick and Amos Cruickshank has given the world its greatest triumphs but it has been found exceedingly difficult to maintain the standard of excellence in cattle so produced. It is stated on the best of authority that Col. Harris had serious trouble along this line. An old Shorthorn breeder of sound judgment who was a frequent visitor at Linwood has told me that had it been at all advisable to use such a bull as the best of Mr. Vaile's production crossed with a Cruickshank cow, or the reverse, the result would have been a splendid thing for the Linwood herd. This, of course, is a theory, substantially supported by practice, but with the discrimination shown in favor of Cruickshank cattle at that period, little more could have been done than was being done by using Norton's Golden Drop. That the bull question was a serious one is well told by Mr. Sanders who was 


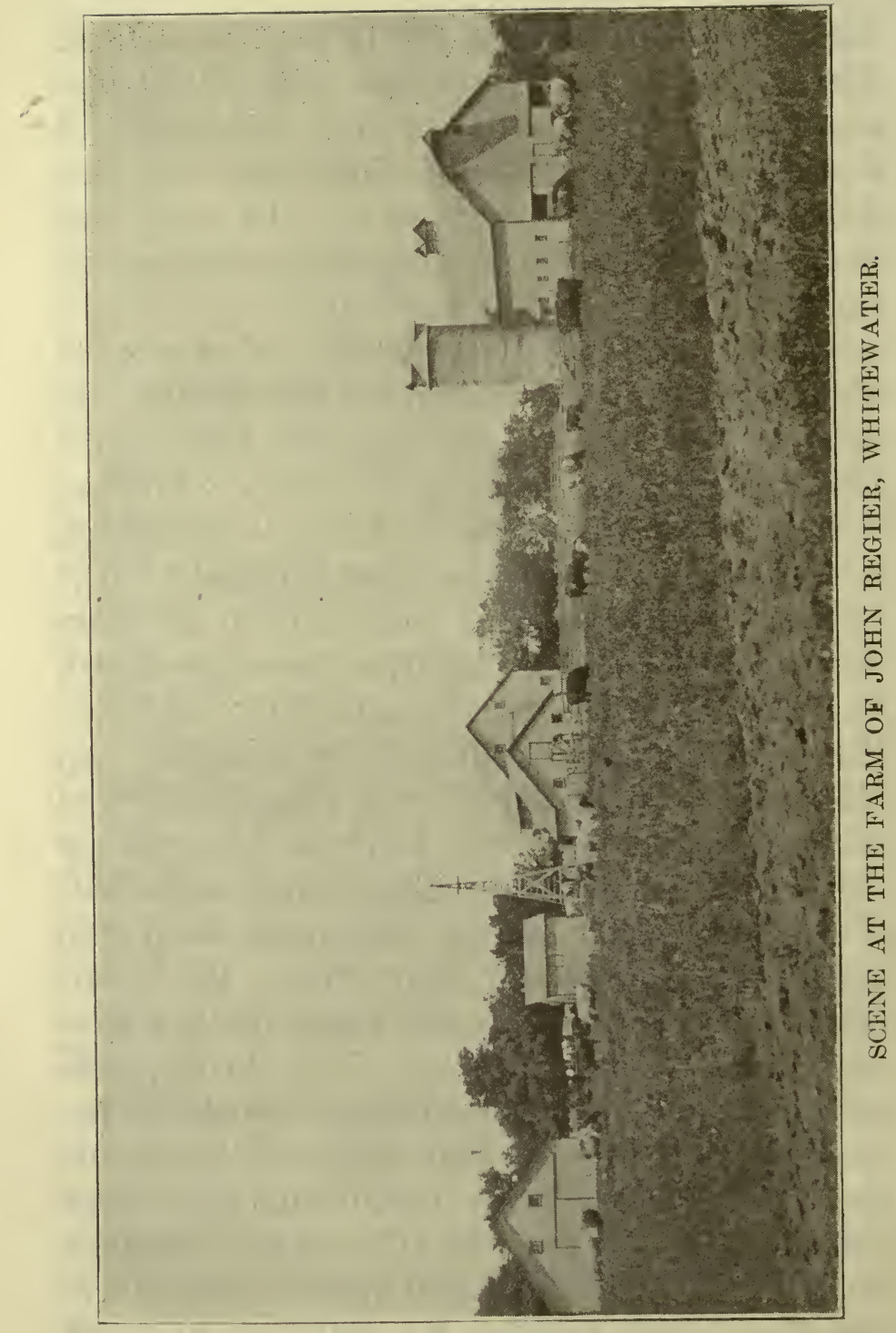


closely associated with the work done at Linwood and Mr. Sanders also states that in this respect breeders of Great Britain are being shown more consideration than is shown in America.

It was to the credit of the people of Kansas that the political wheel of fortune caught the proprietor of the magnificent Linwood herd and made him first congressman-at-large, thẹ United States senator. Old breeders will not admit that Shorthorn interests were served in these honors bestowed on Col. Harris. It was impossible to maintain a goodly degree of success with a herd already up to such a point of excellence, in the absence of the owner, especially under the unfavorable conditions prevailing at that time. Col. Harris had no choice but to offer his herd at public sale. Accordingly a dispersion sale was held May 6, 1896, when sixty-three head sold at an average of $\$ 205$. After serving six years in the senate, Col. Harris entered the employ of the American Shorthorn Breeders Association in which position he served Shorthorn interests until the time of his death. Breeders of Kansas and of the whole nation have honored the memory of Col. Harris by placing a statue on the grounds of the Kansas State Agricultural College at Manhattan.

Kansas State Agricultural College.-The history of the Shorthorn cattle at the Kansas State Agricultural College begins with the year 1873 
when Fred E. Miller, farm foreman, and Regent Hudson purchased from Andrew Wilson of Shawnee county, the bull Zena King 151801 $(\$ 400)$, and the heifers Grace Young 4th (\$800), Grace Young 5th (\$1080), and Kate Kee ( $\$ 400)$. Grace Young 5th proved to be a remarkable breeder and left on the college farm a family of high class cattle. The best cow now owned by the college and one the equal of any cow in any herd is a descendant of the cow Grace Young 5th.

On April 1, 1874 Professor E. M. Shelton assumed the duties of Professor of Agriculture. He was much interested in live stock and built up a very high class herd of Shorthorns at the college. The splendid herd bulls used is a good index to the kind of cattle produced by the college and reflects great credit upon the farsightedness and the splendid interest in live stock shown by the men in charge of the Department of Agriculture.

In 1876 the bull Second Duke of Jubilee 19498 bred by J. M. Woodruff was purchased from Durham Park. The herd being comparatively small it was necessary to secure another bull as soon as the heifers by Second Duke of Jubilee reached breeding age. A. W. Rollins of Manhattan very generously loaned the use of the bull Delight Duke 32132 during the fall of 1878.

In 1879 Prince Constance 36546, bred by A. M. Winslow \& Sons, was purchased. The bull Earl 
of Sharon 43647 bred by A. Renick was used in 1881 and on May 12, 1882 Paymaster 46722 bred by J. W. Burgess was purchased from Durham Park. In 1884 he was succeeded by Grand Gwynne 56310 bred by Wm. Warfield from whom he was purchased.

Professor Shelton early saw the advantage and value of Scotch Shorthorns and purchased the Cruickshank bred Thistle Top 83876 from Jas. Davidson of Canada in 1886. This bull cost the college $\$ 600$. The same year June 8, Professor Shelton consigned eight heifers and seven yearling bulls to the Bill \& Burnham sale. The college bred cattle outsold the other cattle by a nice margin. In 1888 Scottish Chief 89317 by imp. Julius 56643, bred by I. Barr \& Son, was added to the herd.

In 1890 C. C. Georgeson succeeded Proffessor Shelton as Professor of Agriculture. Professor Georgeson was keenly interested in live stock and through his untiring efforts a great deal was done toward solving many perplexing problems confronting the live stock producers of Kansas. In looking back over the work done by Professor Georgeson and taking into consideration the trying conditions under which he worked, one can not help but realize that when Professor Georgeson left the college, Kansas lost one of the biggest and best men that was ever connected with this institution. 
Soon after taking charge Professor Georgeson traded Scottish Chief to Col. W. A. Harris for imp. Royal Pirate 100640 bred by A. Cruickshank. On June 3, 1891 imp. Royal Pirate was traded back to Col. Harris for imp. Craven Knight 96923 by Cumberland 50626 and on January 24, 1894 Professor Georgeson traded Craven Knight to Col. Harris for Golden Knight 108086, a son of imp. Craven Knight out of a Golden Drop cow. Excellent results were secured by breeding Craven Knight heifers to Golden Knight. The college was exceedingly fortunate in having been able to secure such a worthy sire as Craven Knight at the head of its herd.

In 1897 a great calamity befell the live stock interests of the Kansas State Agricultural College. It had been suspicioned for some time that tuberculosis was present in the college herd. Professor Georgeson received permission to have the entire herd tested with tuberculin. Thirty-four per cent of the cattle tested reacted. Of all those reacting only two showed any physical symptoms of the disease. These two were destroyed and showed typical lesions. The other cattle were placed in quarantine for observation and further testing. Professor Georgeson recommended that the cattle be isolated and studied with the hope that some method other than ruthless slaughter might be discovered whereby 
this disease could be controlled and eradicated. It might be worth mentioning that not a single one of the inbred Craven Knight heifers reacted to the tuberculin test.

About this time Professor Georgeson resigned and was succeeded by Professor H. M. Cottrell, and he recommended that all diseased cattle be killed. The herd was retested by Dr. Fisher. Dr. Jas. Law of Cornell and Dr. T. A. Geddes of the U. S. Department of Agriculture were called to counsel with Dr. Fisher in regard to the result of the test. After careful deliberation it was decided to kill all reacting cattle. On October 20-21 these cattle were killed and a public post-mortem was held by Doctors Law, Geddes, and Fisher before a large number of veterinarians, stockmen and others. Every reacting animal was found to be tubercular.

An influential Kansas agricultural paper had for years been bitterly opposed to the idea of the college owning any pure bred live stock. This opposition, aided by the political situation at that time, lead to an order from the Board of Regents that all pure bred live stock remaining on the college farm be disposed of at once. In compliance with this order a public sale was held at the college in November 1897. Golden Knight, the bull that had proved himself such an excellent sire, went to the herd of J. H. Taylor of Dickinson county for $\$ 190$. 
It soon became evident that the Board of Regents had made a serious mistake when it issued the order that no pure bred live stock should be kept on the college farm, and Professor Cottrell was finally permitted in 1901 to purchase pure bred representatives of several breeds of live stock. In this purchase were three Shorthorns. The same year a. Shorthorn heifer was donated to the college by T. K. Tomson \& Sons of Dover.

Professor Cottrell resigned early in 1902 and the live stock work was placed in charge of a dairy husbandman. This arrangement continued until September 1905 when a separate department of Animal Husbandry was created and R. J. Kinzer placed in charge as Professor of Animal Husbandry. The growth of the department under Professor Kinzer was little short of marvelous. The Shorthorn herd he built up from 1905 to 1911 without any appropriation from the legislature was one of which any breeder would have been proud:

The first Shorthorn bull used was Ravenswood Admiration, a son of Lavender Viscount out of a granddaughter of Cumberland 50626. He was followed by Lavender Viceroy 223936, another son of Lavender Viscount out of a daughter of Baron Lavender 2d 72610. One of his sons, Orange Lavender 295670, dropped on the college farm in 1906, was the next bull used. St. Clair 
306509, a Marr bred "Clara" imported in dam, was loaned the college by Tomson Bros. during the winter of 1909-1910. He proved himself to be a wonderfully good sire but he got away before his first crop of calves made their appearance. The bull Sentinel 317021 purchased from Tomson Bros. was used for two seasons and then Matchless Dale 291609 calved December 12, 1906 by Avondale 245144 out of Matchless Mist, came upon the scene having been purchased in the International Shorthorn sale at Chicago in December 1911 for the sum of $\$ 400$.

T. O. Ford, Montgomery County.-Mr. Ford's first purchases were made at the big Hamilton sale at Kansas City in 1878, and consisted of one bull and five cows from the noted herd of $\mathrm{T}$. Corwin Anderson of Kentucky. While his herd assumed only local importance, the close times of the eighties found him with more than 100 Shorthorns on hand. In about 1887 Mr. Ford needed a good bull. Bulls were cheap but money was scarce. Through the writer he arranged a deal for Grand Airdrie, a Hamilton bred son of the $\$ 10,000$ imp. Grand Duke of Geneva, giving the choice of his cow herd in exchange. Grand Airdrie, measured by Bates standard, was a good bull, yet the deal proved to be a mistake which Mr. Ford soon afterward corrected by the purchase of Scottish Emperor. Only those who went through this period 
with a large herd can realize how great were $\mathrm{Mr}$. Ford's trials. In 1893 he sold a number of cows to H. M. Hill and a little later Mr. Hill bought the entire herd including Scottish Emperor. This was Mr. Hill's initiation in the Shorthorn business and while prices were so low that little profit accrued, yet he did well on the Ford cattle.

C. M. Gifford \& Sons, Clay County.-This was one of the most favorably known firms of breeders in the northeast section of the state. Operations were begun by Gifford \& Sons late in the seventies and by 1882 they had a good sized herd. In the fall of that year they bought the red and white, Cordelia's Duke, a popular Renick Rose of Sharon bull that had been a good winner at the leading western shows. He was used with other bulls of similiar breeding. The herd occupied a prominent position and was later kept up by F. M. Gifford, the junior partner. Mr. Gifford made no effort to breed his cattle along any straight line but the general opinion is that he raised good cattle. Some years ago he sold the entire lot to S. B. Amcoats and it was from these cattle that many of the good things on the Amcoats farm have been bred. The herd until recently owned by Warren Watts of Clay Center is also descended from Gifford bred cattle and the output of the herd has been used by numerous others as a foundation.

John McCoy, Brown County.-John MeCoy, a 
native of Ireland, came to Kansas in 1872. In 1878 he bought his first Shorthorn cow at W. S. White's sale for $\$ 100$. In 1881 he bought a red

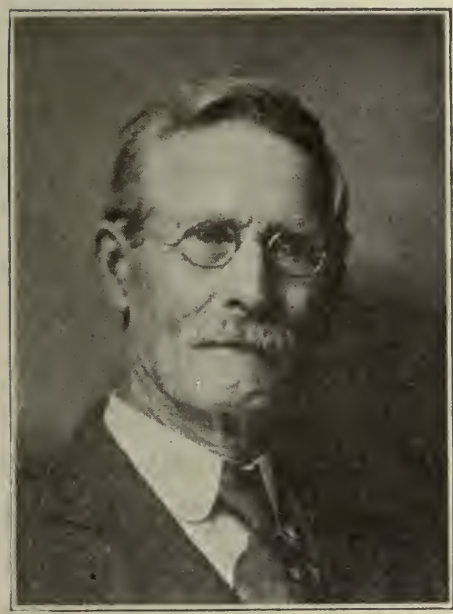

JOHN McCOY

A pioneer breeder

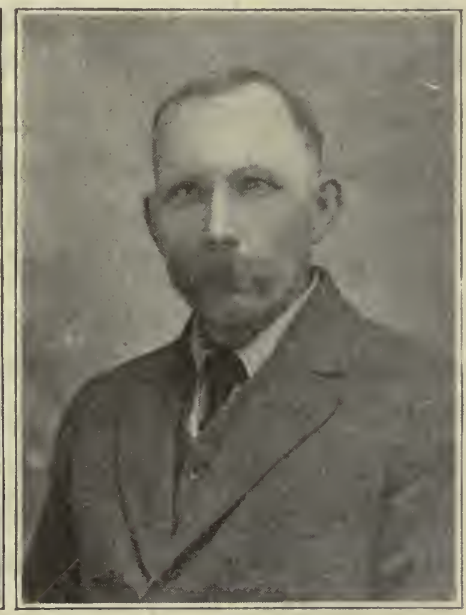

J. W. HYDE

A breeder since 1870

and white bull, Craig, by Loudon Duke 6th of Cowan's and shortly thereafter he secured four cows from the Cowan herd. "They were good ones and they would be good ones now", Mr. McCoy told me. A succession of high class bulls was used. With judicious care and feeding, Mr. McCoy, unhampered by fads, with only real Shorthorn quality in mind, developed his herd into one of great excellence. A further account of the work of John McCoy \& Son is given later in this volume. Mr. McCoy must be considered 
one of the constructive breeders of the state. Now at seventy-nine years of age he enjoys showing the results of his efforts and telling of the bulls that did the work. Among these Pride of Collynie by imp. Collynie out of imp. Mistletoe 15th, is given first place.

Wm. P. Higinbotham, Riley County.-Mr. Higinbotham was a banker in Manhattan who engaged in raising Shorthorns on a large tract of land northwest of that eity. Beginning in about 1880 with stock bought locally, at the Hamilton sales, and at Durham Park, his herd grew to be a large one. Being a good advertiser, Mr. Higinbotham kept his work prominently before the people of the state for several years. In 1884 he bought Double Gloster, a red bull of Mr. Cruickshank's breeding. He believed there was something in a name and nearly all the Double Gloster heifers were given names which would arouse the interest of any devotee of the Cruickshanks, Duchess of Gloster with numerous prefixes having been commonly used. The Blue Valley herd was quite a good one and, had conditions been more favorable, Mr. Higinbotham might have done well but he lived in a day when the best of cattlemen went broke. A financial failure and a dispersion of the herd ended a bright prospect for success.

Hanna \& Co. - S. C. Hanna, Elk County.-In 1882 S. C. Hanna, associated with his cousin 
Geo. S. Hanna of Illinois under the firm name of Hanna \& Co., bought a lot of Shorthorn cows from John D. Gillett, of Elkhart, Illinois. Mr. Hanna describes these as wonderful cattle but they took no pedigrees, simply using them for beef producing purposes.

About 1886 they bought of Elbert \& Fall of Albia, Iowa, a lot of Bates Shorthorns and at Col. Harris' Kansas City sale the same year a yearling heifer named Spirea was bought for $\$ 65$. At F. Bellows \& Sons' dispersion they bought Red Queen, Silver Maid and Georgia by imp. Scotchman. In about 1894 at the Potts dispersion they secured Lavender of Oakland 4th and Sempstress of Oakland 5th, 7th and 8th; also two Fannie Airdries. These were the tops of the sale. 'Sempstress 5th was in calf to imp. King of Aberdeen and produced a bull calf that under the name of Oakland was used in the herd. The Lavender cow was sold to Col. Casey before leaving produce in the herd. Most of the Elbert \& Fall cattle were sold to E. K. Thomas of Kentucky, a few years after their purchase. In 1897 they bought the show cow, Gay Lady, a daughter of Gay Monarch. This wonderful cow weighed 2000 pounds when weaning a calf but show ring requirements had ruined her as a breeder and at eight years old she was sent to market, a barren cow. Up to this time the purchases had been made from severai sources bring- 
ing in Scotch as well as Bates blood and a blending of the two.

In 1898 the firm wanted more good Scotch cows and found the demand had so increased the price in the United States as to make it almost prohibitive. They met for consultation and ascertained that a number of breeders were soon going to Scotland for cattle. They decided to head off the crowd and in less than a week S. C. Hanna was on the road to Liverpool and to Mr. Duthie's and Mr. Marr's. He made purchases of ten heifers and several bulls that have been makers of history for the entire Southwest. "Mr. Duthie offered me all his heifer calves except seven at $\$ 150$ each", Mr. Hanna told me, "and I failed to land the chance of a lifetime". The ten females bought, as well as the bulls, were the choice of the best herds in Scotland and cost. $\$ 250$ a head, a price which, viewed from a later period, seems almost incredible. At Dean Willis' Mr. Hanna saw Bapton Pearl, just returned from the shows. He could probably have bought. her for much less than the price for which she later sold, but of course, he could not forecast the story of Whitehall Sultan. At Mr. Marr's the two heifers selected were Princess Royal 62d and Emma 33d and it took considerable persuasion to pry them loose.

On his return journey Mr. Hanna met Mr. Forbes on his way to Mr. Duthie's, where he 
A HISTORY OF SHORTHORNS IN KANSAS

paid double the price Mr. Hanna had been asked to pay. The consignment as finally shipped from Scotland included the Hanna purchase, a lot for F. W. Harding and the bull Merry Hampton for Mr. Dustin.

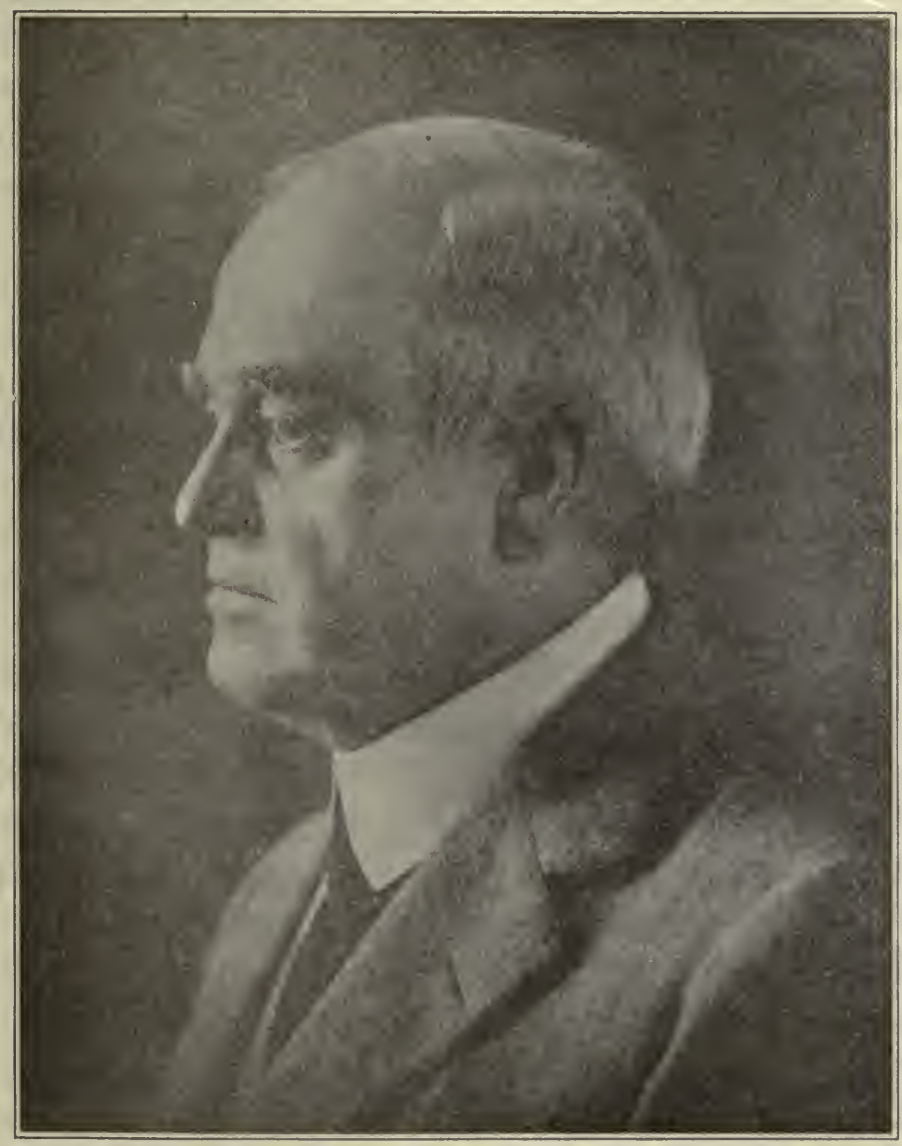

S. C. HANNA 
Mr. Duthie had promised Mr. Hanna that he would find a thoroughly competent man to care for the cattle until landed in their new homes. How well he kept his word the reader will see in the fact that Peter Ross was the man he selected. In telling of this incident, Mr. Hanna remarked, "And Peter may have been the most valuable part of the importation. I could have secured his services but allowed Mr. Harding to outbid me. Of course, I did not know this at the time."

The heifers that reached Palo Duro farm at Howard were Roseleaf and Primrose 4th by Scottish Archer, Mistletoe 15th, Golden Queen and Lavender Lass from Mr. Duthie; Circe 3d bred by John Wilson; Dalmena Mina 5 th bred by S. Campbell; and Lady Spicy bred by Mr. Bruce. These were all purchased from Mr. Duthie. Princess Royal 62d and Emma 33d were bought from Mr. Marr. The bulls bought were Mariner bred by Mr. Marr and Scottish Pride and Collynie bred by Mr. Duthie. With the exception of Lady Spicy that died of milk fever and Lavender Lass that died in calving the heifers all proved valuable breeders. Emma 33d became the dam of Inglewood, the highest priced bull sold until recent years at an American Royal sale. Mistletoe 15th produced Captain Archer, Mr. Stodder's famous sire and Sweet Mistletoe, the dam of the $\$ 4100$ Imperial Mistletoe and the 1919 Inter- 
national champion, Lespedeza Collynie. Princess Royal 62d was the dam of Prince Royal, used for years by Mr. Hanna. Roseleaf was the

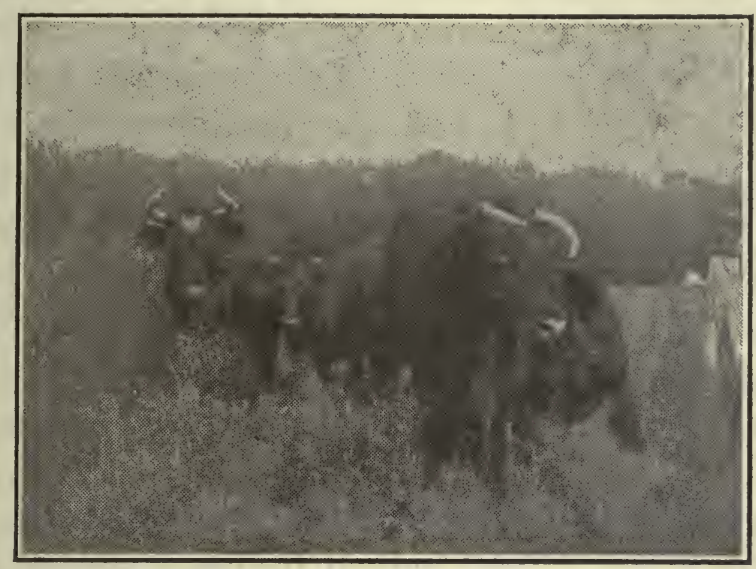

IMPORTED MISTLETOE 15th AND IMPORTED PRINCESS ROYAL 62d

dam of Rosewood, the excellent sire in the Brookover herd and later in Mr. Hill's herd. Dalmena Mina 5th was the dam of Kinnellar, used by Mr. Hill. Circe 3d was the dam of Tomson's great bull, Archer. Primrose 4th produced a lot of excellent heifers that developed into some of the best cows in the herd. Golden Queen was a great producer and left many valuable descendants. Mariner, the oldest of the bulls, was used by Mr. Hanna and later sold to Mr. Hill where he sired a lot of large, beefy cattle. He was the sire of Golden Day used one season in the T. P. Babst 
herd where he got a wonderful lot of cows. Scottish Pride was sold in Illinois instead of being brought to Kansas.

It is around the calf Collynie, the baby of the importation, that the history of the Hanna herd must center; but before taking up this subject, I shall go back to tell of some deals made in Kansas that left an impress on the herd and on southwestern cattle, equal to anything that came from the importation. The reader will have noted that Mr. Hanna bought the heifer Spiraea at the Harris sale for $\$ 65$. She was by imp. Royal Pirate and her dam was imp. Stephanotis, the dam of Scarlet Knight and one of the best cows in the Linwood herd. He had also bought of Col. Harris a bull named Robin, a son of imp. Spartan Hero and out of a Bates bred cow. Notwithstanding his Bates dam, Mr. Hanna had the courage of his convictions and he bred the daughter of the great cow Stephanotis to the bull Robin. A white heifer, Lilac, a good cow and a great breeder, was the result. She was bred to Royal Knight, a son of Col. Harris' magnificent daughter of Field Marshal, imp. Princess Alice, and produced Syringia, one of the best cows of the breed. Royal Knight had been used freely by Mr. Hanna for two years when his accidental death by drowning occurred, and had left many good females, so that in the early nineties the herd comprised the imported cows and 
an equally valuable lot of cows bred on the farm.

Collynie really began his life's work in the Tebo Lawn herd, Mr. Hanna having leased him to Col. Casey for $\$ 1000$ for twelve months use. After his return to Palo Duro, he was used to the limit, siring a class of cattle that as feeders had few equals. A little plainness, especially in the hind quarters was frequently observed, but the Collynie cows were great breeders and sucklers and the bulls, as a whole, were great sires. The improvement made through the Collynie blood and the good cows in the herd, extended from the Missouri river to the Gulf. The occasional adverse criticism on account of the plainness mentioned could not disprove the fact that these cattle made more pounds of high priced beef from the coarse feeds of the farm than almost any other Shorthorns in the territory.

Besides Collynie, there was used the excellent young bull Inglewood, a son of imp. Emma 33d. He was the sire of Inglemaid, the dam of Mr. Hill's Ingle Lad. When Mr. Hanna was at Mr. Duthie's he was greatly impressed with Cowslip 26th, a cow of mixed English breeding. She had been the leading show cow in Great Britain and Mr. Duthie had bought her with a view of getting a bull to use on his Cruickshank cattle. He promised Mr. Hanna a bull from her as soon as 
he could spare one and following this arrangement, Lord Cowslip by the show bull, Lord of Fame, came to the farm. His disposition was not the best and his calves may have been scarcely up to the desired standard, but he was freely used and the fresh blood infused became very valuable. His daughters bred to Collynie as well as to Hampton Spray produced splendidly.

A most fortunate purchase made as a successor to Collynie was the white Dustin bred bull Hampton Spray, a strongly line bred Merry Hampton. He was bought as a calf from N. H. Gentry and was the subject of much criticism by men who thought they knew; but he matured into a great individual and as a breeder, especially a getter of heifers, it is doubtful if he had a superior in the state.

Toward the end of $1915 \mathrm{Mr}$. Hanna, who was not very rugged, felt it would be best to close up his business. He decided to sell the herd and here is the story as he told it. "Col. Supies of Tulsa and W. S. Fears of Broken Arrow came over and I sold them a few head. Then John Kramer, representing $\mathrm{Mr}$. Gillispie, came, and having no children to whom to leave things and not wanting Mrs. Hanna to be burdened in case of my death, I sold the rest of the cattle to him in less than thirty minutes. He took the whole lot at my own price, which was not half their value, but I did 


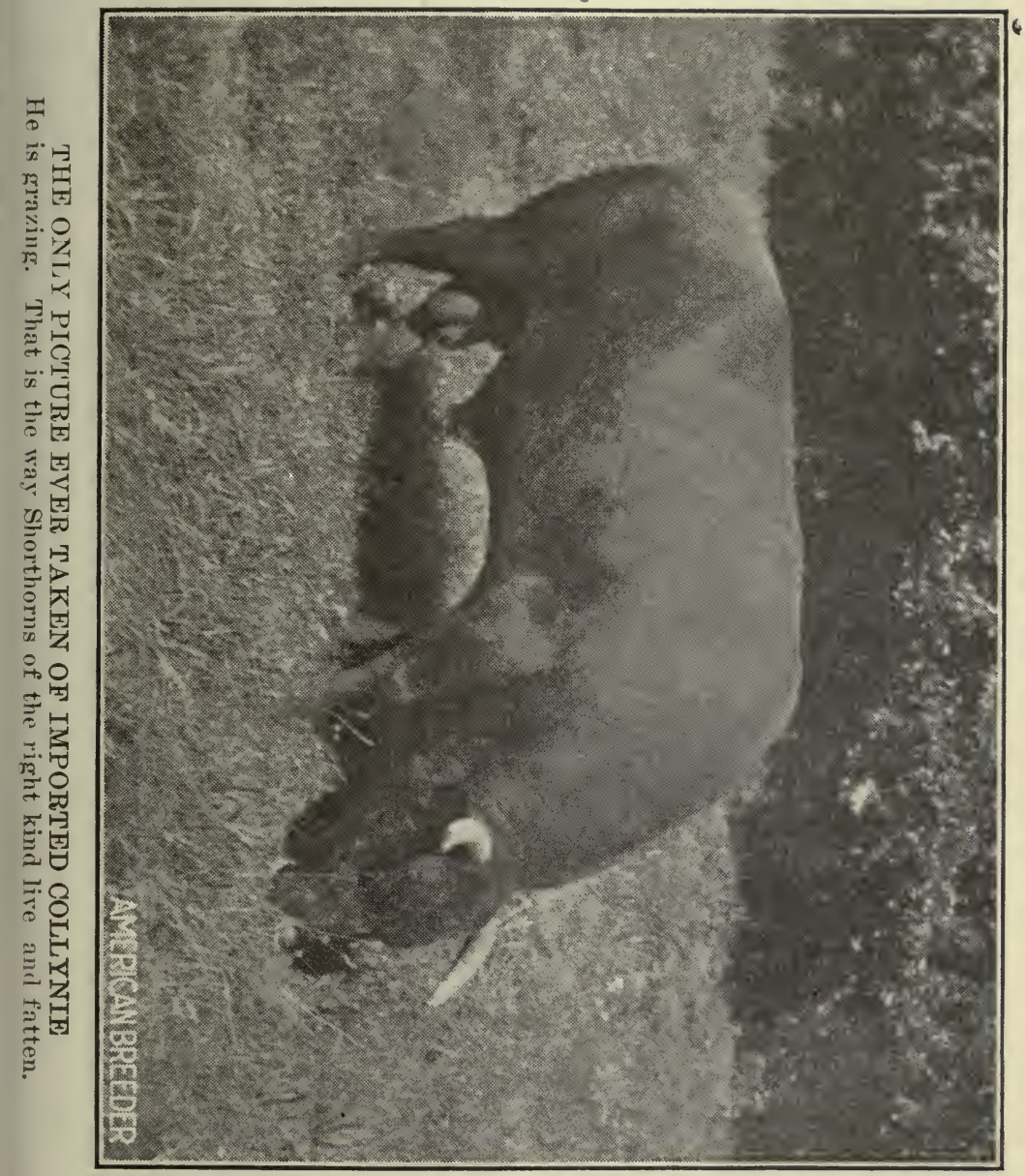


not know it at the time. When I sold them, they were the greatest herd I ever saw."

This is the story of a great herd of Shorthorn cattle, told without any attempt to boast. The monument of their greatness is found all over the country. I cannot finish the story without telling something of the owner. Mr. Hanna was born in Attica, Indiana in 1850. When 31 years old he came to Kansas and the story of his herd is the story of his life until four years ago. Mr. and Mrs. Hanna were childless, but they raised two children, who after being grown and educated, died. Mrs. Hanna passed away two years ago and Mr. Hanna is living in his old home in Howard. Recently two nieces, his nearest relatives, came to make their home with him. When I visited him he was happy in anticipating their arrival. No man ever identified with Shorthorn interests in Kansas is more highly respected than is Mr. Hanna. Modest, unassuming, and thoroughly honest, he has a knowledge of affairs in general and especially of Shorthorn affairs that has given him a keen insight and unusual judgment which he has used not only to his own advantage, but also for the benefit of the entire country.

T. K. Tomson \& Sons, Shawnee County.-It was at a farm sale near Dover, in the fall of 1886 that T. K. Tomson, father of Tomson Bros., made the first investment in a registered Shorthorn 
A HISTORY OF SHORTHORNS IN KANSAS

female. The sale included a rather large offering of grade Shorthorns and one registered cow, Betsy, a descendant of imp. Young Mary. Mr. Tomson made the high bid, $\$ 80$, on her and later in the sale purchased her yearling bull, Wabaunsee, for $\$ 100$. Betsy was in calf and the following

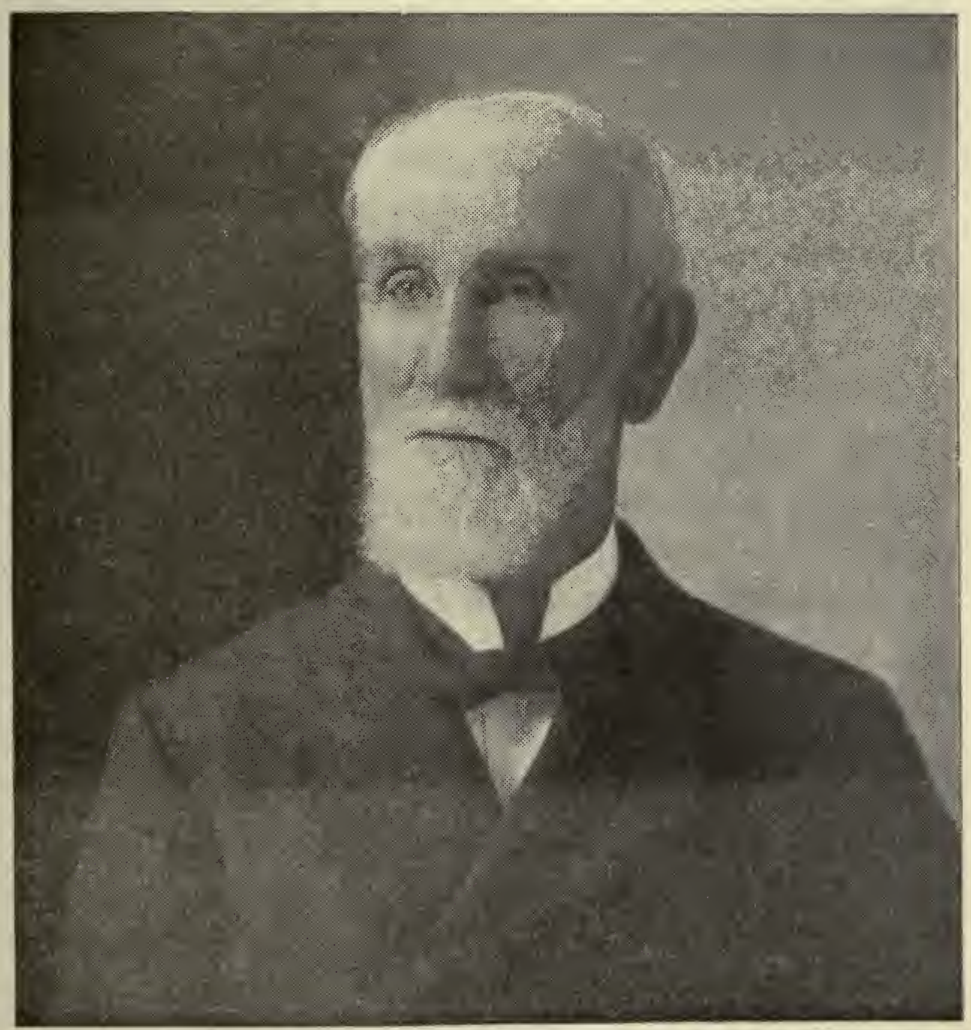

T. K. TOMSON

A man who builded better than he knew. 
spring dropped a level, deep-bodied, red heifer which was named Betsy Dailey, Dailey being the name of the former owner of Betsy.

It was the attractive outline and the thriftiness of this heifer calf, Betsy Dailey, that made such an impression on the Tomson boys that they urged their father to acquire a few more registered females. This was done to a limited extent and by the summer of 1888 there was a herd of a dozen females of miscellaneous breeding on the farm. Another bull was obtained at a mortgage sale in which a bank was winding up the affairs of some unfortunate. The bull, Phyllis Duke, was included in the offering and sold in this forced sale for the fabulous price of $\$ 25$ less five per cent discount, net $\$ 23.75$.

Gradually the pure bred cattle increased and the herd was kept to the desired number by disposing of the surplus grades, a very simple plan in the building of a valuable herd at a small outlay. In the early nineties an incident occurred that proved of great value to the Tomson breeding operations. The well known breeder of that time, T. P. Babst, also of Dover, maintained a large herd and had in use the imported bull, Thistle Top, selected originally by Amos Cruickshank, his breeder, for Colonel W. A. Harris for use in the celebrated Linwood herd, where he was kept in service for two or three years. He was then acquired by Mr. Babst and as his heifers 
accumulated in the herd he exchanged him with the Thompsons of Amity, Missouri for Scottish Chief, also an aged bull and sire of many worthy animals, among them the great breeding cow, Rosedale Violet 9th. It happened as is often the case that neither bull proved sure during the few months following their change of location and the owners decided to change back again. Upon a query from the Tomsons as to what Mr. Babst intended to do with Thistle Top they were advised that they could have him at a very nominal cost. He was then eight years old and there, of course, existed some uncertainty as to his usefulness. He was purchased and for four years proved a sure breeder.

Thistle Top was a red possessing more than usual scale, weighing approximately 2400 pounds with great depth and unusual flesh covering. He was a wonderful feeder. His form was compact, his quarters well rounded and he had a thick coat of curly hair, characteristics whicb he transmitted generally to his get. He was one of the most richly bred of Cruickshank's productions. His daughters were given preference in the Tomson herd and soon it was largely composed of growthy, thick-meated, roomy cows by him.

From the time the first bull calves were offered for sale there was a gradual increase in the values but at best they held to a low level for 
the worth of a pure bred bull as compared with a grade was not generally understood at that time by farmers and cattle growers. Naturally the neighboring farmers contended there was little value to the pure bred feature and that those engaged in fancy stock breeding were very apt to lose out financially. One of these neighbors who was something of a steer feeder happened along one evening as the Tomsons were loading a ten-month bull calf into the wagon of a man who had driven over from another neighborhood. After the calf was safely loaded the man wrote a check for the amount agreed upon and drove away. When he had departed the neighbor said, "I'm curious to know what you got for that calf." The check which called for $\$ 45$ was handed him. He read the amount and returning it said, "By George, it does beat the steer business, don't it." The amount, small as it seems now, looked large at the time. Still the prices kept advancing and in the course of a few months thereafter the Thistle Top calves were leaving the farm at prices ranging from $\$ 75$ to $\$ 125$ each.

When another bull was needed the elder Tomson and the youngest son, James, then a boy, visited the Linwood farm in quest of the desired herd-header. Leaving the train they walked to the farm which was near the station and when within one or two hundred yards of the buildings, several calves came playfully around the corner 
of the barn. James immediately pointed to a very compact, short-legged, red calf remarking, "There's the one we want." His father replied,

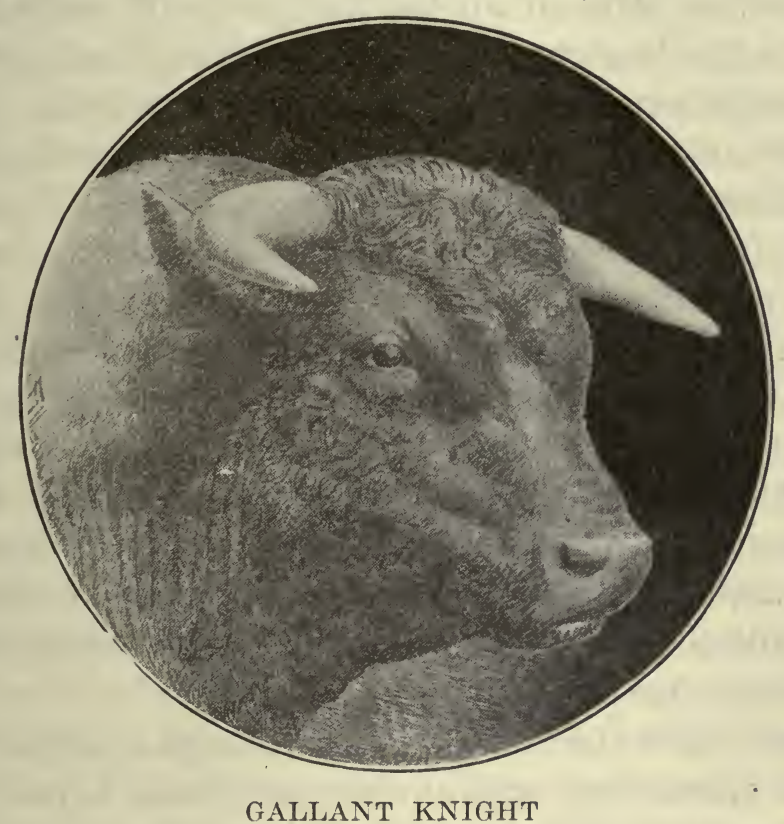

"He looks like a good one but we won't do any picking until we have looked them all over carefully." James said, "That may be but that's the calf we want." And later this calf was purchased. This was Gallant Knight, one of the best productions of the Linwood herd during its longyears of existence. He was of the famous Goldendrop strain regarded as the most valuable of all the worthy tribes that composed that noted herd. 
Gallant Knight combined the blood of imp. Baron Victor, chief of all the sires ever used at Linwood, and Craven Knight, rated as one of the most beautiful of all the Cruickshank bulls imported to this country. Gallant Knight attained a weight somewhat in excess of 2200 pounds. He was a marvel for compactness and smoothness of form. Rarely has a bull been seen with such wonderful quarters and such impressive, cleancut masculinity about the head and horn. For nearly thirteen years he did service in the Tomson herd and for a dozen years his sons and daughters, the latter particularly, were prominent winners in the middle western fairs and shows. The characteristics which always attracted attention were their uniformity of type, smoothness and compactness of form, depth, and fleshing quality.

The first time that Gallant Knight appeared in a show ring was at the American Royal at Kansas City. He was then a three-year-old. The judge was the late W. S. Van Natta of Indiana, famed as a Hereford breeder. He placed Gallant Knight second in class, awarding the first to Lavender Viscount that at the time was carrying a heavier flesh covering. When the ratings were made and the animals left the ring $\mathrm{Mr}$. Van Natta followed Gallant Knight to his stall, the cattle at that time being quartered on the second floor of a building nearly a block away. Arriv- 
ing at the stall he said, "Boys, I don't know who you are but I've come to urge you never to sell this bull. I placed him second here only because the other bull which won first is now in better show form but this in my judgment is certain to be a great sire, so I urge you not to sell him." This manifest interest on the part of so experienced a breeder proved a decided encouragement and confirmed the judgment of the owners.

The story of the Tomson herd after Gallant Knight had made it well known in the West, will be given in Part II.

T. P. Babst \& Sons, Wabaunsee County.--Just across the line from Shawnee county, a few miles southwest of T. K. Tomson's was kept for years a Shorthorn herd that grew up with the country, improving and developing, until it became one of the best in Kansas. There was nothing sensational about its growth. Plain common sense, combined with plenty of energy on the part of the family in properly caring for the cattle, was the whole secret of success.

The original cattle came from local breeders but later some first class additions were made to the herd. On a day memorable in the history of the herd, Lord Mayor, a red two-year-old bull that had been used by Col. Harris, was bought. Three hundred dollars, the price paid, must have seemed exceedingly high. It was at about this 
time that I remember having lain awake nearly all of one night wondering how I could manage to get more than one cent a pound for an elegant 1000 pound grass fat heifer. It was a time that tried cattle men's nerve if not their souls. Shorthorn breeders shared in the general stress and the $\$ 300$ paid by Mr. Babst for what would now be a $\$ 15000$ bull may have made him feel guilty of: reckless extravagance.

Lord Mayor was a success and he made the Babst herd as a really good bull will always make a herd if given a chance. For years the Lord Mayor cows were among the best individuals and the best breeders of all cows in the West. One of them, Emily by name, was held in the highest estimation at the Kansas State Agricultural College for the prize winning steers she produced.

After Lord Mayor had demonstrated his value, females worthy of a place in any herd were added and many of the best cattle in the state are descended from stock bred at Valley Grove, for that was the name of the farm and the herd. One of the notable purchases of cows was that of three full sisters, Forest Daisy, Forest Daisy $2 \mathrm{~d}$ and Forest Daisy $3 \mathrm{~d}$, all bred by B. O. Cowan and sired by his excellent bull Norfolk, out of a granddaughter of imp. Severn Daisy. Two of these cows were later sold to T. K. Tomson \& Sons and Forest Daisy 2d bred to Barmpton 
Knight, produced the sensational New Year's Delight.

In about 1909 the Babst herd was sold to Tomson \& Sons who kept the choicest of the cat-

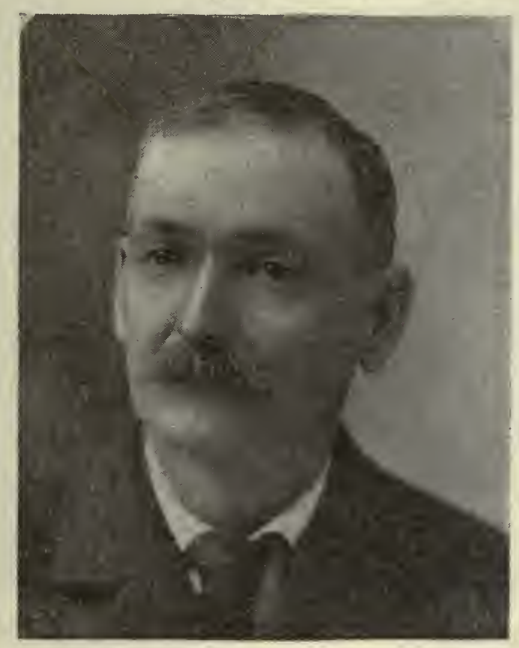

T. P. BABST

tle. Mr. T. P. Babst moved to Topeka and early in 1920 he passed out of life, a shining example of success in Shorthorn production. The sons are again engaged in producing reds, whites and roans on the same farm made famous by old Lord Mayor, one of the breed's great bulls.

D. K. Kellerman \& Son, Linn County.-This herd was established in Ohio in 1876 by the purchase of four heifers of the then popular Rose of Sharon and Matilda families. In 1884 the junior 
partner, Geo. F. Kellerman, located near Humboldt, bringing a few females and a bull with him and in 1888 a farm was purchased near Mound City to which the cattle on hand and a car load of the best from the Ohio farm were sent. Along with the cows came a Renick Rose of Sharon bull, the family at that time not having recognized the great value of the Scotch cross.

Shortly after this a Scotch crossed bull was bought of Col. Harris and he was followed by the bull that made the herd. Armour Bearer by F. Bellows \& Sons' Valley Champion, taken reluctantly because he was a roan instead of the fashionable red, got calves from these Ohio bred cows that were in all respects equal to the best Scotch eattle of the day and the show yard record made by this roan bull's calves at the leading fairs, including the American Royal, was not only an enviable one but it was a tribute to the influence of a good bull when crossed with practically unrelated cows. Armour Bearer lived only eighteen months but during this period he had worked a great change in the red herd. His calves were nearly all roans and, while considered less valpable on this account, they sold at good prices on their merits.

The first Cruickshank cow, 14th Linwood Lavender by Baron Lavender 2d, was bought at Col. Harris' dispersion sale in 1896 and she produced Lavender Dorrit, a bull later used with success 
in the herd. After the loss of Armour Bearer Lavender King 4th by imp. King of Aberdeen was bought of J. H. Potts \& Son. As a calf he had been at the head of the Potts young herd at

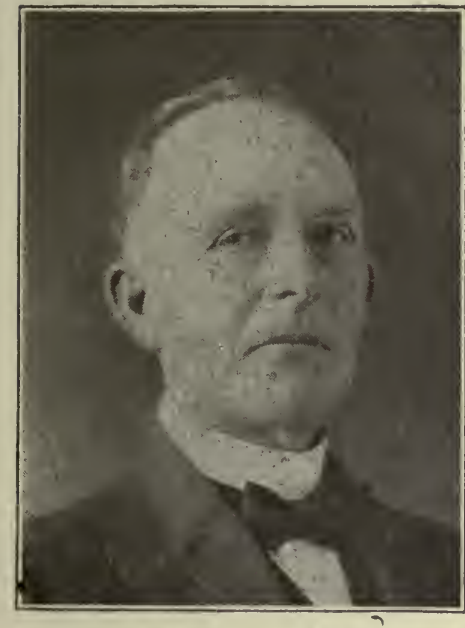

G. F. KELLERMAN Mound City

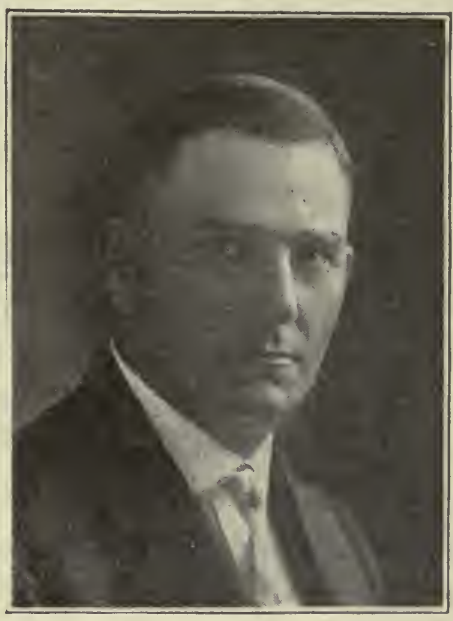

R. H. LISTER Ottawa

the World's Fair and was rated one among the best prospects of his day. While he developed into an excellent bull and did very satisfactory service in the herd, his calves were not the equals of those sired by Armour Bearer, a fact which, however, was not to his discredit, the former having probably been one of the greatest sires of his day in America. Lavender King 4th was followed by Orange Lad, an American Royal prize winner.

The produce of this herd was well received by 
the buying public, a yearling heifer having sold at the Royal sale for $\$ 400$ in 1901 . The herd was dispersed in 1903, leading breeders in Kansas and Missouri having been among the purchasers. The famous Scotch Josephines shown by C. S. Nevius were out of Kellerman bred cows. Descendants of cows bred by D. K. Kellerman \& Son may be found in numerous herds in Kansas, Missouri and Oklahoma.

C. F. Wolf \& Son, Franklin County.-This firm was very prominent in Shorthorn circles from 1895 to 1910. The first Shorthorn cow was bought in 1885 and a year later twenty-eight head were added to the herd. In 1894 the Wolfs decided to devote their entire attention to Shorthorns. They secured a car load of Ohio bred cows from D. K. Kellerman \& Son of Linn county and a little later they bought several Scotch cows including imp. Constance and imp. Pavonia, the latter proving a very valuable producer.

The real effort for production dates from 1894 after which time only good bulls were used. Glendon, later sold to H. C. Duncan; Scutland's Charm by imp. Lavender Lad; imp. Prince Lovely, personally selected from Mr. Duthie's herd by the junior member in 1900; Tillycairn by imp. Collynie; Royal Wanderer, a son of imp. Pavonia and Blythe Conqueror by imp. Conqueror were the principal bulls in service. Unfortunately Prince Lovely did not live long but the few 
calves he got proved the wisdom of his selection. Scotland's Charm was perhaps the most popular of the bulls and, though not a show bull, he was an excellent sire.

The firm did a big business not only in cattle of their breeding but they bought from small breeders and sold to them and during the entire active period of their work they ranked with the leading breeders of the state. The herd was dispersed in 1910, the last sale having been that of forty females to H. C. Lookabaugh, and a number of these became foundation stock for the Oklahoma herd.

Williams Bros., Greenwood County.-Williams Bros. were breeders in Illinois and in about 1886 they moved a herd of twenty cows to a farm six miles south of Eureka. They bought of Col. Harris the extraordinary twelve-month-old show bull, Dr. Primrose, and at once began a successful show yard career. In about 1888 they combined show herds with M. A. Householder of Columbus, and as Williams \& Householder they exhibited at the large fairs of the United States, Dr. Primrose being the leading winner. In 1891 Dr. Primrose was sold and in 1892 the entire herd was sold to C. V. and J. P. Lodge of Monticello, Illinois, E. M. Williams retaining an interest in the partnership. In 1892 Lodge Bros. became convinced that tuberculosis prevailed in the herd and the cattle were shipped to market. 
After Williams Bros. had disposed of the herd, J. F. Williams went to the Fort Worth stockyards and in 1895 E. M. Williams entered the employ of Col. Casey, being in charge of the Tebo Lawn show herd until his death in 1898 or 1899.

Mr. Householder for at least one season owned imp. Cupbearer, the grand champion bull of America. Details as to the connection of Williams Bros. with the exhibition of this bull are meager. Householder, himself, bred little stock that ever found its way to record.

Henry Stunkel, Sumner County.-Mr. Stunkel's first Shorthorns were purchased from Novinger \& Cain of Missouri in 1890. The lot consisted of fifteen head of nicely bred cows with some infusion of Scotch blood. Two cows were secured soon afterward from Joseph and H. C. Duncan. What was probably for some years the largest herd in Kansas was built up from these seventeen cows.

Mr. Stunkel's methods were to buy the best bulls he could get, to raise the heifers cheaply, and to keep them, and to feed the young bulls heavily and sell them at profitable prices. The result was having a cow herd not so attractive as their breeding would warrant and as one would naturally expect to see; but the use of high class bulls made them good producers. This system was kept up for fifteen years and $\mathrm{Mr}$. Stunkel at his death was a wealthy man with 
large land holdings near his home and elsewhere.

The leading bulls in use were Victor Orange and Star Goods, in fact the herd was founded during almost its entire existence on these two bulls. Victor Orange was an unusual breeding bull, and had he been given a chance to show well developed daughters he would have taken rank as one of the best bulls used in Kansas for years. It is only now since his daughters are scattered in many herds that he is being appreciated. Mr. Hill, in his private herd catalog, devotes a full page to Victor Orange. He was by the Bates crossed Scotch Victor Butterfly out of a dam by Scarlet Knight. Star Goods was a full brother to Bellows Bros.' champion, Diamond Goods, and was used on the Victor Orange cows. Most breeders rated him hardly so good a sire as Victor Orange.

Mr. Stunkel was taken sick at the Denver Show and died shortly after reaching home in March 1916. The entire herd of about 250 head, including calves at foot, was sold in August at adninistrator's sale. The cattle were in poor condition and brought an average of about $\$ 150$.

D. P. Norton, Morris County.-D. P. Norton was an enthusiast with a hobby that may not have been devoid of common sense. His hobby was opposition to Bates cattle and methods and a fixed determination to use bulls of Booth blood 
or at least as nearly without Bates blood as possible. He had a large herd southeast of Council Grove near Dunlap and he sold cattle at fair prices all over his section of Kansas. Taken as a whole his cattle were good ones and I find frequent instances of good herds descended from Norton bred cows. Mr. Norton was an effective advertiser and was one of the first to recognize the value of the magic term "imported." Following his custom of buying bulls in Canada, $\mathrm{Mr}$. Norton bought British Lion. He went out to the world as imp. British Lion. Technically this title may have been correct yet its use violated the Shorthorn custom. The Norton herd weathered the worst of the hard times but ceased to exist a number of years ago.

J. B. McAfee, Shawnee County.-Although quite a preacher and considerable of a politician, Mr. McAfee was also a good breeder of Shorthorns. He did not give his herd the publicity some breeder's gave their cattle, yet it is conceded that he produced a class of big, smooth, beefy Shorthorns. Some of the best thing's in T. P. Babst's herd were bred from McAfee cows and one of the cows so bred went to the Kansas State Agricultural College where she produced several outstanding show steers. H. W. McAfee, a son, bred Shorthorns on the farm a number of years after his father retired from the business. The location of the farm made a change in busi- 
ness advantageous and a dairy herd is now supplying milk from the old establishment. There is still a Shorthorn breeder, and a good one, in the family, Harry T. Forbes, a grandson.

C. W. Taylor, Dickinson County.-John Taylor, father of C. W. Taylor, was a Cincinnati merchant. He traveled horseback over Kansas in 1872 and bought a large tract of land in Dickinson county. He made up his mind that any dry land on which prairie grass would grow as high as his head when he was seated on a horse would grow anything and he let that be the test.

Mr. Taylor gave each of his children a section of the land with the injunction to hustle for a living. Besides the land C. W. Taylor received eight Shorthorn cows purchased from the Linwood herd and the bull Vandal used by Col. Harris. From this start the Taylor herd grew until it became one of the largest in Kansas, frequently numbering 300 head and its owner became comparatively wealthy. The herd received good farm care, no effort being made to produce the outstanding: Good bulls were bought and a heavy western and local trade followed.

D. L. Dawdy \& Co., Atchison County.-A firm consisting of D. L. Dawdy, J. W. Dawdy, and Walter Lattimer, all of Abbingdon, Illinois, bought the Shannon Hill Farm and Shorthorns of Governor Glick, November 1, 1891. D. L. 
Dawdy and Walter Lattimer came to Kansas and took charge. There were about ninety head of Bates cattle on the farm, headed by 53d Duke of Airdrie, which were sold at public sale in Kansas City the next spring at an average of more than $\$ 200$ with a top price of $\$ 800$. They bought and sold a number of herds, using the Glick farm as a base for operations until 1901 when they removed to Arrington in Atchison county. Walter Lattimer died in 1902 and after his death D. L. Dawdy handled the business individually.

H. M. Hill, Montgomery County.-It was not intended by Mr. Hill's parents that he should develop into a Shorthor'n breeder. Some of his boyhood friends have told ine of his early education and training for the legal profession and that the influence of an old Frenchman who kept some good grade Shorthorns weighed more heavily than did the ambitions of fond parents. However that may be, the young man, after having been a short time in charge of the family banking interests at Lafontaine, transferred his scene of action to a big tract of land, now known as Sycamore Springs Stock Farm, and in 1893 he bought a lot of Shorthorns from T. O. Ford of Liberty. In the same year he bought eight heifers of Senator Benedict. They were by the Williams Bros.' show bull, Dr. Primrose and by Banker 4th, Mr. Benedict's well known sire. 
Scottish Emperor, a splendid Cruickshank bull, was the sire in use. In $1900 \mathrm{Mr}$. Hill joined with C. E. Wolf \& Son, B. W. Gowdy, and J. F. Stodder in a public sale at Kansas City. Just
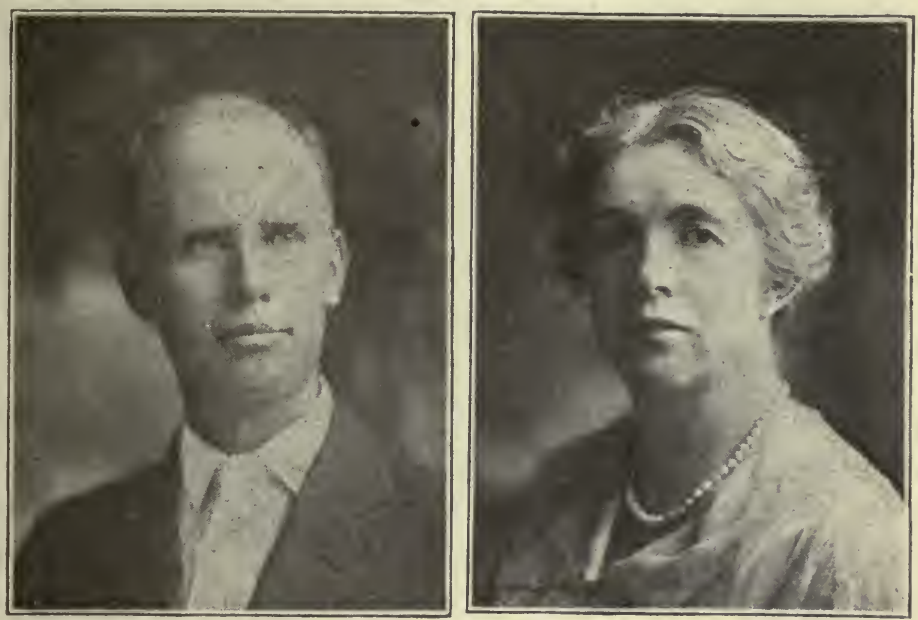

MR. AND MRS. H. M. HILL

prior to this time he had purchased from Hamna $\&$ Co. a few females, some of which were bred to imp. Mariner. Later he purchased imp. Mariner as well as Kinnellar, a son of imp. Dalmena Mina 5th. During a period of about ten years he used Mr. Hanna's importation more largely than did • anyone else, breeding cows amnually to imp. Collynie and making numerous purchases of Collynie cows. Some of the best Shorthorns in Kansas found their way into Mr. Hill's pasture. 
Among them were Syringia by Royal Knight and her great son, Prince of Collynie; Inglemaid by imp. Inglewood the dam of Ingle Lad; Sweet Mistletoe and Sycamore Secret by Collynie. Sweet Mistletoe was later sold to Lespedeza where she gave birth to Imperial Mistletoe and Lespedeza Collynie. Imperial Mistletoe was a leading show bull at two years old and sold for $\$ 4100$ and Lespedeza Collynie was grand champion at the International in 1919. I saw Sycamore Secret as a three-year-old heifer suckling a 600 pound calf and weighing 1700 pounds on grass alone, in August.

Two pastures full of such cows with Prince of Collynie in one and Ingle Lad in the other, wading in limestone blue stem nearly knee-deep-this is what I saw on my first visit to Mr. Hill's and I wondered how many western breeders could duplicate such a scene. It was on the same occasion some twelve years ago that for two days I was the guest of Mr. and Mrs. Hill. I want to add my testimony to that of the hundreds of visitors who have enjoyed Mrs. Hill's charming hospitality-generally credited with having been a great factor in the success of the business.

Both Prince of Collynie and Ingle Lad were freely used for a number of years and sired a lot of calves. Like other breeders, Mr. Hill failed to realize in advance the real value of the heifers. The few Ingle Lad cows now on the farm are 
great breeders and heavy milkers, while the only Prince of Collynie cow on the place is a veritable gold mine, figuratively speaking. Had Mr. Hill been able to foresee the future and save a lot of

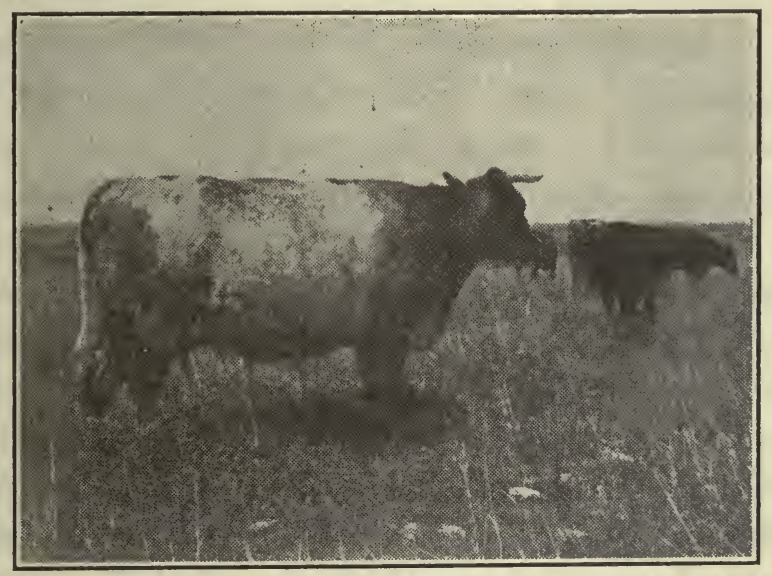

ROAN OLGA

the Prince of Collynie heifers rather than to send the bull to market while still useful, he could have scored one of the greatest hits in Shorthorn history. About five years ago Mr. Hill bought of Forbes \& Son, Master of the Dales by Avondale and the work of breeding Shorthorns has gone steadily forward, a fact which will be apparent to the reader of Part II of this book.

J. F. Stodder, Cowley County.-Mr. Stodder was one of the prominent breeders of southeastern Kansas. He was a good business man and it seemed every investment he made yielded a 
profit. He began his work by buying well bred stock from good herds but he was not a buyer of high priced females. Many of his cattle were purchased at a level of values that today would seem impossible. His first bull, Aylesbury Duke, was widely advertised. It was in the purchase of Captain Archer, however, that he made the hit so much desired by breeders.

This red dehorned son of imp. Collynie and imp. Mistletoe 15th, sired from the Scotch crossed Bates cows a class of stock that, as a whole, discounted the produce from the Scotch cows in the herd. The Stodder bred cattle were soon on the big show circuits winning more than their share of the honors. The cows that raised the show stock from the service of Captain Archer came largely from Fred Cowley's herd and were by Secret Archer, also a son of imp. Collynie and out of a daughter of Royal Knight, a son of imp. Princess Alice. It is not surprising that this mingling of good blood, practically unrelated to begin with, should produce unusual results.

After a few seasons use of Captain Archer. he was found dead in the pasture and the white bull Silvermine was bought and used in the herd. Silvermine sired an exceptionally attractive lot of roan heifers. Mr. Stodder's health failed in 1912 and he sold the herd at public suction in the fair grounds at Burden at an average of about 
$\$ 160$. Silvermine went to Marshall Bros. and for a number of years was one of the good sires in their large herd.

\section{Thomas, Jameison \& Mitchell, Wabaunsee} County.-E. K. Thomas, one of Kentucky's prominent breeders, Mr. Jameison, also of that state and their nephew, S. D. Mitchell, shipped 200 good Shorthorns from Paris, Kentucky to a large ranch near Allen, twenty-five miles north of Emporia. Mr. Thomas had been particularly successful with a family that came to be known as the Thomas Young Marys.

Under Mr. Mitchell's efficient management the herd rapidly took rank with the best in the state. The noted bull Barrister, winner of 247 first prizes, was chief herd bull. In addition to these Young Marys, Mr. Mitchell bought Scotch cows, one of the most notable purchases being the white cow, imp. Bessie 51st. This cow was in calf to the champion, Choice Goods, then at the height of his popularity. She produced a white bull, later well known as White Goods. It is speaking conservatively to say that White Goods was one of the very best of the champion's get. Mr. Mitchell used this bull without hesitancy and also showed him successfully. He proved a breeder of wonderful merit. Another bull used was Orange Viscount.

Mr. Mitchell began showing west of the Mississippi in 1905 and the herd won its full share 
of prizes. Mr. Jameison died in 1908 and the herd was dispersed at public sale in Kansas City, the high average being nearly $\$ 300$. White Goods, the main attraction of the sale, went to Idaho at $\$ 1150$ and became the leading show bull of the Pacific coast. Imported Bessie 51st went into Brown county and became the dam of several good bulls. Harriman Bros. bought 46th Duchess of Gloster with her bull calf. The calf was sold as a yearling to C. S. Nevius where, under the name of Searchlight, he did his share toward building up Shorthorn interests in Kansas and Oklahoma. Mr. Mitchell had a herd of his own when the partnership herd was dispersed and he continued to breed successfully on a smaller seale. An account of his work will be given later.

E. H. Rutledge, Rice County.-In about 1905 Mr. Rutledge established a herd of wonderful promise. The cows had been carefully selected and the outstanding bull, Double Champion, was bought from Tebo Lawn. This bull was by Choice Goods and out of Russella, the dam of the undefeated heifer and cow, Ruberta. Not long after the purchase of Double Champion Mr. Rutledge bought Liberty Boy, a splendid son of the grand champion, Viscount of Anoka. Both of these bulls proved excellent breeders and the herd bade fair to become of state-wide importance. Unfortunately for Shorthorn interests in central Kansas, Mr. Rutledge died suddenly and the entire herd 
was dispersed. Most of the cattle sold locally at a low price to people who did not realize their value. Several good herds in central Kansas, however, descend from the Rutledge herd.

Herds of Minor Importance.-During the years covered by the preceding sketches many herds were founded over the state that were of considerable importance locally. Only a few of these herds left any impress on the cattle of this time yet they are well worthy of mention. It has been possible to obtain data on many of these breeding establishments while probably many others equally worthy of recognition are omitted. These herds are grouped largely by counties and localities rather than according to the period of time in which they existed.

J. Clarence Norton of Allen county was one of the earlier breeders. Mr. Norton was a brilliant man who was very much given to accepting statements as positive facts and coming to conclusions without thorough investigation. One of his hobbies to which he gave much publicity was that cattle would thrive as well or better without salt as with it. He was a frequent contributor to the farm press and a very willing speaker at farmers' institutes. His Shorthorn herd, which was maintained for a good many years, was of medium quality and of local importance only.

Of somewhat more recent origin than the 
Norton herd was that of R. O. Furneaux near Moran. From a modest beginning with medium cattle his herd developed into one of the good herds of the county.

Another Allen county herd was that of Jewell Bros., which for a number of years was probably the best in the county. Both the proprietors are still engaged in the business owning individual herds.

B. W. Gowdy of Anderson county bred quite a number of Shorthorns but was better known as a dealer than as a breeder. He was prominent. in the trade from 1897 to 1905 . His commercial instincts were highly developed, too highly, perhaps, for best results as a breeder.

Walter Lattimer, son of the well known Illinois family of breeders, who was associated with D. L. Dawdy in the ownership and management of the Glick herd also maintained a herd near Garnett. The cattle were largely of the Glick stock and the earlier bulls in service were of Bates extraction. Later Mr. Lattimer changed his course by buying the great Bellows bull, Valley Champion. J. B. Fergus, a well known resident of Allen county, was herdsman for $\mathrm{Mr}$. Lattimer during the time he operated near Garnett.

A. M. Ashcraft of Atchison county was in business from 1894 to 1904. He bought a few females and built up quite a large herd. He did not.at 
first use bulls strong in Scotch blood but later he bought of T. P. Babst the excellent bull, Harmony's Knight, and followed with Scottish Minstrel secured from Thomas, Jameison \& Mitchell. Mr. Asheraft was a good advertiser and people generally found out that he raised Shorthorn cattle. Two of his sons, Asheraft Bros., sueceeded to the business.

Another early Atchison county herd was that of J. L. Miller of Arrington. Several of the family are living in the neighborhood in which this herd was kept and are breeding Shorthorns. John Q. A. Miller, living on the old home farm, has quite a herd.

J. B. Stockstill of Barber coünty built up a large herd from a small start made in the nineties. The cattle produced were of good size and of fairly good quality. Double Ury from Thos. $\mathrm{H}$. Mastin's herd, Joe's Lord by Lord Mayor and Red Oak by imp. Collynie, all good bulls of excellent ancestry, did most of the service. This herd was sold to J. E. Thompson of Fredonia about 1910 and after breeding from them for a few years Mr. Thompson dispersed them at public sale.

Frank Rockefeller of Kiowa county, a near relative of the oil king, was something of a cattle king in his community. His operations at one time extended to several counties and he bred Shorthorns quite extensively. While his cattle 
were kept in the way peculiar to the ranches of the Southwest he succeeded in producing some quite creditable specimens of the breed. The pure bred herd has recently been dispersed.

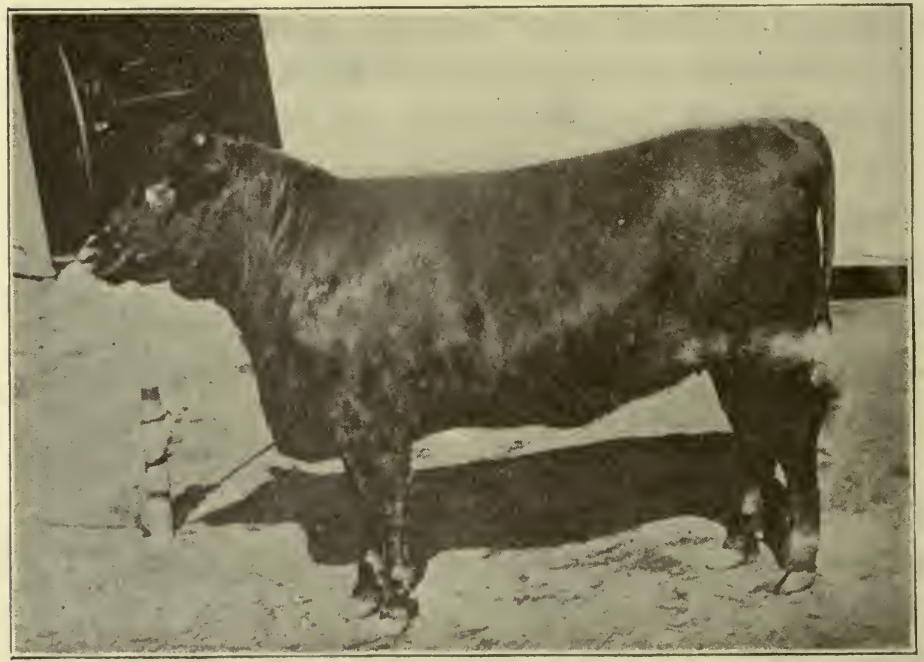

THE FIRST CALF EVER FITTED FOR SHOW BY TOMSON BROS.

Everett Hayes was one of the well known breeders of Brown county. He owned some good cows of very popular breeding and he bought at one of the Chicago sales the white bull, Snowflake, later destined to fame as the sire of Ringmaster, the only bull that has ever been three times International grand champion. The best of the Snowflake calves were in demand to go into good herds and had Mr. Hayes continued 
his operations for a longer time he would doubtless have been classed as a very successful Shorthorn breeder. The herd was dispersed at public sale in 1911.

Another Brown county herd was that of D. E. Reber. Mr. Reber began buying a few Shorthorns soon after 1900 some of which were secured locally but he also patronized the herds of F. O. Lowden and M. E. Jones of Illinois, the Tebo Lawn herd and that of Bellows Bros. From the latter he secured Diamond Emblem, the highest priced bull of his year in the Bellows Bros. sale and a son of the noted cow, Emily by Collynie. The herd was dispersed about 1915, Diamond Emblem going to T. J. Dawe \& Son of Doniphan county who exhibited him at leading western state fairs winning numerous first prizes and championships.

E. D. Ludwig of Sabetha, either accidently or from previous knowledge, purchased a bull that later became nationally famous as the sire of numerous state fair, American Royal and International champions. Barmpton Knight, one of the great bulls of the breed, sired a lot of calves in Mr. Ludwig's herd that made such a favorable impression on Tomson Bros. that they decided to buy and did buy the old bull at the Ludwig dispersion. There is little else to say about this herd for Barmpton Knight was virtually the whole herd, as a bull of his quality always is, and $\mathrm{Mr}$. 
Ludwig's fame as a breeder rests wholly upon the achievement of this great bull.

T. J. Dawe began breeding Shorthorns in Doniphan county in 1882, buying his foundation of

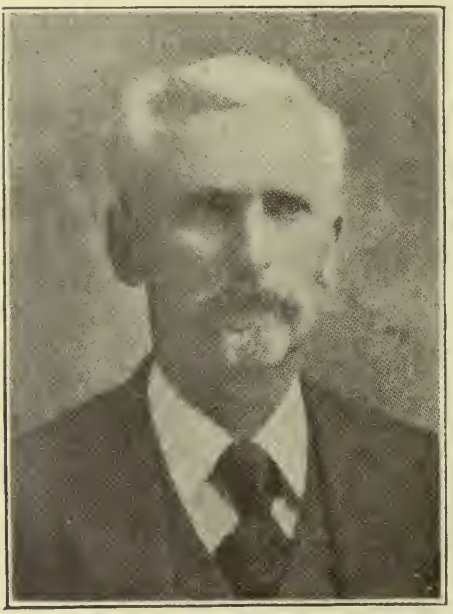

T. J. DAWE Hiawatha

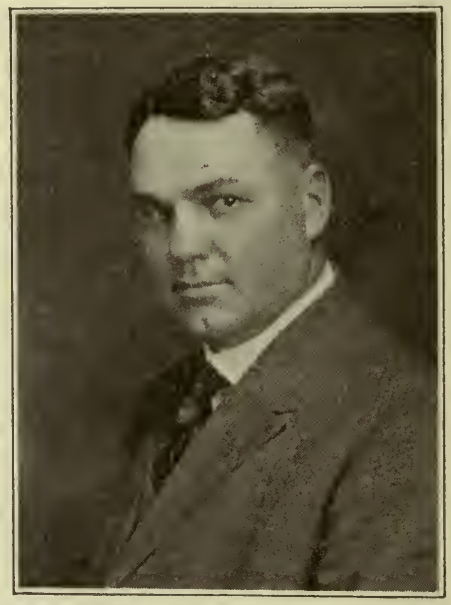

GEO. S. MARSHALL Basehor

local breeders and he has been in the work continuously since that time. In 1910 associated with his son "Jim" under the firm name of T. J. Dawe \& Son, the firm changed its methods of operation by making purchases of choice cattle from the leading herds of America. In 1911 they began showing at the St. Joseph fair and at Topeka and Hutchinson winning their share. of the ribbons. They owned and exhibited Diamond Emblem, one of the best known show and 
breeding bulls in the state, until his death from forage poisoning in 1919. Mrs. E. A. Myer, a daughter of T. J. Dawe, is living on the old farm near Troy and with her husband is engaged in breeding Shorthorns.

W. J. Snodgrass was an old time Butler county breeder of fairly good cattle who happened to buy a bull that made his reputation in south central Kansas. This bull was Scott Jr. by imp. Scottish Emperor. He was bred by H. M. Hill and shown at the Wichita fair where, after having won first prize, he was sold to Mr. Snodgrass. He was liberally used in the Snodgrass herd where he sired an exceptionally good class of calves. In the show ring he seldom, is ever, met defeat and he was exhibited against the entries of such showmen as J. F. Stodder. Several of Mr. Snodgrass' sons took up Shorthorn breeding but they are now all out of the business. Well advanced in years and looking back on an unusually active life, Mr. Snodgrass is living quietly in Wichita.

L. B. Hull is another Butler county breeder who for ten years was well known in local Shorthorn circles. He made no effort to produce anything better than a medium class of cattle.

H. C. Stephenson of Chase county bred Shorthorns for fifteen years, producing a nice, smooth, attractive lot of cattle of excellent feeder's' type which furnished the foundation for 
numerous pure bred herds. On account of $\mathrm{Mr}$. Stephenson's poor health the herd was dispersed privately early in 1919. As will be seen in Part II of this book the Stephenson cattle became a prime factor in building up several herds in the eastern half of the state. Among those who took advantage of this dispersion were W. J. Sayre, H. M. Schoepflin, C. E. McFerrin, F. N. Funk and others.

Master of the Grove, American Royal and International grand champion bull, was developed by J. W. Baker of Chase county and sold by him to Bellows Bros. who exhibited him. It is said that Mr. Baker gave this bull more than usual care which, in view of the fact that he had no family upon which to lavish his affections, is not surprising. Mr. Baker's herd was small and aside from his connection with Master of the Grove he was known only locally.

In founding his herd Fred Cowley of Cherokee county made judicious selections, principally of Scotch crossed Bates cattle. In buying these cattle he had the assistance of that excellent judge of Shorthorns, John McDermaid. He used the Harris bred bull, Rodney by imp. Pirate and the Bellows bred Albion by Valley Champion. His greatest breeding bull was doubtless Secret Archer by imp. Collynie. Secret Archer was the sire of numerous cows sold to Fred Stodder that bred to Captain Archer produced 
a large number of the Stodder show cattle. Mr. Cowley was associated with S. C. Hanna and H. M. Hill in promoting the Fredonia sales held annually from 1906 to 1914.

Another Cherokee county breeder was S. L. Cheney. who owned quite a large herd in the eighties and nineties. The first good bull bought by $\mathrm{Mr}$. Cheney was the well known Goldendrop of Hillhurst, by the way, the first good bull owned by Col. W. A. Harris and recognized as the predecessor of imp. Baron Victor. He was followed by the Potts bred Orange Blossom of Oakland, a son of imp. Antiquary. Later Mr. Cheney bought what became his best known bull, the Davidson bred Orange Blossom Perfection. While most of the cows were of the commoner kind he owned some good ones and the descendants of these, nearly all of the Cruickshank Orange Blossom family, figured in the pedigrees of several good herds.

One of the greatest show bulls ever seen in America was for one season owned and exhibited by a resident of Cherokee county. M. A. Householder of Columbus, associated for a time with Williams Bros. under the name of Williams \& Householder, is credited as having been the exhibitor of imp. Cupbearer. Mr. Householder bred a few Shorthorns but little stock is recorded as bred by him.

Beginning in 1898 Adam Andrew of Craw- 
ford county gradually built up his herd to about fifty females. Local trade took the surplus and in $1914 \mathrm{Mr}$. Andrew held a public sale disposing of all but a few of the best females and the herd bull, Orange Major. He has continued his breeding operations and his herd which is better than ever is dealt with in Part II.

From about 1900 to 1917 Marshall Bros. of Cowley county bred Shorthorns, supplying the local and western trade, and producing a desirable class of cattle with plenty of size. The herd grew to be one of the large ones of the state. Among the best known sires in use was Scottish Prince, a Hanna bred son of imp. Lord Cowslip. At the Stodder dispersion sale Marshall Bros. bought the senior herd bull, the white, Silvermine, the sire of the attractive lot of roan heifers sold by Mr. Stodder. The herd enjoyed an unusually good patronage from Oklahoma breeders until its dispersion in 1917. Lee Marshall who was the active manager of the establishment is now living in Wichita and has transferred his activities from Shorthorns to the manufacture of paint.

Clay Harrington and H. M. Harrington established herds in Sedgwick county near Clearwater in about 1900. Although these herds did not become prominent yet they were numbered among the large ones of the state. The surplus was sold principally in Oklahoma. 
David Ballantyne, a shrewd Scotchman, who came to Dickinson county forty-five years ago, was connected with the Shorthorn industry until the business was turned over to his son, T. A. Ballantyne, in about 1917. The herd frequently numbered as many as 100 head and $\mathrm{Mr}$. Ballantyne, who had the regulation Scotch idea of selecting stock with only merit and adaptability in view, refused to be sidetracked by fads. There were few more practically useful herds in the state than this one. Among the best bulls were Marshall Abbotsburn 3d, bred in Canada; Collynie's Pride by imp. Collynie and Wooddale Chieftain by The Choice of All. Mr. and Mrs. Ballantyne have made frequent trips to Scotland within the past forty-five years and every member of the Ballantyne family has accompanied them on one or more of these trips. Since $1917 \mathrm{Mr}$. and Mrs. Ballantyne are living in Herington.

H. R. Little of Dickinson county had a large herd from which numerous small herds in the state were founded. His activities began in about 1895 and continued for about ten years. Mr. Little was inclined to favor bulls with only a light infusion of Scotch blood and for this reason he did not secure best results. In some cases, however, the cows from his herd have produced wonderful calves when crossed with good Scotch bulls. 
Geo. Channon was another of the early breeders in Dickinson county who raised the foundation stock for a number of smaller herds in central Kansas. His cattle were not given as good development as they should have received but they did well for their purchasers.

C. M. Garver was for a number of years rated one of the best breeders in Dickinson county. He owned the show bull, Royal Gloster by imp. Daydream's Pride. Mr. Garver closed out his herd in 1908 selling Royal Gloster to O. L. Thisler also of Dickinson county.

Mr. Thisler began breeding in 1890 and was quite well known over the state. It was in 1910 that he decided to change his line of business and engage in the production of Percherons. With this object in view he sold his Shorthorns, about fifty head, including the bull, Royal Gloster to John W. Tredway, receiving in exchange a lot of Percheron mares. Mr. Tredway sold these cattle in the fall sale held by the Woodson County Breeders Association at Yates Center in 1910 and several of the best cows were bought by Lauber Bros. of Yates Center. Royal Gloster was sold to E. S. Myers of Chanute.

J.H. Taylor \& Sons of Chapman began breeding during the eighties and one of their first bulls was the famous old sire, Golden Knight, purchased from the Kansas State Agricultural College at the time the college herd was dispersed 
as a result of the political fight which involved the Board of Regents. The Taylors have been in the breeding business ever since and will probably continue indefinitely, at least as long as the boys of the present family live.

Bill \& Burnham of Manhattan began business by buying some of the choicest cattle at Durham Park in 1878 and for the next few years they added to their herd by purchase. They owned the bull Viscount, by the Crane bull Knight of the Purple and out of a daughter of imp. Dorothy. They also bought of Col.' Harris the imported Cruickshank bull, Double Gloster. From the Dryden bred Cruickshank cow, Golden Queen by Royal Barmpton, they raised a bull by imp. Earl of Aberdeen that was named 2d Earl of Aberdeen and used freely in the herd. Bill \& Burnham continued breeding until near the close of the eighties.

B. F. Lorimer of Great Bend was an active breeder in the nineties and members of the Lorimer family have been producing Shorthorns in Barton county until recently.

Ewing Bros. and others of the Ewing family bred Shorthorns in Barton county and adjacent territory for a number of years, producing a good class of cattle which have found their way into other herds.

Geo. B. Ross of Sterling at one time owned a large herd in Rice county and, while it was never 
an important factor in Shorthorn trade, it furnished the foundation for a good many herds in central Kansas and a few in Oklahoma. Occasionally a herd is found in which nearly all the

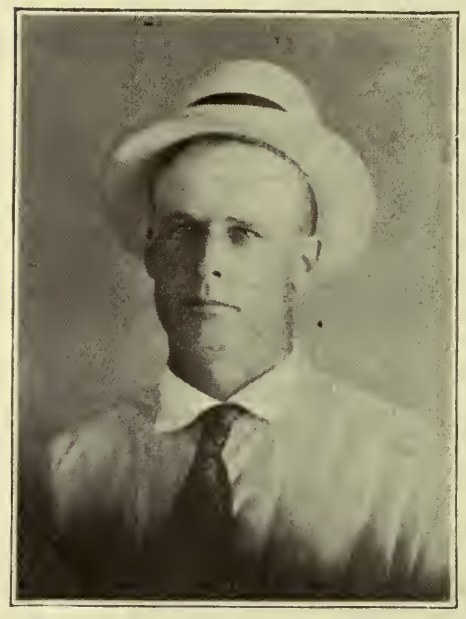

E. S. DALE Protection

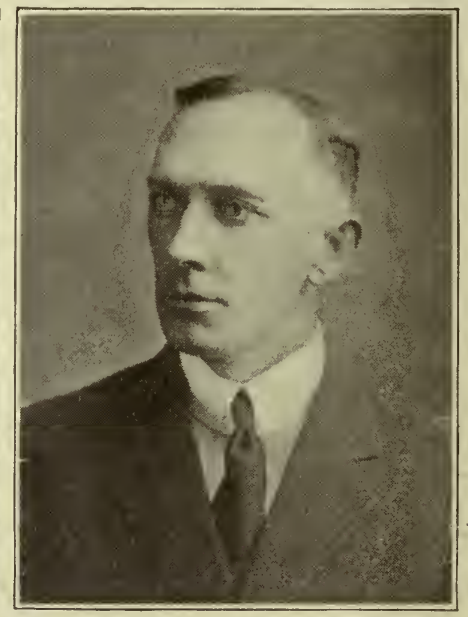

FRED ABILDGAARD Winfield

cattle are descended from Ross stock. Mr. Ross is best known the state over as a leading Democratic politician. He is a man of great ability and it is probable that had he devoted his entire time to the production of Shorthorns instead of dividing his interests between Shorthorns, Percherons, Poland China hogs and politics he would have produced a herd that would grade with the best in Kansas. As it was he produced some really good stock. The period of his active operations extended from 1897 to 1907. 
Dr. R. A. Stewart of Hutchinson is remembered as having owned one of the leading herds in central Kansas. Under his own name as well as under the name of Stewart \& Downs he exhibited at leading shows and for several years cattle of his breeding won many prizes. The best known sire in use was Victor Archer, a Tomson bred son of Archer out of a Gallant Knight dam. This bull later did good service in several other herds and left many worthy descendants in central and south central Kansas. To use on the Victor Archer heifers Forest Knight by Gallant Knight out of a B. O. Cowan bred dam by Norfolk was purchased of Tomson Bros. The herd was dispersed by private sale about 1914 .

J. C. Hyde bred Shorthorns for many years in Harvey county and his name appears frequently in the pedigrees from other herds. His work was of local and western interest and extended until about 1902. One of his sons, J. W. Hyde, is the oldest established breeder in Wilson county and another son, Fred, is also breeding in that county. Several grandsons of J. C. Hyde are engaged in breeding Shorthorns.

J. F. True was one of the best known breeders of Jefferson county during the eighties and nineties. Volume 29 of the American Herd Book contains the pedigrees of five cows and heifers bred by Mr. True and cattle of his breeding are recorded in nearly every volume up to 
60 , also in $64,65,70$, and 71 . He believed in advertising and made liberal use of the press in keeping his herd before the public. The cattle were sold about 1900 or shortly thereafter when Mr. True moved to Topeka. It was he who was given the work of collecting funds in Kansas for the erection of a monument to Col. W. A. Harris on the grounds of the Kansas State Agricultural College.

V. R. Ellis of Franklin county established a herd in about 1884 which furnished the basis for success in numerous other herds. The big beefy bull Godwin, son of imp. Spartan Hero and imp. Golden Thistle, two of the best animals of their day; was used and proved a sire of valuable breeding cows. Sir Charming 4th, a Norton bred bull of his Sweet Charity line was also used. This herd was not appreciated at its full worth until after its sale to T. K. Tomson \& Sons when the Godwin cows added prestige to the Tomson herd in producing show stock.

Records do not show that J. C. Stone, Jr. of Leavenworth county bred any considerable number of Shorthorns. He did, however, do a big business in bringing the so-called Bates bulls and some females from Kentucky during the late seventies and early eighties. He continued handling Shorthorns and breeding a few until 1898 when the last, or one of the last, of his breeding was recorded. Mr. Stone is known in Short- 
horn history as the man who brought Golden Drop of Hillhurst to Kansas and sold him to Col. Harris.

H. E. Hayes of Johnson county for a number of years kept a choice collection of the breed which was dispersed at public sale in 1908. Lord Banff 2d, a son of imp. Lord Banff, was in service practically all the time the herd was maintained and near the close of its existence Baron Marr, an excellent son of Cumberland's Last out of imp. Lady Marr, was purchased. The calves of this bull were of outstanding quality. The best of the females went into good herds and Baron Marr went to the Deming Ranch at Oswego where, after a year's use, he was killed by lightning. The cow sold in the State Association sale, June 1920, at Manhattan for $\$ 3900$ was out of a daughter of Baron Marr purchased in dam by Prof. R. J. Kinzer while head of the Department of Animal Husbandry of Kansas State Agricultural College.

O. E. Morse \& Sons were among the early breeders in Linn county and both the sons, T. W. Morse and S. T. Morse, still sometimes talk like Shorthorns breeders. Their herd, though never large, was a credit to the breed and was dispersed because the junior members of the firm decided not to follow farming. It was a real factor for good while in existence and was closed out at public sale about 1910, local breeders 
taking most of the cattle. The herd bull went to A. M. Markley \& Son where he continued the good work for which he had been noted in the Morse herd.

The work of W. B. \& M. Hawk of Marshall county covered a period of ten years from 1887 to 1897. They used first-class bulls, two of which were Sandoval and the well known Galahad, both of Col. Harris' breeding. Galahad was later bought back by Col. Harris and used at Linwood where he sired much good stock including the noted show and breeding bull, Gallant Knight. Cattle descended from the Hawk herd are frequently found.

D. Tennyson also of Marshall county had a herd of more than ordinary merit. He owned at different times excellent bulls, one having been the imported Cruickshank bull, Prime Minister. Cattle of Mr. Tennyson's breeding were widely distributed and were generally of high quality. One of his sons, A. A. Tennyson of Lamar, is the owner of a splendid herd, a large proportion of which is descended from cattle bred on his father's farm.

Though little known away from home, the name of James Gregg of Seneca carries much prestige in Nemaha county. For a number of years Mr. Gregg owned one of the large herds of the state, recording as high as sixty head in a single volume of the herd book. His operations 
extended from 1895 to 1905 . Like many others who have established large Shorthorn herds Mr. Gregg did not fully appreciate the great value of an extraordinary bull and for that reason, more than for any other, his herd did not assume statewide importance. Probably the best bull he used was the Harris bred Rodney, a Scotch crossed bull by imp. Royal Pirate. The use of this bull was attended with considerable success.

C. W. Merriam of Topeka owned and extensively advertised Aylesdale Farm. Mr. Merriam, who was a land loan and mortgage broker, handled the farm as a side issue and operated it by proxy. He owned at one time a lot of cows bred by T. P. Babst among which the daughters of Lord Mayor were especially attractive. Although he produced some good cattle he did not attain the success that would have been possible had he been a professional cattle man and in a position to give his herd his entire personal attention. Good breeders who knew the establishment well have stated that Mr. Merriam failed to use a bull of sufficient merit to produce best results from such high-class cows as he owned. The herd was dispersed a few years ago at private sale and the farm was sold to $\mathrm{H}$. H. Holmes then of Great Bend and is now one of the well known Shorthorn establishments of the state.

M. A. Lowe of Topeka who began breeding in 
the latter nineties owned a class of cattle that were well appreciated and many of them found their way into good herds. Golden Lad bred by C. B. Dustin and sired by the show bull, Golden Rule out of the noted cow imp. Germanica 2d, was doubtless Mr. Lowe's best bull. A number of the cows from this herd and the bull, Golden Lad, were sold to W. C. Edwards of Wichita for his Pawnee county establishment. This bull was used with much success by Mr. Edwards.

Another Shawnee county herd that won considerable fame during the early part of this century was that of D. C. VanNice of Richland. This herd of Polled Shorthorns was exhibited successfully at some of the large fairs and his big red bull Belvedere was for several years the best known Polled Shorthorn bull in the state. At the 1910 Topeka state fair Mr. VanNice showed a roan cow that, judged for the producion of both beef and milk, had few equals anywhere. The herd was closed out a few years ago.

Hoadley \& Sigmund and George H. Hoadley \& Son established a herd in Sheridan county shortly after 1900. From the beginning they used bulls of better ancestry than were found in most herds, one of the first having been Baronet of Maine Valley, bred by Chandler Jordan. Some of their cows were bred along prevailing fashionable lines. This was one of the herds earliest established in the northwest section of Kansas. 
A HISTORY OF SHORTHORNS IN KANSAS .

S. S. Benedict of Wilson county, extensive farmer and successful politician, was also a suc-

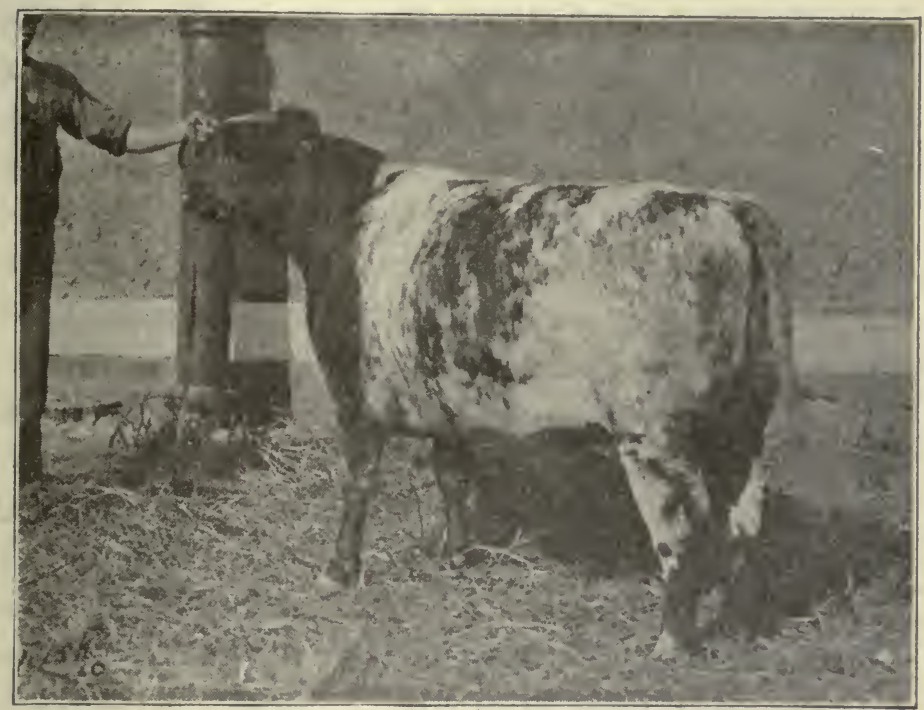

NEW YEAR'S DELIGHT

Grand champion for Tomson Bros. everywhere in the West.

cessful Shorthorn breeder. The herd was best known in southeast Kansas. He used a succession of desirable bulls among which were 20th Earl of Valley Grove by Lord Mayor; Banker 4th, bred by Powell Bros. of Missouri and Williams Bros.' noted show bull, Dr. Primrose. 20th Earl of Valley Grove had been used by F. C. Kingsley of Shawnee county where he proved a great sire of good breeding cows and in Senator Benedict's herd he fully sustained the 
reputation he had established. Many of the cattle used by H. M. Hill in his early operations were of Senator Benedict's breeding.

C. H. Clark and Clark Bros. came from Iowa to Kansas in about May 1895. They had been extensive breeders in that state and brought with them large herds one of which was located in Wilson county and the other near Colony in Anderson county. The Clarks made the common mistake of using herd bulls of only medium quality and for this reason they produced little highclass stock. Cows and heifers from their herds have been scattered widely over southeast Kansas and, though not of the highest quality, have generally proved good breeders and when crossed with high-class Scotch bulls they have given satisfactory results.

C. H. Kimble was one of the old breeders of Wilson county. He did not at any time confor'm to fashion in pedigrees but he produced good cattle. One of the best heifers sold by H. M. Hill in a notable offering at the Fredonia sale was bred from Kimble stock and traced to the so-called American woods.

J. H. Bayer of Woodson county bought a cow in 1883 for $\$ 100$. He sold all the bull calves from this cow and he saved the heifers. In 1897 he bought four heifers at $\$ 25$ to $\$ 40$ each and by 1905 he had sold many Shorthorns at a big profit. Mr. Bayer's experience shows that frequently 
fiom a small outlay can be established a herd that even in a few years will make a man comparatively wealthy. In 1905 he closed out his farm business after starting both his sons and a son-in-law with Shorthorns from his herd. A grandson, Henry B. Bayer, a graduate of the Kansas State Agricultural College, living three miles southwest of Manhattan, is a promising young breeder and several other grandsons are now students at the college.

H. G. Slavens, also of Woodson county, produced Shorthorns from 1895 to 1912 when he was forced to discontinue because of failing health. Dr. Slavens was fortunate in the selection of his foundation stock having bought from a good Iowa herd at a time when fifty dollars would buy a very choice cow. He also made a hit in the purchase of the bull Red Gauntlet by Godoy. Dr. Slavens was a Shorthorn enthusiast, a good feeder, and a close student and had he retained his health he would have made a great success of the breeding business. The herd was dispersed in 1912, five excellent heifers going to Hall Bros. of Allen county.

F. H. Conger of Yates Center was another Woodson county man who developed a large herd. His foundation stock was bred by H. J. Masters of Nebraska and the cows purchased were sired by St. Valentine 12th, an excellent son of St. Valentine. Mr. Conger made a 
fortunate purchase of Lavender's Best from D. K. Kellerman \& Son and a very unfortunate investment in the purchase of a successor to Lavender's Best at a low price. The Lavender's Best cows were an unusually good lot. Nine of them were at one time owned by J. T. Bayer and were the admiration of local breeders. Mr. Conger closed out the herd in 1907, having been in the business for ten years.

Another Woodson county owner of a large Shorthorn establishment which he operated during the same period in which J. H. Bayer, Dr. Slavens and F. H. Conger were actively engaged in breeding, was John A. Seaton. Mr. Seaton and several sons came from Iowa in 1900 bringing with them cattle purchased from several of the well known herds in the vicinity of Newton. They owned 1000 acres of land near Vernon and the cattle had not only plenty of good feed and good care but the herd had the use of a strictly high-class bull in Prince Imperial 2d, an Albert Harrah bred son of Canute. Mr. Seaton died in 1906 and the herd was dispersed by public sale. Prince Imperial $2 d$ that had developed into a first-class show bull and an outstanding sire, only six years old when sold, was allowed by the breeders present to be purchased by a shipper for $\$ 85$ with 4 per cent off for cash to be sent to Kansas City two days later where he brought \$125 for beef. 


\section{THE FINAL TEST}

It has always been claimed by Shorthorn supporters that this breed alone, among all improved breeds, furnishes the kind of cows needed on the small farms where the production of cattle for the beef market must necessarily be from cows that also furnish a reasonable amount of milk. The contention is that the Shorthorn cow will produce as good a beef animal as any cow of any other breed and at the same time will give milk enough to properly raise her calf as well as to furnish dairy products for the family and for market. It is pointed out that no cow of any other breed will do this or that if any cow be found among the other breeds with such an accomplishment to her credit she is a rare exception. In order that some definite figures might be obtained which would show to just what extent beefy Shorthorn cows that would produce good beef calves would also produce dairy products in paying quantity, an experiment was begun at the Kansas Station in 1915.

The Department of Animal Husbandry of the College, then in charge of W. A. Cochel, in cooperation with the Bureau of Animal Industry, U. S. Department of Agriculture, started a breeding experiment that is developing, in fact 
it has already developed, into one of great importance to Shorthorn breeders and to the farmers of Kansas in general. Twenty head of Short-

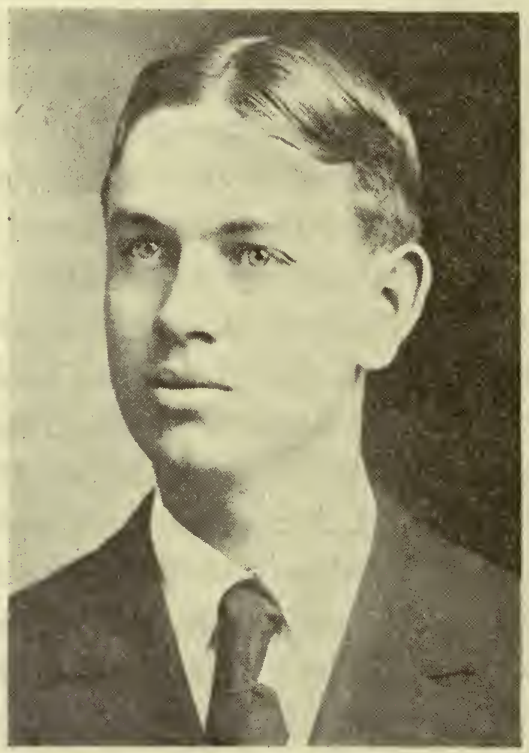

C. W. McCAMPBELL

Head of Department of Animal Husbandry, Kansas State Agricultural College.

horn cows of good breed type and every one at least good as a beef animal were chosen for the experiment which is to last twenty years. The chief object of this experiment as stated in the plan originally adopted was:

1. To what extent does the milk-giving function of the dam influence the beef character of progeny? 
2. By mating thickly-fleshed beef bulis whose dams were heavy milkers and beef cows which transmit beef character to their progeny is it possible to establish a heavy milking strain of beef cattle within a breed, the female progeny of which will be double purpose beef and milk animals and the males strictly of the beef type? In other words, is it possible to retain the typical beef form in the male animals and increase the milking tendency of the females?

Dr. C. W. McCampbell who was placed in charge of the Department of Animal Husbandry July 1, 1920, did not feel that the object had been well stated or that it was practical and changed the plan to one of attempting to show that both male and female can and should be of the same type-broad, deep and thick and that such females can and should be able to produce strictly beef type calves and 6,000 to 10,000 pounds of milk anmually. It is quite apparent that it will require several years to develop such a test yet results to date show that the new plan is both practical and feasible for practically all the cows now in the test are the broad, deep, thick kind and they are producing broad, deep, low-set, thick calves and a heavy flow of milk. Only a few need be mentioned.

1. College Emma 106095, a big, thick, smooth Scotch "Butterfly" is the dam of the first prize junior yearling steer at the International Live 
Stock Show at Chicago. She has a milk record of 7061.5 pounds of milk in a year.

2. Gwendoline 79th 217427, an exceptionally sweet, broad-backed, deep, thick, beautifully bred Scotch cow sired by Leader of Fashion; first dam by a son of Whitehall Sultan, second dam by Knight of the Thistle, third dam by Imp. Cupbearer is producing very sweet, compactly-made, thick-fleshed calves of unusual merit. She also made the Shorthorn registry of merit as a twoyear-old with a record of 5796.1 pounds of milk.

3. Pride's Bessie 206445 is a splendidly bred Marr "Bessie" and a beautiful type of beef cow with a milk record of 9210.5. Her calves since coming into the herd have all been bulls. They are very much in demand as herd headers for good pure bred herds. Pride's Bessie was the first. Scotch cow to be accepted in the advanced milk registry for Milking Shorthorns. Her record is 9210.5 pounds of milk.

4. Red Rose 190448 a Scotch "Queen of Beauty" is a broad, deep, square-ended, thickfleshed cow that is producing splendid calves. She has a milk record of 7027.1 pounds of milk.

5. Lavender $\mathrm{T}$ 180790, a beautifully bred Scotch "Lavender", is a very broad, deep, lowset cow that produces the same kind of calves. She has a record of 7209.1 pounds of milk.

6. Cream Toast 87609 by Ingle Lad, a son of Imp. Collynie, dam by another son of Collynie 
and second dam by Golden Lad, is producing exceptionally thick-fleshed, strictly beef type calves. She has the high record of 10203.2 pounds of milk.

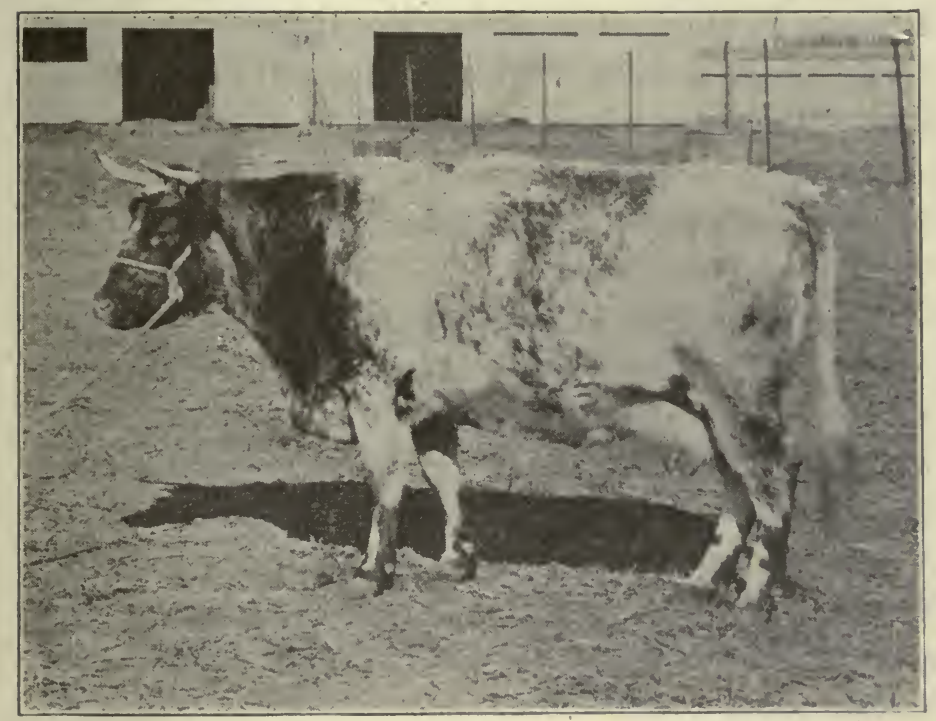

CREAM TOAST

Milk record 10,203.2 pounds. Owned by The Kansas Agricultural College.

7. Matchless Queen 180093 by Matchless Dale a son of Avondale; dam by a son of Collynie, second dam by Lord Thistle, third dam by Imp. Bapton Arrow, is a cow of unusual width, depth and compactness. With this she has a world of quality and character. Her calves are of exactly the same type. She is a full sister to the reserve 
champion steer at the International in 1916 and has a record of 8733.1 pounds of milk.

8. Sultan's Rose 489202 has developed into a cow of outstanding beef type with a lot of character, quality and size. She is sired by a grandson of Whitehall Sultan; her dam by a son of Whitehall Sultan and her second dam by the Marr "Missie" bull imp. Golden Banner. Sultan's Rose made the registry of merit for milk production with a record of 5639.8 pounds of milk as a two-year-old.

An interesting feature relating to these milk records is the fact that none of these cows except Gwendoline 79th and Sultan's Rose were millied until they were mature cows, Cream Toast. for instance being seven years of age before entering the experiment. Neither have these cows been forced for milk production. They have been maintained simply as beef rather than dairy cows.

All heifers will be developed and whenever a heifer develops into a better beef type cow, produces a better beef type calf and at the same time produces more milk than a cow in the experiment then such heifers will be substituted for the less desirable cows in the experiment. 


\section{TWO NOTABLE EVENTS}

The largest importation of Shorthorn cattle ever brought west of the Mississippi was made in 1920 by J. C. Robison of Towanda. For years Mr. Robison had been breeding Percherons, first with his father and later on his own account, and as something of a side line had raised a good many Shorthorns.

Mr. Robison left home July 18, 1919, landing in Southhampton August 2. It had been planned to visit the herds of Great Britain in general but on the day he landed he learned that foot and mouth disease had broken out in England and that trade in cattle would have to be limited to the herds of Scotland. While spending almost three months with Scotch breeders he secured thirty-five females and ten bulls. After many complications the cattle were shipped January 19, and after a very rough voyage of twenty-six days, nearly twice the usual time required on the. trip, they landed at Baltimore with no loss except that of two small calves. The cattle came from Perthshire and Aberdeenshire and included representatives from such noted herds as that of Robert Bruce, James Rennie, James Durno, Sylvester Campbell, Alex Sutherland, and the most noted herd of 
A HISTORY OF SHORTHORNS IN KANSAS

all, William Duthie. Of this importation Mr. Robison sold twelve females and three bulls in the Salter-Robison sale at Wichita, May 15, 1920 and one heifer on May 26 at the

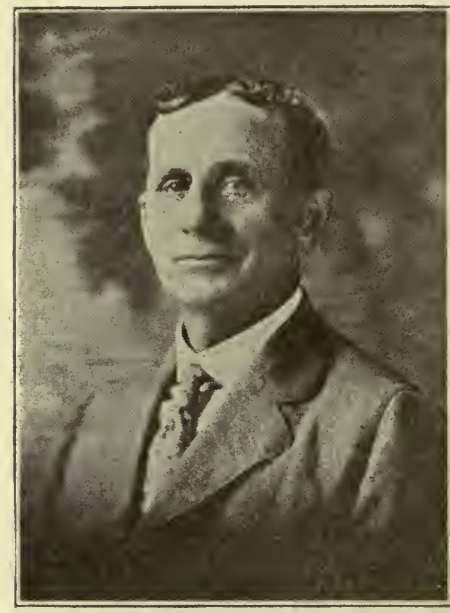

E. A. CORY Talmo

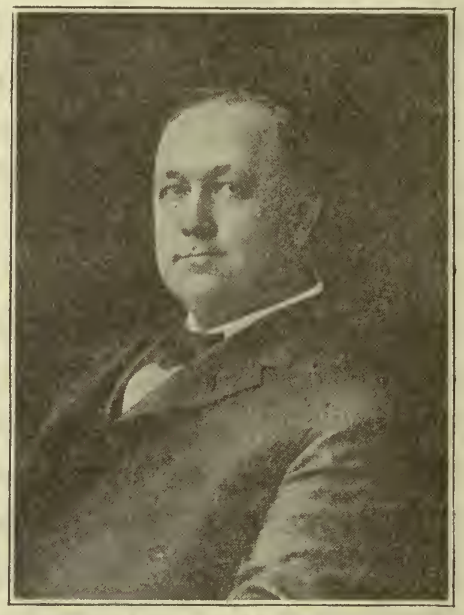

J. C. ROBISON Towanda

State Association sale at Manhattan. In September 1920 he also sold several females to that veteran breeder, J. W. Hyde, of Wilson county. The rest of the females, which included some of the best ones, and two of the bulls were kept for the foundation of a herd at Whitewater Stock Farm four miles west of Towanda in Butler county.

The Salter-Robison Sale.-The Daily Drovers' Telegram gives the following account of the sale 
held May 15, 1920, by Park E. Salter of Wichita and J. C. Robison of Towanda. This sale was held under unfavorable financial conditions but the prices received proved conclusively that firstclass Shorthorns will sell for top prices under almost any conditions. The account follows:

Park E. Salter of Wichita and J. C. Robison of Towanda, Kansas held a partnership sale of Shorthorns in the Forum at Wichita Saturday, selling 48 cattle for $\$ 64,775$ or an average of $\$ 1,339.37$. The Salter offering of 20 head averaged $\$ 1,901$ around, the Robison cattle sold for an average of $\$ 916$ per head. In the eattle consigned by Park E. Salter, there were a number of show animals, including the grand champion, Lady Supreme, which sold to Frank Scofield of Hillsboro, Texas for $\$ 4,800$. Miss Snowbird Sultan by Snowbird's Sultan with a white heifer calf at foot by Fair Acres Sultan Jr., sold to Carpenter \& Ross of Mansfield, Ohio, for $\$ 5,000$, was the top of the females. This is one of the highest, if not the highest price ever paid for a female at auction in the state of Kansas. Pleasant Gloster 2d, another member of Mr. Salter's last year's show herd sold to H. C. Lookabaugh for $\$ 3,000$. H. C. Lookabaugh also purchased Missie's Last, at $\$ 6,100$, which was the top of the auction. Of the cattle consigned by J. C. Robison, over half were imported and had been in the country only a short time. They were not in the best of condition, as they had been in transit for several months, and Mr. Robison had not been able to get them in very good shape. As it was, nine head sold for over $\$ 1,000$ a head. The top price paid for a Robison consignment was $\$ 2,400$, this amount being given by Albert Hultine of Saronville, Nebraska, for imp. Sweet Fragrance bred by William Duthie. The Shorthorn fraternity was well represented, breeders being present from Nebraska, Iowa, Mississippi, 


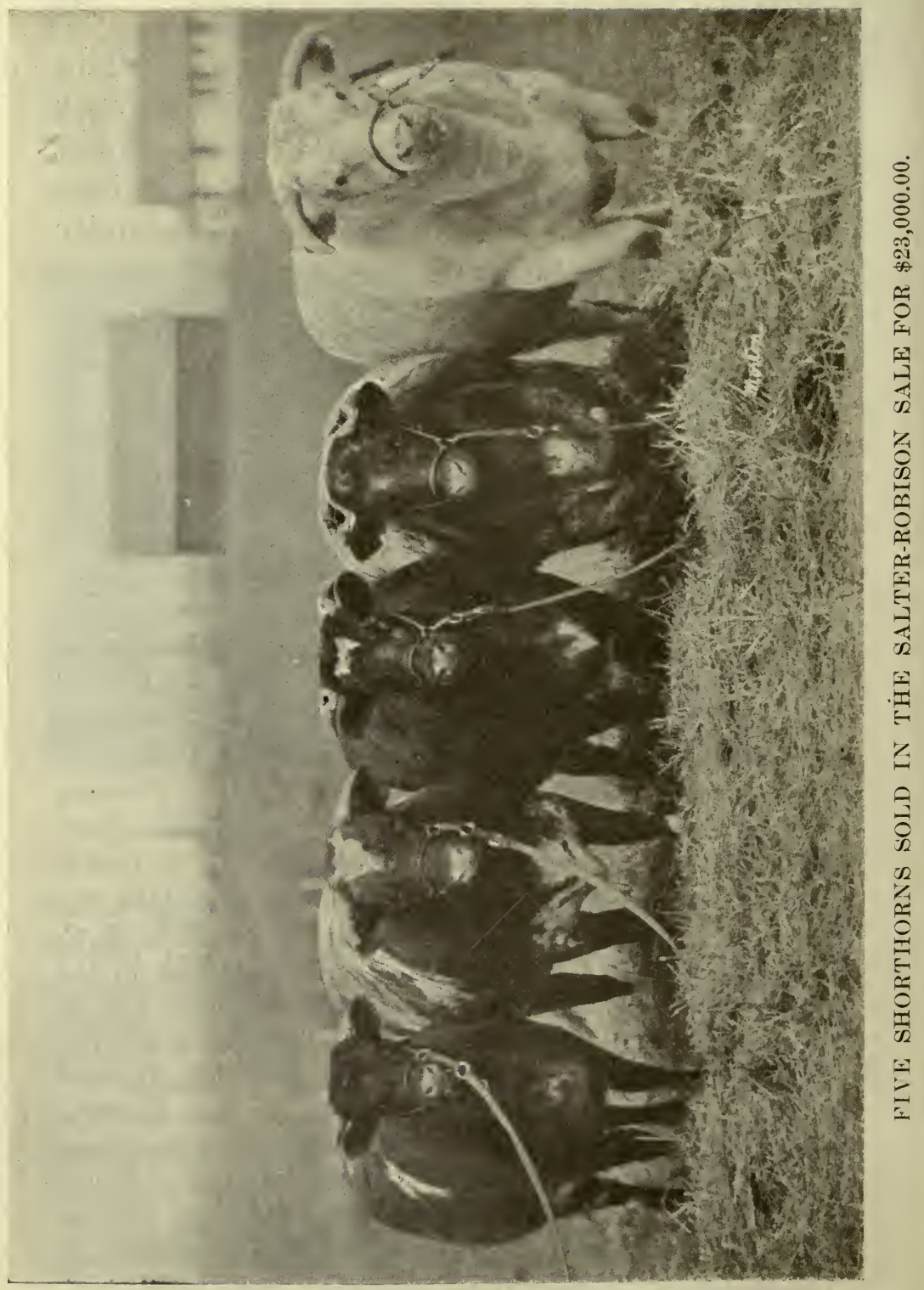


Ohio, Texas, Oklahoma and Kansas. One of the most encouraging features of the entire sale was the fact that over half the offering stayed in the Sunflower state, which is pretty good evidence that they appreciate good cattle in Kansas. A detailed report follows :

Bulls.-Missie's Last, September 1913, H. C. Lookabaugh, Watonga, Okla., $\$ 6,100$; Emblem Jr., December 10, 1918, E. S. Dale, Protection, Kans., \$4,000; Imp. Roan Marhall, March 9, 1919, Gulick \& Son, Ness City, Kans., \$425; Imp. Kinochtry Ensign, June 25, 1919, Frank Kelly, Gardner, Kans., \$725; Imp. Prince Prudent, April 18, 1919, F. S. Kirk, Wichita, Kansas, $\$ 475$.

Females.-Rose Strathallan, June 10, 1913, H. L. Burgess, Chelsea, Okla., \$975; Narcissus Gem 4th, July 10, 1914, K. G. Gigstad, Lancaster, Kans., \$1,350 ; Miss Snowbird Sultan and cow calf, October 20, 1916, Carpenter \& Ross, Mansfield, Ohio, $\$ 5,000$; Lady Supreme, November 2, 1917, Frank Scofield, Hillsboro, Tex., \$4,800; Fair Acres Blossom, March 6, 1918, E. J. Haury, Halstead, Kans., \$1,800; Calla 4th and bull calf, October 6, 1913, E. S. Dale, $\$ 1,000$; Pleasant Gloster 2d, September 10, 1918, H. C. Lookabaugh $\$ 3,000$. Gwendoline 3d, July 15, 1915, Tomson Bros., Wakarusa, Kans., $\$ 1,000$; Grandview Beauty and bull calf, May 27, 1909, H. L. Burgess, $\$ 1,150$; Sycamore Emma 4th, October 26, 1911, H. L. Burgess, \$1,150; Golden Autumn and cow ealf, October 15, 1915, D. S. Smithhisler, Enid, Okla., \$750; Village Maid 2d, December 2, 1918, Frank Kelly, \$525; Mayflower 11th, January 27, 1919, E. S. Dale, $\$ 1,150$; Miss Butterfly 2d, November 26, 1918, E. S. Dale, \$1,125; Emma Searchlight, July 7, 1919, H. B. Gaeddert, Buhler, Kans.,\$1,150 ; Bapton Emma, April 20, 1919, H. L. Burgess, $\$ 1,375$; Narcissus Gem 5th, May 27, 1919, K. G. Gigstad, \$700; Mysie Baron, July 3, 1919, Cal Scott, Hydro, Okla., $\$ 650$; Fragrant's Last, March 23, 1919, H. B. Gaeddert, \$1,500; Imp. Village Diamond, 
December 5, 1910, H. T. Blake, Duncan, Okla., \$825; Imp. Sweet Fragrance, May 24, 1916, Albert Hultine, Saronville, Neb., $\$ 2,400$; Imp. Strathearn Rose and cow calf, April 10, 1916, Henry Adams, Pond Creek, Okla., \$1,200; Gladiolus 7th, May 15, 1916, E. S. Dale, $\$ 1,025$; Imp. Snowdrop, March 2, 1917, Albert Hultine, \$2,000; Imp. Snowflake and cow calf, March 15, 1917, Donald Gunn, Comanche, Okla., \$1,400; Wilda Mysie, May 15, 1917, C. M. Howard, Hammond, Kans., \$775; Roan Alexandrina, November 7, 1917, E. J. Haury, \$825; Imp. Strowan Countess, March 24, 1918, H. T. Blake, $\$ 1,025$; Clara 83d, October 4, 1918, Heberline \& Scofield, Ponca City, Okla., \$900; Clara 85th, October 15, 1918, Carl Scott \$1,025; Clara 81st, August 22, 1918, E. S. Dale, $\$ 1,025$; Empress 2d, April 18, 1918, C. M. Howard, \$600 ; Dottie Mysie, June 22, 1918, C. M. Howard, \$650; Imp. Juliet, September 12, 1918, D. B. Thieman, Higginsville, Mo., \$800; Quality Lady 2d, May 27, 1918, D. Wolfschlegel, Harper, Kans., \$600; Flossie 2d, May 28, 1918, E. S. Dale, $\$ 525$; Lovely Wane Duchess, July 20, 1918, D. Wolfschlegel, \$600; Imp. Vilette, January 10, 1919, D. Wolfschlegel, \$775; Imp. Strowan Sunstar, March $15,1919, \mathrm{D}$. Wolfschlegel, $\$ 775$; Imp. Marjory 2d, January 18,1919 , D. Wolfschlegel, $\$ 775$; Clara 82d, September 12, 1918, D. Wolfschlegel, \$725; Imp. Snowdrift, February 6, 1919, Albert Hultine, $\$ 1,100$; Imp. Strathearn Rose 3d, May 21, 1919, D. Wolfschlegel, \$775. 


\section{SHORTHORN PEDIGREES}

There is no subject connected with Shorthorns upon which I have been asked so many questions, as the one of pedigrees. In this chapter I shall attempt to answer some of the questions asked me from time to time and to convey an idea of what a pedigree really is. Primarily a pedigree is a list of names of the ancestors of an animal. This list may be long or short. What we mean by a Shorthorn pedigree is a document giving such information concerning an animal of the breed as will cause its acceptance for record in the American herd book. This is what you obligate yourself to furnish when you sell a pure bred Shorthorn and this is what you receive when you buy one.

It is a matter of custom from which no deviation should be tolerated, that the seller place on record the pedigree of every Shorthorn he sells except when he sells a cow with a calf at foot in which case he is to furnish the purchaser an application for the registry of the calf and a guarantee that such application will be recorded on payment of the registration fee. He is further obligated to make out and have recorded a certificate of transfer for any animal sold which was on record prior to the time of sale. 


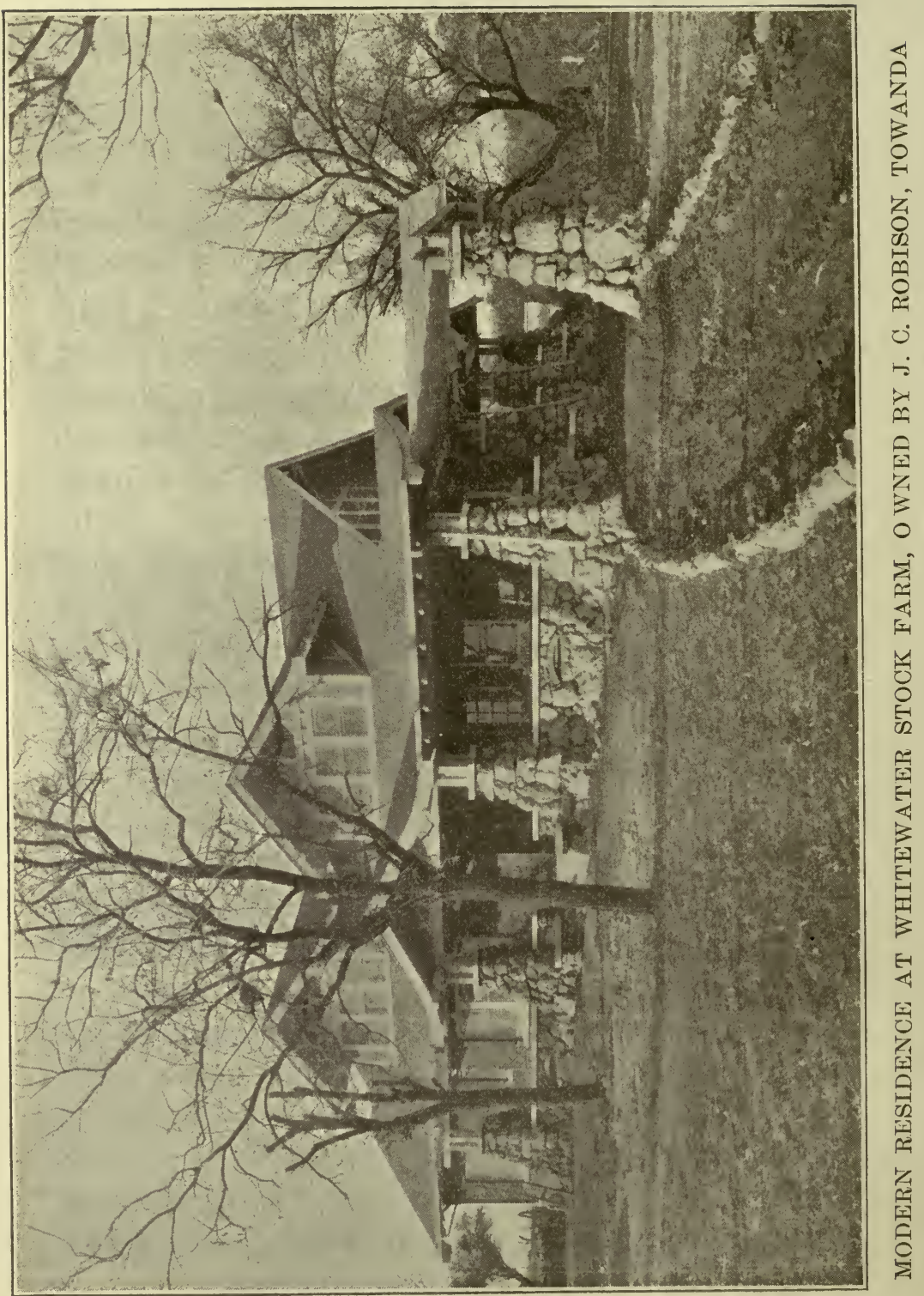


In case he sells a cow or heifer carrying a calf at the time of sale he must, if he owned such female at the time she was bred, furnish the man to whom he sells her, a registry application for such calf after its birth. If he bought her after she was bred, it is his duty to get such application and furnish it to the man to whom he sold the cow after she has a calf. This application must also be signed by the person owning the cow at the time the calf was born. It is then sent along with the customary fee to the American Shorthorn Breeders Association for record and in due time the pedigree in regular Association form is sent the owner of the calf.

Early Pedigrees.-Volume 1 of the American herd book was published in 1846 and it records the pedigrees of 190 bulls and 346 females. Unlike the later volumes, these earlier volumes give all the known crosses of bulls either under the animal's name or by reference to some other animal recorded, usually in the same volume. Some of the pedigrees are very short on ancestry. For instance Fanny, page 145 is given as follows: "Roan; bred in England by $\mathrm{Mr}$. Trim of Lancashire; imported in 1904 and the property of Dr. John A. Pool, Brunswick, New Jersey; calved in October 1836; got by Charley (1817) out of __.' This is one of the briefer ones and was recorded on a certificate furnished by J. C. Etches, a well 
known English buyer, stating that she was pure bred.

2 Going to vol. 3 published the same year $\mathrm{Mr}$. Tipton brought the first Shorthorn to Kansas, (1857), we find the bull, York recorded as follows: "York 2396, bred in Rensselear Co., N. Y.; got by Regent 899 . Interbred from the Golden, Cox and Bullock importations." The editor of the herd book evidently had no positive information beyond the locality of this bull's birth and the name of his sire and it may be well questioned whether the evidence was positive even as to the sire.

This is one extreme. Here is another. In the same volume is recorded the pedigree of Young Belvedere 2409. His pedigree covers one-third of a page and gives the ancestry in regulation Shorthorn form for seventeen generations. A few pedigrees were also recorded later that did not trace to any cow imported from Great Britain. These were what we would now call grades and Mr. Allen justified his course by stating that evidence of their descent from pure bred stock had been furnished him. The recording of these cattle raised such a storm of protest, however, that this practice was not repeated and the descendants of these cows so recorded were popularly referred to as tracing to the "American Woods.' For years, until 1907, ending with vol. 69, the words "Tracing to Imp." were given 


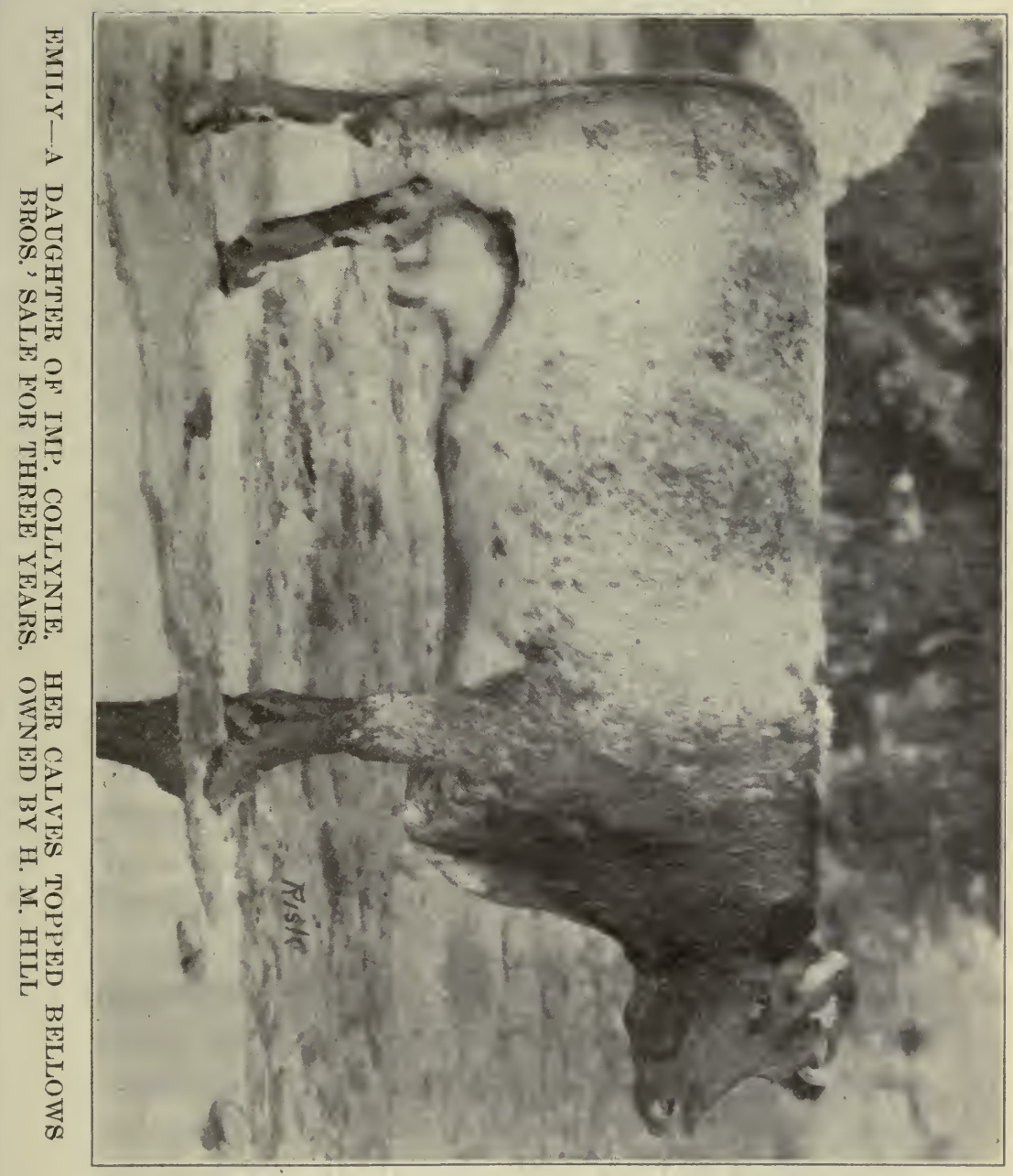


after the ancestry in each pedigree and, as it was impossible to so designate the pedigrees of these so-called American Woods Shorthorns, the pedigree, immediately after the name of the last ancestor, ended in "etc." This designated that they did not trace to an imported cow and they were discriminated against until about 1890 and long after all possible non-Shorthorn blood had been bred out. The champions of these cattle bred from a possible American grade foundation call attention to the fact that the English herd book placed on record animals with only five recorded crosses to which the American purist promptly responded that such Shorthorns, even if bred in England, traced to the "English Woods." Thus it came about that in my youthful days we heard as much about English Woods and American Woods as we do now about equally foolish or more foolish, though modern discriminations.

All Shorthorns originally came from the socalled Shorthorn country in England. From this cradle of the breed they found their way to America, most of them being imported between 1817 and 1850. They were also taken to Scotland and to Ireland. All kinds and lengths of pedigrees went with them ranging from nothing to some almost as long as the moral law. The rankest kind of pedigree discrimination prevailed, based on technicalities.which would now seem 
ludicrous. Sane men lost their heads over the possibility of a concealed cross of unfashionable blood. I recall the well known breeder Chas. E. Leonard's telling me in 1883 that he would be
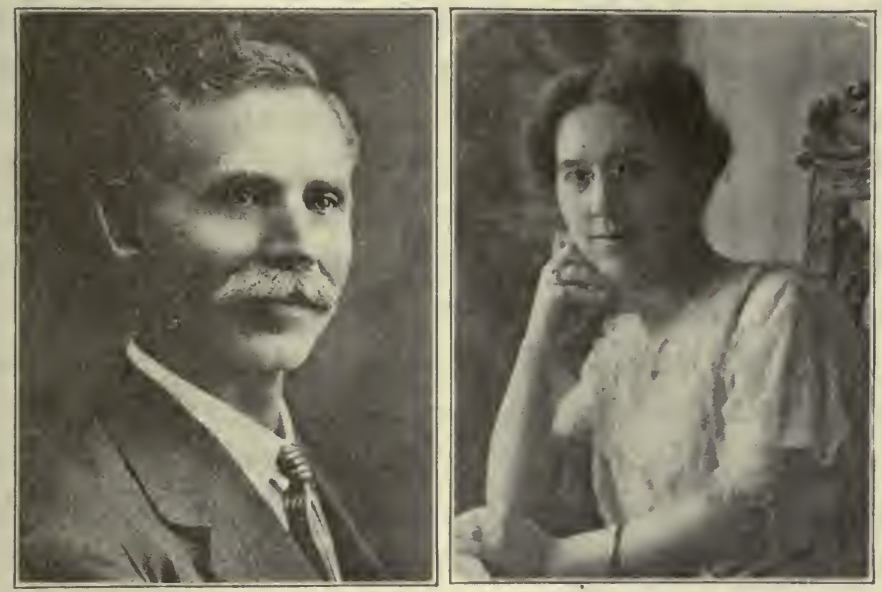

MR. AND MRS. FREMONT LEIDY

afraid to buy any Shorthorns without first having a man like Col. Muir pass on the pedigrees. Somewhere in my attic I have a book entitled "A Record of Unfashionable Crosses in Shorthorn Pedigrees" copies of which many leading breeders used as a safeguard against the possible contamination of their herds. This condition obtained with more or less force, owing to locality, until the time was ripe and the American Shorthorn was regenerated by the then unfashionable cattle from Scotland. 
It would be the height of folly to discriminate at this time between the descendants of these cattle of the seventies, but lest any man be tempted to throw a stone at his neighbor I might mention that some of the very best of $\mathrm{Mr}$. Cruickshank's productions were closely descended from unregistered cows without any sign of a pedigree, long after the early days of the breed. The rise and the passing of the pedigree discriminations proves conclusively that real merit is the only safe and permanent foundation upon which to build.

As stated before, the English herd book records cattle as Shorthorns if they have five crosses of recorded Shorthorn blood. As long as we buy imported Shorthorns at big prices we admit that the breeders are at least the equals if not the peers of those in America and that this rule which has been in force since British breeders began recording Shorthorns has done them no harm. If we care to be consistent we can not well stop to quibble about what went into a pedigree long years ago. It is not my intention to say anything that might be construed as in favor of any particular line of breeding or against it, and if any one is inclined to so construe what I say I shall be sorry. My object is to furnish information, leaving all to draw their own conclusions.

"Scotch".-While this is a word of only one 
syllable and six letters yet, in Shorthorn circles, it is one of the most used and abused of words in the English language. It is given the widest possible meaning and at the same time restricted to the narrowest construction of any word I have ever heard used. It has become a synonym for the type of cattle without regard to the pedigree on the one hand and for a form of pedigree without regard to type of cattle on the other hand. It has been rolled out of the mouths of many as a choice morsel when they knew little of its significance. Like unto the famous "Bates" of the seventies it has been used by speculators to unload unworthy specimens of a great breed of eattle on dupes and the victims of its unworthy use walk up and down the highways and byways of the Shorthorn kingdom fondly hugging to their bosoms the delusion that because of this magie word their cattle must be good.

Origin of the Term.-When the rest of the Shorthorn world had gone pedigree crazy, thereby ruining their cattle, there were left a few breeders in the bleak country around Aberdeenshire in Scotland that had bred cattle with only one object in view, namely, practical utility. These men had perhaps not associated quite so closely with the outside world as had the leaders of the trade in England and America and possibly for that reason had not succumbed to pedigree speculation in order to build up a high 
selling value on their product. It had doubtless come to their ears that their cattle were "plain bred" and that it would be an outrage to cross bulls from their herds with cows bred up by the use of the unfashionably bred Bates bulls. Undismayed by taunts and threats of failure, these old Scotchmen and their few disciples in America pursued the even tenor of their ways.

At the critical time when the masses of the fashionably bred Shorthorns lacked everything worth while except a pedigree of ancient but fallen greatness and were in danger of being cast aside by the Angus and Herefords as unworthy of being perpetuated, these plain bred bulls from Scotland, thrown together indiscriminately, according to the devotees of fashion, and coming from the edge of the jumping-off place of the universe, appeared to rescue the breed. Possessing every essential for the work except a popular pedigree, they wrought a regeneration in American and English Shorthorns such as had not been dreamed of before. First under the name of Cruickshank, the acknowledged leader of the clan, and later as Scotch cows and Scotch bulls they did the work so rapidly and effectually that within less than ten years they became the aristocracy of the Shorthorn world. And so the term "Scotch" became one to conjure with, for it represented a type of cattle superior to anything yet seen. How the names of these old 
breeders thrill us now! Cruickshank and Campbell and Marr and Bruce in Scotland and Davidson and Potts and Pickrell and Kissinger in America; and the more youthful members led

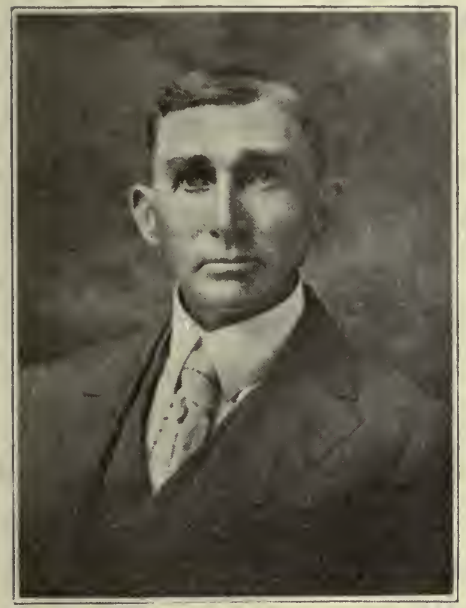

H. O. PECK Wellington

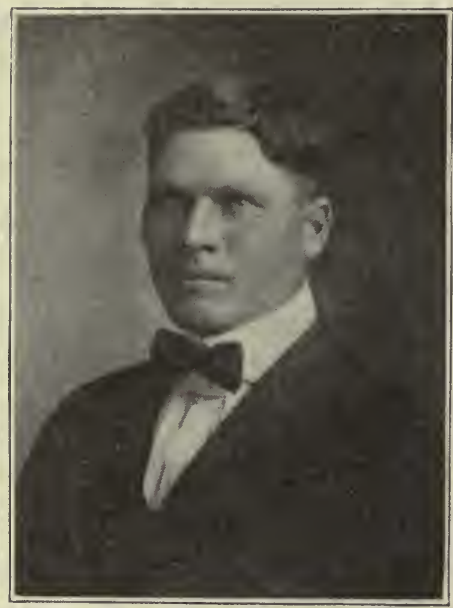

H. B. GAEDDERT Buhler

by the immortal trio, Duthie in Scotland, Dean Willis in England and W. A. Harris of Kansas and the American nation. How we like to see these names in a pedigree, for we know that it means real merit, not ancient ancestry and paper glory. To these men of immortal renown the world owes a debt of gratitude which it can repay only by caring well for the heritage left by them.

The fame of these cattle coming from Scotch 
breeders gradually extended to all the herds of Scotland and later to those of entire Great Britain. There are scarcely any Shorthorns that have not felt the benefits of this good blood and by far the greater number of all Shorthorns are in blood lines practically Scotch. Cattle coming from Great Britain are being generally accepted as Scotch and justly so. While the greater number of British Shorthorns do not descend in the maternal line from cows bred in these Scotch herds, yet it is a fact that in many cases both in Europe and in America the Shorthorns produced by crossing these good Scotch bulls on the English and American cows have become so filled with this Scotch blood that in essentials as well as in non-essentials they are of one type, one family and one breed with the cattle that crossed the ocean since the early eighties.

Scotch Stands for a Type.-Assuming that Scotch in Shorthorns stands for a type, and no one even fairly familiar with the facts in the case will attempt to deny this, it becomes immaterial whether our Shorthorns that are being imported come from England or Ireland or Scotland. So long as they are well loaded with the blood of the cattle that saved the breed, and are good representatives of their race we can accept them. Importers and the buying public recognize the correctness of this principle and at present practically all imported animals are sold on their merits 
as individuals, there being little discrimination on account of the point of origin.

A Contrast.-For years the two great political parties of the United States made ugly faces at each other over what was then known as "protection to American industry." The substance of this was that both parties wanted legal enactments to give the American producer sufficient advantage in trade over foreign producers to virtually allow the American production supremacy. The only question was how much and for want of other "burning issues" the parties divided on the amount.

American Shorthorn breeders do not seem to be of this same calibre for they very generously accept an animal at a big price, if it comes across the water, while an equally good American bred one with equally good or better pedigree and perhaps more individual merit and more real Scotch blood is not even considered worthy to do service in a pure bred herd. This, of course, is pedigree discrimination of the rankest sort and leads to a limitation of choice which should not exist but which suits the speculative element perfectly.

Scotch or Scotch Topped.-Almost daily I am asked "How can I tell whether an animal is Scotch or not?" From the preceding statements it may be correctly inferred that the very great majority of Shorthorns belong in the Seotch class as far as blood lines are concerned 
for they are all well filled with the blood that made Scotch cattle famous. On the other hand the minority, only, belong in the Scotch class

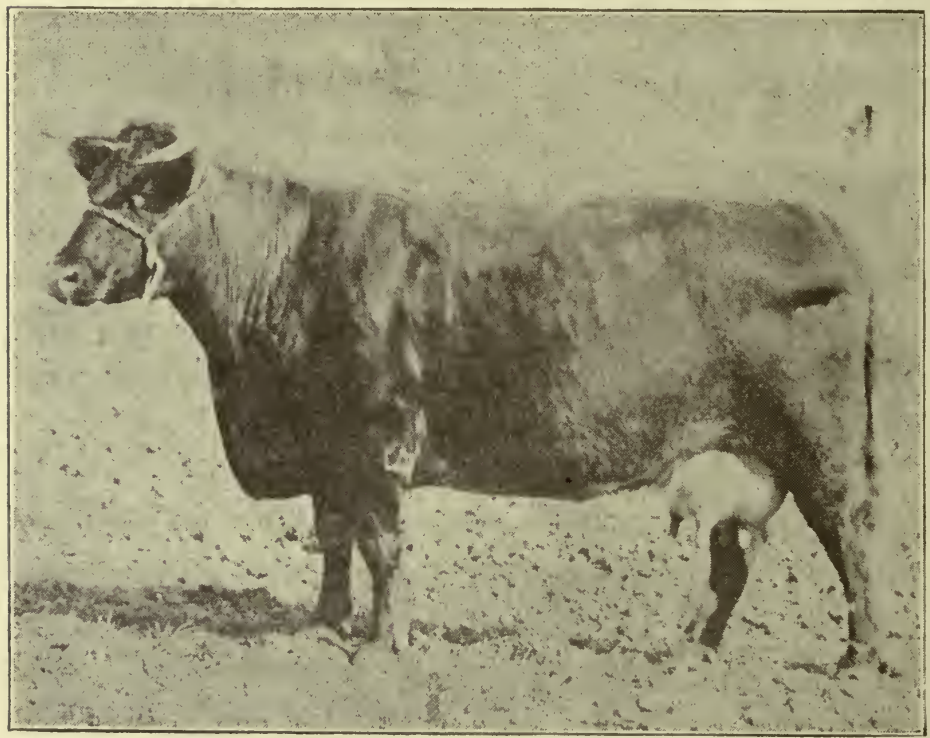

COLLEGE EMMA

A "Butterfly"' with a milk record of more than 7000 pounds. She is the dam of the first prize junior yearling steer at the International Live Stock Show 1919. Owned by the Kansas State Agricultural College.

as far as type and merit go for only the fewer members would be acceptable to the old Scotchmen who gave the world these cattle. But that is not the answer my questioner desires. He wants to know how to distinguish so-called Scotch Shorthorns from so-called Scotch topped ones. The term, Scotch pedigree, as applied in 
America some years ago meant an animal descended in the maternal as well as the paternal line from a cow bred in Scotland. As interpreted now it seems to me it means one descended in the maternal line from a Scotch bred cow or from a cow imported from Great Britain, provided the imported cow appears within five or six crosses from the top. It is also a provision of the acceptance of such pedigrees as Scotch that the bulls used in the crosses above the imported cow come within this Scotch classification or that any deviation from such classification be not easily discovered.

A Scotch topped Shorthorn exists only in the United States and possibly in Canada. Its pedigree shows an animal whose maternal ancestors were bred in America and that generally has. from two to eight crosses of Scotch bulls at the top of the pedigree. The imported cow came from England to the United States in most cases prior to 1880 instead of going first to Scotland and then to the United States or coming from England in the last ten or twenty years. It is hard to lay down a rule which will allow the average man to tell with any certainty in which classification the pedigree belongs, even if he had a list of all the imported cows so that he could tell at a glance whether the imported cow came from Great Britain and when she came over. There still remains the uncertainty as to 
the top crosses of bulls. Barring this uncertainty, in most cases all Shorthorns that trace to an imported cow whose name is one of the first eight mentioned in the present association form, may generally be accepted as passing for Scotch, but this rule is not absolute. To determine the accepted classification a positive knowledge of the imported cow and the bulls above her or a resort to the herd books for investigation is necessary.

Straight Scotch.-Often I am asked whether an animal is straight Scotch or as some say "pure Scotch." I do not believe those who ask this question mean what they say. What they really mean is this, "Is the pedigree one that will be generally accepted as Scotch?" The answer to this question is found in the preceding. As a matter of fact, taking the accepted Scotch blood introduced from the Cruickshank herd and other good herds and which is the basis for our present Scotch cattle, practically all have been outcrossed to their great advantage.

Col. Harris did this with his herd, the greatest Scotch herd in America. Mr. Duthie, Scotland's greatest breeder, used outcrosses. So did Dean Willis in England with the original herd coming from Mr. Cruickshank's. An example of t!ie work of Col. Harris with his Scotch cattle is found in his Golden Drops, all of which came from Norton's Golden Drop, a cow by the Bates 
bull, imp. Underley Wild Eyes. The bull, Golden Knight, extensively used in the Linwood herd, was out of Norton's Golden Drop and Golden

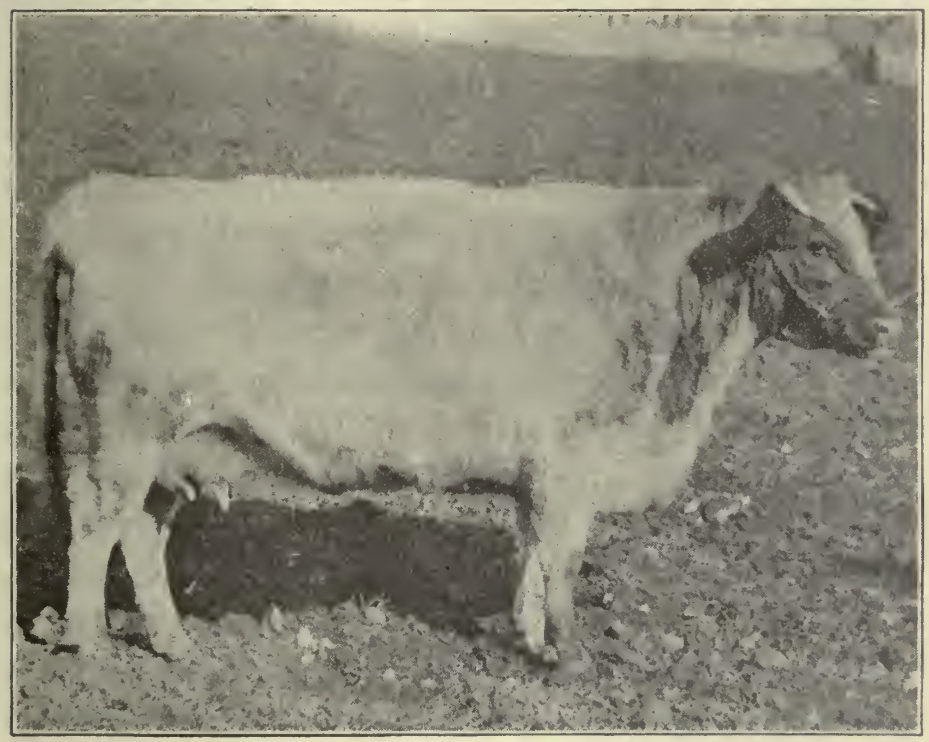

A FIRST-CLASS SHORTHORN COW THAT AS A TWO-YEAROLD HAD A MILK RECORD OF ALMOST 6,000 POUNDS.

Lord, the last bull Col. Harris used, was one of the outcrossed Golden Drops. Mr. Harding tells us that Whitehall Sultan had a Bates cross near the top of his pedigree and we know the same is true of Choice Goods. In view of the fact that the leading Shorthorn herds in America are full of the blood of one or the other or both of these two noted bulls and that neither of them was of 
purely Scotch lineage it would seem foolish to harp on straight or pure Scotch. In fact there is nothing gained by figuring on a proposition so devoid of common sense and so barren of good results.

Fads.-We have always had fads in pedigrees and we shall always have them, in some cases to the detriment of the breed. The American people are by nature and inclination somewhat given to fads and the Shorthorn breeders are not immune to the national evil. Shorthorn fads began in the days of the Collings and continued faithfully through the days of Bates and Booth and came to America with the importations beginning in 1836. On their trail were found pedigree discriminations of the rankest sort. Seventeens, Red Rose by Ernesty and a hundred arid one equally nonsensical terms were heralded as abominations. The Duchess blood alone offered all saving grace, followed by the other Bates tribes and the man who did not possess funds or sufficient credit, sometimes much strained, to buy one of these precious specimens could still be near the extreme outer edge of the circle if he conjured with the Renick Rose of Sharons.

And so the bubble grew and gathered volume until with the arrival of Scotch Shorthorns and the Herefords and the Angus it burst altogether and the elegant Duchesses and Oxfords and Rose of Sharons took their places along with the Mrs. 
Mottes and the Brittanias and the despised sorts from the "American Woods." Those who now deplore the fact that there are fads and discriminations should have been in touch with Shorthorns from 1870 to 1883 and they would have seen the faddist abroad in the land to such an extent that by comparison the Shorthorn breeders of this day seem quite conservative.

I believe the breed is more nearly free from fads and rank discriminations than it has been for fifty years. It is true, pedigree propositions are made in the United States that on their face are extremely ridiculous, but these ridiculous discriminations will always be made not only in Shorthorn pedigrees but also in every other line of human endeavor as is daily evidenced in the clothing and shoe market.

True Worth Only in Merit.-It is a homely but a true proverb that every dog has his day and this is annually exemplified in our changing styles of dress. In the architecture of our homes the change is more gradual as also is the case in Shorthorn pedigrees. Let no man so far delude himself or attempt to deceive his neighbor as to preach the permanency of anything in Shorthorns except real individual merit for that is the only thing that can stand the test of time. I have no quarrel with the man who, to gratify his fancy, pays several times as much for an animal because of certain blood lines as he would pay if 
the pedigree were somewhat differently written. That is his privilege and if the animal is a worthy representative of the breed no possible harm can come from such action. The statement occasion-

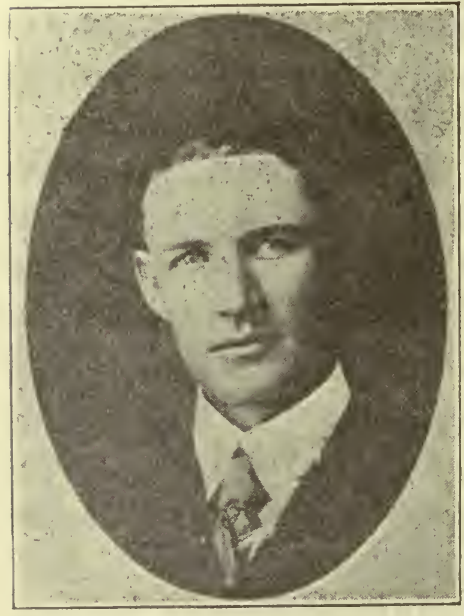

OWEN ONEILL Windom

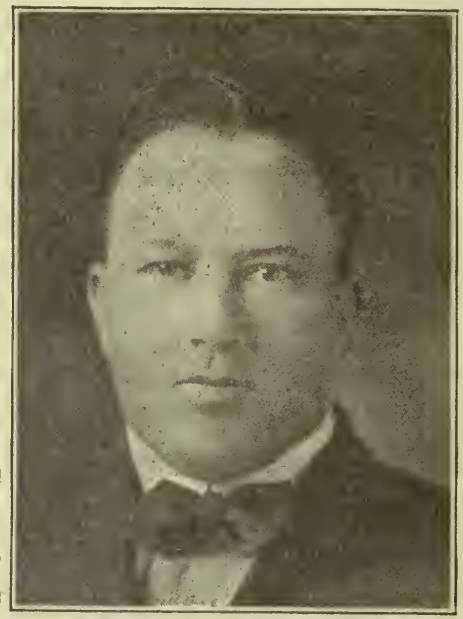

A. W. JACOB Valley Center

ally made that it is a discrimination against Shorthorns otherwise bred seems to me absurd. If there is any observable effect from the paying of high prices, which is largely the game of the rich men or of the breeders who are in a position to secure their trade or of the speculator whose game is to unload on the rich, it is that general Shorthorn values are at least stimulated thereby. A wide range of observation at numerous public sales has convinced me that every animal sold for 
an unusually high price in such sale helped the selling price of the entire offering.

Where the Danger Lies.-There is a danger point in the purchase of Shorthorns of fashionable pedigrees which can not help being an injury to the breed and which should be a discredit to any breeder who encourages it. It lies in the selling of these fashionables for breeding purposes at high prices, when they are not good individuals. We have all seen this done both at public sale and at private treaty. Cattle of approved Scotch pedigrees without merit enough to be classsed as even fairly good have sold for possibly double the amount required to buy an excellent Scotch topped animal, frequently having a stronger infusion of good Scotch blood than the fashionably bred one. In this case the purchaser is either a victim of a false idea of the value of pedigrees or he is a speculator who intends to unload on an unsuspecting buyer. The usual result of such purchase is that the man who makes it has a poor herd, when for less money he might have had a good one. Then there is another consideration which should discourage such purchases. Not every one is in a position to sell at a price above that justificd by the real merit of the individual and the real merit of its immediate ancestry.

What is a Good Pedigree.-There can be only one answer to this. Good is the opposite of bad. 
The pedigree being merely the names of the ancesters of the animal pedigreed, it follows that the pedigree will be good if the animals that go to make up the pedigree were good. If they were not good it is folly to call the pedigree good no matter how fashionable or high priced it is. Reversing this proposition, if a good Shorthorn individual is from good Shorthorn ancestry up to ninety per cent or more of its blood lines, no possible argument could be produced that would make any sane man really believe that such pedigree was not a good one. To call it bad would be to cast aside the common use of the English language and to call the pedigree good if the immediate ancestry consisting of thirty animals were good, bad and indifferent would be equally inconsistent, even though the animal sold for thousands.

The Value of the Pedigree.-The commercial value of all pure bred and registered stock above the price such animals would bring as grades lies in the pedigree. This being the case it behooves every one breeding Shorthorns to make the pedigree good and that means first of all select a good cow descended from good ancestry, then use only an extra good bull from extra good ancestry. A few hundred dollars more or less paid for a bull is not so much of a factor in the case as is the merit and ancestry of the bull himself. One can buy a cow with a good pedigree but unless the 


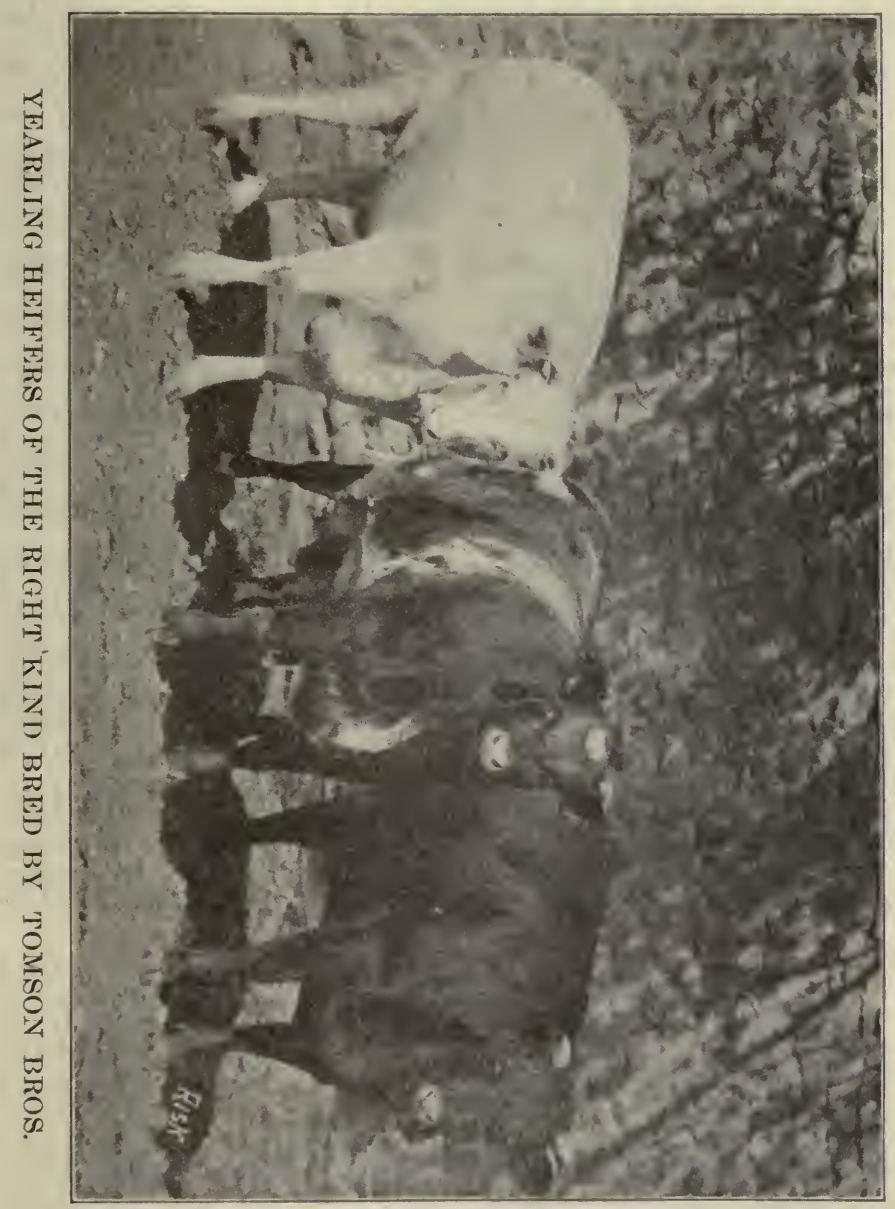


bull is right in all essentials he is putting bad into the pedigree of the calf. If the pedigree of the bow is not just what it should be it can soon be made so by the use of good bulls but a mistake in the bull is very serious and affects every calf he sires. Do not use a bull of the wrong type or from the wrong kind of ancestry no matter how cheaply he can be bought or how good he looks, for the wrong kind of a bull will spoil the whole herd. The bull is the secret of making and keeping the pedigree and the individual good or bad.

The Term "Plain Bred". - I can not close this chapter without calling attention to the misuse of the term "plain bred" as applied to Shorthorns. I am quite sure many cattle of this breed and of all other breeds are "plain bred" but to classify those descended from Scotch or later day British importations.as well bred and those descended from earlier importations as plain bred is a travesty on common sense, and an insult to the intelligence of any self-respecting American citizen.

As before stated, the pedigree of a Shorthorn is only a list of names of the ancestry of an animal. What the individual merit of the ancestors of this animal were as beef producers makes the pedigree. If the immediate ancestry of the animal pedigreed was of the plain, common sort of individuals it is a plain pedigree even if it descends through fashionable crosses to a 
Cruickshank Duchess of Gloster, for a plain or medium Shorthorn ean not be called anything else than plain even in a pedigree. If, however, the immediate ancestry of the animal were excel-

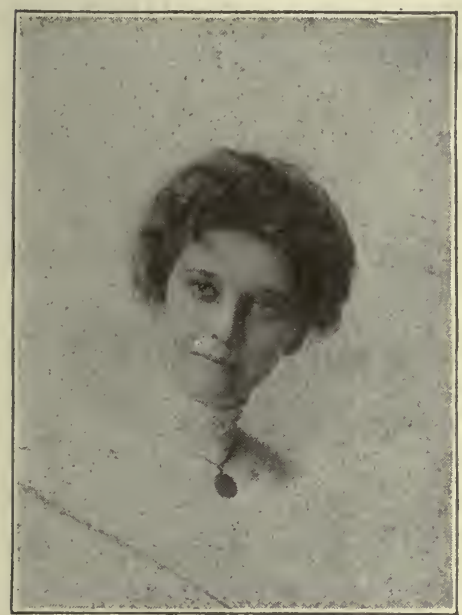

MISS FLORENCE LAUDE Daughter of the author, who assisted in arrangement and revision of copy for A History of Shorthorns in Kansas.

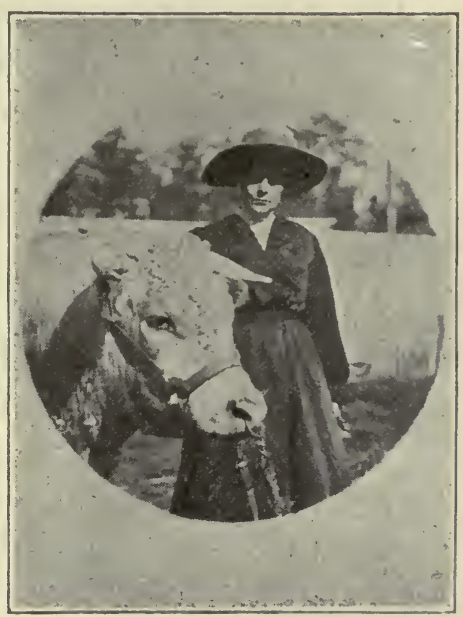

MISS MARGUERITE STANLEY Who determined Harper county should have a Shorthorn Breeders Association though she must constitute the entire membership.

lent individuals it cannot be called anything but a good pedigree and any attempt to discredit an animal so bred by calling it plain bred and bo dwelling on the excellent pedigree of the first mentioned class shows either woeful ignorance or an attempt to deceive. Let us call things what they are and remember that real merit is the only true standard of worth or excellence even in Shorthorn pedigrees. 


\section{KANSAS SHORTHORN ORGANIZATIONS}

The first Kansas State Shorthorn Breeders Association was organized in about 1884. W. S. White of Sabetha was one of the first presidents if not the first and E. M. Shelton, then Professor of Agriculture in the Kansas State Agricultural College, was secretary. Col. W. A. Harris was the leading promoter of the organization which for a few years had a large membership. The hard times and low prices of the late eighties overcame the enthusiasm of the members and the association held its last meeting at Topeka in December 1887. A notable event of this last meeting was the advocacy by Col. Harris of some form of registration which would indicate the quality of the animal recorded if it were of extraordinary merit. The suggestion he made was to adopt a standard for size, general conformation and regard for true Shorthorn type with apparent practical utility and to indicate with a star placed before the name in the American herd book such animals as had successfully passed this inspection. A very lively discussion followed and in this meeting originated the remark that Col. Harris was leader of the progressive element among Shorthorn breeders. Although a strong sentiment 
developed for the plan it was not strong enough to carry through a resolution asking that something be done along this line. The first state association left no record of achievement,

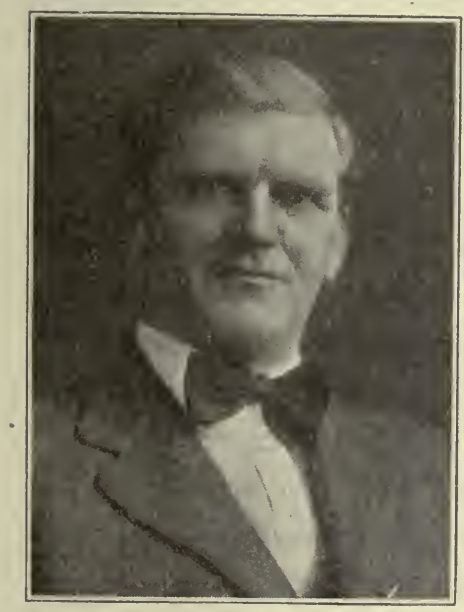

W. A. COCHEL Representing the American Shorthorn Breeders Ass'n.

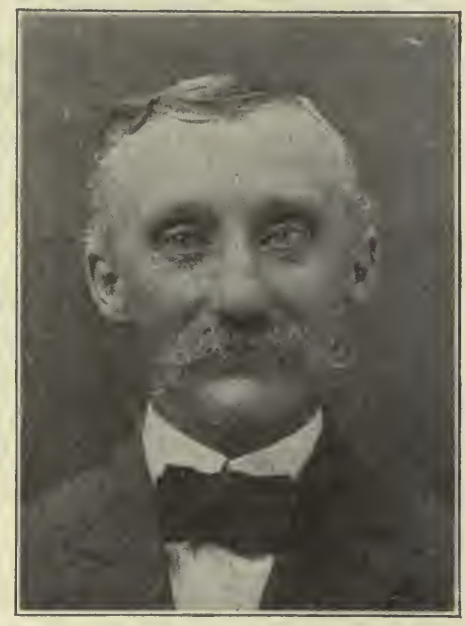

G. A. LAUDE Secretary Kansas Shorthorn Breeders Association.

its meetings having been purely social and educational. Few of the members of the organization are now living.

The present state Shorthorn breeders association was organized at Wichita more than thirtyone years after the death of its predecessor. It was at the time of the Kansas National Show in 1919 that about thirty breeders met at Park E. Salter's office on the night following the Shorthorn sale and, after electing Mr. Salter 
temporary chairman and G. A. Laude temporary secretary, effected an organization by the election of the following-named officers: President, Park E. Salter, Wichita; Secretary-treasurer, G. A. Laude, Humboldt; Executive Committee, Park E. Salter, Chairman; John R. Tomson, Dover; W. A. Cochel, Manhattan; H. M. Hill, Lafontaine and Fremont Leidy, Leon.

Unlike the first association, the new organization went to work and at this initial meeting two hours were taken up in making arrangements for the publication of this history. The work proper was left with the secretary under the direction of the executive committee. It was decided to meet at the Agricultural College on Commencement day, after which the meeting adjourned. The meeting at Manhattan was held June 5, 1919 and it was here that the low price of two dollars for membership fee was fixed. Thirty members were enrolled putting the first cash, $\$ 60$, into the treasury. The matter of holding an association sale was discussed and it was decided that about fifty high-class cattle be sold at the college some time in May or June 1920 under the management of Dr. C. W. McCampbell, head of the Department of Animal Husbandry. Mr. F. S. Kirk, manager of the Kansas National Show, offered a silver loving cup to the county having the largest number of paid members reported by evening of Shorthorn day at the 
Wichita Show in 1920. The next day Park E. Salter offered twenty-five copies of the future Kansas Shorthorn history to the county having second largest membership and, on behalf of the association, the secretary offered $\$ 10$ in cash for the county third in line. The membership contest was started December 15, and resulted in first prize going to Allen county, second prize io Montgomery county and third prize to Osage county.

The association sale was held in the pavilion at the college, consignments having been made by twenty-six leading breeders of the state, all of whose herds are given space in this book. A top price of $\$ 3900$ was secured for College Duchess 2d, a six-year-old roan cow by Matchless Dale that sold with a white bull calf by Magruder at foot. The pair was consigned by the Kansas State Agricultural College and went to Sni-ABar Farm, Grain Valley, Missouri. Tomson Bros. sold the highest priced bull at $\$ 1025$ to Meall Bros., Cawker City and Jacob Nelson of Clay county was a close second with a white yearling that went to a Leavenworth county neighborhood Shorthorn breeders association.

Immediately after the sale the annual meeting of the association was held, when officers were elected as follows: President, John R. Tomson, Dover; Vice-president, Park E. Salter, Wichita; Secretary-treasurer, G. A. Laude, Humboldt. 
No change was made in the executive committee. The do-something spirit was again manifest at this meeting. The president was instructed to file copy of constitution with Secretary Mohler which step completed the affiliation of the association with the Kansas State Board of Agriculture. He was also instructed to confer with the other state pure bred organizations with a view toward presenting to the state tax commission a plea for a uniform and equitable assessment of pure bred stock in Kansas. The executive committee was instructed to investigate the feasibility of employing a competent man to devote his whole time to developing Shorthorn interests in Kansas. The committee was also to devise means for meeting the expense of such plan and to take steps toward putting it into effect as soon as practicable. It was decided to hold another sale at the Kansas State Agricultural College in 1921.

The association now has 375 paid members and it is one of the most active organizations of its kind in the United States.

\section{District Associations}

(As reported to October 1, 1920.)

Eastern Kansas.-A. L. Johnston, Ottawa, president; F. Joe Robbins, Ottawa, secretarytreasurer; place of business, Ottawa.

Southeast Kansas.-Wesley Jewell, Humboldt, president; F. B. Campbell, Altamont, 


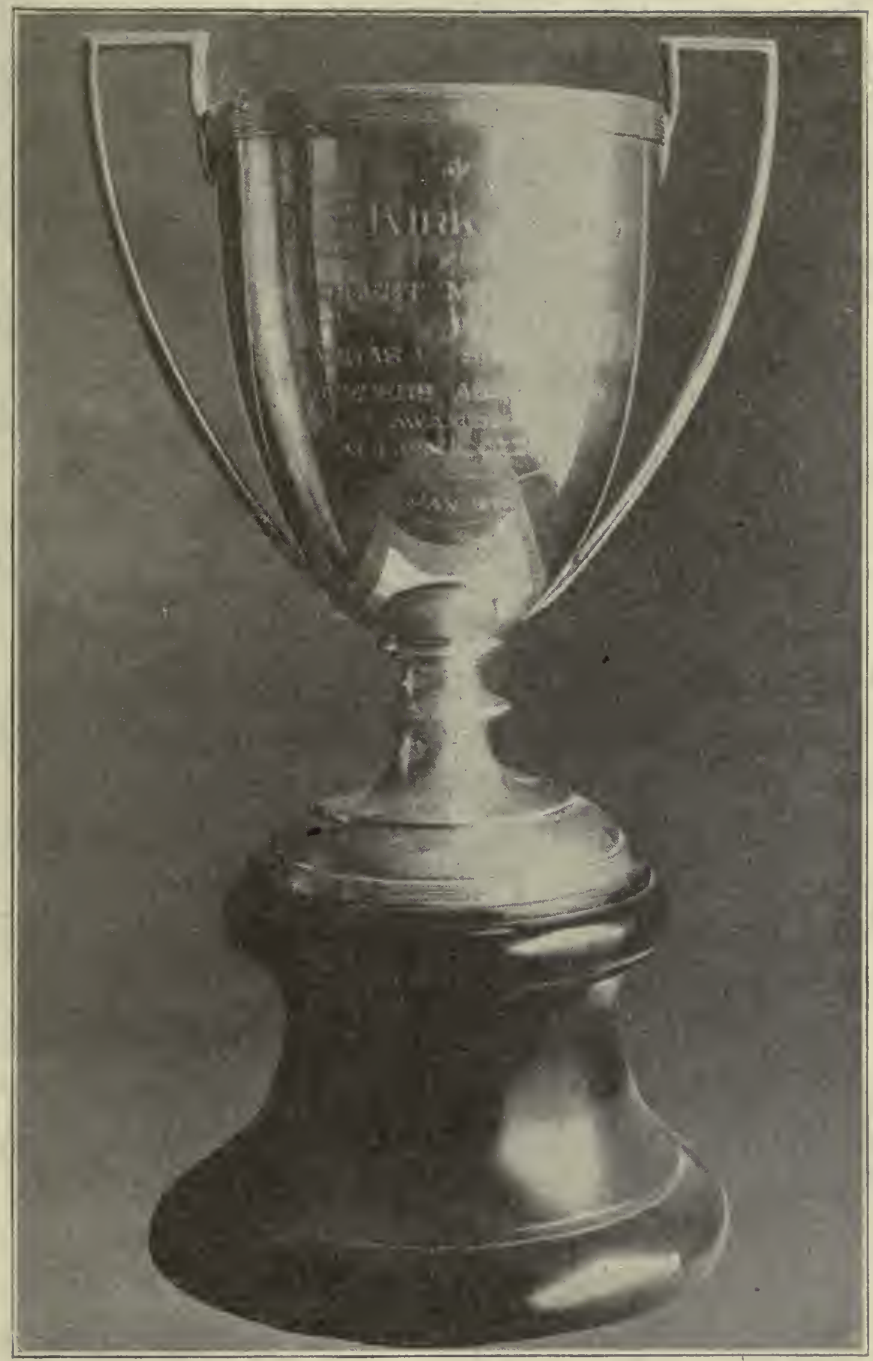

SILVER CUP AWARDED ALLEN COUNTY FOR THE LARGEST MEMBERSHIP IN THE KANSAS SHORTHORN BREEDERS ASSOCIATION. 
secretary-treasurer; place of business, Independence.

Northwest Kansas.-T. M. Willson, Lebanon, president; Forrest Booker, Beloit, secretarytreasurer; place of business, Concordia.

Inter-state.-L. D. Hayes, Bronson, Kansas, president; E. H. Westfall, Richards, Mo., secretary; serves territory around Fort Scott; places of business, Fort Scott, Kans. and Nevada, Mo.

Northeast Kansas.-T. J. Sands, Robinson, president; C. O. Dimmock, Hiawatha, secretary; place of business, Hiawatha.

Peabody District.-O. A. Homan, Peabody, secretary; serves territory around Peabody; places of business, Newton and Peabody.

Cherokee-Crawford.-Ervin Evans, Columbus, president; B. F. Barnes, Columbus, secretary; serves Cherokee and Crawford counties; place of business, Columbus.

Blue Valley.-John O'Kane, Blue Rapids, president; J. M. Nielson, Marysville, secretary; serves Big and Little Blue Valleys and into Nebraska; place of business, Marysville.

\section{County Associations}

Allen.-J. H. Holcomb, Humboldt, president; S. M. Knox, Humboldt, secretary.

Chase.-W. J. Sayre, Cedar Point, president; Frank H. Yeager, Bazaar, secretary. 
Coffey.-C. H. White, Burlington, president; J. H. McAdams, Burlington, secretary.

Comanche.-H. W. Estes, Sitka, president; E. S. Dale, Protection, secretary.

Greenwood.-H. G. Brookover, Eureka, president; Claude Lovett, Neal, secretary.

Harper._John B. Potter, Harper, president: Miss Marguerite V. Stanley, Anthony, secretary.

Leavenworth.-Geo. S. Marshall, Basehor, president; C. A. Spencer, Leavenworth, secretary.

Linn.-E. C. Smith, Pleasanton, secretary.

Lyon.-E. H. Abraham, Emporia, president; I. T. Richardson, Emporia, secretary.

Osage.-James G. Tomson, Wakarusa, president; V. A. Jasperson, Scranton, secretary. 


\section{AUCTIONEERS WHO SELL KANSAS SHOR'IHORNS}

H. L. Burgess, Chelsea, Oklahoma.-Col. Burgess is not only an auctioneer but for years he has been operating a fine farm and keeping some elegant Shorthorns. He is well known as the man who owned and advertised the $\$ 100002 d$ Fair Acres Sultan, one of the best bulls of the breed and the highest priced bull ever sold at public sale in Kansas. Col. Burgess is 100 per cent efficiency and his services are in demand in Illinois, Iowa, Missouri, Kansas, Oklahoma, Texas and Colorado. He is one of the most successful men of his profession in the territory and is booked for many Shorthorn sales in Kansas.

P. IM. Gross, Kansas City.-Col. Gross is a Missourian who for many years was a leading authority on horse and mule sales, and has trans-ferred his activities to Shorthorns. He is the acknowledged orator in the profession and duxing the recent Red Cross campaigns he caused men to weep, who perhaps had never wept before. Gross is so likable that when he looks at you and smiles, asking you for a ten dollar raise you hate to refuse him. He is getting all the work he can handle and is always booked well ahead. 


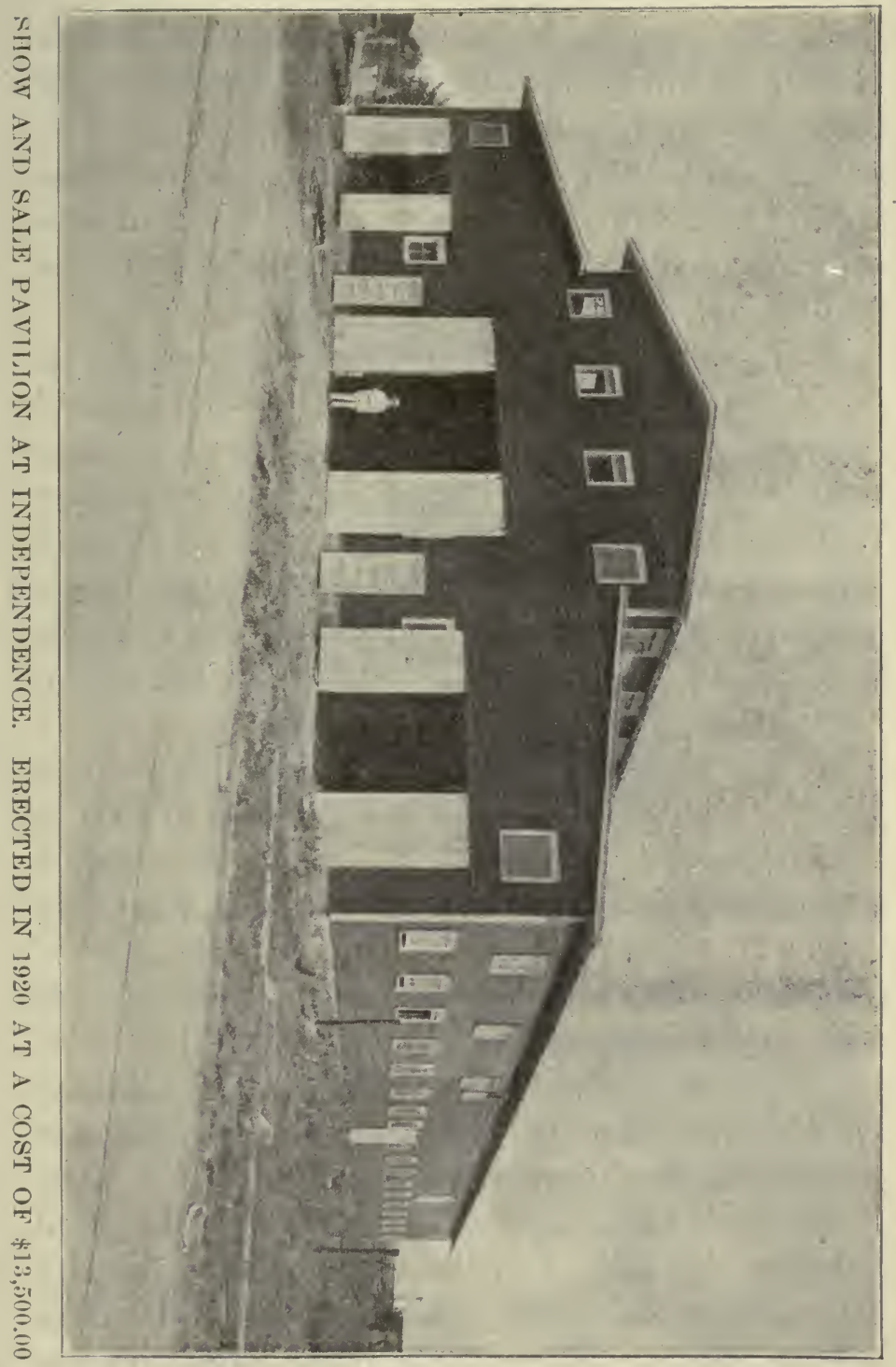


E. H. Herriff, Oklahoma City.-While Col. Herriff is in big demand in his own state he oceasionally breaks over into Kansas. Ed is frequently alluded to as a whirlwind and sales do not lag with him. He throws every bit of his energy into his work and is very popular with his employers.

A. J. James, Lenexa, Kansas.-Col. Andy, as he is frequently called, lives on the borderland between Kansas and Missouri and he practices in both states. He is one of the state's wealthy farmers and one of the most agreeable hosts I have ever met. A visit with Col. and Mrs. James after a few days of hotel is like reaching an oasis in a desert. Col. James is one of the successful auctioneers of eastern Kansas.

H. M. Justice, Paola.-The big sales held at Paola, Col. Justice's home town, are a tribute to his success as an auctioneer. He is immensely popular with those who know him and strangers warm up to him on sight. He is in the prime of life, has plenty of ability and energy and stands well with the breeders in his section.

Jas. T. McCulloch, Clay Center.-Col. McCulloch has a monopoly on a job in north Kansas sales. He has been officially adopted by the Northwest Kansas Shorthorn Association and handles the sales for this, the biggest district association in Kansas. The fact that he keeps on selling for the same people year after year is 
A HISTORY OF SHORTHORNS IN RANSAS

tribute enough to Jimmie, as his friends north of the river call him.

Boyd Newcom, Wichita.-Col. Newcom is quite portly, considered.handsome and is very

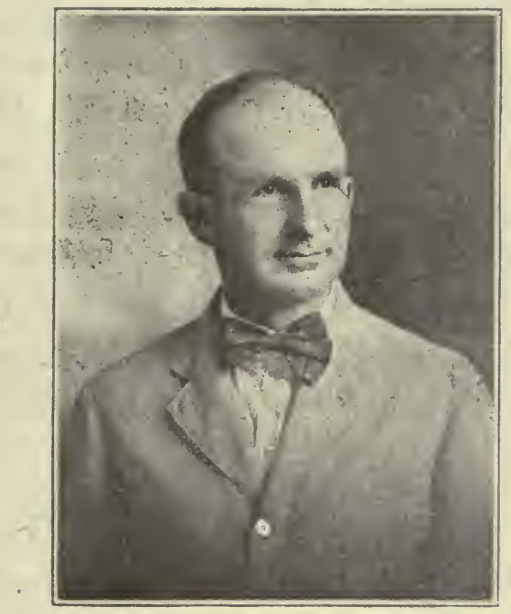

H. M. $\mathrm{COE}$

County Agent, Independence

The man responsible for the building of the pavilion.

popular in southern Kansas and Oklahoma. He is well liked because he gets results and no one better than he knows how to handle a crowd. He is a hustler in the ring and is in demand at many good sales where he always gives satisfaction.

H. T. Rule, Ottawa.-Col. Rule is comparatively a young man. He is strictly business from start to finish and does not fool away any time. "Give me your attention, gentlemen, and 
we will proceed with the sale," seems to be his motto. I have never known any one to employ Rule and not be pleased with him. He is one of the coming auctioneers and his progress is rapid. John D. Snyder, Winfield.-Col. Snyder grew up in south central Kansas. He is an old timer in the pure bred game and now breeds Shorthorns and Poland Chinas. John is serious, earnest and a hard worker. He knows more about Shorthorn cattle and pedigrees and values than most breeders do and in this line is one of the West's best posted auctioneers. He enjoys an extensive patronage in central and south central Kansas and is very popular with those who know him. 


\section{THE BREEDER'S GAZETTE}

It took forty years of highly constructive service to earn for the Breeder's Gazette such affectionate pseudonyms as "the Stockman's Bible" and "the farmer's greatest paper." It is doubtful whether any other agricultural journal is so deeply estcemed by those who read it. Certainly no other farm paper reaches a higher type of rural citizenry. In fact it has been said that merely by riding through the country one could invariably pick out the membership of the Gazette family.

Why? Well, because The Breeder's Gazette presents the ideals, the inspiration and the common sense that enables men to build such farms as stand for what is best in American agriculture.

The Breeder's Gazette is devoted to the science and art of farming the stock farm. Its editor is Alvin H. Sanders, gratefully known to every Shorthorn breeder as the author of "Shorthorn Cattle," the history of the breed in America, and one of the classics of agricultural literature. This book is, within itself, the text for a Shorthorn education such as could not, otherwise, be obtained.

I have been a reader of the Gazette since April 1882, receiving it regularly except when too negligent to renew. Now after nearly forty years, I am willing to ascribe what Shorthorn enthusiasm I possess, more largely to The Breeder's Gazette than to all other influences combined. The stand for common-sense principles and right methods which the Gazette has always taken, invariably appeals to the judgment of the reader. All over this country are found successful Shorthorn breeders who are children of the Gazette family. Its influence is as potent as ever and the breeders who do not read and profit from its teachings are few.

If you are one of those who do not read this valuable paper, send a postal card for sample copy to the Sanders Publishing Co., 542 South Dearborn St., Chicago.

G. A. LAUDE. 


\section{YOU R B R E E D M A G A Z I N E}

If you are one of the very few who do not receive the visit at your home, twice a month, of THE SHORTHORN WORLD, here are a few of the reasons why you should.

1. It is the breed's fearless and independent champion.

2. It is the real friend of the young breeder and the beginner.

3. It has encouraged and developed county, district, and state organizations.

4. It develops markets for your surplus in America, South America and South Africa.

5. It uses the highest grade of paper.

6. Its editorials are printed in large, readable type.

7. It is profusely illustrated and colors are used where needed.

8. It is conceded to have one of the greatest field organizations ever brought together.

9. Finally it is "YOUR MAGAZINE."

Subscription rates are $\$ 2.00$ by the year or $\$ 5.00$ for five years.

If you don't know the publication, send for a free sample copy, otherwise, send your subscription in.

"Once you take THE SHORTHORN WORLD, you never will be without it",

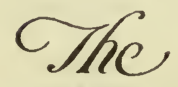

\section{SHORTHORN WORLD}

Home Office

1840-50 North American Building

CHICAGO, ILLINOIS

Ashleigh C. Halliwell, Editor.

David C. Patton, Gen. Mgr. 


\section{THE MOST}

\section{LIVESTOCK ADVERTISING SERVICE FOR YOUR MONEY}

Draw a circle of 60 mile radius (the width of two counties) anywhere in Kansas east of Larned, Hays or Phillipsburg, and you will find that the Kansas Farmer-Mail \& Breeze is read on more farms within that circle than the average circulation for the entire state, of all other farm and livestock papers that solicit advertising from Kansas breeders.

Doesn't that justify the judgment of Kansas breeders in making the Kansas Farmer-Mail \& Breeze their chief reliance, and in paying more for its space than for any other?

Yet the business within that circle is a mere fraction (about onesixth) of the total you are put in touch with thru this great predominating medium of farm and livestock influence. In the whole $\mathbf{s}^{1}$ ate the Kansas Farmer-Mail \& Breeze is first on 100,000 farms and rancles, and in adjoining sections (chiefly Colorado) there are 25,000 more on which it is paid for and read as a regular part of the pleasure and business of the family.

MOST OF THE 125,000 FARMS AND RANCHES YOU REACH IN THIS WAY ARE POTENTIAL MARKETS FOR THE GOOD SURPLUS FROM YOUR HERD.

This is the Way It Works

"Enclosed find check for Shorthorn ad in Kansas Farmer and Mail \& Breeze. We have had ads in different papers, but have had more resul's from six months in the Kansas Farmer and Mail \& Breeze than all others combined.-Meuser \& Co., Anson, Kansas."

For further facts concerning our service (which includes also the Oklahoma Farmer, Missouri Ruralist, Nebraska Farm Journal and Capper's Farmer), address

\section{THE LIVESTOCK SERVICE}




\section{THE LAUDE PRINTING COMPANY}

The Laude Printing Company of Iola is a concern which is directly interested in the pure bred live stock industry of this state. Martin L. Laude, who manages the business, was graduated from the Kansas State Agricultural College in 1911. While in school there he took work in the printing department and also had some special work under Dr. C. W. McCampbell covering live stock pedigrees. Early in 1915, associated with his father, G. A. Laude, he purchased a newspaper in Lyons, Kansas, and while publishing this paper began printing live stock sale catalogs. This branch of the business grew until they were unable to handle it properly in connection with the newspaper, so in 1918 he sold the newspaper and moving to Iola established an exclusive live stock printing house.

The business has grown rapidly since that time and is now serving a territory covering Kansas and the surrounding states. The main idea at all times has been to give prompt service and accurate work. Nothing has been spared to make it possible to meet the demands that the business required and the live stock men of this section have at their command one of the best equipped printing plants in the state. The service offered by this concern includes not only printing but also compiling pedigrees and fürnishing data and infformation that may add to the value of sale catalogs, private herd catalogs, and other work handled. The number of customers who depend on the Laude Printing Company for their work indicates the general satisfaction the service is giving. 



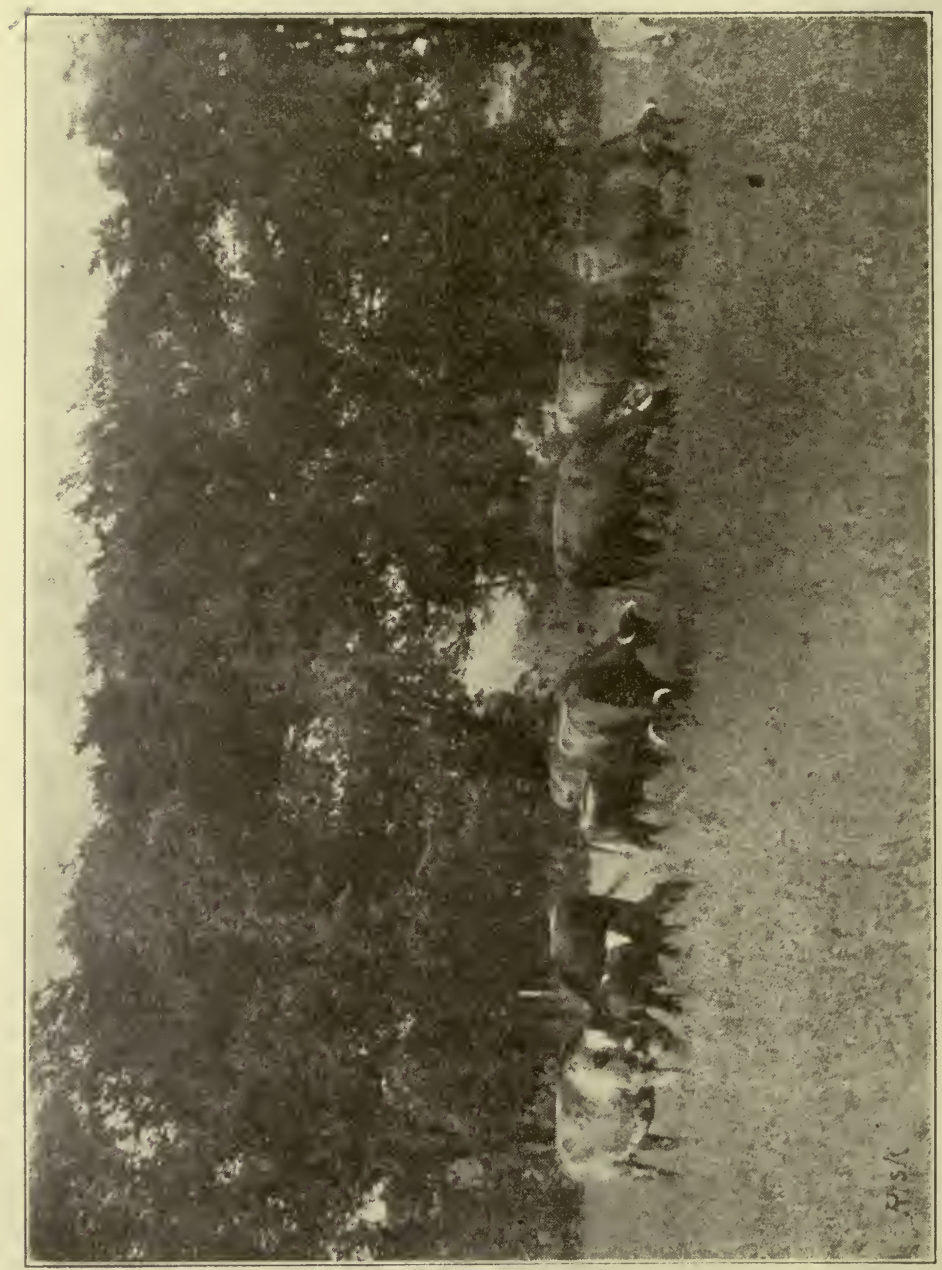




\section{PART II.}

\section{KANSAS HERDS OF TODAY}

Part I of this book has traced the growth of the Shorthorn industry in Kansas up to 1920 in a general way, but little or no attention has been paid to the herds now owned in the state. The purpose of Part II is to place before the reader the herds of those breeders who by their cooperation and financial assistance have made possible the publication and distribution of this volume.

In the year 1919 and in a limited way in 1920 , I had the pleasure of visiting most of the herds of which mention is made and of becoming acquainted with the proprietors. The sketches are in no way overdrawn but represent correctly the impression received from the cattle, their ancestry, the owner and the way in which the herd was handled. The herds not visited have been considered from accurate information otherwise obtained. Matters of pedigree and achievement are based on standard Shorthorn history and the American herd book. There has been no attempt made to create a favorable impression not fully justified by the facts in the case and any deviation from this standard must be classed as an error in judgment on my part.

The reader will find nearly all the leading 
herds of the state and of most localities listed on the pages following. At the State Association meeting held last June twenty-five members from a wide territory consigned representatives of their herds to the association sale and every one of the twenty-five is a supporter of this work and a sketch of the herd of each appears in this book.

The Shorthorn industry over the greater part of the state is based on actual necessity and for that reason it must remain a permanent industry as long as the conditions necessary for its existence continue. If you ask how long this will be, I answer by asking how long will Kansas be the home of the man who tills the soil? The farmer can not afford to keep two sets of cows, one set to produce calves for food and for the market and another set to furnish the dairy products for his family, and the Shorthorn cow is the only cow that will produce a calf capable of being grown into a profitably produced beef animal yet give a reasonable amount of milk. There is, of course, room for special dairy herds of dairy breeds and for the herds of beef bred cows to be kept with 110 dairy production, but by far the greater part of the butter and milk consumed in the state and the greater part of the beef consumed at home and sent to market now is, and always will be, produced on the thousands of smaller farms and in a small way, without consideration for the 
specialty cow. This is why the Shorthorn cow is with us to stay for all time and why the state as a whole must be a Shorthorn country. For this reason, also, the demand for Shorthorns is broader than is the demand for cattle of any other breed.

One thing I observed in my numerous visits with breeders was that by far the greater number of men most successful in the business, who are now leading breeders, began in a small way, keeping the pure bred Shorthorn cows along with the grades and gradually closing out from the grade end. Young men have told me they would be glad to breed Shorthorns if they only had the capital. This statement arises from an erroneous view for it requires no capital to begin breeding Shorthorns. Any man, young or old, worthy of confidence, who wishes to do so can buy on time at a reasonable rate of interest a good cow with a good heifer calf at foot and bred again or he can borrow the money to pay for such purchase without any difficulty. A cow, a big heifer calf and a prospect for another is a start good enough for any one. Abram Renick raised his wonderful Rose of Sharon herd that astonished the world from one heifer and hundreds of men have raised large and valuable herds from the purchase of a single female. The young man of today needs more than anything else to be educated to the fact that it is far better 
to grow a Shorthorn herd from a good, though small, beginning and in doing so to gain the necessary knowledge and skill required for success, than to be placed in possession of means to buy a Shorthorn herd that he is scarcely qualified to handle properly.

To the breeders whose names appear in the pages following I desire to express my gratitude for favors rendered. When the present period of reconstruction following the great war has passed, we should, with speculation largely eliminated, enter upon a period of real Shorthorn improvement such as the people of Kansas have never before known. 


\section{LIST OF SHORTHORN BREEDERS}

The cost of publishing and circulating A History of Shorthorns in Kansas 'has been met by breeders, live stock auctioneers and live stock publications. Breeders who have given financial assistance but who are not mentioned in connection with a sketch of their operations, are listed below by counties:

ALLEN COUNTY-

C. C. Baker, Humboldt

L. T. Cannon, Attorney at Law, Humboldt

R. M. Porter, Banker and Sale Clerk, S. F. Kans. Ass'n, Humboldt

W. F. Fussman, Humboldt

R. L. Works, Humboldt

Wright \& Miller, Humboldt ATCHISON COUNTY-

J. T. Shortridge, Effingham

F. J. Hunn, Arrington

BARBER COUNTY-

Miss Mary Best, Medicine Lodge

J. A. Wise, Medicine Lodge

BOURBON COUNTY-

Caldwell Davis, Bronson

J. M. Davis, Bronson; telephone and station, Blue Mound

Harper Fulton, Ft. Scott, R. R. 5

BROWN COUNTY-

John McGuire Jr., Robinson

CHASE COUNTY-

C. D. Yeager, Bazaar

L. E. Macy \& Sons, Saffordville

CHEROKEE COUNTY-

H. L. Long, MeCune
CLOUD COUNTY-

C. A. Sulanka, Concordia ; station, Aurora

Dale Trundblade, Jamestown COFFEY COUNTY-

F. D. Brazil, Lebo; telephone and station, Halls Summit

R. B. Daily, Waverly

Chester Smith \& Son, Waverly

DICKINSON COUNTY-

Marvin Gfeller, Chapman

DOUGLAS COUNTY-

S. O. Gentry, Lawrence, R. R. 5; station, Lakeview

E. H. Purvis, Baldwin

EDWARDS COUNTY-

E. H. Tallman, Lewis ELK COUNTY-

S. L. Harvey, Grenola

G. B. Payne, Auctioneer, Grenola

GREENWOOD COUNTY-

John Burke, Severy; telephone, Eureka; station, Climax.

HARPER COUNTY-

L. R. Andrews \& Son, Harper

Barrett \& Pedrick, Anthony

R. H. Watt, Anthony 
JEFFERSON COUNTY-

C. H. Thompson, Perry Albert Gramse, Oskaloosa JEWELL COUNTY-

F. H. Hull \& Son, Mankato; telephone, Ionia

KINGMAN COUNTYMcIlrath Bros., Varner

LABETTE COUNTY-

S. M. Oakleaf, Mound Valley

LANE COUNTY-

Robert Edmundson, Dighton

B. D. King, Dighton

LEAVENWORTH COUNTYJohn Murphy, Bonner isprings

LINN COUNTY-

Davis Bros., Prescott

LYON COUNTYAustin Shown, Americus

C. R. Russell, Emporia

MARION COUNTY-

I. N. Smith, Burns

Peter H. Friesen, Lehigh

MONTGOMERY COUN'TY-

J. G. Tharpe, Jefferson

A. L. Bird, Cherryvale

NORTON COUNTY-

H. F. Riemann, Densmore

Samuel Teaford, Norton; station, Calvert

OSAGE COUNTY-

A. A. Adams, Osage City

C. C. Calkins, Burlingame; telephone and station, Harveyville

H. J. Franklin, Melvern

M. C. Hamaker \& Son, Scranton

A. J. Hanna, Burlingame

Earl C. Hepworth, Burlingame

Herb Pieman, Quenemo

OTTAWA COUNTY-

J. S. Reed, Oak Hill

POTTAWATOMIE COUNTY-

C. A. Crumbacker, Onaga

W. A. S. Bird, Belvue; residence, Topeka

RAWLINS COUNTY-

D. E. Frisbie, McDonald
RENO COUNTY-

Harry Leclere, Burrton

Harry Sullivan, Haven

D. J. Shuler \& Son, Hutchinson, R. R. 3 ; telephone and station, Nickerson

REPUBLIC COUNTY-

M. M. Fate, Concordia; station, Talmo

Frank C. Graustedt, Scandia

RILEY COUNTY-

L. S. Estes, Manhattan

Gus J. Klocke, Winkler

W. D. Williams, Bala

ROOKS COUNTY-

A. D. Hull, Woodston

SALINE COUNTY-

G. H. Shier, Gypsum

SEDGWICK COUNTY-

John B. Wetta, Andale

SHAWNEE COUNTY-

J. A. Ostrand, Elmont

J. H. Foltz, Wakarusa

SHERIDAN COUNTY-

A. B. Shoemaker, Lucerne; station, Jennings

L. A. Teel, Lucerne; station, Lenora

SMITH COUNTY-

S. A. Hill, Smith Center

W. A. Bloomer, Bellaire

STAFFORD COUNTY-

Edward Hitz, Hudson

Herman Dohrmann, Hudson

SUMNER COUNTY-

W. G. Buffington, Geuda Springs

W. C. McMillan, Belle Plaine

Worden \& Co., Wellington

WABAUNSEE COUNTY -

Gerloch Bros., Alma; station, Halifax

WASHINGTON COUNTY-

Wm. Brown, Mahaska

W. A. Wells, Mahaska

WILSON COUNTY-

L. D. Connell, Altoona

WOODSON COUNTY-

F. A. Dumond, Yates Center 


\section{ALLEN COUNTY}

S. M. Knox, Humboldt. *-This herd of thirty females was established in 1914 and two years later the grades kept on the farm were all sold. Mr. Knox began showing at county fairs in 1917 and has been showing since that time in Allen, Wilson, Neosho and Bourbon counties. His winnings have been good. The young stock is quite well grown, and while not fitted, is shown in splendid farm condition. He has contributed to the Southeast Kansas sales at both Coffeyville and Independence and at the fall show at Independence in 1919 his entries were good winners.

The first bull used in the herd and one that proved an unusual breeder of good sized, smooth stock was Roan Lord. He was by Lord Mayor 3d, a first-class show bull, that was a son of old Lord Mayor out of Forest Daisy, own sister to Tomson Bros.' Forest Daisy 2d, the dam of the International and Royal champion, New Year's Delight. The next bull was Knox Knoll Dale, a son of the grand champion Whitehall Rosedale out of Village Maid 42 d by imp. Bapton Coronet. This bull was large and bred large, and from the straight-lined cows in the herd attractive, good

Ship on Mo. Pac., Sarita Fe or M. K. \& T. Telephone, Humboldt, LaHarpe or Iola. 
sized, smooth, beefy young things were secured.

Mr. Knox has recently bought the tried sire, Scotch Cumberland. He is by Cumberland's Type, the most sensational American show bull of the times, thirty-seven first premiums being claimed for him in thirty-seven showings at the biggest shows. Scotch Cumberland had been used by John Regier for three years and sired there a very attractive line of calves that are growing into big cows with a promising future. Valuable additions to the female end of the herd were made by purchasing at Independence in 1919 several of the choicest cows from J. H. Holcomb's excellent consignment, and at the spring sale the highest priced cow sold fell to his bidding. Mr. Knox is in a position to carry out plans that will make his herd one among the best in southern Kansas.

J. H. Holcomb, Humboldt.-Working his way up from agent's assistant in a small Iowa town to division freight agent of a trans-continental railroad, then at fifty years of age investing his savings in a choice Allen county farm, tells part of Mr. Holcomb's life story. The rest has been written by his work on the farm and with the Shorthorns since 1900. Mr. Holcomb's first purchases were fourteen high-grade cows from J. H. Bayer followed by four pure bred heifers and a bull. Within a few years he discovered he did not have the quality he needed so he sold them 
and bought better ones. This process was repeated once more when we find him in 1919 with a splendid small herd. In the fall of that year he sold his farm and not knowing what else to do with the cattle he consigned them to the Southeast Kansas sale at Independence where they won the big end of the prizes in the show held in connection with the sale and made an average of almost $\$ 450$.

In Mr. Holcomb's mind his connection with Shorthorns was ended. This was not correct, however, for he could not get along happily without them. He now has a small herd but it is the best he has ever owned. It includes the second prize cow in the State Association show at Manhattan in May 1920 and several others equally as good. - The breeding of these cows is of the best that could be obtained and their calves are by bulls of national and statewide reputation.

The bull that will be used is Victor Swinton by imp. Swinton Liberty, one of the very best of the Scotch bred bulls in Kansas. Victor Swinton is out of a magnificent big cow that is a heavy milker and has been a good prize winner against strong competition. Both sire and dam of this bull are of the choicest breeding and he should develop into a valuable animal.

Warren W. Works, Humboldt.-For a young man just beginning with Shorthorns Mr. Works has a most favorable outlook. The Works farms 
are among the best in this part of Kansas with the choicest pastures and unlimited acreage of alfalfa land and all needed buildings that will enable a man to get the best results in handling cattle. The stock on hand is exceptionally good. It includes the red, Jacintha 2d, an Amcoats bred daughter of Whirlwind by Captain Archer and her yearling heifer by Victor Gloster, the grand champion bull at the 1919 fall Southeast Shorthorn show at Independence. This pair was in the excellent consignment made by J. H. Holcomb to the Southeast Kansas sale and Jacintha $2 d$ was the best producing cow in the Holcomb herd.

Passing by a number of good ones I want to notice Lady Cumberland, a roan by the Owen Kane bred Spicy Pride, a son of Spicy Cumberland by Cumberland's Last. Spicy Pride's dam was Maxwalton Rosewood by Avondale out of imp. Rosewood 86th. The dam of Lady Cumberland is out of a Rapp bred daughter of Gladstone, recognized as one among the better sires by Whitehall Sultan and a bull whose get won many prizes at the big shows. Lady Cumberland herself is one of the best specimens of the breed in this part of Kansas and would make a strong entry in a good show. The bull selected by Mr. Works is a white of outstanding merit. He was bred by John Regier and was considered by Mr. Regier one of the best bulls he ever bred, if not the best. He is unusually deep and thick with as 
good a back, loin, and quarters as could be desired. His head, neck and general appearance are excellent and his ancestry is of the choicest, from whatever viewpoint it may be considered. Bulls of his class are not easily found and Mr. Works should be congratulated on his possession.

R. O. Furneaux \& Son, Moran.-These men are old residents on one of the best kept farms in Allen county. It has been a stock farm for years and Shorthorns have been grown all the time. The first high-class bull used was Golden Sharon by Scott, Jr., a great show and breeding bull by imp. Scottish Emperor. He was followed by the Hanna bred Reflector by imp. Collynie and later by Fashioner 4th, a son of the splendid show bull, Lord Mayor 3d. The use of such bulls gave satisfactory results and a lot of nice young cows are in the herd. Spicy Choice, a Dunean bred son of Choice of All, is in service. This bull is a beautiful roan of medium size, very smooth and even from end to end and the calves indicate he will be a good sire.

Both Mr. Furneaux and his son, John, are wide-awake, energetic citizens and leaders in everything pertaining to advanced agriculture. Theirs is a farm where scrubs of any class are not tolerated and where scrub ideals along any line gain no footing. Besides the Shorthorns, they keep a flock of Shropshire sheep. Messrs. Furneaux are forecasting the future on the larger 
farms in eastern Kansas where soil fertility can be maintained only through the keeping of - live stock. They also realize that Shorthorns are the only breed of cattle that are both good milkers and good beef cows: R. O. Furneaux is classed among the best judges of Shorthorns in the state.

Hall Bros., Carlyle.-Hall Bros. are natives of Allen county. They have an excellent farm on the Neosho River. In one of the pastures there is an elm tree which would easily furnish shade for fifty mature Shorthorns. Near the tree is a running spring supplying the best of water in great abundance. Below the spring is a large field of alfalfa.

Do Shorthorns thrive here? For answer, go up to the higher ground and you will find the cows bearing all evidence of giving a large flow of milk, yet fat enough to sell for good beef. The Hall herd is not large, about ten females of breeding age and a few heifers, but it is a real Shorthorn herd. The bull at the head is White Archer 633595 by Kansas Prince, whose get made a sensational showing at the Southeast Shorthorn show in 1919. He is a full brother to the eleven-month-old White Violet that sold in the sale for $\$ 650$ and he is proving a splendid heifer getter. The cows in the herd are red and the six promising calves from this white bull range from medium to dark roan. 
This story, briefly told, of Hall Bros.' farm and cattle teaches a lesson. A few years ago they bought four heifer calves from Dr. Slavens of Neosho Falls, at very moderate prices. (See Slavens sketch.) Good care, resulting in good development, did the rest: It will pay any one to visit the Hall farm and see what can be accomplished by feeding good Shorthorns on good farm feeds only.

T. E. Holloway, Humboldt.-It is only fair to say that Mrs. Holloway should be included in this sketch. She is not only a Shorthorn enthusiast but she is also an excellent judge and there are those who say that in judging she outclasses the majority of men engaged in the production of Shorthorns. Few new breeders except those of unlimited means have scored the degree of success that has been theirs. That the Holloway herd during its few years of existence has developed into a really good one is probably due to two causes, good care and the use of the bull Sir Hampton, mentioned in the Wesley Jewell sketch.

The heifers by Sir Hampton have developed into big, broad, smooth animals with a breedy appearance. In the summer of $1919 \mathrm{Mr}$. Holloway aequired by purchase the Diver \& Potter herd, retaining the most desirable females. He also bought of J. H. Holcomb an excellent four-yearold cow of very choice breeding and with her won 
first prize at the Neosho county fair. Mr. Holloway is part owner of the bull, Fancy Lad $2 \mathrm{~d}$ (see Wesley Jewell sketch) and this bull is being liberally used. The herd has been shown at local fairs, winning a good share of premiums. At the Shorthorn show at Coffeyville in April 1919, the Holloway entries attracted general attention on account of their size and beautiful roan color. It was here that Mr. Holloway was awarded first prize on produce of cow.

Horville Bros., Iola.-On a big farm near the city is an object lesson that speaks for Shorthorns. The Horville herd is large and excellent and includes cows which would look well anywhere. Most of these cows are grades and it was the continued use of high-class bulls that did the work. This herd is a tribute to Shorthorn blood and the business sense of the owners who give the cattle good care twelve months in the year.

The pure bred cows are descended from good ancestry and with the unusual facilities these men have for carrying on their operations and with their genius and inclination for the work we may reasonably expect to find a great Shorthorn herd on this farm within the next few years.

The bull in use is a massive white that stands very close to the ground. He has a fine head and neck and a great covering of mellow flesh. In strong competition he won the American Short- 
horn Breeders Association bull championship at the Allen county fair in 1919. Two direct crosses to imp. Lord Banff are found right at the top of his pedigree. Any one seeing his calves will admit that he is a great breeder. Something of the Horville method of procedure came out when, in a talk with Mr. L. E. Horville, the subject turned to the pedigree of their bull. "I'll pick my bull first, then we'll see about the pedigree," said Mr. Horville, and I breathed a silent amen.

Wesley Jewell, Humboldt.-Within the past ten years a succession of good, well bred bulls has been used in the Jewell herd. Collynie Goods was by Collynie out of Lavender of Colstock Farm by Choice Goods. His heifers have proved splendid breeders. Roan Mayor was a show bull of the first class. He was by Lord Mayor 3d out of a Tomson bred daughter of Archer. One of the most successful sires used was Sir Hampton. He was bred by S. C. Hanna and was used at Palo Duro before his sale to Mr. Jewell. He was by Hampton Spray out of a dam by Prince Royal, second dam by Collynie, and represented the best of Mr. Hanna's breeding. The heifers by this bull out of the Collynie Goods cows are altogether pleasing, having much size and quality. Two excellent additions were recently made to the herd. A roan Nevius bred cow by Searchlight $\mathrm{Jr}$. is a distinct acquisition. Fancy Lad $2 \mathrm{~d}$ is the 
new herd bull. In G. Wittry's herd he sired heifers that leave little room for criticism and that promise to develop into large, matronly cows with much Shorthorn character. Individually, Fancy Lad 2d is of proper type and conformation. He is out of an excellent cow of choice breeding, a daughter of imp. Fancy $2 d$ and his sire, Prince Valentine 4th, is among the state's best bulls. He comes from Tomson Bros. and is one of their good productions. Mr. Jewell is president of the Southeast Kansas Association.

O. A. Weddle, Savonburg.-Mr. Weddle has plenty of enthusiasm and good cattle sense to guarantee success in producing Shorthorns. He has a herd of twenty-five females. Purchases were made locally and at Wolfe Bros.' sale and include some choice individuals of elegant breeding. One of the good ones is Roan Blossom, a five-year-old by Victor Sultan, a bull of the Whitehall Sultan family through Whitehall Chief. Her dam is by Orange Champion 274875. Another Victor Sultan cow is Hepler Rose. Her dam was out of Barmpton Lady 5 th bred by George Allen and sired by Godwin, one of the best sires of valuable breeding cows in the central West. Lady Barmpton, own sister to Hepler Rose, is also in the herd. Another five-yearold roan is Miss Eva by Searchlight's Bloom, one of the good sons of Searchlight and a sire of much desirable stock. 
Mr. Weddle has little use for a bull of medium quality, and for the past two years he has used Butternut Sultan, a Bellows bred son of Sultan Supreme, the sire of the 1916 International grand champion Village Supreme that sold for $\$ 16500$. To succeed Butternut Sultan Mr. Weddle recently bought of George F. Kellerman an outstanding roan calf, one of the very best things Mr. Kellerman has ever bred. This calf weighed 800 pounds at eight months old and would be considered an extra good one in any of America's best herds.

R. M. Beamon, Bronson.-Mr. Beamon's cows are very uniform in general appearance and conformation. The herd is all red and he is one of the few breeders who will not use a roan or a white bull. Among the cows there is one that attracts attention on sight. She is out of a daughter of imp. Collynie and her dam was purchased by Bellows Bros. at Ed Hall's dispersion for a good price. Two daughters of this cow are in the herd. A new herd bull was bought at the Linn County Breeders sale in November 1919. The Beamon farm is well supplied with good pasture, a prime requisite for best results and one that is not always found in Allen county.

C. H. Ronsick, Humboldt.-Mr. Ronsick started right by buying choice stock at the Southeast Kansas Shorthorn sale which purchase included two heifers from H. I. Gaddis' excellent 
herd. Village Princess is an elegant roan, very feminine, close to the ground, and she was one of the most pleasing things in the sale. Her ancestry throughout is of the best known to American Shorthorn history and includes, right at the top of each one of the first five crosses, bulls that have been breed builders. Hers will be an exceptional case if she does not produce high-class stock. Mr. Ronsick is a neighbor of Wesley Jewell and will be able to use his herd bull which will be a great advantage to him.

Sullivan Bros., Moran.-The Sullivans bred Shorthorns in Iowa before they came to Kansas. They have five big, beefy Shorthorn cows, all of which are being milked, and the calves are being; raised by hand. In this they are doing what many small farmers must do in the future. One of their cows is a splendid specimen of the breed and in appearance is a dual-purpose cow. She was bred by T. K. Tomson \& Sons and is out of a daughter of imp. Thistletop. Three of the cows in the herd are her daughters. The bull in use is by Master of the Dales out of Golden Mistletoe, the Hanna bred daughter of Prince Mistletoe that sold in the Southeast Kansas sale for $\$ 1245$.

J. L. Jewell, Humboldt.-Mr. Jewell was until recently a member of the firm of Jewell Bros. He owns a few females, several of which are of excellent quality, but so far he has bought no bull, preferring to use his choice of three good 
ones that are available. This gives him an advantage the small breeders over the country can frequently have. Mr. Jewell is an admirable care-taker and he is making rapid improvement. One of the best young cows seen in my travels in Allen country was in this herd. She is a daughter of Sir Hampton, a bull used successfully by S. C. Hanna.

Fred Lassman, Savonburg. *-Mr. Lassman is located on a large farm that is well adapted to cattle growing. He has been raising grades under favorable conditions and has recently purchased a dozen nice heifers and a good bull, his intention being to grow into the business by selling off the grade end. Mr. Lassman is young, intelligent, a clear thinker, and makes a success of whatever he undertakes. He will handle his cattle in such a manner as to work constant improvement in the herd and local Shorthorn as well as general live stock interests will be benefited by his becoming a breeder.

C. W. Beeman, Humboldt.-This herd was established two years ago and Mr. Beeman made several valuable additions at the 1920 sale in Humboldt. His herd should become one among the best in the county. Recent purchases include a few splendid females of choicest breeding and the excellent young bull Lord Mysie by Claude Lovett's famous sire, Scotch Lord by Lord

Telephone, Humboldt. 
Avondale. Mr. Beeman is a good feeder and care-taker and will produce real Shorthorns.

S. C. Caldwell \& Son, Moran.-This herd was founded in 1919 by the purchase of four females and a good white bull. Since that time a valuable addition was made in the purchase of a heifer by Prince Valentine 4th, one of the best and most favorably known sires in Kansas. The cows are of good size and are being well kept. It is the plan to add to the herd from time to time.

Fetherngill \& Enfield, Iola.-This firm made the first investment in pure bred females at the Southeast Kansas sale in April 1919, where three excellent heifers from the herds of O. O. Massa and H. M. Hill were secured. The ancestry of these heifers together with their individual merit is a practical guarantee that, if well developed and properly mated, they will be the foundation of a good Shorthorn herd. The prize winning bull owned by Horville Bros. will be used.

C. G. Staley, Moran.-Mr. Staley is a professional cattleman with a few good Shorthorns who will gradually close out his grades and keep only pure breds. His cows are of good size and form and are satisfactory breeders. The bull is by Lord Mayor 3d, a prize winning son of Lord Mayor and out of a Hanna bred dam by imp. Collynie that sold to Bellows Bros.

J. Frank Stevens, Humboldt.-Mr. Stevens 
has made a nice start with two cows bought of J. H. Holcomb. One of these is by Marquis Cumberland, the Saunders bred son of Cumberland's Best, frequently mentioned in this book. The other is by Orange Senator 308511, a bull well known in north central Kansas. Mr. Stevens will add a good cow to his herd occasionally. He is breeding to the high-class bull, Scotch Cumberland, owned by S. M. Knox.

George L. Weatherbie, Moran.-Mr. Weatherbie has a few cows of choice breeding. Red Ruby is by Chief Steward, a son of Clansman out of a dam by Royal Leader. (See T. J. Sands sketch.) Her dam is by a son of Hampton's Best out of a daughter of Valley Champion. The herd bull is by a son of Lord Mayor 3d out of a daughter of imp. Collynie. Such a start will be recognized as a good one.

\section{ANDERSON COUNTY}

G. Wittry, Greeley.-Mr. Wittry has a herd of twenty-five females representing both the socalled Scotch and Scotch topped families. The blood lines in the top crosses of his herd show many of the best Shorthorns of the day and he is giving his cattle the care needed for proper development.

Among the buills that have left a good impression on the herd are Choice of All by Choice Goods out of Rosedale Violet 9th ; Prime Minister 
by imp. Prince of Perth out of Goldfinch, a full sister to the International champion, Lavender Viscount; New Goods at the head of Harriman Bros.' herd at its dispersion; Cumberland's Last, the famous bull in C. A. Saunder's' select herd; Young Abbotsburn, America's greatest show bull; Prince Pavonia and Searchlight, both of inter-state reputation in C. S. Nevius' herd; Godwin, famous sire of great producing cows and other good ones that could be mentioned. It is no wonder that the Wittry cows produce well for theirs is quality by inheritance.

A visit to the Wittry farm will convince any one that right breeding and right feeding are the two requisites in producing good cattle. The young stock on the farm is largely by Fancy Lad 2d, a Tomson bred son of Prince Valentine 4th. His dam is by the M. E. Jones bred Cherry King and the second dam is imp. Fancy $2 \mathrm{~d}$ by Cap-aPie. I saw five yearling heifers by this bull. They were all good ones and two of them were outstanding. Fancy Lad 2d was sold in August 1919 to Wesley Jewell of Humboldt and $\mathrm{Mr}$. Wittry bought Honor Light, a son of Searchlight, the bull so well known as a prize winner and breeding bull for C. S. Nevius. The dam of Honor Light is Maid of Honor of Geo. Bothwell's breeding and sired by Grand Victor out of imp. Winifred 4 th by Scottish Archer, the greatest of Mr. Duthie's bulls. That a bull of such 
excellent descent should give excellent results is only a reasonable conclusion.

There is a practical lesson in this story of $\mathrm{Mr}$. Wittry's work which I wish to emphasize. Everywhere I go I find people who buy quite good cows at moderate prices and buy only a moderately good bull and give the herd only a moderate amount of feed. Success never follows such methods. A good bull and plenty of good feed with good care means a good herd and nothing elsé will produce it.

Henry Sobba, Greeley.-Mr. Sobba made his first purchase of Shorthorns from Tebo Lawn in 1902. The lot consisted of six heifers and an excellent bull. Unfortunately, four head of these heifers were killed by a Missouri Pacific train soon after they reached the farm. The present heid, numbering about forty head, is descended from this purchase. Mr. Sobba has used some highly satisfactory bulls but, like most breeders, he has also used some that fell below the desired standard. The methods of handling have been fairly good but not such as to bring out all there was in the animal and his prices on the young bulls have been moderate. The surplus has been sold locally and it is a matter of note that all around Mr. Sobba's the cattle are of very excellent quality, showing liberal use of good Shorthorn bulls; in fact, he has living monuments to the value of his herd all around him. I feel sure 
that a dozen Sobbas in each county of Kansas would make every bovine in the state look like a Shorthorn.

On the good Tebo Lawn foundation is found the blood and impress of such animals as Orange Viscount, German Laird, Daisy of North Oaks 5th, imp. Prince of Perth, imp. Collynie, Godoy, and through Godoy, imp. Golden Thistle, the largest and perhaps the most showy cow in the Linwood herd. Captain, the present herd bull, was bred by Mr. Hanna and is siring some very satisfactory calves.

E. C. Holt, Greeley.*-This is a small but choice herd that will be increased to meet the requirements of the farm. Mr. Holt is a good feeder and the cattle, as I saw them, were in fine condition. Kansas Girl 2d is an elegant four-yearold red. Her sire was by imp. Collynie out of Cowslip Bloom by imp. Lord Cowslip, second dam by imp. Inglewood. Daisy Sultan is strong in Whitehall Sultan blood and in that of Gallant Knight and Lord Mayor. Pansy Dale is by Cedar Dale, one of the state's best sires of highclass stock. The herd bull, a big, thick, rugged fellow of excellent type and good finish represents the best of the Hanna-Hill breeding with imp. Collynie, Royal Knight, Ingle Lad, imp. Inglewood and Silvermine in the first two crosses. Mr. Holt has selected his foundation

Telephone and shipping station, Garnett. 
stock closely desceended from the best Shorthorns of the day and they are cattle of real excellence.

W. K. Craig, Garnett.-Mr. Craig has been in the business for ten years, having laid his foundation in the purchase of the cow, Secret Airdrie, from H. M. Hill's herd. This cow, as her name implies, united. Mr. Hanna's Secrets and Mr. Hill's Fanny Airdries, two of the best families of Shorthorns in the state. Her sire was the wonderful bull, Prince of Collynie, which gave Mr. Craig a foundation good enough for any practical man. The bulls used since then have been representative of Searchlight, Gallant Knight, Victorious and imp. Collynie. The herd consists of about a dozen females, all descended from the Prince of Collynie cow. Mr. Craig plans to buy a first-class bull soon.

H. C. Doering, Garnett.-Mr. Doering is breeding some good Shorthorns on his farm just outside the city. He has been paying special attention to milking quality and his cows are a nice, even lot of medium size, the kind that raise splendid calves and milk well after weaning the calves. At the time of my visit, the herd consisted of about twenty females and an excellent lot of young things by Ingle Marr, a bull strong in the blood of Collynie, that had been used for several seasons. Besides Ingle Marr some firstclass sires are found in the top crosses of this herd, such as Ingle Lad, Lavender King 4th and 
imp. Scotchman, three bulls that did great service in three southeast Kansas herds.

\section{John L. Jones \& Sons, Garnett.-Mr. Jones} and his three sons comprise this firm. Each boy owns a cow bought from Mr. Sobba and the father owns the bull. The bull is twelve months old, has had good farm care and has wonderful finish. If well carried on, he will be a trouble maker in a show ring. His sire is Sultan's Robin, an Uppermill bred son of Sultan's Last out of a Cock Robin dam. The calf has a right to be good and I saw enough to satisfy me that this herd will do well. I wondered if Mr. Jones was not doing far more for his boys, now of the most impressionable age, by making them his business partners than he could do by leaving them a big cash inheritance in later years.

J. G. Lowry, Harris.-Mr. Lowry has bred Shorthorns for about ten years. He now has eight females, five of which I have seen. They are good individuals and represent nice blood lines, among them being two out of a daughter of imp. Sunnyblink 9th. Mr. Lowry has used the bull, Ingle Marr, and the herd has received the benefits arising from the use of bulls carrying the blood of such animals as Ingle Lad, Kinnellar, imp. Mariner, Orange Viscount and others but has not received the care or attention to detail necessary to secure best results. The stock on hand, or at least most of it, with a good 
bull and proper care, would become the foundation for a valuable herd of Shorthorns.

E. C. Meissner, Colony.-Mr. Meissner's foundation was bought at the Coffeyville sale in 1918 and consisted of a Stunkel bred heifer by Imperial Goods out of a Victor Orange cow, one by Mistletoe Stamp, full of the Hanna-Hill blood lines and two by Mr. Massa's great bull, Kansas Prince, out of cows by Master Prince 6th, son of Prince Pavonia. Mr. Meissner has a fairly good bull, which on these heifers should furnish the prime requisite for the building up of a creditable Shorthorn herd. The impression I gained while at the farm was that if $\mathrm{Mr}$. Meissner decided to put up a first-class herd he would do it.

R. H. Trimmell, Garnett.-Mr. Trimmell has all the requisites for success in the Shorthorn business. He has the disposition to demand quality in whatever goes into his breeding herd and he impressed me as being a good care-taker. The cows come largely from high-class ancestry. One of the best ones is a recent purchase from J. C: Robison, Duchess Aberdeen by Victoria's Coronet 541677. One of the bulls used was Sir Magnet 5th by Searchlight $J r$. Another was Sycamore Sunblaze 2d from the Cowham farm. The present herd bull, I saw as a calf. He bears the popular name, Gen. Pershing, and looks like the making of a creditable bull.

A. J. Tippin, Greeley.-Mr. Tippin is an old 
breeder in a small way, having a nice herd of nine females, the foundation for which was laid twelve years ago. His cattle represent excellent blood lines coming through Prince Pavonia, Scotland's Charm, Winsome Duke 11th, Lavender King 4th and Golden Victor. A good young bull purchased from Mr. Wittry is in use, a son of Fancy Lad 2d (see Wittry sketch) with two crosses to imp. Lord Banff following. This bull should produce satisfactory results and Mr. Tippin's favorable location on alfalfa land should do the rest.

O. H. Carrier, Kincaid.-Mr. Carrier bought a cow at Wolfe Bros.' sale and two others locally. He also bought a good bull, Roan Mayor, by the prize winning bull, Lord Mayor 3d. Roan Mayor's dam was by a Hanna bred son of imp. Lord Cowslip. This bull, now six years old, was a prize winner as a yearling and later saw much service in the herd of S. M. Knox where he proved an exceptional breeder.

\section{ATCHISON COUNTY}

Robert Russell \& Son, Muscotah.*-These men have been breeding Shorthorns for some years and recently decided to put in a herd with pedigrees to which no one would object. This desire to meet the requirements of the most critical has been extended to affect the entire herd and theirs

* Ship on Mo. Pac., Rock Island or Santa Fe. 
is one of the few to be found in Kansas with only so-called straight Scotch cattle on the farm.

The present herd consists of young cows three and four years old, recently acquired by purchase from excellent sources of supply. Some generous prices have been paid and while the stock is not being pushed as in some cases, these young cows are quite an attractive lot and indicate a mature herd of considerable scale and uniformity. Imported Brandsby Augusta 4th was bought at the Ogden sale and is a nice roan of $\mathrm{J}$. M. Strickland's breeding, combining good size, straight lines and pleasing appearance and she is suckling her second calf. Acanthus Beauty, five crosses from Mr. Cruickshank's Acanthus by Barmpton is not only a deep, blocky cow of good beef type and indications, but she shows milking tendency that would interest a professional dairyman. It occurred to me that such cows as this were about what a person should have in a dual-purpose Shorthorn. She is of medium size and her kind would make any farmer money. The five top sires in her pedigree were bred by Carpenter \& Ross, W. D. Flatt, Wm. Cummings \& Son, Wm. Duthie and Amos Cruickshank. Right here I want to state that the young cows of this herd have all produced one or two calves, each cow suckling her calf in good style. Mr. Russell says that a poor breeder or suckler will not have room on the farm. "Just 
a good lot of cows kept on the farm to consume its production" is the way he puts it, "and I want them to be such that if a man found what he wanted he would not object to the pedigree." Whitehall Rosedale, International grand champion, is represented by Autumn Bloom by Fame's Goods, one of his excellent sons and in the second cross by imp. Bapton Coronet, one of the best sons of the famous Silver Plate. In the third are imp. Prince of Perth and Goldfinch, full sister to another International champion, Lavender Viscount. Autumn Bloom's first calf, now twelve months old, speaks for her as a producer. Lavender Princess 10th by King's Secret, International champion, son of the International grand champion, King Cumberland, is out of a dam by Blythe Baron, second dam by the Duthie bred Golden Mist out of imp. Lavender Princess. One of the best three-year-olds in the herd is Lily Cup by Scarlet Secret out of a dam by I:ord Golden Crest. This cow is the dam of an outstanding fourteen-month-old bull, of such size, form and quality as to attract special attention anywhere. This bull was sold at a long price to Kepler \& Wiltse and was the first of the 1919 calf crop to leave the farm. Princess Avondale, anether good three-year-old from the Ogden herd represents top notch breeding, coming through the best breeders. She is large and her first calf went to one of the well known herds in 
the West. Two of America's best known champions, Whitehall Rosedale and Cupbearer, contribute their quality to Queen's Gift. Her sire was a son of the former and her dam was by a double grandson of the latter and out of imp. Margery. The Duthie bred imp. Sittyton Victoria $2 d$ has a granddaughter in the herd in Queen Victoria by Snow King out of a dam by the well known Duncan bull, Headlight.

"By their fruits ye shall know them" applies with special force to a herd bull and Mr. Russell says he is willing to have his herd bull, Walnut Type, so judged. His calves look unusually good. He is by a Harding bred son of Whitehall Sultan and out of the Dean Willis bred imp. Citrina by Silver Plate, second dam by Roan Robin followed by Gondolier, Cumberland, Barmpton and Scotland's Pride, a line of breeding unexcelled. Silver Plate, a white about two years old, is by imp. Bapton Corporal. He is not a show bull but if a young calf I saw by him is a sample of his get, he will make his mark, for it involuntarily reminds one of its grandsire, imp. Bapton Corporal. Mr. Russell considers Silver Plate a very valuable breeding prospect.

K. G. Gigstad, Lancaster.-It is only reasonable to conclude that a man who raised a load of steers that were a national sensation would be well qualified to raise toppy Shorthorns. Th: man who visits Mr. Gigstad's farm expecting to 
see good cattle will not be disappointed. This large herd was founded thirteen years ago and only a few, but very choice, additions have been made since that time. The original purchasos came from excellent sources and were made with the same discriminating judgment shown in the selection of the load of steers. The additions since then have been of such quality as men of Mr. Gigstad's judgment and high sense of excellence would make. It seems superfluous to refer to these cattle in detail, yet I cannot refrain from mentioning one, imp. Millcraie Costly Belle. There is no discounting this cow, either as an individual or as a producer, and it might be mentioned that she has this season suckled two calves, growing them well and she herself carries smooth, thick flesh.

Mr. Gigstad early recognized the importance of good bulls. The first bull that enters into the present herd is Fancy Choice, a Bellows bred son of Good Choice and out of.a Duncan bred cow, Mary Ellerslie, coming as her name indicates from a dam bred by T. J. Wallace and carrying a cross of the great champion, Young Abbotsburn. He was followed by Goods, another son of Good Choice. A few years later, Golden Lancaster, a Duncan bred son of the sensational Choice Goods bull, Golden Goods, the sire of Howell Rees' Ruberta's Goods, was purchased. These two bulls sired the show steers mentioned above. 
Hampton's Spicy by Hampton's Successor, one of the really good sons of Hampton's Best, brought in the Merry Hampton blood and was a splendid sire. Imp. Gallant Favorite, an Anderson bred son of Dunglass Favorite, was used for a time and left a lot of excellent young things. Most of the cows now on the farm are bred to Bapton Charm, a good, big, smooth son of imp. Bapton Corporal and imp. Millcraie Costly Belle and highly satisfactory results are anticipated from this cross. A young bull on the farm that is being watched with interest is Gallant Favor. He is a son of imp. Gallant Favorite and imp. Beauty's Pride 2d, an Anderson bred cow by Proud Brigadier 609477. He is almost a year old, too young to have certain judgment passed on him, but he is very smooth and has great depth of body with fine head and neck. If he fills out well, as he might reasonably be expectes to do, he should be as worthy as any of his prederessors. Valuable additions were made by purchase of some of the best cattle in the offering at the leading 1920 sales, which puts the Gigstad herd in the front ranks.

H. A. MeLenon, Effingham. ${ }^{*}-M r . ~ M c L e n o n$ had been with good grade Shorthorns all his life and a few years ago he decided to put in pure breds instead of grades. He has exceptional pasture conditions with plenty of forage of

Ship on Mo. Pac. or Rock Island. 
different kinds and with the excellent stock on hand and the interest taken in Shorthorns it is a safe guess that he will be a success as a breeder and put up a first-class herd.

A very liberal investment in foundation stock paid out with judgment has resulted in some worthy specimens of the breed being in the herd. Imported Allerton Rosebud 4th is a large red of more size and quality than is found in most of the imported cows I have seen. She is a very heavy flesher, makes a nice appearance and has to her credit the production of a first-class bull now used in the herd, to be mentioned later. Her spring of heart rib joined to unusually smooth shoulders is noticeable at a glance. 'Wimple's Clara bred by C. E. Leonard \& Son and sired by Wooddale Stamp is an attractive, short-legged, smooth caw. She has two daughters in the herd, Miss Wimple by Lord Julian, a son of the noted Lord Avondale and Miss Wimple $2 \mathrm{~d}$ by imp. Swinton Liberty. Both these heifers promise to develop well. Village Victoria $2 d$ by Snowflake and out of Village Victoria 28416 is a big roan closely descended from Mr. Cruickshank's best cattle. There is a large, white cow in the herd that attracts attention at sight. She also is close to Mr. Cruickshank's line of breeding and has two daughters on the farm that show she is not only a good individual but is also a good breeder. Aside from the cows mentioned, the 
herd carries the blood of Bellows Bros.' Good Choice and Victorallan, March Knight, imp. Wood End Stamp, Collynie Archer by Mr. Duthie's great bull Scottish Archer out of a dam by William of Orange and many others of merit though of less reputation.

The bull in service is imp. Swinton Liberty by Sanquhar Searchlight, a son of the very popular sire, Sanquhar Dreadnaught. His dam is imp. Allerton Rosebud 4th, owned by Mr. McLenon and mentioned before. When 1 saw this bull he had been rumning in the pasture with a part of the herd all summer without grain and was rather thin but he impressed me as being smooth beyond the ordinary application of the term. He is a growthy fellow, yet compact and shows good depth of body with fine head and neck and he makes a splendid appearance.

Mr. McLenon was one of the consignors to the State Association sale held at Manhattan in 1920. His one entry, Village Victoria 2d, won second place in the strongly contested show and sold for $\$ 800$ to a critical buyer, J. H. Holcomb, of Humboldt. Mr. McLenon is one of the best educated men of the Shorthorn fraternity and he has unusually good judgment as has been displayed in his operations.

C. A. Scholz, Lancaster.-Fourteen years ago Mr. Scholz bought at one of the Bellows sales a two-year-old heifer with a heifer calf at foot and 
bred again to the noted Bellows bull, Good Choice, from which mating a heifer calf was secured. A short time ago I saw the original purchase and I have seldom, if ever, seen a sixteenyear-old cow carrying a calf and showing so much vigor. She looks about like the average vigorous eight-year-old and by early spring she will have produced her fourteenth calf. This cow, known to the breed as Westlawn Blanche, has to her credit a wonderful family with more size and real beef producing quality than any other family of cows I have ever seen. The mature cows in Mr. Scholz's herd as I saw them looked like 1800 pound animals on grass. They are nearly all suckling excellent calves and the man whose admiration they would not excite certainly has no eye for big, smooth, beefy Shorthorns.

The heifer by Good Choice, after having produced numerous calves and having quit breeding, was shipped to market as an eleven-year-old cow, without any special fecding, bringing a little less than \$250. Numcrous small herds have been started from the daughters and granddaughters of this cow.

A later addition to the herd is imp. Rosehaugh Belle 2d, a roan of accepted Scotch breeding. She is quite a good individual. Imported Sudie Maid bred by the $\mathrm{S}$. Campbell Estate is also in the herd. Her sire, Sittyton Yet, was a Duthie 
bred son of Knight of the Thistle and the five top dams in the pedigree are bred by Campbell. That Mr. Scholz has been using choice bulls may readily be inferred. Barney Boy by imp. Royal Pride was excellent and left good results but the outstanding bull was Symphony's Prince, bred by S. C. Hanna. He was by Prince Royal, a son of imp. Collynie and imp. Princess Royal 62d. His dam was Symphony by Collynie and she was out of Syringia by Royal Knight. On close analysis of this pedigree it becomes clear why this bull proved an exceptional breeder, for his entire ancestry were not only of rarely good descent, but were great individuals of much scale and no bull could claim more inherited merit. Next came Rosedale, a splendid, big, red son of Avondale out of imp. Rosebud $2 \mathrm{~d}$. I saw this bull at eight years old and he is very impressive, with his straight lines, fine head and neck and full quarters and a great, deep body. The bull now in use is imp. Rosehaugh by the Anderson bred Osmond 715169 and out of imp. Rosehaugh Belle 2d, mentioned above. This is a bull of considerable size and the young calves by him please Mr. Scholz very much. He rather thinks he will make one among the best bulls used in the herd.

The Glancys, Atchison.-A big herd maintained under favorable farm conditions is what I found at this place. Most of the cows seem to have been kept at the business of raising calves 
and were a little thin but the few not suckling made a fine appearance. They showed a good deal of size and attractiveness. The foundation for this herd came from a splendid source, the herd of S. L. Cheney, at Empire City. 'Two well known bulls were represented in these cattle, Lord Lucan and Orange Blossom's Breastplate, both of which figure strongly in numerous pedigrees. No effort has been made to carry any certain line of breeding but desirable bulls coming from good herds have been used. The Glancys are constantly working for better development of the young stock and for a better herd for exhibition at stock shows. Twenty head were sold at the Hiawatha Breeder's sale in November 1919. The 1918 heifer calf crop was sold to go into Illinois. The calf crop of 1919 was sold privately at satisfactory prices.

Among the bulls that have been used was the white, Chancellor, an excellent individual bred by E. A. Hess of Iowa. His sire, Choice Knight, was by Choice Goods and out of Lassie of Tebo Lawn. His dam was bred by Mr. McDermott and was out of a daughter of imp. Craibstone. Alexander 233061 came through J. G. Robbins \& Sons from Ohio. His sire, imp. Manchester, came from Geo. Shepherd's and was out of imp. Maud 41st. Good Goods is the bull now used. $\mathrm{He}$ is a big, smooth fellow and his sire, Silk Goods, has been well and favorably known for 
ten years. He is one of the few sons of Choice Goods still in service in Kansas and his dam is Lassie of Tebo Lawn whose dam was out of imp. Golden Hair. The dam of Good Goods is by Mellowhide by Prince Royal, the big son of imp. Collynie and imp. Princess Royal 62d. Mellowhide's dam was by Captain Archer, a great sire of show stock and own brother to Sweet Mistletoe, dam of Lespedeza Collynie, International grand champion in 1919.

H. C. Graner, Lancaster.-Mr. Graner is an old breeder who can recount interesting experiences of early breeders in his locality. He has a new herd, or rather the foundation for a new herd. Imported Maria 30th is a low-set cow of nice appearance, combining the John Wilson line of breeding with that of Duthie and Bruce. Two of her daughter's are in the herd, a two-year-old bred by Carpenter \& Ross and sired by imp. Cluny Royal Windsor and a yearling bred by Mr. Graner and sired by imp. Gallant Favorite. (See Gigstad sketch.) The appearance of these heifers indicates that the cow is a good producer.

Imported Red Rube, despite her bad name, is a good cow, rather an extra good one, with a great top and heart girth and plenty of size. She is by Prince Henry, bred by C. H. Joliffe and out of Rose of Diamonds by the Marr bred Diamond Butterfly. She is a very rapid breeder. Her three-year-old daughter, imp. Red Rube 2d, 
promises to become as valuable as her mother and is now suckling a promising calf. Her next calf is the young roan bull sold to head the herd of A. A. Tennyson at Lamar and the last, a big, lusty heifer by imp. Lord Alexander, is on the farm. It is Mr. Graner's intention to raise his herd from these two imported cows and thejr. descendants, which it should be easy to do, considering their prolificacy.

The herd bull, imp. Lord Alexander, is of large type. I saw him in light flesh and he shows plainly that he has not been pushed. He is straight-lined and quite smooth and his calves are big, thick and smooth. He comes from the Longmore line of cows, the same herd to which $\mathrm{Mr}$. Cruickshank resorted for an outcross on his herd and the line of sires in his pedigree comes from some of Scotland's best breeders.

The cattle described above will be kept on the farm and, to make room for the increase, the large herd which for years has been well known in northeast Kansas will be gradually closed out, the Shorthorns of modern breeding in time becoming the entire herd.

Ashcraft Bros., Atchison.-This is one of the old breeding establishments in northeastern Kansas, Ashcraft Bros. having succeeded their father, A. M. Ashcraft who was one of the well known breeders of Atchison county. Active operations began twenty-five years ago in the purchase of 
five nicely bred heifers from $\mathrm{R}$. C. Thomas. In 1906 an additional purchase was made from W. W. Brown. Harmony's Knight, bred by T. P. Babst \& Sons, a son of the high priced Knight's Valentine and out of a dam by Laird of Linwood, was the bull in early service. Later Scottish Minstrel by imp. Scotch Mist was used. Free use was also made of the Glancy bulls. (See Glancy sketch.)

A splendidly bred aged bull is now in service, A True Cumberland 385024, son of True Cumberland 2d, by Cumberland's Last. His dam is a daughter of imp. Cluny Flora 79th by Royal Pride. $\mathrm{He}$ is attractive even in quite moderate flesh as I saw him, with fine head and neck, good quarters, strong loin and very deep body on short legs. A little openness and coarseness of shoulder are apparent, not a serious fault in an old and neglected bull. His calves look promising though the herd has not been kept for best development and these calves, coming through the line of descent they do, should be paying propositions. There are some good, strong cows here and only a little improvement in handling is needed.

R. M. Bunnell \& Sons, Lancaster.-Mr. Bunnell started a good little Shorthorn herd two years ago but it was only recently that he made most important additions, which can not fail to put his business on a splendid footing. The roan, Orange 
Victress 5th, was bred by W. A. Betteridge. She is one of the thick, smooth kind with much depth of body and stands on short legs. She is a fine prospect as a breeder and comes from the best ancestry found among western Shorthorns. Her sire, Cumberland Dale, is by Masterpiece by Cumberland's Last out of an Avondale dam. Her dam is by the famous old Victorious that rounded out an unusual career for $\mathrm{Mr}$. Gentry and Mr. Betteridge and her second dam is by Lavender Viceroy, the best known son of Lavender Viscount. Lady Avon 4th comes from the Hoply Stock Farm. She has much size and smoothness and is in every way desirable. Her sire is the 5 . R. Hanna bred Eastlawn Champion, a grandson of two famous bulls, Newton Crystal and Villager. Her dam carries the Whitehall Sultan blood through the well known Fond Memory ard her grandam is by a son of Avondale out of a daughter of imp. Royal Girl. The bull being used is Peerless Goods, a very straight, smooth grandson of Ruberta's Goods. His dam is by a son of Snowflake, the sire of Ringmaster, and his grandson is by Afton Clipper, a son of Sweet Afton, own sister to Avondale.

D. L. Dawdy, Arrington.-Mr. Dawdy has been in the Shorthorn business all his life. The occasion of his coming to Kansas from Illinois was the purchase of Governor Glick's farm and herd. (Part T.) The herd in July 1919 numbered 
about twenty-five females of which I shall mention a few. Archer's Lovely is a five-yearold red of good size and rather extra finish. Her sire, Maid's Archer, was by the International grand champion, Ceremonious Archer, out of imp. Ballechin Charming Maid. That she is a good producer and milker was fully proved by the appearance of the heifer calf at foot by Red Line. This bull is a son of imp. Scottish Sentinel and Sobriety 8th by imp. Strowan Star. Red Queen comes from the G. A. Betteridge herd. Her sire is Victor Model by Orange Model. The bull at the head of the herd is Cumberland Chief by Secret Cumberland by Dale's Cumberland 353509, a son of Cumberland's Last and Dale's Golden Gift by Avondale. His dam is the Duncan bred Simplicity $2 \mathrm{~d}$ by Golden Lavender. The herd has passed the government tuberculin test and is fully accredited. Mr. Dawdy has, in the course of his eareer, sold Shorthorns to buyers from fourteen states. He has the most remarkable memory for dates and numbers of any man I have met. He is sales manager for the Northeast Kansas Breeders Association.

W. H. Graner, Atchison. *-Mr. Graner is one of the old breeders of Atchison county. At the Breeder's sale held in Kansas City in 1893 he bought three cows and a bull. A year later he bought another cow and from these his entire

Farm near Lancaster. 
herd of 100 head is descended. During these years many animals of both sexes wore sold for much more than enough to pay the maintainance of the herd. Mr. Graner has been a contributor to sales held in Kansas City and Wichita. The eattle are not developed to the best possible degree but they attain medium size and milking quality is not neglected. It is a region of blue grass, this country around Lancaster, and except in the worst of winter, cattle thrive without much attention.

One of the early bulls used was Victor Archer by Golden Archer 149821 out of Pleasant View Victoria by Blue Valley Duke 3d, a son of imp: Double Gloster and imp. Lovely 41st. Ballechin Archer was by Ceremonious Archer and out of imp. Ballechin Charming Maid. The three bulls now in use are imp. Proud General 77409, Village Minstrel by Sittyton Minstrel out of Magnet's Pride 41823 and Red Villager by Villager Jr. These bulls are all of accepted good breeding. Mr. Graner, while living in Atchison, gives the herd much personal attention and expects to be succeeded by his son, Louis F. Graner.

Ed Heglund, Lancaster.-Three elegant roan cows, even in size, style and color and said by Mr. Heglund to be representative of his entire herd, were what I had the pleasure of seeing in a small pasture near the house. The foundation came from C. D. Bellows and H. C. Duncan with some 
additions made later. One of these cows, it seemed to me, was just what a Shorthorn cow should be, good sized, fine in appearance, finished from end to end and suckling a big calf, yet carrying thick, smooth flesh. In addition to the desirable qualities mentioned, this cow is a heavy milker.

Among the bulls used by Mr. Heglund was Roan Goods, by that outstanding sire, White Goods, by Choice Goods. Another was Goods by Golden Lancaster, dam by Good Choice. (See Gigstad sketch.) This bull was the sire of the cow mentioned above. I liked the young bull now in service. He, like the cows, is a beautiful bright roan and comes from C. P. Tut's herd at Bunceton, Missouri. His sire is Denmark 7th, a D. R. Hanna bred son of Village Denmark, the great Villager bull used at Anoka, and out of an Avondale dam. His dam is by Sultan's Duke, a son of Waverly Dale by Avondale, a line of breeding which should give profitable results. This herd has furnished some valuable foundation stock for other herds, among them for that of Harrison Meyers of Leavenworth county.

John Q. A. Miller, Muscotah.-Mr. Miller was raised with Shorthorns as his father, J. L. Miller, was a breeder forty years ago, owning one of the well known herds of Atchison county. He has a herd of about twenty females, and only one cow has been added by purchase recently, the rest having come from the herd kept on the farm 
since 1880. The cow purchased is by imp. Proud Marshall out of a dam by Pitilivie Chief. In general, I found the cows of good size, straight-lined and indicating that they were reliable breeders and good sucklers. An excellent bull is in service, Rosedale by Avondale, out of imp. Rosebud 2d. This big red is a typical son of Avondale with plenty of size and uniform from end to end. Although eight years old, he would not be a bad show bull if put in anything like show condition. He was used for three years in the herd of C. A. Scholz before coming to Mr. Miller's and his purchase by Mr. Miller should prove one of the fortunate hits of his career. Excellent conditions are found on this farm for the successful production of every kind of live stock. It is a land of good pastures and alfalfa and with the experience the proprietor has had with Shorthorns he should have no trouble, if he chooses to do so, to put his herd well along toward the top in Shorthorn rank and prestige.

Scholz Bros., Huron.*-Scholz Bros. made purchases from C. A. Scholz six years ago obtaining some of the best things from the herd, including Westlawn Blanche. (See C. A. Scholz sketch.) These cows have been very prolific and the firm has had heifer luck. In addition to using the C. A. Scholz herd bulls including Rosedale by Avondale, they have kept a bull of their

Ship on Mo. Pac. or Rock Island. 
own all the time. Golden Prize bred by K. G. Gigstad was by Golden Lancaster. (See Gigstad sketch.) His dam was a Bellows bred daughter of Victorallan, followed by Lavender King 3d and Armour Bearer, all high-class bulls. Golden Prize proved a good sire and much benefit resulted from his use. The present bull is imp. Rosewood Stamp. His ancestry is largely Duthie bred and includes the best of that great herd. He is a big fellow, very compact, carrying thick, even flesh and the calves by him out of the big cows are altogether promising. It is the intention to put up a first-class herd and improvements just constructed will facilitate doing so. The pasture is excellent and there are alfalfa lands and fine water in abundance. With these favorable natural conditions are found the energy and intelligence on the part of the owners to insure success.

Since the article above was written the calves by imp. Rosewood Stamp are developing so well as to attract the general attention of breeders.

M. C. Vansell \& Sons, Muscotah.-This herd has been closely culled. One of the good females in the lot is a roan, Peerless Lady. Her sire, Snowflake Stamp, was by Snowflake and her dam was by the Carpenter \& Ross bred Afton Clipper. Proud Blossom, a two-year-old roan, is by Proud Monarch, a son of the noted sire, imp. Proud Marshal and the imported eow, 
Spicy Beauty 8th. The entire herd is as acceptably bred as the two mentioned, not only through the line of sires but on the maternal side also. One of the bulls that has been used in building this herd is Rosedale by Avondale out of imp.

- Rosebud 2d. Another was Primrose Royal by Mr. Hanna's Prince Royal. One of the choice things in the herd, Dale's Golden Gift 2d, is by this bull. Dale's Cumberland, one of the best known of the herd bulls was a white by Cumberland's Last out of Dale's Golden Gift by Avondale. Another bull that has attracted attention is Beaver Creek Sultan. He went from Vansell's to Tomson Bros.' herd where for several years he did good service. The bull now used is Roan Sultan by that noted sire, The Callant, the white son of Avondale, and the great cow, imp. Rosewood Pride. He is not only the right kind of a bull but he is getting the right kind of calves, that bid fair to develop into high-class cows.

Louthian Bros., Huron.*-This is a firm of young men, nephews of the Scholz Bros., and their foundation was secured from C. A. Scholz. They have some valuable cows and the young things on the farm show good care. The best alfalfa hay I have seen this year was on this farm and alfalfa is a big factor in Shorthorn development. Louthian Bros. have a first-class bull, better than is usually found in a small herd.

* Ship on Mo. Pac. or Rock Island. 
Orange Victor 454255 by Premier Victor 385110 , is a grandson of Whitehall Sultan and out of a dam by the Norton bred Courtier 4th. Orange Victor did some service in Mr. Scholz's herd and is siring a splendid class of calves.

\section{BARBER COUNTY}

V. E. DeGeer, Deerhead.*-In 1908 Mr. DeGeer stepped into the business which his father had established in 1892. There are sixty females in the herd. The calf crop is being sold off every fall and these calves are giving satisfaction. Duchess of Ardlethen is by imp. Ardlethen Mystery and her dam is by Lord Nonpareil 2d, son of Golden Lord, the last bull used by Col. Harris. Emblem's Victoria is by imp. Proud Emblem Jr., one of Oklahoma's popular sires, and her dam is Lovely Victoria by Lovely Sultan 2d 307481. Christmas is by Daring Archer, a Tomson bred son of Archer, he by imp. Collynie out of imp. Circe 3d. The dam of Christmas is by Lavender's Choice, a George Bothwell bred son of Golden Lavender out of imp. Winifred 4th. Some of the cows have pedigrees that would meet with approval anywhere.

Bulls of a splendid line have been used; Baron Godoy by Godoy Butterfly out of Barmpton's Joy, the dam of Barmpton Knight; imp. Ardlethen Mystery used and much advertised by Col.

* Station, Lake City; telephone, Ranchman's, Lake City. 
Ed Green; Royal Pavonia of the same ancestry as Mr. Nevius' Prince Pavonia with imp. Conqueror added and Orange King $2 d$ by the outstanding sire, Victor Orange. The bull now used is Albino by Alfalfa Leaf News 7th, son of Good News out of Nonpareil Victoria of John Regier's breeding for several generations. His dam is by Hallwood Goods, son of Choice Goods and imp. Sylvia.

\section{BOURBON COUNTY}

C. M. Howard \& Sons, Hammond.-This is one of the big herds of Kansas and consists largely of double standard stock. While an effort is being made to breed off the horns it is not carried to such an extent as would effect either the size or the quality of the cattle. I have seen a number of animals from this herd and liked them very much for they had size, finish and a high degree of practical utility. The herd was established in 1898 and now 100 females are kept on the farm a few miles north of Fort Scott. While the cattle are not fed for the best possible development, yet they are being well grown and the cows range in size from medium to large.

The earlier purchase of foundation stock represented good individuals and the bulls used have been such as to work improvement. Later purchases have been more within the line of universal approval as to pedigree and the tendency 
seems manifest to eventually bring the herd to the basis of the more popular blood lines of the day. At the Salter-Robison sale in May, 1920 three heifers, all well along in calf to Dale's Renown, were secured. Each of these heifers is by Public Opinion, a son of the splendid bull, Masterpiece, by Ben Wyvis and the breeding is not only of the best but it is also of the kind that is very popular. Since then Mr. Howard bought Mina Marigold Lady and her heifer calf by imp. Proud Archer. This young cow is not only of the best type but her ancestry is of such quality as to recommend her to the most critical.

I shall mention only two herd bulls, both coming from the leading Polled herd in America. Official Duke bred by J. H. Miller was by Golden Gauntlet, one of the best of Mr. Miller's early bulls. The present herd bull, Forest Sultan, comes from Mr. Miller's. He is by Sultan's Creed by Sultan of Anoka, sire of more highclass Polled herd bulls than any other bull of the breed. Forest Sultan's dam is by Linwood Favorite by imp. Cock Robin, a bull of national reputation as a sire. That Forest Sultan is a great sire is shown in his get and the reason for this may easily be credited to the fact that he represents a strong concentration of Whitehall Sultan and imp. Cock Robin, two of the breed's great bulls.

J. R. Newman, Fort Scott.-Dr. Newman is a very busy man with an exacting practice and, 
like many of his profession, he is building up agricultural and pastoral interests by keeping on a farm near the city some excellent Shorthorns that afford recreation, pleasure and profit.

Waiving consideration of the herd prior to the 1919 American Royal, the purchases made by Dr. Newman at that sale put his herd in a leading position and assure its favorable recognition by all interested in the right kind of cattle. Four cows, selected from among the best of that excellent offering, fell to his bidding and those who are familiar with the class of cattle selected by Mr. Cochel for the Royal sales will admit that Dr. Newman purchased valuable breeding stock. He also purchased at the same sale the outstanding bull, Village Alderman 796609. This admirable roan was bred by Tomson Bros. and he was one of the highest priced bulls in the sale, if not the top. His sire is Village Marshal, a winner of numerous prizes and a breeding bull that in the Tomson herd has attracted national attention. Village Alderman is out of Norwood Augusta $3 \mathrm{~d}$ by the Marr bred imp. Crescent Knight and his grandam is the Bruce bred imp. Augusta 105th by Waverly. The high merit of this bull combined with his elegant pedigree and with the class of cows as indicated, puts the Newman herd in the first rank.

L. D. Hayes, Bronson.-Mr. Hayes has a herd of twenty females that are above the average in 
size. He has been showing at Blue Mound and at the Bourbon county fairs, winning well in all classes shown. He has contributed to the Interstate sales at Nevada, Mo., 1919 and at Fort Scott, 1920. His location in one of the best cattle sections in extreme eastern Kansas gives him a good local market for his production. In the herd are daughters and granddaughters of the Cookson bred Admiral Broadhooks, a son of the well known Young Commodore and imp. Scarlet Bangle; also of the Bellows bred Victor Sultan. Lord Victor, an excellent and desirably bred roan bull, heads the herd.

Elmer McIntosh, Hepler.-Mr. McIntosh has bred Shorthorns for ten years and has kept his herd closely culled. One of his good cows is Madeline Lavender by a Bellows bred son of Chief Sultan 279108, Victor Sultan. Her dam is by Godwin, famous sire of splendid producing females. Roan Isabella, another good cow, is by Marr Cumberland, a son of Cumberland's Last and imp. Lady Marr. Victor Sultan, mentioned above, was much used in the herd. At present the herd bull is Choice Lavender by a son of Best of Goods, well known son of Choice Goods and the excellent cow, Runaway Girl, by imp. Collynie. There are some cows of very attractive breeding in this herd.

Will Edmonds, Hepler.-While Mr. Edmonds has only a small herd, he is making an effort to 
have it a good one. He has used two bulls, both from excellent ancestry. Choice Lavender is a grandson of Bellows Bros.' Best of Goods and his dam is a daughter of the Duthie bred imp. Lavender Champion. The other bull, Victor Sultan 318050, comes from Bellows Bros. and has for sire Chief Sultan by Whitehall Chief and his dam is Beaver Creek Victoria, one of a very popular line of cows.

W. W. Wilson, Walnut.*-Mr. Wilson and his sons, while comparatively new in the business, already have ten females and an excellent white bull. The cows are rather large and the young stock is being well grown out. I have met $\mathrm{Mr}$. Wilson and his boys and feel that they will become successful Shorthorn men. They are cooperating with other breeders in association sales and in everything which will build up general Shorthorn interests.

\section{BROWN COUNTY}

T. J. Sands, Robinson.-Mr. Sands is one of the best and most favorably known breeders of northeast Kansas. He began his operations along pure bred lines in 1893, and to use his own expression, "The cows just had to pay." While this condition may no longer apply, they are paying and will contimue to pay well. Just before my visit to Mr. Sands' farm he had sold two nice

* Station, Savonburg; telephone, Hepler. 
young cows at $\$ 1000$ each to go into a good Missouri herd and had refused the same price for two more because he felt he needed them in his business. Mr. Sands will not be likely to make the mistake so frequently made by breeders, that of selling anything in the herd regardless of whether he can spare it or not. Retaining onc's best is the only way of achieving success as a breeder.

Mr. Sands has proceeded and is still proceeding along what is usually known as the line of least resistance. He intends to sell his customer's what they want rather than to try to sell them what they are not looking for. In order to meet all demands which might be made as far as pedigree is concerned, he has built up his herd on very popular foundations and has used bulls of entirely apploved breeding. This enables him to supply the demand of the man who is critical where blood lines are concerned, in fact he himself is one of the most critical of men in this l'egard, probably because of his desire to have his herd unobjectionable to any one in this respect.

It would be of little interest to tell in detail of purchases made by Mr. Sands nearly thirty years ago and I shall confine myself to the animals that have gone to build up the present herd. Lady Cinderella, bred by George Allen, a daughter of Lord Missie 252006, was out of imp. Lady Clara 4th bred by Duthie and sired by Golden 
Ray, sire of the well remembered Kansas bull, imp. Mariner. Lady Cinderella not only had elegant breeding with the prestige of good breeders but she was also a good individual. Two of her bulls, Classical Sultan and Ċlansman, did satisfactory service in the herd for a time and there are now eight of her daughters and granddaughters on the farm. Another profitable purchase was Naomi's Ruth by Clipper Chief 174 514. She was out of imp. Naomi Ruth $2 d$ by imp. Best of Archers. She has produced a number of good calves and one of her daughters by Classical Sultan is an outstanding producer. Ortiz Victoria 2d from the S. P. Emmons' Sybil family, sired by Lord Lieutenant $2 d$, has been a. good producer and she and her descendants have been very profitable and are highly esteemed by Mr. Sands. Scottish Lady $2 \mathrm{~d}$ by Barmpton Knight has several daughters in the herd and a number of her descendants have been sold. They are large and smooth and are excellent breeders. One of them, Scotch Lady by Royal Leader, has a daughter that is the dam of a show calf. Several of the cows in the herd come from Miss Orange 4 th by Courtier 2d. Miss Orange 4 th was owned by S. L. Cheney, at one time the owner of a splendid herd in Cherokee county. Imported Scottish Belle by Scottish Gem, a son of Gartley Landseer, is a young cow and the dam of an unusually low down, smooth, 
even, red bull. Her dam is by Golden Mascot Favorite out of a cow of William of Orange. Imported Scottish Belle is highly valued by $\mathrm{Mr}$. Sands on account of both breeding and individual merit. Possibly the best purchase made was that of imp. Nonpareil 35th bred by Campbell. Her sire was Kintore Hero. She was bought about ten years ago and the five daughters in the herd, together with their descendants, are highly desirable.

Royal Leader bred by W. A. Betteridge was one of the best bulls used. His sire was Lavender Viceroy, son of the International champion, Lavender Viscount. His dam was a daughter of imp Spartan Hero, second dam imp. Princess Royal 6th by Border Chief. Royal Leader sired a lot of big, smooth, beefy cows that are proving excellent breeders and sucklers. Snowstorm was by Snowflake out of imp. Bessie 51st, the dam of the wonderfully good Choice Goods bull, White Goods. He was a sire of exceptionally smooth, finely finished cattle. Classical Sultan was by the Whitehall Sultan bull, Victor Sultan and out of Cinderella 2d, mentioned above. Clansman, another bull used, was also out of this cow and by Snowstorm. Both these bulls did considerable service in the herd. The present herd bull is Lavender Emblem a two-year-old white. He is large, very close to the ground, has an elegant head and neck, very straight lines, a thick, deep 
body, good quarters and a fine covering of flesh. His sire is Diamond Emblem and his dam is Maxwalton Lavender $2 \mathrm{~d}$ by Avondale. She is a full sister to Carpenter \& Ross' noted sire, Max-

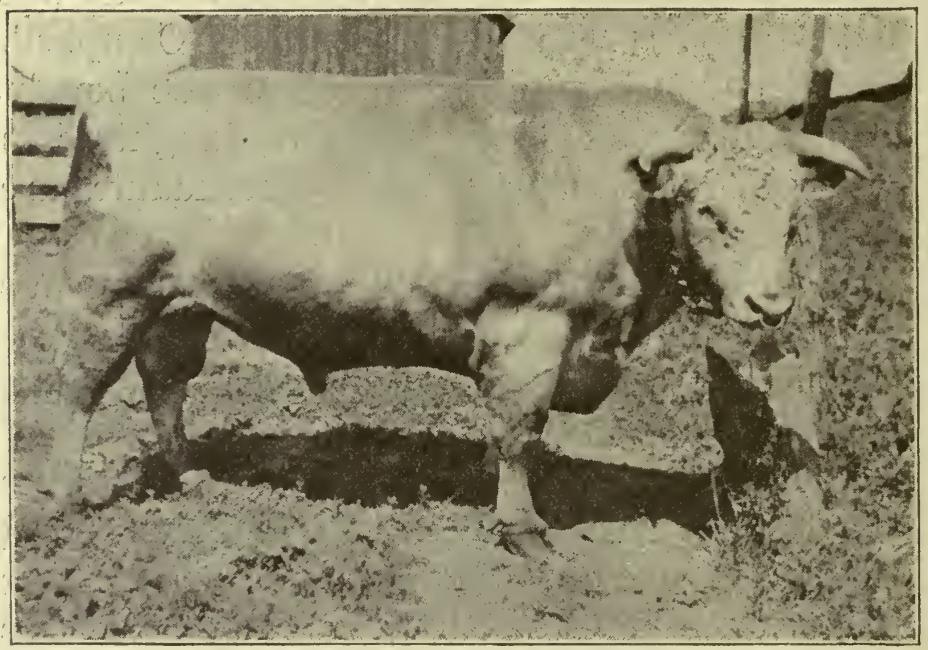

LAVENDER EMBLEM, A NOTED KANSAS STATE FAIR AND AMERICAN ROYAL PRIZE WINNER

walton Renown, second dam imp. Lavender Bloom by Silver Plate. Lavender Emblem was second at Topeka and third at the Royal in 1920. That the merit and breeding of this bull put him in a high class can not be denied and the young calves by him are most promising.

J. F. Lukert \& Sons, Robinson.-More than usual care has been taken in putting this business on foot and there is more than the usual showing found with new breeders. The pure bred herd 
is succeeding a herd of grade cows and it is admitted that the producer of good high grades is well equipped to produce pure bred Shorthorns. The cows selected are uniform in type and that type is good size, close to the ground, straight limes, feminine head and neck, with apparent constitution and at least reasonably good milking propensity. The calves at foot are numerous and of desirable type and quality.

The purchases were made from good herds. John McCoy \& Son furnished several head by Pride of Collynie, Good Scotchman and Gladys' Chief, the first named having been a full brother to the dam of an International grand champion and the last named out of a full sister to the champion, Lavender Viscount. (See McCoy sketch.) Secret Goods by Howell Rees \& Sons' Ruberta's Goods is out of a dam by Norton's excellent Banker's Victor. Lord Lancaster by Governor Shallenberger's His Highness; Orange Lad representing Lavender Viceroy; Lovely's Scotchman by Good Scotchinan mentioned above and other bulls of similar breeding and quality are the sires of the cows found on the Lukert farm.

The bull used the past season, the sire of the calves, is a nice roan, rather large but smooth and even. He is by Augusta's Sultan, bred at Browndale, and out of Sittyton Augusta 2d by Masterpiece. He is satisfactory and would be 
retained longer but for the purchase of a red, imp. Myreton Seal, a Bruce bred son of Sir Star. This bull has good length, he is smooth and even, with nice head and neck and is attractive, but like most of the bulls recently imported, is not so well grown out as our best American specimens. Two other additions to the herd recently acquired by purchase are Saturn Secret and Choice Butterfly. Saturn Secret was bred by Mr. Harshberger and sired by Sir Charming 10th. Her dam was out of a daughter of imp. Knight Templar. Choice Butterfly is by Collynie Goods who was a full brother to Diamond Emblem, he having had for sire the champion, Diamond Goods and for dam the elegant cow, Emily by imp. Collynie. (See H. M. Hill sketch.) If the reader will stop to consider the value of a foundation such as is presented in this herd, he will be convinced that it is the right way to begin. The idea of the Lukerts was to get the kind of cattle they wanted and in doing so they got elegant ancestry as well, for only rarely do firstclass Shorthorns come from any but first-class ancestors.

John McCoy \& Son, Sabetha.-There are few better herds in Kansas than the McCoy herd. It is one of the oldest in the state and after fortyone years is still partially under the care of the founder. The foundation was laid with excellent judgment. Mr. McCoy tells the story of how he 
went to John G. Cowan's in 1881 with money enough to buy, as he thought, seven or eight cows and Uncle John explained to him why he should buy the very best though fewer in number. $\mathrm{He}$ took the advice and went home with four females, two by Loudon Duke 6th and two that were out of his daughters.

Loudon Duke 6th was one of the greatest American bulls and these excellent purchases were worthy of consideration anywhere. Lord Byron, also from the Cowan herd by Bell Duke of Thorndale was a show bull of the first class and proved a good sire. Again the Cowan herd was resorted to for a bull and this time a son of imp. Scottish Lord was chosen. It was the first strong infusion of Scotch blood and on the big, smooth cows a great success was scored.

For years no additions of females were made but later some choice specimens were added. As I saw them they were all of the same old MeCoy type as the cows descended from the Cowan purchases. They are all of the choicest modern breeding. Three of them I especially noted. One came from W. A. Betteridge, one from T. J. Dawe and one from Everett Hayes and a few other choice ones came from R. T. Scott of Nebraska.

Good bulls have always been used in this herd. While this does not mean that in every case they were bred in the latest fashion, yet it would be 
hard to find a more popularly bred bull, or one descended from better ancestry than Pride of Callynie. He was own brother to Captain Archer, Stodder's famous sire, and to Sweet Mistletoe, dam of the $\$ 4100$ Imperial Mistletoe and Lespedeza Collynie, the 1919 International grand champion. Gladys' Chief, another good one, was by Chief Justice by imp. Spartan Hero and out of a full sister to the International champion, Lavender Viscount. Secret Goods, by Ruberta's Goods was used with excellent results for several years and Good Scotchman by Scotchman 245103 out of Good Lassie, a granddaughter of imp. Golden Hair by Choice Goods, grand champion of America, was used until recently, siring a splendid lot of females.

The history of the McCoy herd is one of continuous success. It has almost ceased to be a question of improvement but it is now rather a question of maintaining unusual size and quality. This standard has been attained by sound judgment, liberal feeding and good care. The herd is a living monument to a man who recognized no rule except that of individual excellence.

N. B. Hansen, Willis.-Mr. Hansen apparently has everything needed to make a success of Shorthorns including a first-class farm. More than ordinary judgment has been used in making initial purchases. The cows are good individuals, nearly all of them having plenty of size 
and being of the type usually proving reliable breeders. Bulls from good herds have been used with satisfactory results.

Three of the cows came through Miss Sharon 5th bred by G. Y. Johnson and sired by Royal Sharon, a son of Courtier 2d by imp. Prince Bishop out of Norton's Sweet Charity 4th. Two other's are worthy of special mention. One is Emblem's May by the well known Diamond Emblem, Mr. Dawe's late show and breeding bull, whose get in the Dawe show herd recently won honors at the Missouri state fair. Her dam is by Good Scotchman, the splendid bull used so successfully by D. E. Reber and John McCoy. The other cow is Lady Marshal by Cumberland Marshal, best known to Kansas breeders as the sire of Village Marshal, the big white bull at the head of Tomson Bros.' herd. Her dam is by King Cumberland 2d by Cumberland's Last, a line of breeding not excelled. Mr. Hansen made a valuable addition to his herd in Victoria Dream 756125 bought at the 1920 Central sale and will continue to improve both by breeding and by purchase.

H. V. Kleppe \& Sons, Everest.*-Here is a herd of fifty females descended from excellent ancestry. Matilda, a daughter of the McDermott bred True Goods, is out of Naomi Ruth 5th, a daughter of imp. Naomi's Ruth 2d. Another.

Telephone, Leona Mutual. 
good daughter of True Goods is the red, Goldie. Her dam is by Snowflake Baron, son of Snowflake, sire of the International grand champion, Ringmaster. Scotchman's Helene is a white by Good Scotchman, a bull that did splendid service for years in Brown county. Good Scotchman's dam was the well known Good Lassie by Choice Goods. Emblem's May is by Diamond Emblem, well known sire and show bull in T. J. Dawe's herd. The dam of Emblem's May was by Good Scotchman. The cows range in size from medium to large and the herd is being given liberal treatment.

One of the best bulls used was True Goods, a son of Fair Goods, the son of two famous show and breeding animals, Choice Goods and Ruberta. Choice Goods was America's champion for three years and Ruberta was the undefeated show cow of her day and one of the country's best producers. Clansman, bred and much used by T. J. Sands, was also in service. The present herd bull, Homewood Augusta Lad, is a red by Village Glory out of Village Augusta, both his sire and dam being by Villager Omega, one of the favorably known sons of imp. Villager.

E. E. Taylor, Hiawatha.-Mr. Taylor has a good little herd which he is planning to increase both in numbers and in quality. $\mathrm{He}$ is well located for the business. Recently he has taken steps which make his an accredited herd. Some 
real Shorthorn bulls appear in the immediate ancestry of Mr. Taylor's cattle. Pride of Collynie out of imp. Collynie and out of imp. Mistletoe 15 th was a bull that sired a great lot of cows for John McCoy and he was own brother to Captain Archer and Sweet Mistletoe; Snowflake, owned and well known in Brown county, later the sire of Ringmaster, American grand champion; Victor Butterfly, the sire of Victor Orange, Henry Stunkel's great breeding bull; Dale's Cumberland by Cumberland's Last; Prince of Tebo Lawn; Royal Diadem and Snowstorm, both good ones, used locally; imp. Cupbearer, three years America's champion; Barmpton Knight that went from this locality to Tomson Bros. and became famous all over the West and Hampton's Best, a great sire by imp. Merry Hampton.

The herd bull is Secret Cumberland by Dale's Cumberland and his dam is by Golden Lavender from George Bothwell's herd, out of a Grand Victor cow. It is only reasonable to presume that this infusion of excellent blood both in females and in the herd bull with the practice of proper care and liberal feeding will enable Mr. Taylor to produce first-class Shorthorns.

C. A. Babbit, Willis.-Mr. Babbit keeps only a few cows but he says these may as well be Shorthorns, even though he milks them. The little herd is selected with a view of producing good 
calves and a profitable amount of milk. This line of work will be continued. Thoughtful people everywhere recognize that on high priced land every edge must cut if anything like a reasonable profit is to be made in farming and this plan of Mr. Babbit's with good milking Shorthorns instead of scrubs is rapidly gaining in favor.

\section{BUTLER COUNTY}

Park E. Salter, Wichita.-This is one of the leading herds in the entire central West and its rise to prominence has been very rapid. The farm upon which the herd has been kept until this time is twenty miles southeast of Wichita and consists of about 1000 acres of excellent limestone blue stem land. Good crops of alfalfa are being grown. Mr. Salter has recently bought two farms of 160 acres each, close together, lying ten miles east of Wichita and the three farms will be used in the growing of Shorthorns, the cattle being divided to suit the occasion. It would be difficult to find better natural resources for successfully carrying on the work than are found here-all kinds of pasture, an abundance of running water of the best quality, fertile fields that will grow big crops of forage, with plenty of sheltered locations in belts of timber to furnish shade in summer and comfort in winter. The improvements already on the farms 


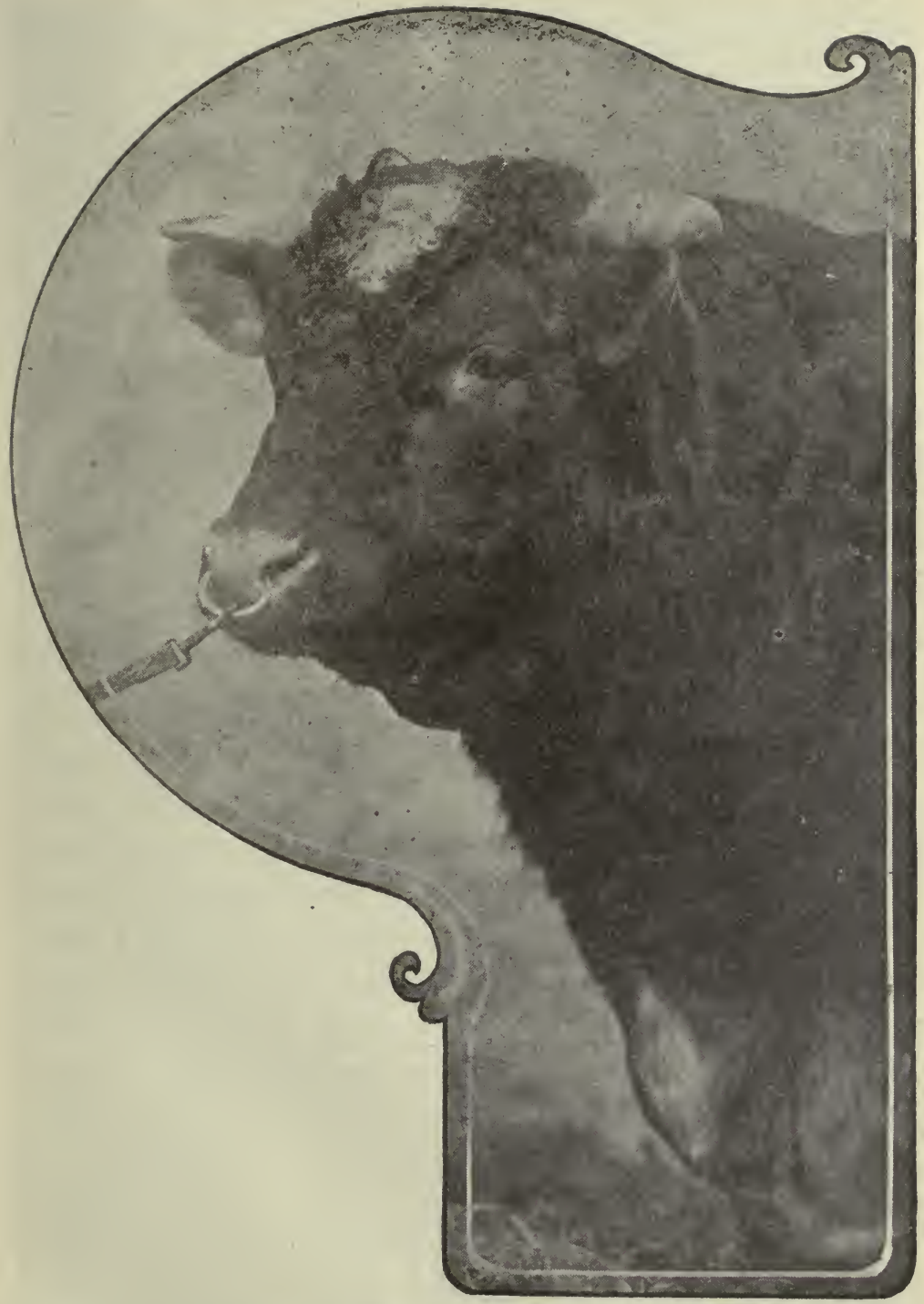

IMP. BAPTON CORYORAL 
and those planned for the future will facilitate the handling of stock in the best possible manner. How Mr. Salter came to take up breeding Shorthorns and what he has accomplished is one of the interesting stories of the development of the industry in Kansas.

It was in the cheap times, about 1890, that $\mathrm{Mr}$. Salter's father bought a red Shorthorn bull calf (they had to be red in those days) and turned it over to Park, then a boy, with instructions to take care of it. The boy did so, not only feeding it well but breaking it to lead and to ride. The bull developed into a big, fine fellow and was the basis of Mr. Salter's early fondness for Shorthorns.

Some years ago while still handling steers in large numbers, as was the custom of all farmers in his neighborhood, Mr. Salter decided that the buying and selling of steers was too uncertain and concluded he would keep cows instead. Being unable to buy a lot of good grade cows, he bought some cheap pure breds but, like many others, he did not adhere closely to the original plan of producing only market cattle. By selling and buying he improved the quality of his cows and, after using medium bulls for two years, he awoke to the fact that if he was to make any mark as a breeder he must have a high-class bull. Rosewood Dale, a son of Avondale, the outstanding bull of his day and out of imp. Rosewood 92d, 


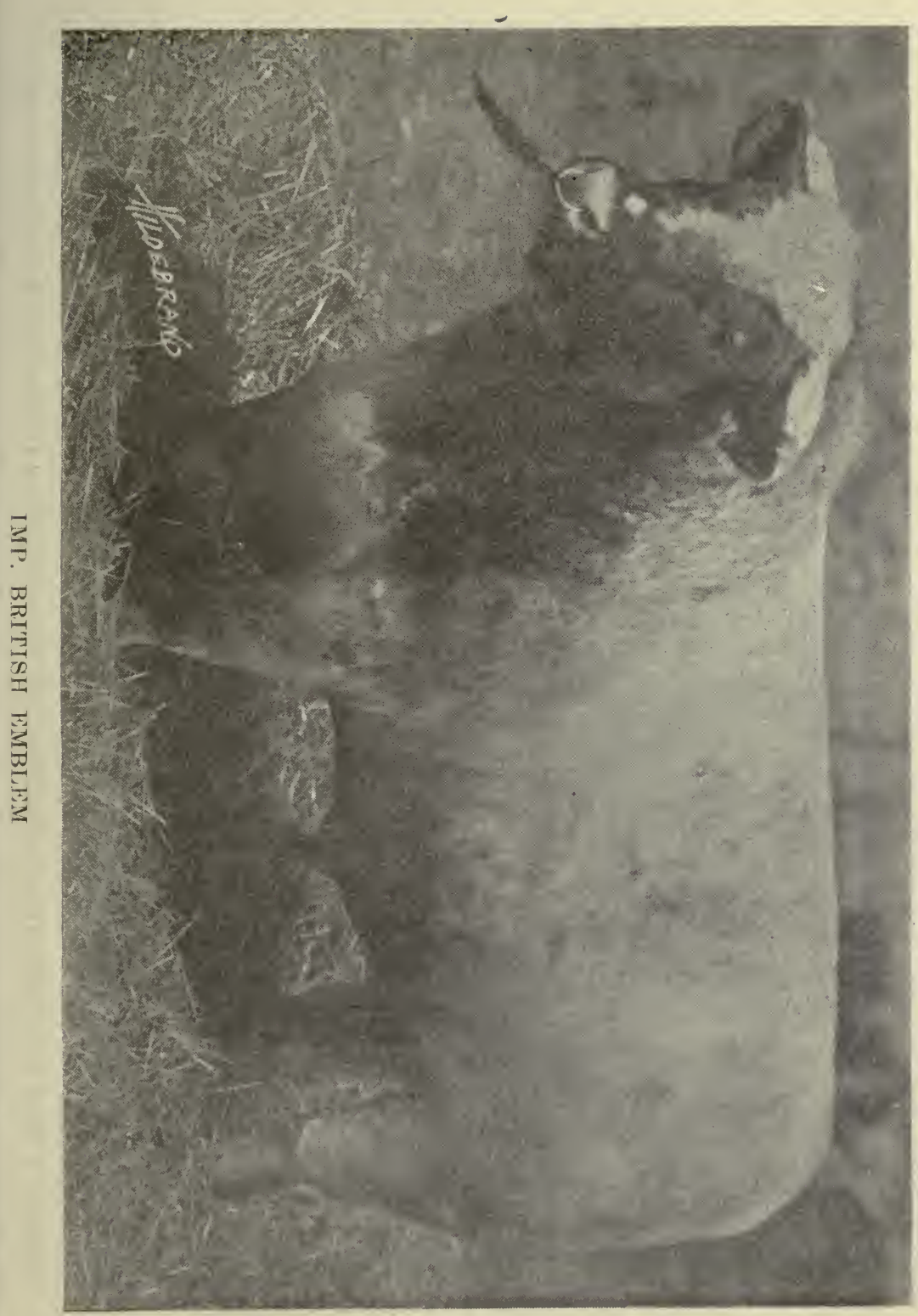


one of the best cows in the Carpenter \& Ross herd, was available and for $\$ 3000$ he was placed at the head of the Salter herd of Shorthorns. Better cows were added, some of the first good ones having been secured at the dispersion of the Hasebrook herd in Wilson county.

Mr. Salter now had some cows of real excellence and an outstanding bull. Most men would have been satisfied with this start and would have settled down to a quite, easy life. It was at this time that I first met Mr. Salter and he told me within fifteen minutes that he was going to have cows as good as any one had and as good a bull to help Rosewood Dale as he could find. The purchase of some excellent cows in Canada along with the bull, imp. Newton Friar, followed. Imported Bapton Corporal, the top bull of the Carpenter \& Ross importation and more high-class cows were added. Imported British Emblem came a little later and all the while Mr. Salter kept his eyes open for cows. This process has been going on and the indications are that it will continue indefinitely.

The buying and selling of the cheaper class of Shorthorns, in which line Mr. Salter did a large business, have been mostly discontinued and it is now the main object to produce as good a herd as possible and to have it unobjectionable in every way to the critical buyer. The material on hand for the production of such a herd is of the 


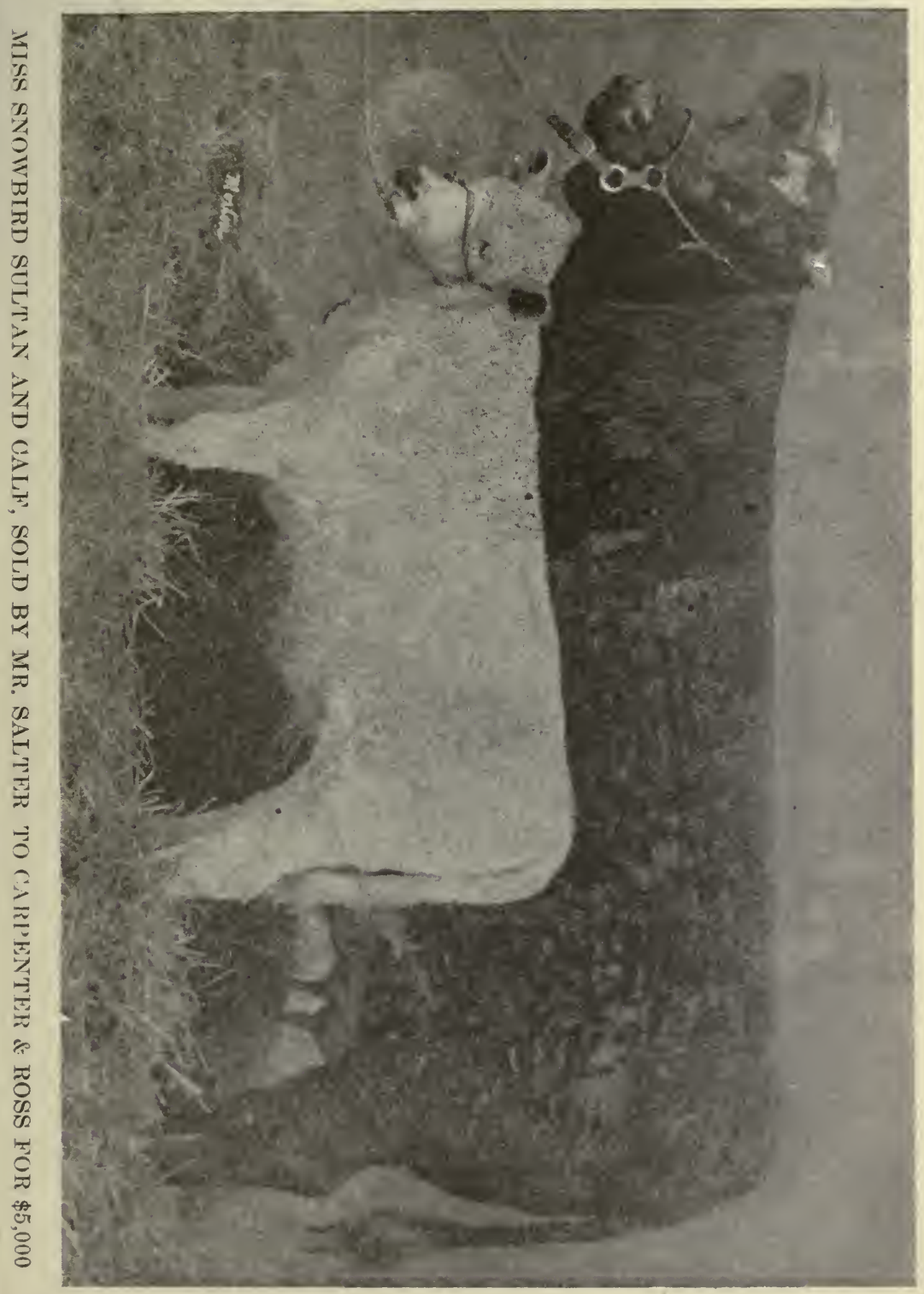


best. In fact, the herd is already on the farm but the same desire for improvement that led Mr. Salter to change from medium to high-class cows and from a common bull at $\$ 150$ to Rosewood Dale at $\$ 3000$ will manifest itself as long as he breeds Shorthorns for by nature and inclination he belongs in the class that seeks betterment.

A visit to the pastures will convince any one as to the quality of the cattle. Good ones are plentiful and it is not difficult to find those of outstanding quality. Among these is Hallwood Lavender by the well known sire, Village Flash. She is the dam of a very promising roan bull calf. Lavender Leaf comes from Canada, from the herds of W. C. Edwards. Her sire, Prince of Orange, was a noted son of Missie's Champion. One of her daughters sold in the 1919 Salter sale for $\$ 2000$. An imported daughter of the noted bull Keep Smiling is Whitehall Mist. She is deep, thick and smooth and her maternal ancestry for several generations comes from Mr. Durno's noted herd. She has a wonderfully promising white calf that looks every inch a real bull and is slated for at least some service in the herd and probably for a show yard career.

It will be recalled that in his 1919 sale Mr. Salter sold a cow for $\$ 3500$. Cherry Blossom 6th is a highly prized daughter of this cow that topped the highest sale ever held in Kansas. Countess 


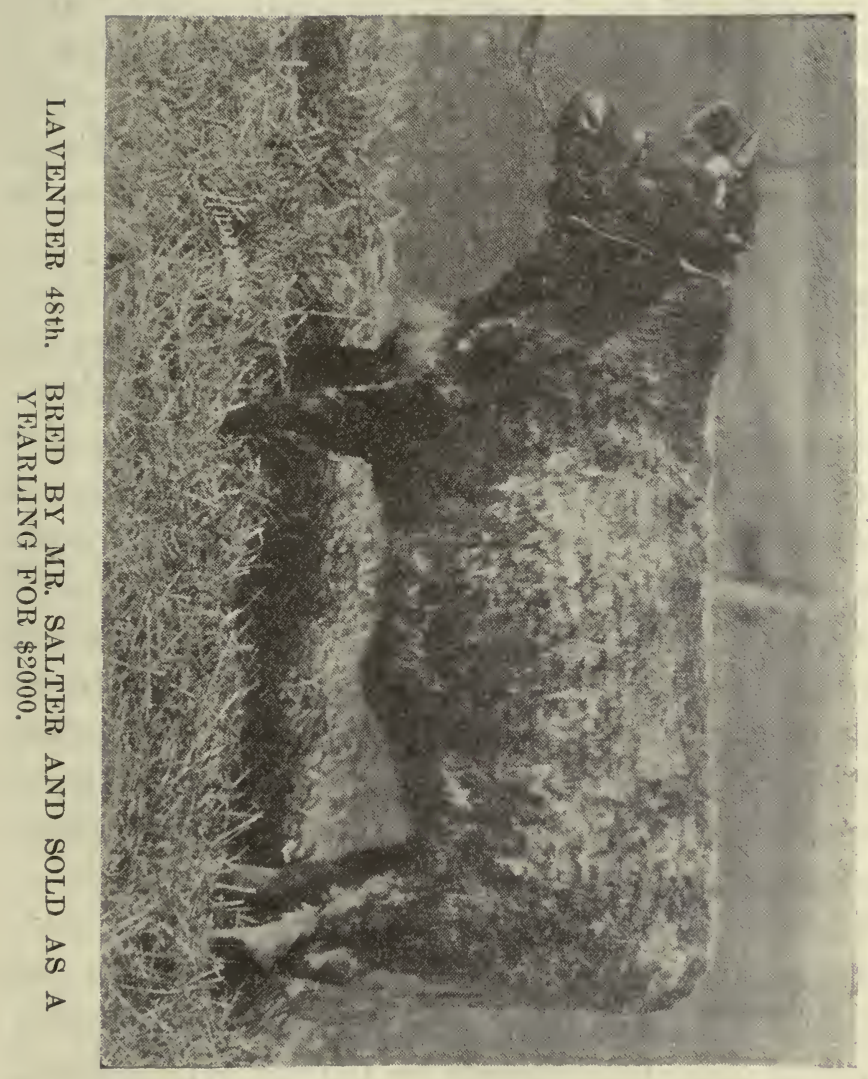


Missie is an elegant light roan and comes from Canada. Her sire was Bandsman Commander and her dam was by imp. Old Lancaster, one of the best bulls among the many good Canadian sires. Fair Mona is by Fair Acres Sultan, the most noted son of Whitehall Sultan ever used in the Southwest and her dam is by Fair Goods, the son of the champion, Choice Goods out of Ruberta, that as a heifer and cow occupies a leading position in American Shorthorn history. I shall not close this account of the cows in Mr. Salter's herd without telling of three splendid daughters of Hampton Spray. These are not show cows; Hampton Spray was not known as a sire of show stock, but he did get heifers that developed into big, rugged breeding cows such as few bulls have to their credit. On their dam's side these cows represent four bulls whose names are household words in Kansas and Oklahoma Shorthorn circles : imp. Collynie, Captain Archer, imp. Lord Cowslip and Royal Knight. (See Hanna sketch.)

The regard in which Mr. Salter's herd is held is best found in the appraisement placed on its products by the buying public. Several public sales had been made prior to 1919 at which good prices had been secured and numerous private transactions had scattered Park Place Shorthorns over a wide territory. The announcement that fifty head from the herd were to be sold at 
auction in Wichita, May 16, 1919, brought out a large crowd from a number of states. The sale was a success in every way with a general average for the entire lot of more than $\$ 1500$ making it the record sale for the state. The top price for bulls was $\$ 10000$ paid for 2d Fair Acres Sultan and for females $\$ 3500$ paid for Cherry Blossom 6th. Two bull calves and two heifer calves by imp. Bapton Corporal brought an average of $\$ 1450$ and a yearling heifer by Rosewood Dale brought $\$ 2000$,

When the 1920 sale was announced for May 15, there were those who wondered if $\mathrm{Mr}$. Salter would be able to secure so high an average as the year before. It was pointed out that he did not have a $\$ 10000$ two-year-old bull to help pull values up and that the money market which was tight would naturally affect purchases of high priced stock. The day was rainy but a large crowd from seven states was present and the entire offering from Park Place Farm was sold at an average of more than $\$ 1900$. Missie's Last a six-year-old grandson of Whitehall Sultan that had been doing service in the herd brought $\$ 6100$ going to H. C. Lookabaugh and the fifteenmonth-old Emblem Jr. by imp. British Emblem went to E. S. Dale of Protection, Kansas at $\$ 4000$. Miss Snowbird Sultan and her white heifer calf by Fair Acres Sultan Jr. went to Carpenter \& Ross at $\$ 5000$ and Lady Supreme, 
grand champion at Denver, the Kansas National, Fort Worth, at innumerable state fairs and at the American Royal was knocked off to Frank Scofield of Texas at $\$ 4800$. By reason of these prices Mr. Salter now holds the record of having made the highest priced and second highest priced sale of Shorthorns in Kansas; also of selling the highest priced bull and the highest priced cow sold in the state and of producing and selling the highest priced fifteen-month-old bull ever sold in the state.

John Regier, Whitewater.-If you do not know Mr. Regier you should get acquainted with him for he is one of Nature's noblemen. Quiet, unassuming, and conservative he is honest as the mid-June day is long. When he makes a statement, it is true. But that is not all. He is a Shorthorn breeder with a record of achievement such as only•a few breeders in Kansas can show. His twenty-five females, with the exception of two, were bred on the farm and most of them are from cows of his own breeding. There is not a second-class animal in the lot.

It is a uniform herd, nothing extremely large. and nothing small, just a herd of good, big, beefy, smooth Shorthorns. Every cow raises her own calf and it grows big and fat. The Regier herd is well fed and well cared for but the feed is not expensive. Ensilage and alfalfa are used with a protein ration for the calves. I saw the cows 
recently, some of them suckling, and they are as thrifty a lot as one could wish to find. This ability to do well on farm feeds is second nature with these cattle, for generations of such feeding

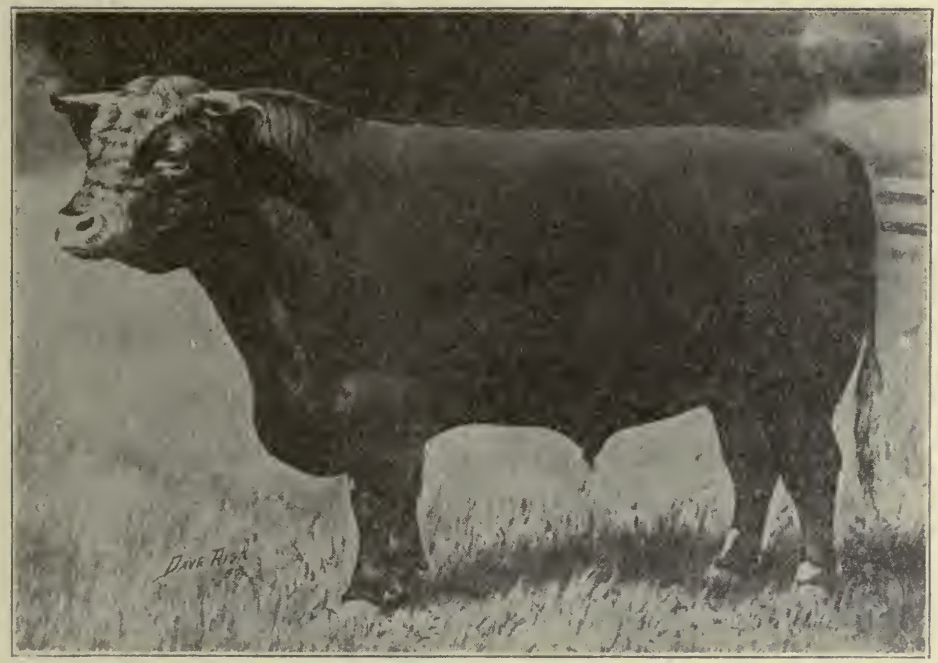

NONPAREIL STAR

with a little culling out-not much culling has becn necessary-has done the work.

Mr. Regier began brceding in 1902. In 1905 he began showing. He went to the Butler county and the Harvey county fairs and quoting his own words, "I got first in every class entered." The next year he ventured farther from home, going to Hutchinson, which was at that time endeavoring to be the permanent location for the state fair, where with plenty of competition he did not 
win everything for which he showed but he won his share, among which was first on bull calf. W. A. Harris was the judge. Later he showed at Topeka, Wichita, Hutchinson and Kansas City,

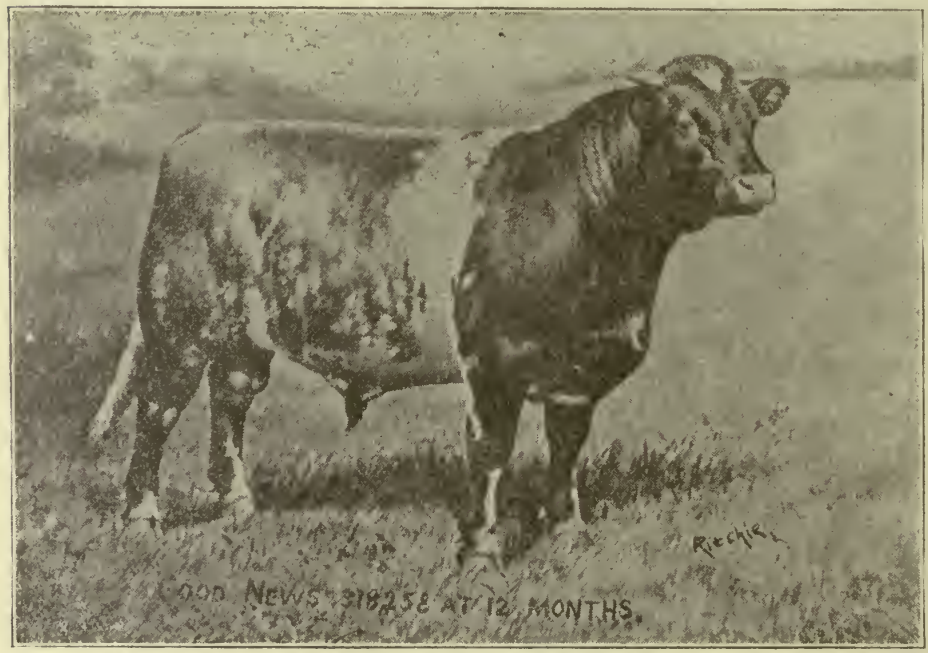

GOOD NEWS

always well in the money but seldom at the top for the reason that most exhibitors had nurse cows and all kinds of dainties and Scotchmen for their cattle while Mr. Regier had only the calf's mother and good ordinary feed and himself as herdsman.

The reader will want to know something of these cows. Calla 2d, a twelve-year-old red, but very vigorous and thrifty, is by Nonpareil Star. Her dam is by Orange Hero, a son of Godoy, he 
by imp. Spartan Hero out of imp. Golden Thistle. Calla 2d's second dam is Bashful 6th by Prince President 2d, the son of imp. Prince President and Mysie 45th, a cow that was the dam of several good herd bulls. Then there is Calla $3 \mathrm{~d}$, a roan daughter of Calla $2 \mathrm{~d}$ by Good News, the bull that was shown at three state fairs and won three firsts, before Mr. Regier bought him. News Victoria-the cattle are named after their ancestry -is one of the good ones and like Calla $3 \mathrm{~d}$ she is a daughter of New Goods but her dam breaks into a new line. When Jas. Tomson, away back in 1897, saw the red bull calf that tickled his fancy and straightway told his father that was the bull they must buy, Gallant Knight had his coming-out party and this daughter of New Goods had for a dam 5th Elderlawn Victoria by Gallant Knight and for grandam Victoria of Maple Hill by Chief Violet of Maple Hill. Another daughter of New Goods is Edelweiss 9th, a seven-yearold roan out of Edelweiss $3 \mathrm{~d}$ a daughter of imp. Lord Banff.

It was in 1904 or 1905 that Mr. Regier wanted a Shorthorn cow as good as the best. M. E. Jones had bought imp. Lord Banff, a bull for which $G$. E. Ward had paid the then unheard-of price of $\$ 5100$ and Jones was selling some cows bred to him and some with calves at foot by him. Imported Edelweiss, probably the best, at least the highest priced one and one of the highest priced 
cows sold in America that year came to $\mathrm{Mr}$. Regier's along with a heifer calf by imp. Lord Banff. This heifer was Edelweiss $3 d$ and it is from this Edelweiss purchase that a cow bred by

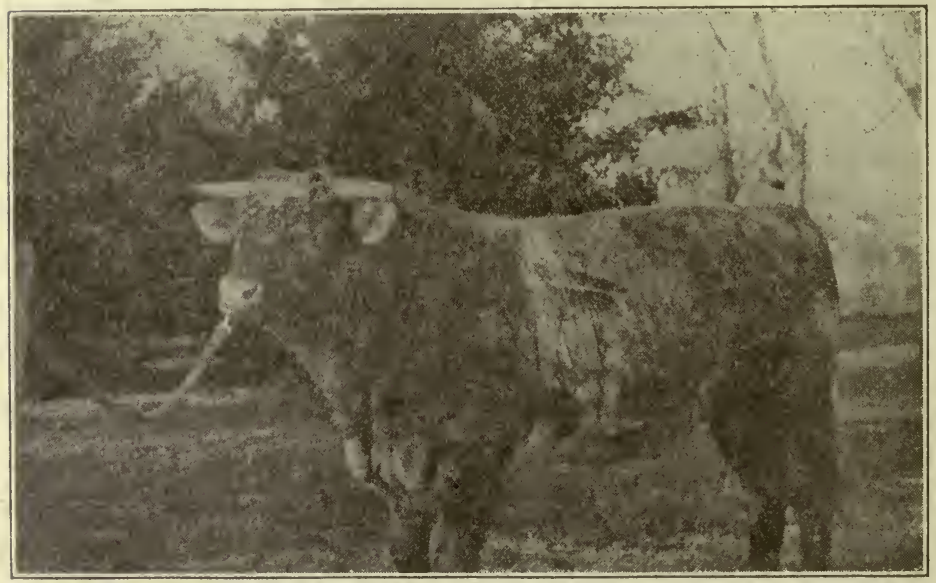

MAXWALTON MANDOLIN

Mr. Regier topped one of the Salter sales at $\$ 1625$.

We have been told and are telling over and over again that the bull is the big end of the business. Nonpareil Star was the first of Mr. Regier's bulls. So good an authority as B. O. Cowan has told us in his History of Missouri Shorthorns that there was little use of any one else showing against George Bothwell and the get of imp. Nonpareil Victor. Nonpareil Star was the bull calf in one of Mr. Bothwell's greatest show herds 
and he was by imp. Nonpareil Victor. His dam was by Chief Violet 4th, a son of Scottish Chief, sire of Rosedale Violet 9th and out of Rosedale Violet 2d, a daughter of imp. Marsh Violet.

Good News is the next bull that left an impress on the herd. His sire was New Goods, a son of Choice Goods out of a cow by imp. Collynie and his dam was by a son of Lavender Viscount, grand champion at the first International show in 1900. Then came Dale Emblem, son of Owen Kane's Double Dale, the great double cross Avondale sire of such unusual excellence. Dale Emblem's dam was by Snowflake, sire of Ringmaster, the only bull ever awarded the International grand championship three times. Scotch Cumberland followed Double Dale. His sire is Cumberland Type, the most sensational show bull of recent years, said to have been shown thirty-seven times at America's biggest shows and to have won thirty-seven first prizes. His sire was by Cumberland's Last, the greatest bull in C. A. Saunders' herd. Scotch Cumberland's dam is by Burwood Royal bred by Herr Bros. \& Reynolds and sold to Mr. Saunders. Maxwalton Mandolin is the present herd bull with a reputation to make and a good chance to make it. He is by Maxwalton Revolution and is a typical representative of his family. His dam is by Avondale.

Since writing the article above, Mr. Regier has 
purchased two yearling heifers of Tomson Bros. for $\$ 3000$. It is needless to say they are from the tops of that excellent herd. It will be of interest to note that his six entries by Scotch Cumberland in the Purple Ribbon sale at Wichita, though only a little more than twelve months old, averaged $\$ 645$.

J. C. Robison, Towanda.-Whitewater Stock Farm is a magnificent body of land, 1040 acres, and every acre except that in the bed of the Whitewater River will grow first-class alfalfa. A blue grass pasture that would look good to a native of Kentucky or of Nodaway county, Missouri, was being grazed upon April 29 by a Shorthorn to the acre and they had been getting all the grass they wanted for some time. In addition to the elegant bungalow, forty by seventy feet, used as a home for the Robison family, there are four other houses good enough to rent for $\$ 25$ or more in the ordinary Kansas town. These houses are occupied by the men employed in the operation of the farm. As they are all married men and are being well compensated for their services, I suspect Mr. Robison is not having labor troubles. The barns are more extensive and better constructed than those I have found elsewhere. If this farm is used to its capacity in the production of Shorthorns, one can only wonder at the possibilities of the herd in the future. 


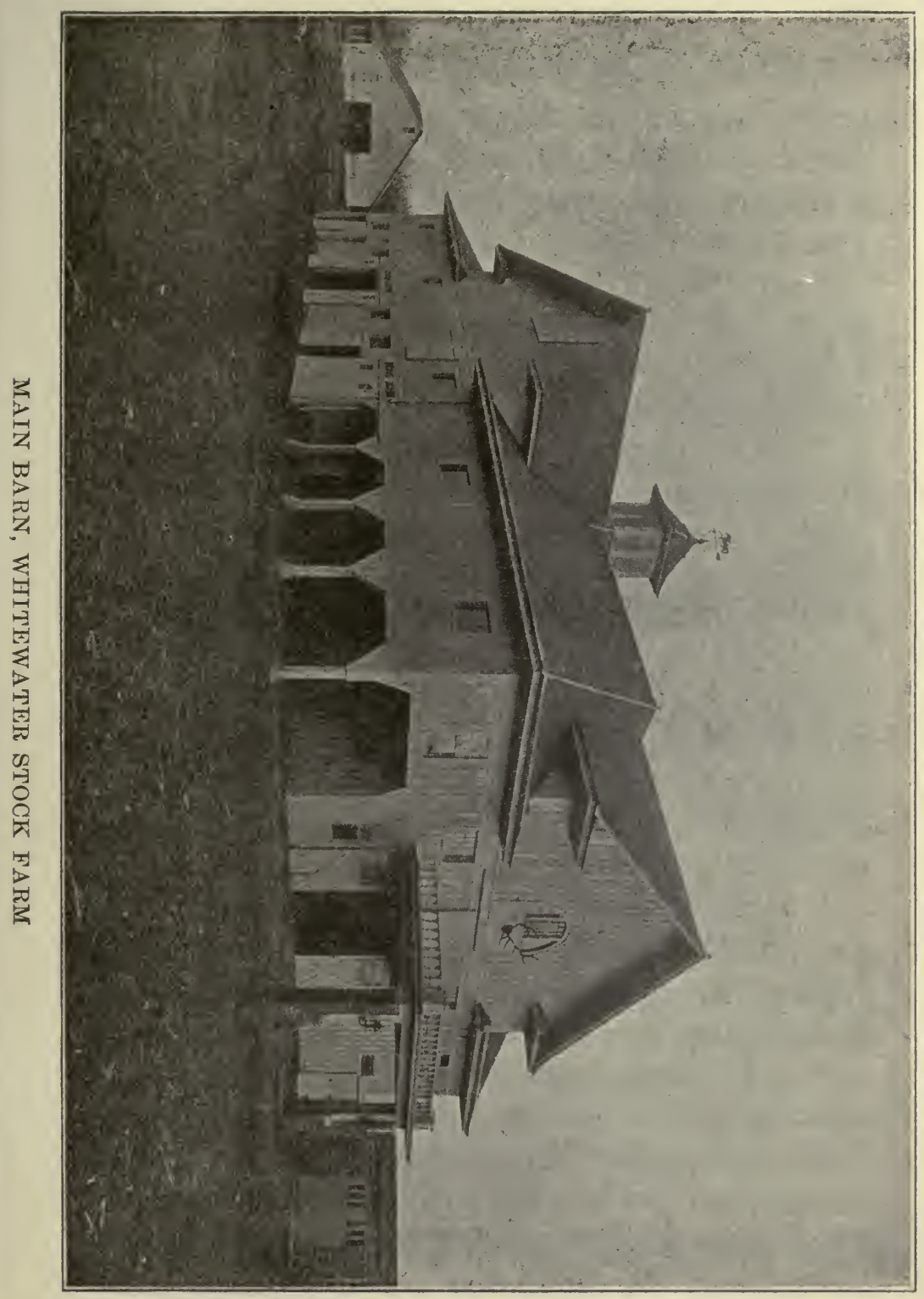


The reader will recall the Robison farm as a great Percheron breeding establishment, the products of which won nation-wide fame. There is a little story connected with its shifting from Percherons to Shorthorns aside from the regular one furnished by the auto and the tractor and the truck. Wm. Ellett, oldest son of the family, is a 1920 graduate of the Department of Animal Husbandry in the Kansas State Agricultural College and wants to specialize in Shorthorns. Mr. Robison, while apparently good for many years, realizes what some middle-aged men do not seem to understand, that natural inclination for any vocation, if properly directed, is an invaluable asset in the race for success. He knows that in the natural course of events his sons should be in the prime of life when for him life's activities have ceased, hence the trip to Scotland for Shorthorns, direct from the locality that has given fame to the breed.

It is an "all-imported" lot of reds, whites and roans that is the foundation for the herd of the future. Some of the younger animals are not as well developed as the better American specimens, and at the time I saw them, April 29, were still showing effects of their recent hardships, incident to importation. They are, however, nice, smooth, breedy looking specimens and within a few years the good pastures and the alfalfa will have done the work so seriously interfered 
with by the war time conditions in Scotland.

There are about thirty females including heifer calves at foot, in the herd. I was particularly impressed with Ballechin Rosewood 3d, a massive four-year-old roan. She stands on very

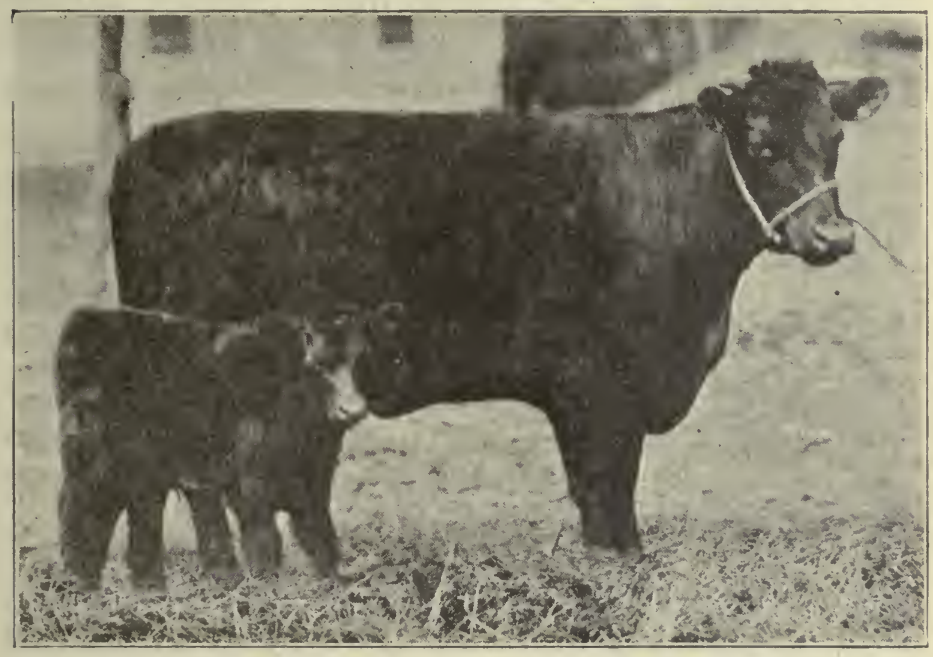

BRIGHT GEM AS A TWO-YEAR-OLD WITH BULL CALF A prize winner in Seotland, imported by Mr. Robison.

short legs, has fine length, great depth and very straight lines. Her head and neck and covering of flesh are superb. Barring a little prominence of hip and unevenness of rump, she could hardly be improved. She is by the Duthie bred Golden Baron out of Rosewood 82d. Her grandam is Rosewood 76th by Waverly, which cow is the dam of imp. Rosewood 92d, dam of John Potter's Rosewood Dale. Bright Gem is a red two-year-old 
daughter of the noted sire, Collynie Bright Star. She stood third in her class at the Perthshire show last season. She is large, smooth and looks like a good breeding prospect. Kintore Beauty 4th and Kintore Victoria came from Sutherlands in Aberdeenshire. Their sire is Cluny Prince Victor, bred by Lady Cathcart. They look like the making of good breeding cows. Bouquhan Bellona Princess is by the highly esteemed bull, Collynie Cupbearer, and in addition to being one of the best cows of the importation, she has proved a breeder of excellent stock, her bull calf being one of the best on the farm. Mayflower Mint is a three-year-old roan, bred by Robert Bruce. She is Bruce bred for ten generations on her dam's side and the sires were bred by Bruce, Duthie, Marr, Taylor, Shepherd and Cruickshank. Those who want something coming from top herds all the way down should be pleased with this pedigree.

I could go on at length and tell of each of the several females on the farm, but I shall do so only in a general way. Some of the choicest herds of Perthshire and Aberdeenshire have been drawn on for these cattle. Among them are those of Messrs. Butter, Drone, Strang, Syms, Hunter, Jaffrey, Wilson, Major Graham Sterling, Robt. Bruce, Rennie, Durno, Stephen, Sutherland, Campbell of Kinnellar fame and Duthie, whose reputation is world-wide. 
Mr. Robison realizes that it is the bull that must be relied upon for a good herd and he has made an effort to get the best arailable. In order to have a better chance at selection, he is saving four young bulls until he can see how they develop. One of these, Herald, (vol. 66 E. H. B.) is a white of unusual promise, low down, wide, smooth, well covered and large. His sire is the Duthie bred Collynie Lavender King. He will be used liberally this season. Another that is now being tried out is the red, Diamond Star, bred by Mr. Drone and sired by Gloaming Star. Though less than fourteen months old at the time of my visit and having had at least some set-back by reason of the long trip and quarantine, he weighed in only light flesh, 1115 pounds. He is of accepted show yard type with a full share of qualifications for the show ring. Another is Lord Aberdeen bred by James Durno. This fellow proved a very poor sailor but is doing well now and will be given a chance to develop into a good bull as Mr. Robison believes he will.

As illustrating the owner's determination to put a top notch bull at the head of the herd, he said to me, "Now if neither of these calves makes as good a bull as can be had elsewhere, I will get one elsewhere, for I am determined to head this herd with a bull of the highest class." I believe the spirit which prompted the purchase of Casino, admittedly the best stallion of his day, for 
the Whitewater Stock Farm will find a parallel in the bull which will head this herd.

At the Salter-Robison sale held at Wichita May 15, 1920, a consignment of twenty-seven head, which included several of the imported cattle, made an average of $\$ 920$. Sweet Fragrance, bred by Wm. Duthie, sold to Albert Hultine of Nebraska for $\$ 2400$, and a number of the American bred females sold for more than $\$ 1000$. It should be kept in mind that the cattle were in thin flesh and that Mr. Robison retained the most desirable ones in his foundation herd.

Fremont Leidy, Leon.*-Mr. Leidy is the oldest breeder of his community. Nine years ago he went to the Alex Fraser dispersion and bought three of the best cows of that excellent herd. Previous to this he had bought from the J. F. Stodder herd a trio of splendid cows. This gave him daughters of Falsetto, the noted Norton bull; Silk Goods, the son of Choice Goods and Lassie of Tebo Lawn and Captain Archer, one of the best sires in the West. They were out of dams by 15th Duke of Hillsdale, one of the last of his great family; Lord Thistle, son of the noted cow, Mysie 45th and Gwendoline's Prince, another son of Mysie 45th. The herd has been very prolific and four sales of about forty head each have been held, the greater part of the offerings having been descended from these cows

* Ship on Friseo or Santa k'e. 
and from two purchased from B. B. \& H. T. Groom. Some of the best of these cattle are still on the farm.

Other purchases of good stock were made of which only a few of those now in the herd will be mentioned. Ewing Acres Victoria, a handsome dark roan, is by Linwood Dale. She comes from the Ewing Bros.' Missouri herd and is by the the sire of numerous prize winners. On her dam's side she combines the blood of four of America's and Europe's great Shorthorns, imp. Nonpareil Victor, imp. Collynie, imp. Craven Knight and imp. Princess Alice. Lady Katherine is a twoyear-old of great promise. She is out of a magnificent cow by Captain Archer and would be a credit to any herd. Lawndale Wildeyes 24 th has been and still is an extraordinary breeder. She is a daughter of Falsetto out of a Falsetto dam, second dam by Prince Royal $2 \mathrm{~d}$ giving her the cross to imp. Princess Alice, the greatest cow of her day. Princess Beauty by Captain Archer must be counted among the best cows I have seen this year. She is large, very attractive, very smoothly covered and has furnished several valuable additions to the herd. Maid of Orleans is another Fraser cow that has added wealth to the herd in raising exceptionally good calves. Two elegant young cows are Rosebud 7th and White Beauty, both bred in Iowa and by Prince Blythesome, a grandson of Victor Baron 
and imp. Craibstone with an imp. Nonpareil Victor cross near the top of the pedigree. They are four crosses from imp. Roseblush bred by Duthie. Secrecy, a good young cow, is a granddaughter of Secret of Hill Farm 3d, a Dustin bred daughter of imp. Merry Hampton. She has a white heifer calf by imp. Bapton Corporal for which tempting offers running near four figures have been refused.

Three additions were made at the Royal sale in 1919. Musical, twenty-five months old with heifer calf at foot, was not only one of the bargains but one of the really desirable things in the offering. Few Shorthorns have such a wealth of ancestry. Among her immediate ancestors are Pleasant Dale $2 \mathrm{~d}$ out of the dam of the $\$ 10000$ 2d Fair Acres Sultan; Captain Archer, own brother to Swect Mistletoe, dam of Lespedeza Collynie, 1919 International grand champion; imp. Collynic, the sire of Sweet Mistletoe and scores of the best Shorthorns ever owned in the central West besides Royal Knight, the best son of imp. Princess Alice, the outstanding cow of her generation. As an addition to a breeding herd Musical should prove of great value. Miss Monarch 2d, two years old with four grand champions of America in the first three crosses, was one of the elegant heifers sold by Harriman Bros. and fell to Mr. Leidy's bidding.

The present herd bull is leaving so great an 
impress that too much could not be said in his favor. In looking over his calves I was struck with their valuable Shorthorn characteristics. They have plenty of size and are uniform in type and general appearance and they are excellent feeders. This bull is Cedar Dale. He is not particularly impressive in appearance and has been dehorned, but as a sire of real Shorthorns he will need to be classed among the truly good Kansas bulls.

Mr. Leidy for the first time entered the show ring at the 1920 Kansas National in Wichita and won more than the usual honors given new exhibitors. His young herd bull, recently bought of Tomson Bros., was placed fifth following the entries of the professional show men with highly fitted animals. His young herd won second place in the contest and two of his junior heifer calves were well in the money. It is a great credit to any breeder to be able to make a showing in such closely contested classes.

Mr. Leidy has creditably served his district as state senator and is recognized as one of the best orators in Kansas. Those who have visited the Leidy home will agree that much of the success achieved with Shorthorns is due to Mrs. Leidy who takes an unusual interest in the cattle and whose judgment on Shorthorns is excellent.

Joe King \& Son, Potwin.-This firm has a large establishment and a pure bred herd has 
been kept for about twenty years. The main herd, however, has consisted of high grades and commercial stock. This is to be changed and in the future they will specialize on Shorthorns. Early in their work they bought of C. S. Nevius a few of his famous Scotch Josephines, one of the best families of Kansas Shorthorns. They also secured Poppy's Pride bred by B. O. Cowan and sired by his great bull, Norfolk, and out of a dam by Victor Knight; Lovely Lassie by Victor Archer 163364, a Prather bred son of Fearless Archer; Paquita by Prince of Tebo Lawn out of a cow by Prince Armour, the great white son of imp. Princess Alice and other's of similar class. This gave them a splendid working foundation. The bulls used have, as a whole, been good ones.

While no extravagant prices have been paid, Messrs. King have held in view first of all the market requirements and profit to the producer and have demanded that their herd bull be a strictly good beef animal. A study of the pedigrees of the bulls used shows them closely descended from the best Shorthorns of the day. Among the first sires in service was Airdrie Viscount bred by C. E. Leonard. His sire was Lavender Viscount, American grand champion and his dam was by the $53 \mathrm{~d}$ Duke of Airdrie, one of the best bulls of the most popular family of Shorthorns in the world. The S. C. Hanna bred Ingle 231949; Master Mason 374696 bred by 
M. E. Jones and Supreme Victor 394156, a Stunkel bred son of Victor Orange, were among the good ones used. The bull now in service bred by H. G. Brookover, Victory $2 \mathrm{~d}$ 690174, is a nice roan descended from choice ancestry. He is a big, smooth, rugged fellow, and, like his predecessors, one of the profitable kind. The conditions under which the herd has been kept are such as to develop medium size and to insure to the purchaser an animal which will continue to do well with good ordinary farm care.

Clarence Leidy, Leon.-I feel sure that Mr. Leidy is going to be a good breeder. Among the excellent females in the herd is Superb Cecelia, a "superb" light roan. Her sire is Superb Omega by Uppermill Omega and she traces through a line of good Canadian breeders to the Campbell bred imported Cecelia 4th. Mysie 2d, a smooth red, carries her credentials as a producer in her twelve-month-old heifer, an extra good one by Cedar Dale. In her immediate ancestry is found the great old bull Lord Mayor and the equally great cow imp. Marigold 50th. Two other cows of the kind it pays to have, come from Mr. Roeingk. The one combines the best Scotch blood lines with Col. Vaile's noted Waterloos. The other is a daughter of Superb Sultan by Whitehall Sultan. She is not only of exceptionally good beef type but is also a heavy milker. At the 1919 Stunkel sale Mr. Leidy bought two choice 
females. Royal Empress 12th is by Cumberland Diamond. She was not only the best heifer in the sale but she would look good in any herd and her breeding is as good as her individuality. Her dam was by Victor Orange, one of the noted bulls of the breed and her second dam was by Star Goods, own brother to Bellows Bros.' champion, Diamond Goods. The other cow is by Star Goods out of a Victor Orange dam and is of the regulation Stunkel breeding.

Mr. Leidy has been using Fremont Leidy's Cedar Dale and the two brothers who live on adjoining farms will continue to co-operate to some extent in the matter of bulls, but it was also deemed necessary to have a bull on this farm. At the Purple Ribbon sale held in January 1920 at Wichita, the excellent young prize winning bull from F. C. Barber \& Sons' consignment was secured at one of the high prices of the sale.

G. W. Brown \& Sons, Leon.-It is a good lot of cattle which this firm is getting together. The herd represents their purchases at the last two sales held by Fremont Leidy where they were quite critical in their selections. About forty females are now on the farm, most of them of the well known Leidy breeding, coming from the Eraser herd through daughters of Falsetto, Silk Goods and Crown Prince of Lawnsdale and from J. F. Stodder through daughters of Captain Archer and Gwendoline's Prince, lines of 
breeding typical of splendid results. They have added to their purchases some of the very best of Mr. Leidy's later acquisitions. Roan Violet, an outstanding three-year-old heifer, a daughter of the excellent sire, Wooddale Chieftain, a son of The Choice of All, is out of a cow by Violet Chunk, an outstanding sire of H. C. Duncan's breeding. Mr. and Mrs. Leidy reluctantly parted with this cow. Roxana, a splendid roan by Secret Robin, now at the head of Miss M .V. Stanley's herd (see Stanley sketch) is out of a dam by Wooddale Chieftain followed by Lord Mayor 3d and Secret Archer, all strictly highclass bulls. Another excellent purchase was the red, Geraldine, that in her three top crosses carries the blood of famous sires such as Lord Lovel, Lavender Viscount and imp. Cupbearer. With proper handling this should become a first-class herd.

A. G. Sowers, Leon.-At the Leidy sale held recently, $\mathrm{Mr}$. Sowers made four valuable additions to his little herd. His cows are of the same breeding as Mr. Leidy's and are good individuals. This herd is built on a foundation largely representative of the most famous cattle of any breed in the world's history, the Bates Oxfords, Kirklevingtons and Duchesses and it is nicely topped out with Scotch bulls. Searchlight Lad by Searchlight; Silk Goods by Choice Goods; Falsetto, the famous sire in the Fraser herd and 
Hampton's Sharon by Hampton Primrose, an excellent Hampton Spray bull, are some of the sires appearing in the top crosses. This insures a select line of breeding cows. Mr. Sowers will be able to use Mr. Leidy's bulls.

Hubert A. Haynes, Rosalia,-Mr. Haynes is a new breeder with ten females and a good bull. Most of his purchases came from Fremont Leidy and a few from J. C. Robison and the cattle are representative of these two herds. The first bull used was by a son of Searchlight out of a Kellerman Scotch Josephine. The present sire is a Leidy bred son of Hampton Sharon, a son of Hampton Primrose:

A. J. Tull, Leon.-Mr. Tull is another one of Fremont Leidy's near neighbors who laid a good foundation at his sale. A very promising roan heifer by Secret Robin. (see Miss Stanley's sketch) should serve as an excellent foundation to which he intends making an occasional addition. This heifer comes from an elegant line of ancestry four generations of which, on both sides, I knew well and admired on account of their merit.

\section{CHASE COUNTY}

W. J. Sayre, Cedar Point.-The man who can breed from his cows a car load of calves and feed them so they will sell at twelve months at a higher market price than any other calves on the 
Kansas City market is not only an accomplished feeder but he is also a breeder of the first class. Mr. Sayre did that, not only once, but he did it nine times out of ten years he has been feeding his calf crop. It was not a load selected from many, but these wonderful market toppers were the entire crop, culls and all. No breeder within my knowledge has to his credit a higher accomplishment than has Mr. Sayre for he has gone to the court of last resort and has received for his cattle and for his methods the strongest possible endorsement. Most of these calves were grades, some were pure breds, probably the eulls of both sexes and the reader can imagine what the choice ones would be when developed.

A new order of things has arisen. The nursery which furnished the material for the conquest of the beef market of the Southwest has now turned into a different channel. The grades have been disposed of and the least desirable of the pure breds have gone into other herds. The fortyfive females now on the farm are such as to meet the exacting requirements of the owner. This means that they are not only first-class individuals but also that they carry through their ancestry an inheritance of merit and uniformity rich enough to almost guarantee they will reproduce their kind. This is an inestimable advantage to the buyer of breeding stock for he can be sure before hand of the kind of calves he will get from 
a bull so descended. A study of the ancestry of Mr. Sayre's cattle reveals the fact that I am correct in making the foregoing statement.

The first bull used was Lopez 231291. His sire was Lord Mayor 112717, a son of Baron Larender $2 \mathrm{~d}$, the most wonderful bull ever produced at Linwood and imp. Lady of the Mcarlow, one of the best breeding cows in the Linwood herd. His grandsire was imp. Baron Victor, the bull that established Cruickshank prestige in America. The dam of Lopez was by Vanquish by Galahad the sire of Gallant Knight, the state's greatest sire of prize winners, and her sire was imp. Master of the Rolls, sire of Master of the Grove, American Royal and International grand champions. Another bull used was Victor Chicf, also out of a Gallant Knight cow. His sire was Dictator by Norfolk, a bull said by B. O. Cowan to have been second only to imp. Scottish Lord. An own sister to Dictator, Forest Daisy 2d, was the dam of New Year's Delight, grand champion everywhere west of the Mississippi and junior champion at the International. Norfolk, by the way, was by Prince Royal, son of imp. Princess Alice, greatest American cow of her day. Anotlier bull was Hampton Crown by Hampton's Best, probably the best son of imp. Merry Hampton.

The bulls now in use are Jolly Dale and Glendale, both by Maxwalton Rosedale, full brother to Whitehall Rosedale, the grand champion bull 
all over the central West and sire of the 1919 champion, Violet Dale. Maxwalton Rosedale was out of the same dam as Pride of Albion, Royal grand champion. They both came from Tomson Bros., being the best bulls of the desired age and out of the best cows in the herd. Female additions by purchase have been few. Eight heifers were recently bought from H. C. Stephenson and what I have seen of Mr. Stephenson's cattle warrants me in saying they are good ones. These heifers are of choicest ancestry. Their sire, Nonpareil Knight, was by Gallant Knight's Heir and their dams are by Cherry Knight by Barmpton Knight out of Cherrybud, dam of one of Tomson Bros.' best prize winning heifers.

In a letter of December, 1920, Mr. Sayre says that Glendale is proving the best bull he ever owned and that his 1920 calves are the best he has ever produced. On a ration of alfalfa and three pounds of oats each, per day they are carrying more flesh than any of the car lots he sent to market carried at a corresponding time.

Mr. Sayre's twelve-year-old son, Paul G. Sayre, bids fair to grow into a good Shorthorn man while working with his father in this excellent herd.

Frank H. Yeager, Bazaar.-Mr. Yeager is one of the most prominent breeders of this section, his herd having been established fourteen years ago and now numbering fifty females. He is 
producing cattle for service that will give maximum results from the feed consumed and one of the requirements is that the cows be good milkers. Pushing for extra development is not practiced, but thrift and a good growth are maintained. The result is that cattle purchased here are not stunted, yet will respond well to good farm care.

The herd consists of choicely bred cows. One of the most valuable and best is Collynie Primrose and she is so royally bred that but few cows in America could be classed as having a pedigree as good. Her sire, imp. Collynie, has the distinetion of being sired by the world's greatest present day breeder, Wm. Duthie. Collynic's dam, Lavender 45th, was Mr. Cruickshank's favorite from among all his Lavenders and her ancestors for five generations were all bred by Cruickshank and were the cattle that made Scotch Shorthorns famous the world over. Collynie Primrose is out of Primrose 6th, one of the smoothest, thickest, large cows in Mr. Hanna's herd when that herd was at its best. Primrose 6 th was by imp. Inglewood, a 2500 pound show bull at four years old and the sire of much outstanding stock including the dam of Ingle Lad, now famous as the sire of great producing cows such as Lad's Emma, second dam of the grand champion, Lady Supreme. But this is not all. Primrose 6 th was out of imp. Primrose 4 th by Scottish Archer, an own sister to the cow that 
for three years produced the highest priced bull in the Duthie sales and to Prince of Fashion, leading show bull in Scotland. I mention Collynie Primrose at such length because Mr. Yeager has several of her daughters and granddaughters and her family is increasing rapidly and becoming a great part of his future herd.

There are other good females, but I shall now call attention to the bulls Mr. Yeager has used. Hampton, bred by Mr. Hanna, was by the 2500 pound Hampton Spray, one of the best sires used in Kansas and sold with the herd to F. A. Gillespie of Muskogee, Oklahoma. Hampton's dam was Golden Queen 3d by imp. Collynie and she was out of imp. Golden Queen, one of the largest cows of the breed. (See Hanna sketch, Part I.) The bulls now in use are Village Champion and Scotchman. Village Champion is by Double Champion, son of Choice Goods, the champion of America for three years and out of Russella, dam of Ruberta, the greatest heifer and cow of her day, and for three years the undefeated female of the American continent. Village Champion's dam is by imp. Invincible and his second dam by imp. Hospodar. Scotchman is by Hampton and out of Collynie's Primrose, both mentioned above. He is an excellent young bull that $\mathrm{Mr}$. Yeager finds it advisable to use on a part of the herd. Any one at all familiar with the Shorthorn history of the past will readily see that Mr. 
Yeager has in his herd, as outlined above, all the elements necessary for success and popularity.

\section{CHAUTAUQUA COUNTY}

Chas. Casement, Sedan.-This is the largest and most prominent herd in Chautauqua county. The cattle are strictly a utility lot, handled to get very good growth and development without. any disposition toward forcing. While the herd could have been better developed without injury, yet it has not been underfed or neglected to the extent that deterioration has taken place, rather, the cattle are in the best possible condition to make profitable returns for increased attention given them.

These cows are from desirable ancestry. Several females by St. Valentine 12 th by St. Valentine were added a few years ago. The herd represents a blending of Scoteh and Bates with a touch of Booth and the blood lines chosen have been good ones. This probably came from a disposition to use the right kind of bulls rather than from a study of pedigree, but as is always the case, good bulls come from good ancestry, so I was not surprised to find in evidence near the top of the pedigrees, Gwendoline's Prince by imp. Prince President, Champion's Best by Valley Champion, Choice Goods, Collynie, the Vaile bred Winsome Duke, Mr. Snodgrass' prize winning Scott Jr. and imp. Scottish Emperor that 
did service for Bellows Bros., T. O. Ford and H. M. Hill.

Among the herd bulls used were Majestic, bred by D. P. Norton by the Canada bred Buccaneer; Sedan Chief, a grandson of Collynic; Hallwood Viscount by Choice Goods Model, a son of Rosedale Violet 9th and Victor Hampton by Hampton Spray. The present herd bull, Lord's Dale, is a big, straight, heavy fellow with a very masculine appearance. While not a bull of extra finish, he is not at all rough and must be classed as a good bull and a good breeder as his calves will prove. He is by Mr. Lookabaugh's Lavender Lord and came from M. W. Babb's herd where he had done satisfactory scrvice.

The article above was written in June 1919. Since then Mr. Casement sent a cow to the Southeast Kansas sale held at Independence April 2, 1920 and she sold for $\$ 625$ to so good a judge as S. M. Knox. Mr. Casement bought for use in his herd a yearling bull, Rose Dale bred by Park E. Salter and sired by Rosewood Dale out of a dam by Count Broadhooks 2d 36437.

M. L. Holroyd, Cedar Vale.-I met Mr. Holroyd frequently while he was a student at the Kansas State Agricultural College in the department of Animal Husbandry. There was a large Shorthorn herd on his father's farm but the cattle had not all been kept recorded. Mr. Holroyd, now in charge of the farm, is building up a 
registered herd from the recorded ones, and additions that will be made from time to time. Croud bulls have been used and the cattle are good. Among recent sires was a son of Careless Conqueror $2 \mathrm{~d}$ by imp. Conqueror out of imp. Blythesome 15th. This bull was out of a dam by Violet Chunk, a Duncan bred show bull by Headlight, and proved an excellent sire. He was followed by a son of Royal Gloster, well known in the Garver herd as a high-class show and breeding bull. This farm, destined to become the home of a real Shorthorn herd, is one of large pastures, splendidly watered, and big fields of alfalfa.

J. M. Hamill, Grenola.-Mr. Hamill has a herd of about thirty females which he is keeping in the ordinary farm way and he is getting fair development. He finds a market for his surplus at moderate prices near home and, while not obtaining the measure of success which would follow more careful handling and more liberal feeding, he is producing a useful class of cattle and is securing far better returns than he could secure from common stock. In addition to the usual crosses from good bulls found in local herds, Mr. Hamill's cattle carry a cross of Forbes Bros.' Baron Gloster and the splendid Bates bull, Peculated Wild Eyes. The herd bull is by Victor Hampton, a son of Hampton Spray.

Chas. J. Buchele, Cedar Vale.-Mr. Buchele bought a few Shorthorns recently. One, Minnie 
Sharon by Refiner 377210, is out of Minnie 37th bred by Abram Renick and sired by his splendid bull, The Professor. This cow, in Mr. Stodder's herd, was an excellent producer of high-class show stock. Mr. Buchele also has a daughter of Minnie 'Sharon by John B. Potter's Avondale bull, Rosewood Dale, formerly much used by Park E. Salter. Other cows of approved breeding are in the little herd which is headed by Red Warrior 612235 by Hampton 2d, a son of Hampton's Demonstrator.

\section{CHEYENNE COUNTY}

R. K. Standish, Saint Francis.-It will doubtless be a surprise to many to learn that in the extreme northwest corner of the state is found a well cared for herd built from very excellent foundation stock. Private sales have taken care of the surplus as rapidly as it could be produced. A silo is to be built and a show herd started out this season (1920) and occasional choice additions will be made by purchase. The herd now consists of forty females. Lady May was bred by Rapp Bros. and is by the sire of American Royal and state fair prize winners, Gladstone, an excellent breeding son of Whitehall Sultan. Victoria Beauty $3 d$ is by Gloster's Favorite, a bull of the choicest breeding, and her dam is of the best blood lines. Lady B. was bred by Geo. Allen and her sire, Victor Sultan, ranks with the best of 
Whitehall Sultan's sons. Her dam is Dorothy B. bred at Browndale from the noted family of that name.

One of the bulls used is Palmetto Cumberland by Roan Cumberland, a son of Cumberland's Last out of Pine Grove Mildred 11th. Another is Model Type by Cumberland's Type out of Marengo Cumberland, a daughter of Cumberland's Last out of imp. Lady Marengo. The roan, imp. Grand Fortune, a son of imp. Modest Princess, was also somewhat used.

Mr. Standish has just written me that he recently purchased the massive roan calf, Supreme 827618 for $\$ 2100$. This calf was well in the money at the Nebraska State Fair last fall. His sire is Royal Supreme by the International grand champion, Village Supreme. His dam is from choice ancestry, having been out of a cow by the champion bull of his day, Viscount of Anoka. This brief outline given an idea of the excellent blood lines found in these cattle. Plans for the future include the production of a large and high-class herd.

\section{CLAY COUNTY}

S. B. Amcoats, Clay Center.-Mr. Amcoats has been very active in Shorthorn circles for ten years. His early purchases were made from $\mathbf{M}$. C. Vansell of Atchison county and later he bought the entire F. M. Gifford herd. The best 
of these cattle were retained and the process of making occasional purchases with the retention of the best has been continued until there is now an excellent herd on the farm. In addition to the purchases mentioned, Mr. Amcoats has drawn on the herd of Governor Shallenberger, $\mathrm{E}$. D. Ludwig, R. T. Scott, W. A. Betteridge and George Allen \& Sons.

The array of good bulls, whose blood was brought into the herd through the cows acquired, includes such animals as Missie's Sultan by Glenbrook Sultan; Victor Sultan by Whitehall Sultan; Godwin, son of imp. Spartan Hero and Golden Thistle; Lord Marr by Lord Mayor out of imp. Marigold 50th; Barmpton Knight by Scarlet Knight; Sempstress Valentine, T. P. Babst's bull that sold for $\$ 1000$ in the era of low prices; Lavender Viceroy, possibly the best known son of the grand champion, Lavender Viscount; Baron Violet by Victor Bashful, the son of Sweet Violet $2 \mathrm{~d}$, and many others that figure at the top, not at the bottom, of the pedigrees.

Among the choice cows in the herd is Matchless Princess by His Highness, dam by Victor Sultan, second dam by Godwin. Her first calf by Type's Goods is the best thing ever calved on the farm and tempting offers have been refused for her. Barmpton Knight has an excellent daughter in the herd that is a great producer. Her bulls have gone to head good herds while her daughters 
have been retained. Butterfly Sultan by Secret's Sultan is a valuable cow with several toppy heifers to her credit.

Secret's Sultan that came from Bellows Bros. was one of the best bulls used. His sire was Missie's Sultan by Glenbrook Sultan and his dam was by the well known Victorallan. His heifers matured into great cows and fine breeders. Type's Goods by Cumberland Type has been used for more than two years. He is a low down, large bull, good all over, but very strong in the back and loin. Like Secret's Sultan he is an exceptional heifer getter and a lot of yearlings by him show a number of prospective outstanding cows. Type's Goods is out of a cow by Carter's Choice Goods, son of Choice Goods and imp. Clara 6th by Silver Plate. Royal Marshal by Village Marshal, an attractive white yearling has recently been purchased from Tomson Bros. His dam is by Victoria's Snowflake by The Choice of All, second dam by imp. Lord Cowslip out of imp. Roseleaf by Scottish Archer. He is an unusually smooth, young fellow with extra depth and he is a first-rate prospect. The outlook for this herd is bright, for Mr. Amcoats has first class facilities for doing good work and he has the modern and successful type of cattle.

Jacob Nelson, Broughton.*-Mr. Nelson has used exceptional judgment in making his

* Ship on Rock Island or Union Pacific. 
chases and he has a herd that should take a leading position in his territory. Among the cows are Charming Butterfly by Sir Charming 10th, dam by Baron Daybreak 292830 and her yearling heifer by Orange Dale, a son of Whitehall Rosedale; the Bellows bred Choice Beauty 2d by Missie's Sultan, son of Glenbrook Sultan and her dam by Good Choice, with an excellent bull calf at foot and Gipsy Cumberland 5th bred by C. A. Saunders and sired by Cumberland's Best out of a dam by Burwood Royal, second dam by Ruberta's Goods. Gipsy Cumberland 5th is a very valuable breeding proposition. Not only does she carry in every cross what is best in Shorthorns, but she is reproducing the type of her good ancestry as may be seen in her excellent white bull calf seven or eight months old. This calf won second prize in the State Association show at Manhattan, 1920, and sold for $\$ 775$.

An outstanding cow is Sweet Carmine, recently purchased from the Kansas State Agricultural College. She is by Barmpton Knight, the bull that in Tomson Bros.' herd sired outstanding breeding and show stock. Her dam is by White Goods, one of the best, if not the best, sons of the champion, Choice Goods and her second dam was by Lavender Viscount, C. E. Leonard's great breeding bull and International grand champion. Other good cows of nice breeding are 
found here and it is Mr. Nelson's intention to cull the herd closely, adding occasionally an especially desirable female.

Imported Lawton Tommy is the herd bull. A single glance conveys the impression that he will be a good breeding bull and he possesses to a high degree the qualities needed in profitable cattle. He was used for some time by Tomson Bros., but owing to their having several other bulls of great excellence, they could spare him so Mr. Nelson was able to buy him. He is by Diamond Favorite 680396 bred by Alex Crombie and his dam. is by Douglas Chieftain by Collynie Marshal. The calves by him at Tomsons show excellent Shorthorn character.

Paul M. Borland, Clay Center.-Mr. Borland has been in the Shorthorn business for nine years. He bought his foundation stock of F. M. Gifford, securing some of the T. P. Babst Butterflys well known in Shorthorn circles then and now. The herd, as a whole, represents excellent breeding, coming through such bulls as Barmpton Knight; Golden Victor Jr.; My Lord by imp. Spartan Hero out of imp. Lady of the Meadow, the dam of Lord Mayor; imp. Cupbearer, American champion; Athenian Coronet 4th by imp. Bapton Coronet; Prime Minister; Clay \& Winn's noted Golden Victor and others of like quality that could be named. The cows are not so well grown out as they should be but they are very 
smooth, of breedy type and good Shorthorn character, descended from excellent ancestors and are producing good calves. The milking tendencies are quite well developed in this herd. The herd bull, Gloster Boy, was bred by S. B. Amcoats. His sire is Secret's Sultan, (see Amcoats sketch) the son of Missie's Sultan out of a dam by Victorallan, the sire of so many good breeding cows in the Bellows herd. His dam is by a son of Captain Archer, J. F. Stodder's bull, second dam by Violet's Prince by Potts \& Sons' Lavender King 3d. Better development of the young stock would be all that would be necessary to produce some really good cattle.

Warren Watts, Clay Center.-Mr. Watts bought his start from F. M. Gifford twelve years ago. These cows were a select lot, nearly all sired by Cordelia's Knight, a son of Red Knight by Pro Barmpton the well known Cookson sire. Cordelia's Knight was an unusually thick, shortlegged bull that carried along with his Scotch blood that of Cordelia's Duke, the noted show bull by 4 th Duke of Geneva. The herd is of correct Shorthorn type and is a profitable lot of breeding cows, the money-making kind. Mr. Watts has exceptional facilities for handling cattle and should he decide to do so, he can build up a first-class herd.

Two good bulls have been used, Newsboy by Gallant Knight out of a dam by the Harris bred 
Laird of Linwood by Galahad and The Cardinal, bred by Governor Shallenberger, a son of Lancaster Lad by Scotch Bank and his dam by Coming Star out of imp. Maud 50th. The present herd bull is Brilliant Type by the champion, Cumberland Type, the greatest show bull of the decade. His dam is by imp. Manchester, second dam imp. Bonnie Belle. Brilliant Type is a show bull. He has fine length, good depth, is very straight-lined, full in all vital points, covers well and has an elegant head and neck. He should make a splendid individual and a successful sire.

M. E. Householder, Clay Center.-Mr. Householder is a new man but one who has made a good start. He has a cow from the Hunt herd at by Nonpareil Star, also a bull of outstanding Blue Rapids by Wodan, the choice Regier bull worth. Her dam is by Grand Lavender 153671 and she is exceptionally good foundation stock. On my visit to Mr. Householder I saw a twoyear-old heifer that impressed me very favorably. She is possibly an extreme beef type, but from the view point of beefy superiority, she grades high. She came from the Amcoats herd. Her sire is Mystic Victor by a good son of Barmpton Knight and her dam was by Lord Mayor, a source of Shorthorn excellence. Mr. Householder is breeding to the Amcoats bull and getting splendid results. This course is highly recommended to smaller breeders. 


\section{COFFEY COUNTY}

C. H. White, Burlington.-Mr. White began operations in 1E06 and for the last ten years he has been one of the leading breeders in southeast Kansas. His herd is kept closely culled and the visitor will find some very good Shorthorns on this farm. Mr. White maintained a show herd from 1911 to 1913 and exhibited successfully at the Nebraska State Fair and at the best Kansas fairs including Topeka, winning well in both open and state classes. He also showed at the American Royal with some of his entries well in the money.

Possibly the best cow that Mr. White owns and one that would be a credit to any herd, is Roan Heather. Her sire, Lord Mayor 3d, was a high-class show bull by Lord Mayor out of Forest Daisy, own sister to the dam of New Year's Delight, American Royal grand champion and International junior champion. Roan Heather was third in her class at Lincoln and Topeka. Her dam was a combination of White Goods, Barrister and Col. Harris' best line of breeding. Sweet Novelette $2 \mathrm{~d}$ is by Richelieu out of one of the best Shorthorn cows of her day, Charm's Novelette by Scotland's Charm out of a dam by Viscount of Anoka. Richelieu was by The Choice of All, son of Choice Goods and the famous Rosedale Violet 9th. Since Scotland's Charm 
put size, quality and milk into nearly everything he sired and was by imp. Lavender Lad out of a cow by imp. Baron Cluickshank and since Viscount of Anoka was a great sire and one of America's greatest show bulls, it is easy to see why Swent Novelette $2 \mathrm{~d}$ should be especially raluable.

Roan Heather and Sweet Novelette $2 \mathrm{~d}$ are representative in value and in quality of ancestry, of the cows. Of the bulls, Richelieu, mentioned above, was probably most used. Castellar 449834, a very rugged, deep-bodied roan, is now in service. On his sire's side he carries the blood of Snowflake, sire of Ringmaster, the only bull ever three times. International grand champion, and that of imp. Bessie 51st, the dam of White Goods, probably the best son of Choice Goods. Castellar's dam is by Victor Sultan, a son of Whitehall Sultan that won fame as an outstanding sire in George Allen's herd.

W. S. Bozeman, Colony.-Mr. Bozeman has been breeding Shorthorns for nine years and at the time of my visit his herd numbered twenty. head of brecding age. Either the foundation purchases were made with exceptional judgment or Mr. Bozeman was unusually fortunate. At any rate, he has a good herd and as is generally the case, it is well loaded with the blood of real Shorthorns. Among the ancestors found in the top crosses are such bulls as imp. Magenta, 
Symphony's Last, Ceremonious Archer, Mystic Archer, imp. Chief Steward, 56th Duke of Airdrie, imp. Collynie, imp. Inglewood, imp. Prince President, Lavender Viscount, Spartan Hero, Whitchall Sultan, Godwin, Good Choice and imp. Conqueror.

The bull at the head of the herd is Chief Steward, bred by T. J. Sands. His sire is Clansman by Snowstorm and his dam is by Lavender Viceroy $2 \mathrm{~d}$, second dam by the Norton bred Courtier $2 d$. I have not seen this young bull but have been told that he is a very thick, smooth, short-legged fellow, attractive in appearance. Mr. Bozeman has good facilities for handling his cattle, he seems to be full of energy and his pride in the business speaks well for future success. If he fails to produce a real Shorthorn herd it is because he fails to live up to his opportunities.

E. E. Heacock \& Sons, Hartford.-Shorthorn breeding which began here in 1916, has made rapid progress. The large herd has been federal tested and is accredited. The cows are of good size and quite smooth and are satisfactory breeders and sucklers. While this is not a herd of skyhigh prices, yet it is well bred and useful and is making money. The management is efficient, feeding is liberal and the young stock is well developed. The local show ring is patronized and at least a full share of the prizes are carried away. The Heacocks have an excellent stock 
farm with aburdant pasture and alfalfa and a silo furnishes succulent winter feed. That the Shorthorn business will continue to be carried on successfully here seems assured for the sons of the family are even more interested than is Mr. Heacock himself:

Several bulls have been used more or less but the leading one is Brawith Heir 351808. He was bred by Tomsons and sired by Gallant Knight's Heir, first prize bull at the Kansas State Fair and elsewhere. His dam is Gratitude 5 th by White Goods, the great son of Choice Goods and imp. Bessie 51st, owned by Thomas, Jameison \& Mitchell. Brawith Heir has been used in the herd with good results. A new bull, Augusta's Archibald by the Anoka bred Right Stamp by Sultan Stamp, has just been bought. Augusta's Archibald is out of imp..Brandby's Augusta 4th and carries the prestige of most excellent ancestry.

C. L. Buchanan, Lebo.-Mr. Buchanan is one of the older breeders of Coffey county, having started with Shorthorns in 1906. A few years ago he held a successful public sale and there are now about thirty females in the herd. The mature cows are of good size for some of the older ones have been sold on the market and the average weight of 1400 pounds off grass proves the assertion. There has been no systematic effort made to keep up with the fashion in blood 
lines or to produce the highest-class cattle, but rather to breed a lot of the practical moneymaking, farmer's sort. To do this, however, it has required the use of pretty good bulls and they are obtained only from good ancestry. Among these bulls has been one sired by Prime Minister whose dam was a full sister to the International champion, Lavender Viscount. The last bull used was Victor Mysie, a splendid breeder, as shown in his get. This same bull also sired the fine cows mentioned in Hall Bros.' sketch. (Allen county.) Aside from the sale referred to above, the produce has been sold locally at satisfactory prices.

Stephen C. Odell, Leroy.-Mr. Odell made his first purchases from the J. C. Thorn sale of excellent cattle and secured some of the choice heifers of the offering. They were sired by the badly named but splendid breeding bull, Kaiscr, a son of the great Collynie cow, Sycamore Secret. In their top crosses they carried the blood of Harding, full brother to H. M. Hill's cow, Sarcasm, the prize winning Lord Mayor $3 d$ and the Choice Goods bull, Choice Prince, whose dam was by Alice's Prince. Three of the best cows in the C. E. Hill sale were added a little later. The herd bull is by Sycamore Victor, a son of Mr. Hill's \$2000 Sycamore Secret 3d and out of the top cow of Mr. Thorn's sale, sold to J. II. Holcomb of Humboldt for $\$ 505$. Mr. Odell is a 
young man of splendid physique and ability that should enable him to build on this foundation a herd that would be a credit to himself and a benefit to the surrounding country.

Wm. Cronin \& Sons, Burlington.-Mr. Cronin began in a small way with Shorthorns in 1909 and in 1919 the firm was able to hold an excellent sale of thirty-five head. The herd is of popular breeding. Stock has been shown with success at the Coffey county fair and it is one of the plans for the future that showing be continued. I'erhaps the best bull was Hall's Cumberland, bred by C. A. Saunders. His sire was See A. Cumberland by Cumberland's Last and his darn was Lady Dorothy 11th by Baron Golddust 3d. Buster Dale, a good young bull, now heads the horrl. He is by Robert Russell's Walnut Type and his dam is by Glenview Dale 3d, a son of Avondale.

Ivy Allen \& Sons, Burlington.-A small herd has been kept here for ten years, but real effort dates from 1920 when the firm added two outstanding cows with heifer calves. More such females and a bull to match were secured a little later. These purchases included Janette 4th by Choice Prince followed by Morning Star and March Knight and Diamond Queen 13th, one of the best cows in the 1920 Royal sale.

E. E. Brott, Burlington.-Mr. Brott has a few good cows and he is planning to increase his numbers and become an active breeder. Practical 
utility will be his guiding star and with a favorable location and bright boys who are taking a lively interest in the Shorthorns, the way to success is clear. These boys especially attracted my attention because of the knowledge they had of the cattle as well as their interest in them.

R. L. Clark, Leroy.-Mr. Clark is laying the foundation for a good herd and aside from sceuring a few nice, cows he has been fortunate in obtaining a bull-that is much better than the average beginner gets. He is one of the best types of bulls I have seen in the county and his ancestry is such as to promise satisfactory results. Nothing more is needed than sticking to the business and giving the cattle proper care.

J. W. Harrington, Burlington.-Mr. Harrington is a new brceder who bought three useful cows and who has a thick, short-legged bull bred by Wm. Cronin \& Sons. Like many others who own land, he realizes that cattle must be kept on the farms and he believes a rugged Shorthorn cow that is a good milker is the practical and profitable kind for the small farmer.

J. F. Knight, Lebo.*-This little herd consists of purchases that are of very nice breeding from C. L. Buchanan and Wm. Cronin \& Sons. The Buchanan cows are by Victor Mysie, an unusually good breeding bull. The bull used is also by Victor Mysic. His dam is by a son of Andrew

- Telephone, Hălls Summit. 
Pringle's Prime Minister, a big, smooth animal of great excellence and the best of breeding.

M. H. Lyon, Waverly.-Mr. Lyon has seven attractive females and a bull. Wenaford 226317 and Beatrice 226308 are five-year-olds from C. L. Buchanan's herd. Their sire is the exceptional breeding bull, Victor Mysie 345498, sire of a number of excellent cows in Hall Bros.' herd at Carlyle. Red Scotch, a desirable bull from the herd of William Cronin, is in service and is getting first-class calves.

Harry Shannon, LeRoy.-Mr. Shannon bought three cows at the R. A. Drummond sale in February 1919 and he is another of those well favored persons who can furnish his cattle everything needed for their best development. The calves that I have seen would indicate that at least two of his cows are excellent breeders, a fact which only men old in the business appreciate at its full value.

\section{CLOUD COUNTY}

F. J. Colwell, Glasco.-Mr. Colwell has a herd of thirty females above the average in size and of good conformation. Maud $2 d$ was sired $b_{3}$ the Rustler, a son of The Lad For Me, International grand champion in 1900, and out of Russella, the dam of Ruberta, undefeated American cow and International grand champion in 1901. The uam of Maud 2d was by Mr. Gifford's outstanding 
bull, Red Knight. 'Flora 185502 is by Marquis, a son of Mr. Hanna's Prince Royal, son of imp. Collynie and imp. Princess Royal $62 \mathrm{~d}$ and out of a daughter of imp. Lord Cowslip. Flora's dam is by Gallant Knight that in Tomson's herd was the sire of many prize winners at the big shows. Red Mollie is by Barmpton Model, a Tomson bred son of Barmpton Knight, one of the best sires ever used in the Tomson herd. Lady Washington 34 th is by Barrister, a bull that during his show yard career won 247 first prizes.

One might continue to write such facts, but enough have been given to show the remarkable line of ancestry in this herd. The bull in use is well selected. He is Gainford Lancer by the great sire, Gainford Champion, a son of imp. Gainford Marquis, junior champion at the International in 1911, later famous as a Canadian sire, and now recognized as one of America's greatest bulls. The dam of Gainford Lancer is by imp. Jilt Victor and from an elegant line of ancestors.

Arden Jewell; Concordia.*-Mr. Jewell's herd was started a few years ago and now numbers thirty females. They range from medium to large and it is the owner's intention to grow his young stock as large as he can. With all kinds of good grass including alfalfa, with big wheat fields and plenty of alfalfa hay, he will be

* Station and telephone, Talmo. 
ênabled to come out with a herd of more than average size. The original purchases came from Blank Bros. \& Kleen of Nebraska and from F. C. Kingsley of Auburn. The bull being used is Marshall's boy 751953 by Marshall's Choice 340687. Mr. Jewell is fortunately located near other breeders among whom co-operation is practiced in the larger sense.

\section{COMANCHE COUNTY}

E. S. Dale, Protection.-Eastern Kansas breeders do not usually associate a high-class Shorthorn herd with the short grass country, but had they observed Mr. Dale at the SalterRobison sale in 1920 as he bid in $\$ 400$ installments on Missie's Last up to $\$ 6000$ against H. C. Lookabaugh and then saw him buy Emblem Jr. for his Comanche county herd for $\$ 4000$ over the bids made by Peter Ross, they might have changed their ideas. His action is typical of the man and is reflected in the herd of cattle he owns. Improved methods of feeding and handling are being adopted and the second public sale from this herd will be held in 1921. Local shows have been patronized and good winnings have resulted.

More than fifty females are now on the farm. The roan six-year-old, Lovely Goods 2d, is by that outstanding sire, Ruberta's Goods, whose get are among America's most popular 
prize winners and good producing cows. Lovely Goods' dam is by Lady Rose of Ardmore by Scottish Pride. Lavender Mist came from Tomson Bros. and is by Mystic Chief, one of the best known sons of Barmpton Knight out of a Lord Mayor dam. Lavender Mist's dam is by Archer, the splendid son of imp. Collynie and imp. Circe $3 d$.

Several different bulls have been used. Collynie Lad combined the blood of Prince of Collynie, imp. Collynie and Royal Knight; Marigold's Chief, a Tomson production, that of

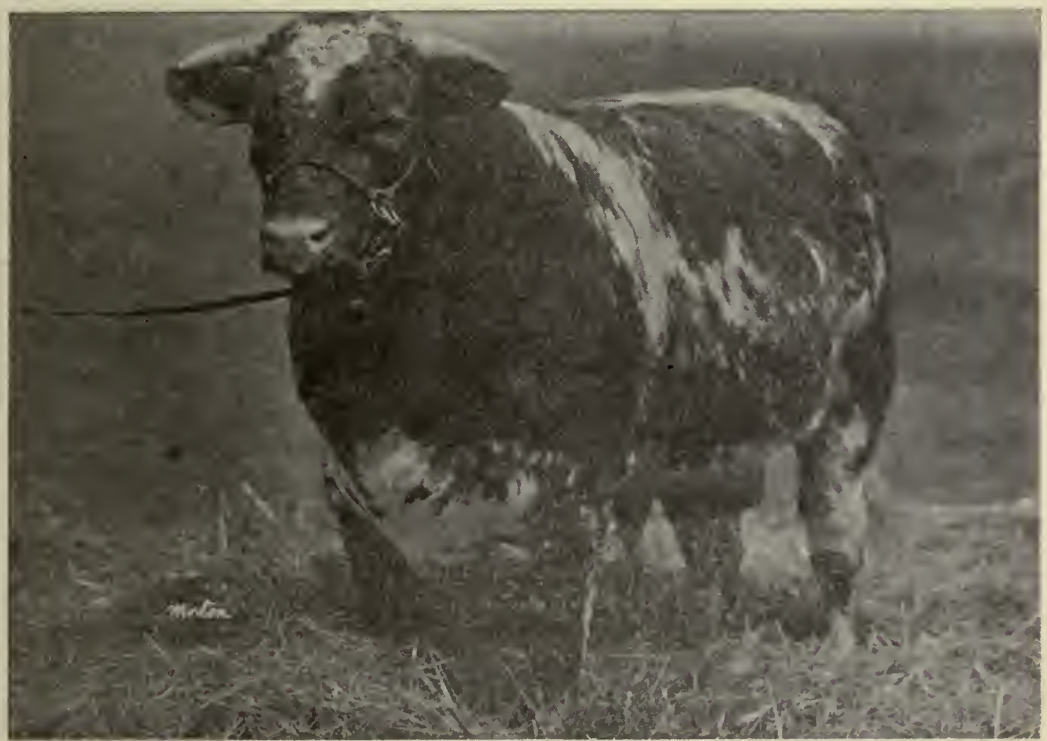

EMBLEM JR., HIGHEST PRICED FIFTEEN-MONTH-OLD BULL EVER BRED AND SOLD.IN KANSAS 
Barmpton Knight and imp. Marigold 50th. Roan Monarch was bred by H. T. Forbes and was by Royal Monarch out of Sweet Orange. (See Forbes sketch.) Butterfly Royalist, now in service, is by imp. Butterfly Duke out of imp. Lady Marion 2d. In the purchase of Emblem Jr. for $\$ 4000 \mathrm{Mr}$. Dale secured what will probably be his best investment, for the bull is even better than his picture shows him. His sire, imp. British Emblem, was one of the most promising young bulls in the entire country and his dam is a cow of great excellence by Prince Valentine 4th, one of the best sires in Kansas.

\section{COWLEY COUNTY}

Fred Abildgaard, Winfield.-When ' I first met Mr. Abildgaard I made up my mind that here was a man who would become a real Shorthorn breeder. A few hours conversation with him later, confirmed this opinion and when I reached his home, looked over the cattle, observed his methods and listened to his statements, I knew that Mr. Abilgaard was already a real breeder. He has an additional guarantee of success in his sons who take a very active interest in the Shorthorns and who are giving them personal attention not often given except by professional herdsmen. The results of such care and attention are apparent.

Mr. Abildgaard is no novice in the business. A 
few years ago he was owner of a herd in northern Missouri, which was sold to Bellows Bros. and some of these cattle brought high prices in their sales and since then have been resold at from $\$ 2000$ to $\$ 4000$. Threc years ago Mr. Abildgaard located near Winfield.

There are ten cows in the herd, all reds, all three to four years old, all good ones and as matured cows they should be a grand lot. Eight of them are sired by Athene's Scotchman, a splendid bull of H. F. Brown's breeding, one is by Rosewood Dale and one by a son of Maxwalton Renown. Each of these cows either has a calf at foot or will calve shortly. It is needless to say that they carry the blood of excellent Shorthorn sires. They are being bred to a white bull and elegart calves, all roans, are the result.

This bull, Villager Magnet, is worthy of attention. He is about five years old, a son of Village Fancy 417901 out of a cow by imp. Mutineer that sold in Bellows Bros.' 1917 sale for $\$ 1750$. In lookirg over my notes I find this entry in regard to Villager Magnet: "Can't say anything too good about this bull and his calves." He is the big, deep, thick kind and a wonderful breeder. He might stand a little closer to the ground but he is so massive and has such good Shorthorn character that he can not fairly be subjected to serious criticism, especially when his two-year-old heifers are under inspection. 
While this herd is splendidly developed along beef producing lines, special attention is being paid to milk development. All the cows are far above the average as milkers and Villager Magnet, the herd bull, is from heavy milking ancestry of the best Scotch type, his dam having given six gallons of milk per day.

In a general way, Mr. Abildgaard handles his cattle for best results without overcrowding. The herd receives liberal care and the young stock is grown and developed to reach what the merit of its good ancestry makes possible. It is evident that the cost per day does not enter into the calculation so much as does the result to be obtained and the ultimate profit to be derived from intelligent care and feeding. Mr. Abildgaard's location on an ideal stock farm and the co-operation of such boys as his sons, assures for his cattle a leading place among Kansas herds.

Since the article above was written, Mr. Abildgaard has purcliased J. E. Paton's excellent herd. This includes two cows of outstanding merit. One comes from the Kansas State Agricultural College and is by that great sire, Matchless Dale. The other comes from C. E. Leonard and represents the very best of the ancestry for which that herd is famous. He has also bought a splendid producing daughter of Captain Archer out of a Bellows bred Cruickshank Columbia cow and two Stunkel bred Star Goods 
Victor Orange cows. The acquisition of these cows, together with the stock already on hand, gives Mr. Abildgaard one of the choice herds of southern Kansas.

J. E. Paton, Winfield.-Mr. Paton has demonstrated his ability as a successful breeder and handler of Shorthorns as few young men of my acquaintance have done, for nowhere in my travels did I find any one who secured better

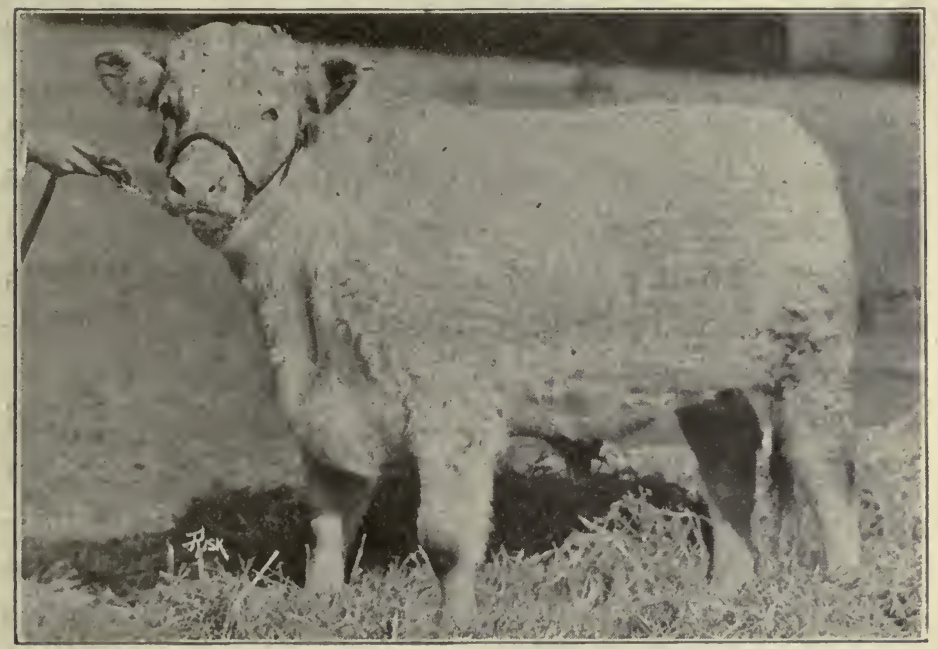

VELLE'T TYPE

results from a herd that did he. The stock on Shady Brook farm at present consists of only five high-class females and the herd bull. Emerald's Choice is a big red, bred by C. E. Leonard \& Son. Her sire, Rosedale's Choice is 
one of the three noted sons of the champion, Choice Goods out of the famous Rosedale Violet 9th. Her dam is imp. Emerald 4 th from Wm. Norie's herd and sired by Wrangler, son of Mr. Duthie's greatest bull, Scottish Archer. Silver Lavender is a promising daughter of Cumberland Star 703360 out of a Leonard bred daughter of Wooddale Stamp, one of the best known sons of the Choice of All. This heifer, judged by her ancestry ard her merit, should develop into a magnificent cow. The herd bull is Velvet Type, a prize winner at the Kansas Naational and a bull of such quality as is seldom found at the head of a small herd. His sire is Narcissus Type, the Cumberland's Type bull used at the Kansas State Agricultural College, and his dam is Golden Lavender 4th by Wooddale Stamp out of a cow by Marengo's Viscount.

Chas. M. Baird, Arkansas City.-Mr. Baird has the large herd of Cowley county and it is a good, useful one, where cattle are kept in a natural way, reaching normal development and responding well to care and attention. The cows represent a desirable line of ancestry, well bred bulls have been used ever since breeding operations were begun. The herd is descended from such sires as Golden Victor Jr., used for a number of years by H. M. Hill; Scott Jr., locally famous as a show bull in the Butler county herd of W. J. Snodgrass ; Galahad, Col. Harris' bull and 
many other good ones that might be mentioned. At no time has any effort been made to use special blood lines, Mr. Baird demanding size and true Shorthorn character rather than certain kinds of breeding. He has had local demand for the bulls and the females have so far been retained in the herd. There are now on the farm a lot of heifers sired by Marshall's Best, a son of the Hanna bred Scottish Chief and to mate with these, the massive roan bull, Silverheel, has been purchased. He is by Silvermine, well known in Stodder's and Marshall Bros.' herds. He is a good one from end to end and he should be a valuable breeding bull. Mr. Baird is one of the state's heavy farmers, progressive and up to date in every way, and the Shorthorns produced here . will be satisfactory to purchasers.

J. A. Fasken \& Son, Atlanta.-J. A. Fasken \& Son have a splendid tract of land on which to handle cattle. They began breeding in Morris county about fourteen years ago, going to Cowley county seven years ago. The present herd. was founded by purchases from David Ballantyne \& Sons of Herington and those who knew the Ballantyne herd know there was a rare opportunity to select foundation stock. Five of the cows secured were by Collynie Pride, a splendid Hanna bred son of Collynie, that had for dam one of the excellent cows coming from Elbert \& Fall, and four were by Marshall 
Abbotsburn 3d whose sire was out of Mary Abbotsburn 7th, the unrivaled cow of her day.

A splendid bull was secured from S. D. Mitchell, a son of White Goods, dam by 47th Duke of Airdrie. (See Mitchell sketch.) Another one was by Captain Lovely out of a dam by $\mathrm{Mr}$. Stodder's great Captain Archer. The present herd bull is a massive roan by Mr. Hanna's Hampton Spray out of Golden Queen $3 d$ by imp. Collynie, second dam, imp. Golden Queen. (See S. C. Hanna history.) This is a very desirable bull and those who like the big, beefy, deep, thick kind could not help liking him. A promising yearling bull, recently bought from E. L. Stunkel, will also be tried. He is by Cumberland Diamond, dam by Star Goods, second dam by Victor Orange.

J. W. Sickles \& Sons, Winfield.-Substantial care is being given the good sized herd of Shorthorns on this farm but they are not being pushed for extra development. The appearance of the calves speaks well for the cows as producers. I was impressed with the fact that the Sickles have ample facilities for handling their cattle and that it would probably be only a question of time until their ambition would lead them to put up a high-class herd. The material they have on hand is good enough, if mated with the right kind of bulls and developed rightly, to produce such results. 
In common with all the cattle of this territory, the blood of imp. Collynie is found strongly infused in the top crosses, also that of Prince of Collynie, imp. Scotchman and 47th Duke of Airdrie, three bulls that figure prominently in many of the cattle coming from H. M. Hill's herd. From the Stodder herd, located near by, came the blood of the noted sire, Captain Archer. Mr. Palmer's Commander; the Bellows bred Champion's Best; the well known Valley Champion; Scott Jr., an outstanding show and breeding bull; Dr.Primrose, the great son of Baron Victor owned by Williams Bros. and others of like quality are much in evidence. With good sized, strong females of such ancestry and a high-class bull which the Sickles intend to secure, the task of producing real Shorthorns will not be difficult.

\section{CRAWFORD COUNTY}

Theo. Jagels, Hepler.-This is a substantial herd founded in 1916 to which some outstanding females, that could not fail to attract general and favorable attention, have recently been added. Mr. Jagels has the practical utility idea firmly fixed in his mind and the cattle I have seen that went into his herd convince me that here will be an establishment that will turn out a splendid class of best money making Shorthorns.

Three of the choicest heifers in Col. Burgess' 
sale at Fort Scott in June 1920 fell to Mr. Jagels' bidding. Village Butterfly and Rosebud's Goods 9th are both low down, thick, beautiful specimens of the breed and show animals of the best type. The first is by Brawith Villager by imp. Villager and her dam is by imp. Mutineer out of a cow by the Duthie bred imp. Royal Fancy. The other is by Golden King, a son of Mr. MeDermott's famous Cumberlard Marshal out of a Fair Goods cow. Her dain is by a son of Morning Star out of a granddaughter of Carter's Choice Groods. Banff's Cecelia, while.not of such pronounced show yard type, is a big, smooth twoyear-old that promises to become a valuable breeding cow. Her sire is by an excellent son of imp. Lord Banff, the first Scotch bull to sell for more than $\$ 5000$.

A herd bull worthy of such females is found in Barmpton's Villager. His sire is Mina's Avon Villager, a son of Village Flash out of Maxwalton Mina 9th by Maxwalton Renown out of an Avondale cow. His dam is by the Norton bred Crown Prince, an outstanding and well known sire used by A. O. Stanley, and the rest of - the pedigree is of the best and most popular blood lines of the breed. With Mr. Jagels' judgment and determination to produce the best, his success can not be doubted.

H. I. Gaddis, McCune.-I have seen quite a number of Shorthorns from Mr. Gaddis' herd 
at different sales and they were all good ones. A recent visit to the farm has added to the favorable impression I held of the cattle and of $\mathrm{Mr}$. Gaddis himself: There are more than fifty females on the farm. They are of medium size, both extremes being well avoided. They are an unusually neat lot of cows with good heads and necks, feminire, yet not delicate, in appearance, the class of females that experienced breeders would select as profitable producers. Bulls sold from this herd have proved these assertions in several instarices by winning in state fair contests. Mr. Gaddis has been a contributor to the Central Sale at Kansas City, the Kansas National at Wichita and the Southeast Kansas both at Coffeyville and Independence and his offering is always well received. The herd was founded in 18c8 by his father and himself and he has been sole owner for a dozen years.

Sultan's Queen by Red Sultan is one of the best cows. Her sire is by Village Sultan, a son of Whitehall Sultan out of imp. Village Maid 30th. Her dam is Village Cup 3d. Rosebud 5th is by Orange Model, one of the most favorably known sires in the West and her dam is by Laverder Viceroy by the International grand chainpion, Lavender Viscount. A large part of the raddis herd is of similar breeding and most of the herd is of the most popular blood limes throughout. 
It would hardly be practical to mention in detail all the bulls that have been used. Among the valuable ones was Scottish Viceroy. He was by Lavender Viceroy, mentioned above, and out of Pride of Orchard Farm B 15th by Secret Barmpton. This line of breeding is now very popular in the herds of. W. A. Betteridge and Bellows Bros. Scottish Viceroy was directly descended from some of America's best Shorthorns including Lavender Viscount, Baron Lavender 2d and imp. Baron Victor. Choice Collynie, used with success, represented on bis sire's side imp. Collynie and Choice Goods. He was out of the excellent cow Wistful (see H. M. Hill sketch) giving him another cross to Collynie and through Royal Knight to imp. Princess Alice, one of the country's greatest cows. Secret Baron, used until recently, was by Snowstorm, the best known western son of Snowflake, sire of Ringmaster, three times International grand champion. Secret Baron sired a splendid lot of stock and he was perhaps the best known of the Gaddis bulls. The bull now used is Challenger's Knight by Dale's Challenger by Double Dale, one of the most noted of Arondale's sons. His dam is White Marigold by imp. Crescent Knight out of imp. Scotch Marigold. He is a good young bull from the very choicest ancestry.

E. L. Holstine, Girard.-Mr. Holstine's early purchases included an excellent daughter of 
Baron Marr, one of the best sons of Cumberland's Last. For several years Lord Hampton by Hampton's Challenger 287618 was used with satisfactory results. In $1915 \mathrm{Mr}$. Holstine bought the bull that proved an outstanding sire. Hampton Primrose by Hampton Spray out of Primrose 6th, one of the best cows in Mr. Hanna's herd, has been used by him for five years and the herd now consists largely of his daughters. I have seen many of Hampton Primrose's calves and all were good ones. His dam was by imp. Inglewood and his second dam was imp. Primrose 4th bred by Mr. Duthie and sired by Scottish Archer, Mr. Duthie's greatest bull. This herd of young cows by such a sire should prove very valuable. Roan Robin, a young bull of excellent type and quality, is now in use. His ancestry on both sides is of the best.

Adam H. Andrew, Girard.-Mr. Andrew has been with Shorthorns all his life and since 1895 he has been breeding on his own account. A successful sale was held in 1914. It is planned to make an occasional addition by purchase and to exhibit at the county fair. The cows are of very popular breeding and are medium in size with deep bodies set on short legs. They are maintained in thrifty condition on the ordinary farm feeds. The herd has always been kept closely culled. Such bulls as the Kellerman bred 8th Prince of Vinewood; Mayor of Valley View by 
Lord Mayor and the well known sire, Orange Major have been used. Edgewood's Stamp by Clara's Choice is now in service. Mr. Andrew has recently added to his herd an elegant, big, red cow by that great sire, March Knight. Such cows are not usually fourd in small herds and her value can not be estimated.

\section{DICKINSON COUNTY}

C. W. Taylor, Abilene.*-It is a farm worth looking over that furnishes the home for the Taylor Shorthorns. Several large houses and large barns and sheds provide shelter for men and animals required in carrying on operations on this tract of 1760 acres of excellent, tillable land. Everything is done on a big scale on this farm. Just now the herd is comparatively small -between 100 and 200 head-having been reduced temporarily in order that more wheat could be raised. Its normal size is from 200 to 300 head. Everything indoors and out is under the immediate supervision of William Harvey and his estimable wife, who came from Scotland some ten years ago to take charge of this big farm. The proprietor devotes much time and thought to the business and every minute spent with him reveals the wide awake man of big affairs.

* Farm near Pearl on Rock Island. Ship on Mo. Pac., Santa Fe, Union Pacific or Rock Island. 
Mr. Taylor has followed the plan of having herd bulls and females of true Shorthorn type and usefulness. The cattle have been kept on a reasonable amount of feed and not pushed for more than good development, the theory being that the customers were not heavy feeders and that the output would give better satisfaction in the long run than if developed to a point beyond that maintained by the man into whose hands they would fall; and that if the purchaser cared to feed more heavily the product of this farm would respond to such a system. Local and western trade have taken the surplus at satisfactory prices and at no time in recent years has there been a lack of customers. The Shorthorns are paying well and giving general satisfaction to the buyers, which is as high a compliment as can be paid any establishment.

The herd was founded with eight cows from Col. Harris' Linwood herd. These, of course, were of excellent ancestry. With them came the bull, Vandal, bred and used by Col. Harris. Few female additions have been made but those bought have been carefully selected. One of them is Lassie 79626 by Senator bred by Col. Harris and sired by Godwin, the excellent son of imp. Spartan Hero and imp. Golden Thistle. Senator's dam was 20th Linwood Victoria by Galahad. The dam of Lassie was Lula Lancaster by Barmpton Bud 152945. Roan Seraphina was 
one of the cows purchased earlier. Her dam came from Linwood and her sire was Golden Knight, the son of imp. Craven Knight and Norton's Golden Drop, that was used so freely by Col. Harris. Seraphina's dam was by Galahad, sire of Gallant Knight. This gives an idea of the quality of the cow foundation.

As before stated, Vandal was the first bull used. One of the next was Lafitte by Royal Knight, one of the best bulls of the breed used by Col. Harris and later by Mr. Hanna. Bold Knight came from Tomsons and was by Gallant Knight, the bull that made the Tomson herd one of national importance. His dam was by imp. Thistle Top. (See Tomson sketch.) Headlight $2 \mathrm{~d}$ was bred by Joseph Duncan and was by Knight of Meadow Farm 3d out of the Harris bred Starlight by Galahad. Valiant was bred by Tomsons and was by St. Clair, a son of imp. Crescent Knight, out of imp. Clara 59th. Marengo's Pearl, a bull much used, came from C. E. Leonard. He was by Marengo's Choice, one of the best of later day Ravenswood sires.

Two bulls are now doing service. Village Heir comes from Uppermill and is a son of the great Villager and his dam is Rosetta Grassland 2d, a daughter of imp. Conqueror out of imp. Rosetta 12th. Victor Dale is by Maxwalton Rosedale, well known sire in the Pringle and Tomson herds. This gives these bulls close connection 
with the best Shorthorn breeding in America.

There is much to recommend the general policy of Shorthorn production as practiced by Mr. Taylor. Securing fair development on ordinary farm feeds is the ideal way of producing cattle and stock so produced is always responsive to increased feed. The success of Mr. Taylor's establishment has rested and will continue to rest on the satisfaction given by its output.

T. A. Ballantyne, Herington.-For nearly forty years David Ballantyne raised an excellent class of Shorthorns and his son, T. A. Ballantyne, is his successor in the business. The Ballantyne cattle were first of all practical and useful for the old Scotchman had enough of the sound sense with which Scotch breeders are credited to avoid anything that would not pay its way and put money into his pocket. His was the method of procedure which, ignoring all minor considerations, demanded a good animal.

The twenty females with which T. A. Ballantyne began in 1917 were the more desirable of the young animals in this herd. Most of them were by Choice Orange descended through a line of bulls coming from good herds and having had the best of care. They represent on the side of both sire and dam the work of the real breeder. Mention is made of a few to give an idea of the blood lines. Fancy $2 \mathrm{~d}$ is by Choice Orange bred by E. L. Stunkel. The sire of Choice Orange was 
the Bellows bred Star Goods, own brother to the champion, Diamond Goods. His dam was by Victor Orange, referred to in these sketches, a sire of outstanding merit. The dam of Fancy $2 \mathrm{~d}$ is by Wooddale Chieftain, one of the best sons of Mr. Gentry's Choice of All. Her second dam was by Marshall Abbotsburn 3d, one of the most highly prized bulls used in the herd. Another Choice Orange cow is Golden Lady 4th out of a cow by Director, a son of Gallant Knight out of a Godwin cow. Her second dam was by Marshall Abbotsburn 3d. A third daughter of Choice Orange is Miss Emma 5th out of Miss Emma 2d by the International grand champion, Master of the Grove. Miss Emma 2d was one of the few additions the elder Mr. Ballantyne made to the herd. It was a two-year-old heifer from this herd, by Wooddale Chieftain out of a Pride of Collynie dam, that stood first in class at the big Central Show at Kansas City in 1918. Pride of Collynie was by imp. Collynie out of a dam by Royal Knight and he was one of the best bulls used.

The student of Shorthorns will recognize in this outline a herd of cows with ancestry of the most desirable kind. The herd bull is a worthy animal. Roan Model 528012 as I saw him in 1919 was one of the best, big bulls I had seen. He weighed more than 2100 pounds at thirty-six months and he had splendid finish and quality. In pasture condition he would have made quite a 
gocd show. He comes from G. A. Betteridge and is of the regulation excellent breeding of that herd.

Few young men breeding Shorthorns in Kansas have begun business urder more favorable corditions than Mr. Ballantyne who grew up with cattle ard can not remember the time he was not identi ied with the work of a superior Shorthorn herd.

E. P. Flanagan, Chapman.-Mr. Flanagan belongs in the class of breeders that should be more generally known. He has evidently been keeping quiet about his cattle but the quality of those I have seen from his herd would justify more publicity. He made a nice little exhibit at Wichita in 1920 ard his herd bull, Sultan's Pride, stood third in aged class, which is quite a compliment to any new exhibitor.

Audrey's Princess is one of Mr. Flanagan's best cows. Her sire is by Choice Goods Model, one of the well known bulls of his day, a son of Choice Goods and Rosedale Violet 9th, the greatest breeding cow in the Tebo Lawn herd. Rosedale Violet 9th was dam of The Choice of All, Rosedale's Choice and Runaway Girl, the dam of Bellows Bros.' Best of Goods. Another cow by the same sire is Janet's Princess. Her dam is by the Dryden bred Golden Prince by Prince Gloster, sire of the $\$ 10000$ Prince, Imperial and her second dam was a daughter of 
Golden Knight and comes from the Harris herd. The herd consists of about sixty females with two bulls in service, Sultan's Pride, mentioned above, and Linwood Topsman. Sultan's Pride

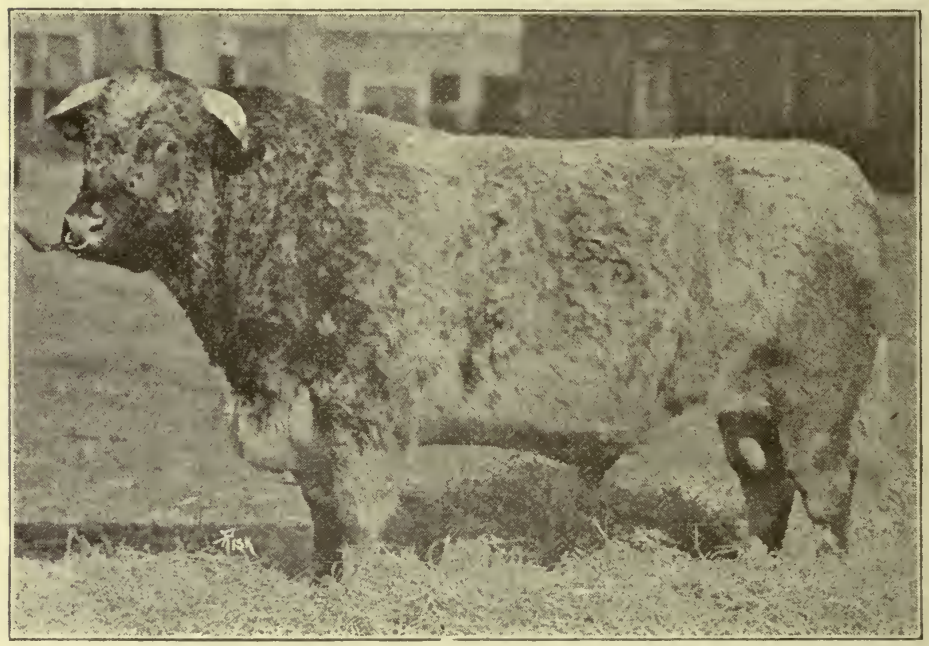

SULTAN'S PRIDE

is strong in the blood and characteristics of Whitehall Sultan. He is an unusually even, well developed bull from end to end and stands close to the ground. As a sire he is giving such satisfaction that Mr. Flanagan expects to use him for at least two more years in order to get more cows by him. Linwood Topsman was bred by Forbes \& Son of Henry, Illinois. He has plenty of size and is very true in his lines and smoothly covered. His sire is Selection's Gold 
551519 by Selection, grand champion at the International in 1909. His dam is by Scottish Consul 181231, son of imp. Consul and imp. Violet 3d, second dam by imp. Golden Fame out of imp. Scottish Ringlet. Mr. Flanagan seems to be a good care-taker and there is nothing in sight to interfere with success.

\section{J. H. Taylor \& Sons, Chapman.*-Mr. Taylor} began the Shorthorn business when he bought four cows and a bull of $\mathrm{A}$. H. Lackey \& Son in 1885. Two years ago he purchased nine desirable heifers. One of his best cows is Ruth $3 \mathrm{~d}$ by Marengo's Pearl 391962 by Marengo's Choice, the splendid son of Rosedale's Choice and imp. Marengo's Lavender Countess. Another one by Marengo's Pearl is Goldie 533001. Her' dam is by Silvery Knight by Gallant Knight out of a cow by Strathallan Chief.

The herd has had the benefit of the use of good bulls. Students of Shorthorn history will recall Baron Lavender $2 \mathrm{~d}$ as one of the most wonderful bulls ever produced in America, and Emma 5th as the famous twin with Emma 4th in the Potts show herd. Lord Lovell, a calf from these two celebrities, was one of the Taylor herd bulls. Golden Knight, the famous old sire used by Col. Harris, was one of the earlier bulls purchased by the Taylors. Marshal Goods by

* Telephone and railroad station, Pearl. Ship on Rock Island or Union Pacific. 
Star Goods and out of the outstanding cow, Miss Belle, was another. Baron Butterfly 2d from the herd of H. I. Gaddis, is now in service. His sire, Snowstorm, is by Snowflake, sire of Ringmaster, the only bull ever awarded three International grand championships. His dam is by Scottish Viceroy by Lavender Viceroy, the best known son of the International grand champion, Lavender Viscount.

William Woodson, Chapman.-Mr. Woodson is a Shorthorn beginner. He has four females all nicely bred. Birdie Gloster 3d is by Baron's Pride, one of R. E. Owen's Queen of Beauty bulls. Her dam is by The Cherub by imp. Prince Oderick. Sultan's Pride Jr. heads the herd. The young stock is being well cared for, and it is the intention to keep the heifers. Mr. Woodson has two sons, Wilfred L. and Edgar W. who are growing into Shorthorn men.

\section{DONIPHAN COUNTY}

T. J. Dawe \& Son, Troy and Hiawatha.-No herd in northeast Kansas is better known than that of T. J. Dawe \& Son. It has been shown at the state fairs of this section, winning its share of honors, and liberal expenditures have been made for breeding stock from some of the best sources in the country. The herd is being kept in excellent condition and visitors always find the cattle looking well. The elder Mr. Dawe 
began breeding forty years ago but not until 1910 did the firm buy really high-class stock. In 1911 the Dawes began showing, exhibiting at both Kansas state fairs and at St. Joseph, Missouri.

In the space allotted I can not tell of all the good cows. The three-year-old Last Rose comes from H. H. Kupper. She is by imp. Scottish Sentinel out of a daughter of imp. Strowan Star, second dam by Baron Kear 2d.' An outstanding cow is the roan, Maxwalton Lavender $2 \mathrm{~d}$ by Avondale and out of imp. Lavender Bloom by Silver Plate, second dam by Roan Robin. This cow is a full sister to the famous Carpenter \& Ross sire, Maxwalton Renown. In the herd is a daughter of Maxwalton Lavender 2d by Maxwalton Revolution, that is very promising and representing, as she does, an extreme concentration of Avondale blood, she may prove exceptionally valuable. Villager's Baron 4th by imp. Villager out of a daughter of imp. Evening Baroness, carries near the top the blood of imp. Cupbearer, America's champion bull. Wayside Lavender is by Maxwalton Revolution out of a dam by Avondale. A typical Ruberta's Goods heifer of the best type is the four-year-old Nonpareil E. that proved herself a fine breeder. Miss Ramsden 6 th by Baron Pride 275479 is not only a good cow but she raised and suckled a calf good enough to be well in the money at the Missouri State Fair in 1919. This calf was sold to M. R. 
Peterson, Mr. Dawe's neighbor. ' Sobriety 8th by imp. Strowan Star out of imp. Sobriety $2 d$ is the dam of two heifers that were in the 1919 show herd and were winners. She has produced and raised five calves within considerably less than five years. Autumn Queen Star is an elegant four-year-old. She is by imp. Scottish Sentinel out of a dam by imp. Strowan Star. Her calf, an excellent prospect, was in the show herd in 1919. 'The old herd bull, sire of much of the good young stock on the farm and winner of many prizes, died recently. He was Diamond Emblem, a son of Diamond Goods and the noted breeding cow Emily by imp. Collynie. He was the highest priced bull in the Bellows sale of his year and was one of the smoothest aged sires on the show circuit. The herd bull of the future is the white two-year-old, Rosewood Pride, bred by Carpenter \& Carpenter. Asked for a description of this bull Mr. Dawe said "He is the right kind."

A. A. Hoverson, Moray.-Mr. Hoverson has been breeding Shortliorns for fourteen years and he now has a large herd of good cows. His original purchases and a few subsequent ones were made from such herds as that of T. J. Sands, Robinson, T. J. Dawe \& Son, Troy, D. P. Rickebaugh, Sheridan, Missouri, E. C. Holland of Iowa and E. D. Ludwig of Sabetha. They were by bulls such as Morning Star; Topsman by 
Red Cup, son of imp. Cupbearer, the grand champion of America for several years; imp. Master of the Mint and others of the same class.

Among the bulls used was Bashful Conqueror $2 \mathrm{~d}$, bred by T. J. Wornall \& Son. His sire was imp. Conqueror and his dam, Bashful 5th by Prince President 2d, second dam Bashful 4th by Knight of the Thistle out of imp. Bashful $2 d$. Baron Blythesome, another herd bull was by a son of imp. Blythesome 27th. His dam was a McDermott bred cow by Senator, a son of imp. Fashion's Favorite and imp. Augusta Bruce, second dam by imp. Craibstone. This bull was used for six years, proving an exceptional breeder and a great factor in building up the herd. The two bulls now in service are Silver Star and Barmpton Butterfly. Silver Star bred by H. S. \& W. B. Duncan was by Cumberland Again 370944 out of Sunlight 10th by Banker's Victor, the well known Norton sire. This is a big fellow and Mr. Hoverson is well pleased with him. The other, Barmpton Butterfly, is by a son of Missie's Sultan out of a dam by Hampton's Best. His dam is by Acanthus King by Godwin. He is a big, heavy, smooth bull and very satisfactory in service.

Mr. Hoverson has a definite object in view and is working consistently toward that end, his object being to produce with regularity a class of good, useful cattle of medium size and good 
feeding quality which will enable them to do well on ordinary farm feeds. He avoids any extremes such as pushing or starvation and finds his business profitable. The cows, as I saw them, indicated the degree of development as outlined by Mr. Hoverson and they have every appearance of practical utility.

M. R. Peterson, Troy.-Mr. Peterson has been in the business only two years but he has a nice herd of females of splendid conformation and good blood lines, some of which would satisfy any one. Countess Gloster 6th comes from S. B. Amcoats. She is by Secret's Sultan, a son of Bellows Bros.' Missie's Sultan out of a dam by Lord Marr, a son of Lord Mayor and imp. Marigold 50th, second dam by imp. Prince Oderick. Countess Gloster 6th is a splendid breeder. Another daughter of Secret's Sultan is Secret of Cedar Lawn by Baron Violet by Victor Bashful, a son of the noted cow, Sweet Violet $2 d$. This cow is the dam of two fine heifers, one a last September's calf that could show in strong class. Hampton's Emblem by Diamond Emblem, dam by Hampton's First, a son of Hampton's Best is a typical Diamond Emblem heifer. She is big, thick and smooth and has a splendid calf at foot. The dam of this heifer is one of the extra good ones. She has a bull calf that is hard to beat, that, lightly fitted for show, was a winner at the big Free Fair at Topeka in 1919. Besides 
the cows mentioned above, there are other good ones. Three of them are by Goods, a Gigstad bred son of Golden Lancaster, out of a dam by Good Choice. Thomas, Jameison \& Mitchell's great bull, White Goods, comes in through a cow sired by one of his sons, Roan Goods, while Searchlight is represented in Redbud Lady.

Orange Count 716175, the sire of excellent calves, has been used, combining Barmpton Knight and Lord Marr. A new herd bull has been secured from T. J. Dawe \& Son, the excellent roan calf in their present show herd, a winner at the Missouri State Fair. $\mathrm{He}$ is a big-bodied,'good-quartered, thick-fleshed, smooth fellow and is a splendid prospect for a breeding bull. His sire is Diamond Emblem and his dam is Miss Ramsden 6th by Baron's Pride 275479, second dam by imp. Red Velvet out of imp. Marietta.

J. F. Libel \& Son, Leona.--This is a comparatively new firm working on a small scale but with a splendid start for a choice herd. At D. E. Reber's sale they bought the cow, Edna, by Scotchman by Royal Pride 149651, a son of imp. Helen 20th and several of her descendants are in the herd. There are a few heifers by Vain Valentine, a son of Bapton Valentine out of Park Violet 5 th and out of dams by imp. Conqueror. A cow that is making good is Marvel by The Conqueror out of Lavender Rose (vol. 51) by the 
J. G. Robbins \& Son bull, Golden Dutchman. One of the bulls used was Magnet Searchlight by Searchlight out of a cow by Prince Pavonia, the two bulls that established C. S. Nevius as a breeder. The second dam of Magnet Searchlight came through imp. Golden Gem 2d and Lord Lovel. The present herd bull is an excellent one, New Year's Emblem, bred by T. J. Dawe \& Son, by Diamond Emblem, their show bull by Diamond Goods out of a dam by imp. Collynie. New Year's Emblem's dam is Sobriety 8th by imp. Strowan Star out of imp. Sobriety 2d. (See Dawe sketch.). This bull is not only a good individual but it will be noted he is of great ancestry and he is proving a fine breeder.

The Libel herd, as a whole, impressed me very favorably, not only as consisting of a lot of valuable cattle, but also because surrounding conditions indicated almost certain success.

E. A. Myers, Troy.-Both Mr. and Mrs. Myers know good Shorthorns and a visit with them convinced me that they understood how to handle their cattle. Mrs. Myers is a daughter of T. J. Dawe and is as much interested in Shorthorns as any other member of the Dawe family. The start was made two years ago by the purchase of five desirable cows from the Dawe herd and they now have fifteen fimales. Autumn Queen Rose is by imp. Strowan Star out of Autumn Queen by Baron Kear $2: 1$ and comes from $H$. $H$. 
Kupper. Lily $2 \mathrm{~d}$ is by Dale Clarion, now winning fame as a sire of show stock. Fair Mysie is by Fair Knight $2 d$ by Choice Knight. Sobriety Bess is by imp. Scottish Sentinel out of Sobriety 8th and Mysie Treasure is by Master Mysie Sultan.

The reader is asked to consider this sketch in connection with the T. J. Dawe \& Son sketch and thus see clearly the excellent blood lines these cows represent. The cows bought had calves at foot by the Dawe show bull, Diamond Emblem. As he was used as long as he lived, practically all the young stock is sired by him. The Myers herd, as I saw it, was altogether excellent and all conditions favoring judicious development were being well met. Rosewood Pride, the present Dawe herd bull, regarded as an outstanding animal, is being used and should maintain high quality in the Myers herd.

\section{DOUGLAS COUNTY}

Willis R. Colman, Lawrence.-At Mr. Colman's I found a number of excellent females and a very superior bull, for Mr. Colman is an example of the rare irdividual who received far more in a purchase than he knew, or expected to receive. He had a few good Shorthorns and, being in need of a new bull, he bought of G. F. Brown who was selling his cattle, the herd bull, Marquis Cumberland 388134, and a red cow, 
Cambay 66241, the latter bred to the bull mentioned, from which service he has an excellent heifer. The purchase of these animals was made at a very moderate price and, added to the already good start, it has put Mr. Colman in line for a real Shorthorn herd, conditioned on proper care and feeding. The cows and heifers are of good size and are attractive in form with fleshing quality. Apparently they are heavy milkers. They represent in the top crosses such sires as Silk Goods, the son of Choice Goods, and the Norton bred Falsetto, both of which proved excellent sires in Alex Fraser's herd; Sempstress Valentine; Prince Royal, T. H. Mastin's well known son of imp. Princess Alice and imp. Craven Knight.

It was in the purchase of Marquis Cumberland that Mr. Colman was fortunate. This bull is of medium size, six years old, very smooth and well covered. He impressed me as being a little light in the hind quarter and in the flank but he is every inch a bull and his calves up to three years old which I saw, indicate that he is an exceptional breeder. Marquis Cumberland was bred by C. A. Saunders and was in Mr. Saunder's 1913 show herd as junior calf, winning first at Des Moines and at the South Dakota State Fair and he was a good winner at the American Royal, the National Shorthorn Show and the Minnesota State Fair. $\mathrm{He}$ is by Cumberland's Best and his dam is 
Anoka Mildred bred by F. W. Harding, she by Anoka Sultan, second dam imp. Pine Grove Mildred 11th.

Asher \& Allison, Lawrence-Mr. Asher is with the Watkins bank and Mr. Allison is on the farm. They own a herd of cows, a number of them bred along fashionable lines, and all are of acceptable breeding as indicated by a wealth of ancestry. The herd includes two highly prized reds purchased from Tomson Bros, one by the great Stunkel bull, Victor Orange, and her daughter by Nonpareil Victor 2d, a full brother to the bull sold by 'Tomsons for $\$ 2000$ to go to California. The herd is representative of such bulls as Victor Orange, Star Goods, White Goods, Orange Viscount, Baron Marr, Gallant Knight, Archer, Barmpton Knight, Village Marshal, Avondale, Whitehall Sultan and others of merit that might be mentioned.

The bull at the head of the herd impressed me favorably. He is a two-year-old white by Maxwalton Rosedale, full brother to Whitehall Rosedale, grand champion at the American Royal and at the biggest western shows. His dam is by imp. Crescent Knight and the second dam is imp. Augusta 105th. He is a big, deep-bodied fellow with much natural flesh and though quite thin, shows smooth. Those who demand a fancy head and neck might consider these points a little coarse but he has a well-shaped Shorthorn bull 
head that is anything but delicate and with 400 pounds of flesh, which he could easily carry, he would be called a good bull anywhere.

Perkins \& Alley, Lawrence.-In this partnership we have a commendable case of co-operation between the man who owns the land and the man who does the farming. Mr. Perkins is a banker in Lawrence who owns valuable farm lands near the city. He was wisely placed live stock on his land and J. W. Alley is his partner. The Shorthorns I saw on my visit to the farm left no doubt as to the excellence of the selections or as to the care given them.

One of the best cows I have seen in looking over Kansas herds I saw here in June 1919. She is of the kind that never gets thin, as we generally understand the term, for she is naturally thick, besides she is large, weighing 1650 pounds, feminine in appearance and a heavy milker. Her yearling heifer is very similar in type and general characteristics and the calf at foot was an extra good one. The best cows are being bred to Willis Colman's outstanding bull, Marquis Cumberlird, a C. A. Saunders bred son of Cumberland's Best, son of Cumberland's Last and sire of Cumberland's Type. This story is dedicated to bankers of Kansas who own farms, with the hope that others will follow the example of $\mathrm{Mr}$. Perkins.

John Black, Wellsville.-Mr. Black is one of 
the state's old breeders who closed out in 1919 but likes Shorthorns so well he can not do without them. The small, but choice, herd recently acquired consists of two heifers coming froln Tomson Bros.; two bought at the 1920 Central Sale, one of which is among the best young cows I have seen lately and the fifteen-month-old grand champion heifer sold at the Southeast. Kansas Show and Sale April 1920 for \$\$०). Park E. Salter furnished the bull. $\mathrm{He}$ is by Rosewood Dale out of a dam by Sultan Victor, the well known George Allen bred son of Victor Sultan. Mr. Black has grandsons who plan to succeed him in the Shorthorn business.

\section{EDWARDS COUNTY}

J. P. Ray \& Sons, Lewis.-I have seen an excellent young bull from the Ray herd and as I write I have before me a photograph of three calves from eight to thirteen months old that settles the question of size and quality. Mr. Ray bought two cows in 1903 and two more in 1904. Nothing has been purchased since except herd bulls, yet he has sold a lot of stock and is now holding annual bull sales from his herd of about 100 head. This is my idea of a safe and sure business. No young or middle-aged man, who does as Mr. Ray has done, need worry about the wolf at the door in old age.

One of the early bulls was Buccaneer by imp. 
Collynie out of a dam by imp. Mariner. This bull was used extensively and those who know his ancestry need not be told more. He was followed by a son of Forest Knight, a son of Gal-

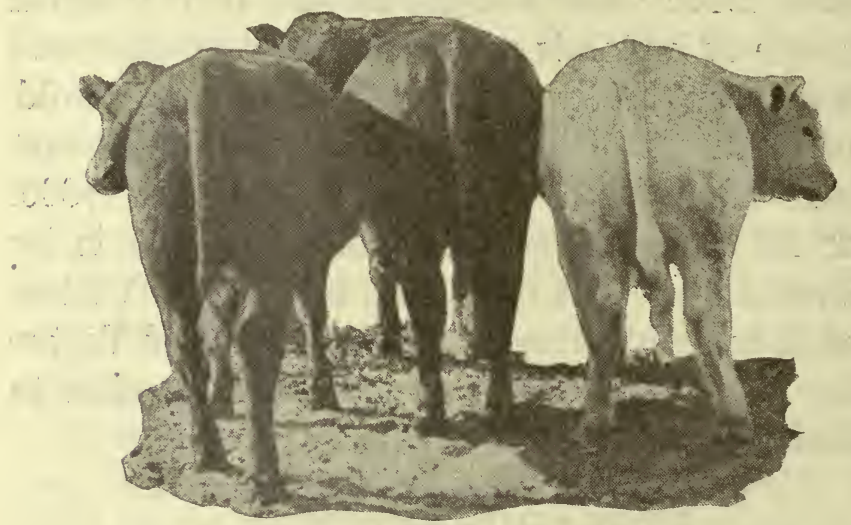

THE KIND PRODUCED IN THE RAY HERD

lant Knight, and the Cowan bred Lily Forest 8th by Norfolk, second dam by imp. Scottish Lord. Mabel's Goods 442060 by Henry Stunkel's Star Goods, own brother to the champion, Diamond Goods and out of a cow by Victor Orange, was one of the next bulls in service. The two bulls now being used are Victorious by Nonpareil Victor, own brother to the Stunkel bred son of Victor Orange sold to Tomson Bros. and sold by them for' $\$ 2000$ to go to the Pacific coast, and Cumberland Hero 668018. Cumberland Hero is by E. L. Stunkel's Cumberland Diamond and his dam is by Victor Orange which gives him, right 
at the top of the pedigree, two exceptionally good bulls.

\section{ELK COUNTY}

M. W. Bower, Grenola.-Mr. Bower bought a few desirable cows two years ago and he is taking good care of them. Rebecca 7th is by Lord Novette, an excellent bull owned by H. G. Brookover and out of Rebecea by Rosewood. She has a wealth of good ancestry. Lord Novette was by imp. Collynie, dam by Lord Mayor, both among the state's greatest bulls of all times. Rosewood was by imp. Inglewood that until recently held the record of the top bull sold at the American Royal sale and out of imp. Roseleaf by Scottish Archer, Mr. Duthie's greatest bull. There are a few other cows of very similar breeding, in fact all the cows in the herd are of these elegant blood lines. A roan bull of choice ancestry is used. A valuable object lesson to be found in $\mathrm{Mr}$. Bower's methods is that in starting a herd the cows selected should be closely descended from well known sources of excellence as his were.

Geo. L. Dickie, Grenola.-Mr. Dickie bought a cow in northwest Missouri some years ago and he now has five females. He sells his bulls. Mr. Dickie is in business in Grenola and has no farm but hires his cattle kept. He owns them for pleasure and he says they are making money besides. They are nicely bred, representing in 
ancestry such herds as that of J. F. Finley of Missouri and such top crosses as are represented by Chief Violet 4th, Lord Lovel, Collynie and Hampton Spray. The bull now being used is Scottish Lad by Silvermine out of a dam by Captain Archer. If Mr. Dickie can make Shorthorns pay while he hires everything, why should not the man with his own feed and labor make the business profitable?

W. W. Gragg \& Sons, Severy.-Two of the bulls used in this herd were Hardy Knight and Masterstroke. Hardy Knight was by Gallant Knight out of a dam by Lord Mayor, second dam by imp. Thistletop. Masterstroke was by imp. Collynie. His dam was by Admiral Godoy, second dam by Duke of Oakland 2d. Admiral Godoy was by Godoy out of a dam by imp. Barbarossa. The union of Scotch bulls on American bred cows strong in Bates blood has been one of the best crosses known in Shorthorn history. The few cows I saw at Mr. Gragg's were good and such as one would expect from this line of breeding. The present bull is Aeroplane, a rugged fellow, strong in Collynie blood.

\section{ELLSWORTH COUNTY}

Roy Helmer, Geneseo.-Mr. Helmer bought three cows from H. C. Lookabaugh that are by Rosebud's Light, a son of Watonga Searchlight out of a daughter of imp. Rosebud 2d. Their 
dams are by such bulls as Violet's Searchlight and Owen Kane's Augustire by Villager. A few more were bought locally. Mr. Helmer's cows are for family use as well as for raising good Shorthorns, since he believes it more profitable to keep pure breds for this purpose than to keep scrubs or grades, and in this view he is correct. His bull was bred by Rousseau Smith \& Son and is out of one of their best cows. (See Smith sketch.) He is large, thick and smooth and from a herd in which the cows are heavy milkers.

O. E. R. Schulz, Ellsworth.-Mr. Schulz has been in the breeding business for six years. He has a nicely bred herd of twenty females and the good bull, Color Bearer by Maxwalton Rosedale, full brother to the champion, Whitehall Rosedale. Color Bearer's dam is by Gallant Knight and out of imp. Clara 59th. There are some valuable cows in the herd, one of which is Model Milkmaid, bred by W. A. Betteridge by the well known Orange Model out of a dam by Victorious out of Rose of Autumn 21st. This is exceptionally good breeding and is very popular. The bull used prior to the purchase of Color Bearer was Abbotsford Lad by Wooddale Chieftain, a son of The Choice of All. Mr. Schulz has a splendid local demand for his stock.

\section{FINNEY COUNTY}

R. J. Ackley, Garden City.-Mr. Ackley's 
large herd is composed of some excellent material. Among other good cows is Pleasant Jealousy $2 \mathrm{~d}$ by Watonga Searchlight out of a dam by imp. Shenstone Albino. Harriet Sunshine is by Secret Aberdeen, a son of Aberdeen by imp. Collynie and out of the splendid cow, Lilac Bloom. The bull, Secret Aberdeen was much used in the herd. Another herd bull was Fancy Velvet by Fancy Lord, coming through Tomson Bros. from R. O. Miller. The bull now in use is Avondale Villager, an Owen Kane production by Augustine. His dam is by the great son of Avondale, Double Dale. A herd with such ancestry should be a desirable source of supply.

\section{FRANKLIN COUNTY}

R. H. Lister, Ottawa.-On this farm conditions present a bright outlook for the future. Mr. Lister has had successful experience in breeding and feeding cattle and appearances indicate that he should be good for enough lease on life to put up a herd of extraordinary merit. The cattle are almost exclusively high-class females, selected not from the pedigree standpoint but for individual worth and they are of the true Shorthorn money making type. Mr. Lister has paid little or no attention to the blood lines, though as is invariably the case, when the right kinds of Shorthorns are selected, they are from the right kinds of ancestry for "Figs do not grow on 
thistles" any more than they did 2000 years ago. An inspection of three crosses in the pedigrees of these cattle, selected as Mr. Lister says, without regard to pedigree, reveals much high-class material.

Among the bulls are Searchlight, sire of the $\$ 3500$ cow in the 1919 Salter sale; Prince Pavonia, the noted son of the noted cow imp. Glendale Pavonia; Golden Victor, the Baron Victor show and breeding bull; Golden Day out of imp. Mistletoe and sire of the dams of International prize winning steers; Lavender Viscount, International grand champion and famous sire at Ravenswood; Lord Mayor, one of America's greatest bulls that lived fifteen years in Kansas; Choice Goods, America's champion show bull and leading sire of his day; imp. Hospodar sold to go to South America; the splendid Bellows bred Valley Champion; Barmpton Knight, sire of prize winners and breeding cows in great numbers; Matchless Dale, the noted bull at the Kansas State Agricultural College and sire of dozens of America's champion steers and Cumberland Type, the undefeated and sensational bull bred and developed by C. A. Saunders.

Mr. Lister's herd was founded in 1916 and the first bull used was the Nevius bred Searchlight Bloom, a son of Searchlight out of a dam by Golden Day, (see previous mention) a sire of great breeding cows in the T. P. Babst herd. 
The bull now in service was bred by $\mathrm{H}$. $\mathrm{H}$. Holmes. He is a roan son of Prince Valentine 4th, a successful show and breeding bull used by C. S. Nevius, Tomson Bros., H. H. Holmes and A. L. Harris. His dam is by Captain Archer, noted sire of show stuff in J. F. Stodder's herd. The calves sired by this bull have size, depth and thickness with nice finish and if they mature as they promise, they will make the right kind of Shorthorns. Mr. Lister's operations, covering a period of only three years, show that if a man really knows good cattle and will give them the right kind of care, he can be successful from the start without special Shorthorn knowledge.

A. L. Johnston, Ottawa.-Mr. Johnston is president of the Eastern Kansas Shorthorn Breeders Association and of the Duroc-Jersey Association of the Ottawa territory. He is nicely located near town and has a number of high-class Shorthorns and his herd should become one among the best in the state. About two years ago the first purchase of extra good stock was made when he secured among others Rosewood Cathay by the $\$ 6100$ Missie's Last, and this cow produced in 1919 an elegant roan heifer calf by imp. Bapton Corporal. Another valuable purchase was Emblem's Butterfly by imp. Proud Emblem Jr. that now has a calf by imp. British Emblem. This cow earries right at the top of her pedigree such sires as Fair Knight 2d, Choice Goods and Mr. 
Duthie's noted bulls, Joy of Morning and Scottish Prince. Pavonia 6th, a Tomson bred yearling by Village Marshal out of Glendale Pavonia, a daughter of imp. Glendale Pavonia, should prove especially attractive to eastern Kansas breeders who know so well what these Shorthorns have done for breed interests. This heifer is safe in calf to imp. Bapton Mariner, the excellent herd bull now in use.

Bapton Mariner comes from England's leading herd, that of J. Deane Willis and his sire, Hoar Frost, is one of the most noted bulls ever used by Mr. Willis. He is generally well regarded by breeders and Mr. Johnston considers the $\$ 2500$ he paid for him an excellent investment.

Vail \& Scott, Pomona.-Two years ago these men came from Missouri where Mr. Vail had been breeding Shorthorns for quite a number of years. Their herd includes about twelve females of good size and quality and of very nice breeding, some of them meeting the demands of sticklers for certain Scotch blood lines. Among the well known bulls found in the top crosses might be mentioned Lavender Viceroy of the W. A. Betteridge herd; imp. Daydreams Pride; Galahad, sire of Gallant Knight; Baron Lavender $2 d$, possibly the outstanding bull of Col. Harris' production; Silk Goods, the son of Choice Goods used by Alex Fraser and later by 
H. E. Huber of Meriden; Choice Goods, grand champion of America; The Conqueror, Senator Wornall's well known son of Choice Goods and other good ones. The herd bull is a nice red, bred by Owens Bros. of Iowa. He is of fair size and acceptable Shorthorn type, quite smooth, and the calves I saw by him indicate that he has been a satisfactory sire. He is by the Bellows bred Sultan's Goods and comes from the Owens Queen of Beauty line.

Vail \& Scott are in a natural small farm stock country and conveniently near to the great cattle section of the state so that their business is both pleasant and profitable. Building up a herd from a start like theirs should be easy.

H. F. Cornell, Ottawa-This herd was founded in 1919 and now numbers ten females, coming from splendid sources of supply and from excellent ancestry. Lady Harmony is by Baron Marr, an outstanding son of Cumberland's Last, famous in F. O. Lowden's and C. A. Saunder's herds, out of imp. Lady Marr. Lady Harmony's dam came from T. P. Babst and was by Proud Orion by imp. Daydreams Pride, second dam by Laird of Linwood, almost a full brother to Gallant Knight, third dam by Lord Mayor. The richness of these blood lines should satisfy the most critical. Amy came from Kelly Bros. Her sire, Aberdeen, was by Lord Banff, the first Scotch bull to sell for more than $\$ 5000$ and a 
show bull and sire of unusual merit. Pine Queen, a nice roan is by Pine Champion, a Purdy Bros. production by Lord Champion, a well known Purdy sire out of the famous cow, imp. Lady Douglas, dam of Cumberland's Last. The dam of Pine Queen was by Lord Lovel, one of the West's famous sires. While Mr. Cornell holds extensive banking interests he has a natural inclination toward live stock.

R. S. Maag, Pomona-This is a herd of twenty females, founded in 1916. The cows are of medium size and, like the majority of Shorthorns in this section, they receive good farm care. Desirable blood lines and ancestry are found in this herd. Pride's Beauty came from J. A. Lorimer and her sire was by Baron Marr, the excellent son of Cumberland's Last and imp. Lady Marr. Baron Marr was also the sire of College Duchess, dam of College Duchess 2d, sold in the State Association sale in 1920 for \$3900. Other Lorimer bred cows are Peggy Princess $3 d$ by Prince Pavonia and Fanny 2d, a five-yearold roan by a son of Baron Marr. The herd bull is Lovely Knight by a son of Gallant Knight's Heir and his dam is Lovely of Parkdale $3 \mathrm{~d}$ by Good Choice. Lovely Knight is of very popular breeding.

John Miller, Richmond.-Mr. Miller has nine cows representing, like most Franklin county cattle, thoroughly good blood lines. He is well 
located to produce stock, having limestone pasture and alfalfa land and with such facilities and a previous successful experience in raising market topping grades, he should have no difficulty in builüing up a good pure bred herd. Tho bull in use, not yet two years old, is a very large one, pleasing in general appearance, but possibly a little lacking in depth and thickness for best results, although the small calves by him looked quite promising.

T. C. Brown \& Bro., Ottawa.-The Browns, old breeders of Franklin county, have a herd of useful cattle of very nice breeding. They have not been developing to the point required for best results and the produce has been sold locally at moderate prices. Like many others who have followed this plan, the Browns think of putting more into their Shorthorns and when they do, their herd will become a strong factor in local cattle improvement.

Floyd Carter, Rantoul.-Mr. Carter has been breeding grade Shorthorns ever since he began raising cattle. Three years ago he bought a few cows from the well known McEchron herd at Richmond and a bull from Henry Sobba of Anderson county and he is now building up a pure bred herd. He is favorably located where Shorthorns are popular and he should succeed for with good management success is certain in such communities. 


\section{GEARY COUNTY}

George J. Caspar, Alida.*-Five years ago Mr. Caspar bought his start in Shorthorns from H. H. Holmes and he acted wisely in buying good cows from good ancestry. Riverside Lady is by Clipper Model (see Holmes sketch) and out of a dam by Captain Archer, own brother to Sweet Mistletoe, dam of the International grand champion in 1919. Lena Lady came from G. H. White and is by Hampton's Counsellor by Hampton's Best, a son of imp. Merry Hampton and a sire of outstanding merit. Her dam is by the Duthie bred imp. Lavender Champion. Rose Victorious is by Victorious, famous sire in N. H. Gentry's herd, a son of Lord Mayor out of a dam by imp. Baron-Victor. (See Holmes sketch.) The bull used is Silver Stamp by Viscount Stamp 2d out of Hallwood Golden Drop. It is only necessary to state that this bull combines the blood of the best Shorthorns from the Ravenswood herd and from Ed Hall's herd. Such a selection of foundation stock should, with the good feed and care, being given the cattle, put Mr. Caspar in line with the best breeders of his section or any other.

\section{GREENWOOD COUNTY}

H. G. Brookover, Eureka.-Mr. Brookover has the oldest herd in Greenwood county, the

* Telephone, Upland. 
foundation having been laid in 1900 by purchase from O. L. Thisler. Later two cows, Sunny Maid $3 \mathrm{~d}$ and Happiness, were bought from Tomson Bros. Sunny Maid 3d was by the Barmpton Knight bull Lord Marigold, dam by imp. Crescent Knight, second dam imp. Sunny Blink 6th and Happiness was by Gallant Knight, dam by Lord Mayor, second dam by imp. Thistletop.

Mr. Brookover has been careful in his selection of herd bulls and, as might be expected, the herd has taken on a uniformity far beyond that of most herds. The care and feed given have been such as to mature a desirable class of cattle, the matured cows off grass that have been sold weighing about 1400 pounds. Among the first bulls used in building up this herd was Greenwood, bred by V. R. Ellis and sired by Sir Charming 4th, a grandson of the noted cow, Sweet Charity. This bull was followed by one of the best ever owned on the farm, a bull that would have been a credit to any herd, the massive red roan, Rosewood, bred by S. C. Hanna. His sire was the splendid show and breeding bull, imp. Inglewood, the highest priced bull sold at an Americal Royal sale until within the last few years. His dam was imp. Roseleaf by Mr. Duthie's greatest sire, Scottish Archer. After being used to the limit, Rosewood was sold to H. M. Hill for whom he sired much good stock including the white bull, Silvermine, J. F. Stodder's 
successor to Captain Archer. Then came Bapton Lord a Forsythe bred grandson of imp. Bapton Arrow, one of the great bulls of the breed. Another Hanna bred bull was then used, Lord Novette by imp. Collynie out of an excellent cow by Lord Mayor. Next was Victory, a roan by Hampton Spray, out of one of Mr. Hanna's cows by Count Violet.

Two good bulls are now in use. One is by John Regier's Dale's Emblem, a son of Double Dale. His dam is by the outstanding show and breeding bull, Nonpareil Star. He is siring a nice lot of cattle, both bulls and heifers being of splendid form and quality. The other is Master Sultan, a Tomson bred son of Beaver Creek Sultan, for which $\$ 1000$ was paid recently. His dam is by Barmpton Knight and, while hardly more than a calf, he will bear very close inspection and he should prove a highly acceptable herd bull.

$\mathrm{Mr}$. Brookover is one of the most modest of men and is conservative in his statements almost to a fault. This is especially true when he speaks of his own cattle, which buyers have learned are fully as good as they have been represented. In this he might well serve as a model to all but especially to young breeders, who seldom realize the value of a conservative description.

W. H. \& B. Brookover, Eureka.-These young men have about twenty females of breeding age 
which represent the choicest specimens from the herd owned by their father, W. J. Brookover. Their cattle descend from two cows, Collynie Lass and Princess Violet 3d. Collynie Lass by the 2800 pound Prince of Collynie, dam by Golden Lad, a son of Mr. Dustin's Golden Rule and imp. Germanica $2 \mathrm{~d}$, represents a line of breeding that from the standpoint of excellent ancestry and desirable blood lines could hardly be improved. The other cow, Princess Violet 3d, was bred by C. S. Nevius and sired by Prince Pavonia and was purchased with a splendid heifer calf by Searchlight at foot. The dam of Princess Violet 3d was by the Westrope bred Gloster and the line of descent further down is of the best, doubtless such as to meet the approval of the most critical. Mr. Brookover paid $\$ 525$ for this cow and calf in the days when $\$ 100$ bought a very good cow. It is not surprising that satisfactory results have followed the use of good bulls on such foundation stock and that this herd is in line for recognition in the near future.

In the main, the bulls in use have been the excellent ones owned by H. G. Brookover, also the splendid show and breeding: bull, Blythe Conqueror, used and shown successfully by C. F. Wolf \& Son. He was by imp. Conqueror out of imp. Blythesome 15th and a few big, beefy cows by him speak well for his worth as a sire. A 
nice lot of young things are by the Dale's Emblem bull, Oscar. (See H. G. Brookover sketch.) These heifers are large and show admirable finish, among them being a senior calf that at the time of my visit was a favorite among calves of its age for show in the fall.

The bull in service is Village Master, selected by one of the best judges in Kansas for use in this herd. He was bred by J. F. Prather of Illinois and his sire is Mr. Prather's herd bull, Silver Knight, a bull that stood high in his class at the International. The dam of Village Master is by Matchless Robin by the great Forbes bull, imp. Cock Robin, out of a cow by Baron Gloster, second dam by the well known Fearless Archer. It is putting it mildly to say that I liked this big, beefy, two-year-old bull. He is an animal of the type that will give the maximum returns for the feed consumed. He stands close to the ground, his proportions of length and depth are right, he has an elegant bull head and neck and carries a wealth of natural flesh beyond that usually found in good bulls. I saw ten of his calves and from them picked out three that would be real show prospects anywhere. Village Master has been shown twice at the Greenwood county fair, winning first place each year. He also won the American Shorthorn Association championship in 1919 and 1920, and he would be a strong bull in larger shows. 
Claude Lovett, Neal.*-Mr. Lovett is a graduate from the Department of Agronomy in the Kansas State Agricultural College. He has an excellent farm that produces alfalfa and has plenty of limestone pasture. He began farming on his own account four years ago and has kept Shorthorns since that time. His first purchase was made at H. E. Huber's sale in 1916 where he secured two choice heifers from which he has made good sales of bulls. A yearling heifer descended from this purchase was fitted for show and won first honors at several fairs. Subsequent additions were made to the herd at strong prices, a lot of four heifers having been purchased in one sale at an average of $\$ 700$.

Taken as a whole, the breeding of this herd is most acceptable and includes some of the popular blood lines of the day. The individual merit of the foundation stock is such as to make if fit for a real Shorthorn herd. The bull in use at the time of my visit was Scotch Lord, a splendid, big, beefy roan, bred by J. G. Robbins \& Son, sired by Lord Avondale, one of America's most popular bulls, whose get have been selling for exceedingly high prices. The dam of Scotch Lord represents two great bulls, Choice Goods and Spicy Robin and his second dam is imp. Golden Gem by the Marr bred Scotch Thistle. This bull is a breeder of heifers of pronounced excellence

* Station, Tonovay; telephone, Eureka. 
and light colors, the young females in the herd by him being very uniform and of most pleasing Shorthorn type and character.

I glanced over the pedigrees of Mr. Lovett's cattle and found a wealth of Shorthorn excellence near the top. Whitehall Sultan, Gaveston Collynie, imp. Salamis, Victor Orange, Nonpareil Victor, Choice Goods, Silk Goods, imp. Inglewood, March Knight, Spartan Hero, Prince Pavonia, Searchlight, Lavender Viscount and Baron Lavender 2d give an idea of the breeding of the herd. Among the choice cows are Longbranch Queen whose name indicates her origin, Scotch Lady by Royal Sultan 380246 out of Scotch Mysie 7th 141050 and Lady Wharton of M. H. Lyon's breeding.

Mr. Luvett's method of handling is in keeping with the general character of the herd and its owner. Constant growth is the desired object. While good blood lines do not always insure good cattle, yet Mr. Lovett has met the final test. His herd is not large, numbering only thirty head but from this little herd he made showings at Eureka, Fredonia and Iola in 1919, winning every first in each class except two at these three fairs. In 1920 a larger showing was made with even greater success. Three head were shown at Topeka and all were well in the money, his two-year-old heifer having stood third in open class.

T. M. Etherington, Hamilton.-Mr. Ethering- 
ton has a large herd of Shorthorns which is being handled in a way to bring out the degree of development found in the average herd. Fair size, smoothness and uniformity are noticeable features. Mr. Etherington started some years ago with a few. cows bought from local breeders. He has been using good bulls and retaining the heifers, selling his bull calves to the farmers near by. It is evident that the herd has been prolific and profitable.

One of the first bulls used was bred by D. P. Norton and was sired by Buccaneer. Then came Vindicator by Collynie out of Belle Abbotsburn by Young Abbotsburn, the grand champion of America for several years. From Kellerman \& Son was secured a bull by Lavender Dorrit out of a dam by Lavender King 4th. A dash of Bates blood was introduced through a son of Winsome Duke 11th. H. G. Brookover's herd furnished a son of Rosewood, the son of imp. Inglewood and imp. Roseleaf by Scottish Archer. The last purchase came from Ed Stegelin and is by True Sultan, International grand champion, a son of Anoka Sultan and one of the best bulls in the state or nation. Roan Acacia, a big fellow bred by D. C. VanNice and sired by the well known Belvedere, the excellent prize winning and breeding bull used so long by Mr. VanNice, is also in service.

J. C. Parks, Hamilton.-Here is a herd that 
receives close personal attention and shows corresponding results. The young stock is large and has quality as well as size. The cows are kept in thrifty condition and range from medium to large. There are about twenty-five females in the herd. Roan Calla 6th is a five-year-old by Our Choice. She represents a blending of the blood lines of Choice Goods, Whitehall Sultan and other high-class bulls, less known. Miss Ellen is another cow with an infusion of Choice Goods blended with imp. Collynie. Morning Glory is a roan by Snowball, son of Mr. Hanna's Hampton Spray out of a dam by imp. Lord Cowslip. Another good cow by Snowball is Miss Phyllis 12th, a roan out of a dam by Orange Master. - (See H. T. Forbes sketch.)

One of the bulls used was Ingle Lord by Ingle Lad. Ingle Lad was an excellent breeding bull and sired many great producing cows, including Cream Toast, dam of the champion milking Shorthorn at the Denver show. Lavender V, grand champion at the Southeast Kansas Shorthorn Show in 1920, is the herd bull. He is by Clansman, a son of Lavender Viceroy by the grand champion, Lavender Viscount. His dam is by the famous Tebo Lawn bull, The Conqueror by Choice Goods, used so succeessfully by Senator Wornall.

F. L. Gilbert, Hamilton.-Mr. Gilbert keeps many cattle on his farm and he has put in a few 
Shorthorns, about ten cows, because of the fact that profits seem much surer to him in raising cattle than in regulation steer handling and he is not alone in realizing that cattle growing is safer than annual buying. His Shorthorns are of good ancestry and are nice individuals, tending toward the dual-purpose type, a kind that is meeting with much favor from farmers just now. The herd represents in selection and blood lines two local herds, T. M. Etherington's and W. E. Hogan's and that of Andrew Pringle of Eskridge and is typical of these herds, which means that a rich infusion of best blood on a good American foundation is found. The bull in use is a smooth, short-legged, straight-lined fellow and the young calves look promising. Mr. Gilbert has a chance to handle his cattle well and he seems to be making use of his opportunities.

J. T. Martin \& Son, Madison.-This herd of ten females was founded in 1912 and is located in one of the choice live stock sections of the state. Alfalfa, ensilage and the best pasture are the rule. Blythesome, a large red cow, is a daughter of the splendid bull, Athenian Coronet 4th, a son of imp. Bapton Coronet out of Augusta 111th by Scotch Fame. Her dam is by Sir Knight, a son of Col. Harris' Golden Knight and imp. Sorrel by Roan Gauntlet. Royal Paquita was bred by Mr. Hanna. She is by Prince Royal and her dam is Tebo Lawn Paquita by Prince Armor, the 
white son of the great imp: Princess Alice. Snowbird is another Hanna bred daughter of Prince Royal out of a dam by Choice Prince, son of Choice Goods out of a Prince of Tebo Lawn cow. Perfection, a bull combining imp. Collynie, Rosewood and others of Mr. Hanna's herd is in service. The Martin herd is strong in the blood of some of the best stock of the state.

Kenneth Wilson, Hamilton.-That Mr. Wilson has the right ideas of Shorthorn type and the best methods of handling cattle was quite apparent during a half day spent with him in visiting other herds. Mr. Wilson's cattle represent a mingling of blood lines rather than the straight Scotch cross and they are good, big, smooth cows bred for individual merit from the best ancestry but not put together in such a way as to win the unqualified approval of the stickler for "straight." Nevertheless, he is getting results and the herd, strong in Scotch blood of the very best kind, is perhaps better for a seeming disregard of straight blood lines. As an evidence of success it may be mentioned that a calf of $\mathrm{Mr}$. Wilson's production won first at the Greenword county fair last fall and was recently sold to W. J. Brookover, an old Shorthorn breeder, for use in his steer breeding operations, the final test of merit in Greenwood county.

Rawlings Bros., Eureka.-This firm has been raising high grade Shorthorns for some time, 
using high-class bulls. Five years ago a pure bred cow was bought from David Ballantyne. She was by Collynie's Pride, the outstanding sire by imp. Collynie, out of a daughter of Royal Knight, son of the famous imp. Princess Alice. Later another good cow was added from a local herd. The herd bull was bred by O. O. Massa and is representative of Prince Pavonia through one of his best cows. Rawlings Bros. intend keeping a Shorthorn herd and their location for the business is a most excellent one.

L. E. Downing, Hamilton.-Mr. Downing has made a start in Shorthorns by buying three good cows. One of them is an unusually large, matronly red, that if bred to a suitable bull, should prove valuable. It is $\mathrm{Mr}$. Downing's intention to continue in the business and to improve his cattle and a young man with such an ambition will succeed. He has not yet bought a bull but plans to buy one for another year.

W. E. Hogan, Madison.-Mr. Hogan succeeded his father in 1908 and the quality of his cattle that I have seen testifies to his success. The cows are of good size, smooth and feminine, reflecting the character of the bulls used, such as Vindicator by imp. Collynie, dam by Young Abbotsburn, Snowball by Hampton Spray and Red Prince by Prince Violet, dam by Godwin. This is one of the oldest and best known herds in northern Greenwood county. 


\section{HARPER COUNTY}

D. Wohlschlegel \& Sons, Harper.-From high grades to pure breds is only a step but a very logical one to take on $\$ 100$ an acre land and the men who take such a step almost invariably put up the best Shorthorn herds. The Wohlschlegel herd will be no exception. Two years ago a start was made with a few cows bought from local breeders. Later the imported cow, Kier Jip, was bought of Park E. Salter. She is a very excellent individual and was in calf to imp. Bapton Corporal and produced a splendid-red heifer. At the Salter sale in May 1919 the Wohlschlegels bought imp. Viola Gem in calf to imp. Aberdeen and also the Tomson bred Lady Violet $2 \mathrm{~d}$ by Beaver Creek Sultan. The dam of Lady Violet 2d was by Barmpton Sultan 3d by Geo. Allen's Victor Sultan,-a son of Whitehall Sultan. Prior to this they had bought Stamford Bess, a Canadian bred cow by Royal Star, a son of Choice Star 611569 out of Lovelace 6th by Scottish Beau. These are all cows of great excellence and, added to several very good ones already on the farm, give a working herd that will be recognized in the future. One of the cows on hand from the earliest purchase is Clear Echo, a white by Scotch Laddie, a son of the fine sire, Prince Valentine 4th. Her dam is by the Hanna bred Symmetrical out of Gayety by imp. Collynie. Another 


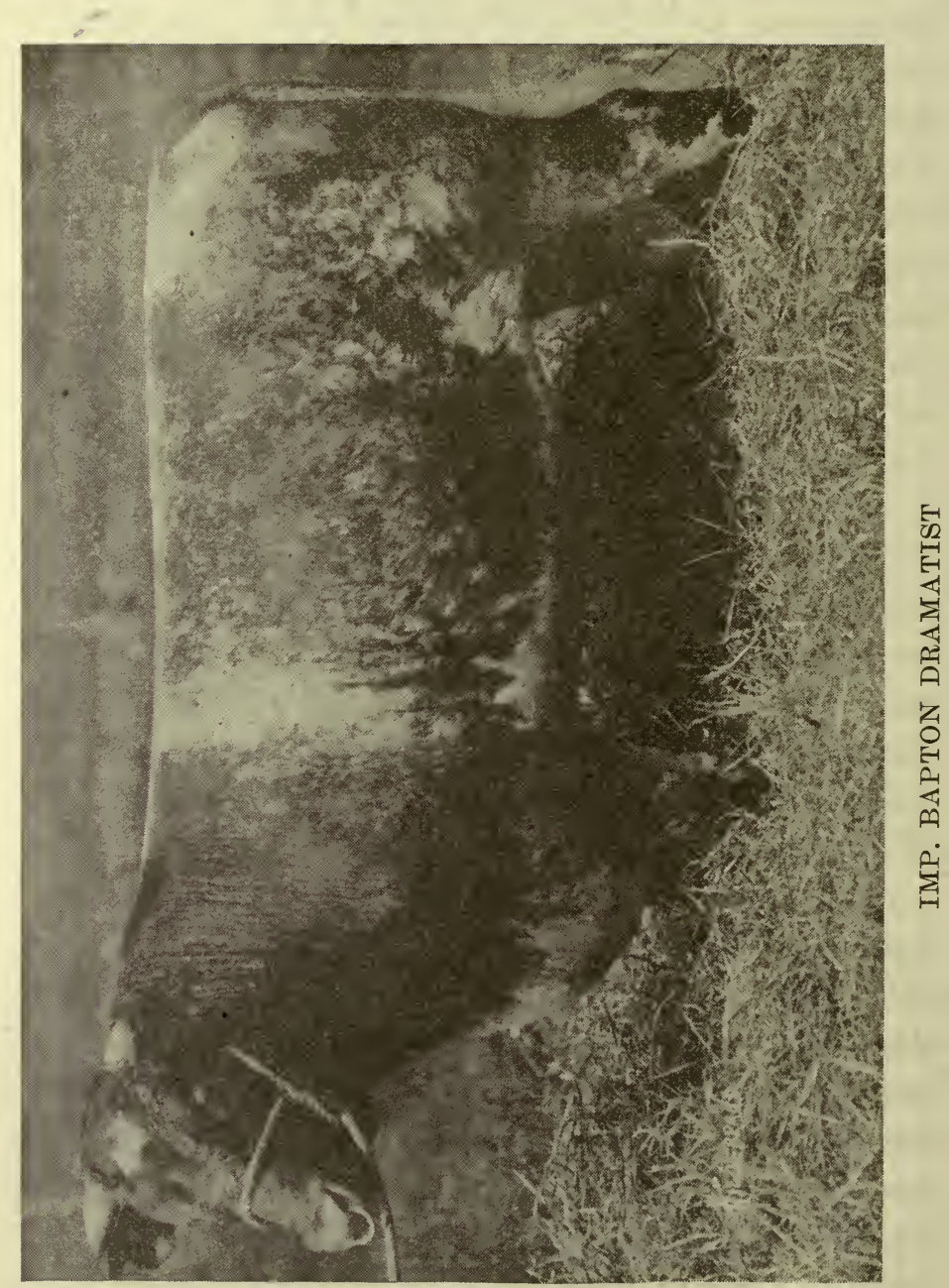


one, Silver Poppy, is a yearling by White Hope 486354 out of a dam by Henry Stunkel's great sire, Victor Orange, second dam by Purdy Bros.' Lord Lovel.

An excellent bull, Alfalfa Leaf Dale bred by John Regier, has been used. This bull is by Dale's Emblem, a son of Double Dale and out of Edelweiss 8th, the cow that topped Park E. Salter's 1917 sale at $\$ 1625$. She had a heifer calf at foot that has long since sold for $\$ 1500$ and the cow herself sold in an Iowa sale for $\$ 1800$. I mention this to show the kind of ancestry the bull had. In the recent Carpenter \& Ross sale one of the good young bulls of the offering was bought. He was imp. Bapton Dramatist by Boquhan Stamp and his dam was by Newbliss Augusta's Champion. This youngster was bred by Deane Willis. He is a remarkably smooth yearling, very straight, with thick loin and a great covering of mellow flesh. He looks like the making of a good sized bull and, barring a slight unevenness on the rump, he is exceedingly hard to fault.

The conditions for the production of highclass Shorthorns are the best. There is plenty of pasture. Alfalfa, ensilage and other feeds are abundant and the Wohlschlegels are not afraid to feed them. Best of all, the four junior members of the firm are strong, husky boys with a great deal of enthusiasm for Shorthorns and 
they look after details almost to perfection-a guarantee for a well grown herd in the future.

Not less than eight good females have been added to this herd since June 1919. Probably the most important purchase was that of four imported heifers secured at the Salter-Robison sale. In the same sale one of the best American bred females was also bought. These heifers will be bred this season, 1920, to imp. Bapton Dramatist and the calves from this cross should be among the most valuable Shorthorns ever produced in Kansas.

John B. Potter, Harper.-Mr. Potter will be a permanent man in the Shorthorn business. He has some excellent cows in his herd which is quite large. A big-bodied roan by Searchlight is one that attracts attention and a nice lot of females recently bought of northwest Missouri breeders with a dozen excellent ones from D. A. Ewing and others raised locally, make up the herd. Good bulls have been used. One of the latest in service and a bull of real worth, which quality he transmitted to his calves, was Master Pavonia by Prince Pavonia. A number of the cows are by Hallwood Goods, a son of Choice Goods out of imp. Sylvia. Forest Knight by Gallant Knight out of a Cowan bred cow by Norfolk; Chief Archer by Whitehall Chief, son of Whitehall Sultan and Butterfly Abbotsburn by the champion, Young Abbotsburn, are among 


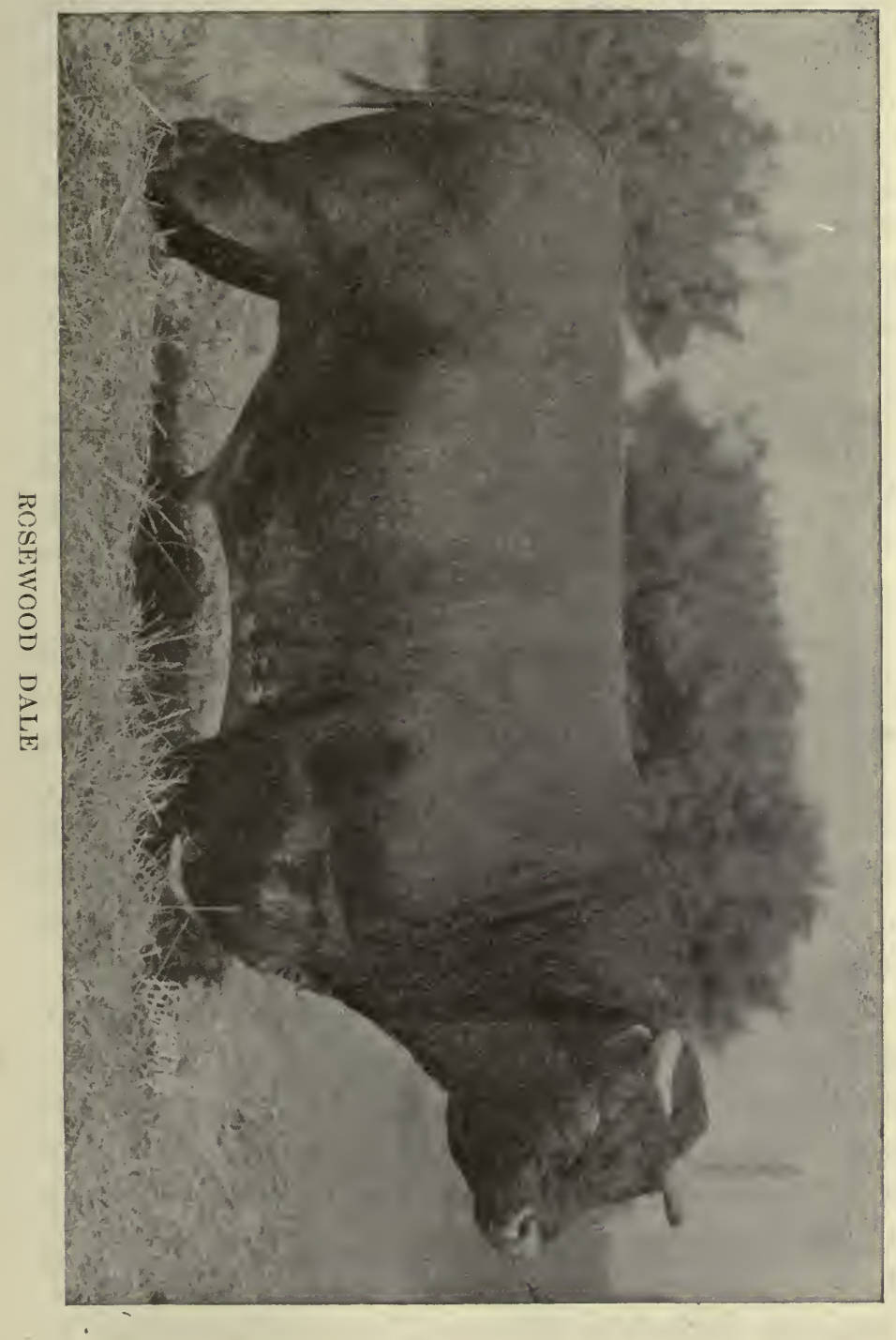


the sires of cows in the herd. Some of the younger heifers are by Rosewood Dale and imp. Bapton Corporal.

Rosewood Dale by Avondale out of imp. Rosewood $92 d$ was recently purchased at a long price and is now doing excellent service. He is the sire of the highest priced female of her age sold in Park E. Salter's record sale at Wichita in 1919, as well as of the highest priced heifer in a sale held previously. His reputation as one of the great bulls of the breed is fully established and his use adds much prestige to Mr. Potter's herd.

Miss Marguerite V. Stanley, Anthony.-Miss Stanley is the only lady of the fraternity introduced in these pages. In the data of her herd, sent me by request, Miss Stanley has told her story so well that I am using her own version as she has written it. Her herd is from the very best sources of supply and those who see it will like it. Miss Stanley is the leading organizer and publicity agent for Shorthorn interests in her county.

"Having been my father's boy for a number of years, I naturally developed a love for stock. Seven years ago I bought three grade cows but soon saw where to make more money and today I take pleasure in introducing to the public my modest little herd of twenty Scotch cattle, strong in the famous Collynie blood, with some infusions of Avondale blood. I am endeavoring to 
develop my herd for size, bone, flesh and milking qualities.

"My herd bull Secret Robin should fill this bill. He is a deep, broad, thick-fleshed, smooth, white three-year-old bull weighing 2000 pounds in farm condition with ordinary care and promises to be as good as his splendid ancestry suggests. His sire, Linwood Victorious, bred by Forbes \& Son was a very massive, short-legged, wide-out, smooth, beefy bull and a double grandson of imp. Cock Robin. . Secret Robin's dam, Snow Secret, is a half sister to the grandam of Lady Supreme, International grand champion female, 1920, both sired by Ingle Lad by imp. Collynie. His grandam, Wistful, is a half sister to the dam of Lespedeza Collynie, International grand champion bull, 1919, both sired by imp. Collynie. (See H. M. Hill sketch.)

"We have in our herd one real cow, sired by imp. Collynie; one, a half sister to the $\$ 3500$ Cherry Blossom, sired by the grand champion, Searchlight; another, a large, deep, wide, smooth heavy milker, by Hampton Spray, her grandam by imp. Collynie; Dale's Superb by Master of the Dales, a direct descendant of Sempstress of Oakland 8th of Mr. Pott's famous show herd and the dam of fifteen calves; one granddaughter of Glenfoyle Magnet, with yearling heifer from imp. Village Maid foundation; one wide, thickfleshed heifer by Baron Excelsior, a grandson 
of imp. Villager, sired by Augusta Baron; one heifer by a grandson of Craven Knight and from the Duthie Jealous Girl foundation also some good heifers by Rosewood Dale by Avondale.

"We feel that our crop of calves by Secret Robin from these good cows and heifers will be little gold nuggets and we take pleasure in showing them to visitors or prospective buyers. We have a few females for sale at all times, also some nice Scotch bulls. We meet trains upon request at Anthony, Ascot or Harper at any time."

S. D. Cox, Harper.-Mr. Cox had an excellent herd of grade Shorthorns which might as well have been pure breds. Seeing the mistake, he bought two cows by Fame's Goods, son of Ruberta's Goods and imp. Princess Fame. These cows were out of dams by Secret Prince, a son of Prince Pavonia and a good Gallant Knight cow. He also bought two heifers by Hampton, son of Mr. Hanna's Hampton Spray out of Golden Queen 3d by imp. Collynie, second dam imp. Golden Queen. Their dams were by Royal Butterfly by W. A. Betteridge's Lavender Viceroy and by Oakwood, a son of imp. Inglewood. It will be seen from this that a select foundation is being laid from excellent ancestry.

For a bull Mr. Cox bought Alfalfa Leaf News 10th bred by John Regier. He is by Good News, a son of the Choice Goods bull, New Goods that 
headed Harriman Bros.' herd at the time of its dispersion. His dam is by Nonpareil Star, a son of imp. Nonpareil Victor, famous as a sire of show stock in George Bothwell's herd and out of a cow by the well known Chief Violet 4th. This is a tried sire of merit and a good individual. Mated with Mr. Cox's cows, and with the offspring given the generous treatment he is said to give his cattle, we may expect to see some valuable Shorthorns on this farm.

R. H. Cunningham, Harper.-Not all has been smooth sailing with Mr. Cunningham since he embarked in the cattle business but he has something to show for his work and he is sticking to it. It has been his plan to buy a few more females and to build up as good a herd as he is capable of making. His location is very favorable for best results in cattle growing.

The stock on hand at the time of my visit was good. Silver Belle is by a son of Tomson's great sire, Barmpton Knight, out of a cow by the Bellows bred Hampton's Crown by Hampton's Best. Her dam is representative of imp. Inglewood that for years was the highest priced bull sold at an American Royal sale, and of Prince Pavonia. One of the best things is a heifer by Master Pavonia, (see John B. Potter sketch) dam by Joe's Lord, a son of Lord Mayor out of: an imp. Thistletop dam.

The herd bull is Secret Prince; bred by H. M. 
Hill. His sire is Linwood Victorious by Forbes' outstanding Victor Linwood out of a dam by Victor Linwood. Secret Prince has for dam one of the splendid cows of the breed descended from cows and bulls not equalled in quality by many Shorthorns and his breeding is along the very best Cruickshank lines. He was used for nearly two years by J. C. Thorn \& Son where he proved himself a capital sire.

W. M. Nye, Harper.-This herd does not run as even as some, owing to stock having been purchased from several sources yet there are few herds that, as a whole, are descended from a better line of ancestry. The sires of the cows are such bulls as Violet's Goods by The Choice of All and out of Violet Mist 7th, the dam of Mr. Hanna's Hampton Spray; Villager Sultan, a son of Double Sultan by Sultan Anoka and out of a dam by Villager; Protector by Barmpton Knight and out of a dam by Lord Mayor; Victor Archer by Archer and out of a dam by Gallant Knight. Their dams were by such bulls as White Sultan by a son of Glenbrook Sultan and out of a dam by Good Choice; Sandoval by Baron Lavender $2 d$ out of imp. Sorrel; Oakwood by imp. Inglewood and out of Sempstress of Oakland 8th by Thistlewood; Golden Lad by Golden Rule and out of Germanica 2d; the Duthie bred imp. Lavender Champion and the Marr bred imp. Conqueror. 
A big, straight-lined, massive bull is in service, Butterfly Sultan 300788. He is by Baron Sultan, a son of Whitehall Sultan out of Athene of Rosedale by Victoria's Count. His dam is by Victoria of Evergreen Park 5th 184632 and his second dam is by the C. C. Norton bred Chief Lavender 139145. Alfalfa and ensilage are available and Mr. Nye should become a successful breeder.

Walter Simonson, Anthony.-Mr. Simonson has been handling cattle on a large scale and some years ago he bought a few Shorthorn cows which have been kept with satisfactory results. I found here some very good cows and the herd, as a whole, is a fairly good one. It is the plan to let the pure breds increase with a view of gradually closing out the grades.

Among the best cows on the farm is one by Victor Archer out of a dam by Mr. Stodder's Geo. Archer, a son of Captain Archer. Her dam is by Sempstress Valentine, a son of St. Valentine. Another Victor Archer cow is Silver Girl 5th. Her dam is by imp. Aylesbury Duke. Beauty Belle 3d, bought at one of the recent Salter sales, sired by Rosewood, the splendid son of imp. Inglewood and imp. Roseleaf by Scottish Archer, has a bull calf by Sultan's Last by Whitehall Sultan.

Mr. Simonson is using a bull bred by Mitchell Bros., Ontario, Canada. His sire is imp. Lochiel 
and his dam is by Roan Chief 361556. More females will be added by purchase and plans are being laid for improvements in methods of feeding and handling. There are facilities here for keeping a large herd and the foundation is on hand for making a good one. The outlook for success is increased by the fact that a son of the family is strongly inclined toward Shorthorns.

Fred Maninger, Harper.-Here are sixteen well bred females by good bulls. Choice Echo that did valuable service for Miss Stanley and Bennington Bros.; White Sultan by Missie's Sultan and out of a Good Choice cow; Scottish Prince by imp. Lord Cowslip, dam by imp. Scotchman and others of this class show the cows well descended. The bull used was Hampton Archer by Mr. Babb's Silver Hampton out of a cow by Captain Archer, own brother to Sweet Mistletoe, dam of Lespedeza Collynie, International grand champion in 1919. A splendid white bull, Favorite 836696, was bought of John Regier in December 1919. He is by Scotch Cumberland, the excellent son of Cumberland Type, most sensational show bull of his day and out of Edelweiss 9 th by Good News, shown three times at state fairs and the winner of three firsts. It goes without saying that the use of such bulls will, with proper care, make any herd good.

Marcel Duphorne, Harper.-As I stood on the street corner in the eity of Harper, order book 
in hand, talking to Mr. Potter, I chanced to mention the matter of securing subscribers to A History of Shorthorns in Kansas. Mr. Duphorne, banker and Shorthorn enthusiast, overheard part of our conversation and before I had finished he seized my book with the remark "I'm in on this if it's for Shorthorns.." He filled out and signed an order for ten copies.

When David Wohlschlegel wanted an imported bull and could not leave home to attend the Carpenter \& Ross sale, he sent Mr. Duphorne as his representative. Does this banker know Shorthorns? Take a look at imp. Bapton Dramatist (Wohlschlegel sketch) and you will find the answer.

Note--Respectfully dedicated to bankers of the Southwest.

Jesse Rork, Anthony.-Harper county is full of new breeders and Mr. Rork is one of them. At Miss Stanley's 1918 sale he bought three cows. Lady Lou by a son of imp. Count Violet is out of a cow by imp. Trout Creek Clan Alpine. Roan Aline, by a son of Captain Archer, has two famous bulls in the next two crosses, Winsome Duke 11th and St. Valentine, sire of the undefeated Ruberta. Lady Waterloo is of similar breeding. Later Mr. Rork secured a daughter of Pleasant Dale, son of Maxwalton Avèrne, dam of the $\$ 100002 d$ Fair Acres Sultan and other good ones. He has been using Miss Stanley's 
384

A HISTORY OF SHORTHORNS IN KANSAS

Secret Robin, first prize bull at the Harper County Shorthorn show and a breeder of unusual merit.

\section{HARVEY COUNTY}

E. J. Haury, Halstead.-Mr. Haury is in the business to stay. This is evident when you talk with him and especially when you look over his cattle. Like nearly all Harvey county farmers, he is heavily engaged in wheat growing, but I suspect he has the vision of the time when, by reason of natural law, live stock must be kept on the land and he knows that the Shorthorn will come into its own on practically every farm in his locality.

The original purchases were made some years ago, from good Kansas herds. The bull Abbotsford has left proof of satisfactory service and another bull that left his mark was Monarch by Crusader, one of the very best sons of Barmpton Knight, a bull liberally used by Tomson Bros. The Tomson bull Archer and Col. Harris' Galahad also figure in the breeding of the herd. Besides the females that have been on the farm for a number of years, a recent addition of three cows was made from Park E. Salter, a daughter of The Goods, J. R. Evans \& Bros.' well known bull, and two bred in Canada. Scottish Maid 55th has great size and good form and will attract attention any time. The smaller one, 
Ramsden's Jessie, a cow of medium size, nice length, true top and bottom lines, short legs and very breedy, impressed me as an especially valuable animal. The third, a big, smooth, roan daughter of Ingle Lad should, by virtue of inheritance, be one of the best in the herd. She is out of Sycamore Spiraea, one of the great cows in $\mathrm{H}$. M. Hill's herd and a full sister to Prince of Collynie, one of the beefiest bulls and greatest sires of useful Shorthorns I have ever known. The cow is so good that one can readily overlook a plain horn and I would consider her very valuable as a foundation cow. Her bull calf by Master of the Dales topped Park E. Salter's young bull sale in 1917 and Mr. Haury is to be congratulated on owning her.

The bull being used is known as Gus Villager, a roan yearling by Village Glory, son of imp. Villager. His dam is Village Augusta by Village Omega, also a son of imp. Villager, second dam by imp. Crescent Knight. When I saw him he was in rather light flesh but he impressed me favorably. He has enough size with length and depth in right proportion and a good head and neck.

At the 1920 Salter-Robison sale Mr. Haury secured Fair Acres Blossom for $\$ 1850$. She is an elegant roan daughter of Fair Acres Sultan and is well along in calf to imp. British Emblem. She is a.valuable addition to the choice lot of 
cows on hand, and calves from her, if well developed, should be in demand at strong prices. This establishment is a great credit to Harvey county.

O. A. Homan \& Sons, Peabody.-When Mr. Homan was a young man he worked twentyeight months on a Shorthorn farm in Illinois and during this time he caught the spirit. $\mathrm{He}$ decided that as soon as he could, he would own a good herd of Shorthorns. His chance came twenty-five years ago when he began breeding in a small way. Later he bought ten cows and heifers of Col. Ed Green, then of Florence. All these cows were sired either by imp. Ardlethen Mystery or Double Champion and some of the Ardlethen Mystery cows were carrying Double Champion calves. It was a satisfactory pur.chase, not only because of the quality of the stock, but also because it included cows that in some cases were of the most desirable blood lines of the day.

One of these cows was Pride of Greendale $2 d$ out of Village Pride by imp. Invincible. This cow has numerous descendants in the herd. There are still on the farm six cows by Ardlethen Mystery, two by imp. Aberdeen and two by Double Champion. The Double Champion cows have been a good lot wherever I have seen them and, being from a bull of merit and first-class ancestry, they should be so. Double Champion was by the champion, Choice Goods, and his dam 
was Russella, the dam of the undefeated $\mathrm{Ru}$ berta. Three cows by the Hanna bred Victor Hampton, a son of Hampton Spray, were added to the herd a year ago.

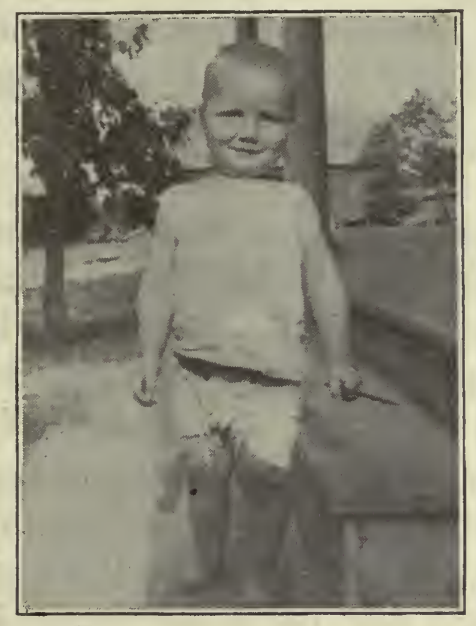

THE YOUNGEST OF SIX SONS, ALL MEMBERS OF THE FIRM OF O. A. HOMAN \& SONS

The bull used is White Hope. His sire is Archer's Victor, a son of the well known Tomson bull, Archer, the sire of many excellent cattle and numerous prize winners. His dam is by Ingle Lad, a bull that in H. M. Hill's herd sired a lot of breeding cows, practically all of them heavy milkers. His second dam was by Captain Archer, J. F. Stodder's sire of many prize winners and full brother to Sweet Mistletoe that at Lespedeza produced Imperial Mistletoe sold last 
year for $\$ 4100$ and Lespedeza Collynie, 1919 International grand champion. It will be seen that White Hope's sire, grandsire and great grandsire were all by imp. Collynie and he imparts to his get the thick meatiness of the old bull, with fine finish. Individually he is a good specimen of a large Shorthorn bull, short-legged and of fair finish, a beefy fellow, though not a show bull.

The Homans have quite a record as developers of young cattle. At the Wichita show and sale of 1918 they sold a sixteen-month-old bull weighing 1550 pounds that topped the sale for bulls of his age and the year before they had topped the sale on heifer calves with a pair of ten-month-old heifers. These heifers, according to the figures furnished by Mr. Homan, made a gain of nearly five pounds a day for some time. I remember seeing them and recall that they were generally much admired.

A. H. Taylor \& Son, Sedgwick.-The Taylors are located one and one-quarter miles west of Briggs Station on the Arkansas Valley interurban between Wichita and Newton. Cars run every seventy-five minutes, giving visitors unusual opportunity for seeing the herd.

This firm has Shorthorns much above the ayerage in size, form and finish. The greater number are of blood lines such as would appeal even to the most particular. The foundation was laid 
at the J. F. Stodder dispersion where one of the cows purchased was Jeanie by Silvermine, Mr. Stodder's splendid son of Rosewood that sired the great lot of heifers sold in the sale. Her dam was by Victor of Evergreen Park 4th. This was one of the Stodder show heifers and she had been a winner all along the line. Splendid breeding cows from her are now in the herd. Another cow is Orlena, a massive Tebo Lawn production sired by the well known Victor Bashful out of a dam by Duke of Oakland 2d. Knight's Victoria, one of the attractive things on the farm, is a big roan by the Gentry bred Knight Templar. Her sire was by Victorious, the Linwood bred son of Lord Mayor. Knight's Victoria was purchased with a good heifer calf at foot by Hallwood Model, a son of Choice Goods Model. Two desirable cows were added later, the last addition having been a red bought at the 1919 Breeders sale in Hutchinson. The herd bull is a son of Searchlight, a nice roan and very much like the best Searchlight bulls and he is satisfactory as a breeder. His dam was by Prince Pavonia, the son of imp. Glendale Pavonia.

The method of handling the cattle as practiced by the Taylors is such as to develop the animal well, as may be seen in the size of the matured cows, yet it is entirely practical and comparatively inexpensive. Good pasture, alfalfa and careful handling, the prime requisites for 
successful cattle growing in Kansas, are given this herd. The cattle are kept in that condition of growth and flesh that is best for the man who buys them.

Mr. Taylor tells me they grow Shorthorns as a side line and sell their bulls readily when twelve months old or younger at satisfactory prices. The farm is in the heart of the wheat belt where land sells high but they recognize the necessity of raising cattle and if these Shorthorns, big, massive and smooth, are kept as a side line only, it might be well for others to adopt their policy. The Taylor operations, in the section where wheat is grown as a main crop, should be an object lesson to the farmers of central Kansas in general. The farm has for years been used in producing Percherons of high class and the same energy and good management which contributed to the successful production of horses will be manifest in the production of Shorthorns.

G. O. Thomas, Walton.-Mr. Thomas bought a few females at the breeders sale in Peabody in 1918. They were principally from the Homan consignment. One heifer is by the Homan-Wilson bull, White Hope, (see Homan sketch) out of a cow by imp. Ardlethen Mystery. The others are of the same breeding as the Homan herd which gives them a good infusion of very desirable blood. Mr. Thomas has used White Hope, mentioned above, until recently and has secured 
excellent results. He has just purchased a firstclass young bull which completes his herd.

\section{JACKSON COUNTY}

Ed Stegelin, Straight Creek.-Few, if any, Kansas Shorthorn breeders are better known than Ed Stegelin. He has been a fixture on the big show circuits for a number of years and as a winner he has excelled prominent exhibitors and has carried off many blue and purple ribbons. It was about ten years ago that I first met Mr. Stegelin at the Topeka fair. He was there with a string of his cattle and the regularity with which he took second and third places was almost striking. He said little while awards were being placed but after the show he remarked "When I go out to show again, I will have cattle that can win first place." He meant it and he carried out the resolve.

At Mr. Stegelin's sale in 1918 the show herd was dispersed and since then no showing has been done. At the time of my visit to the farm in July 1919 there were about forty females in the herd and it was a rare treat to look them over. Half of them are by the many times grand champion bull, True Sultan, and every one of these True Sultan heifers I saw was not only big but was also finished from end to end. The other twenty cows are from excellent ancestry. Rosedale Charity is out of a dam by Prince Imperial, 
a son of Snowstorm out of a Royal Leader dam. (See Sands sketch.) Snowstorm will be remembered as a son of Snowflake, sire of Ringmaster, the only bull that was ever three times International grand champion. Lancaster Lady is by Red Archer, a son of Ceremonious Archer, International grand champion in 1903. Her dam is by Royal Rosewood by Royal Archer out of imp. Rosewood 97th. An extraordinary twoyear-old is Sultana Waterloo by True Sultan. Her dam is by Matchless Dale, sire of more International prize winning steers than any other bull of any breed, living or dead. Her second dam is by Orange Lavender by Lavender Viceroy followed by imp. Master of the Rolls. Another splendid white yearling heifer by True Sultan is True's Princess out of a dam by Searchlight, second dam by Prince Pavonia, a line of breeding that should make her a good producer. There were also on the farm two imported females. Mayflower Maid is a three-year-old roan, bred by Robert Bruce, and her maternal ancestry is of Bruce breeding for ten generations. Her sire, Golden Primrose, was bred by Durno. Mr. Stegelin had also made a purchase of eight females of very choice breeding which had not yet reached the farm.

The first high-class bull used was Orange Lad $2 \mathrm{~d}$ and still it remained a proposition to get a bull as good as was desired. At the International 
in 1912 a white from the famous J. H. Miller herd of Peru, Indiana, struck Mr. Stegelin's fancy. John Tomson assisted in looking him over and he was bought at the big price of

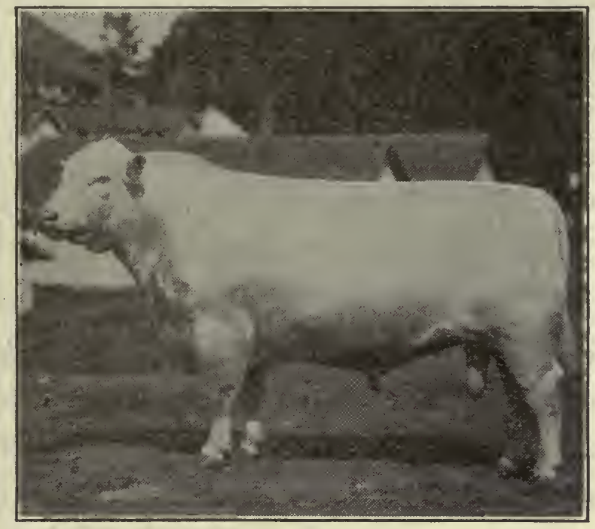

TRUE SULTAN

$\$ 550$. With transportation charges of $\$ 36$ he arrived at Straight Creek. This was True Sultan, a bull that did for Mr. Stegelin what Baron Victor did for Col. Harris, Gallant Knight for Tomsons and Collynie for Mr. Hanna. He was rarely, if ever, defeated in the show ring and he put the Stegelin herd among the tops of the classes. He was by Sultan of Anoka, a son of Whitehall Sultan out of imp. Lady in Waiting. His dam was by Marshall of the Mound in whose ancestry is found near the top four famous Shorthorns-imp. Craven Knight and imp. Princess Alice through their son Young Marshall 
and Mary Abbotsburn 7th, the most wonderful cow in America and a daughter of Young Abbotsburn, possibly the greatest show bull of any breed in America.

The show record of the Stegelin herd covered three seasons and in that time the cattle were exhibited at Burlington and Des Moines, Lincoln, Topeka, Hutchinson and Oklahoma City. In these shows they won 134 firsts, 22 seconds, 19 thirds, 8 fourths, and 3 fifths, 42 championships and 27 grand championships. In 1914 at the Nebraska State Fair, True Sultan was made reserve champion over all breeds.

A pleasing feature of the work on Mr. Stegelin's farm is the spirit of co-operation shown by and with the two sons of the family, ten and twelve years old, who own several of the best things in the herd. The boys plan to be ready to buy farms, when they shall need them, with the proceeds from their cattle. Mr. Stegelin thinks with the start the boys now have there is hardly a question of their being able to buy and pay for a quarter section of rich Jackson county land by the time they are twenty-one.

Tom Bottom, Soldier.-One must meet $\mathrm{Mr}$. Bottom to appreciate him. He is one of the most enthusiastic Shorthorn men I have known and I am sure that when you have been with him an hour you will feel as rested as after a summer vacation. Here is a big farm with plenty of fine 
pasture, plenty of alfalfa and a disposition to grow good Shorthorns that allows no thought of failure. Mr. Bottom is not thinking of the neat, tidy, round, little type, easily fattened on grain, but of the big, smooth, massive kind that can go out and graze to the best advantage, then winter well on the farm feeds.

Constant improvement is being planned for the herd and it is no mean one that meets the visitor's eye at this time. With few exceptions the cows are large and of correct Shorthorn type, and they are producing calves that are being well suckled and are growing into good cattle. As I recall it, practically every cow in the herd was suckling a calf or would produce one shortly. This is no doubt largely due to the commonsense method of keeping them neither fat nor lean, just thrifty. In general the breeding is very similar to that in Mr. Clement's herd.

Kansas Pride, a large, attractive roan comes from Loch Bros. Her sire Walnut Duke, is a Bellows bred son of Hampton's Successor out of a Victorallan dam. Her dam represents Good Choice and Merry Hampton. A Tomson bred daughter of Barmpton Knight is out of a dam by the Harris bred Vanquish, a son of Galahad, sire of Gallant Knight. This cow has been an excellent breeder and her bull calves have all sold at good prices before being old enough to wean. She is now suckling a nice heifer. Another attractive 
roan is Walnut Glen Girl by Scotch Goods. Three of her heifers in the herd are fine specimens of the breed, one of them, a yearling by Orange Lad, being an especially admirable prospect for a big, smooth, breeding cow.

The herd bull bears the gentlemanly name of Mr. Marshal. He was bred by Tomson Bros. and Mr. Bottom says he was the best young bull in the bunch when he was there and that is why he bought him. Really he is a good one, in fact, I have seen few bulls in my rounds that impressed me more favorably. He is a beautiful roan, a show yard type and out of a cow by Barmpton Knight. Later when I visited James Tomson I saw the mother and grandmother of this bull. They were not only two of the best cows in the herd but Mr. Tomson said they were among the very best bull producers on the farm. One of these two cows is the dam of Marshal's Crown, the outstanding Village Marshal bull retained for service in the Tomson herd. That Mr. Marshal will be a satisfactory breeder is indicated in a letter received from Mr. Bottom July 18, 1920 in which he says "I have thirty of the best calves in Kansas."

Ivan Clements, Havensville.-I saw a number of cows and some calves here which Mr. Clements said were fairly representative of the herd and they were real Shorthorns. They combine plenty. of size with good finish, several of them 
being very attractive and they would be creditable specimens in any herd. Plenty of roughage including alfalfa, and pasture, are the feeds which have done the work.

The purchase of foundation stock descended from a line of good bulls gives a clue to the success of things. "The earliest purchases are in the main representative of such bulls as D. P. Norton's British Lion, Clay \& Winn's Golden Victor Alex Fraser's Crown Prince of Lawndale and 15th Duke of Hilldale, Purdy Bros.' Lord Champion, V. R. Ellis' Godwin, Harriman Bros.' Proud Monarch and New Goods, Kelly Bros.' Banning, John McCoy's Pride of Collynie, Tomsons' Barmpton Knight, Bellows Bros.' Good Choice and Merry Hampton and Peculated Wild Eyes, two of the breed's great bulls to which no special individual can lay claim. It is only natural that cows descended from such a line of bulls and given a chance for development should be highly satisfactory in a breeding herd.

One among the best cows that I saw is a big roan, Augusta by name. Her sire is by Pride of Collynie, a full brother to Mistletoe 15th, dam of the 1919 International grand champion. She is suckling a big, lusty calf and will easily weigh 1600 pounds on grass alone. Another excellent cow is Alma Rose 4th bred by Loch Bros. of Nebraska. She is by Scotch Goods, a son of Good Choice, 
out of a Merry Hampton dam. Her dam is by Peculated Wild Eyes and her second dam is the grandam of Barmpton Knight. Kelly Bros. are represented in the herd by a good two-yearold by Scotch Monarch, a grandson of imp. Lord Banff, while Dr. Harkey's herd furnished Duchess of Oxford 2d, by Baron Cumberland. The dam of this heifer was Mr. Fraser's Duchess of Independence. She unites through her maternal ancestry the highest priced family of Shorthorns the world has ever produced with bulls of modern Scotch breeding and type and no one who has observed closely would deny the profitable results of such crossing.

The herd bull, a big, thick fellow, is Warwick 452253 , bred by Babst Bros. His sire is the Tomson bred Donald 359930. His dam is by Ingleside For Me, an elegant white used by T. P. Babst and sired by Rosewood, a son of imp. Inglewood and imp. Roseleaf by Scottish Archer, the best of Mr. Duthie's many great bulls. Mr. Clements is also freely using Mr. Bottom's excellent bull. (See Bottom sketch.)

C. P. Humphrey, Denison.-Mr. Humphrev, a banker owning and operating a farm, made his start with a cow bred by Mrs. A. G. Devlin and from her he raised four heifer calves. This cow was by Lord Butterfly by Golden Victor Jr., out of 8th Butterfly of Valley Grove by Lord Mayor. Her dam was by My Lord, son of imp. Spartan 
Hero and imp. Lady of the Meadow followed by two crosses of imp. Thistletop. Later a nicely bred cow from J. C. Stone was added and several of her descendants are now on the farm.

Well bred bulls have been used. An extra good one was Modern Scotchman by imp. Magenta, out of Victoria Butterfly by Victoria Baron. Another was Orange Cumberland by Dale's Cumberland out of a Lavender Viceroy dam. This bull stood third as a calf in a strong ring at the American Royal. The present herd bull was secured at the 1919 Ogden sale. He is a roan almost a year old and looks like the making of a good one. His sire Type's Lord is by Cumberland's Type out of a dam by Cumberland's Last. He is out of a cow by imp. Mutineer and she is a daughter of imp. Bapton Magnet by Silver Plate. Mr. Humphrey's farm is a rich one with much alfalfa land. It is located where Shorthorns have no active competition and where all conditions favor their best development.

J. W. Waynant, Holton.-There are few beginners who are as discriminating in their purchases and who are giving their cattle such care as is Mr. Waynant. His farm is splendidly located with pastures, fine water and soil that will grow any kind of forage. Since proper feeding and care go with animal husbandry here 
one may expect a splendid herd to be produced as a result of these conditions.

I have seen four of the five females in the herd and there is little room for adverse criticism of these cows. An unusually large and well matured three-year-old bred by Henry Kupper of Nebraska would attract attention anywhere. She is by imp. Scottish Sentinel and her dam is by imp. Strowan Star. A yearling heifer from this cow is quite pleasing and a two-week-old heifer calf by Superior Rosedale makes her purchase a fortunate investment.

The herd bull, Superior Rosedale, was bred by Howell Rees. He is by the grand champion, Whitehall Rosedale, and his dam is by Superimint, a grandson of Mr. Duthie's great Pride of Morning, second dam by a son of Pride of Morning. With one exception he is the heaviest and most massive bull of his age I have seen in twenty-two counties. He was junior champion at Topeka in a big show and this fairly indicates his form and quality. The young calves by him are promising.

Geo. Zeller, Meriden.-Mr. Zeller is a young man who a few years ago came to the conclusion that there would be no room in his plans for scrub or nondescript stock. As a result of such decision he bought four Shorthorn cows from which he has raised a creditable little herd. Two of these cows came from Iowa and one, bred by 
John E. Smith, was sired by Parson's Proud Duke, a son of the well known Victor Baron out of a dam by Duke of Oakland. Later several cows were secured from Dr. F. M. Marks of Valley Falls. They were by Choice Lancaster, a son of C. H. White's show bull, Richelieu, a state fair and American Royal winner, and were out of nicely bred dams.

The herd bull is medium in size, compact and smooth. He is by the Bellows bred, Double Diamond, whose sire and dam were both by the champion, Diamond Goods. He is out of a cow by Modern Scotchman, a well known son of imp. Magenta. The calves by this bull indicate progress in the right direction. Mr. Zeller, with good accommodations for cattle, plenty of enthusiasm and a well defined idea of what he wants, should be a success.

F. B. Arnold, Holton.-Mr. Arnold has a very creditable herd of fifteen cows and practically all were suckling good calves when I saw them. They have fair size, are straight-lined and smooth and are the kind of cows that if bred to a first-class big, thick bull can be depended upon for satisfactory results. Among high-class bulls appearing in the three top crosses are Archer Boy by Ballechin Archer, a son of Ceremonious Archer; Modern Scotchman by imp. Magenta, dam by Victoria Baron; George Cook by $\mathbf{M y}$ Lord, dam by Lord Mayor; Rosedale by 
Avondale out of imp. Rosebud 2d; Violet Lad by Golden Lad, son of Golden Rule; Village Lad, son of Village Boy by Bapton Sovereign; Victor's Baronet, a son of the noted Baronet and others of like ancestry. These show the line of breeding from which the cows come. A straight-lined, smooth bull heads the herd. He has sired an excellent lot of calves that speak better than anything else could both for him and for the milking qualities of the cows.

Joe L. Evans, Holton.-There are about twenty-five females in this herd and they are satisfactory breeders or splendid prospects for such. The cows are suckling well and producing good calves. They are of medium size and the conditions under which the herd is being kept have been such that they will respond well to liberal farm care instead of going down as is the case where forcing has been practiced. Mr. Evans is working a gradual betterment in methods of handling and by the use of high-class bulls he will be able to keep up improvement in the cattle. The present herd bull was bred by J. W. Dawdy and seems to be a success, as indicated by the calves.

H. J. Haag, Holton.-Mr. Haag has set out to produce a good Shorthorn herd, his idea being to correct mistakes he may make by avoiding them in the future. The females come from Theo. Olson \& Sons of Leonardville. Two of 
these are by Defender, a son of Barmpton Knight, out of a cow by Sir Charming 4th. The dam of these cows is by St. Valentine 12th, one of the sons of the great St. Valentine, and their grandam is by 86th Duke of Wildwood, a son of the noted show bull, Golden Victor. Another Defender cow comes through Athenian Coronet 4th by imp. Bapton Coronet and her dam is by Prime Minister by imp. Prince of Perth. Both Athenian Coronet 4th and Prime Minister were well known in Andrew Pringle's herd. The bull on the farm at the time of my visit was not up to the desired standard but he will be replaced by a better one as soon as a change can be made. Mr. Haag lives near Mr. Waynant and will use Superior Rosedale until he secures a satisfactory bull of his own.

J. Mack, Soldier.-Mr. Mack has a herd of fifty-five cows and he has been breeding for twelve years. His original purchase was made from Henry Haub and the entire herd is descended from this purchase. The method of handling has been to grow the cattle on the ordinary farm feeds without effort to secure extraordinary growth, yet to make conditions such as to develop fair size. Mr. Mack tells me that the dry cows and non-breeders sent to market have weighed about 1400 pounds. Bulls have been purchased from Knox of Missouri, Merriam of Topeka, Brown of Onaga and Rolf of Whitmore. 
The present sire is Sunlight, used by H. S. Anderson, a ton bull and a good breeder. Local demand has taken all the bulls and for the past two seasons the heifer calves have also been sold at satisfactory prices. Mr. Mack is inaugurating a system of culling out and improving by selestion but the general plan outlined above will kie carried on. He expects to stay in the business permanently.

Arthur Steward, Mayetta.-I found Mr. Steward's cattle much better than he had told me they were. Among the twenty cows on the farm are some first-rate ones and while the herd, as a whole, is not up to the high standard he desires, his is one of the most hopeful cases I have found. Mr. Steward says he had not been using good enough bulls in the past so he went toTomson Bros. and bought one and while I did not inspect the bull closely, he impressed me as being one among the best I have seen recently. $\mathrm{He}$ is a white by Village Marshal. His dam is by the Harding bred Sultan's Commander by Whitehall Sultan and his grandam carries a strong infusion of Forbes' Baron Gloster. The cows are from standard American families and are nicely Scotch topped, and the calves from this bull will undoubtedly prove very desirable.

Mr. Steward has plenty of pasture and alfalfa land and he is planning to cull over his females 
and add a few to his best. When this is done he will have a toppy Shorthorn herd.

E. T. Ralston, Holton.-Twelve years ago Mr. Ralston bought a cow of Henry Haub and from this purchase he has sold $\$ 5000$ worth of stock and has ten cows left. He gives his Shorthorns ordinary farm care, using them to produce milk and butter and to raise calves. By this method he can not raise the highest type of beef cattle but he is producing good, profitable farm cattle that solve the problem of keeping cows on high priced land and Mr. Ralston's Shorthorns are of the size and quality of many others where no attention is paid to milking.

Wm. Wischmeier, Mayetta.-Mr. Wischmeier does not expect to produce an outstanding herd but he is confident that he can raise good farm cattle by way of the Shorthorn route. His foundation stock came from the herd of $\mathrm{H}$. C. Graner in Atchinson county which carries assurance of both quality and breeding. These cows combine the blood of Modern Scotchman, frequently alluded to in these sketches and Symphony's Last, a bull of great worth in Mr. Graner's herd. The herd bull eomes from D. C. VanNice, is out of a good cow and by a son of True Sultan.

L. A. Trundle, Holton.-Mr. Trundle has decided that he can not afford to keep the common kind of cows on high priced land and even 
though he keeps only a few and uses them to produce milk and butter for the family, they had as well be good milking Shorthorns. He plans to stay in the business, using the Shorthorn cows as outlined above, and expects to produce pure bred cattle much more profitably than grades.

\section{JEFFERSON COUNTY}

H. E. Huber, Meriden.- "I was born on this farm and have lived here all my life and my shoes have seldom been free from Shorthorn fertilizer," Mr. Huber told me not long ago. In 1884, when eighteen years old, he began the business on his own account and he now has a herd of nearly sixty females. They are medium in size and smooth, with quality. The young stock is well fed, better than in the past and as a result more size will be attained in the future.

The show ring has not tempted Mr. Huber often but in 1918 and again in 1919 he took a few head to Valley Falls and both years won the female championship. He was a contributor to the Hiawatha sale in 1919 and to the 1919 American Royal sale. Three choicely bred cows were added to the herd by purchase in 1919. Several public sales have been held in these thirty-five years and the herd has become well known through a large part of the state.

There are cows in the herd that in point of merit and breeding would be a credit almost 
anywhere. Among these are Orange Lass by Fair Acres Stamp, a son of the noted sire Fair Acres Sultan out of Orange Blossom 36th 108985. Her dam is by Bapton Valentine, a son of imp. Bapton Arrow, the outstanding bull owned by W. R. Nelson and later by W. A. Forsythe \& Son. Butterfly Lady is by a son of Crusader, one of the best sons of Barmpton Knight and her dam is by Butterfly Goods by Silk Goods. Silk Goods Violet, a four-year-old, is by Silk Goods and out of Lord Marr's Violet by Lord Marr, the son of Lord Mayor and imp. Marigold 50th, second dam Scottish Violet 4th by Golden Lad, a son of Robert Miller's Golden Rule.

About twenty years ago, Golden Crown by Golden Victor Jr., later used extensively by $\mathrm{H}$. M. Hill, was in service. The dam of Golden Crown was 9th Butterfly of Valley Grove by Lord Mayor. The Sultan 227277 came from F. L. Hackler and had for sire imp. Daydreams Pride. His dam was by Lord Thistle, a well known Mastin bred son of Baron Ury. Silk Goods is the bull most heard of now in connection with Mr. Huber's herd. He was bred by Col. Casey and is nearly fourteen years old. Alex Fraser bought him as a yearling at Tebo Lawn and after siring a magnificent lot of roan heifers he was sold by Mrs. Fraser in the 1910 sale. He is of royal descent, being by Choice Goods out of Lassie of Tebo Lawn by Duke of Oakland 2d, 
second dam Golden Lassie by Gaveston out of imp. Golden Hair. Proud Sultan, a Tomson bred son of Beaver Creek Sultan, was used for two seasons and excellent results were secured from him. Recently Mr. Huber has gratified his ambition to own an imported bull and the white, Imperator, was purchased. He is a big, smooth, stretchy yearling that looks like the making of a first-class sire.

Mitchell Bros., Valley Falls.-The sixty females in the Mitchell herd range in size from medium to large. It is the intention of the proprietors to improve conditions in order to sucurc better development each succeeding sias.m. The start was made in 1914 by purchases finm H. E. Huber and other local breeders.

In looking over the pedigrees I found an unusual number of noted bulls appearing in the top erosses. Among them were Barmpton Knight, one of the best ever used in the Tomson herd; My Lord out of imp. Lady of the Meadow; Mellowhide by Mr. Hanna's Prince Royal cut of a dam by Captain Archer, own brother to Sweet Mistletoe, dam of the International grand champion in 1919; Silk Goods, excellent son of the champion, Choice Goods, now at twelve yeaj:s doing service for H. E. Huber ; Falsetto, the ontstanding sire in Alex Fraser's herd where his get from Bates bred cows looked like real Cruickshanks; Modern Scotchman, used with great 
profit by John McCoy and next to Collynie's Pride one of his best bulls ; Sir Knight by Golden Knight out of imp. Sorrel by Roan Gauntlet; imp. Thistletop, a great sire in the Babst and Tomson herds; imp. Salamis, the Cruickshank bull used by C. C. Norton; Crown Prince of Lawndale, the Bates Scotch son of Prince Royal, son of imp. Craven Knight and imp. Princess Alice and many others of high rank.

It is only natural that a herd built on this kind of foundation should possess individual merit which will be transmitted with reasonable certainty. Kansas Girl by a son of Victor Archer is one of the best cows in the herd. She has a number of desirable heifers on the farm and her dam is still an excellent producer. It is a real pity that more attention has not been given to the production of such cows as Empress of Oxford 4th, the Fraser bred daughter of Falsetto. She is large and is a good looker as a beef cow, she is a great breeder, a heavy milker, and is the dam of the best and highest priced bull sold in the Jefferson County Breeders Sale in 1919. A herd like Empress of Oxford 4th would enrich any owner who gave his cattle care. Her heifers are staying in the herd.

The Mitchells have recently bought a firstclass bull of the Kansas State Agricultural College. Matchless Dale, the superb sire of show steers and Bessie's Pride, an outstanding beef 
cow with a milk record of more than 8000 pounds, are sire and dam of the young bull that should be able to qualify for blue ribbons anywhere. Not only should he show well, but he should sire bulls and heifers that will carry along the greatest features of the breed, firstclass beef cattle and cows that are heavy milkers.

Dr. M. F. Marks, Valley Falls.-Dr. Marks has been in the Shorthori business for ten years. He has two distinct objects in view, uniformity in type and color and the maintainance of milking quality. The color is dark red and the type is that of the Shorthorn cow of medium size, straight lines and a good development of udder. His herd is quite true to the standards he has set and consists of about fifty females.

The original purchases were made from local breeders, principally from E. Kaufman and J. J. Freeland and the bulls used have, in the main, come from good herds and have represented good breeding. Two of the best sires in use were Scotchman 331565 and Choice Lancaster 364763, the latter bred by C. H. White and sired by his show bull, Richelieu, an American Royal prize winner and a son of The Choice of All. The cows by these two bulls indicate they were satisfactory breeders. Double Diamond by Diamond Goods, dam by Diamond Goods, has left some nice young things that are especially pleasing in head, neck and horn. The present herd bull is Clipper Dale 
652047 bred by Thos. Stanton of Illinois. His sire is Sittyton Sultan's Dale by Avondale out of a Whitehall Sultan cow. His dam is by Archer's Hope by Nonpareil Archer 236802 out of Rosa Hope 16th by Royal Prince.

John W. Sherwood, Dunavant.*-It is a real inspiration to look over the big, smooth, elegantly finished cows on this farm. The foundation was bought at the Fraser sale in 1911 and it was an excellent offering. Under Mr. Sherwood's care the cattle have gained, it seems to me, and I shall credit this fact to his aceidental purchase of a high-class bull. Nonpareil Avondale, a son of Avondale, was a red of 1906 and as an aged bull he virtually made the Sherwood herd what it is. Notwithstanding this, he cost less than a cheap bull would now.

There are nineteen females in this herd. Good care is given and natural conditions favor development. Empress of Oxford 3d, a daughter of Falsetto, the great sire in the Fraser herd, and representing on her dam's side the highest-class families of cattle of any breed in the world's history and on her sire's sides the best lines of modern Scotch Shorthorns, is still producing excellent calves. Her daughter, Little Empress by Nonpareil Avondale, is also an outstanding cow. While the bull now used is a good one, yet in comparison with his predecessor he can not be

Telephone, Winchester. 
seriously considered; still this is not a reflection on him. He was the first prize bull at the show held in connection with a sale in Jefferson country and he topped the sale, an honor which was very worthily bestowed.

John A. Yost, Perry.-Mr. Yost is building up a herd from a small start made three years ago. Two of his good cows are Kate's Pride 9th and Wildeyes. Kate's Pride 9th is by Baronet of Maine Valley bred by Chandler Jordan, the breeder of Mr. Saunder's great bull, Cumberland. Wildeyes is by Scotchman's Model and her dam is from the Fraser herd and by Falsetto. The herd bull is Golden Orange 738541.

\section{JOHNSON COUNTY}

Andy J. James \& Sons, Lenexa.*-Some years ago I formed the acquaintance of Col. James and since that time I had thought of him as a successful auctioneer with a leaning toward farm life and Shorthorns. This opinion was true in a very small sense only. It was my pleasure to be the guest of Col. and Mrs. James and to get an insight into farming and farm life within view of a big city. Picture a 400 acre farm of the very choicest land, in a rich part of Kansas, the commercial value of which is easily $\$ 300$ per acre, every acre of which will grow alfalfa or great

* One and one-half miles from Overland Park on Strang (inter-
urban) Line. 
blue grass. It lies four and one-half miles from the corporate limits of Kansas City and about ten miles from the Union depot. To me, this farm of rolling land and rich valleys was rest-

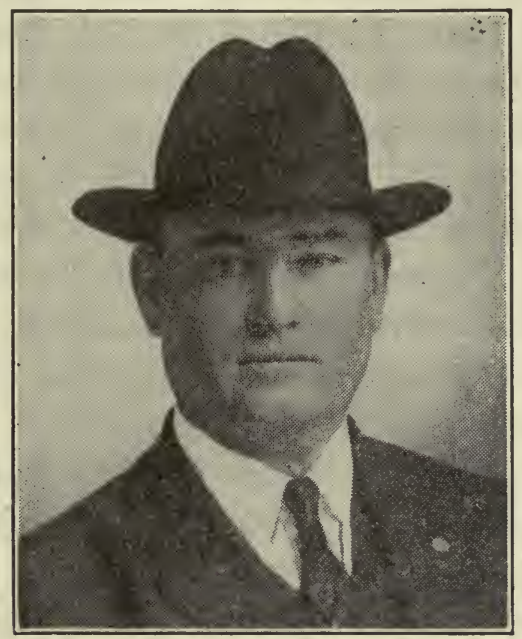

COL. ANDY J. JAMES

ful almost beyond comparison. This is Meadowbrook Stock Farm.

The James family consists of two grown sons and one daughter. The sons are not only splendid specimens of manhood but they promise to develop into real Shorthorn breeders. Both Col. and Mrs. James are in the prime of life and to be a guest in their home is a real pleasure.

But this is to be the story of Shorthorns on the farm. The cattle are a worthy lot and are going to 
be better in the near future. The herd was established twenty-one years ago, but the present herd comes from purchases made from Alex Fraser, representing Prince Royal 2d, Falsetto and Silk Goods, on the great foundation of cows, nearly all coming from George Allen. A later addition to the herd was a lot of cows bought from Adams and Grant that were sired by the excellent bull, Kingdom Come. This bull was a son of Fair Goods, out of a daughter of the noted Young Nominee. There were also added some cows by Villager Valentine, a good son of the great Villager and a few by Baron Marr and Lord Banff $2 \mathrm{~d}$ came from the H. E. Hayes herd. Recently there have been purchased a few daughters of Prince Valentine 4th, recognized as one of the best bulls in the state.

Good bulls have been consistently used. A McDermott bred son of Fair Goods, one from Bronaugh by Clara's Choice and a nice. smooth roan now in use coming from Fleming Bros. were all of choice breeding. The herd has numbered a hundred head but recent sales have reduced it to less than one-half that number. Col. James is planning additions by purchase shortly and these are to be strictly high-class representatives of the breed.

A suitable bull to head such a herd is already on the farm. He is a roan of September 1918 and bred by F. A. Gillespie \& Sons. His sire, 
Roan Lord sold for $\$ 10000$ at the Gillespie dispersion and was considered by many the most valuable bull in the sale. He is by the noted Carpenter \& Ross sire, Maxwalton Revolution and out of Maxwalton Roan Lady, the greatest cow of her day in America. I saw this yearling bull as a ten-month-old calf. He was very massive and though not at all in high flesh he weighed 814 pounds and impressed me as one of the very best herd bull prospects I have seen. As much as a bull calf could suggest resemblance to a cow, he recalls Maxwalton Roan Lady with her almost incomparable wealth of real meat and fine finish. It seems safe to predict that this young fellow, having his great ancestry and his individual merit, could hardly fail to become a good sire.

Frank X. Kelly, Gardner.*-Mr. Kelly succeeded Kelly Bros. and is one of the best known breeders in eastern Kansas. It is his aim to work a constant improvement and he is rapidly getting together a Shorthorn herd worthy of his best efforts. The first public sale was held at Ottawa June 6, 1919 when fifty head sold at an average of about $\$ 300$. A notable feature of this sale was the very liberal support given by the Johnson county neighborhood.

In general the original purchase of females did not differ materially from those found in

* Three-quarters mile west of Clare station on Santa Fe. 
other herds in Johnson county. It consister of good reliable cattle carrying in the top crosses the best blood of the breed as introduced by Col. Harris, H. E. Hayes, C. F. Wolf and others. This brought in the blood of imp. Lord Banff, Young Abbotsburn, Violet Knight, imp. Collynie, Kinnellar, Sir Charming 4th, British Ision, Peculated Wild Eyes, Lord Champion and Baron Sussex and was surely a foundation good enough for any future operations. Besides these cows, a number of which are still on the farm, additions have been made by purchase that should put Mr. Kelly in a leading position as a breeder.

At Park E. Salter's 1919 Wichita sale, the Kellys bought the elegant roan yearling, Lavender 48 th for $\$ 2000$. This was doubtless the best heifer in the sale and her sire, Rosewood Dale, is the well known son of Avondale now owned by John B. Potter. Her dam is the Edwards, Canada bred Lavender Leaf by Prince of Orange, second dam, by imp. Cyclone, by Star of Destiny, a son of Star of Morning. They also bought two other strictly high-class young cows, both bred to the $\$ 100002 d$ Fair Acres Sultan. One is by the Gerlaugh bred Morning Flash. Her dam, Missie May by Pride of Morning, is out of imp. Missie 139th. With this cow was secured a roan heifer calf by Overlook Flash.

It takes a high-class bull to head a good cow 
herd and in Lavender Stamp Mr. Kelly has such a one. He has plenty of size, is very straightlined, smooth and well fleshed and stands elose to the ground. His head and neck are almost ideal and he makes a fine impression at first sight. The best imported bull in the Salter-Robison 1920 sale was Kinochtry Ensign. This bull was secured by Mr. Kelly and will be used on the Lavender Stamp heifers. He was bred by J. P. Sym. His sire is Kingston of Edgecote and his dam is an excellent cow by the famous Collynie Cupbearer. He is large for his age, is very strong in the back and has an elegant coat of hair.

The objective in Mr. Kelly's operations is to produce cattle of good size, but not extremely large, that are typical Shorthorns in appearance as well as in the most valuable characteristics of the breed.

Murdoch Bros., Edgerton.-These men impressed me very much as being what is usually termed coming breeders. Their local conditions favor the production of cattle and I saw the evidence of their ability in a herd of grade Shorthorns, better in size and quality than many pure breds. They have unbounded enthusiasm and, with their previous successful experience, will, no doubt, be able to put up an excellent Shorthorn herd. The foundation which consists of a half-dozen females and a bull was wisely laid and makes a favorable impression on the visitor. 
In the herd is a nice roan cow, Winsome, bred by and bought of $\mathrm{C}$. $\mathrm{H}$. White of Burlington. Her sire is Harding, a son of imp. Collynie, out of Sittyton Sarcasm 3d by imp. Bapton Magnet. Her dam is by imp. Conqueror and her second dam is by the grand champion, Viscount of Ancka. On the farm is also a yearling heifer out of this cow by Happy Choice that is quite attractive and promising. Another good one is $\mathrm{V}$. V. Orange Blossom by Sultan Champion, a son of the well known Whitehall Sultan bull, Sultan Mine. Her dam is by a son of Avondale out of a daughter of Archer's Sunray. Fair Acres Sultan, one of the most popular bulls of the breed, comes into the herd through Violet Queen, a daughter of Regal Sultan. This heifer gives every promise of developing well and her splendid ancestry should make her a valuable breeding proposition. Violet Princess, by Choice Knight, a son of Good Knight and imp. Honeyflower $2 d$ and out of a dam by Good Knight, completes the list of females with which Murdoch Bros. made their start.

The bull being used is by Maxwalton Rosedale, a son of Avondale and imp. Rosewood Pride. His dam is by Gallant Knight, sire of dozens of prize winners at the big shows. His second dam is imp. Clara 59th by Princely Victor. This bull is a big one with a deep, thickly covered body. He is much the type of Whitehall 
Rosedale, a full brother to his sire and for three years grand champion at leading western state fairs and the American Royal. Murdoch Bros. figure rightly that it is better to pay out a little more money at the first in order to begin with good Shorthorns than to buy a cheap lot and gradually improve. They were fortunate in securing a nice lot of heifer calves which gives them a good start toward putting up a real herd.

C. S. Catlin \& Son, Olathe.-This herd of cows impressed me very favorably. They are large and smooth, close to the ground and thick-fleshed. Their breeding is of the kind that has produced so many excellent cattle, a crossing of choice Bates cows with thick Scotch bulls. The herd is largely descended from one cow, Kirklevington Duchess of L. Her sire and dam were both bred by Geo. Allen \& Sons and her grandam was imp. Kirklevington Lady by the famous $2 d$ Duke of Weatherby. Winsome Magnet 6th, one of the best cows, is by Matchless Avon by Matchless Dale, the great son of Avondale, that at thirteen years old is still siring valuable cattle at the Kansas State Agricultural College. The dam of this cow was by Roan Choice a son of $\mathrm{C}$. J. Wood's prize winning Roan Hero. Winsome Magnet is a Matchless Dale type and the other cows in the herd are very similar to her in conformation.

The bull is a big, straight, thick fellow, not a 
show bull, but one of the kind that usually gives proper account of himself as a breeder. His calves are all that could be desired. He is by Reporter, one of the well known and excellent Polled Shorthorn bulls. The Catlins have a single object in view and that is the production of first-class Shorthorns. The herd receives good feed and good care, the owners doing the rustling instead of allowing the cattle to do it.

Dr. W. C. Harkey, Lenexa.-Dr. Harkey comes before the reader with a reputation as one of the best feeders in Johnson county and, having a good lot of breeding stock, it is needless to say that the herd is good. He has been raising pure breds for nine years and has been using pure bred bulls on a high grade herd for thirty years. His cows came from Alex Fraser, E. Ogden \& Son, T. J. Sands, the Bronaughs and Col. Andy James. Dr. Harkey was not a man who would deliberately buy any inferior animals and as these are all creditable herds it is evident that a start was made with desirable females.

The other half of the herd on the Harkey farm, the bull, is good. He is Realm's Count 2d, a Leonard bred son of Wooddale Stamp. His dam is a daughter of the International champion, Lavender Viscount, and she is one of the Leonard Fancy of Ardmore cows. Realm's Count 2d won first prize and was made grand champion bull at the 1917 Central Show, his full brother 
having won the same honor in 1919. This bull is exceptionally low down, deep-bodied, thickfleshed, good in general conformation and quite pleasing in appearance. In Dr. Harkey's judgment, based on early results, he will be very satisfactory as a sire. The Harkey cattle are kept in a locality where blue grass grows at its best and supplies succulent feed the greater part of the year.

W. F. Kerr, Olathe.-Mr. Kerr is a new breeder who has made a beginning with the right kind of stock and who by reason of environment will be able to make a success of Shorthorns. One of his best purchases is the massive roan cow, Queen Lil, that weighs about 1800 pounds in breeding condition. She is wide, smooth and deep and carries finish from end to end. Her sire was by Lord Banff $2 d$ out of a daughter of Aberdeen Chief and her dam was by a son of the excellent bull, Albion, by Valley Champion. The man who is looking for real merit in ancestry should be pleased with this pedigree. Another foundation cow is Joan 2d, also by a son of Lord Banff 2d. Her dam comes through such noted Shorthorns as Young Abbotsburn, the grand champion show bull of America and the well known Harris bred Lady Athelstone of Linwood. The bulls whose blood enters into the herd along with those mentioned above, are Harriman Bros.' New Goods; the well known 
Headlight by Grand Victor 4th; imp. Daydreams Pride; imp. Thistletop; Lord Mayor and others of equal merit and popularity. The herd bull is a big beefy fellow and is a son of Queen Lil, mentioned above.

Mr. Kerr is located conveniently near Olathe, in a locality where all kinds of tame grass flourish and where Shorthorns have always been very approved.

W. D. Lorimer, Olathe.-Mr. Lorimer made his purchases from herds such as that of W. A. Forsythe \& Son, Ogden \& Son, and from the good local herd of J. A. Lorimer. Among the foundation stock is the Leonard bred Dixie G. by Rosedale's Choice and her dam by Golden Crown out of a daughter of Lavender Viscount, International grand champion. Dixie G. would be a very attractive cow in any herd. One among the best cows is Geneva whose sire was by the excellent Cumberland's Last bull, Baron Marr, and her dam was by a son of Prince Pavonia. Others in the herd are descended in the top crosses from such bulls as Godwin, Good Choice and Giltspur's Knight.

Lethia's Goods, a bull used for some time, was strong in the blood of White Goods, one of the best sons of Choice Goods. He also carried a strong infusion of imp. Merry Hampton. The present herd bull is an exceptionally even, well proportioned fellow from end to end. While his 
calves are not old enough to determine what he will do as a breeder, they are quite promising. On his sire's side, he is representative of Mr. Gentry's Victorous and Leonard's Lavender Viscount while his dam is by the show bull, Blythe Conqueror and out of imp. Pavonia, one of the best imported cows ever owned in eastern Kansas. Mr. Lorimer is secretary of the Johnson County Shorthorn Calf Club.

Gallanaugh Bros., Gardner.-It sometimes happens that I talk with a young breeder and decide almost immediately that he will be a success. Such was the case when I visited Gallanaugh Bros. They have laid a good foundation, drawn from reliable sources of supply, and they intend making additions by purchase and devoting their energies toward producing real Shorthorns. The females carry the blood of strictly high-class bulls from some of the best herds in eastern Kansas and with their good breeding they combine individual merit. One of the cows comes from Donhams. Her sire is a son of Prince Pavonia, favorably known in the Nevius herd, and her dam is by Giltspur's Knight. This line of breeding is recognized in eastern Kansas as having produced excellent result..

Hoover's Dale, the bull in service, is from the well known herd of E. S. Stewart, Sturgeon, Missouri. His sire, Wooddale Stamp, is one of 
she carries the blood of imp. Collynie, Choice Goods and Prince Gloster, three of America's gieatest bulls and through Ingle Prince, her dam's sire, she has Prince of Collynie, imp. Inglewood and Royal Knight. It would be strange if she were not good. The other cows are of similar breeding. The bulls are from the best Polled herds, the present sire, Airdrie Evergreen, comirig from J. H. Walker.

Rothwell \& Sons, Gardner.-Here is a highly commendable case of co-operation between father and sons and they are all in earnest about their work. Their purchase consists of one cow, two heifers and a bull. The cow was bred by ( $V_{0}$. Andy J. James and it will be interesting to know that she was bred from the family of cattle that were at one time the highest priced and most popular in the world's history. With this cow they secured a nice heifer calf at foot by Lavender Stamp. The bull being used is a thick fellow of very pleasing appearance and good breeding. He comes from T. J. Sand's herd and is by Clansman out of a dam by Classical Sultan.

A. E. Wedd, Lenexa.-Mr. Wedd bought a few cows from Col. Andy J. James some years ago. They came to Col. James from the Alex Fraser herd and wherever found these Fraser cows have been good breeders and good milkers. $\mathrm{Mr}$. Wedd is using a bull sired by the Betteridge 
bred Cicelie's Model out of a dam by Braceful Conqueror, a son of imp. Conqueror and imp. Bracelet. There is no way to get better cattle than by breeding such females to first-class bulls. Mr. Wedd can, if he puts the necessary care and feed into this herd, soon have a lot of cattle of which any man would feel proud. He is located in a community of Shorthorn breeders where co-operation is practiced.

A. L. Wiswell, Ocheltree--Mr. Wiswell is a new man in the Shorthorn business, but he is full of enthusiasm for the work. The three cows he has purchased are good ones and are intended as a foundation. Cottonwood Belle is by Handsome Prince by a son of Blythe Pavonia and out of a dam by Graceful Conqueror. Golden Nell is by Golden Glow, a son of Andrew Pringle's Golden Prince, out of a dam by imp. Thistletop. Agatha's Fashion is one of Col. Andy J. James' breeding, her ancestry being from Alex Fraser's herd of Scotch cross Bates Shorthorns. This cow has a promising yearling heifer by Kelly Bros.' Lavender Stamp. These four females are of exceptional value in establishing a herd.

Boyd Lorimer, Olathe.-Mr. Lorimer, a member of an old Johnson county Shorthorn family, recently bought of Kelly Bros. two Shorthorn cows.' The one was bred by Col. Andy J. James and is by one of his good bulls and out of a cow from the Alex Fraser herd. The other cow came 
she carries the blood of imp. Collynie, Choice Goods and Prince Gloster, three of America's greatest bulls and through Ingle Prince, her dam's sire, she has Prince of Collynie, imp. Inglewood and Royal Knight. It would be strange if she were not good. The other cows are of similar breeding. The bulls are from the best Polled herds, the present sire, Airdrie Evergreen, comirge from J. H. Walker.

Rothwell \& Sons, Gardner.-Here is a highly commendable case of co-operation between father and sons and they are all in earnest about their work. Their purchase consists of one cow, two heifers and a bull. The cow was bred by (Col. Andy J. James and it will be interesting to know that she was bred from the family of cattle that were at one time the highest priced and most popular in the world's history. With this cow they secured a nice heifer calf at foot by Lavender Stamp. The bull being used is a thick fellow of very pleasing appearance and good breeding. He comes from T. J. Sand's herd and is by Clansman out of a dam by Classical Sultan.

A. E. Wedd, Lenexa.-Mr. Wedd bought a few cows from Col. Andy J. James some years ago. They came to Col. James from the Alex Fraser herd and wherever found these Fraser cows have been good breeders and good milkers. Mr. Wedd is using a bull sired by the Betteridge 
bred Cicelie's Model out of a dam by Braceful Conqueror, a son of imp. Conqueror and imp. Bracelet. There is no way to get better cattle than by breeding such females to first-class bulls. Mr. Wedd can, if he puts the necessary care and feed into this herd, soon have a lot of cattle of which any man would feel proud. $\mathrm{He}$ is located in a community of Shorthorn breeders where co-operation is practiced.

A. L. Wiswell, Ocheltree.-Mr. Wiswell is a new man in the Shorthorn business, but he is full of enthusiasm for the work. The three cows he has purchased are good ones and are intended as a foundation. Cottonwood Belle is by Handsome Prince by a son of Blythe Pavonia and out of a dam by Graceful Conqueror. Golden Nell is by Golden Glow, a son of Andrew Pringle's Golden Prince, out of a dam by imp. Thistletop. Agatha's Fashion is one of Col. Andy J. James' breeding, her ancestry being from Alex Fraser's herd of Scotch cross Bates Shorthorns. This cow has a promising yearling heifer by Kelly Bros.' Lavender Stamp. These four females are of exceptional value in establishing a herd.

Boyd Lorimer, Olathe.-Mr. Lorimer, a member of an old Johnson county Shorthorn family, recently bought of Kelly Bros. two Shorthorn cows.' The one was bred by Col. Andy J. James and is by one of his good bulls and out of a cow from the Alex Fraser herd. The other cow came 
from the J. C. Lorimer herd, which has been a genuine source of supply for the territory north of Olathe. The breeding represented here is the best Bates foundation crossed with good Scotch bulls and this has produced splendid results. Mr. Lorimer is using Dean Lorimer's high-class bull.

J. R. Miller, Gardner.-Mr. Miller is the first and only barber I have found who owns Shorthorns and takes an active interest in them and I have been assured that he is a good Shorthorn man. He bought five heifers of Barrett \& Land and is keeping them well and breeding to Kelly Bros.' excellent bull, Lavender Stamp. This system will insure better results and the buyers of his output will get better cattle than if he kept a bull of medium quality as many small breeders do, and the cost is not greater.

Vint Trusine, Wellsville.-Mrs. Trusine is a daughter of Mr. Rhoads and the small herd on the Trusine farm came from her fathers. Mr. Trusine intends building up a Shorthorn herd and staying with the business. The cows on hand, bred to the right kind of bulls, with the produce properly grown out, will make a very satisfactory foundation for the future herd. The bull in use comes from John Black and is a son of Hampton Serene. The location is favorable for the production of Shorthorns and local market conditions in the Ottawa territory are good. 
H. J. Waddell, Olathe.-Mr. Waddell has made satisfactory selections, one of his cows being by Matchless Avon, a son of the noted Kansas State Agricultural College bull, Matchless Dale, one of the most renowned sons of Avondale. On her dam's side she combines the blood of imp. Princess Lovely, a grandson of Mr. Duthie's famous Scottish Archer and Senator Benedict's well known Banker 4th. Another cow is by King Gloster, a bull of T. J. Blake's breeding and out of a cow by Prince Pavonia, one of Mr. Nevius' best herd bulls. The herd bull comes from S. B. Haskins and is by the J. H. Walker bred Rube Evergreen.

\section{KINGMAN COUNTY}

Bennington Bros., Rago.*-Thirty-five years ago, C. Bennington began breeding Shorthorns in Iowa. Twelve years ago he eame with his family to Kansas, bringing fourteen cows with him. The firm was known as C. Bennington \& Sons until after the father's death which occurred three years ago when it became Bennington Bros. A large grade herd has been kept along with the pure bred one, but the Benningtons say that the day of the grade cow is almost past with them because they find the pure bred much more profitable.

Their herd is descended from three cows which

* Telephone, Harper. 
were bought in Iowa thirty-five years ago. No effort has been made to attain the highest standard, yet practical utility has always been insisted upon. The cows are of good size and are quite uniform. Since well bred bulls have always been used the herd represents desirable breeding. The men from whom herd bulls have been obtained are Chandler Jordan, Abe Renick, C. C. Bigler, M. E. Jones, C. S. Nevius, Howell Rees and H. H. Holmes. Students of Shorthorn affairs will concede that bulls coming from these herds should have been very good ones. One of the best used was Cherry Grove Banff 19th, selected by the elder Bennington and the senior member of the present firm as the best young bull on the M. E. Jones farm. He was almost a facsimile of his sire, imp. Lord Banff, and proved to be an outstanding breeder.

Two bulls are now being used. Fame's Goods is by Ruberta's Goods out of imp. Princess Fame and he carries two direct crosses near the top of his pedigree to Scottish Archer, Mr. Duthie's greatest sire. Fame's Goods had been used before coming to Benningtons and has an established reputation as a breeder. The other is Choice Echo, a big white, by New Echo, a son of New Goods and his dam was a daughter of imp. Ethel, the very excellent cow that went from Geo. Bothwell's to Harriman Bros.' herd. Both these bulls are tried sires of merit and, with their use 
and some proposed changes in handling, an excellent herd should be built up here.

\section{J. F. Birkenbaugh, Basil.*-Though founded} in 1916 and now consisting of only twelve females, this herd is worthy of much consideration. The cows are medium to large and the young stock is fed for splendid development. The ancestry of the foundation cows was of the better class and the bulls used should insure constant improvement. Lady Barmpton is by Satin Royal, a son of Captain Archer, own brother to Sweet Mistletoe, dam of Lespedeza Collynie, 1919 International grand champion. Satin Royal's dam was Mr. Stodder's famous show cow, Innocence, by imp. Bapton Arrow, one of the best bulls in the West, making him a full brother to Crystal Maid, leading Kansas show cow for three years. Silver Beauty comes from Mr. Stodder and is by Silvermine, a bull known all over southern Kansas for the excellence of his get and his wealth of good ancestry. Silver Beauty's dam is by Prince Pavonia, one of the state's best bulls. Secret Thought is by Banff Boy, a grandson of imp. Lord Banff, leading show bull in America and the first Scotch bull to sell for more than $\$ 5000$. Pollyanna is the daughter of Choice Archer, a son of Captain Archer (see above) out of a granddaughter of Choice Goods, American champion for three years.

* Telephone, Kingman. 
The first sire used was Ozark Sultan. He wás by a son of Princely Sultan by Whitehall Sultan, greatest American bull of this generation. The roan, Village Emblem, is now in service. He is by imp. Proud Emblem Jr. whose sire, Proud Emblem, is one of Great Britain's most popular sires. Village Emblem's dam is by the great sire, imp. Villager, out of Butterfly Maid, a daughter of Jubilee Maid. Mr. Birkenbaugh is pursuing the right course in selection and in the care of his herd, which bids fair to become one of the leading ones of south central Kansas.

George W. Allen, Norwich.-Mr. Allen's cows are of medium size and come from excellent ancestry. The young stock is well cared for and with the use of good bulls a first-class herd will be built up. The original purchases of cows made two years ago were strong in the blood of imp. Collynie and to use on these cows Mayor Alcott 618504 was secured. He was by Mayor Dale, a son of Maxwalton Rosedale by Avondale out of the famous cow, imp. Rosewood Pride. Mayor Dale's dam was by Prime Minister of the same breeding as the champion, Lavender Viscount. The bull now used is by Mr. Hanna's Hampton Spray out of Golden Queen 3d, a daughter of imp. Collynie and imp. Golden Queen, one of the best lines of Shorthorn breeding to be found. 


\section{LABETTE COUNTY}

L. M. Dunaway, Edna.-Mr. Dunaway has been breeding Shorthorns for a dozen years and in this time he has sold large numbers of cattle to his neighbors. His persistent disposition to sell has resulted in the herd's being cut down to twenty females, but he has certainly done his share toward popularizing the breed in his locality. He has even started a bright, ten-year-old grandson in business by selling him three heifers. The boy is a Shorthorn enthusiast and talks cattle like a veteran.

Mr. Dunaway's cows impressed me as smooth, even, attractive, medium-sized ones and showed a very decided tendency to give much milk, milking quality having been specially developed since the herd was founded. He has been using good bulls and the appearance of the herd indicates sensible, practical care. The present herd bull is Sycamore Marshall, a Stunkel bred son of Orange Marshall out of a Victor Orange cow, thus giving him a double cross of Victor Orange, one of the bulls that helped make Shorthorn history in the Southwest. Sycamore Marshall can hardly help adding to the value of the herd. The work Mr. Dunaway is doing is an important one and such a herd as his, developed for beef and milk, with good Shorthorn character and attractiveness, grown on the ordinary feeds of the farm 
is an object lesson to the people of any community.

D. S. Romine, Oswego.-When in company with F. B. Campbell and O. O. Massa I drove to Mr. Romine's home, I involuntarily recalled Mr. Sanders' description of the Shorthor'n country in England, for nowhere else in southern Kansas have I seen such grass as on the large lawn. In the pasture on the lower ground, running in blue grass, knee-deep, were twelve Shorthorn cows, every one of which would be called high-class. They are large, fat and smooth and the calves get all the milk they want.

Mr. Romine says he always selects the kind of cow he likes, paying absolutely no attention to pedigree but I examined the three top crosses in the pedigree of each cow and found all of them well loaded with the blood of such animals as imp. Collynie; Hampton Spray; Prince Royal: imp. Clover Flower, the dam of Cumberland; Gallant Knight; Prince Gloster, sire of the \$10000 Prince Imperial; imp. Scottish Lord, Mr. Cowan's great sire; and that quartet from Mr. Hanna's importation, Lord Cowslip, Inglewood, Mariner and the cow Mistletoe 15th, dam of Captain Archer, Sweet Mistletoe, Collynie's Pride and Golden Day. The selection and production of such a herd proves conclusively that one need not be a pedigree expert in order to select good cattle, as such cattle invariably come 
from good ancestry which gives them good pedigrees and I thought it might be a fine thing if more breeders selected their stock with only individual merit as their guide.

Lant Bros., Dennis.-This firm some years ago made a very fortunate purchase of a first-class daughter of imp. Inglewood and out of a cow by Royal Secret, second dam by imp. Scotchman. From this cow they have sold numerous animals at good prices including two young cows at $\$ 400$ each and they have a well selected, though not large, herd on hand. To the original purchase was added in 1919, a roan daughter of Linwood Victorious, a Cock Robin, Forbes bred bull of great excellence also a heifer by Secret Baron, purchased from H. I. Gaddis. At the fall Southeast Kansas sale, they secured a valuable cow with heifer calf at foot by Master of the Dales.

The herd bull comes from Canada and his pedigree is strong in Duthie and Marr breeding. $\mathrm{He}$ is an attractive roan, smooth and close to the ground and the young calves I saw by him looked good. Lant Bros. won a reputation as breeders of Durocs and I have reason to believe they will handle these Shorthorns in a manner that will get results.

E. E. Fiske, Cherryvale.-Mr. Fiske had been breeding Shorthorns for four years when he decided to improve by selling off all but the best. The animals retained consisted of a 
few cows bred by L. M. Dunaway and typical of Mr. Dunaway's best cattle which is the dual-purpose type. (See Dunaway sketch.) There were also retained a few cows carrying the blood of such bulls as Lord Mayor 3d, an outstanding show bull by Lord Mayor; imp. Collynie; imp. Daydreams Pride; Golden Day, a son of imp. Mistletoe 15th by imp. Mariner; Baron Rupert and Golden Victor Jr., a bull much used by H. M. Hill. The lot retained also included a few heifers from these cows sired by Lad's Prince, an Ingle Lad bull out of a daughter of Godwin, the big son of imp. Spartan Hero. These cows furnish a real foundation for a herd, which with care and development, should be a credit to the breeder and a benefit to the community.

F. B. Campbell, Altamont.-The genial and very efficient secretary of the Southeast Kansas Breeders Association has been raising Shorthorns for eighteen years. He has been selling liberally and when I saw his herd it consisted of only fourteen females. They are nice, smooth, straight-lined cattle, but $\mathrm{Mr}$. Campbell pleads guilty to the charge of insufficient feeding for best development, a condition which is being remedied at this time. Four bulls have been used in this herd in the last dozen years, all of which were purchased from H. M. Hill and are representative of Mr. Hill's breeding. The one now in use is Sagamore Sultan by the International 
winner, True Sultan, son of Whitehall Sultan. His dam is by Golden Crown by the Duthie bred Scotland's Crown.

Col. D. Christmann, Oswego.-Col. Christmann has a large farm and a herd of cows that show all evidence of being profitable producers. Milking tendency seems to be a strong feature of the herd. The cattle are of good size but they lack somewhat in infusion of Scotch blood, a condition which may easily be overcome in the first cross. The bull now in use is a nice, smooth fellow, strongly representative of the Hanna-Hill blood lines, backed by such ancestors as Ingle Lad, imp. Collynie, Royal Knight and Secret Archer. That this herd of cows is valuable if properly crossed is an established fact and the owner is now working along this line. Col. Christmann is president of the Labette County Shorthorn Breeders Association.

W. E. Cobb, Valeda.-Mr. Cobb, whose farm adjoins that of Mr. Townsend, is joint owner with him of the excellent Orange Viceroy, a bull whose individual merit and wealth of inheritance makes him a great acquisition to the Shorthorn interests of Labette county and adjacent territory. Here is one of those commendable cases where neighbors appropriated sufficient money to buy two fairly good bulls and paid it all out for one that was extra good. Mr. Cobb has only a small herd in numbers but a toppy one in 
quality. It includes an excellent Cruickshank Butterfly cow recently purchased at a long price and representative in the top crosses of Lord Banff, Godwin, King of Aberdeen and Thistletop, four of America's great bulls, all connected with Shorthorn breeding in Kansas.

A. E. Townsend, Valeda.-Mr. Townsend, who has been handling Shorthorns for six years, made a recent addition of two females to his small herd and jointly with W. E. Cobb bought what should prove to be a very valuable bull. He is a white and has for sire Pleasant Dale $2 \mathrm{~d}$, followed in order by Mr. Harding's Sultan Mine, Betteridge's Lavender Viceroy, imp. Master of the Rolls and Roan Gauntlet. Students of Shorthorn history and pedigrees will note the rich inheritance which this young fellow receives from his ancestry. It is only reasonable to expect satisfactory results from such a bull when mated with the right cows and the herd is given the right kind of attention.

A. C. Braunsdorf, Parsons.-The Grand View Stock Farm herd is good and comes from highclass ancestry. The females represent three great bulls, imp. Collynie, imp. Mariner and imp. Inglewood. The stock was purchased from Lant Bros. in 1916 and included an excellent three-year-old bull, Fashioner 7th, by Hampton Primrose, son of Hampton Spray, out of Primrose 6th, one of the best of Mr. Hanna's cows. 
G. W. Massa, Edna.-Like a number of others in Labette county, Mr. Massa uses a few registered Shorthorns as milk eows, giving the calves good care and selling them for breeding purposes. By this means he is enabled to get much greater net returns than from cows of any other breed. I saw an excellent individual of very pleasing appearance in his pasture, a real dualpurpose cow, the type of the future for the small farm.

A. H. Neville, Valeda.-Mr. Neville has a small herd, the foundation of which was purchased locally and which, like others in the vicinity, represents a useful type of farm eattle. As these cows are almost invariably good milkers, they solve the question of making cattle pay under the more costly conditions now met on the small farm. Mr. Neville is using a bull from the Nevius herd, typical in character and breeding of that establishment.

W. J. Walker, Altamont.-Mr. Walker is one of F. B. Campbell's neighbors. He bought a cow a few years ago and now has several very creditable Shorthorns. His bull, purchased from Fred Cowley, comes through such ancestry as Ingle Lad Jr., a son of Sweet Mistletoe, famous as the dam of the 1919 International grand champion. The dam of Mr. Walker's bull is by Secret Archer, one of the noted Kansas sires of his day. 


\section{LEAVENWORTH COUNTY}

$\mathrm{H}$ a r ris o n Meyer, Basehor.*-Mr. Meyer started in business a few years ago with the idea "that extra good Shorthorns were the kind to buy for a foundation and he has carried out his ideas in the most approved way., The herd of twenty females contains some very excellent animals. The big, smooth, deep-bodied, wide, well covered cows have true Shorthorn character and show in their calves that they are good breeders and heavy milkers.

Among the especially attractive things on the farm is a red heifer by Diamond Gloster 422421 out of a dam by Roan Goods by White Goods, possibly the best son of Choice Goods. Viscountess, bred by Loch Bros., is a very large and showy cow and a first-class specimen of the breed. Her sire, Scotch Goods, is a son of Good Choice out of a Merry Hampton dam. One of the best breeding cows on the farm comes from Kelly Bros. She is by Banning, a grandson of imp. Lord Banff. An excellent, large, red cow by Clara's Choice, the son of Choice Goods and imp. Clara 58th is worthy of special notice. The dam of this cow is by Courtier 4th and her second dam is by the grand champion, Viscount of Anoka. One of her heifers is among the best things on the farm. The animals

* Ship on Santa Fe or K. C. \& N. W. 
mentioned are representative of the entire herd.

Walnut Duke, the bull in service, came to Leavenworth county with an established reputation as a breeder. He is a big fellow, not entirely faultless in conformation, yet not fairly subject to serious criticism. He was bred by Bellows Bros. and his sire, Hampton's Successor, was one of the good bulls used in that herd. His dam is by Victorallan and his second dam by imp. Merry Hampton, one of the best individuals ever sent out of Scotland. Walnut Duke is breeding true to his ancestry and must be classed among the valuable bulls of northeast Kansas.

Mr. Meyer is one of four breeders located in the Basehor neighborhood who are co-operating in their business to a very commendable degree. This gives intending buyers visiting in a community a distinct advantage.

Henry Ode \& Son, Leavenworth. *-Twentyfive cows are kept on this farm. They are grown in a profitable way, but they have not been fed for as good development as is planned for the future. While the herd is now a creditable one, present conditions are such as to work a constant improvement. The original purchase was made from T. F. Stone of Weston, Missouri and numbered five females. Later five more were added from the same herd. Sales of both males and females have been made locally and the demand

Rural Route 5. 
for the production of the farm has been strong. The Stone bred cows were excellent individuals, descended from the best of ancestry through long use of high-class bulls. Among these cows was Ruby 24th by Secret Goods, a son of Best of Goods out of Secret of Hill Farm 2d by imp. Lavender Lad. Her dam was by Sirias, a Norton bred son of imp. Salamis. Violet $3 d$ was also by Secret Goods out of a Sirias dam.

The first bull used in the herd was Leavenworth 393487, bred by Alex Fraser. His sire was by Silk Goods, possibly the only son of Choice Goods now doing service. Leavenworth's dam was by Falsetto, a great sire in Mr. Fraser's herd. This Scotch crossed Duchess bull proved an exceptional breeder for Mr. Ode. The bull used until recently was Hampton 5 th bred by $\mathrm{K}$. G. Gigstad. He is a son of Hampton's Spicy by Hampton's Demonstrator and out of a cow by Goods, Mr. Gigstad's excellent breeding son of Good Choice. His second dam is by Golden Lancaster.

The Ode community is such as to render necessary a class of cows capable of raising good beef cattle and at the same time giving a good yield of milk. Some of the best guarantees for the permanent success of this establishment are found in the enthusiasm and ability of the junior partner, in the necessity for keeping cattle as a means of maintaining soil fertility and in the 
inclination of Leavenworth county farmers toward Shorthorns.

W. H. Lewis, Basehor.-Mr. Lewis had been raising good grades but advancing land prices demanded the best live stock that could be produced and so he changed from grades to pure breds. Good size, attractiveness and smoothness are characteristics of the cows in this herd while desirable ancestry tells the story of their pedigree. Two of the best are by Rock Springs Pride, a son of Pride of Collynie, own brother to Sweet Mistletoe, dam of the 1919 grand champion show bull. The dam of Rock Springs Pride was by Gladys' Chief, a bull out of an own sister to Lavender Viscount, the bull carrying off the International grand championship. In general, the cows in this herd are well filled with the blood of such bulls as imp. Scottish Lord and Barmpton Knight, two of the best and most favorably known bulls of their day. A daughter of Walnut Duke is one of the excellent things on the farm.

Mr. Lewis is using the bull, Princess Goods $2 \mathrm{~d}$, formerly used by Henry Ode \& Son. He is conveniently located near Harrison Meyer's and is making liberal use of Walnut Duke. (See Meyer sketch.) He is one of the four breeders in the vicinity of Basehor who are co-operating in every way to advance Shorthorn interests in their community and the excellent cattle on hand with a few choice additions planned will 
make for the successful building up of a herd.

George S. Marshall, Basehor.-On Mr. Marshall's farm I found eleven good cows and a spirit of enthusiasm and energy on the part of the owner that bespeaks success. Two of the best cows in the herd were bred by Ed Heglund of Atchison county. One is by Goods 374898 by Golden Lancaster, sire of the Gigstad show steers. (See Gigstad sketch.) She has a good heifer in the herd by Diamond Gloster 422421. Another cow is Village Lovely $3 d$ by Village Lord, son of Villager out of a dam by Whitehall Sultan. Village Lovely $3 d$ is out of a cow by Good Choice whose dam was by the Duthie bred imp. Lavender Champion. Barmpton Knight, the very popular Kansas bull, is represented by an excellent cow sired by one of his sons. Two are by Clara's Choice by the Choice of All out of imp. Clara 58th. The herd of Loch Bros. has been drawn on for a splendid heifer by Walnut Duke. (See Meyer sketch.) Her dam is by Scotch Goods, a son of Bellows Bros.' Good Choice out of a dam by imp. Merry Hampton. Students of Shorthorn history and pedigrees will recognize the fact that Mr. Marshall's cows are as well descended as any that could be obtained.

The new bull is Lavender King. I saw this fellow as a big yearling last summer. His breeding is of the best and he is very beefy, close to 
the ground and smooth and should make a firstclass sire.

\section{J. A. Mussett, Basehor.-This herd consists of} only five females but they make up in quality what they lack in numbers. They have plenty of size, smoothness and Shorthorn character. A heavy milking cow and a fine breeder is Cambria Maid by Clansman, son of Lavender Viceroy by the grand champion, Lavender Viscount. An aged cow bred by H. C. Duncan and sired by Headlight, out of a dam by Scottish Chief, is still vigorous and bids fair to raise several more calves. Her individuality and the ancestry from which she comes should make her calves valuable. Her heifers will all be retained. Clara's Choice, the well known Gentry bred bull, has a good daughter in the herd.

Mr. Mussett is acting wisely in using Harrison Meyer's bull instead of keeping one of medium quality such as he feels he could afford to buy and in this he is setting an example to small breeders who in many cases are using a quite common bull. Co-operation on the bull should be practiced wherever possible. The size of $\mathrm{Mr}$. Mussett's herd is not an indication of his future operations for he is planning more purchases of females and they will be good ones. He has all the resources necessary for putting up a Shorthorn herd including plenty of enthusiasm, both in himself and in a growing son. 
A. L. Withers, Leavenworth.*-Mr. Withers is located three miles from the heart of the city and on his high priced land he figures cows must raise good calves and give milk for market. The five Shorthorn cows I saw being milked are doing this and the calves are being well raised by hand. The reader will recall that Thos: Bates did the same thing with his famous Duchess cows and produced the greatest herd the world had seen up to that time. A first-class herd bull by Villager Jr. was recently bought from G. F. Kellerman. This bull is big, thick and smooth and must be considered one of the county's best Shorthorns. The fact that he did service in the Kellerman herd guarantees his quality.

\section{LINN COUNTY}

A. Hamm \& Son, Prescott.-This firm is counted among the leading breeders of Linn county. The herd which was started seven years ago now numbers about thirty-five females including one imported cow, Sister Susie 729813. The object is not to produce abnormally large cattle but rather to avoid the extremes in size and to build up a herd of smooth, uniform type with the quality required for good Shorthorns. The young stock is being well cared for.

The Hamms exhibited at the Linn county fair in 1919 and won in the classes including first

Rural Route 1. 
on aged bull, first on junior calf and second on herd. They contributed materially to the success of the Linn County breeders sale in 1919, their entries having been well appraised by the bidders. They sent an elegant white heifer calf to the Kansas National show at Wichita in 1920 , which was much admired and, though not at all fitted, was good enough in general conformation to be a credit to any breeder.

Among their cows is Gwendolyne Princess, a three-year-old roan by Beaver Creek Sultan from Tomson Bros.' herd. Her dam was by Primrose Royal bred by S. C. Hanna. He was by Prince Royal, son of imp. Collynie and the Marr bred imp. Princess Royal 62d and his dam, one of the best cows in the Hanna herd, was by imp. Inglewood out of the Duthie bred imp. Primrose 4th by Scottish Archer. Another cow, Wrangler's Countess, comes from Leonards. Her sire, Majestic Viscount, was by Wooddale Stamp out of a dam by Rosedale's Choice. The dam of Wrangler's Countess is imp. Ravenswood Emerald of Norie's breeding. Village Marshal, Tomson's great son of Cumberland Marshal, has a roan daughter in the herd, Victoria Queen. Silver Queen, another roan, is by Beaver Creek Sultan. Both these heifers are of the choicest and most acceptable breeding and are among the strictly good animals on hand. A roan three-year-old is Lady Gloster by Gloster's 
Choice, son of Marengo's Choice, the excellent son of Rosedale's Choice and imp. Marengo's Lavender Countess. Her dam is by Victoria's Snowflake by the Choice of All.

Fancy Dale, a white son of Maxwalton Rosedale, is the bull used. His dam is Norwood Fancy by imp. Crescent Knight and his second dam is imp. Fancy 2d. It will be recalled that Maxwalton Rosedale is by Avondale and out of imp. Rosewood Pride. He is a full brother to Whitehall Rosedale, western state fair champion and champion at the American Royal. He is out of the same dam as the noted Pride of Albion, a great winner at the biggest shows and sire of Pride of Oakdale, the 1919 prime favorite east of the Mississippi. Those familiar with Shorthorn pedigrees will recognize in this story a herd of the very choicest breeding.

G. F. Kellerman, Mound City.-I first met Mr. Kellerman in 1884 and the most noticeable feature about him was his great liking for Shorthorns. For several years we lived near enough to visit and of course it was Shorthorn talk on both sides. I shall omit a considerable part of his active life for that is told in the story of $\mathrm{D}$. K. Kellerman \& Son, G. F. Kellerman having been the son. He had shown in the management of the partnership herd, unusual ability as a breeder and handler of cattle and when I learned that he was breeding Shorthorns on his own 
account I was not surprised to hear that he had a very choice herd. A visit to the Kellerman farm and a study of the methods employed to get as much as possible out of a young animal would be the best investment any young breeder could make.

The Kellerman herd is not large, comprising only fifteen females, but the man who is particular about pedigree or merit could buy with his eyes shut, since the owner is probably more particular than he. 'The breeding will pass muster anywhere for here are cows that would be a credit to any breeder. One of the more valuable ones is Columbia 5th, a three-year-old white. She suckled a white bull calf eight months old that weighed nearly 800 pounds and he must be classed as one of the very best calves I have seen. Columbia 5th is by Parkdale Baron, the well known Bellows sire. Her dam is by Star of the Mist by Choice of All out of Violet Mist 6th, one of the best cows Mr. Gentry got in the purchase of the Dustin herd. Gregg Farm's Lavender is a remarkably short-legged, big-bodied young cow by Gregg's Villager, now conceded to be one of the best Villager bulls in service. Her dam is by Gallant Knight's heir, Kansas State Fair champion and much used in the Tomson herd. Her second dam is by Archer, son of imp. Collynie and imp. Circe $3 \mathrm{~d}$. One of the best cows in the herd and one of the best I have seen anywhere is 
the massive red, Victoria May 2d, by Count Commodore. This cow is just what I would want the mother of my herd bull to be. Besides being an outstanding beef cow, she is a heavy milker and her calf weighed 800 pounds the day he was eight months old and at that age he was sold to O. A. Weddle of Allen county for $\$ 700$. Closely approaching Victoria May $2 d$ in size, quality and milk is the four-year-old roan, Hattie C., a Tomson production by Prince Valentine 4th. Her dam is by Lord Marr, one of the best sons of Lord Mayor and her second dam is Harmony 6th by imp. Thistletop.

The future herd bull is the white calf mentioned above, out of Columbia 5th. If this calf grows out as he promises and as his ancestry would justify, few bulls in Kansas will equal him either as an individual or as a sire.

E. C. Smith \& Son, Pleasanton.-The Smiths began their work in 1915 and have forty females in the herd. The cows are large and the young stock is being well fed and cared for. They have been doing some showing and have a record of winnings very creditable to any one not keeping cattle especially for show. In 1919 they contributed to the Central Sale at Kansas City and in the show held before the sale they won second and fourth places on their entries which sold at $\$ 700$ and $\$ 425$ respectively. At the 1919 Linn county fair they were awarded first place on 
herd, on aged bull, on aged cow and on senior heifer calf and second on junior heifer calf. They also received the $\$ 25$ bull championship offered by the American Shorthorn Breeders Association. An addition was made to the herd in 1919 by the purchase of two high-class females and the work of improvement is going steadily forward.

Among the best cows on the farm is Bridesmaid $2 d$ by Gallant Knight's Heir, the son of Gallant Knight kept by Tomson Bros. for show and breeding. Her dam is by a Norton bred son of Banker's Victor. Gloster's Girl, a five-year-old red, is by Mutineer's Last, a son of imp. Mutineer and out of Duchess of Gloster 29th by Royal Marshal, one of the good sons of Whitehall Sultan. Victoria Girl, another excellent young cow, is by Count Commodore, a nicely bred bull from the Corkss nerd and her dam comes from H. C. Duncan and was by his favorably known Headlight. Nonpareil Maid 2d is a Kansas bred daughter of Maxwalton Rosedale, the Avondale bull used so successfully by Tomson Bros. and the Pringles. Maxwalton Rosedale enjoys the distinction of being own brother to Whitehall Rosedale, for two years grand champion almost everywhere west of the Mississippi. The winnings of this herd indicate with assurance that there are some real Shorthorns here and the cows show excellent ancestry. 
The bull that has been at the head of the herd for some time and is still retained is Village Goldfinder. He was bought as a young fellow in 1917. His sire is Gregg's Villager, son of imp. Villager and imp. Belle of Ordeans. His dam is Bridesmaid 2d by Gallant Knight's Heir by Gallant Knight. It was an own brother to Village Goldfinder that was used by G. F. Kellerman in 1918, siring the remarkable calves seen at Mr. Kellerman's the past season.

E. C. Smith \& Son are among the most public spirited breeders in Kansas and are leading promoters of the work being done by the Linn County Shorthorn Breeders Association, a strong organization which is making the county known as one of the best Shorthorn sections of the state.

A. M. Markley \& Sons, Mound City.-These men are the oldest breeders in Linn county, their operations having extended from 1892 to the present time and in these years they have sold Shorthorns to go to more than half the counties in Kansas and to several other states including Missouri, Arkansas, Oklahoma and Texas. Considerable showing has been done with very satisfactory results. During the period from 1908 to 1917 the herd was exhibited at Mound City, Pleasanton, Iola and Uniontown, winning its full share, or more, of premiums. In 1914 the winnings at these four fairs, numbered fifty-two prizes. 
The conditions for growing cattle on this farm are good. Alfalfa and all tame grasses flourish and ensilage is used in the ration. The breeding herd now numbers about thirty-five cows and heifers. The cows are given good farm care and the young stock is fed grain. Most of the matured cows are medium in size and some are large. In addition to the cows longest on the farm, which came from such herds as Kellermans and that of Morse \& Sons there have been added in the past two years some desirable females. Occasional additions by purchase are contemplated. Orange Lad and Orange Major, two of Linn county's best known bulls, have been used, followed by the Nevius bred Duchess Searchlight by Searchlight. King's Choice, an excellent, big, red bull of approved breeding and with an unusual covering of flesh in the valuable parts, is now being used.

Guy Rowley \& Son, Prescott.-The aim on this farm is to produce a class of Shorthorns good for beef and milk and to raise these cattle so that they will be within reach of the farm trade. A start has been made in this direction with twentyfive females of breeding age. Robinetta 4 th is a typical cow of the class desired. Her sire, Mistletoe Archer, is out of Sweet Mistletoe, the dam of Lespedeza Collynie, the 1919 International grand champion. Her dam is a daughter of Robin, the bull selected from Col. Harris' herd 
by Mr. Hanna to work an improvement in the milking quality of the Palo Duro herd. A daughter of this cow, Sycamore Robinetta, carrying the Ingle Lad cross is said by Mr. Rowley to surpass everything else on the farm for quantity and quality of milk.

Splendid results have been obtained, not only in Mr. Rowley's herd but by several neighbors, from the use of the Tomson bred bull, Mr. Mysie, by Maxwalton Rosedale. The present herd bull, Supreme Marshal, is a big, stretchy white, by Village Marshal. His dam is by imp. Crescent Knight out of a daughter of imp. Sunny Blink 4th. There is room and plenty of patronage for just such establishments as Rowley \& Son propose to maintain, and the material on hand, coming as it does from Shorthorns noted for production of both beef and milk, furnishes them a solid working foundation for building up a clualpurpose Shorthorn herd.

Mantey \& Harriman, Mound City.-R. E. Harriman, of the same family as Col. Bob, the popular auctioneer, is the wide-awake young man in charge of this herd. The farm, almost ideal for a Shorthorn establishment, is located in a real Shorthorn community and Mr. Harriman has plans for the future which can hardly fail to result in a good herd. $\Lambda$ start is made with a dozen females. Rosedale Lady, a nice red, combines the blood of Victor Orange, a 
famous sire in the Stunkel herd with that of Gallant Knight. Helen, a four-year-old roan, was bred by Kelly Bros. and is by Banning, a bull strong in the blood of imp. Lord Banff. One of the bulls used was Sycamore Lad. He carried a double cross of Ingle Lad, now rated an outstanding sire of producing cows. The present herd bull is Royal Star, by the well known Clansman, a bull used successfully by T. J. Sands and W. H. Vail. Royal Star's dam was by the Conqueror, one of the best known sons of Choice Goods.

G. A. McClaughey, Mound City.-Dr. McClaughey has three females. $\mathrm{He}$ is giving them proper care and is using some of the best bulls in Linn county which guarantee satisfactory results. A heifer by Emma's Valentine bought in 1916 of $\mathrm{Mr}$. Nevius furnished the start and she was a good one. A nineteen-month-old heifer of Dr. McClaughey's breeding was first in class at the Linn county fair in 1919.

Ted D. Paddock \& Sons, Mound City.-This is a firm of beginners. One of their cows was bred by A. Hamm \& Son. She is a daughter of Model Gcods by Hallwood Mint, a son of Choice Goods Model. They also have an excellent heifer by Fancy Dale, a son of Maxwalton Rosedale out of Norwood Fancy by imp. Crescent Knight. The Paddocks live near G. F. Kellerman and can have the benefit of his co-operation. 


\section{LYON COUNTY}

E. H. Abraham, Emporia.-Mr. Abraham deserves credit for having very successfully hidden his light under a bushel. I had heard little about him but it seems to me that Jim Tomson once told me of selling an extra good bull to a man at Emporia by the name of Abraham. It is the object of this book to rescue from obscurity just such modest men as Mr. Abraham and to introduce them to the breeders and farmers of the state. While he was going along so quietly as to occasion no comment, he was gathering up a few Shorthorns that suited him, using good bulls, selecting choice heifers and feeding his cattle well. The result is a herd of thirty females, bred and grown on the farm during the past twelve years, that have virtually cost Mr. Abraham nothing, for the sales from the herd, while made locally and at very modest prices, have much more than paid all expenses and the price of the original purchases. The results of good ancestry, wise selection and judicious care are apparent, for when you see these cattle you know they are real Shorthorns.

Looking over the pedigrees I found noted bulls in evidence everywhere. Among them are Lavender Viscount, famous sire at Ravenswood and International grand champion; Barmpton Knight, Tomson's wonderful breeding bull; 
Gallant Knight, leading western sire of prize winners in his day; Victorious, famous in N. H. Gentry's herd ; imp. Knight Templar, by Cumberland and out of the same dam as imp. Baron Victor; Imperial Victor, the Stunkel bred son of Victor Orange that sold for $\$ 2000$ in the cheap times; St. Valentine, sire of the undefeated Ruberta ; Prince Royal, son of imp. Craven Knight and the Peerless cow, imp. Princess Alice and imp. Scottish Lord that sired B. O. Cowan's World's Fair prize winners.

The herd bull is Victor Marshal, a Tomson bred son of Village Marshal. His dam is Vanity, a cow by Archer that has been a prize winner in the Tomson show herd. The rest of the pedigree is as good as that given above. This is one of the thickest, meatiest young bulls I have seen. He is very low down and even and does not fall short of best show yard standards. Mr. Abraham has exhibited at fairs only once. At Wichita in 1918 he sold two young bulls at long prices and incidently put them in the show, winning first and second in the Kansas specials and second and third in the open classes.

Among other good herds that have been founded with cows of Mr. Abraham's breeding is that of Owen Oneill of Windom and the excellence of the Abraham herd is strongly reflected in the Oneill cows. It is worth much to any man to be able to breed and sell foundation stock for herds 
established by discriminating buyers and in this Mr. Abraham is doing his full share toward developing Shorthorn interests in east central Kansas.

E. L. Moreland, Americus.-Mr. Moreland's farm is located in a section that has always appreciated good stock. He began business in 1919 by buying choice females instead of common ones. Crestmead Beauty 3d, one of the cows, is by that excellent sire, Prince Valentine 4th. This heifer is one of the regulation Prince Valentine 4th quality, attractive and breedy in appearance. Her dam is Crestmead Beauty $2 \mathrm{~d}$ by the fine sire, Orange Model. She represents the select line of breeding so popular in the W. A. Betteridge herd. Golden Rose 6th is by Wooddale Chieftain, one of the best sons of the Choice of All, and her dam is by Marshall Abbotsburn 3d. Both these bulls did service in the David Ballantyne herd and were two of the best breeding bulls in Kansas as by virtue of their individuality and ancestry they had reason to be. Golden Rose is a first-class Shorthorn cow and an excellent producer. Evangeline 5th is a four-year-old by Choice Orange, son of Stunkel's Star Goods, own brother to Diamond Goods. Her dam is by Headlight $2 \mathrm{~d}$, a son of Duncan's Headlight, much used by C. W. Taylor. What is probably the most valuable cow in Mr. Moreland's herd and one that would be desirable anywhere is the roan, 
Cumberland Princess, bred by J. W. McDermott and sired by Cumberland Marshal out of a daughter of Fair Goods. This young cow has proved herself an exceptional producer and her pedigree is one of the most highly prized kind.

Mr. Moreland was exceedingly fortunate in securing a first-class bull for service in his herd. Golden Magnet, a yearling by Golden Search, was the outstanding bull in the 1920 Nevius sale, and few better bulls were sold in Kansas that year. He is an unusually attractive, smoothly covered red with elegant head and neck, very straight lines and as good a back as one could wish. He is massive and close to the ground. It would seem superfluous to say much about his ancestry for in every remove they are closely descended from some of the best cattle bred by Mr. Cruickshank and as individuals they would class as outstanding.

J. G. Lumley, Emporia.-Mr. Lumley has been breeding in a small way for eight years. The herd now consists of a half dozen females, several of which are very good ones. Two of the heifers are by E. H. Abraham's bull. Rather than keep a medium bull of his own and obtain only medium results, Mr. Lumley is breeding to Mr. Abraham's bull, and his action is worthy of consideration by other small breeders who are similarly situated. Two years ago $\mathrm{Mr}$. Lumley bought an excellent Gallant Knight cow 
of Tomson Bros. She was bred to Village Marshal and produced a heifer calf by that noted sire and now has another heifer calf. This goes to show that at a moderate expense one can frequently get a start of very desirable Shorthorns.

H. C. Anderson, Americus.-Mr. Anderson's connection with Shorthorns dates back to 1917. He has ten cows that came from two very reliable herds, those of E. H. Abraham and David Ballantyne. The Abraham purchases were by the Tomson bred Diamond Victor, whose dam, Daisy Queen, was Western state fair and American Royal grand champion in 1911. This cow was of the same breeding as the famous New Year's Delight. The Ballantyne purchases were by Wooddale Chieftain, one of the best sons of The Choice of All, a noted bull by Choice Goods. The bull now used is Bloom's Corporal by the grand champion, imp. Bapton Corporal and out of Golden Bloom 2d by Lord Strathallan 207608.

Conway Rees, Emporia.-Among the cows of this new herd are some elegant ones. Becky Barrister 11th came from S. D. Mitchell. Her sire is Colonel Carvel (see S. D. Mitchell sketch) and no more need be said to any one who has seen Colonel Carvel. Her dam is by Barrister, the noted son of Craven Knight with 247 first prizes to his credit in the show ring. Roan Signet bred by H. T. Forbes has been used by Mr. Rees with good results. He is by Royal Monarch, 
an excellent bull and valuable sire for Mr. Forbes. (See Forbes sketch.) A Leonard bred son of Marengo's Choice out of a dam by Rosedale's Choice now heads the herd. The ancestry of the Rees cattle is of the best.

Joseph J. Sobke, Bushong.*-Four years ago $\mathrm{Mr}$. Sobke made his start and he now has thirty females. The cattle are raised under favorable conditions and are given reasonably generous treatment. In 1918 a nice addition of five females was made by purchase from T. A. Ballantyne and in 1919 a consignment from the herd was made to the Eastern Kansas Breeders sale at Ottawa. Mr. Sobke went to a splendid herd, that of S. D. Mitchell, for his bull. He is the son of Victoria's Best, a Leonard bred son of Marengo's Choice. His dam is Orange Best 6th, a cow bred by T. C. Robinson, the breeder of Master of the Grove, International grand champion.

\section{MARION COUNTY}

J. R. Ely, Marion.†-The Ely family has been raising Shorthorns in Marion county for more than twenty-five years and J. R. Ely just grew into the business. He has a stock farm with plenty of pasture, alfalfa and ensilage and is in a position to get results from the farm feeds. His herd is largely descended from the original

\footnotetext{
* Telephone, Allen.
}

$\dagger$ One mile east of Aulne. Telephone, Marion or Aulne. 
purchase made by his father which came from the best herds in the surrounding territory and an occasional female is being added. The cows are of good size and the twenty yearling heifers seen in one pasture are an attractive lot. The production of this herd furnishes an example of what a young man did at very little more expense than would have been incurred in raising grades and the net profits have been much greater. In quality and size the cattle are quite even, but I noticed one cow that would attract attention anywhere. She is similar in breeding to the rest and is by Pride of Aulne, a C. W. Taylor bred bull by Silvery Knight. Three daughters of this five-year-old cow are in the herd and all promise to develop into cows of her type and quality. As a foundation this cow and her heifers are a fine prospect.

In general, Mr. Ely has used bulls of good type and breeding and has obtained very satisfactory results. Two came from D. P. Norton. Crescent was by Buccaneer out of a cow by Cora's Commander 102268 and the other was by Lord Lieutenant 120019. Knight of Hope was by Jubilee Knight bred by the Kansas State Agricultural College. Golden Mariner by imp. Mariner and Aulne Duke by a son of the Harris bred Vandal were two of the bulls last used. A first-class young bull was secured, April 1920 in Red King bred by Jos. Duncan \& Son. He is 
of the best of the well known Duncan breeding and is an unusually thick, smooth individual with a pedigree that would please the most critical. Coupled with the strong, rugged cows raised in this good cattle country, this bull of almost unrelated blood should get results of a most satisfactory kind.

E. C. Schafer, Marion.*-Mr. Schafer has been breeding Shorthorns for twelve years, having bought his start from H. S. Martin. This purchase included two cows from which the herd is largely descended. Lady Fogathorpe 48th, a Bates cow of B. B. \& H. T. Groom's breeding was by Scotch Duke, a Stodder bred son of Gwendoline's Prince, out of a dam by Mr. Vaile's well known Winsome Duke 11th. The other cow was by Duke of Evergreen 8th, a son of Glen Aberdeen 128626 out of imp. Glen Ythan 4th. These Scotch crossed Bates cows have always been reliable material for a foundation and they have proved to be so for $\mathrm{Mr}$. Schafer.

Desirable bulls have been used and the conditions for general development are favorable. One of the best bulls that did service in the herd was Comet, a son of Double Champion, the well known son of Choice Goods and Russella, dam of the undefeated Ruberta. Comet's dam was by Liberty Boy bred by Senator Wornall and sired

One mile from Canada station on Santa Fe. 
by Viscount of Anoka, the outstanding show bull of his day. Scotty, bred by Ballantynes, was also a good sire. Golden Crown, bred by H. C. Stephenson of Chase county, was the son of Hampton's Crown by Hampton's Best and Golden Crown's dam was by Rosemary Victor 12th, a Geo. Bothwell bred son of Grand Victor.

The present herd bull is named Albert. He comes from John Regier's and like all Mr. Regier's output is very desirably bred and of good size and quality. His sire is Dale's Emblem by Double Dale out of a dam by Snowflake, the sire of Ringmaster. Albert's dam was also bred by Mr. Regier and is by Nonpareil Star, a prize winning son of imp. Nonpareil Victor, a bull with few equals as a sire in America. Albert had been used locally for several years and Mr. Schafer bought him on account of his real worth. General improvements both in management and in additions to the herd have been planned.

F. N. Funk, Canada.*-Mr. Funk's herd consists of five females bought from H. C. Stephenson and he will raise his cattle from these and from others which he intends to buy. The Stephenson herd was an excellent one and these cows are no exception. In looking over their pedigrees I found the source of their wealth revealed in the top crosses, through such bulls as

* Telephone, Marion or Hillsboro. Ship on Santa Fe or Rock Island. 
Barmpton Knight, Gallant Knight and Gallant Knight's Heir, all well known in the Tomson herd, Banker, bred by John McCoy, Golden Knight of Enterprise, Peculated Wild Eyes, said by good breeders to have been the equal of the best Scotch bulls of his day, Good Choice, sire of grand champions, Grand Victor, Hampton's Best and Choice Goods. That cows from such ancestry are valuable as breeders is an established fact. The present herd bull is on trial as all young bulls should be. While he promises to be fairly satisfactory, it has already been decided to replace him with a high-class bull.

Mr. Funk impressed me as a man of more than average energy and ability with a determination to breed good Shorthorns and in this he should succeed, for he has the fundamental elements needed for success in his lot of cows and plenty of feed, including alfalfa.

B. L. Taylor \& Son, Peabody.-Not many herds of four years existence are as good as the herd on Fairland Farm and not often is the young stock so well cared for. The result of this policy clearly forcasts an excellent herd for the future. Among the best cows are the eight-yearold Nevius bred Victoria by Searchlight out of a dam by imp. Prince Oderic and the Bellows bred Scotch Lavender $2 d$ by Good Choice, dam by Victorallan and Nellie's Lassie from the

* Telephone, Marion or Hillsboro. Ship on Santa Fe or Rock Island. 
C. C. Cochran herd by Grand Lad 260127, that give some indication as to the character of this herd. The first bull used was Buster Gazelle. He was by Ingle Lad Jr., a son of Ingle Lad out of. Sweet Mistletoe, dam of Lespedeza Collynie, the 1919 International grand champion.

A. L. Cumberland bred by John Regier is now being used. He is an unusually short-legged, thickset fellow and was one of the good bulls in the 1918 American Royal sale. His sire is Scotch Cumberland by Cumberland's Type recently sold as an aged bull to S. M. Knox for $\$ 1000$ and his dam is of the excellent breeding of all Mr. Regier's cows. The Taylors have been successful contributors to the breeders' sales held at Peabody and are for everything that tends to advance Shorthorn interests, which makes them desirable acquisitions to the fraternity.

F. P. Wilson, Peabody.-Mr. Wilson is a new breeder that has made much more than ordinary progress. His first Shorthorns were bought at the Stunkel dispersion in 1916 and with these cows he was unusually successful, the calves at foot having sold within eight months at the Wichita sale for enough to pay the bill.

Mr. Wilson added to his herd by purchase at the Park E. Salter fall sale in 1918, three head: the Nevius bred Strawberry Secret 4th by Searchlight Jr., dam by the Hanna bred Fortune, a son of imp. Collynie out of a Lord 
Cowslip cow ; Superb Augusta by Superb Omega, a son of Uppermill Omega, dam of Norwood Augusta by imp. Crescent Knight out of imp. Augusta 105th and a Canada bred cow by Prince of the Byre out of a dam by Nonpareil Champion. The recent purchase of a massive, smooth, red cow by King Cumberland by Cumberland's Last was made from J. C. Robison's herd. This daughter and granddaughter of International champions, if prolific, should add much value to the establishment. Mr. Wilson owns, with Mr. Homan, the bull, White Hope, and has been getting good results from his use. Six yearling heifers by him all nice roans of the same type and very similar in appearance, prove him a firstrate sire. - Indications are that this herd will be constantly improved.

John Unger, Peabody.-Either Mr. Unger has used exceptional judgment in laying his foundation or he has been lucky. Two of the cows he bought are not only choice in quality but they carry very attractive pedigrees. One came from John R. Young of Marion. Her sire was Roan Victor, a grandson of Whitehall Sultan, out of a cow by Secret Goods by Best of Goods. Her dam is by Clara's Choice, son of the Choice of All and imp. Clara 58th. The next three crosses represent what is best in modern Shorthorns. The other cow is from the Homan herd. She is by White Hope; her dam by Double 
Champion, followed by imp. Ardlethen Mystery, imp. Invincible and imp. Hospodar. Mr. Unger will add a few choice females and until he secures a first-class bull of his own he will use B. L. Taylor's herd bull. (See Taylor sketch.) Both Mr. and Mrs. Unger are enthusiastic about Shorthorns and nothing less than an excellent herd will satisfy them.

\section{MARSHALL COUNTY}

\section{H. J. Bornhorst, Irving.-Mr. Bornhorst is a} man of unusual energy and ability. Ten years ago he began breeding Shorthorns on a rented farm near Marysville and the character of his herd as seen in 1919 indicates clearly that he was a good judge of beef cattle when he bought his foundation stock. That he is a first-class cattle man is shown by the admirable way in which he handles his stock. Early in 1920 he moved to a big ranch which he bought near Irving and on this land he has what is almost a cattle paradise where Shorthorns will do their best.

Mr. Bornhorst has a lot of cows that are descended from choicest ancestry, consequently the bulls from his herd can be classed as dependable because whatever merit they may possess is inherited and almost certainly will be transmitted to their get. Some of these cows are bred along fashionable and popular lines and practically all are good individuals. I was especially impressed 
with Missie Dale, an Owen Kane production. She is a daughter of Marengo Dale, a son of Double Dale, one of the most noted of Avondale's get and the sire of many great herd bulls. Marengo Dale is out of Lady Fragrant, a daughter of imp. Lady Marengo, and the dam of Missie Dale is by King Archer, a son of Ceremonious Archer, one of the outstanding bulls of the breed. That this cow is a valuable breeding proposition is shown in her white bull calf, a young fellow of much promise.

The bull now being used is Roan Goods, one of the best things produced by G. F. Hart. He would stand ligh in a fairly strong show and looks every inch like a good breeding bull and his calves, as far as can be judged at a young age, indicate that he will fulfill all that his appearance promises. His sire, Scotch Knight, is one of the best sons of imp. Scottish Sentinel and he is out of one of Mr. Hart's best cows. Mr. Bornhorst is among the most optimistic men I have ever met for he does not seem to think there is any such thing as being unable to succeed. His fondness for Shorthorns is part of his nature and it would be out of place to question his success.

A. H. Gallup, Blue Rapids.-In 1888 George Gallup bought Jennie Rivers from the herd of R. T. Scott and from this cow is descended the entire herd now on Hillerest Shorthorn Farm. Thousands of dollars worth of cattle have been 
sold besides. This is the only case of which I know where a whole large herd is descended from one cow. Among the bulls used was Violet Lad by Golden Lad, a son of Robert Miller's great Golden Rule and the noted cow Germanica 2d, a daughter of imp. Germanica. Another was Defendant, a son of Tomson's Crusader by Barmpton Knight and out of Daisy of Valley Grove by Lavender Prince out of Forest Daisy 2d. New Year's Delight, that as a yearling heifer was grand champion everywhere in the West and junior champion at the International, was out of Forest Daisy 2d. As Crusader was by Barmpton Knight, the relationship of Defendant to this great heifer is very close. The present herd bull is Village Victor bred by Tomson Bros., sired by Village Marshal and out of a cow by the H. C. Duncan bred Orange Magnet 263743, second dam by his well known Headlight. Village Victor is of the large type with heavy bone and plenty of stretch. $\mathrm{He}$ is smooth, symmetrical, and splendidly covered. He should cross well with the smooth, medium-size cows in the herd and add a little scale, always a desirable attribute.

Griffee Bros., Marysville.-Although these men began business only two years ago they have gotten together quite a nice herd. The cows are sired by True Goods by the famous sire, Fair Goods, son of Choice Goods and Ruberta; 
Blythesome Baron by Victor Baron out of imp. Blythesome 27th; Lord Hampton by My Choice by Good Choice, sire of the champion, Diamond Goods; Crown Prince by Royal Diadem a son of imp. Red Lady 5 th and others of like quality. A daughter of Fair Acres Sultan is by virtue of her sire one of the attractions of the herd. She has not been well grown out but is straight and smooth and is a good producer. The cows as a whole have straight lines and fleshing quality and the condition of the calves indicates that they are heavy milkers.

Two bulls are being used. One is Secret Sultan $2 d$ bred by Achenbach Bros. and sired by their well known Intense Sultan. His dam is by Secret Conqueror, son of imp. Conqueror out of a Lord Lovel dam, second dam by Choice Goods. $\mathrm{He}$ is a big, beefy fellow, strong in the vital points but a little lacking in finish. His calves, however, appear to be unusually smooth and are quite promising. The younger bull in service is by a son of Maxwalton Rosedale out of a daughter of imp. Crescent Knight. He is strong in the blood of Barmpton Knight and old Lord Mayor. The outlook for the success of Griffee Bros. is favorable.

J. M. Nielson, Marysville.-Mr. Nielson is secretary of the Blue Valley Shorthorn Breeders Association. He has been breeding for seven years and has a desirable lot of cows, not so 
uniform as he wishes but of good quality. An outstanding, large red that has been a satisfactory breeder is by Baby Conqueror bred by Senator Wornall by The Conqueror, the son of Choice Goods and imp. Clara 58th. An excellent white two-year-old is by Pleasant Dale Sultan by Lavender Lord. She has a good heifer calf. Another Pleasant Dale Sultan heifer is Lady Sultana, by some considered the best thing on the farm. The S. B. Amcoats herd furnished a yearling by Type's Goods, the son of Cumberland Type. Her' dam is by Victor Sultan 2d out of a Godwin dam, giving her unexcelled breeding from almost any point of view.

A roan bull, bred by $H$. H. Holmes, was in service for two seasons. He was by Clipper Model 444189 and his dam was strong in the blood of the noted sire, Captain Archer and other good bulls. A new bull was purchased at the 1920 Central sale. He is a beautiful roan bred by H. I. Gaddis and was a wimner in the show which preceded the sale. He is a calf of unusual finish and smoothness of flesh and comes from a line of cows noted as producers in $\mathrm{Mr}$. Gaddis' herd. His sire, Secret Baron, is by Snowstorm, probably the best breeding son of Snowflake.

Dan O. Cain, Beattie.-Mr. Cain began his Shorthorn operations when a boy and he still has a long life of usefulness before him. His 
foundation stock is carefully selected. Cassandrea Maid was bred by Henry Kupper and sired by imp. Scottish Sentinel. Nonpareil Alice, five year's old, is by Snowflake's Stamp, son of Snowflake, sire of the three times International grand champion, Ringmaster. Birdie Gloster 8th, a six-year-old red, is by Scotch Knight, a son of imp. Scottish Sentinel. The cows range in size from medium to large and the twenty females in the herd include some animals of choice breeding that are being properly cared for. The first bull used was Orange Banker $2 \mathrm{~d}$ by Dale's Cumberland. White Goods 825293 is now in service and is considered by Mr. Cain a splendid bull. He is by Gloster's Goods, son of Ruberta's Goods, the sire of much high-class stock shown successfully all over the central West. Mr. Cain should be able to make his Shorthorn business a very creditable one and reap a reward such as comes to the man who lays a strong foundation and cares well for his stock.

\section{McPHERSON COUN'TY}

Owen Oneill, Windom.-When in company with V. M. Emmert, county agent, I drove up to Mr. Oneill's, we saw a last October bull in the lot with a halter on and he looked good. This is a trifling incident and I mention it only to show that the cattle on this farm are being handled with a view toward real development. We 
had been seeing young bulls left to shift and to fight flies and this one that had an owner who did the rustling was elegant in comparison.

Mr. Oneill has been breeding Shorthorns for six years. He has been successful in producing quite good ones but his greatest success lay in a deal made in 1919 whereby he acquired ten young cows bred by E. H. Abraham. (See Abraham sketch.) I saw a number of these cows and they are just the kind the experienced man would select if he were looking for a lot of prospective breeding cows. They are to be the basis of future operations. In their ancestry they have the benefit of the splendid lines of bulls used in the Abraham herd, prominent among which are Diamond Victor, whose sire was sold by Tomson Bros. for $\$ 2000$ in the days when such sales were almost sensational, and whose dam, Daisy Queen by Barmpton Knight was a Western state fair and American Royal champion. Another bull of national reputation, entering into the immediate ancestry of these cows, is Bessie's Heir by Orange Viscount, the sire of Searchlight and out of imp. Bessie 51st, the dam of White Goods. (See S. D. Mitchell sketch.)

Mr. Oneill has been equally fortunate in getting a herd bull. Lavender Search is a remarkably smooth, even, well finished fellow, with a very deep body on unusually short legs. He has proved a breeder of good stock and has inherited 
this quality as well as his power of transmission. His sire is Searchlight, one of the most popular of Kansas bulls. His dam is by Choice Goods, one of the greatest show and breeding bulls of America. His second dam is by imp. Lavender Lad and his third dam by Golden Rule. Lavender Search did four years service in Fred Walton's excellent herd.

Luther Elmquist, Lindsborg.-Mr. Elmquist is comparatively a new man in the Shorthorn business. He bought a few cows of Peterson Bros. and of other local breeders, on which he used a Tomson bred bull with good results. He is now using a thick, short-legged bull by Orange Lovell, a son of Henry Stunkel's Victor Orange, one of the best southwestern bulls of his day. His dam is by Valiant 346162, whose sire, St. Clair, was by imp. Crescent Knight.

Mr. Elmquist impressed me as a man of quick apprehension, with a realization of the need of good cattle on the farms in his locality. He holds sound views on live stock management and comprehends what many men fail to see, that one can not expect cattle to grow without sufficient feed to produce growth. $\mathrm{He}$ is enthusiastic about Shorthorns and understands that the bull is half the herd. He is situated so as to carry out a liberal policy in the care and management of his cattle and satisfactory returns may be expected from the cows he has selected. 
Carl Johnson, Inman.*-In Mr. Johnson's herd there is a promising heifer a little more than a year old. She is by the excellent Cumberland bull, Marquis Cumberland. (See Willis Colman sketch.) As though it were a matter of small importance Mr. Johnson told me that she had stood third or fourth at the Kansas State Fair last fall. From what I have seen of the Marquis Cumberland stock, I should think this heifer would make an extra good one. The bull in use is by Victor Archer, that made a reputation for Dr. Stewart. Mr. Johnson intends to build up a first-class herd and he has the facilities for doing so.

Anton Peterson, Lindsborg.-Mr. Peterson is the successor of Ingwert Peterson and of Peterson Bros. He has twenty good cows and their calves. These cows are nearly all the tops of the Peterson Bros. herd and they have plenty of size. They are descended from a line of bulls beginning with such sires as Col. Harris' Golden Knight, Geo. Bothwell's Grand Victor, imp. Thistletop and imp. Collynie, all animals of national reputation. The use of good bulls on this foundation has given satisfactory results. Mr. Peterson is looking for a high-class bull and with the herd reduced in size he is planning to give his cattle such attention as will develop

* Telephone and station, Windom. Ship on Santa Fe or Rock Island. 
first-class cattle. His farm is well suited to the work.

\section{MIAMI COUNTY}

Frank W. Wilson, Wellsville.-Mr. Wilson has been known as a breeder of good Shorthorns since 1914, but it was not until the day of the Nevius sale in 1920 that he made purchases which attracted the attention of breeders over the entire territory when three of the best females in the excellent offering fell to his bidding. Winifred Maid 4th is by Emma's Valentine, a son of Prince Valentine 4th, out of the cow that produced the dam of the grand champion, Lady Supreme. She is large and attractive and $\mathrm{Mr}$. Wilson secured a prize in this two-year-old and her calf. Searchlight Maid, a daughter of Searchlight Jr. and out of the best cow in the Nevius herd, is a show cow and an exceptional producer, as her November calf at foot plainly indicated. Victoria S. is by that well known sire New Goods, by Choice Goods out of a Collynie cow. Her dam is by Choice Goods, second dam by imp. Baron Cruickshank. A better lot of foundation cows could hardly be found.

Rosedale's Secret is the bull used. He comes from Robert Russell's herd and is by his excellent sire, Walnut Type. (See Russell sketch.) His dam is the splendid cow, Queen's Gift 523258 by Rosedale's Gift. Mr. Wilson has the 
knowledge and experience, as well as a suitable location to enable him to score a signal success with his cattle.

\section{MITCHELL COUNTY}

Meall Bros., Cawker City-Meall Bros. have one of the large, well known herds of the state and their operations cover a period of twentyfive years. The cattle receive the constant attention of the three brothers who comprise the firm. They have provided all facilities for handling cattle in a practical, economical and careful way and their system results in the production of young stock so raised as to do well for the purchaser and yet to have sufficient development. Further improvements are being considered and these mature men of successful experience, still in the prime of life, will do things in the future that will count for Shorthorn advancement not only in Mitchell county but in a larger territory.

The Meall herd is a good one as a whole, but it lacks somewhat in uniformity both in the essential and in the less important points. This is doubtless largely due to the fact that in recent years several excellent cows from different sources have been added. It is from these, rather than from the old foundation of a quarter of a century back, that the herd of the future will be built. The use of bulls of uniform type 
and of good size can safely be depended upon to do the work and is doing it.

I saw at least ten cows of very choice breeding that should be good enough for any man and the calves they are raising qualify them as firstclass Shorthorn cows. Glen Hall Aconite 4th 211769 is by Choice Prince, a son of Prince of Tebo Lawn out of Good Lassie by Choice Goods. Her dam is by Leader 378375 and her second dam is by the grand champion, Master of the Grove. Glen Hall Aconite is not only a splendid individual but is the dam of several of the best heifers in the herd. Fairy Dawn by Upland Viscount (see below) is an extra smooth cow. Her dam is by Snowflake's Star by Snowflake and her second dam is by imp. Prince Oderic. Highland Mary, a roan by Snowflake's Star out of a Prince Oderic dam, attracts attention on sight and is one of the highly prized members of the herd. Miss Marigold 3d, a large red of elegant appearance with a big, deep, smooth body would be considered attractive anywhere. She is by Victorious King by Mr. Gentry's Victorious and her dam is by Lord Mayor out of imp. Marigold 50th.

Two fairly good bulls had been in use. The desire to own a strictly first-class herd bull was gratified at the State Association sale at Manhattan in 1920 where Meall Bros. purchased Lavender Marshal for $\$ 1025$, the top price paid for 
a bull. Lavender Marshal was grand champion of the state show. He is by Tomson's outstanding sire, Village Marshal, out of a Rees bred heifer strong in the blood of Ruberta's Goods and Choice Goods. The selection of this calf seems wise as his ancestry is second to none in America.

H. Borger \& Son, Cawker City.-From a purchase of two heifers bought for less than $\$ 100$ fifteen years ago, H. Borger \& Son have forged ahead until their herd is one of the best in north central Kansas. This growth has been accomplished by later purchases of choicely bred stock, by using good bulls, and by a liberal system of development whereby medium size and uniformity have been attained. Golden Dream is an excellent cow by Athenian Coronet 4th, a firstclass bull by imp. Bapton Coronet out of Augusta 111th by Scotch Fame. Her dam was by Prime Minister, a son of imp. Prince of Perth out of a full sister to the International grand champion, Lavender Viscount. A daughter of Golden Dream by Ury Dale is one of the best things in the herd. Rosedale's Jill is a choice daughter of Maxwalton Rosedale, the full brother to the grand champion, Whitehall Rosedale. Her dam, Jessica, is still one of the best producers in the herd. Golden Maid, one of the valuable cows on the farm, is by Golden Gloster, a son of imp. Daydreams Pride. Her dam is Ruby Lass 2d 
by imp. Trout Creek Clan Alpine and out of imp. Ruby Lass. Lassie's Choice is one of the highly prized cows. She is by the International

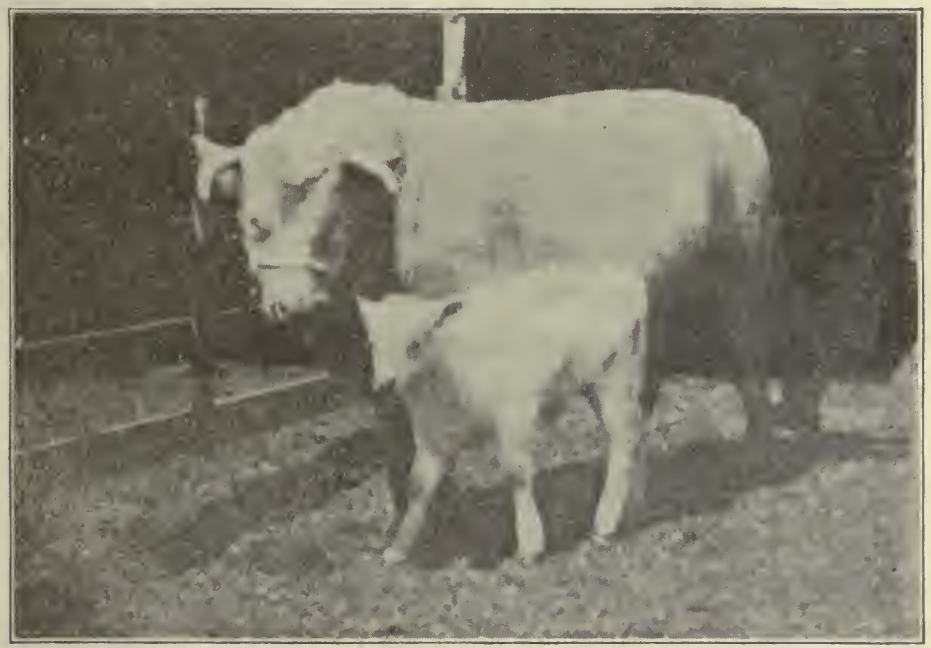

FAIR CHAMPION AND THE FIRST CALF HE SIRED

This calf now heads the herd of E. A. Cory \& Sons.

grand champion, Lavender Viscount and out of Buchan Lassie 6 th by Buchan Hero.

Although in the early period of the herd's existence good bulls from good herds were used, yet advancement has been made in this respect. About six years ago Borger \& Son bought of Howell Rees the roan, Fame's Goods, a son of Ruberta's Goods, one of the great sires of the United States. Fame's Goods is out of imp. Princess Fame. He proved an excellent sire and was followed by Fair Champion, a son of the 
noted Fair Acres Sultan. Fair Champion is very popular among Shorthorn men and will do his share toward boosting the Fair Acres Sultan family. One of his daughters from the Borger herd, only a little past a year old, sold at the Royal sale in 1919 for a big price written in four figures.

George W. Bemis, Cawker City.-These cattle are exceptionally well kept. The cows are even in size and conformation and conditions for developing a first-class herd are unusually favorable. Ury Dale, a well known son of Avondale, has done service in the herd and has left an impress for good, quite apparent to the visitor. Mated with daughters of such bulls as Prime Minister by imp. Prince of Perth out of an own sister to Lavender Viscount; Proud Orion, T. P. Babst's son of imp. Daydreams Pride; Golden Prince, the Dryden bred son of Prince Gloster, sire of the $\$ 10000$ Prince Imperial and numerous others of similar quality, results could not be disappointing. The output of the Bemis herd has been well appraised by the buying publie wherever offered.

C. L. Hendricks, Glen Elder.-"Shorthorns for beef and milk" is Mr. Hendricks' slogan and with ten females and an outstanding bull he will proceed in the production of that kind of cows. Matchless Collynie was first prize bull in the Milking Shorthorn class at the Denver Live 
Stock Show in 1919. He comes from the Kansas State Agricultural College and is by Matchless Dale, sire of more prize winning and grand champion beef steers at the Royal and International than any other trio of bulls of the breed. Matchless Collynie's dam, Cream Toast, would make a strong show in beef classes, yet she gave more milk during the test now under way at the college than any other of the twenty good milking cows in the herd. Her sire is Ingle Lad, every one of whose daughters is a great breeder of beefy Shorthorns and every one is a heavy milker.

E. W. Runft, Cawker City.-Mr. Runft is a new man in the Shorthorn business. He has youth, a good location in which to build up a herd, and the determination to have a good herd. His cows carry prestige through their sires. He has daughters of Missie's Sultan, son of Victor Sultan out of Sinnissippi Missie; of Fame's Grods, son of Ruberta's Goods and imp. Princess Fame and of Sir Hugo by Snowflake's Stamp 350358 out of Fairy Daybreak 2d. His herd bull is Happy Prince, a Tomson bred son of Prince Valentine 4th, a show and breeding bull of the first class. Happy Prince is out of Harmony 18th by Golden Day, half brother to Sweet Mistletoe, dam of the $\$ 4100$ Imperial Mistletoe and Lespedeza Collynie, International grand champion in 1919. 


\section{MONTGOMERY COUNTY}

H. M. Hill, Lafontaine.*-Those who have read the H. M. Hill sketch in Part I will be aware of the fact that a splendid foundation for a real Shorthorn herd was well laid. Those who have not read it are asked to do so before reading this. Sycamore Springs Farm is almost an ideal home for cattle. The best quality of grass, an abundance of spring water, good alfalfa land, two silos and natural shelter furnish the means of producing the best kind of cattle.

About forty high-class females and two bulls are kept on the farm. Some of these cows have an individual history, not only as great specimens of the breed but as great producers. A number of them are considered foundation cows for the herd. Among those so classed is the big roan, Wistful, by Collynie out of Wistaria by Royal Knight, second dam, Spirea by imp. Royal Pirate. (See Hanna sketch.) She has to her credit a dozen calves. Every one of her bulls went to head a good herd at a good price and her heifers grew into good cows that are regular breeders. This cow, though fifteen years old, suckled a calf last summer and hardly looked her years. Her pedigree, whether from the viewpoint of present popularity or of individual merit in ancestry could not be excelled and a lot

* Ship on Mo. Pac., Santa Fe or Frisco. 


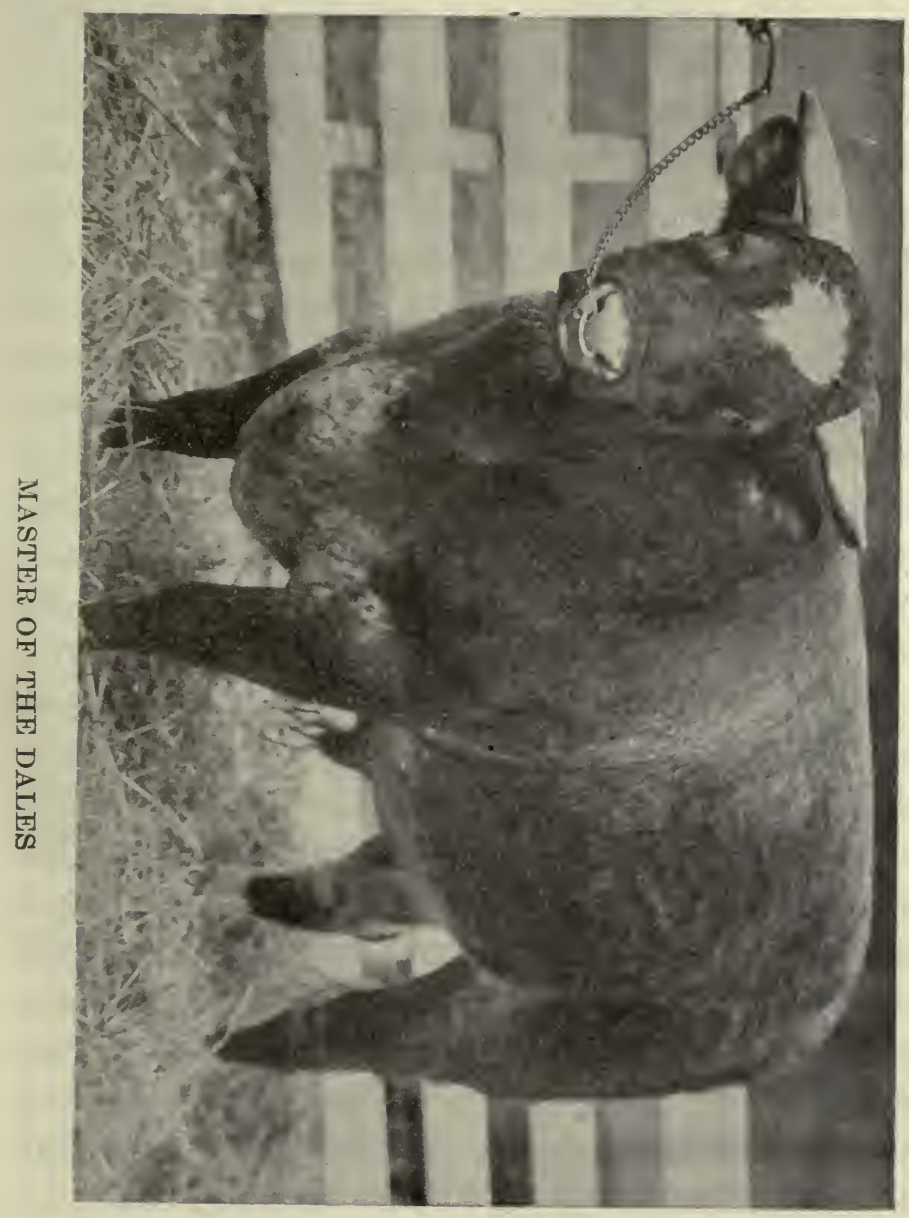


of young cows of her breeding, size and quality would be almost invaluable.

I might continue in this way with a number of the cows but shall call attention in detail to only a few. Princess Columbia, an elevenyear-old, 1800 pound cow on grass alone, is the only daughter of Prince of Collynie left in the herd. One of her bulls, Kansas Prince, is the sire of a sensational lot of calves shown by $O$. O. Massa at the Southeast Kansas Shorthorn Show at Coffeyville in April 1919. Another, a three-year-old bull now used by Barrett \& Land, is one of the best young bulls I have seen and reminds me of old Prince of Collynie, his grandsire. Another Collynie cow in the herd is the roan, Emily, sold as a heifer to Bellows Bros. for $\$ 500$. She raised the bulls that for three years topped the Bellows sales and was bought by Mr. Hill in one of their sales as a ten-year-old cow for $\$ 1000$. Sycamore Spiraea, also by Collynie and an own sister to Prince of Collynie, is another massive 1800 pound breeding cow with numerous descendants in the herd. Still another Collynie cow is Sarcasm that went from Mr. Hanna's to Bellows Bros. and found her way back to Sycamore Springs. She is a typical big Shorthorn.

This sketch might become tiresome to those who are not Shorthorn enthusiasts if I should undertake to tell of each of the animals, 
individually, especially since the cows mentioned are foundation stock and will suffice to indicate the quality of the herd. A valuable addition was made at the Holmes-Harris sale in November 1918. Crystal Maid, bred by J. F. Stodder and sired by Captain Archer, one.of the best bulls of the breed and out of the show cow, Innocence, by Mr. Nelson's imp. Bapton Arrow, was bought at the top price of the sale. This cow is not only by the sire of show stock of international repute and out of a show cow sired by a wonderful bull, but she'herself has a showyard record not equalled by any other Kansas cow now living. In addition to this she is very prolific and an excellent breeder and she, as well as the calf annually shown with her at the Kansas State Fair, has excited the admiration of the Shorthorn fraternity.

At the Gillespie sale where a rare collection of top cows called out buyers from many states, Mr. Hill bought three excellent cows by Hampton Spray. They were all bred to Roan Lord, the son of Maxwalton Roan Lady and were selected with the view of getting a herd bull for use at Sycamore Springs. Three bull calves are now following these cows in the pasture and are being closely watched for development. That they are good prospects goes without saying.

The sketch above was written in June 1919 and it applies now as forcibly as it did at that time.

Mr. Hill is not partial to any blood lines to 


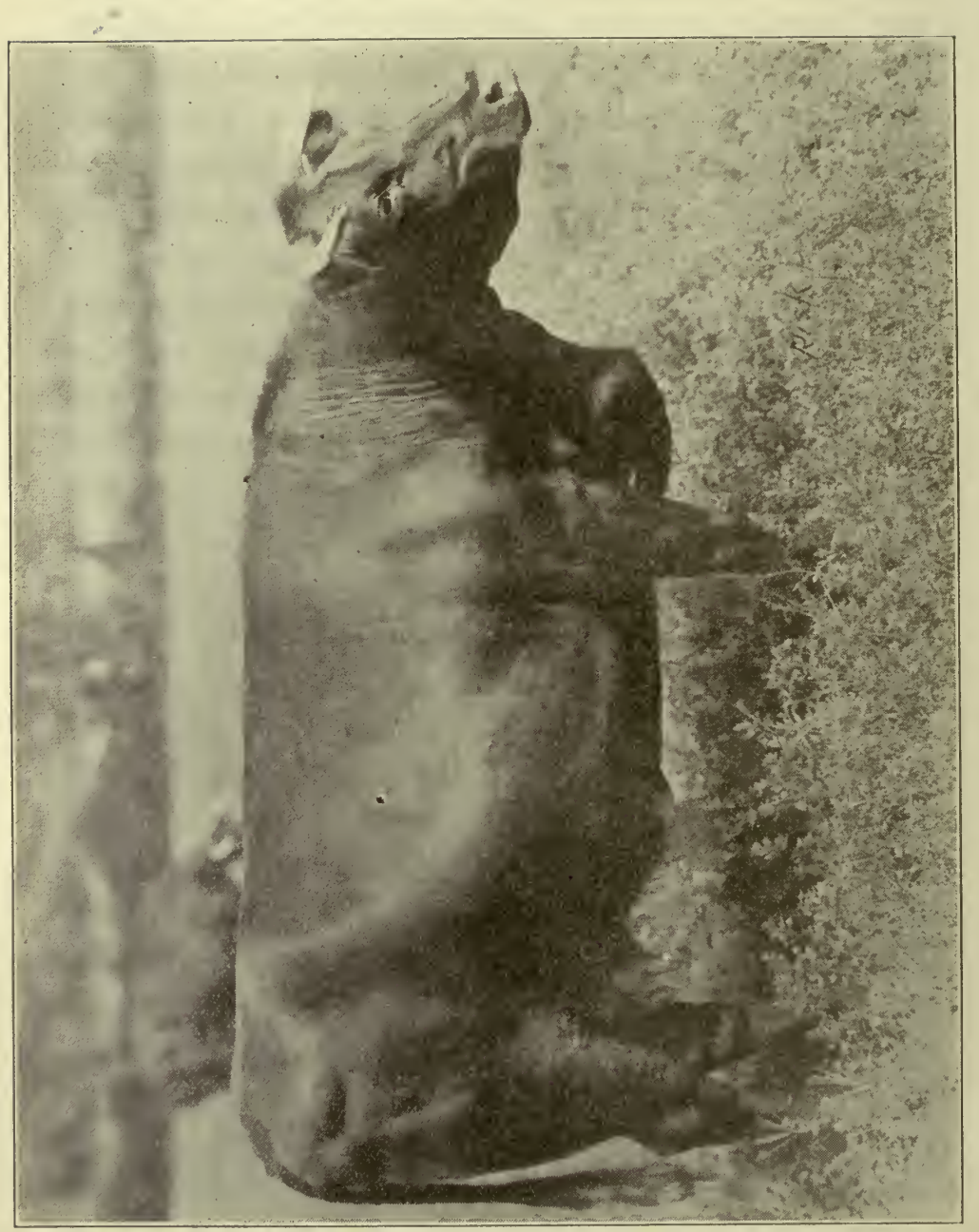

年 
the point of placing individual merit second. $\mathrm{He}$ recognizes, full well, that the Scotch cattle saved the American Shorthorn, but he refuses to accept the theory that all merit rests in the so-called Scotch families. On this farm are found several very valuable cows and their descendants that come from Mr. Vaile's noted importation from the J. I. D. Jefferson herd. These cows are by Secret Archer, a full brother to Wistful, mentioned above. The two-year-old heifer, that in John Kramer's herd won top honors and sold at

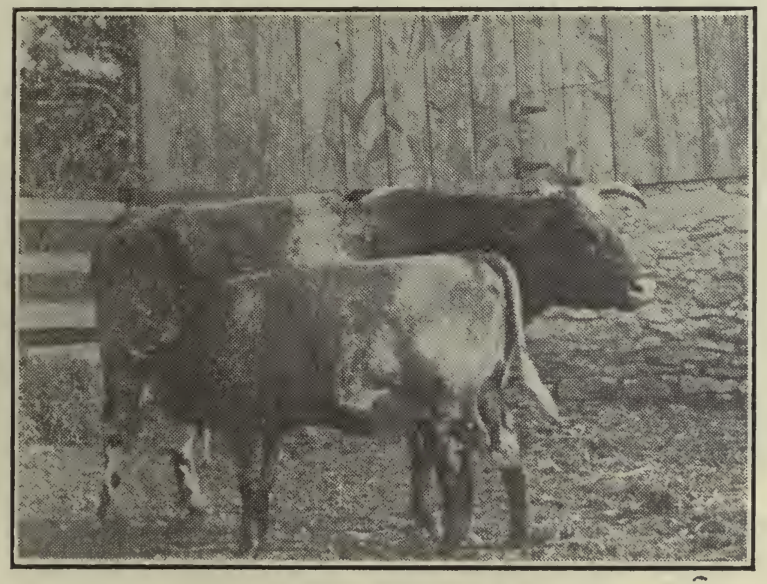

GAZELLE 8TH AND CALF

Noted prize winners have come from this family.

the American Royal Sale in November 1918 for $\$ 1250$ for export to South America was out of one of these cows and by Mistletoe Archer, a bull of Mr. Hill's breeding. He is selling with 
regularity his calves from these and other cows of similar breeding at the same scale of prices as those from Scotch families. As a matter of fact, the blood lines and the individual merit are the same.

Among the bulls in recent use at Sycamore Springs was Mistletoe Archer by Prince Royal, Mr. Hanna's son of imp. Collynie and imp. Princess Royal 62d. Mistletoe Archer's dam was

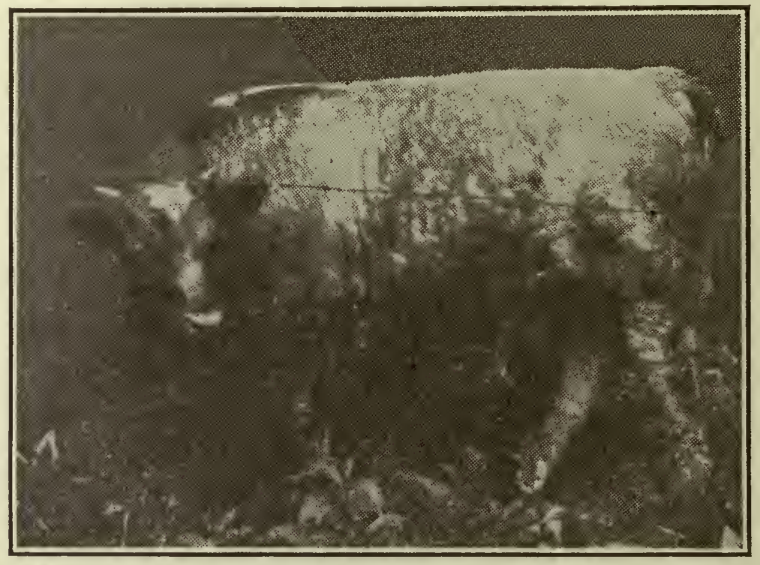

A SAMPLE OF SYCAMORE SIRINGS PRODUCTION

Sweet Mistletoe also by Collynie and out of imp. Mistletoe 15th. Sweet Mistletoe is not only an own sister to Captain Archer and Pride of Collynie, but she is the dam of the $\$ 4100$ Imperial Mistletoe and of Lespedeza Collynie, the 1919 International grand champion. Mistletoe Archer 
proved an exceptional sire and several young cows of his get are on the farm.

In 1915 it seemed advisable to introduce a bull of new blood for use on the strongly bred Collynie cows and Master of the Dales by Avondale was bought of Forbes \& Son. A full brother to this bull made quite a reputation in the Robbins herd and the calves in the Forbes herd by Master of the Dales gave Mr. Hill reasonable assurance that the bull would be a success with him. In this he was not disappointed for Master of the Dales has corrected the only serious fault urged against the get of imp. Collynie, a plainness in the hind quarter and, while I have seen few of his get older than yearlings, I was much impressed with their uniformity. They have been in great demand at good prices which indicates that they are prime favorites with the buying public. In numerous instances a high price has been fixed on the heifers purposely to retain them in the herd, but even then buyers have taken most of them away.

It may readily be inferred from the preceding statements that Mr. Hill holds in high esteem the get of Mistletoe Archer. In fact he was sold before his real worth as a sire had been demonstrated. The old bull being no longer available, Mr. Hill has bought back one of his sons and he is being liberally used this season (1920). This bull is a big, stretchy roan out of Ingle's Secret 
by Ingle Lad and, barring the possibility of too close a relationship with the Sycamore Springs cows, he should prove an outstanding sire, for his immediate ancestry consists of Shorthorns remarkable for size, beefiness, milking quality and smooth covering of flesh.

I have perhaps spoken at greater length of $\mathrm{Mr}$. Hill's operations because I have had occasion to

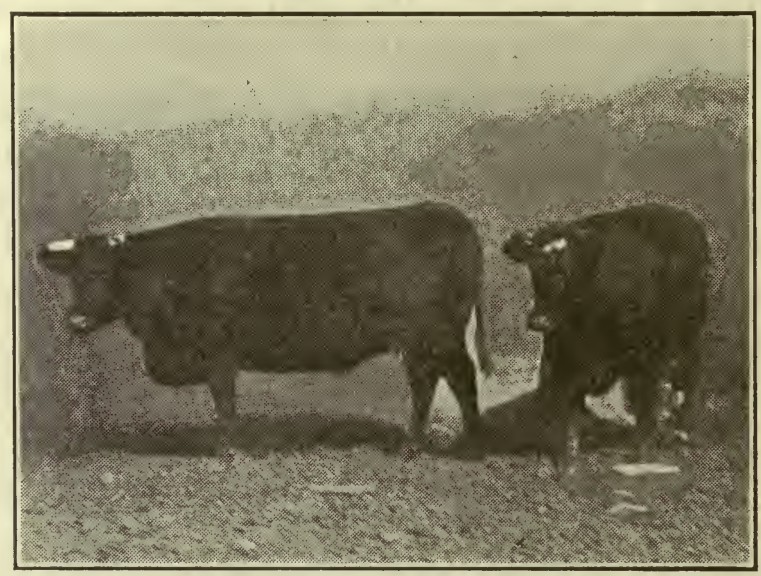

TWO OF THE COWS THAT LEFT SYCAMORE SPRINGS STOCK FARM AND MADE A REPUTATION AS GREAT PRODUCERS

Left-Princess Airdrie sold to go to Montana where she produced cattle that were excellent winners in the big western shows.

Right-Sweet Mistletoe, sold to Lespedeza farm in Tennessee where she produced Imperial Mistletoe, leading American show bull, sold for $\$ 4100$ and Lespedeza Collynie, the 1919 International grand champion.

become familiar with his work and from frequent inspection I have come to know the herd quite well. I might suggest that had he kept his best females, instead of putting a price on 
them and letting them go, in most cases where they were lost to the breed, he would have substantially advanced his interests as a breeder.

When I think back over the great array of cows and heifers that have been sold from this herd, that if retained would have given material such as few breeders ever gather together, I am inclined to state as my best judgment that had Mr. Hill's make-up been such as to exclude commercialism, the Sycamore Springs herd would stand today with few rivals. I do not question his success as a breeder for not many men in Kansas can show results such as he has shown. I am only thinking that selling such cows as Sycamore Secret, Collynie Violet, Sweet Mistletoe and others I could mention, and pricing his best young cows and heifers only to have them taken off the farm, may be good business but it certainly has limited his possibilities as a breeder.

Mr. Hill, while enthusiastic for Shorthorns, is also a leader in all things pertaining to rural life. $\mathrm{He}$ is a farmer in the larger sense. He is president of the County Farm Bureau and always the right hand man of the county agent. His activities extend to everything in which his community and his county and his neighboring counties are interested. Fourteen years of quite intimate acquaintance justifies the assertion that southeast Kansas could ill spare Howard M. Hill and his fine family. 
O. O. Massa \& Sons, Jefferson.-Mr. Massa has a herd of more than forty females, several of which are additions made in 1920. Princess Violet 4 th by Prince Pavonia has size and is an exceptional breeding cow. Her bulls have gone to head Shorthorn herds and three of her heifers are among the best cows on the farm. Fashionette 7th is by Wooddale Chieftain, one of the best sons of Mr. Gentry's Choice of All. Her dam was by Lord Mayor $3 d$ of the same breeding as New Year's Delight, grand champion everywhere in the West including the American Royal. Another of the valuable cows is Alma 2 d. Her sire was by imp. Collynie out of a daughter of imp. Lord Cowslip and her dam was an elegant large cow by Violet's Knight 177894. Matchless Dale, the grand old son of Avondale with more prize winning steers to his credit than has any other bull of any breed that ever lived, has a splendid three-year-old daughter in the herd, Miss Nominee. She comes from the Kansas State Agricultural College and her dam was from W. I. Wood's noted Ohio herd. Her twelve-month-old heifer is a promising roan by Narcissus Type, one of the best sons of Cumberland Type. Emblem's Alicia is a 1600 pound beefy daughter of the Dawe show bull, Diamond Emblem. This cow is feminine and breedy in appearance and is from the best ancestry. A remarkable pair are the roan heifer Laura Belle and her 
six-month-old heifer calf. This young cow is only twenty-six months old and both she and the calf are large and exceptionally smooth. Indications are that they will be very valuable. Carrie Rosamond, two crosses from C. E. Leonard's Charming Rosamond, is by Senator, a bull bred at Elmendorf and sired by Marino's Champion. Her dam is of the regular Leonard line of breeding. Sultan's Beauty, a massive four-year-old roan, is by the International grand champion, True Sultan. This cow has an unusual spring of rib, a deep body and a very thick covering of flesh and is a splendid daughter of the great sire. Royal Queen bred by Ewing Bros. is an elegant 1600 pound cow that is suckling a bull calf by that outstanding sire of prize winners, Linwood Dale. This calf is big and lusty but he was three and one-half months old before he could take all the milk his mother gave. As a typical dual-purpose Shorthorn cow Royal Queen has few equals. One of the elegant females on the farm is the threeyear-old red, Lady of Walnut Grove 2d, bred by W. A. MeMehon of Missouri. At least two good judges have pronounced this heifer superb. Her sire is by Sultan's Heir, a son of Glenbrook Sultan. Her dam is by Prince Mistletoe, a son of Mr. Hanna's Prince Royal out of Mistletoe 2d, an own sister to Sweet Mistletoe, dam of two of America's most noted bulls, also to Captain Archer, famous sire of show stock for J. F. Stodder 
and to Pride of Collynie, a great sire in John MeCoy's herd. Her second dam is by Golden Lancaster, almost a full brother to Lavender Viscount. This cow is suckling a seven-month-old heifer that is a first-class show and breeding prospect and the cow herself is carrying smooth, heavy flesh on grass alone. Another of the best things on the farm is a red by Village Archer, a son of Gregg's Villager, out of a daughter of Barmpton Knight. Her dam is also by Barmpton Knight followed by Gallant Knight and Viscount of Anoka, giving her in the first four crosses four of the best bulls that could be found west of the Mississippi. The cows in the entire herd are well loaded with the best blood of the breed. They are good producers and are being bred to one of the best sires ever owned in southeast Kansas, the roan, Kansas Prince.

Kansas Prince is a massive son of Mistletoe Archer. He is open to slight criticism at each end but he has a great middle and stands near the ground. As a sire Kansas Prince has few equals in the state. Every one of his calves I have seen is almost faultless and, regardless of the class of cows, the calves are show stock of the better type and great growers and fleshers. $\Lambda$ t the Southeast Kansas Shorthorn Show in Coffeyville the Kansas Prince calves took second place in only one instance. It seemed next to useless to show against them. The oldest of 
these calves at twenty months weighed 1550 pounds and he had not been pushed heavily. Kansas Prince comes by this worth honestly. His sire is by Prince Royal, son of imp. Collynie and imp. Princess Royal $62 \mathrm{~d}$ and out of Sweet Mistletoe, the ram of Lespedeza Collynie, grand champior at the international in 1919. The da:n of Kansas Prince is Princess Columbia, an 1800 pound daughter of Prince of Collynie, one of the most remarkable, big, beefy bulls I have ever seen. He, too, was by imp. Collynie and his dam was by Royal Knight, probably the best son oi the great cow, imp. Princess Alice.

I. L. Swinney, Independence.*-Mr. Swinney's original purchases were mainly of stock coming through the Hill and Hanna herds and typical of their lines of breeding. One of the splendid females bought was the Hanna bred Sempstress, a big roan of excellent quality by the show bull imp. Inglewood. This cow, bought high at an American Royal sale, was the dam of a number of bulls, one of which was Inglelynie, well known in the herds of J. T. Bayer and Lauber Bros. When seventeen years old, Sempstress produced a heifer calf, sold for $\$ 500$ at twelve months in the 1919 Independence sale. A number of her other descendants are still retained. A later purchase was Secret Goods, a large

* Rural Route 5; near Crane Station on Santa Fe; telephone, Elk City. 
showy cow bred by G. H. Hasebrook, sired by the Good Choice bull, Roan Goods, out of a dam by Lavender Viscount 2d. A Tomson bred daughter of Archer, dam by Gallant Knight, and a MeDermott bred daughter of Fair Goods furnish an idea of the blood lines acquired by purchase in recent years and add to the attractiveness of the herd.

The bulls used have been such as to enhance the value of the blood lines and conserve the high standard of the cattle. Captain, a son of Collynie out of Mr. Hanna's excellent cow Lilac, (see Hanna sketch) was one of the best breeders and the few heifers I have seen by him were of outstanding merit. Fortune was another Collynie bull used liberally. Royalist, a son of Prince Royal, was another. Prince Royal, himself, was used for a while and Mr. Swinney also used the well known Sultan Victor. A few more bulls, all of like quality and breeding, have seen service in the herd.

Among the best things recently acquired are five heifers bought in 1919. They are attractive in appearance and their pedigrees will please. With the wealth of ancestry represented, Mr. Swinney will be able to attain any reasonable degree of success for which he works. The cattle sold from his herd have responded to feeding and have almost invariably been a good buy for the purchaser. 
John Frye, Independence.-Mr. Frye is one of the men who by reason of environment is able to secure great results in the production of live stock. His location on a farm with excellent pasture and heavy crops of alfalfa and forage, is ideal. Furthermore, Mr. Frye is equipped by years of training in farming and he has had almost a life association with Shorthorns. Mrs. Frye is a daughter of one of the old Shorthorn families of Iowa and was a near neighbor of prominent Shorthorn breeders. Both Mr. and Mrs. Frye are active physically and mentally and have unbounded enthusiasm for the work. "We have been wheating it and getting this high priced alfalfa off these war times and have neglected our cattle," Mr. Frye said to me, and results proved the correctness of his assertion.

Never-the-less, the Frye cattle are worthy of more than passing notice. There are now eighteen good females in the herd, nearly all descended from a Potts Emma cow, Lady Emma by Ingle Lad, purchased from H. M. Hill some years ago. This cow, in common with most Ingle Lad cows, was a great milker and her descendants in the herd are a splendid lot of cows of good size that would excite the admiration of even a dairyman, yet they are of true Shorthorn type and represent the class of cattle needed by the average farmer on a small farm who must produce both 
beef and milk. A recent and valuable addition is a young cow of Mrs. Grace Blake's breeding, sired by Lavender Lord. Shortly after Mr. Frye had purchased this heifer she gave birth to a first-class heifer calf by imp. Bapton Corporal. A Bellows bred bull has been used for several years and, being desirous of continuing the building of a high-class herd, Mr. Frye is on the lookout for a good tried sire which will be all that is needed in his operations.

P. P. Asher \& Son, Independence.-The Asher farm is favorably located for the production of cattle. In initial purchases made at the Coffeyville sale in April 1919 the Ashers showed unusual discrimination and as a result they have a small herd that would attract attention anywhere. They further showed their judgment and enterprise by sending females to Sycamore Springs to be bred to Master of the Dales. Their purchases included the good young cow, May Rose by the splendid show and breeding bull, Lord Mayor 3d, with bull calf at foot by Secret Robin, the bull bought by Miss Stanley of Anthony to head her high priced herd. The dam of May Rose is by Secret Archer, sire of J. F. Stodder's cows, that bred to Captain Archer produced his show cattle. Another is Belle of Havana 4th, by a son of Captain Archer, full brother to Sweet Mistletoe, dam of Lespedeza Collynie, grand champion at the International in 1919. 
The bull that was bought to head the herd is Chanute Pride. His sire, Royal Gloster, is by imp. Daydreams Pride, not only a show bull but also a fine breeder. His dam is by Aberdeen, practically a full brother to Mr. Hill's Ingle Lad and out of Sycamore Spiraea, an 1800 pound cow on grass, and own sister to Prince of Collynie, one of the great bulls of the breed. Syringia, dam of Sycamore Spiraea, is one of Mr. Hanna's best productions.

Watkins Bros., Cherryvale.-This firm began breeding Shorthorns three years ago and results observed while visiting the herd prove that their foundation stock was wisely selected. The top crosses in the pedigrees show an infusion of blood from such well known bulls as Silvermine, Collynie, St. Valentine 12th, Scotland's Charm, Fortune, Searchlight, imp. Prince Lovely, Sul$\tan$ Victor, Good Choice and Best of Goods. This should furnish a most satisfactory foundation for the practical man but this is only half the herd.

The other half, doubtless the more important, is a white bull by True Sultan, International prize winning son of Whitehall Marshall, International grand champion and one of the best sons of Whitehall Sultan. This young bull is a big, beefy fellow by virtue of inheritance. His dam was Ingle's Secret by Ingle Lad. Ingle's Secret as a six-month-old calf weighed about 600 pounds 
and sucked a three-year-old heifer that weighed more than 1600, while the cow and calf were on pasture without grain. This heifer and her calf were a most remarkable pair for their ages. The heifer was Sycamore Secret by Collynie, full of the best blood known in Shorthorn history. Watkins Bros. had the honor of winning the junior and grand championships on bulls at the Southeast Kansas Shorthorn Show at Coffeyville in 1919, with a ten-month-old calf of their breeding.

R. E. Webb, Wayside.-Mr. Webb engaged with his father in breeding Shorthorns in 1905 and for the past eight years has been working on his own account. One of his best cows is Catherine Victoria by Rosewood 2d, a son of Rosewood by imp. Ingleweod out of imp. Roseleaf by Scottish Archer. Two good cows were purchased at the Stodder dispersion and one of these, Silver Creek Sylvia by Lord Thistle, is still on the farm with several female descendants. Butterfly's Fortune by Alice's Fortune is another of the more desirable cows. Her sire is by Fortune, a well known son of Collynie, used for several years by I. L. Swinney. Mr. Webb has a bull that should be highly satisfactory. His sire is Secret Baron by Snowstorm, son of Snowflake, sire of the three times International grand champion, Ringmaster. His dam is by Collynie Choice, a son of Collynie out of a daughter of Choice Goods. 
Mr. Webb's location near a section given to cattle breeding is in his favor and guarantees a market for all the stock he can produce.

C. D. Bird, Cherryvale.-Mr. Bird bought three good bred heifers at the Coffeyville sale in 1919 and raised three calves from them that scason. Two were by Sir Hampton, a sire of splendid stock. Sir Hampton was by Hampton Spray out of a Prince Royal dam. The dams were by Collynie Goods, Rosewood and Prince Imperial 2d, three excellent bulls. Victor Gloster, the bull sold at Independence in 1919 with the Holcomb herd, is the sire in use. One of the best young bulls ever shown and sold at any Southeast Kansas sale was consigned by Mr. Bird to the 1919 fall sale.

C. A. Chamberlin, Cherryvale.-Mr. Chamberlin has seven females which he uses partially for dairy purposes, believing this necessary under small farm conditions. That returns are satisfactory is demonstrated by a visit to the farm. 'The cows are strong in the blood of Collynie, Choice Goods and Alice's Prince. Farther down the $y$ carry the blood of Baron Victor, Godoy and Scarlet Knight. Mr. Chamberlin is using Mr. Watkins' bull. (See Watkins sketch.)

J. C. Foster, Cherryvale.-Mr. Foster bought good milking Shorthorn cows of Peck \& Son and Mr. Peck assures me the cows were well chosen. The object is to produce a good sized Shorthorn 
cow that will raise profitable beef cattle and give sufficient milk to fully pay her keep. Mr. Foster will find a broad demand for the produce of these cattle as the small farmer must eventually have this very class of stock.

W. C. Hall, Coffeyville.-Dr. Hall, proprietor of Hall Stock Farm, believes in breeding the horns off and is using strongly bred Polled bulls. Among the cows Ingle Princess, one of the best, comes from H. M. Hill. Her sire, Sunblaze, was by Ingle Lad out of old Wistful, one of the outstanding cows of the breed. The dam of Ingle Princess was from the Nevius herd. Ingle Rose, a double standard, is by Ingle Lad out of a Polled cow by Field Marshall 164475. There are fifteen females in the herd and the breeding of Shorthorns is to be continued. The double standard bull, Evergreen Sultan by the International grand champion, True Sultan, is in service. The product of this farm should be a valuable adjunct to Montgomery county agriculture, as well as being a source of much recreation to Dr. Hall.

H. L. Higday, Independence.-Mr. Higday is making a start with Shorthorns. He has a number of good cows among which is Rosebud's Lavender by Rosebud's Secret, a son of Secret Archer, one of the best bulls in southeast Kansas. In addition to Rosebud's Secret there was used a bull, Imperial Duke by Fortune, a well known son of imp. Collynie out of a Lord Cowslip cow. 
Another dash of excellent blood comes in through Captain by Collynie out of the well known cow, Lilac. Twentieth Earl of Valley Grove by Lord Mayor also contributes to the quality of the herd. Six select females purchased from J. C. Robison have recently been added. Like all of $\mathrm{Mr}$. Robison's cattle, these cows have plenty of size, combined with finish. Alfalfa and a silo complete the story of Mr. Higday's operations.

J. L. Knotts, Caney.-For about twenty years Mr. Knotts has been connected with the Shorthorn industry and for the past ten years he has been breeding on his own account. His herd of nine cows is descended from one cow that carried in two top crosses the blood of Rosewood, son of imp. Inglewood and imp. Roseleaf by Scottish Archer and of imp. Craven Knight. Mr. Knotts also owns a splendid producing daughter of Harding, a full brother to Mr. Hill's Sarcasm. He is using the bull, Hallwood Goods by Hallwood Mint, a son of Choice Goods Model and Hallwood Violet by Headlight. The breeding of this bull is elegant and he has proved his worth as a sire by three years service in the herd of $\mathrm{A}$. Hamm \& Son.

A. G. Powell, Liberty.-Mr. Powell has been breeding Shorthorns for eleven years. He has a herd of about twenty females, nearly all descended from a Cruickshank Orange Blossom cow purchased from L. T. Frederick of 
Nebraska. Mr. Powell has not given his cattle the attention necessary to secure the most profitable returns but he has decided to make a business of the matter from now on and with a nice and very popularly bred foundation and with plenty of alfalfa he will be able to put up a real Shorthorn herd. The bull in use is a Hanna bred son of Hampton Spray with the great, smooth middle characteristic of these cattle, a good head and neck and good quarters. $\mathrm{He}$ is a typical Shorthorn.

Alex Thomason, Havana.-Mr. Thomason is a prince of good fellows with an excellent large farm and a good sized herd of practical, useful Shorthorns. His cattle are kept in medium condition, just right to do well for the purchaser if given fair treatment. The herd has received an infusion of Captain Archer blood through two bulls, Free Knight and Free Knight 2d. This indicates quality, for Captain Archer was an own brother to Sweet Mistletoe, the dam of the 1919 International grand champion. Mr. Thomason has been a contributor to the Southeast Kansas Breeders sales and a heifer of his breeding was first in a hotly contested class at the Southeast Kansas show at Coffeyville in 1919. At the 1919 fall show at Independence Mr. Thomason bought a good heifer representing the Hanna breeding with that of H. C. Duncan and W. A. Harris. 


\section{MORRIS COUNTY}

F. G. Houghton, Dunlap.-Mr. Houghton has bcen breeding Shorthorns for eight years. While his herd has not been pushed for best development, yet like most breeder's he realizes his mistake and will correct it. $\mathrm{He}$ is well located, having both pasture and alfalfa land and the twenty-five females now in the herd are of the desirable breeding kind. They are practically all descended from good bulls of good ancestry and out of good herds. Among the sires appearing are the Kellerman bred King Edward; Chief Mist bred by N. H. Gentry by the Choice of All and out of Violet Mist 7th, dam of Hampton Spray; Gállant Knight's Star by Gallant Knight out of a dam by Lord Mayor; Lord Barmpton by F. M. Gifford's well known Lord Marr, a son of Lord Mayor; Choice Prince by Prince of Tebo Lawn out of a daughter of Alice's Prince; Royal Goods by Select Goods, dam by Laird of Linwood and Victorious King by Victorious, dam by Secret Barmpton. Their dams were from bulls coming from such herds as those of Tomsons, Gentry, Tebo Lawn, Joseph Duncan, Fred Gifford, S. C. Hanna and Col. Harris' Linwood herd.

Eighth Josephine 141817 is one of the best cows. She is by Lord Barmpton by Lord Marr. Pride 5th comes from Meall Bros. Her sire, 
Royal Goods, was by Select Goods, a son of the champion, Choice Goods out of a cow by Alice's Prince, the $\$ 2000$ son of imp. Princess Alice.

A roan bull from John Regier heads the herd. Sir Edelweiss is by Good News, a bull used for a number of years by Mr. Regier with much success. He was shown at three state fairs, winning three firsts. His sire was New Goods by Choice Goods out of a cow by imp. Collynie. The dam of Sir Edelweiss, Edelweiss 4th, was by Nonpareil Star that as a calf was in George Bothwell's great show herd and the dam of Edelweiss 4th was by imp. Lord Banff, one of the best bulls of his day. Mr. Houghton successfully managed the 1919 and 1920 Morris County Breeders Sale held at Council Grove.

Robert P. Dent, Council Grove.-With an excellent location for a Shorthorn breeding establishment, Mr. Dent has decided that high priced land and poor grade cattle do not balance the account and that it is absolutely necessary to produce the right kind of cattle. He bought a few cows just for a start and they are being well cared for with satisfactory results. Butterfly, bred by D. A. Ewing of Great Bend, was sired by Choice Echo, a 2600 pound bull used by Miss Stanley and now owned by Bennington Bros. He is a son of New Goods out of a dam by Captain Archer. Collynie Briseis by imp. Collynie out of a dam by imp. Mariner, sire in 
H. M. Hill's herd, is one of the best cows in the lot. Clarice by Victor Archer, the well known bull owned by Dr. R. A. Stewart, Minnie 4th by Happy Choice a son of Good Choice and Queen's Pride by the Tomson bred Cherry Knight by Barmpton Knight are three good cows that bred to a good bull should give the desired results. In the ownership of a bull, Mr. Dent is co-operating with his two sons, or rather he is furnishing the bull for the three herds established by the family. This is mentioned that other fathers may be encouraged to do likewise. The bull is a roan, medium in size, very evenly covered, thick mellow fleshed, a fine looker, and what-is best of all, a sire of first-rate calves.

R. E. Hailey, Wilsey.-Both Mr. and Mrs. Hailey have the natural qualifications that make for success in the Shorthorn business. They also have a location amid surroundings where cattle do their very best, developing size, flesh and vigorous constitution. Besides this, they have ten females in the herd, that judged from any reasonable view point, are fit to be the ancestors of an excellent herd. Miss Rose 3d, a twelve-year-old roan that looks like a six-yearold, is from the famous Browndale farm, the nursery of countless numbers of high-class and prize winning Shorthorns. This cow would be the kind to select in buying the foundation for a breeding herd. Miss Rose 4 th by Defender is 
a roan three-year-old daughter of Miss Rose $3 \mathrm{~d}$. Defender is a son of Barmpton Knight, sire of state fair, American Royal and International champions and of many great breeding cows. His dam was by the Norton bred Sir Charming 4th. Elmwood Bettie is by Bonnie Count, whose sire, Goodline, was by imp. Collynie out of a cow by imp. Lord Cowslip. Her dam is by Leader, a son of Silvery Knight by Gallant Knight.

Mr. Hailey's first purchase of a bull was not in keeping with his requirements. He early recognized what all breeders must learn, sooner or later, that a bull can not be too good. The present herd bull, Captain 545855, not only has a strong line of ancestry but he also holds his credentials of excellent service in the record of having been the sire of a considerable part of a car load of Kansas City market topping twelvemonth-old baby beeves. He carries through his sire a blending of the best line of Tomson Bros.' breeding and on his dam's side, through her sire, Hampton Crown, the Merry Hampton blood. He is a smoothly finished fellow of good size, close to the ground, and is a good feeder.

Clyde E. Dent, Council Grove-Mr. Dent is avoiding the mistake made by many young men, in beginning right instead of having either scrubs or grades. In looking over his herd it must be admitted that he has shown judgment in selecting his original purchases. Two years ago he 
bought five females and from these he expects to develop his Shorthorn herd. One of his cows is by Rosewood Prince, a son of Rosewood out of a dam by imp. Collynie. Rosewood was by imp. Inglewood, Mr. Hanna's show bull, for years the record priced bull of the American Royal sales, out of imp. Roseleaf by Mr. Duthie's great bull, Scottish Archer. Collynie Briseis 2d, another good cow, is by Reflection, a Collynie bull out of a dam by imp. Mariner. Her dam is also by Collynie. Louise, a heifer that has been a local prize winner, is by Bettie's Albion, out of a dam by Pride of Avondale. Oak Pearl 2d is by Roan Cowslip, a son of imp. Lord Cowslip out of a dam by Red Oak by Collynie out of one of Mr. Hanná's Sempstress of Oakland cows. She was bred by J. E. Thompson of Fredonia. A daughter of Collynie Briseis 2d completes the list. It will be noted that four of these cows are strong in Collynie blood which is as strong a foundation for a breeding herd as could be found, and the fifth carries the Avondale cross. The bull used is Prairie King. (See Waldo Dent sketch.)

M. A. Metzger, Council Grove.-Mr. Metzger bought five cows of $\mathrm{C}$. H. Williams \& Son and a bull of Meall Bros., which insures a good foundation. In looking over the pedigrees of the cows I find in the top crosses some noted bulls. Royal Gloster, a show and excellent breeding 
bull owned by C. M. Garver; Double Champion, son of Choice Goods and Russella the dam of Ruberta; imp. Thistletop (see T. K. Tomson sketch, Part I) ; imp. Prince Oderic and imp. Burgomaster. Cows of this blood should prove satisfactory breeders. The herd bull is by Snowflake's Stamp by Snowflake, sire of Ringmaster, three times International grand champion. With proper care this should develop into a profitable herd.

Waldo E. Dent, Council Grove.-Though Mr. Dent is one of the youngest breeders in his county he has an excellent start for a beginner. Lassie is by Bettie's Albion 399451, and her dam is Brawith Missie by Pride of Avondale, son of Avondale and imp. Rosewood 86th, second dam Brawith Lass by New Year's Gift 198621. Lady Lucerne comes from the H. C. Stephenson herd in Chase county. (See W. J. Sayre and H. M. Schoepflin sketches.) Her sire, Cherry Knight, was by Barmpton Knight, one of the best bulls ever owned in Kansas and sire of two noted champions at the American Royal and International. Her dam was by Happy Choice by Bellows Bros.' Good Choice, son of the champion, Choice Goods and sire of the champion, Diamond Goods. Kentucky Belle $2 d$ is also a Stephenson product and is by Happy Choice out of a dam by Rosemary Victor 12th, a bull of George Bothwell's breeding. Mr. Bothwell will be 
remembered as owning the leading western show herd of his day.

Mr. Dent has a snap in his bull. It is understood that he is co-operating with his father and brother in the ownership, but the fact is that the father bought the bull and the sons are using him. The elder Mr. Dent selected a very good bull, for Prairie King by Sir Edelweiss (see Regier sketch) is out of a daughter of Wooddale Chieftain, one of the best bulls by The Choice of All ever sent out by Mr. Gentry.

H. O. Mott, White City.-Mr. Mott's connection with Shorthorns dates back to 1905, the present herd consisting of twenty females. Purchases of foundation stock were made from Richard Roenigk, Thos. B. Reid, of Franklin county and others. These cows were of good descent, carrying much of the blood of two noted Kansas herds, those of C. W. Merriam and C. F. Wolf $\&$ Son. The bulls used were Prairie King 442970 and Crimson Light 656773 . The latter was bred by J. H. Taylor \& Sons and is now in use. His sire is the well known Marengo Pearl, a bull that did great service in C. W. Taylor's herd. Mr. Mott is located in a cattle country where all conditions are favorable to live stock production.

L. W. Reeves, Parkerville.-The Reeves farm seems ideally located for the production of Shorthorns since it furnishes everything that should go to develop the young stock well and 
economically. Alfalfa and plenty of prairie pasture, shade and good water are found here. There are thirty females in the herd, which was established in 1911. The cows range in size from medium to large and it is Mr. Reeves' intention to give the calves liberal feed and care which will insure a good growth. Among Kansas herds that have contributed to the upbuilding of this one are those of John McCoy and Thomas, Jameison $\&$ Mitchell.

\section{NEMAHA COUNTY}

Milton Poland \& Son, Sabetha.-I found this a uniform herd in splendid condition with few, if any, animals that needed culling out. The cows have fine heads and necks, are of good size and carry enough flesh to give them a very pleasing appearance. A lot of nicely grown, fleshy calves show that the cows are desirable as breeders and milkers. Everything indicates not only judgment in mating but also capable general management.

Royal Nonpareil by Royal Leader out of Nonpareil 37th, a daughter of imp. Nonpareil 35th, is the sire of a number of the cows. Snowflake Baron by Snowflake; Trooper, by Barmpton Knight; Brigham Young by Pride of Collynie and Barmpton Knight appear frequently in the top crosses. Eight excellent heifers are by Oakdale King by a son of Avondale. On their dam's 
side they come from a worthy line of sires. $\Lambda$ number of these heifers are of outstanding quality and would look well anywhere.

King Rex, an unusually low down, level bull is in service. He is smooth, well fleshed and a good looker as well as a satisfactory breeder which is evidenced in his calves. His sire is the Westrope bred Le Boyne Rex and his dam is by Knight of Greeley bred by C. A. Saunders, thus uniting stock from two of Iowa's best herds. A new bull will be needed shortly and it is Mr. Poland's intention to get one of the best he can obtain.

J. C. Aeschliman \& Son, Sabetha.-One of the guarantees that could be given for the success of this herd is the great enthusiasm of the son, about twelve years of age and Mr. Aeschliman, by the way, is not lacking in this respect, either. Their foundation was wisely laid. The first purchase was the top cow in the dispersion of the excellent D. E. Reber herd. She cost $\$ 500$, a big price at that time and equal to several times that amount now. She is by True Goods, one of the best known sons of Fair Goods, son of Choice Goods and Ruberta. The heifers out of this cow are by a son of Scotchman, sire of Good Scotchman. They carry the blood of C. C. Norton's Sir Charming 10th and his well known Sweet Charity cows.

There is nothing in sight that should prevent 
this firm from building up a choice Shorthorn herd and if future additions are made with the same judgment shown so far, they will succeed. The Aeschlimans have access to several good bulls and are using one of the best in Nemaha county.

H. Heimann \& Son, Seneca.-Mr. Heimann has made up his mind that there is no reason why his son should produce grade cattle just because he himself did so he has bought some good Shorthorns and the young man is in charge. He is enthusiastic and I think will be a real success. The cows selected for a start are of the medium size, smooth kind. Dorothy, a three-year-old red, comes from L. V. Sanford. Her sire is Orange Premier, a son of the well known Orange Model out of a cow by Lavender Viceroy by Lavender Viscount. A number of the younger females come from Dr. Mark's herd in Jefferson county and are by Double Diamond, a nice, smooth bull with a double cross of the champion, Diamond Goods, and a crop of calves to his credit speaks well for him.

Trooper's Model is the bull used. He is by Trooper, the Barmpton Knight bull used so successfully by Mr. Sanford and his dam is by Matineer bred by John McCoy. In addition to this stock on hand, Mr. Heimann is contemplating the purchase of some strictly high-class cows bred along most popular lines and a first-class 
bull. The object is to make the herd one of the best in this section of the country and with the unusual facilities for carrying out these plans there is little doubt as to the ultimate success of the project.

James Jackson, Sabetha.-I found here two outstanding heifers due to calve soon and three good yearlings of pleasing form. Favorable working conditions and enthusiasm, with sound cattle sense on the part of both Mr. and Mrs. Jackson, mean a first-class herd on the farm. They have one of the most pleasing prospects I have found in a herd established less than a year ago. The three yearlings mentioned are by Roan Duke 540756, said to have been an excellent bull. Their dams are by a son of Barmpton Knight that was out of a cow by imp. Mutineer. A big, smooth two-year-old is Lavon by Oakdale King, son of Forest Dale by Avondale. Her dam is by the J. G. Robbins bred bull, Golden Dutchman. Marcella, another two-year-old by Oakdale King, must be classed among the best of her age $I$ have seen recently. She has the form and finish of a show cow and is an exceptional breeding proposition. Mr. Jackson is to be congratulated on making such a success of his initial purchases.

The bull used in this herd is a big one, but he is straight and smooth. He comes from John McCoy \& Son and is by Good Scotchman and out of 
one of Mr. McCoy's best cows, which is equivalent to saying that his dam is one of the best cows in Kansas. There is little chance of any man's making a mistake in buying such a bull.

Sam'1 C. Jackson, Sabetha.-This is another case of increasing land prices bringing about the necessity for better cattle and $\mathrm{Mr}$. Jackson is supplanting the grade with the pure bred. He has five cows of acceptable breeding and they are satisfactory producers. While lacking somewhat in uniformity, mating with a good bull will correct this irregularity. Among the sires of these cows is Wodan, a son of Nonpareil Star and one of the best bulls that went out from John Regier's herd. Another is by Rock Springs Pride, the excellent McCoy bred son of Pride of Collynie. Royal Hero by Secret Prince 206457, a son of imp. Strawberry, is the sire of another. Prince of Tebo Lawn and Choice Goods enter largely into the pedigrees of these cows. Mr. Jackson is a good feeder. He has access to several bulls in his community, which will enable him to soon own a herd of the desired quality, backed by some of the choicest ancestry found in western Shorthorns. This is what constitutes real worth in all pure bred cattle.

L. V. Sanford, Sabetha.*-Mr. Sanford has a herd of twenty-five females, all of which were bred on the farm. They range in size from

Telephone and station, Oneida. 
medium to large and, generally speaking, are good. Some of the original stock, possibly all, came from the James Gregg herd and carried an infusion of the blood of Col. Harris' imp. Royal Pirate.

As is the case where the cattle are all home bred, the quality of the bulls used indicates what is in the herd. The first bull was Mutineer 274110. He was bred by John McCoy, which fact is in itself a recommendation. His sire was Gladys' Chief by imp. Spartan Hero and out of a cow that was own sister to Lavender Viscount, International grand champion. To follow Mutineer, another good herd was patronized. Trooper came from Tomson Bros. and was by Barmpton Knight, sire of state fair and International prize winners and of many big, beefy Shorthorns. Trooper's dam was by Curator, a son of imp. Aboyne and imp. Lady Myra, both from the Cruickshank herd. Orange Premier is now in use. He was bred by W. A. Betteridge and came to Mr. Sanford through Bellows Bros. His sire is Orange Model, a bull that figures much in Shorthorn pedigrees, and his dam is by Lavender Viceroy, one of the best known sons of Lavender Viscount. Mr. Sanford has bred and sold the foundation stock for numerous herds in his part of the state.

C. H. Wempe, Seneca.-Mr. Wempe has been handling pure bred stock for years. His herd 
consists of twenty-five females bred along nice lines. Among the cows are daughters and granddaughters of Diamond Emblem, the bull that made a record as a sire and show bull for T. J. Dawe, Rock Springs Pride by Pride of Collynie and Good Scotchman. A very attractive roan bull was bought in 1919 from G. F. Hart and he was one of the best from that good herd. I noticed a valuable feature about this young bull. Though only a yearling and running with the herd on rather short pasture where he had been all summer, he was in a condition indicating rather extra grazing quality. $\mathrm{He}$ is of the most desirable breeding.

\section{NEOSHO COUNTY}

A. Austin, Galesburg.-Among Mr. Austin's best cows is New Goods, a daughter of Good News, the well known prize winner and breeding bull owned by John Regier for several years. Violet's Pride, the white bull that sold at Coffeyville in 1919 as a 1550 pound yearling is in service. He comes from O. O. Massa and is by that unusual sire of good stock, Kansas Prince. A heifer calf exhibited by Mr. Austin at Independence in 1919 won first in class over strong competition.

\section{NESS COUNTY}

W. F. Baer, Ransom-Mr. Baer is located in a section not much given to Shorthorn breeding 
and his herd will be an advertisement for the breed. The cows sired by good bulls are numerous. Captain Archer, an outstanding sire, and own brother to Sweet Mistletoe, dam of the 1919 International grand champion; Falsetto, sire of the excellent cows sold by Mrs. Fraser; Barmpton Knight, sire of prize winners by the score, including New Year's Delight, American Royal grand champion; Maxwalton Rosedale, own brother to Whitehall Rosedale, grand champion all over the West and sire of Violet's Dale, noted western champion bull, are the sires of some of the cows in the herd. Marigold, a five-year-old roan, is a recent addition. She is by Merry Goods, the son of Good Choice.

With this foundation and with proper care and feed, resulting in good development, it remains only to observe the bulls in service to get a fair idea of what to expect here. Augustus is a roan son of Crusader by Barmpton Knight, a bull that was retained in the Tomson herd and liberally used by them. His dam is Augusta 105th by Waverly. The other herd bull is Village President 565266 bred by J. F. Prather. He is by Superior Knight 408979 with several generations of the best Prather breeding back of his dam. Mr. Baer's cattle were successfully exhibited at the Kansas State Fair in 1920.

Wm. Gulick \& Son, Ness City.-This is one of the older and larger herds of western Kansas, 
having been established in 1900 and now numbering more than 100 females. A considerable part of the herd is by the Hanna bred Royal Victor by Prince Royal, the well known son of imp. Collynie and imp. Princess Royal 62d. Several good bulls have been used, one among the earlier ones having been Red Monk 227225. Another was Ravenswood Hero by a son of Godoy, the favorably known son of imp. Spartan Hero and imp. Golden Thistle. Ravenswood Hero's dam was by Baron Lavender 3d, sire of Lavender Viscount and out of a daughter of imp. Sunbeam.

One of the bulls now in service is Baron Ramsden 509817. The dam of Baron Ramsden is Lady Ramsden 4th by Lavender Goods, a son of Bellows Bros.' Good Choice. The Gulicks bought at the Salter-Robison 1920 sale imp. Roan Marshal, vol. 66 E.H.B. He is a yearling of more than usual scale with plenty of spread and great depth of body. He was bred by Alex Sutherland and is by the Durno bred Golden Marshall, a son of Collynie Golden Dream. His dam is by Cluny Prince Victor of Lady Cathcart's breeding. Mr. Gulick's aim is the production of smooth cattle of medium size and of the best type to utilize farm feeds and imp. Roan Marshall should sire the desired class of stock.

This herd is not kept in a country noted for its great number of Shorthorns, yet the patronage shows an increasing demand for these cattle. 


\section{NORTON COUNTY}

R. W. Dole, Almena.-Although this herd dates only from 1917, Mr. Dole was able to hold a very successful sale in 1919 and another in 1920. Several choice additions have recently been made and there are now thirty-five females in the herd. Some of these cows are of the most popular breeding, while all are strong in good Scotch blood. Roan King, a grandson of Ruberta's Goods and imp. Rose of Tyne, was one of the sires used with success. Another was Clipper Goods, a splendidly bred white, out of a daughter of Snowflake, the sire of Ringmaster. At present the leading herd bull is Roan Sultan 668451. This bull comes from ancestry of much prestige and should give excellent service in the herd.

\section{OSAGE COUNTY}

A. F. Kitchin, Burlingame-Mr. Kitchin comes from an old Kentucky Shorthorn family, both his father and his grandfather having been breeders of the reds, whites and roans. He has built up a herd of thirty females and has all the facilities needed for making cattle growing a success. A few year's ago he made a very fortunate investment in buying the cow, Miss Acorn. She was sired by the Prather bred bull, Highlander and her dam was Wealthy Acorn 5th, one of the best cows in Mr. Gentry's herd and dam of 
Wooddale Chieftain, used so profitably in the herd of D. A. Ballantyne \& Sons. Miss Acorn, still very rugged, is a splendid individual. One of her daughters is a five-year-old roan of medium size and much quality and she has three choire heifers to her credit besides having produced a bull calf that sold for $\$ 300$.

I am mentioning these cattle especially, because Mr. Kitchin intends to select his breeding stock from the descendants of these five females. The other cows in the herd are good, in fact not a poor or unworthy animal was seen among them. The general appearance of all the cattle indicates efficient management and if all breeders would give their herds the same intelligent care that Mr. Kitchen is giving, and use high-class bulls as he has been using, lectures on care and herd bulls would be unnecessary.

It was here that I found a seven-year-old bull of remarkable beefiness, a white son of Prince Valentine 4th, the successful show and breeding bull used by Tomsons. I do not recall having seen anywhere, in recent years, a much better specimen of a beef animal. He is almost abnormally short-legged with a wonderfully deep, thick body, covered with a wealth of smooth flesh. Though running out in the pasture with a few cows and getting no grain, he might prove a troublesome opponent even in a pretty strong show. This bull was purchased of C. S. Nevius, 
his breeder. His dam is the Bellows bred Keepsake $2 \mathrm{~d}$ by Good Choice, second dam by Victorallan, third dam by Armour Bearer. Quite a number of excellent heifers by him are being retained.

The other herd bull is North Americus purchased at the Gillespie dispersion at Muskogee. Aside from his size and quality his claim to distinction rests on the fact that he comes from the same cow, or from a cow closely related to the dam of Americus, the bull that sold for $\$ 38000$ in South America, which was the highest price paid for any bull of any breed up to that time. North Americus is a smooth, rather large fellow and should give proper account of himself on this farm. There is material here for a high-class herd and Mr. Kitchin is still active and able to go ahead and get the results.

Barrett \& Land, Overbrook.-This herd, started in 1910, usually numbers about 100 head and it is one of the best known establishments in east central Kansas. Scotch topped cows of a good class are kept and given good farm care, the young stock being well grown. Several public sales have been held and liberally patronized. Cattle have been sent to the Eastern Kansas sale at Ottawa and to the Kansas National sale at Wichita.

The herd has had the service of a number of excellent bulls. Prince Knight was by Crusader, 
one of the best sons of Barmpton Knight and his dam was Glenwood Pavonia, a daughter of imp. Glendale Pavonia. Hector, a bull used until 1919, was by Prince Valentine 4th. His dam was by Barmpton Knight out of Harmony 6th by imp. Thistletop. Hector had three crosses of the best of Kansas bulls.

Sultan's Seal, one of the present herd bulls, is a roan by Beaver Creek Sultan, the grandson of Whitehall Sultan that for Tomsons sired some of the highest priced Shorthorns sold in this territory. His dam came from H. C. Duncan and was by his excellent Golden Lavender. The other bull is Silver Dale, a big white of outstanding quality. Both in ancestry and individuality he has everything which should make a desirable sire. He is by Master of the Dales by Avondale and his dam is the 1800 pound Princess Columbia, one of the greatest breeding cows in the West.

Charles Hothan \& Son, Scranton.-Fifteen cows are kept here under ordinary farm conditions and good calves are being raised from them. The herd includes some splendidly bred ones. Annie Laurie, a red three-year-old, comes from Forrest Nave, Lexington, Missouri. Her sire is Nonpareil Victor by Victor Orange, one of the best of Kansas bulls, prominent in the herd of Henry Stunkel. Her dam is also by Victor Orange and her grandam came from the 
Wm. Cummings herd, a leading herd of Illinois.

Five of the cows on the farm are by Ingle Prince, a bull of exceptional ancestry, his sire having been Prince of Collynie by imp. Collynie and his dam Ingle Maid, the dam of Mr. Hill's Ingle Lad. It is doubtful if many bulls in Kansas or anywhere else are so well descended. He is very close to Mr. Cruickshank's best cattle and his ancestry for generations were outstanding. individuals. The dams of these cows were by Joe Pavonia, a Nevius bred son of Prince Pavonia, a bull famous as a sire in both Kansas and Oklahoma. A white bull from Tomson Bros. is being used on these red cows. He is by Beaver Creek Sultan and his dam is by Dale's Cumberland, a bull carrying the blood of International grand champions and of many choice Shorthorns. He combines in the two top crosses, Whitehall Sultan, Avondale and Cumberland's Last, the most famous bulls of this period.

V. A. Jasperson, Scranton.-Mr. Jasperson is the pleasant and efficient secretary of the Osage County Breeders Association. He has been breeding for three years and has a herd of twenty females, representative of such excellent bulls as imp. Collynie, sire and grandsire of some of America's greatest Shorthorns; Choice Goods, for three years acknowledged champion of America; Ingle Lad, a great sire of breeding cows; Senator Wornall's imp. Conqueror; 
Prince Pavonia, one of the best bulls ever owned by C. S. Nevius; Archer and Gallant Knight, both great sires in the Tomson herd and old Lord Mayor, the bull that made 'T. P. Babst known as a breeder. To this list could be added many others. From such a herd of cows it is possible to produce almost any results desired.

The herd bull purchased in 1919 from Tomson Bros. is Secret Sentry by Beaver Creek Sultan. His dam is by White Goods, one of the outstanding sons of Choice Goods, second dam by Lavender Viscount, famous Ravenswood sire and International grand champion. Since the bull is the big half of the herd it is important to note that but few herd headers carry such a wealth of ancestry as does Secret Sentry.

Mr. Jasperson, like many other young men who sometimes see things more quickly than do older ones, knows that the day of profit in scrubs has passed.

H. Olson \& Sons, Scranton.-You can not help liking Mr. Olson and having confidence in him for every bit of his six foot frame makes you feel that way. He is a comparatively new breeder who is going to succeed because he has decided to do so. There are about twenty females of breeding age in the herd and all are of a useful type with some especially good ones among them. The cattle come from local herds of excellent quality along with the breeding common to the majority 
of Osage county Shorthorns. The Olson cattle have received an infusion of blood through Hampton Spray and Prince Royal two outstanding ton and a quarter bulls that represent not only the best, but also some of the most popular blood lines of the last quarter century. These bulls were both well known in S. C. Hanna's herd where they left much good stock.

The herd bull in use, bred by W. T. Pruitt \& Son of Missouri is a large roan and carries the appearance of a real breeding bull. The calves by him are promising. His sirè, Sultan Lad, was by the noted bull Glenbrook Sultan, one of the greatest sires of prize winners in America and considered by many. as second only to Avondale among the sons of Whitehall Sultan. His dam is by. Victor Robin, a Spicy Robin bull, and his second dam is by New Goods, the Choice Goods bull that headed Harriman Bros.' herd at their dispersion sale.

H. M. Schoepflin, Quenemo.-This herd, founded two years ago, is a good one. A nice lot of heifers bought early in 1919 are from the $H$. C. Stephenson herd. They have plenty of size, are smooth from end to end and are very feminine and attractive. Their sire is Nonpareil Knight, a bull bred by Tomson Bros. and sired by Gallant Knight's Heir. Nonpareil Knight's dam was bred by N. A. Lind and was by his well known Fancy's Pride. These heifers are out of 
cows by Hampton's Crown, a son of Hampton's Best, the outstanding son of imp. Merry Hampton, considered by many breeders the best Scotch bull ever imported. Some females in the herd are by Cherry Knight, a son of Barmpton Knight, the bull that did such excellent service for Tomsons, out of a granddaughter of the famous bull, Village Hero. This is the same line breeding as that of Young Abbotsburn, the greatest show bull ever exhibited in America. From this it may be seen that the Schoepflin females come by their size and quality honestly. Mr. Schoepflin, in partnership with a neighbor, C. E. McFerren, owns the Tomson bred Victor Sultan. There is a bright prospect for this herd for it was founded on correct principles and it will receive all necessary attention.

Mr. Schoepflin is one of the public spirited breeders of his county and is doing his full share in pushing Shorthorn interests.

Thomas Gray, Lyndon.-This is a herd of twenty-five females of more than average merit. They have been produced through the use of bulls representing such sires as Prince Valentine 4th, a show bull for Mr. Nevius and a noted breeding bull in the Tomson herd where he sired numerous great producing cows; Lavender King 3d; imp. King of Aberdeen, sire of J. H. Pott's show cattle; Prime Minister by imp. Prince of Perth; Royal Wanderer and Scotland's Charm, 
both well known in the C. F. Wolf \& Son herd and Norfolk, famous sire for B. O. Cowan and grandsire of New Year's Delight, American Royal grand champion. The bull recently in service came from C. S. Nevius and the one now in use was bred by E. S. Myers, both representing the best of the herds from which they came. Mr. Gray keeps his cattle in thrifty condition through common sense methods, such as any careful farmer can practice.

C. E. McFerren, Quenemo.-Mr. McFerren made a start in 1919 with four heifers. Among them is a two-year-old that is a rarely good individual and her calf indicates that she will be a valuable-breeding cow. These heifers descend from a line of bulls strong in best Scotch blood and they reflect credit on their breeder and their owner. Mr. McFerren has a half interest with Mr. Schoepflin in the splendid bull, Victor Sultan, recently purchased from Tomson Bros., an unusually attractive young fellow of the right type. He is by Beaver Creek Sultan and his dam is one of the desirable cows in the Tomson herd. Coupled with the choicely bred females we may reasonably look for unusual results. Mr. McFerren's heifers came from the H. C. Stephenson herd in Chase county and are of the same lot as those purchased by Mr. Schoepflin and Mr. Sayre. How much better for the beginner to buy the right kind as Mr. MeFerren did 
than to save a few dollars and take inferior stock. W. T. Dickson \& Son, Carbondale.*-This herd was founded twenty years ago. The bulls that have been used in that time are a first-rate recommendation of quality in the herd. Silver Archer was by Archer's Victor, a Tomson bred son of Archer out of a Gallant Knight cow. His dam was by Lord Mayor. Good Conqueror was by The Conqueror, son of Choice Goods and imp. Clara 58th. The present herd bull comes from G. F. Kellerman and topped the Linn county sale in 1919. He is by Gloster's Best 667327 and his dam by Prince Valentine 4th is one of the best cows in the state. His second dam is by Lord Mayor.

M. C. Pollard, Carbondale.-This is a small herd of ten good females established in 1917. Dale Ruby, one of the cows is. by Ury Dale, the elegantly bred son of Avondale so well remembered in north central Kansas. Cedar Pride comes from Cowham Stock Farm and is by Marr Lad by Ingle Lad, one of the best sons of imp. Collynie and sire of numerous high-class producing cows, including the grandam of Lady Supreme and the dam of Matchless Collynie, grand champion at the Denver show in 1919. Mr. Pollard is using Fair Goods 757579, a son of Fair Champion, an excellent Fair Acres Sultan bull that is becoming very popular in north central

* Telephone and station, Overbrook. 
Kansas. Mr. Pollard is a near neighbor of J. G. Tomson and is one of numerous breeders in his vicinity.

V. O. Simpson, Scranton.-Mr. Simpson's female purchases came from the Babst herd and are proving very useful. They were sired by Donald, a Tomson bred son of St. Clair, and represent the same breeding that produced New Tear:s Delight and Daisy Queen, two noted channions at America's biggest shows. (See 'Tomson sketch.) The herd bull is typical of the choice breeding from the well known C. E. Leonard herd. The calves produced will carry in the two top crosses the blood of Barmpton Knight, one of the best bulls ever owned in Kansas and that of Rosedale's Choice, the son of Choice Goods and the famous cow, Rosedale Violet 9th, dam of four ealves sold for $\$ 6000$ in the time of low prices.

C. L. Troudner, Carbondale.-Among the good things in this nicely bred herd are a lot of heifers by Dale's Cumberland and others strong in the blood of Barmpton Knight through one of his best sons. Both these bulls are well known as typical of the best in Shorthorns and the heifers cim not but prove valuable. The herd bull comes from Tomson Bros. and represents their breed-ing for several generations. $\mathrm{He}$ is by Beaver Creek Sultan, the massive grandson of Whitehall Sultan that did service in the Tomson herd 
for several years. His dam is by Gallant Knight's Heir by Gallant Knight and his second dam is by Barmpton Knight. Bulls bred as this one can hardly help being first-class sires.

C. G. Williams, Lyndon.-Mr. Williams made his start in February 1919 in the purchase of five females from the Stephenson herd in Chase county. These cattle are not only individuals of approved type for profitable farm cattle but their ancestry which is a blending of scotch and American blood has given good resuits as it almost always does. The bull in use came from Barrett \& Land and is a grandson of Prince Valentine 4th with Pringle's Sir Knight and the Potts bred Lavender King 3d strongly represented on his dam's side. These three bulls did service in three excellent Kansas herds. Prince Valentine 4th was owned by Tomsons, Sir Knight by Andrew Pringle and Lavender King 3d by D. K. Kellerman \& Son.

A. A. Adams, Osage City.-Mr. Adams has a pleasant location near town where he can grow alfalfa, watch the Shorthorns and enjoy life. A year ago he bought eight females from $H$. $H$. Churchill. They are the practical kind and show milking quality, the kind that when properly mated always give satisfactory results. A number of them are by the excellent Saunders bred Marquis Cumberland by Cumberland's Best, a bull of outstanding character and ancestry. Cows 
by this bull can hardly help becoming valuable breeders and all that is required to make them profitable is to given them care and see that they are properly mated.

\section{Ross A. Coffman \& Son, Overbrook.-Coff-} man \& Son bought a few Shorthorns in 1919 and will fall into Shorthorn line which is quite easy in Osage county. The only mature cow in the herd has plenty of size, something they intend not to neglect. With abundant alfalfa and blue grass they have the best of facilities for raising cattle. So far no bull has been secured but a good one will be bought soon.

\section{OSBORNE COUNTY}

L. M. Noffsinger, Osborne.-Those who saw the exhibit made by Mr. Noffsinger at the Royal in 1919 will not be surprised to hear that he has an excellent herd. Both his herd bulls were well in the money which is much to the credit of any breeder, especially when his entries are not highly fitted. The females which he exhibited were the kind that were good enough to attract notice anywhere and they were of the true money making type. It is not likely that a man of $\mathrm{Mr}$. Noffsinger's energy will stop at anything short of the best.

The roan, Scottish Duchess, is by Cumberland Dictator, a son of the well known Burwood Royal out of a cow by Cumberland's I Iast, the most 
noted bull of the Cumberland family. Gloster Goods is a six-year-old roan by Ruberta's Goods, himself a high-class show bull and the sire of many prize winners. Ruberta's Goods was by the noted sire, Golden Goods, and out of the undefeated cow, Ruberta. Roan Martha is by Monarque Cumberland, a combination of Whitehall Sultan and Cumberland blood, the two families of Shorthorns that are now holding public prestige and largely controlling show ring awards. Avondale's Miss, a red, is by Avondale's Choice, son of Avondale, greatest bull of his day out of Burwood Lady, a daughter of imp. Gwendoline. Nonpareil 55th comes from Canada from the W. C. Edwards herd, a birthplace of good Shorthorns. She is by Royal Butterfly, a sire of note.

Fancy Lord, one of the bulls used early came to Tomson Bros. through their notable purchase of cows from R. O. Miller. He was by Lord Lancaster, a son of the Duthie bred imp. Lord Mistletoe and imp. Lancaster Pet. Prince Luster, a son of Prince Pavonia, was also used and reflected credit on his sire, one of the best bulls of his time and a son of imp. Glendale Pavonia. It will be admitted that bulls from such ancestry as those mentioned when bred to good cows and the produce is well cared for would build up a first-class herd.

In the purchase of the bulls now in use $\mathrm{Mr}$. 
Noffsinger has shown that only the best will satisfy him. Pleasant Dale Sultan is an American Royal wimner of 1919 without fitting. His sire is Lavender Lord by Avondale. His dam is Pleasant Jealousy by imp. Shenstone Albino, sire of the great prize winner and breeding bull, Pride of Albion. His second dam is Maxwalton Jealousy by Avondale and his third dam is Sultan's Jealousy by Whitehall Sultan and out of imp. Jeanie by Count Arthur. If a person were writing a pedigree with a view to combining the best blood lines of the day he might write a little different combination though he could hardly improve this. The bull is large and he is a firstrate sire. The other and younger bull is Fair Acres Choice by Fair Acres Sultan, one of the very best sons of Whitehall Sultan and sire of many of the highest priced American Shorthorns of the last few years. The dam of Fair Acres Choice, Gloster Goods, (see above) is also in the herd. This combination bringing in, as it does, so many animals of extraordinary merit, can hardly fail to produce good results through the use of this big, stretchy three-year-old bull.

Wales \& Young, Osborne.-These men have some very creditable show and breeding stock in their herd. The cows come through an excep)tional line of ancestry. Barmpton Knight, that great sire not only of show stock but also of the best class of utility Shorthorns, has several 
daughters on the farm, one of which is out of a cow by Lord Mayor, second dam by Gallant Knight, a sire of more western prize winners at the shows than any other bull of his day. Her dam is by imp. Thistletop. Maxwalton Rosedale, (wn brother to the grand champion Whitehall Rosedale, is represented by some good cows among which is Rosebud 3d, a daughter of Rosebud $2 d$, mentioned above. Prince Valentine 4th, the splendid show and breeding bull used for a time by Tomson Bros., is the sire of Bonny Belle. She is out of a Barmpton Knight cow whose dam was by Gallant Knight. Josephine Daisy is by the Tomson bred Village Knight, a son of Gallant Knight's Heir, out of a Barmpton Knight dam.

The herd bull is Auburn Dale 569935. He is by Maxwalton Rosedale out of Norwood Augusta 3d by imp. Crescent Knight. His second dam is imp. Augusta 105th. His breeding could not be improved and he is acknowledged to be one of the best sires of his section.

Wales \& Young were leading contributors to the Northwest sale at Concordia in 1919.

Herman A. Johnson, Osborne.-Mr. Johnson is considered a capable judge of cattle and his friends think he is well qualified to build up a herd. His stock is not pushed for high development but is kept in thrifty growing condition. A considerable part of his foundation, possibly all, 
was bred by Wm. Wales, some of the cows having been by the Tomson bred Scottish Knight. The bull is use is Spicy Dale 755076 by Maxwalton Rosedale, the son of Avondale used so successfully by Tomson Bros. and Andrew Pringle. Like many other small breeders, Mr. Johnson, with plenty of enterprise, good feeding and good breeding can make his herd occupy a commanding position and he seems to have the ability to do the work.

R. R. Walker \& Sons, Osborne.-It is the intention of the owner's to establish a great Shorthorn herd and as far as can be seen everything is in their favor. Pasture, water, buildings and silos as well as location furnish the prime requisites of success. The herd is not yet large but it is being maintained in good breeding condition. The bull in use is Knight of Elm Lawn, a twoyear-old bred by Wales \& Young. He is by Village Knight. (See Wales \& Young sketch.) His dam-is Ethel 3d 214199. The cows come from such herds as that of L. M. Noffsinger and with the use of high-class sires and attention to detail the Walkers will succeed in realizing their ambition.

\section{OTTAWA COUNTY}

A. A. Tennyson, Lamar.*-Mr. Tennyson comes from a Shorthorn family and has the

Ship on Santa Fe or Union Pacific. 
instinct in a well developed form. Mrs. Tennyson and the sons are also enthusiastic to an unusual degree. The herd was founded thirteen years ago and its appearance indicates purposeful and constructive breeding. It is a large one, numbering probably fifty females of breeding age and I failed to find one that was not good. There are uniformity and close adherence to true Shorthorn type that are combined with pleasing head and neck. Most of the cattle have very nice horns and, as a whole, they make an elegant appearance. In size, both extremes are well avoided, there being no very large or very small ones. The calves speak well for their mothers as milkers.

Everything is in thrifty condition but is not overdone and the entire herd is kept on pasture only, during the summer and, excepting the young stock, all are kept on ensilage, alfalfa and other roughage in the winter. This is one of those herds that it is a real pleasure to visit and to study, not on account of grèat outstanding merit for I am not elaiming that, but on account of genuine worth as a Shorthorn breeding herd handled in an economical and practical way easily within the reach of any progressive farmer. Agricultural interests and general Shorthorn interests would be well served if the country were full of such breeders as Mr. and Mrs. Tennyson.

Going back to the herd itself, the cows purchased were good and of nice breeding and good 
bulls were consistently used. I shall mention only a few of the bulls. Golden Prince 292034 was bred by Geo. Bothwell. His sire, Golden Lavender, was a son of Grand Victor out of imp. Sittyton Lavender 6th. His dam, Maid of Honor, was also by Grand Victor and out of imp. Winifred 4th, considered by some the best cow in the Bothwell herd. Athene's Scotchman, bred by H. F. Brown, is one of the productions of the famous Browndale Farm. He was by Athene's Victor 2d 251153 out of Harmon's Athene 4th. The grand lot of mature cows and big smooth heifers on the farm makes it needless to say much about him. He is also the sire of the ten elegant cows in Fred Abildgaard's herd near Winfield.

Crown Prince, the present herd bull, bred by T. J. Dawe, is by Royal Diadem. (See Dawe sketch.) His dam is Secret Beauty bred by Owens Bros. by Secret Barmpton, second dam by Baron Kerr 2 d. This is a big and very beefy bull of the most profitable producer's type. $\mathrm{He}$ is a little coarse in the shoulder and shows possibly a little too much prominence of hip but he has a fine head and neck, fine quarters and a great body set on heavy, short legs. I was very much pleased with his heifers. They are large, smooth and deep and have elegant heads and necks.

True to the precedent established of using only high-class bulls, Mr. Tennyson has just 
purchased of the Kansas State Agricultural Collége, Clara's Type, a roan by Narcissus Type out of a dam by Matchless Dale. This young fellow is large with fine head and neck, good top and bottom lines and a great back and spring of ribs. He combines through his dam and sire, Avondale, the greatest son of the world's greatest breeding bull, and Cumberland's Type, the most remarkable prize winning bull of the twentieth century, a wealth of merit in ancestry which should make him an outstanding breeding bull.

Morse Bros., Delphos.*-These men laid their foundation two years ago in buying some good. heifers from Johnson Bros. They were by Athene's Scotchman and out of cows by Double Champion, the Choice Goods bull so extensively advertised by Col. Ed Green. Other cows in the herd are by the Kellerman bred Scottish Gloster and by Lord Marr, Mr. Gifford's well known son of Lord Mayor and imp. Marigold 50th. The herd bull comes from Tomson Bros. His sire is Maxwalton Rosedale by Avondale out of imp. Rosewood Pride. His dam is Glendale Pavonia by Happy Knight, son of Gallant Knight out of a Lord Mayor dam, second dam, imp. Glendale Pavonia by Bold Count. There is no better breeding and I have seen few better young bulls this year. Though running out with the herd as a yearling on pasture and in thin flesh, he is

Ship on Santa Fe or Union Pacifie. 
not easily faulted except in some minor points.

There can be little just criticism made either in the breeding or in the type of the cows of this herd but the conditions under which they are kept are not such as to bring out the individual merit that should justly be theirs by virtue of inheritance. No one realizes this more fully than the owners and they are laying plans to improve in these details. When they have succeeded they will be in a position to put up a real Shorthorn herd.

Johnson Bros., Delphos.-An excellent herd properly handled and in splendid condition is what I saw on the Johnson farm. Shorthorn type, breeding, character, size, fleshing quality, with good milking tendency covers a description of the cows.

The foundation was laid at Mr. Amcoats' sale eight years ago. Later additions of cows were made and the well known show and breeding bull, Gallant Knight's Heir, was purchased from Tomson Bros. He left a lot of nice cows in the herd and a young bull by him out of one of the choice cows on the farm is the sire of ten good yearling heifers I saw in one of the pastures. Athene's Scotchman, so successfully used by A. A. Tennyson, also proved valuable here.

Miss Orange Blossom, coming from Fred Gifford, is one of the best cows by Lord Marr, a son of Lord Mayor and imp. Marigold 50th. Her 
dam, Orange Blossom 33d, came from the Kellogg: Stock Farm and was by Scotchman 447180 by the Bellows bred Ambassador out of Galanthus by imp. Barbarossa. Secret Lass is by Double Champion, the excellent son of Choice Goods and Russella, the dam of one of the greatest of American cows, Ruberta. Secret Lass is out of a daughter of Baron Violet, a son of the sensational Sweet Violet 2d. A Tomson bred son of Beaver Creek Sultan heads the herd and is doing satisfactory service.

B. M. Lyne \& Sons, Oak Hill.-Mr. Lyne is one of the old breeders who has bred his herd and has made but few additions by purchase. He has held five public sales, all classed as successful. There is uniformity and much indication of milking quality in the herd, two valuable characteristics in any lot of cows. Fair size, straight lines and evident usefulness were also apparent. The calves, the test of the cows, were unusual and reflected the use of a good bull. Mr. Lyne has not given his cattle the development he should but is now instituting a reform in this respect.

Romeo, one of the herd bulls by imp. Bapton Coronet was very satisfactory. Red Laddie by Captain Archer out of Red Lady 7th by Lord Thistle was bought at the Stodder dispersion. He had been at the head of the show herd the previous season and was a winner. After the death of his sire he had been used in the breeding 
herd. Violet Search $3 \mathrm{~d}$ by Searchlight and out of Violet Bloom by Golden Bloom came from Mr. Nevius' herd. Both Red Laddie and Violet Search 3d left splendid stock. The present bull is Royal Type by Cumberland Type, dam by Burwood Royal, second dam by King Marengo, a son of King Champion out of imp. Lady Douglas followed by Cumberland's Last and Fitz Eustace. He looks worthy of his ancestry and should prove valuable.

F. D. White, Ada.-Mr. White bought three cows in 1916 and he now has a good start. These cows were all by Victor Chief 236981, a T. K. Tomson \& Sons bred bull by Dictator out of Elder Lawn Victoria by Gallant Knight, second dam, Victoria of Maple Hill, the dam of Gallant Knight's Heir. When we consider that Dictator was own brother to Forest Daisy 2d, dam of the International grand champion, New Year's Delight, we get an idea of the foundation Mr. White laid. The bull in use is by Red Laddie, for one season at the head of the Stodder show herd, a state fair prize winner by Captain Archer, own brother to Sweet Mistletoe, dam of Lespedeza Collynie, the 1919 International grand champion.

\section{RENO COUNTY}

Gaeddert Bros., Buhler.-In 1917 Gaeddert Bros. made the first purchase of foundation 
stock securing some of the better animals from the Lookabaugh and Bellows herds. Among the best females secured was Parkdale Clipper 5th, a roan by that excellent heifer getter, Cumberland Diamond, well known in Kansas as chief

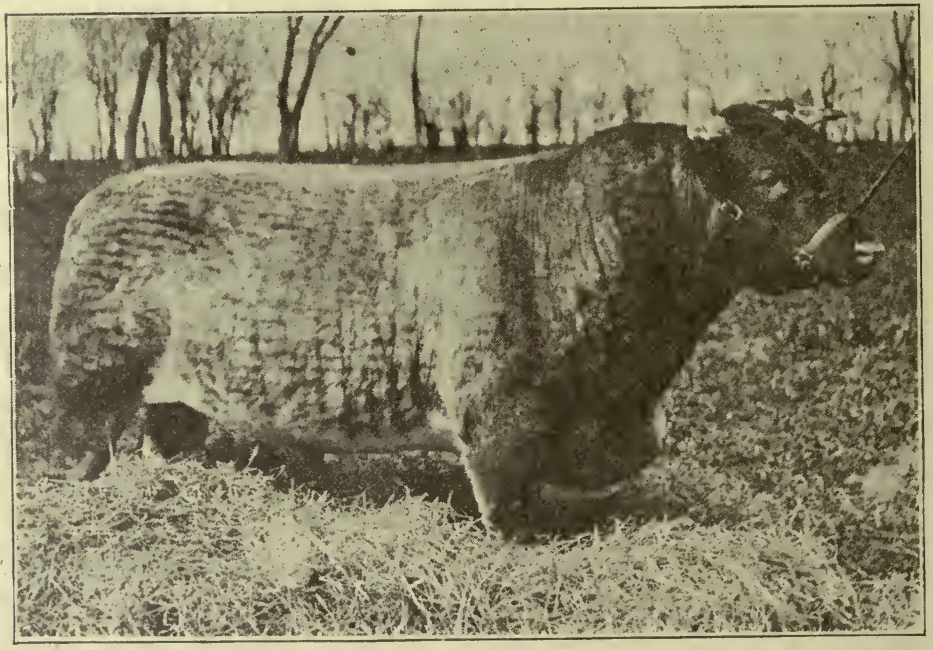

PLEASANT ACRES SULTAN

herd bull owned by E. L. Stunkel. Parkdale Clipper was in calf to Village Supreme and her heifer calf from the International grand champion was first at both the Kansas and Oklahoma state fairs and stood second in a class of twentyeight at the Kansas National Show in 1920. Before this heifer was a year old, $\$ 2500$ had twice been refused for her. Another excellent cow is Crimson's Daughter, a stretchy red that is very 
close to the ground and is an extraordinary milker. A bull calf from this cow, though showing at a big disadvantage as to age, was well at the top of his class at Muskogee, at Dallas, and

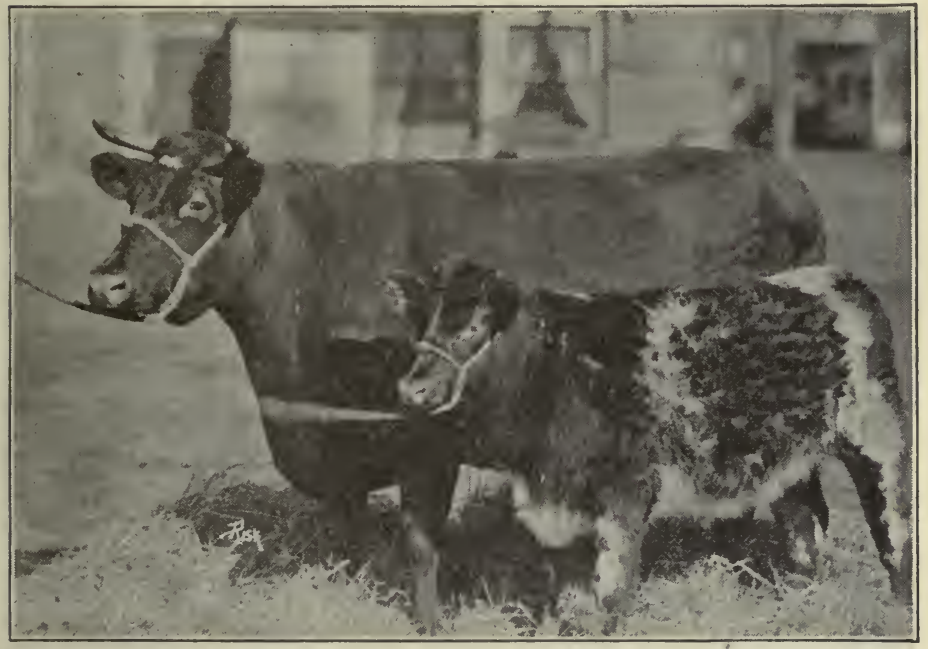

LAVENDER PRINCESS 7 : $\mathrm{h}$ THAT TOPPED THE 1920 PURPLE RIBBON SALE FOR GAEDDERT BROS.

at the Kansas National. A red heifer by Pleasant Dale Sultan out of Crimson's Daughter is one of the highly prized young things on the farm. Lady Geraldine 9th, a red by Geo. Allen \& Sons' noted son of Whitehall Sultan. Victor Sultan, is out of a cow by a son of imp. Lavender Lad followed by imp. Baron Cruickshank. Her first calf, Roan Geraldine, sold at the Purple Ribbon sale at Wichita in 1920 for $\$ 1225$. This cow is closely descended from a long line of sires 
and dams bred by Mr. Cruickshank himself and the pedigree is especially attractive.

The cows mentioned in the foregoing are only a few of the good ones in the Gaeddert herd, the

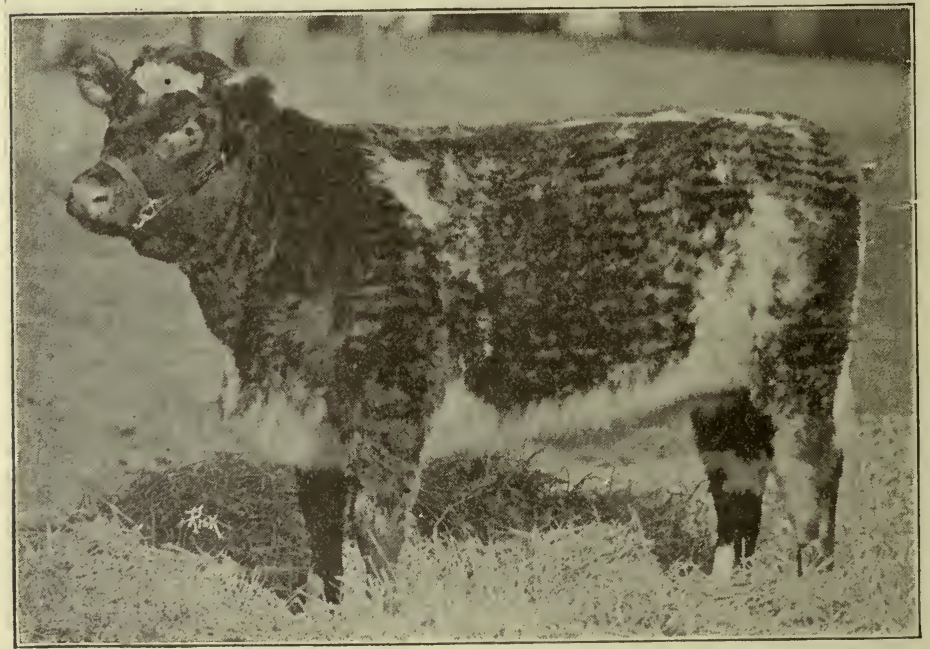

SUPREME CLIPPER

rest being of the same desirable breeding and conformation. It will be evident to any one interested in Shorthorns and possessing a fair knowledge of Shorthorn pedigrees that the Gaeddert cattle properly belong, by virtue of inherited quality, among the tops of the breed.

As in all worth-while herds, the bull is the first consideration. In the purchase of Pleasant Acres Sultan Gaeddert Bros. went to one of the fountain heads of Shorthorn excellence for a sire. In 
1917 this bull was the senior calf in the Lookabaugh show herd and he stood first in class at four state fairs. He was also at the head of the first prize young herd and of the first prize calf

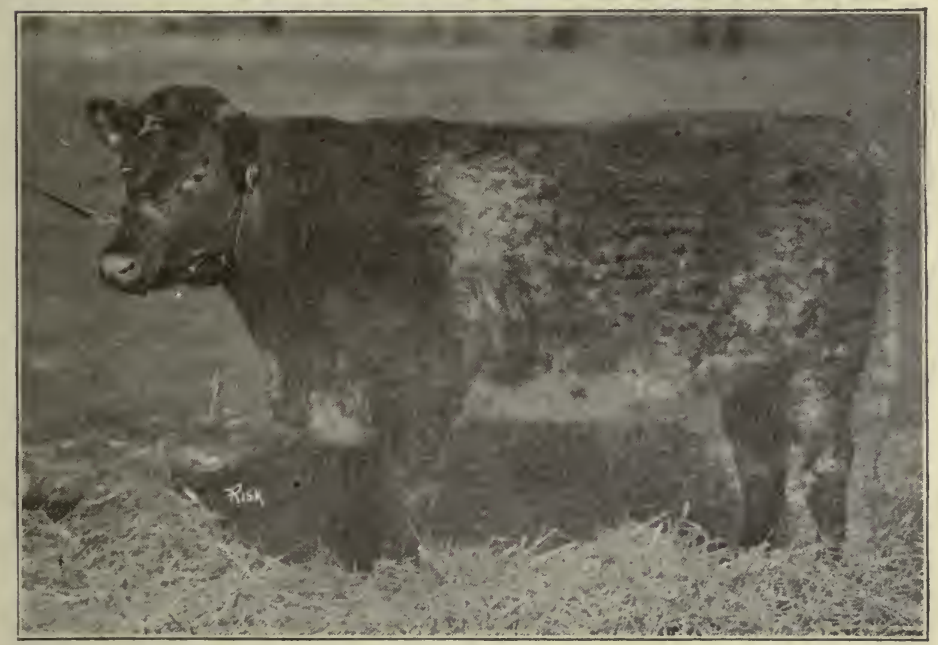

ROAN GERALDINE

herd and he was one of the group that won the get of sire prize, for his illustrious sire, Fair Acres Sultan. Of this calf Mr. Lookabaugh says, "Pleasant Acres Sultan was undefeated at the state fairs where he was shown. He looks very much like his half brother, Rosewood Reserve that sold for $\$ 8100 . "$ As a four-year-old bull Pleasant Acres Sultan shows a magnificent front with straight top and bottom lines and few bulls show as much finish, especially at the tail 
head as he. As a sire he is all that could be desired. His calves are easy feeders with the same soft touch, excellent finish and splendid carriage as their sire.

Seyb Bros. \& French, Pretty Prairie.-This firm consists of J. C. Seyb and W. H. Seyb, brothers, and L. R. French, a brother-in-law. Each owns and cares for his own cattle but they own their pasture lands and herd bulls in common and co-operate in any commercial transactions in the way of sales. The quality, as well as the blood lines of these herds, is largely the same. All of these men are in the business to stay and they plan to become real Shorthorn breeders making their herds first-class and passing the business on to the boys of the families. They have sufficient pasturage, plenty of alfalfa with ensilage and an abundance of water. With the care they are giving their herds they will, without question, be able to carry out their undertaking.

The cows are straight and smooth and are the kind that look like good producers. The breeding of pure breds began eight years ago following the raising of high grades, a few of which are still in the herds but which will gradually be closed out as the pure breds increase. The original purchases were made from the herds of Dr. R. A. Stewart and other local breeders and include two splendid cows bred by Alex Fraser, 
one of which, a great roan, by Falsetto, represents the high priced Duchess line crossed with the best Scotch bulls of the day. Among the sires of the cows are slich bulls as Lord Banff $2 d$, favorably known son of imp. Lord Banff; Victor Archer, Dr. Stewart's show and breeding bull; Forest Knight by Gallant Knight out of a dam by Norfolk, a famous sire in B. O. Cowan's herd and Dictator by Norfolk out of Daisy of North Oaks 5th. This last bull was a full brother to the dam of New Year's Delight, one of America's greatest show heifers. A recent addition of two cows was made from the herd of R. E. Gallatin of Missouri and they fit nicely with those on hand.

While good bulls have always been used Mr. J. C. Seyb says the last two have been the best of the lot. They both came from John Regier. White News was a big, thick, stretchy fellow and an exceptional breeder as a lot of heifers by him show. He was by New Goods out of Edelweiss 5th by Nonpareil Star and she was out of imp. Edelweiss by Star of Destiny. The present bull is a very smooth, good sized red, a wimner at the Kansas State Fair, and judging by four calves of his get, now nearly a year old, he is an unusual breeder. His sire, Dale Emblem, is by Double Dale and his dam is by New Goods out of a cow by imp. Lord Banff. The pedigree value of this bull is enhanced by the fact that Double Dale is frequentiy rated the best breeding son of 
Avondale while imp. Lord Banff was the first Scotch bull to sell for more than $\$ 5000$.

J. C. Banbury \& Sons, Plevna.*-This is a herd of 175 head, practically all of which are Polled Shorthorns. It has been built up by the use of excellent bulls from herds noted for quality of output, the three leading Polled herds of America having been heavily drawn on for breeding stock. One of the cows, Miami Golden Drop 2d, came from J. H. Miller, Peru, Indiana, the world's greatest Polled breeder. Her sire is Sultan of Anoka, one of Mr. Harding's best productions by the world's greatest sire, Whitehall Sultan. The other cows in the herd are rightly bred and are of very popular blood lines, including splendid specimens from leading herds in Indiana, Missouri and Kansas.

One of the herd bulls, Orange Champion, came from J. H. Miller's twelve years ago. He was by Roan Archer, also bred by Mr. Miller, in fact, the ancestry of this bull was largely of the Miller breeding. Sultan's Pride is by the International grand champion Polled bull, True Sultan, a noted sire of prize winners, a son of Sultan of Anoka, and one of the smoothest, best finished bulls of any breed ever seen on the western show circuit. Sultan's Pride was also a first-class show bull having been first and junior champion

* Farm in Reno and Pratt counties. 
in 1915 at Lincoln, Topeka, Hutchinson and Oklahoma City. In 1916 he was first at Burlington, Des Moines and Hutchinson where Mr. Banbury bought him out of the Stegelin show

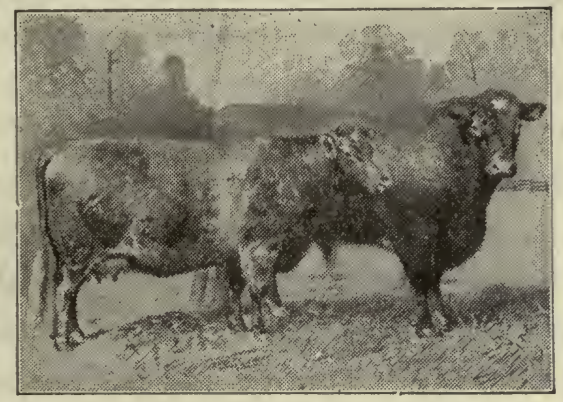

These cattle are in the Banbury herd and represent the Banbury type.

herd and put him to siring calves which show him to be even greater as a breeder than as a show bull. Roan Orange, one of the largest bulls of the breed and a son of Orange Champion, is still one of the leading herd bulls and is doing excellent service. Grand Sultan, a son of the noted sire, Meadow Sultan, is also winning fame for his owners and for the breed.

The conditions under which these cattle are kept insure the production of the profitable kind that give maximum returns for the feed consumed and they will do their full share in driving out the scrubs as well as the horns.

W. J. Holloran, Castleton.-Mr. Holloran has 
been breeding Shorthorns for six years. The cows purchased represent a good line of sires such as Ideal Archer by Victor Archer, Secret Prince by Prince Pavonia out of a dam by Gallant Knight and Fame's Goods by Ruberta's Goods out of imp. Princess Fame. The herd bull Rosewood Villager, is by Rosewood Dale, his dam is by Good Choice and his second dam is by Fitz Eustace, a son of Cumberland, the bull that made C. A. Saunders famous. These cattle have not been handled for best results but Mr. Holloran is making some improvements which will work for better conditions and consequent better development of the herd.

F. H. Oldenettel, Haven.-Mr. Oldenettel is a new breeder who bought a bull and a few cows from Tomson Bros. in 1919. Violet Lady is one of the good ones. Her sire, Butterfly Collynie by Secret Abbotsburn, carries near the top of his pedigree the blood of imp. Collynie, sire of Sweet Mistletoe, dam of the 1919 International grand champion and that of Young Abbotsburn, grand champion of America. The bull is Village Rex by Village Diamond, son of imp. Villager. His dam is by Cumberland Marshal, sire of the noted McDermott bred Village Marshal, now in use in the Tomson herd.

D. M. Beitler, Sterling.-Though Mr. Beitler has only a few cattle now, he has been handling Shorthorns for the last twelve years. His herd 
is largely representative of Victor Archer, the excellent son of Archer, that in Dr. Stewart's show herd made quite a reputation. A dash of imp. Collynie was also secured through the use of The Kaiser 577443. A son of Victor Archer is in service at present.

\section{REPUBLIC COUNTY}

R. B. Donham, Talmo.-Mr. Donham was raised in a Shorthorn family in Johnson county. He has a herd of twenty-five females and half of them are outstanding specimens of the breed. He demands that his cows be large, though not extreme in size, and his system of feeding is such as to produce as thick flesh and good general development as is consistent with future usefulness.

Mr. Donham has been exhibiting at the Republic, Clay and Mitchell county fairs, winning num-rrous prizes and at each of these fairs his herd bull, Victoria's Baron 2d, was made the grand champion against strong competition. He has been a contributor to both the Northwest Association sales held at Concordia and he has held one sale on his own account which was rated as very sucressful.

The help problem has been solved on this 320 acre farm by employing permanently a married man. The farm is devoted almost exclusively to pasture and the growing of alfalfa, ensilage and cattle. The Shorthorn herd will be increased 
both by retaining the best of the heifers produced and by making an occasional purchase. The cows in the Donham herd represent the most popular of the Cruickshank and Marr families and some of the pedigrees are especially attractive.

Miss Lavender, a roan bred by T. J. Blake, is good enough to have won the grand championship at the 1919 Republic county fair. Her sire, Royal Gloster, was by the popular Royal Diadem and her dam, Lady Acorn, was by Barmpton Bud 152945. Red Alexandria is a daughter of Orange Lad, a son of Geo. Allen's Victor Sultan, one of the best Whitehall Sultan sires. Her dam is Miss Dale by Merry Dale, a son of Avondale out of imp. Matrimony. At the 1920 sale held by C. S. Nevius \& Sons, Mr. Donham strengthened his herd by buying Valentine's Violet, a white twoyear old by Emma's Valentine, for $\$ 1325$. This is one of the richest and most popularly bred heifers in Kansas or elsewhere, for this line of breeding has produced Lady Supreme, the 1919 and 1920 grand champion cow west of the Mississippi and Lespedeza Collynie, the 1919 grand champion bull at the International. Valentine's Violet and her heifer calf by Golden Search would add great value and prestige to any herd. Golden Signet, an elegant twelve-month-old red heifer by Golden Search, also fell to Mr. Donham's bidding. 
In April 1918 at a sale of good Shorthorns, a friend asked me to pick out for him the best bull in the sale and I selected Victoria's Baron $2 d$. Mr. Donham saw this bull a week later and by paying my friend $\$ 200$ profit, he secured the calf, then just twelve months old, for use in his herd. He has grown into a splendid show and breeding bull, which is only what could reasonably be expected of him, for his ancestry has a rich inheritance of what is best in Shorthorns. Secret Baron, his sire, was probably the best son of Snowstorm, the elegant breeding son of Snowflake, sire of the three times International grand champion Ringmaster. His dam is by Choice Collynie, a bull that in the first remove descends from Choice Goods and imp. Collynie, Royal Knight and the two great cows, Wistful and imp. Princess Alice.

E. A. Cory \& Sons, Talmo.-The senior member of this firm is well known as sales manager for the Northwest Kansas Association. This is an old established herd and there are now almost 100 females on the farm. One of the best cows from which the herd descends is Belle of Evergreen 30th, sixteen years old, the dam of thirteen calves, ten of them heifers. She has weighed 1960 pounds and is considered by Mr. Cory a first-class Shorthorn cow. The size as indicated by this cow is one of the features of the herd which includes numbers of animals of 
more than usual quality. The original line of cattle has been supplemented from other herds. Jewell Star came from Blank Bros. \& Kleen and her sire, imp. Strowan Star, holds a reputation that adds prestige to his get. Being from good ancestry on her dam's side, she is a worthy addition to the herd. Redbird, a fouryear-old, is by Missie's Sultan 361372, son of Victor Sultan one of the favorably known western sons of Whitehall Sultan.

During the past season six valuable females have been purchased. These are of present day popular-blood lines and include Lancaster's Lady, first prize and champion female at the Republic county fair. Her sire is Village Flash of inter-state fame in the herds of Ed Hall and Evans Bros. and a son of imp. Villager. The dam of Lancaster's Lady is Sultana Lancaster by Sultan Supreme, sire of Village Supreme, International grand champion in 1916. Splendor Belle, another four-year-old, strong in Villager blood, is by Augusta's Villager by imp. Villager and her dam is by imp. Scottish Sentinel, both bulls of much excellence. The six heifers are considered by Mr. Cory a rare lot and, coming as they do from good herds and being backed up by ancestry of acknowledged merit and popular breeding, they can hardly help proving a wise investment.

Two bulls are needed in this large herd. One 
of them is the three-year-old Village King 649268 from Henry Kupper's herd, sired by Augusta's Villager by imp. Villager. Village King's dam is Autumn Queen Mary by imp. Scottish Sentinel, second dam by imp. Strowan Star. It is only, reasonable to presume that the use of this bull would give excellent results. The other one is Sultan's Champion 728280. His sire is Fair Champion, one of the good sons of the noted sire, Fair Acres Sultan. (See Borger sketch.) His dam is by Maxwalton Rosedale, own brother to Whitehall Rosedale, American Royal and western state fair grand champion. As this is written he is just twenty-one months old and $\mathrm{Mr}$. Cory writes me that he weighs nearly 1700 pounds.

The Cory herd is being kept in a section where Shorthorrs grow big and are supreme, helping to maintain the size of the breed.

E. A. Campbell, Wayne.-A herd of thirty females is found on this farm. The cows are of good size and the young stock is well grown. Mr. Campbell was an exhibitor at the Republic county fair in 1918 and 1919 and won his share of the ribbons each year. He was one of the contributors to the Northwest sale at Concordia in 1919 .

Cumberland Gem, a four-year-old roan cow, is by Double Sultan by Sultan of Anoka, one of the best of Whitehall Sultan's sons. Her dam is by True Cumberland 2d by Cumberland's Last, 
most famous sire of the family. Golden Lady is a three-year-old roan by Kansas Lad, a son of Pride of Collynie, not only an excellent sire but a bull with prestige of ancestry and own brother to Sweet Mistletoe, the dam of Lespedeza Collynie, International grand champion in 1919.

The bulls in the past were Choice Master $2 \mathrm{~d}$ 414200, and Kansas Lad, the Pride of Collynie bull mentioned above. Two bulls are now in the herd. Royal Diamond by Sittyton Minstrel 386816 out of Diamond Victoria 190666 by the champion, Diamond Goods and Lord Albion 819181 by Pride of Albion, the wonderful white bull that has been a consistent prize winner all over the Shorthorn country. It does not require much stretch of the imagination to predict for $\mathrm{Mr}$. Campbell a successful Shorthorn career.

Since the article above was written Mr. Campbell has greatly strengthened his breeding herd by the addition of two of the best females sold in the 1920 Nevius sale, Violet's Gratitude 836415 and Cherry Blossom 10th 836409. Both these heifers are of the best known Scotch breeding and Cherry Blossom 10th is of the same family and blood lines as the cow that topped the Park E. Salter sale at $\$ 3500$ in 1919.

\section{RICE COUNTY}

Fred Walton \& Sons, Sterling.*-The original

* Ship on Santa Fe, Mo. Pac. or Frisco. 


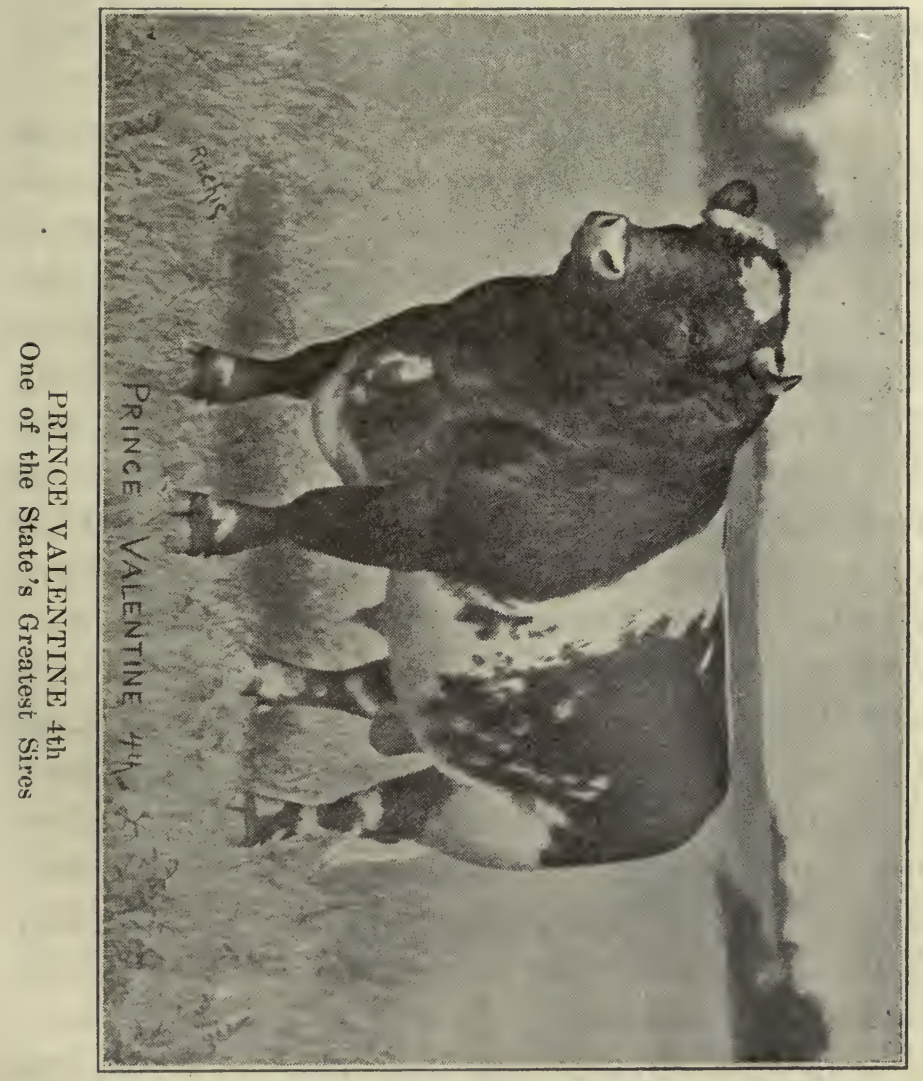


purchases for the Walton herd came from local breeders and were strong, rugged cows of quite good blood lines, but as in most cases they represented no concentrated effort to secure definite results. There was especially lacking that uniformity so desired by experienced breeders.

The first bull that was able to put his impress on the herd and make a marked advance toward the desired end was Lavender Search 405668,·a son of Searchlight. His dam was one of $\mathrm{Mr}$. Nevius' good cows, sired by the champion, Choice Goods. His dam was by imp. Lavender Lad, Mr. Dustin's great son of Scottish Archer, and the next cross was Golden Rule, the famous Robert Miller show and breeding bull. Lavender Search is very close to the ground, carries heavy flesh and is good from end to end. About twenty of his daughters of all ages will be in the herd and they are of the even, smooth, attractive kind that are almost invariably satisfactory breeders. A number of acceptable additions have been made recently, among them a beautiful red twoyear-old from Park E. Salter's herd and sired by Rosewood Dale. An occasional female will be added by purchase.

A most fortunate selection of a herd bull was made in 1914, Prince Valentine 4th, one among the best of Kansas bulls. He is now being used and will probably be continued in service here as long as he is useful. This ten-year-old bull was 
one of the best things that Mr. Nevius ever produced. As a show bull he had few equals and in my travels over eastern Kansas I have found a lot of his get of both sexes and every one is good. His calves have stood high at leading shows and both his bulls and heifers are such as to place him in the list of high-class sires. He has been used with much success by Mr. Nevius, Tomson Bros., and H. H. Holmes and Mr. Walton was fortunate in getting him.

Since the article above was written Mr. Walton bought seven of the top females sold at the 1920 Southeast Kansas sale at Independence as well as a few choice ones elsewhere. Prince Valentine 4 th is very sure and the building of an excellent herd is in rapid progress.

A. Case \& Sons, Sterling.-The sons of this firm are students of the Kansas State Agricultural College, the older one being a graduate veterinarian. Six years ago they bought of Tomson Bros. five heifers, two by Gallant Knight's Heir and three by Barmpton Knight. Their dams were of choice Tomson and Babst breeding. These heifers have developed into nice cows, several of them being of show yard type. The bull bought at that time was Lord Mayor 3d by Lord Mayor out of Forest Daisy of Norfolk. He was not only a satisfactory breeder but he was also a high-class show bull. This is not surprising since a full sister to his dam produced for 
Tomson Bros. the great heifer, New Year's Delight, International junior and American Royal grand champion. Little of the increase has been kept in the past but it is now planned to enlarge the herd by production. They have added to their equipment a big silo and a field of alfalfa.

A bull has been purchased (1920) from H. M. Hill, said by Mr. Hill to be one of his best products. His sire is Master of the Dales by Avondale and his dam is Emma Lady by Ingle Lad, followed by 47th Duke of Airdrie, Thistlewood and imp. King of Aberdeen. The Ingle Lad cows are rated among the best breeding cows in Kansas and this particular family in Mr. Hill's herd has produced uniformly good cattle.

G. N. Leclerc, Lyons.*-Ten years ago Mr. Leclere bought one Shorthorn cow, Mable 41318, and the entire herd comes from her. The old cow, now thirteen years old, is vigorous, is suckling a lusty calf and looks equal to having several more calves. While there are some good cows in this herd, yet it lacks somewhat in the uniformity that might be expected in the descendants of one cow, due probably to the use of bulls varying in type. One of the best bulls was Lord Archer. (See Smith sketch.) His get is smooth and even. The entire herd produces well and a very promising young bull is in service. He

* Telephone, Mitchell. 
is a correct Shorthorn type, very straight with a big body, fine head and neck and a disposition to do well on pasture seldom found in a bull of his age. His sire is by Star Goods, full brother to Diamond Goods and out of a cow by Victor Orange, probably Henry Stunkel's best bull. The young bull is out of a cow by Buccaneer, a son of imp. Collynie out of a daughter of imp. Mariner and his grandam is by Scottish Prince, a son of imp. Lord Cowslip out of Red Queen by imp. Scotchman. Mr. Leclerc is located near a splendid cattle country where cattle of the right kind are appreciated and he should have no trouble in disposing of his surplus. He is proving that a young man can successfully grow a Shorthorn herd from one cow-and his method should be followed by others.

Rousseau Smith \& Son, Lyons.*-We have here a striking illustration of the value of one cow. Eight years ago Mr. Smith bought a big red cow, Peerless, by Liberty Boy, a son of the champion, Viscount of Anoka. Her dam was by the Gentry bred Peris Victorious by Victorious. From this cow he has about twenty females, among them ten breeding cows of splendid Shorthor'n type with size and fleshing quality, and all of them prolific and suckling their calves abundantly. He has probably sold enough in these years to pay the keep of the herd.

* Telephone, Mitchell. 
At the same time Mr. Smith also bought a cow by Double Champion, the Choice Goods bull out of Russella, the dam of Ruberta and, though she soon became barren, several valuable females from her have been retained. In the herd there is an especially attractive cow that would be a credit to any one and all the cattle are good. The bulls used have been Lord Archer by Protector, a son of Barmpton Knight and out of a dam by Dr. Stewart's Victor Archer and Buster by Double Champion and out of a cow by Viscount of Anoka. Plans are now being made to put in service a first-class bull, the one thing lacking to make this a No. 1 herd. Mr. Smith is a good care-taker. He pays attention to detail and feeds well and with the bull that is to be secured we may expect the results that follow proper mating of good cows and caring well for the herd.

Hunter Bros., Lyons-This is the W. E. Hunter herd taken over by sons at Mr. Hunter's death. It is the oldest herd in Rice county and at this time consists of about twenty-five females. The young men intend keeping up the business, working improvements as they have opportunity to do so. Conditions are favorable as they have good pasture and alfalfa. The present herd bull is a large, stretchy, even-lined fellow that should impart plenty of size to his get and increase the scale of the cow herd. Like nearly all the herds 
of Rice county this lot of Shorthorns carries the blood brought in by E. H. Rutledge through Double Champion and Liberty Boy and the many good cows which composed that herd.

John J. Donnelly, Little River.-Mr. Donnelly has only made a start but the cattlemen of his community have always made good and he will do so. A sample of his herd is found in Ruby Lavender. Her sire, Lavender Search, is a great individual by Searchlight out of a Choice GoodsCollynie cow. The foundation comes from good herds and the output of this herd will be worthy of recognition.

\section{RILEY COUNTY}

Theo. Olson \& Sons, Leonardville.-One is apt to form an opinion of a herd by the cattle seen at different places and from this viewpoint I had formed a very favorable one of the Olson herd. What I have seen recently has confirmed my opinion. At a meeting of the Northwest Kansas association the Olson entries to the sale were highly creditable and one, a fourteen-month-old heifer, must be counted among the best things I have seen this season.

It is amid the most favorable surroundings that this herd is kept-two silos, 100 acres of alfalfa, blue.stem, alfalfa and blue grass for pasture, along with the needed grain to get development without any of the injurious effects of 
forcing, have produced good cattle and it is no wonder that there are some outstanding ones in the herd.

The seventy-five females range from medium to large. Royal Pauline is by Royal Marshall, grand champion and sire of big, beefy, smooth Shorthorns in great numbers. Royal Pauline's dam comes from Purdy Bros. and was by Lord Champion, a sire noted all over the West. True Good's Fashion is a roan of excellent form and character. Her sire, True Goods, was by Mr. McDermott's Fair Goods, the white son of the champion, Choice Goods and Ruberta the undefeated. Her dam is by Lady Acorn 2d by Barmpton. Diana is by Roan King, a son of Snowflake, sire of Ringmaster, the only bull that was three times an International grand champion. Her dam is Orange Belle by Hampton's Fashion, son and grandson of two of the greatest. bulls of Europe and America, imp. Merry Hampton and imp. Baron Cruickshank.

As to the bulls that did service in this herd, Rover, a roan, was by the Deane Willis bred Bapton Coronet, a son of the famous Silver Plate. Rover's dam was by Golden Archer, a son of imp. Master Archer by Best of Archers and out of imp. Lady-in-Waiting. Defender came from Tomson Bros. His sire was. Barmpton Knight, one of the best bulls of his day and sire of many show cattle at big shows including the 
Intermational. At present there are two bulls in service. Sultan is by Village Beau, son of the great Villager and imp. Belle of Ordeans. His dam is by Geo. Allen's Victor Sultan, one of the best sons of Whitehall Sultan. Village Boy is by Pleasant Dale 2d, sire of Lavender Lord and Maxwalton Averne, dam of the $\$ 100002 d$ Fair Acres Sultan. His dam is by Sultan's Last, the Whitehall Sultan bull used at Uppermill along with Villager, second dam by Proud Sultan, also by Whitehall Sultan. The get of the first named bull which can be seen as young cows will please critical visitors. In general they carry the type of Village Beau, his noted sire.

The W. J. \& O. B. Burtis and Henry B. Bayer Herds, Manhattan.-These herds are operated under separate ownership and management but are similarly located. Mr. Bayer is a son-in-law of the elder Burtis and the farms adjoin. They co-operate on the herd bull, in the matter of selling and in many other details. The herds should be considered together as intending purchasers will have access to both establishments. The farms consist of excellent corn and alfalfa lands and the best of upland limestone pasture with plenty of spring water. In addition to the Union Pacific and Rock Island railroads at Manhattan only three miles away, the Interurban from Junction City to Manhattan runs through the farms and cars stop at the doors. The Golden 
Belt highway also runs through the farms.

Both herds were established in 1919. It was not until April 1920 that a herd bull was secured, Jealous Dale, the splendid bull at Bluemont Farms, having been used prior to that time. When it was decided to buy a bull Mr. Walter Burtis attended the Central Sale at Kansas City and he will be remembered as the bidder up to $\$ 3500$ on Sanquhar Sultan, the Tomson bull that sold for $\$ 3550$. Failing to get this bull, they took advantage of the opportunity and bought his sire, Beaver Creek Sultan, from Tomson Bros. This grandson of Whitehall Sultan is a big, thick, short-legged white with a reputation as a great sire, his get having sold at big prices and matured into splendid animals.

The Burtis Cows.-Dale's Helen is one of the best daughters of Master of the Dales. Her dam is Helen 51st sold in one of the Southeast Kansas sales for $\$ 1000$. Sycamore Pavonia, also by Master of the Dales, is out of Glendale Pavonia $2 \mathrm{~d}$ by the excellent sire, Scotland's Charm, second dam, imp. Pavonia. This is the same ancestry as Mr. Nevius' Prince Pavonia. Queen Mistletoe (No. 24 H. M. Hill Herd Catalog) is a red five-year-old cow whose calves have sold in Southeast sales at $\$ 805$ and $\$ 1000$. Golden Mistletoe, the dam of Queen Mistletoe, has also been purchased for this herd. She is by Prince Mistletoe, a son of Mistletoe 2d, own sister to Sweet 
Mistletoe, dam of Lespedeza Collynie, sensational two-year-old show bull and 1919 International grand champion. This cow sold at the 1918 Southeast sale for $\$ 1245$.

The Bayer Cows.-Worthy of special mention is Sempstress 2d bred by S. C. Hanna. Her sire, Prince Royal, was by imp. Collynie out of imp. Princess Royal 62d. Her dam, Sempstress of Oakland 8th, was one of the highest priced cows in the Cox dispersion sale and her sire, Thistlewood, and grandsire, imp. King of Aberdeen, were two of America's noted bulls. The white, Butterfly Belle, is a Dryden bred daughter of Archer's Hope and her dam is out of imp. Butterfly 51st. Sycamore Secret 5th is by Master of the Dales by Avondale and her dam, Ingle's Secret by Ingle Lad, was out of Sycamore Secret by imp. Collynie. There are no cows better descended than these.

Kansas State Agricultural College, Manhattan.-The Shorthorn herd at the College now consists of forty-eight head of splendid, well bred eattle. Many of the best families are represented, including the Duchess of Gloster, Butterfly, Orange Blossom, Mina, Lavender, Queen of Beauty, Gwendoline, Jealousy, Bessie and Clara.

Matchless Dale, the senior herd bull, is known by the winnings of steers sired by him. None of his heifers have been shown at the big shows, but his daughters are wonderful cows, broad, deep, 
thick and smooth with a lot of quality and sweet feminine character. Only recently, May 26, 1920, one of his daughters, College Duchess 2d, sold for $\$ 3900$ in the Kansas Shorthorn Breeders Association Sale. She sold right out of the pasture in ordinary flesh. Matchless Dale, now thirteen years old, is as active and vigorous as a two-yearold and he still maintains that wonderfully kind and gentle disposition.

When it was necessary to have a bull to cross upon the daughters of Matchless Dale, having noted the splendid success attained by our foremost breeders by line breeding, the College sought and found a bull rich in the blood of Avondale. He is sired by Revolution by Avondale and is out of the good show cow, Maxwalton Mina 8th. She and her dam were both sired by Avondale. This makes the blood of the new bull Marauder, five-eights Avondale. His first crop of calves now coming (1920) are an exceptionally promising lot.

Until recently only a few bulls have been sold by the College but this order of things has been changed and excellent youngsters are now going out to do service in Kansas herds.

Otto Bros., Riley.-Otto Bros. have a herd of fifteen good females descended from a small purchase made seven years ago. They are growing the young stock well and with plenty of pasture and alfalfa will be enabled to produce size 
as well as quality. While the herd bulls of the past have carried the blood of some worthy ancestry, it is only within the last year that a real effort has been made to obtain the kind of a bull that should attract attention. Those who saw and read the last April edition of The Shorthorn in America may recall having seen a picture of a roan bull calf by Matchless Dale alongside his dam, Pride's Bessie, a first-class beef cow with a milk record of more than 8000 pounds. This young bull, Best of Dales, is Otto Bros.' herd bull. He represents not only what is best for the producer of beef as shown in the fact that Matchless Dale has sired more prize winning beef steers than has any other bull of any breed living or dead and that his dam would be a strong contestant in a beef class show, but he represents the very thing needed by the small farmer whose cows must raise good beef cattle yet give milk for the family and frequently also for market. Pride's Bessie, dam of Best of Dales, is illustrated on page 11 of this book. In lending their aid to the solution of the farm cow problem Otto Bros. will not go unrewarded.

Bluemont Farm, Manhattan.-This lot of forty females is one of the well selected Kansas herds, including daughters of Avondale and Villager and of other good bulls as well as of some imported cows. The object is to develop, along with the prestige of best ancestry, a herd of cows 
weighing near 1500 pounds and giving 7000 to 9000 pounds of milk a year. The bull used is Jealous Dale by Matchless Dale, dam by Avondale, second dam by Whitehall Sultan. The owners of this herd are two of the best known cattlemen in the United States with whom the Bluemont Farm project is a minor line of business.

W. J. Weisner, Manhattan.-Mr. Weisner is located a short distance from the city on a farm well adapted to growing Shorthorns. He expects to build up a good herd and he has a nice foundation coming from Andrew Pringle and representative of the excellent breeding bulls Mr. Pringle has always used. This gives him the blood of such famous sires as Col. Harris' Golden Knight, imp. Thistletop and the great cow, imp. Golden Thistle by Roan Gauntlet, imp. Baron Victor and others of the leading western sires. His herd bull has one of the best possible recommendations in that he combines the blood of four outstanding herds, the two Betteridge herds, Tebo Lawn and that of B. O. Cowan.

\section{SEDGWICK COUNTY}

A. W. Jacob, Valley Center.-Treating the present herd as a foundation, Mr. Jacob has abundant material with which to achieve any degree of success he may wish to attain. There are some excellent cows in his herd, closely 
descended from bulls that have produced the best class of Shorthorns in south central Kansas. Red Royal by Royal Knight, son of the great cow imp. Princess Alice; Star Goods and Victor Orange, both of inter-state reputation in the Stunkel herd; Captain Archer, own brother to Sweet Mistletoe, dam of the 1919 International grand champion; imp. Prince of Perth, through a son out of Goldfinch, own sister to the International grand champion, Lavender Viscount; Lord Mayor, famous sire for Col. Harris and T. P. Babst and a host of good ones of lesser reputation are much in evidence in the top crosses. A valuable addition to the cow herd, Broadhook's Gem, in calf to Dale's Renown, was secured at the Robison sale in 1919.

Mr. Jacob has been in the business long enough to know that the big end of all breeding operations lies in the bull at the head of the herd. $\mathrm{He}$ recently bought Bonny Emblem, a very promising white yearling. He is a son of imp. Proud Emblem Jr. whose sire Proud Emblem is one of the most popular bulls in Scotland as well as the sire of numerous American bulls of national reputation.

O. B. Hall, Oatville.-Two years ago Mr. Hall bought a few Shorthorns and he is planning to carry on breeding along with his extensive wheat raising. Several of the cows came from E. L. Stunkel and represent the select Stunkel 
line of breeding so favorably known in south central Kansas. A very good cow of excellent blood lines was added at the Wichita spring sale in 1919. A promising young bull out of a daughter of Maxwalton Rosedale is one of the splendid prospects. Mr. Hall has ample facilities for handling Shorthorns successfully and should he decide to make a real business of it he would succeed in getting together an outstanding herd.

B. J. Spexarth, Colwich.-Mr. Spexarth has five good females descended from the cow Violet 9 th bought at the Stunkel dispersion. This cow is by Star Goods, own brother to the champion, Diamond Goods; and her dam is of the approved Stunkel breeding. The herd bull came from $\mathrm{A}$. W. Jacob and was by a son of Captain Archer, own brother to Sweet Mistletoe, dam of the 1919 International grand champion bull. Mr. Spexarth has plenty of pasture and alfalfa. He has the assistance of his sons who intend to breed Shorthorns for themselves later.

\section{SHAWNEE COUNTY}

Tomson Bros., Dover and Wakarusa.*_-I like. the story of the rise of Tomson Bros. because it is so natural that its very simplicity appeals to me. When the first Shorthorn was bought at a farm sale in 1886, there was probably nothing to indicate that the three boys of the family

* Station for Dover farm is Willard on the Rock Island. 
would ever be known outside their own vicinity. He would have been considered foolish indeed, who should have pointed out the oldest as future president of the American Shorthorn Breeders Association; the second, editor of the official organ of that association: and the third, then an overgrown boy, as one of the best judges of beef cattle in the world and one of the best beloved members of the entire Shorthorn fraternity. Yet such advancement has resulted from the first purchase of a good Shorthorn and subsequent purchases made by a wise father and urged by the enthusiastic sons, who were good cattlemen and who learned that there was something better in store for them than could be gained by competing in a crowded industry, trying to make over an article that had been made or marred by someone else.

There was plenty of room at the top. It was possibly not until the days when Gallant Knight's calves began to show the quality of his wonderful ancestry that the Tomsons saw visions and dreamed dreams of a great future for them and their favorite breed of cattle. What they saw has come to pass. When the leading Shorthorn breeders of America are listed, the name "Tomson Bros." is always near the top of the roll.

It was accomplished by enthusiasm, the quality called stick-to-it-iveness, and conservative 


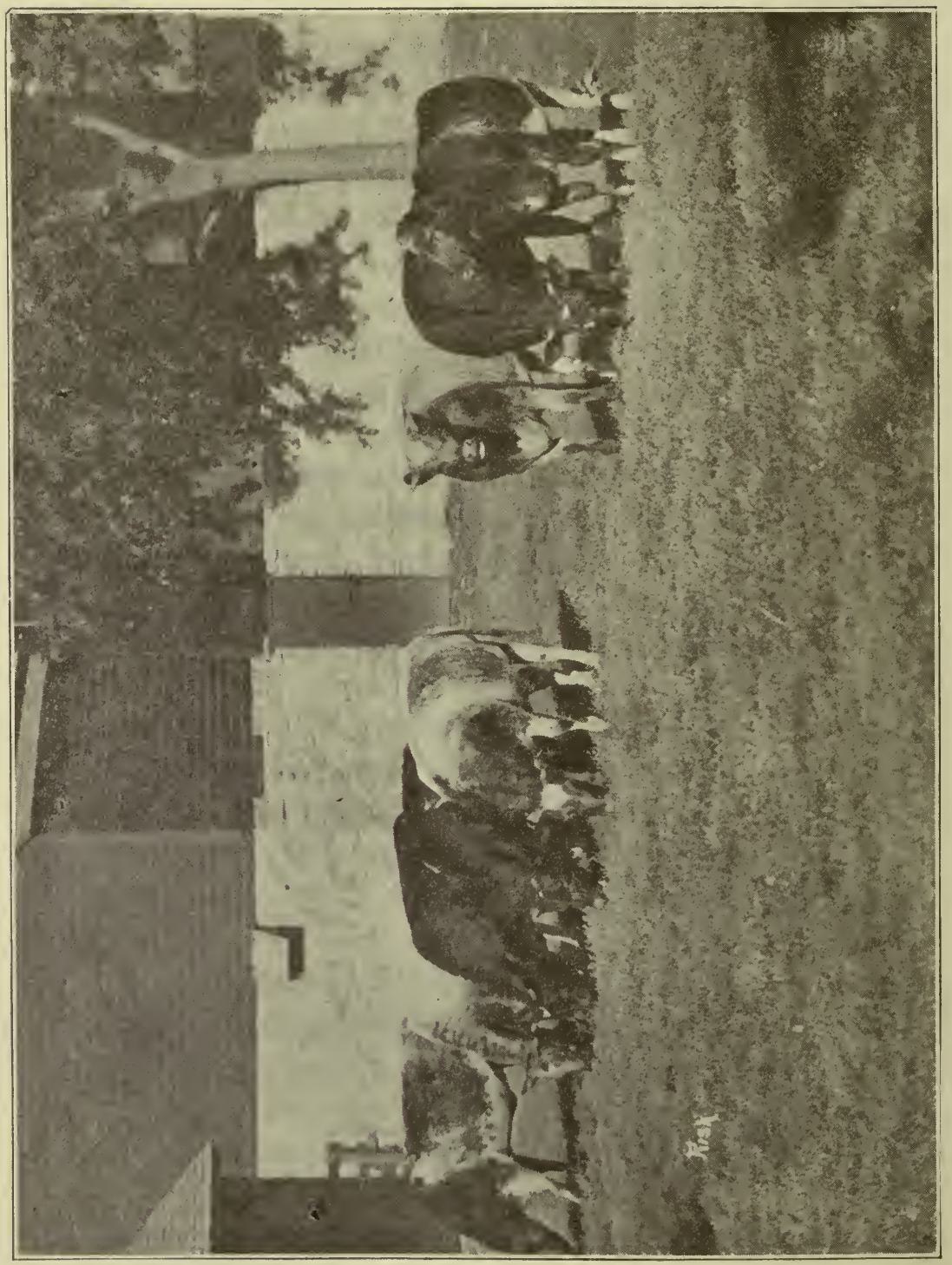

学 
methods. Tomsons have never been plungers. Every purchase has been carefully considered. Every dollar has been paid out only when it was clear that the investment was a wise one. So year after year they have climbed a little higher. There is a valuable lesson in the history of this firm. The path to the same success Tomson Bros. have achieved is still open and opportunities are as good now as they were for them. It is true, Shorthorns can no longer be bought for what they paid for their start; neither does the beginner have to sell his produce for from $\$ 25$ to $\$ 50$ each as T. K. Tomson \& Sons did in their early experience.

It was stated in Part I that the real history of the Tomson herd began with Gallant Knight. It is doubtful if many bulls of the past two or three decades proved as good sires of females as Gallant Knight, though he did not have the benefit of great matrons as many sires of the present day have. Scarcely a year of the twelve in which his get were shown in the fair circuits but that one or more of his daughters claimed a championship. His use in the herd brought about a uniformity in type that gained wide popularity for the Tomson productions. The Gallant Knight females proved of great value as producers and the Gallant Knight blood is still a factor in the Tomson herd.

Archer, a dark roan of generous scale, a son 
of imp. Collynie and imp. Circe $3 d$, was purchased and for several years used extensively in the herd. He possessed great robustness, easy feeding quality, strong, well covered back, much thickness and was set on the best of legs. He had a rather plain horn and a tendency to droop a little at the tail, but he proved a valuable cross on the Gallant Knight daughters. Archer was the sire of Christmas Lassie, champion female at western state fairs and at the American Royal and was sold before his value was fully realized.

With the expansion of the business, preference was shown for the more fashionable breeding and gradually there have been drawn into this herd representatives of the families held in highest favor by the breeders on both sides of the Atlantic, until at the present time the combined herd of Tomson Bros. which numbers normally 200 head, represents these tribes exclusively.

Probably no sire up to that time proved a more valuable acquisition than Barmpton Knight. He was an intensely bred Cruickshank bull by Scarlet Knight, a widely known son of Craven Knight. Barmpton Knight was bred by E. S. Myers, now living near Chanute. Attention was attracted to him while in the hands of his former owner, E. D. Ludwig, Sabetha, Kansas, where his calves showed remarkable uniformity though from dams of all types. He was secured and for 
five years did exceptional service, siring many high-class show animals and ranking with Gallant Knight as a sire of outstanding females. A number of his daughters are rated among the most valuable individuals and producers in the Tomson herd today. Barmpton Knight was a rich red of wonderful feeding propensity. His coat and flesh covering were like that of imp. Thistletop.

One of the best known of Barmpton Knight's get was New Year's Delight, the heifer that as a junior yearling won the grand championship all along the western show circuit and at the American Royal and was made junior champion at the International. This wonderful heifer was sold to Thomas Johnson and in his herd produced a calf good enough to win high honors in the steer class a few years later. New Year's Delight was out of Forest Daisy $2 \mathrm{~d}$, one of three sister's by Norfolk, that had been bought of B. O. Cowan by T. P. Babst and had been transferred to Tomson \& Sons along' with the Babst herd of 100 head, in 1907. Another daughter of Forest Daisy 2d bred to Barmpton Knight produced Daisy Queen, champion winner on the western state fair circuit in 1911. This heifer was sold into Idaho where she became the dam of the Portland champion steers for four years. It was a granádaughter of Forest Daisy 2d, Daisy May by Lord Mayor, that bred to Barmpton Knight 


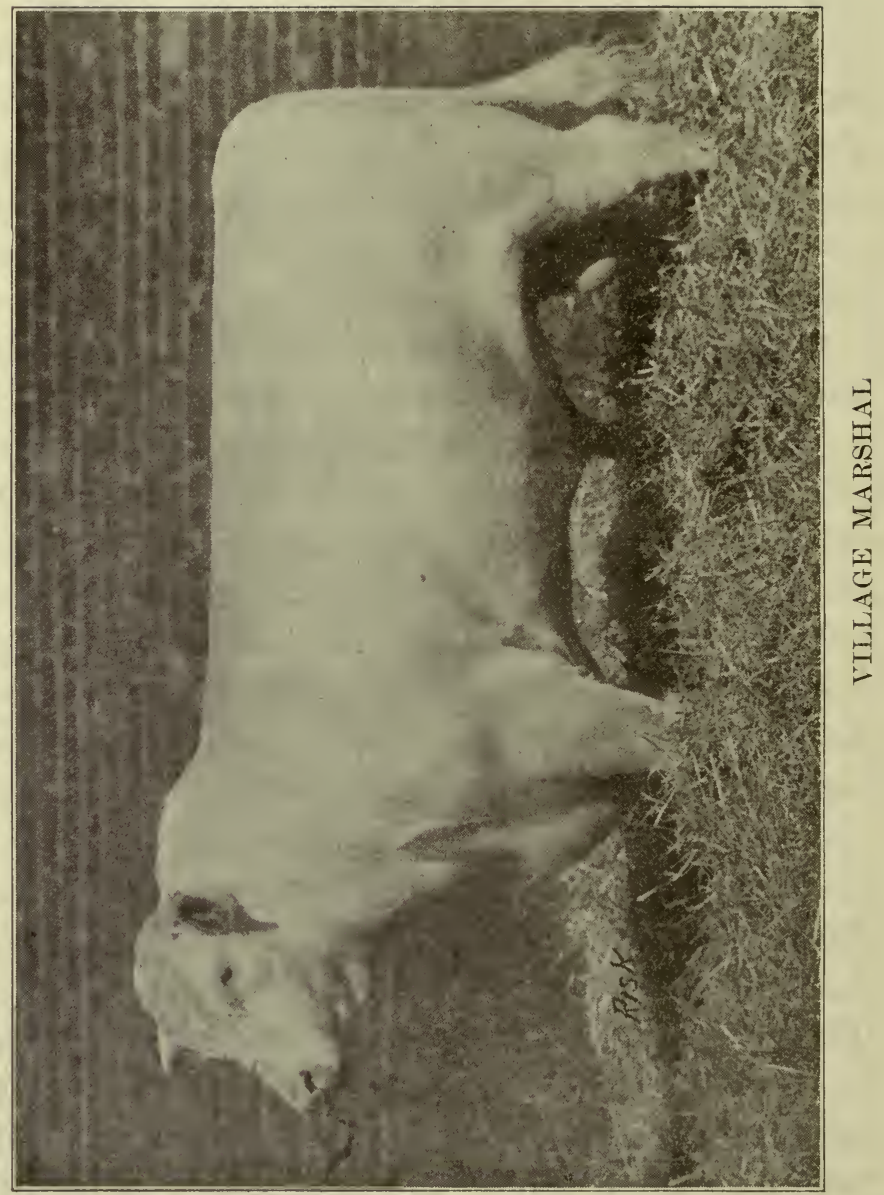


produced May Daisy 3d, the dam of May Daisy 6th. May Daisy 6th was a prize winner at the American Royal in 1919 and one of the tops in the Royal sale. Forest Daisy $2 d$ and her immediate family crossed with Barmpton Knight produced many excellent animals. It was from Tomson bred Barmpton Knight cows that the Kansas State Agricultural College bred a number of its prize winning steers.

Several of Barmpton Knight's get were used in the herd, one of which was Crusader, an outstanding roan. In 1913 Maxwalton Rosedale came to the farm with the Pringle herd. This bull had the prestige of his sire, Avondale, and of his dam, imp. Rosewood Pride, one of the best of all the Carpenter \& Ross cows. She was the dam of Whitehall Rosedale by Avondale and of Pride of Albion by imp. Shenstone Albino, both American Royal grand champions. Maxwalton Rosedale gave satisfactory service for several years.

To succed Barmpton Knight the champion futurity calf, Village Marshal by the great sire, Cumberland Marshall, was secured and is now one of the chief stock bulls and rated one of the outstanding sires of the breed at the present time. He combines in his top crosses the blood of Whitehall Sultan, Cumberland's Last, Villager, Bapton Diamond and Silver Plate. He is white, of unusual compactness and has the 
remarkable quarters that characterized Gallant Knight. He carries a heavy, smooth flesh covering, level top, and possesses rare breed character. His calves have never failed to attract favorable attention. While very little showing is done now by Tomson Bros. the get of Village Marshal have made an impressive showing whenever exhibited. His calves as a rule are beautiful roans and possess a uniformity and conformation that meets the favor of the most critical judges. One of his sons out of a dam by Barmpton Knight is being retained for service, Marshal's Crown, a bull of very remarkable depth of middle, thickness and fullness of quarters. His head approaches the ideal. He is one of the great young bulls of his time. He descends from imp. Marigold bred by the late W. S. Marr of Scotland. Another great bull which at this writing is in service is Beaver Creek Sultan, also a white by Sultan, a son of Whitehall Sultan. The dam of Beaver Creek Sultan was imp. Victoria Mary, one of the greatest cows brought to America in recent years. Beaver Creek Sultan is a wonderful flesh carrier, a natural feeder, possessing ample scale and bone. He is a very prepotent sire.

The herd as composed represents the blood of practically all of the leading sires of the present day. The various tribes, as the Shorthorn folks are in the habit of designating the maternal ancestry, represent the Augusta, Marigold, Roan 


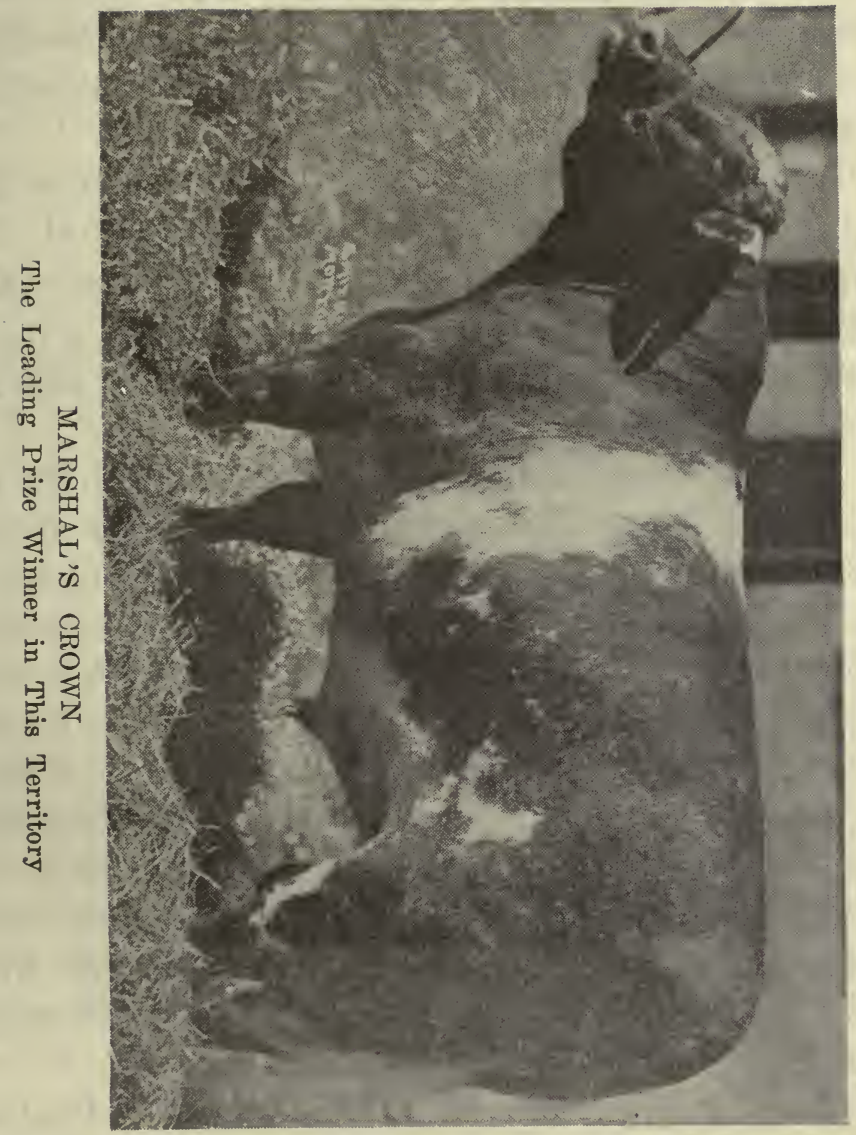


Lad, Jilt, Lavender, Victoria, Duchess of Gloster, Orange Blossom, Mayflower, Clara, Violet, Spicy, Gwendoline, Simplicity, and others of similar merit and popularity. But it is always the individuality that has claimed first consideration of Tomson Bros.

The farm acres have grown from a modest beginning to approximately 1300 acres and the plans contemplate a continuance along the established lines through the junior members, a later generation, who are still on the youthful side of twenty years.

The present members of the firm are John $\mathrm{R}$. Tomson, Dover, for many years a director of the American Shorthorn Breeders Association, serving two terms as president of the association; James G. Tomson, Carbondale, both being generally known as skilled judges and called to officiate in such capacity in many parts of this country and Canada and Frank D. Tomson, Lincoln, Nebraska, editor "The Shorthorn in America" the official organ of the American Shorthorn Breeders Association. He was formerly a member of The Breeder's Gazette staff for a number of years.

H. T. Forbes, Topeka.-Mr. and Mrs. Forbes are both much interested in their Shorthorns. They have an elegant farm four miles west of Topeka and they have an elegant herd of cattle on the farm. The herd represents eighteen years 
of selection and care and a good foundation to start with. The cows are large, at least there are none that incline toward being small. They are kept in thrifty condition and the young stock is kept growing all the time. Sales have been good, too good in fact, for the herd in numbers is below what it should be and what it is intended it shall be in the future.

Of the twenty-five females on the farm I did not see one that needed to be culled out. Sweet Orange $3 d$ was bred on the farm. She is a roan by Model Gloster and is out of a granddaughter of imp. Master of the Rolls, sire of much excellent stock, including Master of the Grove, International grand champion. Golden Dale, another roan, is by Maxwalton Rosedale, own brother to Whitehall Rosedale, American Royal grand champion and out of imp. Rosewood Pride, dam of Pride of Albion, another American Royal grand champion. The dam of Golden Dale came from the Davidsons in Canada. Cassandria Beauty came from H. H. Kupper and is by imp. Scottish Sentinel, a bull of wide reputation in Nebraska. Her dam was by imp. Strowan Star. Orange Baron, the herd bull recently acquired, has a three-year-old daughter on the farm out of a dam by Gloster's Choice by Marengo's Choice. I do not know that it was because of this heifer's excellence that Mr. Forbes wanted her sire but it is a safe guess that were she not good, he would 
not have bought her sire. I have given an idea of the females in the herd both as individuals and from the pedigree viewpoint. Before leaving them I wish to add that this herd of cows looked and acted like good producers. The shy breeder and apparently barren animals were not in evidence and the calves looked like they had milk.

Royal Violet was one of the early bulls. He was by Prime Minister that was by imp. Prince of Perth and out of Goldfinch, own sister to the International grand champion Lavender Viscount. The dam of Royal Violet was by Golden Prince, a Dryden bred son of Prince Gloster, sire of the $\$ 10000$ Prince Imperial. A son of Royal Violet, Orange Master out of Sweet Orange, was also used some. Master Barmpton came from Tomsons and was by Barmpton Knight.

I always feel a special degree of enthusiasm when I write of Barmpton Knight for from this great sire came a whole family of Shorthorns that were the real kind to make the cattle grower rich. Master Barmpton's dam was by Lord Mayor, one of the greatest bulls of the West, that advertised T. P. Babst \& Sons as only an outstanding buli can do. Model Gloster was by Choice Goods Model, son of the champion, Choice Goods, and Rosedale Violet 9th, the famous Tebo Lawn matron that had to her credit more high priced calves than any other cow of her day. She 
was the dam of Leonard's Rosedale's Choice, of Gentry's Choice of All, of Hall's Choice Goods Model and of Runaway Girl, dam of Bellows Bros.' Best of Goods, besides six excellent lesser

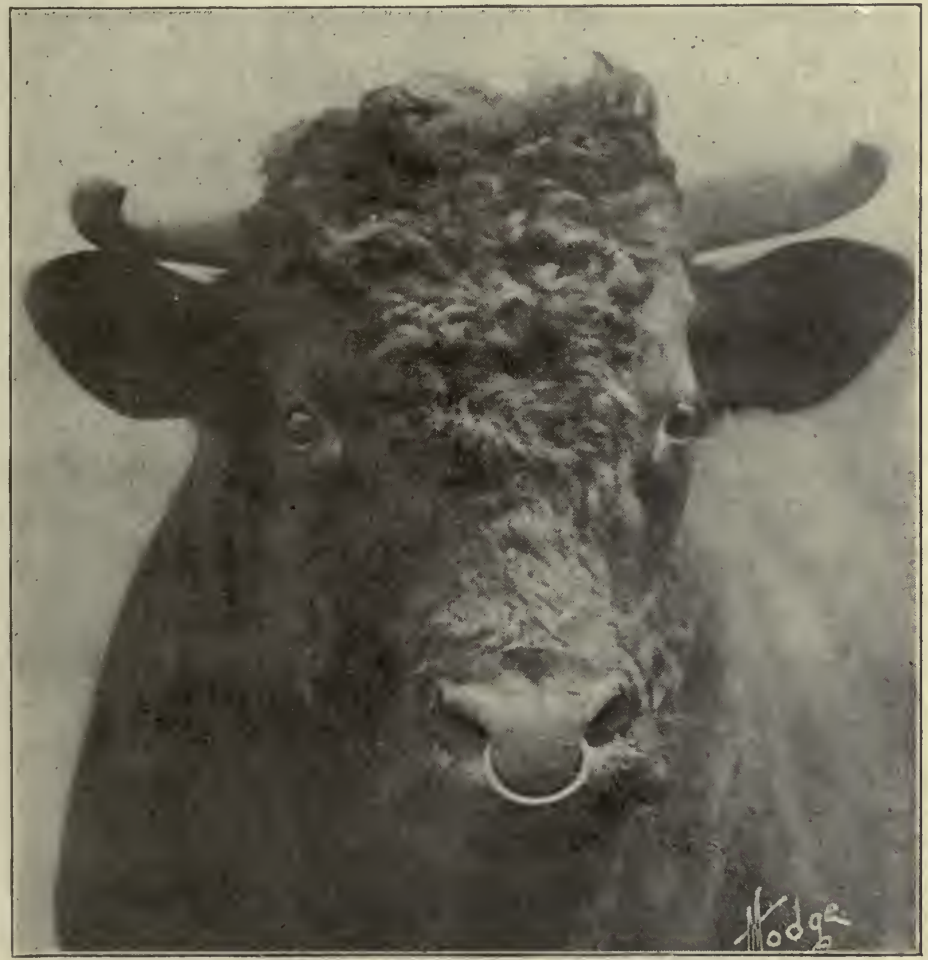

ORANGE BARON

Used by Tomson Bros. and Sold by Them to Mr. Forbes

lights of the Shorthorn universe. The dam of Model Gloster was Glenfoyle Duchess of Gloster 2d by Scotch Fame 151799. Royal Monarch was 
by Harriman Bros.' Proud Monarch, a son of New Goods, the Choice Goods Collynie bull that headed their herd at the time of its dispersion.

Recently a new bull was bought. He is Orange Baron, cut on a very generous scale, yet close to the ground, with a deep, thick body. He has plenty of spread but covers smoothly. His head and neck are fine. He is by Orange Model by Victorious and his dam is also by Victorious, famous son of Lord Mayor out of a daughter of imp. Baron Victor.

H.H.Holmes, Topeka.*-Mr. Holmes has been well known in Kansas Shorthorn circles for ten years. He lived at Great Bend until 1918 when he bought and moved to the much advertised Aylsdale Farm five miles southwest of Topeka. He keeps his herd within the prescribed line of universal approval so far as pedigree is conecrned. When he suits a prospective purchaser on an animal he wants to know before the deal is closed that the pedigree will suit. Most of the herd descends from purchases made from W. A. Betteridge and other selections come from equally cautious and discriminating breeders.

The Holmes herd consists largely of Cruickshank Orange Blossoms with a few Queen of Beautys and other good families. Rose Victorious is by Victorious, known the country over as a great bull and some consider him the best son

* Rural Route 28. 
of Lord Mayor. He went from Linwood to N. H. Gentry as a youngster and after serving there for ten or twelve years he worked for Mr. Betteridge until he died. His dam was by imp. Baron Victor, the outstanding Cruickshank bull of America. The dam of Rose Victorious came from Russell's Canadian herd and it will be of interest to know that her dam was by Stanley, the noted sire of prize winners at the Columbian Exposition.

Emma S. is a roan Kansas bred daughter of Searchlight, grand champion of several state fairs, a winner at the American Royal and sire of the cow that topped Park E. Salter's sensational female sale at $\$ 3500$. The dam of Emma $\mathrm{S}$. is Lady Emma by Ingle Lad, a Kansas bred bull now winning fame through his great producing daughters. Emma S. is the dam of the grand champion, Lady Supreme, and this prize winning heifer was calved on Mr. Holmes' farm and developed by him. Her dam and an own sister to Lady Supreme are now in his breeding herd.

Honor Maid is another roan by Searchlight. Her dam, Maid of Honor, came from George Bothwell's great prize winning herd and was by Grand Victor out of imp. Winifred 4th. Hallwood Golden Drop 5th was bought at the Ed Hall dispersion sale as a calf and she looked like the best calf in the herd. Her sire, Village Flash, by the great Villager sold in the sale to J. R. Evans \& Bros. for more than $\$ 2000$ and her dam 
was by Choice Goods Model, the $\$ 1500$ prize winning son of the champion Choice Goods and Rosedale Violet 9th, the leading American producing cow. The reader will bear in mind that these prices were obtained in the cheap times.

Riverside Queen, a six-year-old red by Clipper Model, is out of Crestmead Beauty 2d by Orange Model, the bull used much and successfully by Mr. Betteridge and sired by Victorious. (See above.)

Only brief mention can be given the bulls of the past. New Echo 360066, after being used some, was sold to Miss M. V. Stanley who later sold him to Bennington Bros. (See Bennington sketch.) Clipper Model, before mentioned, and Clipper Brawith 444189, a son of Clipper Model were representative of the Betteridge breeding. Prince Valentine 4th, a bull that did much for the herd and sired only first-class stock, was by Prince Pavonia, Mr. Nevius' great son of imp. Glendale Pavonia. He was a show bull and until three years old was kept in show condition. He also did good service for Tomson Bros. It is certain that Mr. Holmes let him go before he fully realized his value.

Cumberland Champion is now in service. He is a $\$ 2000$ son of imp. Newton Champion 650059 whose first crop of bull calves it is said averaged $\$ 3500$. His dam is by Cumberland Marshall, a bull that in Mr. MeDermott's herd 
not only made the herd but also its owner famous. The other bull is Count Valentine 4th. A full brother to this bull was a prize winner at the big shows and a high seller a year ago. I saw this bull in July 1919. The man who wants a hard job might try to seriously fault him.

Mr. Holmes is popular with the breeders of the state and is a model to others in the attention he gives to his correspondence. He has at all times the invaluable assistance of his daughter, Miss Helen, and to her he gives much credit for whatever success he has achioved with Shorthorns.

F. C. Kingsley, Auburn.-Mr. Kingsley has been raising Shorthorns for nearly thirty years and has been a heavy producer from few purchases. He first bought three cows from T. P. Babst, two of them by imp. Thistletop. Some years later he bought two of Andrew Pringle. These five cows carried the lines of breeding for which the Babst and the Pringle herds were noted. The Pringle heifers especially were nicely descended and both were bred to Maxwalton Rosedale from which service each produced a heifer calf. Bulls of good breeding have been used in this herd and many of the cows show real Shorthorn character.

Among the first bulls in service was Red Laird from the Babst herd sired by Laird of Linwood, a bull bred almost the same as Gallant Knight. Golden Dawn came from Pringles and he was 
by Golden Prince by Prince Gloster, sire of the $\$ 10000$ Prince Imperial. The dam of Golden Dawn was by The Baron, a bull used by T. J. Wallace. He was by Baron Sussex, dam by imp. Burgomaster. Tom Thornton came from Gen. McAfee and was by Earl of Gloster, an exceedingly well finished son of imp. Double Gloster. Maxwalton Rosedale. was the sire of the next bull and he bore the name of Dodd Gaston, probably out of local pride.

It would hardly be interesting to mention all the bulls used during the thirty years. Those listed will represent the rest but one other must not be overlooked. Twentieth Earl of Valley Grove by Lord Mayor, a bull with a reputation in Wilson county later, was bought of T. P. Babst as a calf. He was used in the herd for four years, then sold to Senator Benedict where he sired much excellent stock, especially breeding cows. The bull in use at present is Big Ben 707309. His sire, Kansas Collynie, is by Mistletoe Archer, whose dam, Sweet Mistletoe, is also the dam of Lespedeza Collynie, International grand champion in 1919. Big Ben also carries the blood of Ingle Lad, sire of the dam of Lady Supreme, American Royal grand champion in 1919.

H. H. Churchill, Topeka.-Mr. Churchill is a man who never does a thing by halves. His herd is not yet large but he is building in a judicious 
manner and, being a good feeder, he will be suecessful. The hord includes a few elegant young cows by Marquis Cumberland, son of Cumberland's Best, sire of the sensational Cumberland's Type. (See Willis Colman sketch.) An attractive and finely bred young cow is Juanita, bred by E. S. Myers. Her sire combines the blood of three well known bulls, imp. Collynie, imp. Lord Cowslip and Duncan's Headlight. Her dam is by Choice Prince by Prince of Tebo Lawn and her second dam is by the McDermott bred Morning Star. I saw Juanita with a promising heifer calf at foot and consider her a valuable young cow. At the Salter sale in 1919 Mr. Churchill bought Lavender Lassie by Golden Gloster, a young cow of choicest breeding. It. is the intention to make further additions of good females.

At Kelly Bros.' sale in June 1919 Emblem's Dale, probably the best bull in the sale, went to Mr. Churchill. He is a roan, good sized, close to the ground, with deep, thick body, well covered, and good head and neck. Emblem's Dale is not deserving any serious criticism and he should make a satisfactory sire. He is by imp. Proud Emblem Jr. and his dam is by a son of Avondale, second dam by a son of Choice Goods.

Mr. Churchill is one of the men who will go out of the way to help push any interest with which he is identified. 


\section{SMITH COUNTY}

Springbrook Stock Farm, Lebanon.-T. M. Willson is owner and K. M. Davison is manager of Springbrook Stock Farm, a leading Polled Shorthorn establishment of the state. It is the intention to breed only Polled cattle on this farm. Thirty females of breeding age are now in the herd among which are some outstanding ones. The young stock is well fed, the object being to get as much size as possible without injurious forcing. Alfalfa and ensilage with grain for the young stock and the excellent native grass pastures of that section make the production of good cattle easy. Consignments have been made to breeders sales, including that at Omaha in 1919, and arrangements are now being made to put out a show herd.

The foundation cows have been secured from the leading Polled herds of the country and were of the best lines of breeding to be obtained. Desirable bulls, both in type and in breeding, have been consistently used with the result that always follows such course of action. The two bulls now used are Baronet 516167 and Cumberland Sultan 795793. Baronet came from the Walker herd in Nebraska. He is strong in the blood of Roan Hero, one of the noted bulls of the breed. Cumberland Sultan is a two-year-old from Achenbach Bros. On a choice Cruickshank foundation 
coming from Tebo Lawn he descends through an elegant line of bulls. His sire and grandsire, Imperial Sultan and Intense Sultan, both bred by J. H. Miller, were among the best bulls of the breed.

\section{SUMNER COUNTY}

E. L. Stunkel, Peck.-Ever since E. L. Stunkel was a small boy his life has been associated with Shorthorns. Those who have read the sketch of his father and especially those who knew Henry Stunkel will understand that a boy raised with an old cattleman such as he was would take up the business and follow it successfully. Ed Stunkel is breeding Shorthorns because he would feel lost without them. At the time the big Stunkel herd was dispersed he owned a number of cows and, taking advantage of his intimate knowledge of the animals in the sale and the rather low prices which prevailed, he bought some of the most desirable females sold. These were all daughters or granddaughters of Victor Orange, a bull that, had he been given a chance, would have proved one of the best sires in the entire Southwest.

A number of the cows were by Star Goods out of Victor Orange dams. Star Goods was own brother to Bellows Bros.' show and breeding bull, Diamond Goods. The Stunkel herd as now constituted descends mainly from cows purchased 
by Henry Stunkel from Jos. Duncan of Missouri and is largely the result of the use of four good bulls. Some of the cows are bred within the so-called Scotch lines while others are not, but all are from excellent ancestry and of the choicest breeding.

The four bulls referred to, named in the order used, are Knight of Meadow Farm 3d, Victor Orange, Star Goods and Cumberland Diamond. Knight of Meadow Farm 3d was a Forbes-W. A. Harris product, his sire, Baron Golddust 3d, having been by Baron Gloster and his dam by Lord of Linwood, a son of imp. Baron Victor out of imp. Lady of the Meadow, a cow later destined to become famous as the dam of Lord Mayor. The cows by Knight of Meadow Farm $3 d$ developed into exceptional breeders. Victor Orange was a bull that left the rather unusual record of having sired extra good breeding bulls and extra good producing cows. These cows were not generally of show yard type but every one I have seen was a big, rugged, straight lined, good bodied cow with feminine head and neck. They all produce strong, lusty calves and it became a recommendation for size and quality for any calf to have a Victor Orange dam. Victor Orange came by his ability to sire such cattle, honestly. His sire was by Victorious and his dam by Scarlet Knight, two of the best bulls of their day and both sires of outstanding merit. 
Star Goods was a Bellows Bros. production. His sire was Good Choice by Choice Goods out of Silene $2 d$ by a son of imp. Burgomaster. His dam was by Victorallan, a sire of many of the breeding cows in the Bellows herd. He was a bull of more finish than Victor Orange and his daughters were perhaps more pleasing in appearance than were the Victor Orange cows, but the general opinion of old breeders seems to favor the Victor Orange cows. The Star Goods cows out of Victor Orange dams have, however, proved good producers and would be valuable breeding cows in any herd.

Cumberland Diamond, the last of the quartette of bulls that have made this herd, is a massive white. Bred to the herd of nearly all red cows he has almost invariably sired nicely colored loan calves. His heifers are especially pleasing. 'They are very feminine in appearance, are of good size, straight lined, and look like real breeding prospects and a man starting out with a lot of Cumberland Diamond heifers backed by Star Goods, Victor Orange and Knight of Meadow Farm 3d on the dam's side would have something of which to be proud. Cumberland Diamond is by Cumberland Chief, a son of Cumberland's Last out of Hampton's Lovely by Hampton's Best. His dam is also by Cumberland Chief. His second dam is by Banker's Victor, one of the best breeding bulls ever used in C. C. Norton's 


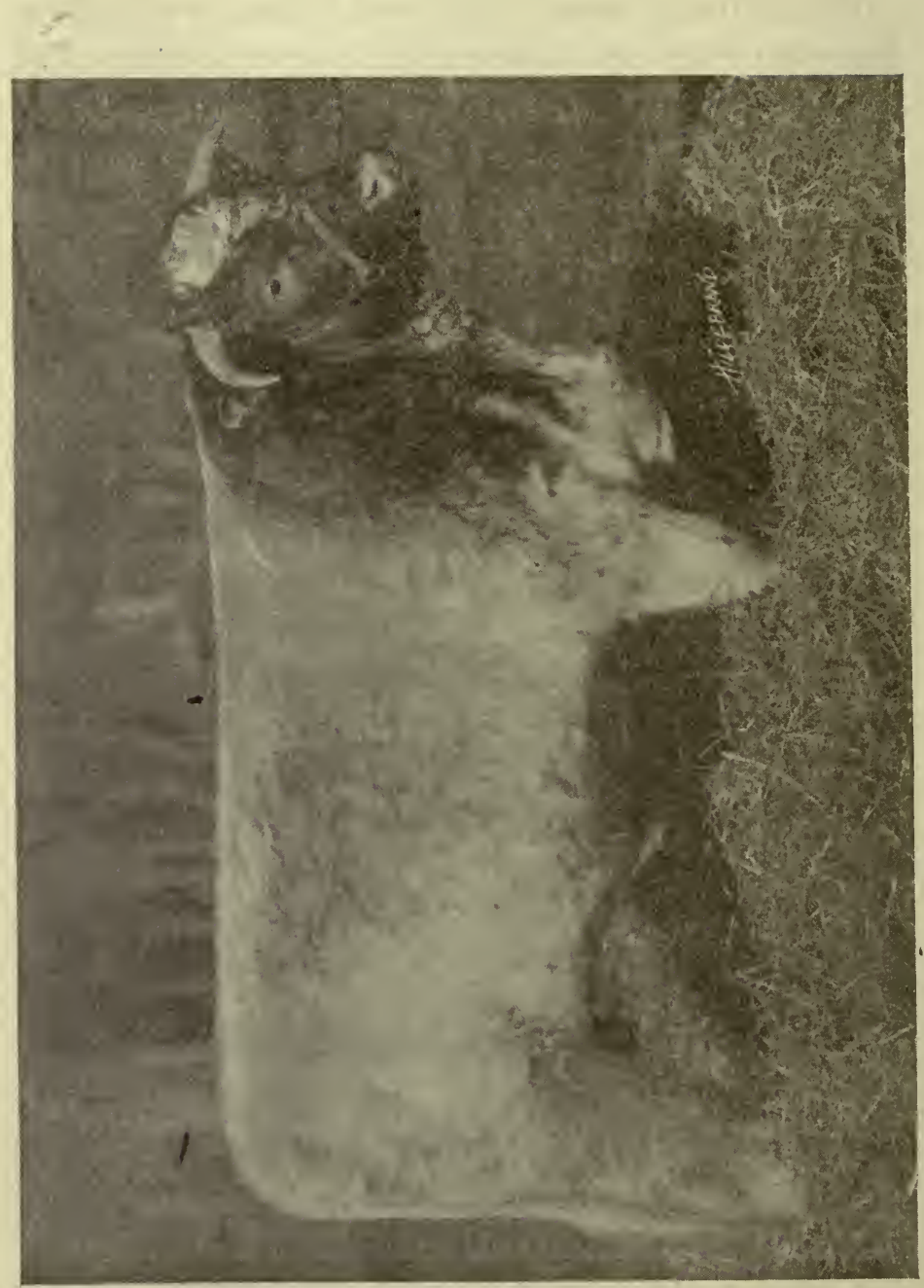

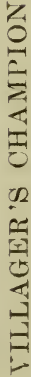


herd and the next dam is the Crombie bred imp. Diamond 31st. Such a wealth of ancestry should make any bull a good sire and Cumberland Diamond is only transmitting what he has received from his sire and dam.

To use on the Cumberland Diamond heifers Mr. Stunkel has secured Villager's Champion, a short-legged, thick roan that stood third in class at the American Royal, fifth at the International in 1919 and second at Wichita in 1921. He is probably the best bull used in the herd since Victor. Orange and combines some of the most desirable ancestry known to Shorthorn history. His sire is Village Perfection, a son of imp. Villager. His dam is by Lord Champion, the famous son of imp. Lady Douglas used with much success by Purdy Bros.

Meuser \& Co., Anson.*-Sixteen years ago Wm. and Chas. Meuser bought a Shorthorn cow and two year's later they bought four heifers. They had extreme bull luck for several years and increase was slow but during this time the sale of bulls paid well for keeping the herd. As the later purchases of females were balanced by females sold we may fairly say that the present herd of nearly 100 cows and heifers comes from the small outlay made fourteen years ago. Pedigree was considered, but not until after the animal had been selected on account of its real merit

Telephone, Conway or Riverdale. 
and qualification for handling the ordinary farm feed and turning it into salable commodity at the maximum of profit.

This system has been applied to animals for retention in the herd and the Meuser Shorthorns hold their place on the farm only while they pay. No nurse cows are needed here because forcing is not practiced but more especially because a poor milking cow is worth more for beef than for a breeder. Mature cows are of good size, 1200 to 1400 pounds being demanded of them in breeding condition. As a result of avoiding either extreme in feeding Mr. Wm. Meuser states they have had no complaints from any of their numerous bull customers in all these years. There is an object lesson here for farmers who care to use ordinary business sense in substituting pure breds for grades or scrubs.

The bulls, as in all other herds, have furnished the clue to the success of the owners. Pride of Orange and Lovel Goods both came from Henry Stunkel. The first was by Star Goods and sustained the reputation of his sire. The second was by Star Goods out of a dam by the excellent son of St. Valentine, Lord Lovel. Two rather extra good bulls are being used. Sycamore Chunk is a big son of Mistletoe Archer, one of the sons of Sweet Mistletoe, the dam of the 1919 grand champion. His dam is Snow Secret 2d, a cow that is also the dam of Miss Stanley's Secret 
Robin. This bull is full of the blood of the best of the breed and it is no surprise to find he is a successful sire. Hamlet comes from Tomson Bros. He is a well finished son of Maxwalton Rosedale out of a dam by Gallant Knight's Heir, second dam by Barmpton Knight, breeding to satisfy any one.

The only attempt made at showing was at the 1918 and 1919 Kansas National at Wichita when the Meuser entries demonstrated their worth by winning thirteen ribbons, the bull Hamlet, then a senior yearling, winning third place in open class and the Kansas-Oklahoma Special. The real success which the Meusers have attained is within reach of any progressive farmer.

H. O. Peck \& Son, Wellington.-Ten years ago H. O. Peck \& Son bought several cows at the J. F. Stodder dispersion and a few more of local breeders. The selections were wisely made and from these cows they have built up a useful herd. The cows range from medium to large and are, generally speaking, of good quality, of nice straight lines, with fine heads and necks. They are the type of cows that prove good breeders and sucklers and can be depended upon to show a profit. The cows bought were of desirable ancestry and blood lines. In some cases they were exceptional and the use of the right kind of bulls has made the herd what it is.

It was at Mr. Peck's that I saw one of the 
hopeful signs, not only for the future of the breed, but also as indicating what the breeder of the future must do if he expects to maintain his prestige against competition. It was a lot of pure bred steers from eight to eleven months old and only one appeared unfit for a fairly good bull. Two whites were especially attractive and one of them was almost an ideal of the true money making Shorthorn type. This indicates that the Pecks have a high standard for the bulls they sell and sets an example for breeders in general. This lot of steers, as well as some elegant heifers, were by the present herd bull, Master Marshal.

There is little need of going into detail as to the breeding of the cows since the bulls used in the top crosses indicate it. These came from such herds as those of Henry Stunkel, C. B. Dustin, Williams Bros., T. P. Babst, J. F. Stodder, S. C. Hanna, J. G. Robbins \& Son, N. H. Gentry and H. C. Lookabaugh, all herds of national reputation and unexcelled as sources of supply for bulls. Two worthy bulls used by the Pecks were Banff Boy and Butterfly King. Banff Boy was by Cherry Grove Banff 49th, a son of imp. Lord Banff out of a Choice Goods cow. Butterfly King came from J. F. Stodder. His sire was Silvermine and his dam was by Captain Archer, two crosses not easily surpassed. The bull in use, Master Marshal, second prize 
winner 1919 Kansas National, is a white of most pleasing form. I feel sure I could say nothing more of this bull than is richly deserved, for he is a typical Shorthorn of the highest class. From head to tail, and from his back to the ground, he is not open to any serious criticism. He has plenty of size and what is best of all, his calves, although a little young to be used as a positive basis of judgment, are altogether promising.

The disposition of this firm is to produce an outstanding herd and they have the enthusiasm, as well as the facilities, to carry out their intentions.

Just as we go to press we learn that H. O. Peck \& Son have bought a Bellows bred son of the International grand champion Village Supreme to follow Master Marshal.

Thos. Murphy \& Sons, Corbin.-This is one of the well known Shorthorn breeding firms of the county. The foundation stock came from such herds as those of Henry Stunkel and Marshall Bros. and the bulls were from equally reputable sources. One of the Marshall bred cows was by Scottish Prince, a son of imp. Lord Cowslip out of Mr. Hanna's Red Queen by imp. Scotchman. The Stunkel bred cows were either by Victor Orange or they were well filled with the good Stunkel breeding.

One of the early herd bulls came from T. J. Wornall \& Sons. He was by Silver Consul by a 
son of imp. Consuelo 2d, out of a daughter of imp. Magenta. The bull used longest and the one that had the most beneficial effect on the herd was Orange Goods 370667. He was a handsome, finely finished red bred by E. L. Stunkel. He was by Star Goods, the popular Stunkel sire, a son of Good Choice and own brother to the champion, Diamond Goods. His dam was a daughter of Victor Orange, regarded all over southern Kansas as one of the best breeding bulls of his day. That Orange Goods, combining as he did the blood of the noted sires, became an outstanding breeding bull is not surprising. The Murphy herd is largely of the same blood lines as the Stunkel herd.

A. M. Reece, Oxford.-This herd of twenty females was established in 1912 by the purchase of two heifers in ealf to Silvermine, the well known bull used by J. F. Stodder and later by Marshall Bros. The cows are of good type and good size. Among the excellent females of the herd is Quintella by Silvermine, dam by Captaiu Archer. This should insure size and quality as well as good production. Silver and Silverine, both reds, are by Royal Archer 2d, a son of Aberdeen, practically a full brother to Ingle Lad. Royal Archer's dam was Syringia, one of the best cows of her day in Kansas. Silverside is a six-year-old roan daughter of Silvermine out of Silverine, mentioned above. 
The two bulls prominent in this herd are Silvermine and Captain Archer bred directly from the best importation of Duthie and Marr bred Shorthorns. Other bulls used were Marshall's Best by a Hanna bred son of imp. Lord Cowslip; Silver Heel by Silvermine and Diamond Major, present herd bull, by Cumberland Diamond. The dam of Diamond Major represents the Stunkel Star Goods and Victor Orange crosses. The lines of sires and dams below this come from the most noted breeders of their day and the bull is worthy of his ancestry.

Mr. Reece has shown locally with fine success and is a contributor to the Sumner county breeders sales.

\section{E. Wooderson, Caldwell.-Mr. Wooderson} is among the best known breeders in this territory. His herd which consists of twenty smooth females has not been so well developed in size as the best interests of the establishment may have demanded but facilities for handling the stock have been improved and the younger animals have been well grown out. The cows are nearly all bred along very popular lines and only choicely bred bulls have been used so that the Wooderson cattle usually find no objectors on account of pedigree.

Golden Gloster was bred by F. M. Hackler. He was a son of imp. Daydreams Pride, the sire of numerous herd bulls used in eastern Kansas 
and western Missouri. Golden Gloster's dam was by Lord Thistle, an excellent. Mastin bred son of Baron Ury and Rose of the Thistle 2d. Supreme Goods was by Star Goods (see Stunkel sketch) out of Supreme, one of the daughters of Glendon, that was bought by Henry Stunkel from Jos. Duncan. Gloster Cumberland is a roan son of Cumberland's Best, son of the great show bull and sire, Cumberland's Last and sire of the sensational prize winner Cumberland's Type. The dam of Gloster Cumberland was 77th Duchess of Gloster by See A Cumberland, another son of Cumberland's Last, giving him a concentration of the blood that has made Mr. Saunders' herd one of the most famous in America.

Otto B. Wenrich, Oxford.-The first purchases for this herd were made three years ago. Princess Phyllis came from C. S. Nevius and is by that splendid sire, Prince Pavonia, out of a dam by Gallant Knight followed by Norfolk and imp. Scottish Lord, a succession of four great bulls. Silverside is a daughter of Silvermine, a noted bull in the herds of J. F. Stodder and Marshall Bros. Her dam is by a son of the outstanding cow, Syringia by Royal Knight. Valley Daisy 8th comes from E. L. Stunkel through the fine Star Goods-Victor Orange line. A son of Matchless Dale, sire of International prize winners at the Kansas State Agricultural College, 
has been used. Victoria's Emblem, an outstanding son of imp. British Emblem, is now in service.

George D. Vaughn, Wellington.-This herd of fifteen females has some animals that attract attention. Silver Heiress is a six-year-old white by Rosewood Dale, the $\$ 3000$ son of Arondale that made his reputation in the herds of Park E. Salter and John B. Potter. A number of other cows of nice breeding are also found here. The bull used until recently was Dale's Signet by Dale Clarion, a bull whose get are now winning high honors at the biggest shows. The dam of Dale's Signet was from H. G. Carson's herd and was by Malaka Banff. The present herd bull is a white by Symphony's Last, a son of Symphony's Best, the sire of the excellent cows in the C. A. Scholz herd.

\section{THOMAS COUNTY}

A. H. Arneal, Colby.-This herd of twentyfive females is composed of choice selections from the L. M. Noffsinger herd. The beginning was made in 1917 and four of the best things on the farm are by Fancy Lord, a splendid sire from Tomson Bros. Mr. Arneal also has a number of heifers by Pleasant Dale Sultan, an American Royal prize winner that combines the blood of imp. Shenstone Albino, Avondale and Whitehall Sultan and breeds true to ancestry. The good 
young bull, Secret Dale, is the sire in use. Mr. Arneal is in the part of Kansas where Shorthorns are not numerous and he will be able to present an object lesson to the people of his community.

\section{WABAUNSEE COUNTY}

S. D. Mitchell, Allen.*-This is largely a story of Col. Carvel, a bull whose monument of greatness as seen in S. D. Mitchell's cows is so impressive that the visitor, if he be a student of Shorthorn history and an admirer of really good cattle, will take off his hat to Mr. Mitchell, the first man I have found in Kansas, who with exceptional judgment, displayed the backbone of Amos Cruickshank.

Going back to the story of Thomas, Jameison $\&$ Mitchell, the reader will note that Mr. Mitchell owned a herd individually at the time of the dispersion. In the former herd were two good sized, thick fleshed, smooth, straight lined, red cows. They were by the great show and breeding bull, Barrister. Bred to White Goods, they produced a pair of roan bull calves. Mr. Mitchell did not say when he became convinced of the fact that these were remarkable calves, but when Andrew Pringle, that excellent breeder, came buying bulls he priced him his choice at $\$ 200$ with the statement that he would keep the other for his

* Present address, Lexington, Kentucky, Rural Route 2. 
own use. He did keep him and under the name of Col. Carvel he was taken from the pasture and without fitting he won third place in a strong class at the American Royal. I had the pleasure of seeing this bull as a long two-year-old and thought him one of the best individuals I had ever seen.

The Mitchell herd consists of twelve cows of outstanding excellence. Six of these are by Col. Carvel, four are out of his daughters, and one is by White Goods, his sire. It is doubtful if in any other herd in this state can be found the same number of cows by one bull or out of his daughters that are equal in size, elegant appearance, smoothness, fleshing quality, milking capacity and as breeders, to this lot of cows.

As I saw these cows in the pasture in 1919, all except one suckling calves by Jealous Renown 498758, I could not help thinking what a pity it was that so many breeders allow their commercial instincts to seriously interfere with their success as real breeders. Mr. Mitchell did not do this and he has the results of his devotion to high Shorthorn standards shown in these cows. Becky Barrister 8th, the only daughter of White Goods left in the herd, is thirteen years old and is suckling an elegant heifer calf. If this calf fulfills its promise, some one will have to take notice later. Baron Hampton, a Dustin bred Merry Hampton-Baron Cruickshank combination, is 
the sire of several of the cows out of Barrister, White Goods and Col. Carvel cows. When we think of imp. Merry Hampton and imp. Baron Cruickshank as two of the best bulls ever imported from Scotland, of White Goods as one of the greatest sons of Choice Goods and of Col. Carvel as a Shorthorn wonder, we can get an idea of the ancestry. Back of all this is Barrister, winner of 247 first prizes at leading shows, and imp. Craven Knight his sire, frequently referred to as the most beautiful and perfect bull of his day. As to the herd bull, Jealous Renown is three years old. His sire is Maxwalton Renown, one of the truly good sons of Avondale. Jealous Renown is out of a dam by Avondale, second dam by Whitehall Sultan, third dam by Count Arthur and fourth dam by Star of Morning. If there is anything in being elosely descended in every remove from the world's greatest Shorthorns, Jealous Renown will be a great sire. If judgment may be passed on the appearance of eleven calves from ten days to four months old, he is a great sire.

Whatever others may think of Mr. Mitchell's course, it seems to me he has achieved a triumph in constructive breeding not attained by any one else of whom I have knowledge for, breaking away from all accepted regulations, he mated cows of most admirable breeding with a bull of pre-eminent merit, and has reaped 
results fully up to any possible anticipations.

The article above was written in June 1919. Since that time Mr. Mitchell has closed out his Kansas holdings and he and Mrs. Mitchell are living in the choicest section of Old Kentucky, their ancestral home. These elegant Kansas bred Shorthorns are on a fine farm near Lexington where they will do their share toward restoring Kentucky to the pinnacle of Shorthorn glory it occupied prior to 1880 .

George J. Appleton \& Son, Maple Hill.-This herd dates from 1895 and numbers thirty-five females. The original purchase was from L. A. Knapp, followed by selections from the herds of Andrew Pringle, Tomson Bros. and Babst Bros. One of the Pringle cows was by Sir Knight by Col. Harris' Golden Knight and out of imp. Sorrel by Roan Gauntlet. Another Pringle bred cow is Kalona by Prime Minister, a son of Imp. Prince of Perth out of an own sister to the champion, Lavender Viscount. Roan Butterfly is a good cow by Modern Scotchman, a son of imp. Magenta. Her dam is by a son of Golden Victor Jr. and out of a Lord Mayor dam. Lavender Choice was recently bought of Tomson Bros. Her sire is Ingle Lad, a son of imp. Collynie, that is regarded highly, especially in southeast Kansas. Her dam is Lavender of Calstock Farm by the champion, Choice Goods, followed down the line by the 
choicest Cruickshank breeding. A six-year-old red, Woodbine Lovely, is another purchase from Tomsons. Her sire is Lavender Prince 6th 384932 and her dam is by Pleasant Hill Master, a son of the International grand champion, Master of the Grove.

A number of good bulls have been used in the herd. The first was a son of Knight Templar. 141953 out of a dam by Major Richmond 112835 . The T. P. Babst herd furnished one strong in the blood of Lord Mayor. Athenian Coronet 4th by imp. Bapton Coronet was probably one of the best of the early bulls. He had been used for a time by Andrew Pringle and was followed in the Appleton herd by a son of Prime Minister (see above) out of a daughter of Golden Prince whose sire, Prince Gloster, was also the sire of the $\$ 10000$ Prince Imperial. Lavender Chief, now in use, comes from Tomsons and combines the blood of Barmpton Knight, Gallant Knight and imp. Baron Victor. This bull is an outstanding breeder. Victor Crown by Beaver Creek Sultan, dam by Orange Magnet, second dam by Headlight, is a new bull from Tomsons, considered by Mr. Appleton a splendid prospect.

Babst Bros., Auburn.-The name Babst brings up visions of a Shorthorn herd that had a wide reputation some years ago. It was on the Babst farm that Lord Mayor ended his life after thirteen years of great service. When the Babst 
herd was sold to Tomsons it was the intention and for a short time the practice to keep a Shorthorn herd as producers of market cattle but the Babsts had been in the pure bred game too long to be permanently satisfied with this method, and so, quite naturally, they began selling breeding stock.

The present herd consists partly of cows bred by A. A. Clark. Good cows from other herds were also secured and the Babst herd now numbers about 100 females. Among additions outside the Clark cows was Lawnsdale Duchess 43d, bred by Alex Fraser and sired by Falsetto. Her dam was by Prince Royal 2d. Red Olga's Victor by Golden Victor Jr. out of Red Olga by Scottish Emperor was from one of H. M. Hill's best families of cows. An especially attractive, young cow is the Tomson bred Lady Marshal by Village Marshal out of a dam by Lord Mayor, second dam by Vanquish, a well known Harris bred son of Galahad. There is also in the herd one by Beaver Creek Sultan out of the same dam and these two heifers are giving Babst Bros. the same class of females as the best of their herd at the time of its sale to Tomsons.

The bulls in use have been good ones. Archer's Victor was by Archer, the son of imp. Collynie and imp. Circe $3 d$ and out of Elderlawn Victoria by Gallant Knight. Ingleside For Me, a white, bought to change the herd from red to roan not 
only did that job well, but he proved a splendid sine. He was by Rosewood, a son of Collynie and the Duthie bred imp. Roseleaf by Scottish Archer. Prince Marigold was bred by Tomson Bros. and sired by Prince Valentine 4th. His dam is by Barmpton Knight, second dam by imp. Crescent Knight out of imp. Marigold 146th. A recent purchase is Victor Beaver, a Tomson bred son of Beaver Creek Sultan. He is out of a dam by the Duncan bred Orange Magnet and is a worthy successor to the bulls that have preceded him.

J. A. Pringle, Eskridge.*-Mr. Pringle is a son of Andrew Pringle and has been with Shorthorns all his life. His herd of twenty-five females will be increased and improved. Roan Lady $2 \mathrm{~d}$ is by Captain Archer, sire of prize winners at state fairs, the American Royal, and the International and an own brother to Sweet Mistletoe, dam of the 1919 International grand champion bull. Filbert is a good cow out of the home herd by Athenian Coronet 4th, son of imp. Bapton Coronet and Augusta 111th by Scotch Fame. Her dam is by Prime Minister, a bull out of an own sister to the International champion, Lavender Viscount. Loraine 6th is a daughter of Royal Violet, a son of Prime Minister (see above) out of a daughter of Golden Prince by Prince Gloster, sire of the $\$ 10000$ Prince

Station and telephone, Harveyville. 
Imperial. Her dam is by Sir Knight, grandson of Mr. Cruickshank's great Roan Gauntlet. This will suffice to show the blood lines in the Pringle herd.

Maxwalton Rosedale, own brother to the grand champion, Whitehall Rosedale, originally boug ${ }^{3}$ t by Andrew Pringle and sold to Tomson Bros., tlee sire of much high-class stock, was used for a time in this herd. Golden Laddie, now used, is a roan by Maxwalton Rosedale and out of Golden Bloom by Prime Minister, a big, smooth bull and a capital sire. There are few herds better filled than this one, with Amos Cruickshank's best blood.

E. L. Knapp, Maple Hill.-Fifty years ago Mr. Knapp was born in the house in which he now lives. His father, L. A. Knapp, a well known breeder, had just come from Illinois bringing some Shorthorns with him. The present herd descends in part from these cattle brought to the Kansas farm in 1870, making Mr. Knapp's one of the oldest herds in the state. The herd is not large, numbering only about ten cows, which are used to raise good calves and give milk for the family and occasionally some for market. It goes without saying that cows kept for this purpose are heavy milkers. The bull in service comes from the Appleton herd.

C. R. Wyker, Belvue.*-Mr. Wyker is beginning a herd with three good cows and a bull-a

Station and telephone, Paxico. 
sufficient start for any one. Two of the cows came from St. Marys College. Through Baron Marr they bring in the blood of Cumberland's Last and imp. Lady Marr. The herd bull, a white, is by Cumberland's Knight 412231, which puts the best blood of the breed among the ancestry into this foundation. Mr. Wyker is located in a splendid cattle country and he has plenty of blue grass and alfalfa. He is planning to raise big Shorthorns.

R. Scott Buck, Eskridge.*-Mr. Buck has been in the Shorthorn business for twenty years and has a herd of thirty females which are being developed as Polled Shorthorns with special attention to milking quality. The bulls used have, in the main, come from the outstanding Polled herds. The present herd bull is Emancipator 459969 bred by W. G. Martin and sired by Dual Evergreen 367499.

\section{WASHINGTON COUNTY}

The Miller Stock Farms, Mahaska.-The Miller Stock Farms, Clyde W. Miller, operator, is an establishment equipped to produce cattle of the highest quality as is seen in its three silos, its 300 acres of alfalfa and the prize winning blood employed in the herd foundation. The pure bred Polled Shorthorn herd is well started and will in time supersede the grade herd.

* Keene Central telephone. 
Among the cows are daughters of Meadow Sultan, a sire of national reputation, whose sons and daughters have been good winners at the big shows. In these pastures are also found thick fleshed daughters of True Sultan, grand champion of the breed, and in one instance, reserve grand champion with all breeds competing.

Select Goods x8719-353693, the 2200 pound senior herd bull, is an International champion and his get have been prominent winners at the state fairs and at the International. These great bulls of strong Scotch blood were all bred by J. H. Miller. The junior herd bull, Sultan's Marvel, is by True Sultan. His dam is by Matchless Dale, the greatest sire of prize winning steers of any bull of any breed. Sultan's Marvel has two direct crosses to Whitehall Sultan, one of them through Avondale.

The objective is the production of a superior herd of breedy, useful cattle. The beefing quality is emphasized, but scale and milk producing ability are insisted upon. The cattle always carry plenty of flesh, though no heavy grain ration is allowed the breeding herd. Here is to be found true Shorthorn character in all respects except the horns.

M. Z. Duston, Washington.-Mr. Duston has a nice herd of cows of fair size, uniform in appearance and of real Shorthorn character and type. They are raising good calves, which indicates 
they are good milkers. Such men as C. W. Taylor, R. T. Scott, G. Y. Johnson, Achenbach Bros., F. M. Gifford and E. A. Hess, whose herds give a substantial foundation upon which to build, furnished the cows. I was impressed with conditions as I found them here. Mr. Duston is not a man who feels he knows it all. He is intelligent and is a close student of whatever he undertakes and he has succeeded in getting together a dozen or more cows of just the right kind to make money for the farmer. The element of speculation was wisely left out of consideration. The production of real Shorthorns is the aim, which I feel sure will be carried out. The foundation is well selected and the farm furnishes plenty of pasture, alfalfa and good water, the three main requisites for success.

E. A. Ostlund, Clyde.-A graduate of the Kansas State Agricultural College with a natural inclination toward Shorthorns should make the little herd on this farm develop well and grow in numbers. Mr. Ostlund has the true breeder's instinct in his desire for improvement and in making any purchases, betterment of the herd will be the objective. He has some good females and the cows must not only raise their calves but must also supply milk and butter for the family, which they are doing. The herd bull is Lord Mystic 617633, an Amcoats bred son of the Tomson bred Mystic Victor out of a cow by Lord Marr, 
Gifford's good son of Lord Mayor. Mr. Ostlund is acting wisely in not overlooking milking quality in his cows.

\section{WILSON COUNTY}

M. J. Roney, Benedict.-Some years ago in one of the Fredonia sales H. M. Hill sold an excellent lot of roan heifers and he also included Ingle Lad, (see H. M. Hill sketch) the sire of nearly all his young stock. Mr. Roney was the high bidder for the bull and through this purchase became known as a man with a good bull at the head of his herd. The heifers by Ingle Lad developed into first-class cows, all good milkers and good breeders and those in Mr. Roney's herd are no exception to this rule. One of these cows is out of a granddaughter of imp. Craibstone Shepherdess, the dam of the well known Craibstone. Another is out of a cow by Field Marshall by Marshall Abbotsburn, a son of Mary Abbotsburn 7th, the greatest prize winning cow in America and by Young Abbotsburn, probably the most wonderful of all American show bulls. In common with practically all Wilson county herds, Mr. Roney's cattle have a strong infusion of the blood of imp. Collynie and the Ingle Lad cows, as well as the rest of the herd, nicked well with the next bull, Golden Hampton, a son of Hampton Spray, one of the best bulls ever owned in southern Kansas. Golden Hampton was out 
of Golden Queen 3d by imp. Collynie, second dam imp. Golden Queen, one of the choice cows of the Hanna importation. Mr. Roney will follow Golden Hampton with a bull of such quality as to work improvement.

R. E. Schwartz, Fredonia.-Mr. Schwartz has a good herd and he has the enthusiasm for the work which is a guarantee of success. In 1915 he bought one cow and two years later he bought a few more. A good bull was also secured and after two years a better one was bought to succeed the first. His have all been sensible and conservative methods of procedure and with natural facilities for handling his stock and a pleasing personality in the man, we can safely forecast a successful future for the herd.

Sycamore Rosebud is a roan by Sunblaze, a bull used for some time by H. M. Hill. She is a granddaughter of two of the best cows of their day, Syringia by Royal Knight and Inglemaid by imp. Inglewood. Scotch Bessie is by Orange Marshall, the Victor Orange bull used so successfully by Stunkels. Sycamore Emma is by Master of the Dales, a bull that has a wide reputation as a sire. Her dam is by Ingle Lad, now recognized as one of the best getters of heifers ever owned in Kansas. At the Southeast Kansas sale in 1920 Proud Archer, junior champion of the show, was secured for service in the herd. This bull is an outstanding one by Kansas 
Archer, son of Mistletoe Archer, whose dam Sweet Mistletoe was also the dam of the 1919 International grand champion. Mr. Schwartz is secretary of the county Shorthorn breeders association and one of the promoters of the calf club.

R. C. Watson \& Sons, Altoona.-This is one of the promising firms of breeders, for the boys are enthusiastic and seem to be developing agricultural inclinations based on the production of pure bred stock. The herd is quite good and will grow to be better. There are now twenty-five females on the farm. Bertha Daybreak $2 d$ is by Pride of Riverdale, a son of Star of the Realm. A daughter of this cow by Orange Duke, son of the well known Orange Model, is also in the herd. April Princess is by Royal Prince by Mr. Hanna's Prince Royal out of Princess Airdrie, own sister to Ingle Lad. Lassie $2 d$ is another daughter of Royal Prince and on her dam's side carries the blood of Kinellar, the son of imp. Dalmena Mina.

A bull used until recently was Golden Lad. His sire combined the blood of imp. Collynie, Royal Knight and imp. Inglewood and his dam was by imp. Master Walton out of a cow by the noted bull 47th Duke of Airdrie. The present bull is White Goods used by Mr. Hyde for several years with good results. He is a big, strong, robust fellow from large ancestry. His sire, 
Prince Violet, was by a son of Collynie out of a daughter of Choice Goods and his dam was by Godwin, the well known son of imp. Spartan Hero and imp. Golden Thistle. I have seen exceptional calves by this bull.

J. W. Hyde, Altoona.-Mr. Hyde, the oldest breeder in Wilson county, was born and raised on a Shorthorn farm (see J. C. Hyde sketch, Part I) and his sons and daughters are getting into the business. He has been a patron of Mr. Hill and Mr. Hanna and as a result has a herd strong in Collynie blood. He owns the excellent Prince of Collynie cow, Robinita Winsome and twenty of his forty females are her descendants. Mr. Hyde has consistently used good, well bred bulls and has insisted on the bulls being out of heavy milking cows. The dual-purpose Shorthorn is his object and he is succeeding, for his herd shows a lot of good sized cows of decided milking tendencies. He is now using a bull by Master of the Dales.

Later.-Mr. Hyde has just purchased several imported females, including the prize winning two-year-old Bright Gem and her bull calf (see page 277) of J. C. Robison and the old establishment is taking on new life. When you count the men who have produced the profitable kind of cattle in southeast Kansas, J. W. Hyde must be named near the top.

John A. Kepler, Altoona.-Mr. Kepler has a 
dozen excellent females and a high-class bull. The first purchase made at the Thorn sale was followed by judicious selections at the 1919 Independence sale and at Fremont Leidy's sale. Three choice females were secured at the Central sale and three at the 1920 sale in Independence. The herd is far above the average in quality and includes cows of select breeding with pedigrees that any one would consider very desirable. The bull is a large, massive, young fellow bred by Ogden \& Son and sired by Diamond Baron, a bull that has made a reputation as a sire. His dam is not only a good cow, but she is also a heavy milker, a thing it does not pay to overlook. Mr. Kepler has made the right start for a real Shorthorn herd.

Mait Wiltse, Earlton.*-This herd including a dozen females from good cows and by good bulls is going to be even better. The original purchases were from George McFadden and J. C. Thorn and three more were added at Fremont Leidy's sale. Imported Collynie and Lord Mayor, two of the. best bulls ever in Kansas, are the sires with whose blood the cows are filled. Mr. Wiltse is using one of the best young bulls in the state. He is by Diamond Baron at the head of Ogden \& Sons' herd. His dam is from Robert Russell's herd and is by Lily Cup by Scarlet Secret, dam by Lord Golden Crest. If this young bull

Station and telephone, Altoona. 
deyelopes as he should, he will be fit to go into any show ring and as a breeding prospect he is one of the best I have seen.

J. F. Campbell, Benedict.-Mr. Campbell is among the older breeders of the county and keeps only a small herd. He has produced good cattle and now has a few heifers that would be a credit to the owner of a large herd. He knows the value of the right kind of a bull and also knows how to feed and develop young stock to grow them into first-rate breeders.

R. R. McDonald, Altoona.-Mr. McDonald has a splendid farm on which to keep Shorthorns and he has some good ones in the herd. One of the attractive young things is a heifer by Silver Dale now at the head of the Barrett \& Land herd. Fortuna, an excellent short-legged red by the Hanna bred Fortune, would be a valuable cow in any herd. Mr. McDonald owns a dozen females. The sire in use is Funston 694476, by a first-class breeding son of Sycamore Secret. (See H. M. Hill sketch, Part I.)

O'Dell Bros., Fredonia.-This firm。 is making rapid progress in building up the right kind of a herd. In common with all Shorthorns of this section the cows are strong in the blood of imp. Collynie and the valuable stock distributed by Mr. Hanna and Mr. Hill. The bull in use represents Royal Prince (see Hyde sketch) and his dam is by Ingle Lad, a bull now winning much 
fame as a sire of great producing cows. O'Dell Bros. should be heard from in the future.

\section{WOODSON COUNTY}

Henry F. Lauber, Yates Center.-Mr. Lauber has been a breeder of good Shorthorns since 1909 and before that time he had been producing splendid high grade cattle, always using highclass Shorthorn bulls. The foundation cows for the present herd were bought at the annual sales of the Woodson County Breeders Association and at the J. T. Bayer dispersion, the better females, only, being retained. The culling out process has been carried on and the results are seen in a herd much better than the original purchases. The care and feed given the herd have not been the best, yet have been sufficient to mature a very creditable lot of cows that are breeding well and suckling their calves in nice shape. Mr. Lauber has decided, however, to dispose of the grades and give his pure bred herd the care and consequent development a first-rate Shorthorn herd should have.

The cows with which he began business were nearly all by good bulls and the two high-class bulls used in the herd have added to the quality of the cattle until the young animals are in type, conformation and in actual blood lines, worthy specimens of the breed and the kind that give the maximum returns for the feed consumed. 
The first bull purchased was the red, Ingleynie, by imp. Collynie out of a Potts Sempstress cow by imp. Inglewood. He was a show calf of unusual finish that matured into a bull of good size and as a breeder was satisfactory. Quite a number of the young cows in the herd are by him. The bull now in use, Secret Hampton, was bred by H. M. Hill. He is a large, big-boned, deepbodied, short-legged fellow, not a show bull but what is better, a bull of unusual merit as a sire, his calves being big, pleasing, modern Shorthorns. His sire, Mistletoe Archer, out of Sweet Mistletoe, dam of Lespedeza Collynie, 1919 International grand champion, is considered by Mr. Hill one of the best bulls he ever owned. His dam by Mr. Hanna's great Hampton Spray has recently been sold by Mr. Hill for $\$ 2000$ to go to Pennsylvania:

C. E. Hill \& Son, Toronto.-Mr. Hill bought six heifers and a bull in 1914 and was able to hold a sale of fifty head in 1919 . The herd now numbers twenty females. Albion's Missie is by Bettie's Albion, a well bred Scotch bull from J. R. Whisler's herd. Her dam is Brawith Missie by Pride of Avondale the son of Avondale and imp. Rosewood 86th. Ravelstone Girl is a big roan by Goodline, son of imp. Collynie, dam by imp. Lord Cowslip. This cow is proving an unusual breeder. Golden Lavender, a medium roan, has in her top crosses a wealth of good 
ancestry, including imp. Daydreams Pride, imp. Trout Creek Clan Alpine and the Harris bred Vandal.

A recent purchase included Band Light Mist by Hampton Mist, son of Hampton Spray out of a Collynie cow. Her dam is by Bandmaster, son of imp. Fashion's Favorite and imp. Augusta Bruce. Bettie's Albion, the bull mentioned above, was used for several years and in 1918 a new sire was secured from Carpenter \& Ross. He comes from Canada and is of blood lines quite popular in that country. His dam is out of Rosewood 90 th by imp. Lord Mistletoe and is a daughter of imp. Rosewood 87th.

Elmer Hill, the junior member of the firm, while still a boy, is the making of a Shorthorn man of more than ordinary ability. Mrs. Hill also takes much interest in the cattle.

Herbert Laude, Rose.-Mr. Laude was a junior partner in the firm of G. A. Laude \& Sons and in 1915 he took over the herd owned by them. This was sold in 1918 and the present herd has been acquired recently. Ten females of correct breeding type are now on the farm and these cows and others that may be purchased will be kept only as long as they produce excellent calves. A few of the best bulls will be sold for breeders, the greater number being destined for the beef market. Real merit in the animal and in its ancestry is the objective. The females 
include a very choice daughter of Prince Valentine 4th, several by Matchless Gloster, son of Matchless Dale and a splendid heifer by Silk Goods, Mr. Huber's well known son of Choice Goods.

The bull in use is Goldspur, a Hanna bred son of Hampton Spray out of Golden Queen 3d by imp. Collynie. His grandam is the Duthie bred imp. Golden Queen. Not many bulls in Kansas or elsewhere have ancestors that combine so much beef and milk. Goldspur has proved a sire of the best and most profitable class of Shorthorns and his elegant pedigree would be acceptable anywhere.

J. L. Jackson \& Son, Rose.-The herd includes only five females but they are from excellent ancestry and lack only better development to make them strictly good ones. A four-year-old cow by Hampton Primrose, one of the best bred bulls of the breed and out of a daughter of imp. Mariner is suckling a first-class heifer calf by Secret Robin now owned by Miss Stanley of Anthony. The Jacksons co-operate with Herbert Laude on herd bulls and the bulls are always good ones. 


\section{CONCLUSION}

The year 1920 ushered in a readjustment in prices brought about by wartime conditions, which, coming several years sooner than expected, had a marked effect on prices paid for Shorthorns. It is the general impression that prices are more nearly stable than they have been since. 1915 and that but little, if any, reduction from present range of values will take place. Good Shorthorns are now selling and will continue to sell at prices that will make their production very profitable. The wide market for cattle of this breed insures a steady and healthy demand for all the good specimens that can be produced and the placing of values on a permanent basis will encourage many farmers in making a start with the reds, whites and roans.

Some early summier sales held values well, but nearly all later ones witnessed sharply reduced prices. In June Col. H. L. Burgess sold forty head at Fort Scott, securing $\$ 3150$ for a bull and $\$ 1025$ for a yearling heifer. The entire sale made a good average. The fall sale season was opened by A. L. Johnston at Ottawa and followed by the Southeast Kansas sale at Independence. Both these sales were particularly unfortunate in that farmers had been kept out of the fields for several weeks and were just well started sowing 
wheat. It was impossible to get out the crowd. Mr. Johnston sold a number and stopped the sale. The Southeast association sold their entire offering to a very small crowd at low prices. On October 7, A. L. Harris sold thirty-five head at his farm near Osage City at an average of about $\$ 250$ and the same day Frank H. Yeager sold in Chase county at prices showing a decline of 25 per cent. The next day the Morris County Breeders Association sale at Council Grove sold a lot, nearly all in thin condition, that went begging for bids much above market value. On the 9th, Phillips Bros. dispersed their herd at Council Grove at prices steady with 1920 spring sales. Chas. Casement sold at Sedan on October 12, securing prices of a year earlier. The sales at Ottawa and Pleasanton were fair and the one at Fort Scott was a failure. The Allen county association sold fifty head at Humboldt at strong prices that showed but little decline. A big sale held at Leavenworth on October 28, was draggy and 40 per cent lower and the association sale at Hiawatha was reported as much as 50 per cent off from the high point. The American Royal sale was probably 40 per cent below that of 1919. North central Kansas sales held up better, although there was a lowering tendency all over the state.

Shawnee county breeders made an excellent offering December 15, and secured good prices. 
The Lyon county association sold at Emporia on the $22 \mathrm{~d}$, the worst day of the winter, with only forty persons present. Prices ruled low. The big sales at Wichita were quite snappy and the prices received, while sharply lower, were very satisfactory. Breeders were generally agreed that Shorthorn values had suffered a loss of from 25 to 50 per cent from the peak.

A number of counties have forged ahead within the past eighteen months in a manner worthy of special mention. About forty new breeders have been started in Leavenworth county and a large sale pavilion has been erected. I. N. Chapman, county agent, and Otto H. Wulfekuhler, banker, should be given credit for being among the foremost pushers.

Harper county fairly jumped into rank as one of the leading Shorthorn counties. There are now more than fifty breeders in the county. A large sale pavilion has been built and big Shorthorn shows are being held. While a number of persons deserve credit for this, it is conceded that a woman did it. Miss Marguerite V. Stanley is the leading spirit in the work and secretary of the county association. She had the satisfaction of seeing her herd bull, Secret Robin, made grand champion at the 1920 show.

Sumner county is doing much in an educational way for the Shorthorn breeders. It is an 
old county that is carrying on a revival promising lasting results.

The Kansas National Show held at Wichita in 1921 was remarkable for the excellent showing made by Kansas breeders. Tomson Bros. were the leading winners, outclassing both Carpenter \& Ross and H. C. Lookabaugh. E. L. Stunkel succeeded in getting his herd bulls well in the money, having received second in the two-yearold class and fifth in aged class. E. P. Flanagan's herd bull stood immediately below the professional showmen in the aged class. Fred Abildgaard had several entries of his young stock in the money, as did also Fremont Leidy. Gaeddert Bros. were, as usual, good winners, receiving third on aged bull, with all their entries well in the money. J. C. Robison won five prizes on his entries of imported cattle and $H$. E. Huber won a good place on his imported bull, Imperator.

All over the state there is a feeling that the era of high prices induced speculation that was not conducive to herd improvement. Speculation has now had its day and we may expect the breeder to lose some of his commercial spirit and to devote more time to producing good stock. 


\section{INDEX}

Abildgaard, Fred, 316, 541.

Abraham, E. H., 181, 456, 459, $460,474$.

Ackley, R. J., 351.

Adams, A. A., 534.

Aeschliman, J. C. \& Son, 515.

Airdrie 2478, 60.

Airdrie Duchess 2d \& 3d, 34.

Airdrie Evergreen, 426.

Albion, 120.

Alexander, R. A., 19, 60.

Alfalfa Leaf Dale, 373.

Alfalfa Leaf News 10th, 378.

Alkire, M. J., 26.

Alkire \& Wardell, 25.

Allen, Geo. \& Sons, 419.

Allen, George W., 432.

Allen, Ivy \& Sons, 310.

Allerton Rosebud 4th, Imp., 226.

Amcoats, S. B., 76, 298, 304, 543.

American Woods Shorthorns, $152,167$.

Andrew, Adam, 121, 327.

Anderson, H. C., 460.

Appleton, Geo. J., 613.

Anderson, W. G., 55.

Archer, 579.

Archers Victor, 615.

Ardlethen Mystery, Imp., 241, 386.

Armour Bearer, 98.

Arneal, A. H., 609.

Arnold, F. B., 401.

Asheraft, A. M., 114.

Asheraft Bros., 115, 232.

Asher and Allison, 345.

Asher, P. P. \& Son, 500.

Associations, County, 180.

Associations, District, 178.

Associations, State, 174.

Athene's Scotchman, 317, 541, 543.

Athenian Coronet 4th, 614.

A True Cumberland, 233.

Auburn Dale, 538.

Augustus, 521.
Austin, A., 520.

Avery Bros., 50.

Avery, R. H., 50 .

Aylesbury Duke, Imp., 110.

Babbitt, C. A., 257.

Babst Bros., 614.

Babst, T. P. \& Sons, 90, 95, 104, 115, 131, 233.

Baer, W. F., 520.

Bailey, G. W. K. \& Sons, 47.

Bailey, W. E. W., 47.

Baird, Chas. M., 320.

Baker, J. W., 120.

Ballantyne, David, 123, 321, 370, 460.

Ballantyne, T. A., 123, 331.

Ballechin Rosewood 3d, Imp., 277.

Banbury, J. C. \& Sons, 552.

Baneroft, W. C., 58.

Banker 4th, 133.

Bapton Corporal, Imp., 224, 262, 267.

Bapton Dramatist, Imp., 373, 374.

Bapton Mariner, Imp., 355.

Bapton Pearl, 80.

Barmpton Knight, 97, 117, 580, 582, 588.

Barnes, B. F., 180.

Baronet of Maine Valley, 132.

Baron Marr, 129, 327, 356, 357.

Baron Victor, Imp., 64.

Barrett \& Land, 428, 525.

Barr, I. \& Son, 71.

Barrister, 111.

Basil Duke, 49.

Bates, Thos., 18, 19.

Bayer, Henry B., 135, 569.

Bayer, J. H., 134, 200.

Bayer, J. T., 136.

Beamon, R. M., 209.

Beaver Creek Sultan, 240, 570.

Beeman, C. W., 211.

Beitler, D. M., 554.

Bellows Bros., 117, 209, 317.

Bellows, C. D., 236. 
Bellows, F. \& Sons, 79.

Belvedere, 132, 366.

Bemis, Geo. W., 482.

Benedict, Sen. S. S., 106, 132.

Bennington Bros., 429.

Bennington, C. \& Sons, 429.

Bessie 51st, Imp., 111, 249.

Best of Dales, 572.

Betsy Dailey, 90.

Betteridge, W. A., 234.

Betty's Albion, 628.

Bill \& Burnham, 125.

Bill \& Burnham Sale, 71.

Bill, O. W., 55.

Bird, C. D., 501.

Birkenbaugh, J. F., 431.

Black, John, 346.

Blake, Mrs. Grace, 500.

Bluemont Farm, 573.

Bonnie Emblem, 575.

Booker, Forrest, 180.

Booth, Thos., 18.

Borger, H. \& Son, 480.

Borland, Paul M., 302.

Bornhorst, H. J., 468.

Bottom, Tom, 394.

Bower, M. W., 349.

Bowman, John, 43.

Bozeman, W. S., 306.

Brandsby Augusta 4th, Imp., 221.

Brott, E. E., 310.

Braunsdorf, A. C., 438.

Brawith Heir, 308.

Breadalbane 2d, 45.

Breeders Assn., Blue Valley, 471.

Breeders Assn., Labette Co., 437.

Breeders Assn., Osage Co., 527.

Breeders Assn., Wilson Co., 623.

Breeder's Gazette, 187.

Bridesmaid 2d, 451.

British Emblem, Imp., 462.

British Lion, 104.

Brookover, H. G., 181, 285, 359, 362.

Brookover, W. H. \& B., 361.

Brookover, W. J., 362, !369.

Brown, F. R., 58.

Brown, G. W. \& Sons, 286.
Brown, Jas. N. \& Sons, 27, 61.

Brown, T. C. \& Bro., 358.

Buchanan, C. L., 308, 311.

Buchele, Chas. J., 296.

Buck, R. Scott, 618.

Bunnell, R. M..\& Sons, 233.

Bureau of Animal Industry, 137.

Burgess, Col. H. L., 182.

Burgess, Col. H. L., Sale 324.

Burkham, W. S., 54.

Burtiss Bros., 55.

Burtiss, C. L., 55.

Burtis, W. J. \& O. B., 569.

Butterfly Sultan 300788, 381.

Caldwell, S. C. \& Son, 212.

Calf Club, Johnston Co., 423.

Calf Club, Wilson Co., 623.

Campbell, E. A., 559.

Campbell, F. B., 178, 436.

Campbell, J. F., 625.

Cane, Dan O., 472.

Captain 545855, 510.

Captain Archer, 110, 120.

Carpenter \& Ross, 145, 221

Carrier, O. H., 220.

Carter, Floyd, 358.

Case, A. \& Sons, 563.

Casement, Chas., 294.

Caspar, Geo. J., 359.

Casterline, Armenia, 55.

Catlin, C. S. \& Son, 419.

Cedar Dale, 283, 285, 286.

Central Sale, 450.

Chaffee, N. L., 27, 58.

Challengers Knight, 326.

Chamberlin, C. A., 502.

Chancellor, 230.

Channon, Geo., 124.

Chanute Pride, 501.

Cheney, S. L., 121, 230.

Cherry Blossom 6th, 264, 267.

Cherry Grove Banff 19th, 430.

Chief Steward, 307.

Choice Goods, 111, 165.

Christmann, Col. D., 437.

Churchill, H. H., 534, 594.

Clansman, 248, 256.

Clara's Type, 542.

Clark Bros., 134.

Clark, C. H., 134.

Clark, R. L., 311.

Clark, Thos. R., 42. 
Classical Sultan, 248.

Clements Ivan, 396.

Cobb, W. E., 437.

Cochel, W. A., 137, 176.

Coffman, Ross A. \& Son, 535.

College Emma, 139.

College Duchess 2d, 177, 572.

Colling Sale 1810, 18.

Collynie, Imp., 84, 85, 107, 110.

Collynie's Pride, 123.

Collynie's Primrose, 292.

Colman, Willis R., 343.

Colonel Carvel, 460, 610, 611, 612.

Color Bearer, 351.

Columbia 5th, 449, 450.

Colwell, F. J., 312.

Conger, F. H., 135.

Constance, Imp., 100.

Cook, Robert, 53.

Cornell, H. F., 356.

Cory, E. A. \& Sons, 557.

Cottrell, Prof. H. M., 73, 74.

Count Valentine 4th, 573.

Cowan, B. O., 96, 272, 284.

Cowan, John G., 253.

Cowley, Fred, 110, 120.

Cox, S. D., 378.

Craig, W. K., 217.

Crane, Albert, 32, 33, 34.

Craven Knight, Imp., 72.

Cream Toast, 140, 142.

Crespigny \& Seiver, 39.

Crimson's Daughter, 546.

Cronin, Wm. \& Sons, 310, 311.

Crusader, 582.

Crystal Maid, 487.

Cumberland Champion, 592.

Cumberland Diamond, 599.

Cumberland Sultan, 596.

Cundiff, Dr. W. H., 50.

Cunningham, R. H., 379.

Cupbearer, Imp., 102, 121.

Dale Emblem, 273.

Dale, E. S., 181, 314.

Dales Cumberland 240, 257.

Dales Signet, 609.

Davis, M. V., 56.

Dawily, D. L., 234.

Dawdy, D. L. \& Co., 105.

1)awe, T. J. \& Son, 117, 118, $336,341,343$.

1)efender, 568 .
DeGeer, V. E., 241.

Deming Ranch, 129.

Dent, Clyde E., 510.

Dent, Robert P., 508.

Dent, Waldo E., 510.

Devlin, Mrs. A. G., 398.

Diamond Emblem, 117, 118, 256, ว338, 343.

Diamond Victor, 474.

Dickie, Geo. L., 349.

Dickson, W. T. \& Son, 532.

Dimmock, C. O., 180.

Diver \& Potter, 205.

Doering, H. C., 217.

Dole, R. W., 523.

Douham, R. B., 555.

Donnelly, John J., 567.

Double Champion, 112, 386.

Double Dale, 551.

Double Gloster, Imp., 78, 125.

Double Ury, 115.

Downing, L. E., 370.

Dr. Primrose, 64, 101, 106, 133.

Drummond, R. A., Sale, 312.

Duchess Cow, 18.

Duchess of Independence, 425.

Duchess of Geneva 8th, 60 .

Duke of Airdrie, Imp., 19, 60 .

Duke of Airdrie 23d, 32.

Duke of Airdrie 53d, 36 .

Duke of Hazelcote 19th, 39.

Duke of Jubilee 2d, 32, 70 .

Duke of Shannon Hill, 36 .

Dumbauld, Levi, 56.

L. M. Dunaway, 433, 436.

Dunean, H. C., 36 .

Duncan, S. C., 39.

Dunn Herd, 55.

Duphorne, Marcel, 382.

Durham Park Herd, 32.

Duston, M. Z., 619.

Duthie, Wm., 164, 280.

Earl of Aberdeen 2d, 125.

Earl of Athol, 52.

Earl of Valley Grove 20th, 133, 594.

Eaton, Lanson, 59.

Edelweiss, Imp., 271, 272.

Erlmonds, Will, 245.

Edwards, W. C., 132.

Elbert \& Fall, 79.

Ellis, V. R., 128.

Elmquist, Luther, 475. 
Ely, J. R., 461.

Emblem's Butterfly, 354.

Emiblem's Dale, 595.

Emblem Jr., 267, 314, 316.

Emima S., 591.

Empress of Oxford 3d, 411.

Empress of Oxford 4th, 409.

English Woods Shorthorns, 154.

Estes, H. W., 181.

Etherington, T. M., 365, 368.

Evans, Ervin, 180.

Evans, Joe L., 402.

Evergreen Sultan, 502.

Ewing Bros. (Barton Co.), 125.

Ewing Bros. (Mo.), 283.

Expansion, A Period of, 31 .

Fads, 166.

Fair Acres Sultan, 266.

Fair Acres Sultan 2d, 267.

Fair Acres Choice, 537.

Fair Champion, 481.

Fame's Goods, 430, 481.

Fancy Dale, 448.

Fancy Lad 2d, 207, 214.

Fashioner 4th, 203.

Fashioner 7th, 438.

Fasken, J. A. \& Son, 321.

Favorite, 382.

Fears, W. S., 86.

Fergus, J. B., 114.

Fetherngill \& Enfield, 212.

Final Test, The, 137.

Fiske, E. E., 435.

Flanagan, E. P., 333.

Flat Creek Marys, 61.

Flinn, D. M., 51.

Flinn, Simpson, 51.

Forbes, Mr. and Mrs. H. T., $105,586$.

Ford, T. O., 75, 106.

Forest Daisy, 96.

Forest Daisy 2d, 96, 581.

Forest Knight, 127.

Foster, J. C., 503.

Fraser, Alex, 280, 407, 414, 426, $427,550$.

Frye, Mr. and Mrs. John, 499.

Funk, F. N., 120.

Furneaux, R. O., 114.

Furneaux, R. O. \& Son, 203.

Gaddis, H. I., 209, 324, 336, 472.

Gaeddert Bros., 545.
Gainford Lancer, 313.

Galahad, 130.

Gallanaugh Bros., 423.

Gallant Knight, 93, 91. 95, 271, 579.

Gallant Knight's Heir, 543.

Gallant Knight's Star, 424.

Gallup, A. H., 469.

Tarver, C. M., 124.

Georgeson, Prof. C. G., 71.

Fifford and Sons, 76.

Gifford, F. M., 76, 302, 303.

Gigstad, K. G., 16, 223, 442.

Gilbert, F. L., 367.

Gillespie, F. A. \& Sons, 414, 487.

Gipsy Cumberland 5th, 301.

Glancys, The, 229.

Glendale, 290, 291.

Glendon, 100.

Glick, Geo. W., 29, 34, 49, 105.

Godwin, 128.

Golden Crown, 407.

Golden Drop of Hillhurst, 63, 121, 129.

Golden Drops, 164, 165.

Golden Goods, 224.

Golden Hampton, 621, 622.

Golden Knight, 73, 124, 335.

Golden Lad, 132.

Golden Laddie, 617.

Golden Magnet, 459.

Golden Sharon, 203.

Goldspur, 630.

Good Choice, 228.

Good News, 273.

Good Scotchman, 254, 256.

Gowdy, B. W., 107, 114.

Grace Young 4th \& 5th, 27, 70.

Gragg, W. W. \& Sons, 350.

Grand Airdrie, 75.

Grand Duke of Kansas 1st, 26, 28.

Grand Duke of Oxford 3d, 26.

Graner, H. C., 231, 405.

Graner, Louis F., 236.

Graner, W. H., 235.

Grant, George, 40.

Gray, Thos., 530.

Green, Col. Ed, 386.

Greever, Geo. W., 28.

Gregg, Jas., 130, 131, 519.

Griffee Bros., 470. 
Gross, Col. P. M., 182.

Guild, Joseph E., 50.

Gulick, Wm. \& Son, 521.

Gus Villager, 385.

Gwendoline 79th, 140, 142.

Haag, H. J., 402.

Hailey, Mr. and Mrs. R. E., 509.

Hall Bros., 135, 204.

Hall, Dr. W. C., 503.

Hall, O. B., 575 .

Hallwood Lavender, 264.

Halls Cumberland, 310.

Hamill, J. M., 296.

Hamiltons, 61.

Hamilton Sales, 58, 59.

Hamlet, 603.

Hamm, A. \& Son, 446, 505.

Hampton, 293.

Hampton Primrose, 327, 630.

Hampton Spray, 86, 266.

Hanna, S. C., American Cows Bought, 79, 120.

Hanna, S. C., Importations, 80 , 207.

Hanna, Mrs. S. C., 88.

Hanna, S. C., 66, 78, 88, 360, 361.

Hansen, N. B., 254.

Harding, F. W., 81, 82, 165.

Harriman Bros., 112.

Harrington, Clay \& H. M., 122.

Harrington, J. W., 311.

Harris, W. A., 36, 46, 52, 62, $72,90,125,128,164,165$, $174,270,329$.

Harris, W. A., Dispersion, 69.

Harris, W. A., Imported Cows, $64,66$.

Hart Bros., 30.

Hart, C. L., 30.

Hart, G. F., 469, 520.

Harkey, Dr. W. C., 420.

Harper Co., 633

Hasebrook Herd, 262.

Haskin, S. B., 425.

Hasty, Imp., 28.

Haub, Henry, 405.

Haury, E. J., 384.

Hawk, W. B. \& M., 130.

Hayes, Everett, 116.

Hayes, H. E., 129.

Hayes, L. D., 244.

Haynes, H. A., 288.
Hayes, L. D., 180.

Heacock, E. E. \& Sons, 307.

Headlight, 445 .

Heglund, Ed, 236, 444.

Heimann, H. \& Son, 516.

Helmer, Roy, 350.

Hendricks, C. L., 482.

Herd Bull, Selecting, 279.

Herds of Minor Importance, 113.

Herriff, Col. E. H., 184.

Higday, H. L., 504.

Higinbotham, Wm., 78.

Hill, C. E. \& Son, 628.

Hill, Elmer, 629.

Hill, H. M., 12, 66, 76, 106, 119 , $120,134,176,436,484,564$.

Hill, Mrs. H. M., 108.

Hoadley \& Sigmund, 132.

Hoadley, Geo. H. \& Son, 132.

Hogan, W. E., 368, 370.

Holcomb, J. H., 180, 200, 227, 309.

Holloran, W. J., 553.

Holloway, Mr. and Mrs. T. E., 205.

Holmes, H. H., 131, 359, 590.

Holroyd, M. L., 295.

Holt, E. C., 216.

Homan, O. A., 180.

Homan, O. A. \& Sons, 386.

Hoover's Dale, 423.

Hopley Stock Farm, 234.

Horville Bros., 206, 212.

Hothan, Chas. \& Son, 526.

Houghton, F. G., 507.

Householder, M. A., 102, 121.

Householder, M. E., 304.

Hoverson, A. A., 338.

Howard, C. M. \& Sons, 242.

Huber, H. E., 23, 364, 406, 408.

Huber, J. M., 23.

Hull, L. B., 119.

Hultine, Albert, 145.

Humphrey, C. P., 398.

Hunter Bros., 566.

Hunton, G. E., 53.

Hyde, Fred, 127.

Hyde, J. C., 127.

Hyde, J. W., 127, 142, 625.

Imperator, Imp., 408.

Importation, 1817, 18. 
Importation, R. A. Alexander, 19.

Importation, Albert Crane, 33.

Importation, Geo. Grant, 41.

Importation, S. C. Hanna, 80, 207.

Importation, Leavenworth's, 39 .

Importation, Ohio Co., 18.

Importation, J. C. Robison, 143.

Ingle Lad, 108, 367, 532, 621.

Ingle Maid, 108.

Ingle Prince, 527.

Ingleside for Me, 615.

Ingle's Secret, 501.

Inglewood, Imp., 85, 108, 360, 379.

Ingleynie, 628.

Inlow, John, 26, 27.

Jackson, Mr. and Mrs. Jas., 517.

Jackson, J. L. \& Son, 630.

Jackson, Sam'l, 518.

Jacob, A .W., 574.

Jagels, Theo., 323.

James, Col. Andy J. 184, 412.

James, Col. and Mrs. Andy J. $412,413$.

Jasperson, V. A., 181, 527.

Jealous Dale, 570, 574.

Jealous Renown, 611.

Tennie Rivers, 469.

Jcwell Arden, 313.

Jewell, J. L., 210.

Jewell, Wesley, 178, 207, 214.

Joan of Are, 33.

Joe's Lord, 115.

Johnson Bros., 543.

Johnson, Carl, 476.

Johnson, G. Y., 30, 25.5.

Johnson, Herman A., 53 ?3.

Johnston, A. L., 178, 354.

Jones, John L. \& Sons, 218.

Justice, Col. H. M., 184.

Kahl, Samuel, 49.

Kansas Agricultural College, $15,27,69,177,190,409,571$, 582.

Kansas Farmer-Mail \& Breeze, 189.

Kansas Herds of Today, 194.

Kansas National Show, 283, 546, 547, 603, 605, 634.

Kansas Prince, 496.
Kansas Shorthorn Breeders Association, 174.

Kansas State Fair, 521, 551.

Kellerman, D. K. \& Son, 97, 100.

Kellerman, Geo. F., 98, 209, $446,448,452$.

Kelly, Frank X., 415.

Kepler \& Wiltse, 222.

Kepler, John A., 624.

Kerr, Archibald, 42, 43.

Kerr, W. F., 421.

Kier Jip, Imp., 371.

Kimball, C. H., 134.

King, Joe \& Son, 283.

King, Rex, 515.

Kingsley, F. C., 133, 593.

Kinnellar, 107.

Kinochtry Ensign, Imp., 417.

Kinzer, R. J., 74, 129.

Kirk, F. S., 176.

Kissenger, J. H., 61.

Kitchin, A. F., 523.

Kleppe, H. V. \& Sons, 255.

Knapp, E. L., 29, 617.

Knapp, L. A., 29, 35, 617.

Knight, J. F., 311.

Knotts, J. L., 504.

Knox, S. M., 180, 199, 295, 466.

Kraft, John, 58.

Kramer, John, 86, 489.

Kupper, Henry, 400.

Lackey, A. H. and H. H., 56 335.

Lady Cumberland, 202.

Lady Emma, 499.

Lady Marshall, 255.

I iady Sale of Atchison, 36.

Lady Sale of Brattleboro, 36 .

Lady Supreme, 267.

I ant Bros., 435.

Lassman, Fred, 211.

Lattimer, Walter, 105, 114.

Lauber Bros., 121

Lauber, H. F., 627.

Laude, G. A., 176, 177.

Laude, Herbert, 629.

Laude, Martin L., 190.

Laude Printing Co., 190.

Laury, J. G., 218.

Lavender Best, 136.

Lavender Chief, 614. 
Laventer Emblem, 249, 250.

Lavender King, 444.

Lavender King 4th, 98.

Lavender Marshal, 479.

Lavender Seareh, 474, 562.

Lavender Stamp, 417, 428.

Lavender T., 140.

Lavender Viceroy, 74.

Lawton Tommy, Imp., 302.

Leach, Frank, 55.

Leavenworth Co., 633.

Leclere, G. N., 564.

Leidy, Clarence, 285.

Leidy, Fremont, 23, 176, 179, $280,286,288$.

Leidy, Mr. and Mrs. Fremont, 283.

Leonard, C. E., 61, 226.

Lewis, W. H., 443.

Libel, J. F. \& Son, 341.

Liberty Boy, 112.

Lilac, 84.

Linwood Lavender 14th, 98.

Lister, R. H., 352.

Little, H. R., 123.

Loch Bros., 397.

Lodge, C. V. \& J. P., 101.

Lookabaugh, H. C., 101, 145.

Lopez, 290.

Lord Abraham, 33.

Lord Albion, 560.

Lord Alexander, Imp., 232.

Lord Archer, 564.

Lord Banff 2d, 129, 356.

Lord Cowslip, Imp., 86.

Lord Mayor, 66, 95, 96, 97, 131, 614.

Lord Mayor 3d, 212, 563.

Lord Mystic, 620.

Lorimer, Boyd, 427.

Lorimer, J. A., 422.

Lorimer, W. D., 422.

Luudon Duke 6th, 253.

Loudon Duke 13th, 32.

Louthian Bros., 240.

Love, H. W., 424.

Lovett, Claude, 181, 211, 364.

Lovett, John J., 59.

Lowe, M. A., 131.

Ludwig, E. D., 117.

I cukert, E. D., 117.

Lukert, J. F. \& Sons, 250.

Lumley, J. G., 459.
Lyne, B. M. \& Sons, 544.

Lyons, M. H., 46, 312.

Maag, R. S., 357.

Mack, J., 403.

Maninger, Fred, 382.

Mantey and Harriman, 454.

Marcy \& Son, 46.

Marcy, T. M., 45.

Marauder, 572.

Maria 30th, Imp., 231.

Mariner, Imp., 107.

Markley, A. M. \& Sons, 130, 452.

Marks, Dr. M. F., 401, 410, 516.

Marquis Cumberland, 213, 343, 344,346 .

Marshall Abbotsburn 3d, 123.

Marshall Bros., 122.

Marshall, Geo. S., 181, 444.

Marshall Lee, 122.

Marshall's Crown, 396, 585.

Martin, H. S., 463.

Martin, J. W., 56.

Martin, J. T. \& Son, 368.

Massa, G. W., 439.

Massa, O. O., 370, 494.

Master of the Dales, 109, 491, 626.

Master of the Grove, 120, 614 .

Master Marshal, 604.

Master Pavonia, 374.

Masters, H. J., 135.

Matchless Collynie, 482.

Matchless Dale, 8, 15, 75, 419, 572.

Matchless Queen, 141.

Maxwalton Mandolin, 273.

Maxwalton Rosedale, 47, 451, $582,617$.

Mayor Alcott, 432.

MeAdams, J. H., 181.

McAfee, H. W., 104.

McAfee, J. B., 104.

MeCampbell, Dr. C. W., 139, $176,190$.

MeClaughey, Dr. G. A., 455.

MeCoy, John \& Sons, 251, 252.

MeCulloch, Col. Jas. T., 184.

MeDermaid, John, 120.

MeDonald, R. R., 626.

MeFerrin, C. E., 120, 531.

MeGregor, 16.

MeHardy, F., 56. 
McIntosh, Elmer, 245.

MeLenon, H. A., 225.

Meall Bros., 177, 478.

Meissner, E. C., 219.

Mellowhide, 231.

Merriam, C. W., 131.

Merry Hampton, 81.

Metzger, M. A., 511.

Meuser \& Co., 601.

Meyer, Mrs. E. A., 119.

Meyer, Harrison, 440.

Meyers, E. S., 124, 595.

Milleraie Costly Belle, Imp., 224.

Milk Production, Breeding for, 52.

Miller, J. H., 552.

Miller, J. L., 115, 237.

Miller, John, 357.

Miller, John Q. A., 115, 237.

Miller, J. R., 428.

Miller Stock Farms, The, 618.

Miller, Wm., 53.

Mina Marigold Lady, 243.

Mina's Avon Viillager, 324.

Minister, 27.

Miss Acorn, 523.

Missie's Last, 267, 314.

Miss Snowbird Sultan, 267.

Mistletoe Archer, 490, 491.

Mistletoe 15th, Imp., 110.

Miss Watson, 26.

Mitchell Bros., 408.

Mitchell, S. D., 322, 610.

Modern Scotchman, 399.

Mohler, Sec. J. C., 178.

Moody, Joel, 25.

Moreland, E. L., 458.

Morris \& Becar, 19.

Morse Bros., 542.

Morse, O. E. \& Sons, 129.

Mott, H. O., 513.

Mr. Marshal, 396.

Mr. Mysie, 454.

Murdoch Bros., 417.

Murphy, Thos. \& Sons, 605.

Mussett, J. A., 445.

Myers, E. A., 342.

Myers, Mrs. E. A., 342.

Myreton Seal, Imp., 252.

Nelson, Jacob, 177, 300.

Nelson, W. R., 37.

Nevius, C. S., 112, 214, 284, 362.
Neville, A. H., 439.

Newcom, Col. Boyd, 185.

New Echo, 430.

Newman, Dr. J. R., 243.

Newton Friar, Imp., 262.

New Year's Delight, 470, 581.

New Year's Emblem, 342.

Nielson, J. M., 180, 471.

Noffsinger, L. M., 535, 539, 609.

Nonpareil 35th, Imp., 31, 249.

Nonpareil Avondale, 411.

Nonpareil Star, 272.

Norris, C. B., 28, 48.

North Amercius, 525.

Norton, D. P., 103, 462.

Norton, J. Clarence, 113.

Norton's Golden Drop, 65, 66.

Oakdale King, 514.

Ode, Henry \& Son, 441.

Odell Bros., 626.

Odell, Stephen C., 309.

Ogden \& Sons, 624.

O'Kane, John, 180.

Oldenettel, F. H., 554.

Olson, H. \& Sons, 528.

Olson, Theo \& Sons, 402, 567.

O'Neal, James \& Son, 29, 59.

O 'Neill, Owen, 457, 473.

Ostlund, E. A., 620.

Otto Bros., 572.

Outcrosses in Scotch Pedigrees, 164.

Orauge Baron, 590.

Orange Blossom of Oakland, 121.

Orange Blossom Perfection, 121.

Orange Goods, 606.

Orange Major, 121, 328, 453.

Orange Premier, 519.

Orange Viscount, 111.

Ozark Sultan, 432.

Paddock, Ted D. \& Sons, 455.

Parks, J. C., 367.

Paton, J. E., 318, 319.

Pavonia, Imp., 100.

Peck, H. O. \& Son, 13, 603.

Feerless, 565.

Percherons to Shorthorns, 276.

Perkins \& Alley, 346.

Peters, T. J., 58.

Peterson, Anton, 476.

Peterson Bros., 475, 476. 
Peterson, M. R. 338, 340.

Phyllis Duke, 90.

Pickrell, J. H., 61.

Piper, John F., 28.

Pleasant Acres Sultan, 548, 549.

Pleasant Dale Sultan, 537.

Poland, Milton \& Son, 514.

Pollard, M. C., 532.

Polson, Geo. T., 58.

Potter, John B., 181, 374.

Powell, A. G., 505.

Pride of Collynie, 78.

Pride's Bessie, 140.

Prime Miuister, Imp., 130.

Prince Imperial 2d, 136.

Prince of Collynie, 108, 109, 254, 486.

Prince Lovely, 100.

Prince Royal, 498.

Prince Valentine 4th, 208, 212, 316, 562, 592, 630.

Princess Columbia, 486.

Pringle, Andrew, 46, 610.

Pringle, J. A., 616.

Proud Archer, 622.

Purple Ribbon Sale, 274.

Queen Lil, 421.

Ralston, E. T., 405.

Ravenswood Admiration, 74.

Rawlings Bros., 369.

Ray, J. P. \& Sons, 347.

Realm's Count 2d, 420.

Reber, D. E., 117.

Red Gauntlet, 135.

Red Laddie, 544.

Red Oak, 115.

Red Rose, 140.

Red Rube, Imp., 231.

Reece, A. M., 606.

Reed, Thos. B., 513.

Rees, Conway, 460.

Reeves, L. W. 513.

Regier, John, 200, 202, 242, 268, $269,361,464,551$.

Renick, Abram, 60.

Renick Rose of Sharons, 60, 195.

Reynolds and Pritchard, 54.

Rhoads, Jas., 425.

Rice Co., Herd, An Early, 50.

Richardson, I. T., 181.

Richelieu, 306.

Ringmaster, 116.
Ridiculous Propositions, 166, 167.

Roan Geraldine, 547.

Roan Heather, 305.

Roan Lord, 199.

Roan Marshall, Imp., 522.

Roan Model, 332.

Roan Sultan, 523

Robbins, F. Joe, 178.

Robin, 84.

Robinetta 4th, 453.

Robinita Winsome, 625.

Robison, J. C., 142, 145, 274, 504, 626.

Robison, Wm. Ellet, 276.

Rockefeller, Frank, 115.

Rock Springs Pride, 443.

Rodney, 120, 131.

Roenigk, Richard, 513.

Rollins, A. W., 44, 70.

Romine, D. S., 434.

Roney, M. J., 621.

Ronsick, C. H., 209.

Rork, Jesse, 383.

Rosedale, 229, 238, 240.

Rosehaugh, Imp., 229.

Rosehaugh Belle 2d, Imp., 228.

Rosewood, 360 .

Risewood Cathay, 354.

Ruservood Dale, 261). 'stic, 264, 267, 376.

Rosewood Pride, : $33,3 \pm 3$.

Rosewood Stamp, Imp., :":?.

Ross, Geo. B., 125, 126.

Ross, Peter, 82.

Rothwell \& Sons, 426.

Rowley, Guy \& Son, 453.

Royal Gloster, 124.

Royal Knight, 84.

Royal Leader, 249.

Royal Marshal, 300.

Royal Nonpareil, 514.

Royal Pirate, Imp., 72.

Royal Type, 545 .

Royal Violet, 588.

Rule, Col. H. T., 185.

Runft, E. W., 483.

Russell, Robert \& Son, 220, 477.

Rutledge, E. H., 112, 113, 567.

Ryan, Matthew, 39.

Sales, Auction, 1919, 631, 632, 633.

Salter, Park E., 145, 176, 258. 
Salter, Park E., Sale, 416, 446, 591.

Salter-Robison Sale, 145, 176, 243, 280.

Sanborn, J. P., 53.

Sanders, A. H., 67, 68, 187.

Sandoval, 130.

Sands, T. J., 180, 246, 426.

Sanford, L. V., 518.

Sanquhar Sultan, 570.

Sarcasm, 486.

Satin Royal, 431.

Sayre, Paul G., 291.

Sayre, W. J., 13, 120, 180, 288.

Schoepflin, H. M., 120, 529.

Scholz Bros., 238.

Scholz, C. A., 227, 238.

Schwartz, R. E., 622.

Scofield, Frank, 145.

Scotch Cumberland, 200, 273.

Scotch Lord, 364.

Scotland's Charm, 100.

Scott Jr., 119.

Scottish Chief, 71, 72, 90.

Scottish Emperor, 75, 76, 107.

Scottish Prince, 122.

Scottish Viceroy, 326.

Searchlight Bloom, 353.

Seaton, John A., 136.

Secret Archer, 110, 120.

Secret Airdrie, 217.

Secret Baron, 326.

Secret Hampton, 628.

Secret Prince, 379.

Secret Robin, 377, 378, 384, 500.

Secret Sentry, 528 .

Secret Sultan 2d, 471.

Secret's Sultan, 300 .

Select Goods, 619.

Sempstress, 497.

Seyb Bros. \& French, 550.

Shafer, E. C., 463.

Shakers, The, 20.

Shannon, Harry, 312.

Shannon Hill Farm, Sale, 37.

Shannon Hill Herd, 34.

Shelton, Prof. E. M., 70, 71, 174.

Sherwood, John W., 411.

Shorthorn Breeders by Counties, 197.

Shorthorn Cattle, Sanders, 187. Shorthorns, Disposition of, 9, 10.
Shorthorns, First in Northwest Kansas, 51.

Shorthorns, First for Barton County, 45.

Shorthorns for Baby Beef, 13, 289.

Shorthorns for Beef and Milk, 8, 11, 137, 194.

Shorthorns in Kansas, 1857 to 1880, 20.

Shorthorns in Kansas, 1880 to 1920,60 .

Shorthorns, Introducing, 5.

Shorthorns, Minor Operations, 53.

Shorthorns on Beef Market, 12, $13,16$.

Shorthorn Organizations, 174.

Shorthorns, Record Price, $7,8$.

Shorthorn Review, 1810 to 1857 , 18.

Shorthorn Show S. E. Kansas, 496.

Shorthorn Show Steers, 15, 16.

Shorthorns, Universal Adaptability, 10 .

Shorthorn World, The, 188.

Shorthorn Pedigrees, 149-173. What is a pedigree?, 149.

The seller's duty, 149 .

Early pedigrees, 151.

Early controversies, -152.

Unfashionable crosses 1850 to $1890,154$.

English Herd Book rule, 156.

Seotch, 156.

Origin of term, Scotch, 157.

Breeders of Scotch cattle, 158.

Seotch Shorthorns, 159.

Scotch stands for a type, 160 .

A contrast, 161.

Scotch or Scotch topped, 161. Straight Scotch, 164.

Outcrosses, 165.

Fads and discriminations, 166.

True worth only in merit, 167.

Paying high prices, 168 .

Where the danger lies, 169.

What is a good pedigree? 169.

Value of the pedigree, 170.

Plain bred, the term, 172. 
Shotwell, S. L., 53.

Shulz, O. E. R., 351.

Sickles, J. W. \& Sons, 322.

Silk Goods, 230, 407.

Silver Dale, 526.

Silverheel, 321.

Silvermine, 110, 111, 122, 606, 607.

Silver Plate, 223.

Simonson, Walter, 381.

Simpson, V. O., 533.

Sir Charming 4th, 128.

Sir Edelweiss, 508.

Sister Susie, Imp., 446.

Slavens, Dr. H. G., 135, 205.

Smith, E. C., 181.

Smith, E. C. \& Son, 450.

Smith, Rousseau \& Son, 351, 565.

Sni-A-Bar Farm, 12, 37, 177.

Snodgrass, W. J., 119.

Snowball, 367.

Snowflake, 116.

Snowstorm, 249.

Snyder, Col. John D., 186.

Sobba, Henry, 215.

Sobke, Joseph J., 461.

Soil Fertility, 5.

Sorvers, A. G., 287.

Spencer, C. A., 181.

Spexarth, B. J., 576.

Spiraea, 79, 84 .

Springbrook Farm, 596.

St. Albans, Imp., 45.

St Clair, 74.

St. Valentine 12th, 135.

Staley, C. G., 212.

Standish, R. K., 297.

Stanley, Miss M. V., 181, 287, $376,500$.

Star Goods, 103, 597, 599.

Star Shorthorns, 174.

State Assn. Sale, 176, 177, 178.

Stegelin, Ed, 391.

Stephenson, H. C., 119, 120, 529.

Stevens, J. Frank, 212.

Steward, Arthur, 404.

Stewart, Dr. R. A., 127, 550.

Stockstill, J. B., 115.

Stodder, J. F., 107, 109, 119, $280,359$.

Stodder, J. F., Dispersion, 603.
Stone, J. C. Jr., 63, 128.

Stone, T. F., 441.

Stratton, H. A., 49.

Stunkel, E. L., 331, 597.

Stunkel, Henry, 102.

Stunkel Sale, 285.

Sullivan Bros., 210.

Sultan, 569.

Sultan of Anoka, 552.

Sultan Seal, 526.

Sultan's Champion, 559.

Sultan's Marvel, 619.

Sultan's Pride, 334, 552.

Sultan's Robin, 218.

Sultan's Rose, 142.

Sumner County, 633.

Sunnyblink 9th, Imp., 218.

Superior Rosedale, 400.

Supies, Col., 86.

Supreme, 278.

Swain Bros. \& Bates, 52.

Sweet Carmine, 301.

Sweet Fragrance, Imp., 280.

Sweet Mistletoe, 108, 490.

Swinney, I. L., 497.

Swinton Liberty, Imp., 227.

Sycamore Chunk, 602.

Sycamore Marshal, 433.

Sycamore Spiraea, 486.

Sycamore Prince, 229.

Symns Bros., 16.

Syringia, 108.

Taylor, A. H. \& Son, 388.

Taylor, B. L. \& Son, 465, 468.

Taylor, C. W., 105, 328.

Taylor E. E., 256.

Taylor, J. H. \& Sons, 73, 124, 335.

Taylor, John, 105.

Tebo Lawn, 216.

Tennyson, A. A., 130, 232, 539.

Tennyson, D., 130.

Thisler, O. L., 124.

Thistletop, Imp., 71, 90, 91.

Thomas, G. O., 390 .

Thomas, Jameison \& Mitchell, $111,112,115,610$.

Thomason, Alex, 505.

Thomas Young Marys, 111.

Thompson, J. E., 115.

Thorn, J. C., 309, 380.

Thorne, Sam'1, 19.

Tippin, A. J., 219. 


THIS BOOK IS DUE ON THE LAST DATE STAMPED BELOW

RENEWED BOOKS ARE SUBJECT TO IMMEDIATE RECALL

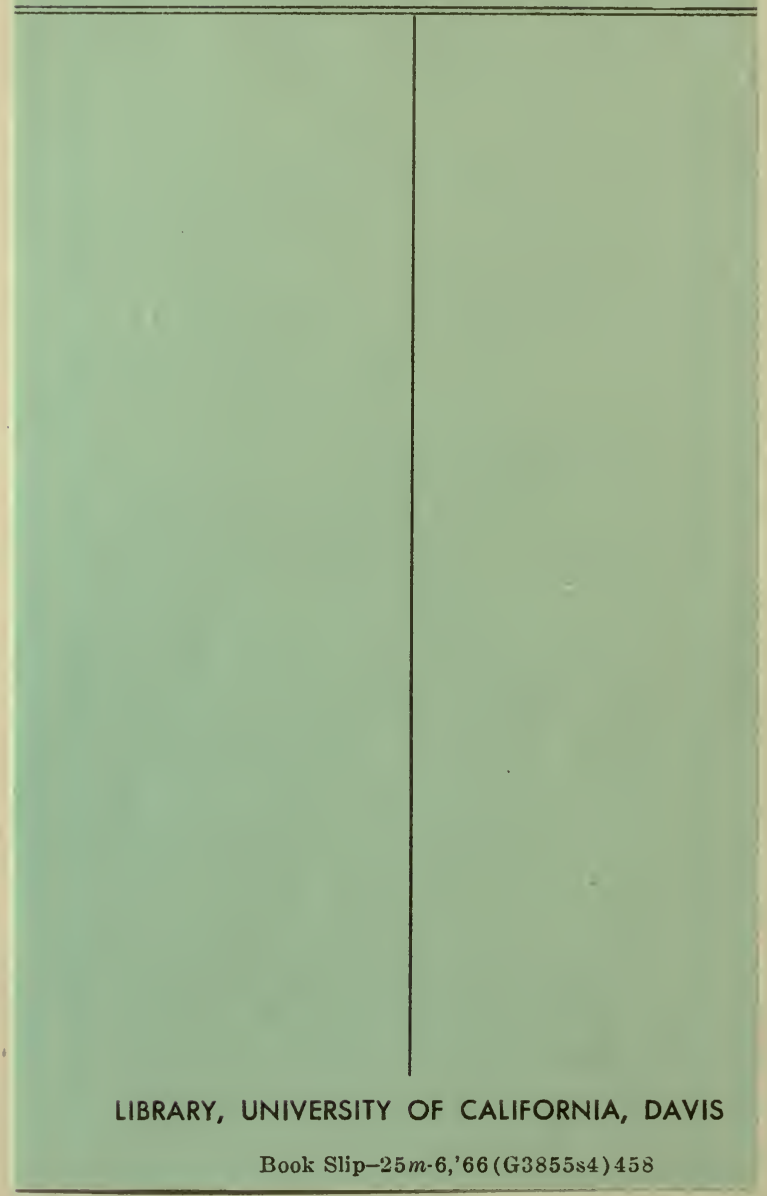

Book Slip-25m-6,'66 (G3855s4)458 


\section{No 540294}

Laude, G.A. SF199

Kansas shortS5 horns. 
